\title{
Normstelling en expertise : waarborgen voor technische deskundigheid in het bijzonder bij vergunningverlening in het milieurecht
}

Citation for published version (APA):

Heldeweg, M. A. (1993). Normstelling en expertise : waarborgen voor technische deskundigheid in het bijzonder bij vergunningverlening in het milieurecht. [Doctoral Thesis, Maastricht University]. SDU, Juridische en Fiscale Uitgeverij. https://doi.org/10.26481/dis.19931126mh

Document status and date:

Published: 01/01/1993

DOI:

10.26481/dis.19931126mh

Document Version:

Publisher's PDF, also known as Version of record

Please check the document version of this publication:

- A submitted manuscript is the version of the article upon submission and before peer-review. There can be important differences between the submitted version and the official published version of record.

People interested in the research are advised to contact the author for the final version of the publication, or visit the DOI to the publisher's website.

- The final author version and the galley proof are versions of the publication after peer review.

- The final published version features the final layout of the paper including the volume, issue and page numbers.

Link to publication

\footnotetext{
General rights rights.

- You may freely distribute the URL identifying the publication in the public portal. please follow below link for the End User Agreement:

www.umlib.nl/taverne-license

Take down policy

If you believe that this document breaches copyright please contact us at:

repository@maastrichtuniversity.nl

providing details and we will investigate your claim.
}

Copyright and moral rights for the publications made accessible in the public portal are retained by the authors and/or other copyright owners and it is a condition of accessing publications that users recognise and abide by the legal requirements associated with these

- Users may download and print one copy of any publication from the public portal for the purpose of private study or research.

- You may not further distribute the material or use it for any profit-making activity or commercial gain

If the publication is distributed under the terms of Article 25fa of the Dutch Copyright Act, indicated by the "Taverne" license above, 
Normstelling en expertise 
Van dit proefschrift verschijnt ook een handelseditie onder ISBN 90540906707 


\title{
NORMSTELLING EN EXPERTISE
}

\author{
Waarborgen voor technische deskundigheid \\ in het bijzonder bij vergunningverlening \\ in het milieurecht
}

\section{PROEFSCHRIFT}

ter verkrijging van de graad van doctor aan de Rijksuniversiteit Limburg te Maastricht, op gezag van de Rector Magnificus, Prof.dr. H. Philipsen, volgens het besluit van het College van Dekanen, in het openbaar te verdedigen op vrijdag, 26 november 1993 om 16.00 uur

door

Michiel Adriaan Heldeweg 
Promotor:

Beoordelingscommissie:
Prof.mr. A.Q.C.Tak

Prof.mr. F.A.M.Stroink (voorzitter)

Prof.mr. P.C.Gilhuis

Prof.mr. N.H.M.Roos 


\section{Voorwoord}

Zijn burgers, bestuursorganen en rechters in staat tot een verantwoord oordeel over de technisch-wetenschappelijke merites van complexe beslissingen? Deze vraag is in het bijzonder actueel bij beslissingen inzake de verlening van technisch-complexe milieuvergunningen. Steeds duidelijker is immers dat kennis van de milieuproblematiek het terrein van gespecialiseerde deskundigen is geworden.

Mijn twijfel over technische deskundigheid van betrokkenen bij complexe (milieu-)beslissingen bracht me vooreerst tot de vraag hoe de inbreng van deskundigheid in besluitvorming kon worden verbeterd. Alras diende zich echter verschillende problemen aan. Allereerst werd ik geconfronteerd met de principiële en praktische gebreken in wetenschappelijke kennisvergaring. Op voet daarvan rees de vraag naar maatstaven voor de inbreng van deskundigheid en de wijze waarop in juridische procedures met deskundigheid moet worden omgegaan. Met behulp van een beknopte theorie over rationeel beslissen heb ik vervolgens getracht - voor deze problematiek - een relatie te leggen met enkele juridische waarborgen voor het overheidshandelen. In het verlengde daarvan kwam ook de rechtsstatelijke rolverdeling tussen bestuur en rechter in beeld.

In deze studie is gekozen voor een gemengde aanpak. Enerzijds is er sprake van een algemene benadering van de problemen die zijn verbonden aan de inbreng van deskundigheid bij normstelling. De 'rode draad' van deze studie wordt daardoor bepaald. Daarnaast vormt de vergunningverlening in het milieurecht voor deze studie een soort van exempel, van waaruit problemen worden aangekaart en waarop de uitwerking van die problemen vervolgens wordt toegepast.

De last van het schrijven van een proefschrift wordt menigmaal uitgedrukt in termen van vele, hartelijke dankzeggingen. Maar is het eigenlijk wel zo'n opgave?

Als je een relatief eenvoudige computer een relatief eenvoudig tekstprogramma geeft, met daarin alle grammaticale benodigdheden, dan zou deze computer in beginsel alle denkbare teksten kunnen schrijven. Natuurlijk zou de(ze) computer niet beter 'weten' dan dat het eindresultaat van deze oefening zou bestaan uit een overzicht van alle mogelijke verzamelingen van de beschikbare tekens, gegeven de spelregels. Wij zouden echter zien dat zich in deze totale verzameling bij voorbeeld klassiekers uit de literatuur zouden bevinden, alsmede een groot aantal varianten daarop, met andere personages en andere 'plots'. 
Ook zou zich in deze verzameling het voorliggende proefschrift bevinden - puur als resultaat van rekenkundige bewerking! De kunst zou echter zijn om het voorliggende proefschrift te selecteren uit de berg van teksten die als varianten daarop (met andere theorieën en andere conclusies) zijn te beschouwen. Je moet dan maar net weten welk geschrift je moet hebben en dat vergt in elk geval een schier oneindige hoeveelheid kritisch leeswerk. Zo beschouwd is de keuze om het boek dan maar zelf te schrijven eigenlijk een vorm van luiheid.

Ook vergelijkenderwijs valt het allemaal best mee. Toen ik met het schrijven van het manuscript begon was mijn zoontje Micah net geboren. Nu, twee-eneen-half jaar later, bij de voltooiing van deze tekst, rent en praat hij en 'zorgt' hij voor z'n jongere broertje Tomas. Vergeleken bij dit alles is het schrijven van een proefschrift kinderspel.

Niettegenstaande deze relativeringen wil ik toch enkele personen oprecht bedanken. Allereerst mijn promotor, Twan Tak, die ik zeer dankbaar ben voor de ruimte die hij mij in den beginne heeft gegeven en zijn timing bij het inluiden van de afronding van het onderzoek. Bovenal heb ik waardering voor het feit dat hij een openhartige sfeer wist te scheppen waardoor mijn schroom om voorlopige en onzekere hersenspinsels te bespreken kon worden overwonnen. Nettie Litjens wil ik van harte bedanken voor de uiteindelijke vormgeving van de tekst en voor haar 'moral support' bij de laatste loodjes. Caroline Forder en Rob Bakker ben ik zeer erkentelijk voor het maken van de engelstalige samenvatting van het manuscript. Mijn vader ben ik zeer dankbaar voor zijn vele nuttige op- en aanmerkingen bij het manuscript en Yvonne voor haar tekening voor de omslag van het boek. Qua inspiratie kan de rol van mijn ouders, Yvonne, Micah en Tomas nauwelijks worden overschat.

De tekst van dit proefschrift is afgesloten op 1 mei 1993. Intussen schrijdt de rechtsontwikkeling voort. Zo ligt er thans een voorstel tot wet bij de Raad van State inzake (de rol van) het ambtsbericht in milieuzaken en is door Verschuuren recent voorgesteld om een zogenoemde Milieu-ombudsman in te stellen. Deze en andere actuele ontwikkelingen konden niet meer worden meegenomen. Net als bij vergunningverlening in een technisch-dynamische omgeving, moest op een bepaald moment de knoop worden doorgehakt. Dat is ook nodig om het wetenschappelijk discours over de aangesneden materie verder te kunnen voeren. Ik hoop dat dit proefschrift daaraan in positieve zin zal bijdragen.

Maastricht, september 1993 


\section{Beknopte inhoudsopgave}

Deel I Object, probleemstelling en opzet van onderzoek

Hoofdstuk 1 Probleemstelling en domein van onderzoek ........ 3

Hoofdstuk 2 Normstelling in het milieurecht . . . . . . . . . . . 13

Hoofdstuk 3 Expertise en open normering .............. 43

Deel II Aanknopingspunten voor rationeel beslissen

Hoofdstuk 4 Rationeel beslissen .................61

Deel III Rationeel beslissen in de non-contentieuze procedure

Hoofdstuk 5 Rationaliteit en rechtmatig bestuur . . . . . . . . . . . . 119

Hoofdstuk 6 Bestuursrechtelijke eisen voor rationeel beslissen . . . . 143

Hoofdstuk 7 Expertise in het milieurecht . . . . . . . . . . . . 219

Deel IV Expertise en de administratieve rechter

Hoofdstuk 8 De functie van de administratieve rechter . . . . . . . 283

Hoofdstuk 9 De feitenvaststelling in het bestuursproces . . . . . . . 321

Deel $V \quad$ Conclusies en aanbevelingen

Hoofdstuk 10 Normstelling en expertise . . . . . . . . . . . . . . 389 
ran

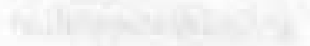

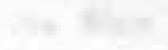

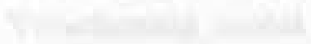

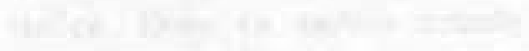

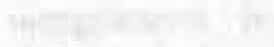

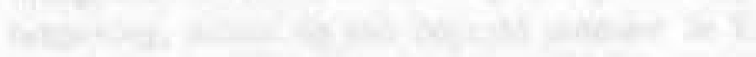

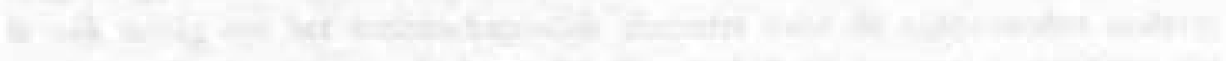
Than

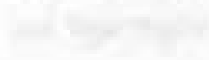

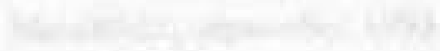




\section{Inhoudsopgave}

Voorwoord ....................... V

Beknopte inhoudsopgave . . . . . . . . . . . . . . . VII

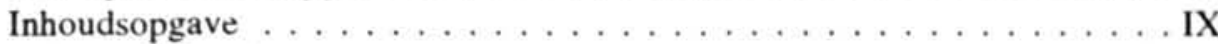

Lijst van afkortingen $\ldots \ldots \ldots \ldots \ldots \ldots \ldots \ldots \ldots \ldots \ldots \ldots$

\section{Deel I Object, probleemstelling en opzet van onderzoek}

\section{Hoofdstuk 1 Probleemstelling en domein van onderzoek}

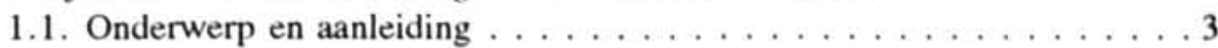

1.2. Probleemstelling . . . . . . . . . . . . . . 4

1.3. Opzet van het onderzoek . . . . . . . . . . . . . . 9

Hoofdstuk 2 Normstelling in het milieurecht

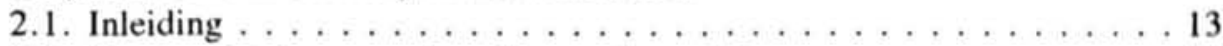

2.2. Karakteristieken van de milieuproblematiek .......... 14

2.2.1. Ontwikkeling van de milieuproblematiek . . . . . . . 14

2.2.2. Naar 'duurzame ontwikkeling' . . . . . . . . . . 15

2.2.3. Karakteristieken: ecologisch, technologisch-dynamisch . . 17

2.2.4. Verwetenschappelijking: milieu als 'complex belang' . . . . 20

2.3. Normstelling in het milierecht: open en gesloten normen . . . 21

2.3.1. Empirische context en juridische normen ........ 21

2.3.2. Poreusheid, open omschrijvingen en gebreken . . . . 22

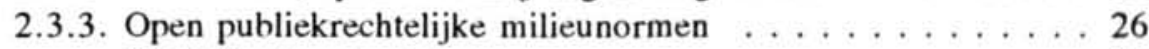

2.3.3.1. Grondrechten . . . . . . . . . . . . 26

2.3.3.2. Vergunningen . . . . . . . . . . . . 26

2.3.3.3. Zorgplichten . . . . . . . . . . . . . 27

2.3.3.4. Milieudelicten . . . . . . . . . . . 30

2.3.4. Open privaatrechtelijke milieunormen . . . . . . . 31

2.3.4.1. Onrechtmatigheid en wetenschap . . . . . . 32

2.3.4.2. Van schuld naar risico . . . . . . . . . 33

2.3.5. Gesloten milieunormen: algemene regels . . . . . . . 36

2.4. Voortschrijdende normstelling: conclusie . . . . . . . 40

Hoofdstuk 3 Expertise en open normstelling

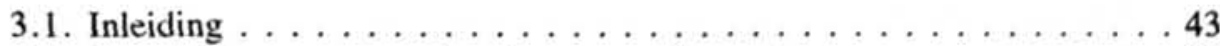

3.2. Openheid van normen inzake vergunningverlening $\ldots \ldots \ldots . \ldots 44$

3.2.1. Open normen en vage termen . . . . . . . . . 44

3.2.2. Beoordelingsruimte, beoordelings- en beleidsvrijheid ... 45 
3.2.3. De rol van expertise bij 'beoordeling' . . . . . . . . . 48

3.2.4. De rol van expertise bij 'beleid' . . . . . . . . . . 49

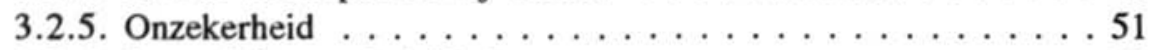

3.2.6. Beoordeling en beleid als proces $\ldots \ldots \ldots \ldots \ldots \ldots$

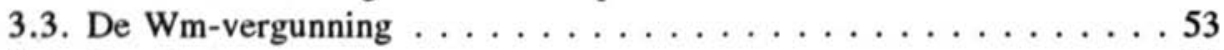

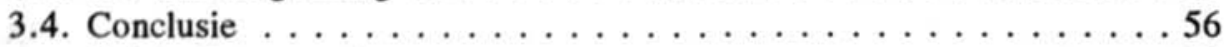

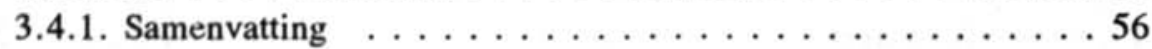

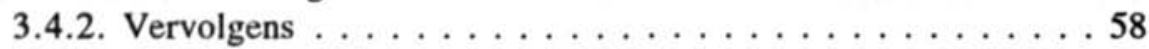

\section{Deel II Aanknopingspunten voor rationeel beslissen}

\section{Hoofdstuk 4 Rationeel beslissen}

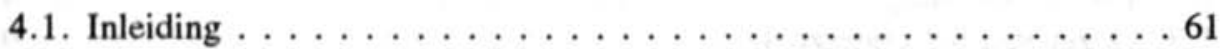

4.1.1. Wijze van aanpak ................ 61

4.1.2. Opbouw van het vervolg $\ldots \ldots \ldots \ldots \ldots \ldots \ldots$

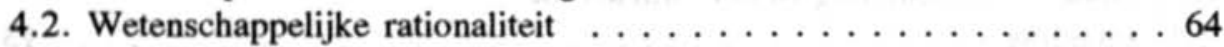

4.2.1. De waarheid . . . . . . . . . . . . . . . 64

4.2.2. Fundamentele onzekerheid: onderdeterminatie . . . . . . . 64

4.2.3. Waardeoordelen in de wetenschap . . . . . . . . . 68

4.2.4. De wetenschap als 'sociale consensus' . . . . . . . . . 73

4.2.5. Conclusie wetenschappelijke rationaliteit $\ldots \ldots \ldots \ldots \ldots 75$

4.3. Economische rationaliteit . . . . . . . . . . . . 77

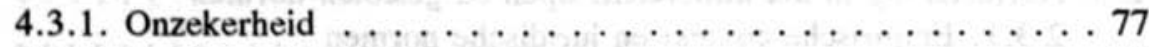

4.3.2. De bevredigende oplossing $\ldots \ldots \ldots \ldots \ldots \ldots \ldots \ldots 78$

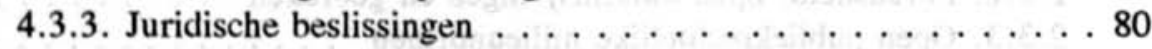

4.3.3.1. Juridische condities . . . . . . . . 80

4.3.3.2. De selectie . . . . . . . . . . . 82

4.3.3.3. Het onderzoek . . . . . . . . . . 85

4.3.3.4. De toetsing aan het aspiratieniveau . . . . . . . 89 89

4.3.3.5. Een juridisch bevredigende beslissing ...... 91

4.3.4. Beperken van onzekerheid . . . . . . . . . . . 93

4.3.5. Conclusie economische rationaliteit . . . . . . . . 94

4.4. Juridische rationaliteit $\ldots \ldots \ldots \ldots \ldots \ldots \ldots \ldots \ldots \ldots \ldots$

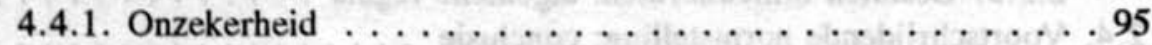

4.4.2. Legitimiteit . . . . . . . . . . . 96

4.4.3. Legitimatie bij beslissen in onzekerheid . . . . . . . 99

4.5. Enkele praktische kwesties . . . . . . . . . . . . . 104

4.5.1. Accenten ... . . . . . . . . . . . . . . 104

4.5.2. Enkele kwesties .................. 105

4.5.2.1. Wanneer expertise inwinnen? ......... 105

4.5.2.2. Eenduidige kennis . . . . . . . . . 105 
4.5.2.3. Schijnzekerheden .............. 106

4.5.2.4. De deskundige . . . . . . . . . . . . . 107

4.5.2.5. Onathankelijkheid ... . . . . . . . . 108

4.5.2.6. Soorten adviezen . . . . . . . . . . . . . 108

4.5.3. Afronding 'praktische kwesties' . . . . . . . . . 110

4.6. Conclusie . . . . . . . . . . . . . . . . . 115

Deel III Rationeel beslissen in de non-contentieuze procedure

Hoofdstuk 5 Rationaliteit en rechtmatig bestuur

5.1. Inleiding . . . . . . . . . . . . . . . . . 119

5.2. De juridificering van het besturen . . . . . . . . . 120

5.2.1. Drie dimensies . . . . . . . . . . . . . 120

5.2.2. Rechtsbescherming en het democratisch tekort ...... 121

5.3. Democratie en rationaliteit . . . . . . . . . . . . . 122

5.4. Rationaliteit als postulaat of evidentie . . . . . . . . . . 124

5.4.1. Het rationaliteitspostulaat van Van Male . . . . . . . . 125

5.4.2. De evidente rationaliteit volgens Nicolaï . . . . . . . . 125

5.4.3. Tussenbalans . . . . . . . . . . . . . . . . 127

5.5. Het willekeurverbod als bestuursrechtelijk paradigma . . . . . 128

5.5.1. Het algemeen belang en de burgerlijke vrijheid . . . . . 128

5.5.2. De behartiging van het algemeen belang . . . . . . 130

5.5.3. De centrale rol van het willekeurverbod . . . . . . . 134

5.6. Een algemene eis van rationeel bestuur? . . . . . . . . . . 139

Hoofdstuk 6 Bestuursrechtelijke eisen voor rationeel beslissen

6.1. Inleiding: de publiekrechtelijke legitimatie $\ldots \ldots \ldots \ldots \ldots$

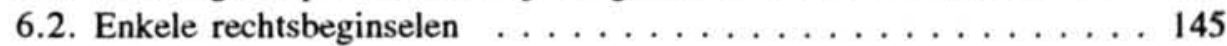

6.2.1. Willekeur . . . . . . . . . . . . . . . 145

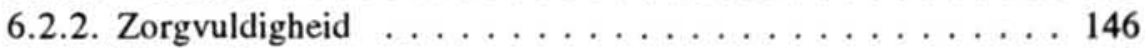

6.2.3. Motivering . . . . . . . . . . . . . . . 149

6.3. Non-contentieuze procedures volgens de Awb . . . . . . . 150

6.3.1. Inzet van de Awb . . . . . . . . . . . . . . . 150

6.3.2. De algemene standaardprocedure . . . . . . . 151

6.3.2.1. Gegevensverschaffing . . . . . . . . . 151

6.3.2.2. Het horen . . . . . . . . . . . . . 153

6.3.2.3. De advisering . . . . . . . . . . 155

6.3.3. De openbare voorbereidingsprocedure . . . . . . 155

6.3.4. De uitgebreide openbare voorbereidingsprocedure(s) . . . . 157

6.3.4.1. Karakteristiek . . . . . . . . . . . . . . 157 
6.3.4. De uitgebreide openbare voorbereidingsprocedure(s) . . . 157

6.3.4.1. Karakteristiek . . . . . . . . . . . . . 157

6.3.4.2. De procedures op hoofdlijnen . . . . . . . 158

6.3.4.3. Advisering . . . . . . . . . . . 162

6.3.5. De bezwaarschriftenprocedure . . . . . . . . . . 164

6.3.5.1. Motieven . . . . . . . . . . . 165

6.3.5.2. Procedure . . . . . . . . . . . . . 166

6.3.5.3. Kritiek . . . . . . . . . . . . . 170

6.3.6. Algemeen commentaar . . . . . . . . . . . . . 175

6.4. Gerichte deskundigen-advisering . . . . . . . . . . 177

6.4.1. Inleiding . . . . . . . . . . . . . . 177

6.4.2. Verwerving van het advies ... . . . . . . . 178

6.4.2.1. Verantwoordelijkheid, bevoegdheid en plicht . . . 178

6.4.2.2. Formulering van de adviesvraag . . . . . . 180

6.4.3. Kritiseerbaarheid: voorzorg en controle . . . . . . . 181

6.4.3.1. Voorzorgen . . . . . . . . . . . . . 181

6.4.3.2. Controle op het advies ... . . . . . . . 188

6.4.4. Het gezag van het advies . . . . . . . . . . . 191

6.4.4.1. Verantwoordelijkheid . . . . . . . . . . . 191

6.4.4.2. Het volgen van een advies . . . . . . . . . . 193

6.4.4.3. Afwijken van advies . . . . . . . . . . . 193

6.4.4.4. Zorgvuldigheid (en aansprakelijkheid) . . . . . . 195

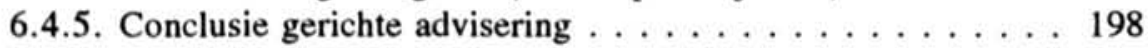

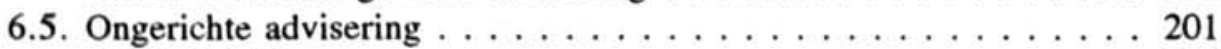

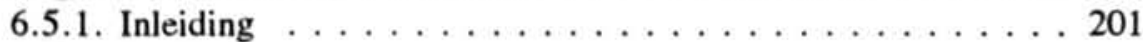

6.5.2. Motieven . . . . . . . . . . . . . . 202

6.5.3. Richtlijngevers . . . . . . . . . . . . . . 202

6.5.4. Juridisch gezag . . . . . . . . . . . . 203

6.5.5. Afwijken van een richtlijn . . . . . . . . . 206

6.5.6. Beoordeling . . . . . . . . . . . . . 208

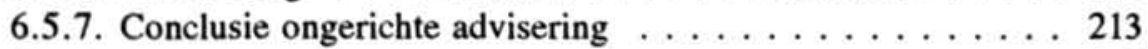

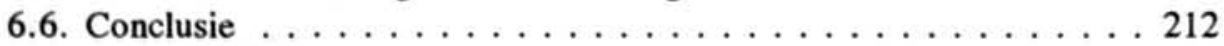

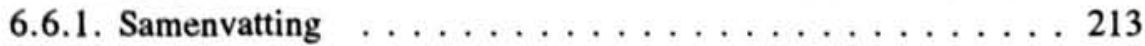

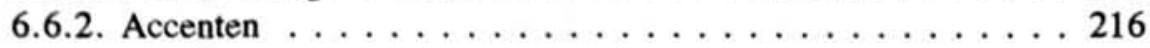

Hoofdstuk 7 Expertise in het milieurecht

7.1. Inleiding . . . . . . . . . . . . . . . . 219

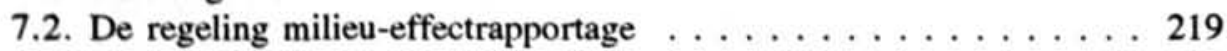

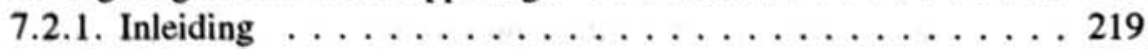

7.2.2. Bestaande procedure . . . . . . . . . . 221

7.2.2.1. De voorfase . . . . . . . . . . . . 221 
7.2.2.2. De vooroverlegfase . . . . . . . . . . 222

7.2.2.3. Het opstellen van het MER . . . . . . . . 223

7.2.2.4. De aanvaardbaarheid van het MER . . . . . . . 226

7.2.2.5. Inspraak, advies en toetsing . . . . . . . . 227

7.2.2.6. Het besluit . . . . . . . . . . . . . . 230

7.2.2.7. De evaluatie . . . . . . . . . . . 236

7.2.3. De werkingssfeer . . . . . . . . . . . . . 237

7.2.4. Het regeringsverslag . . . . . . . . . . . 240

7.2.5. Conclusies . . . . . . . . . . . . . . . . 247

7.3. Zorg voor de deskundigheid van burgers . . . . . . . 252

7.4. Vaste deskundigen . . . . . . . . . . . . . . 255

7.4.1. Inleiding . . . . . . . . . . . . . 255

7.4.2. Vergelijking Cmer-Milieu-inspectie . . . . . . 257

7.4.3. Taakstelling en ratio . . . . . . . . . . . 260

7.4.3.1. De oplossing in de markt . . . . . . . . . . . 261

7.4.3.2. Een vast advies aan de rechter . . . . . . . 263

7.4.4. Conclusie . . . . . . . . . . . . . . . . . . . . 264

7.5. Reductie van onzekerheid . . . . . . . . . . . . 265

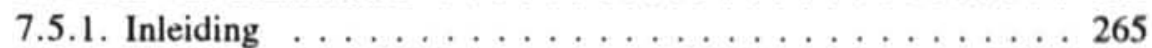

7.5.2. Het onderzoek . . . . . . . . . . . . . . . . 265

7.5.3. Beginselen . . . . . . . . . . . . . . 267

7.5.3.1. Het ALARA-beginsel . . . . . . . . . . . 267

7.5.3.2. Het voorzorgsbeginsel . . . . . . . . . 269

7.5.4. Het voorkomen van missers . . . . . . . . . . . . . . 270

7.5.5. Verzekering en compensatie . . . . . . . . 272

7.5.5.1. Compensatie . . . . . . . . . . . 272

7.5.5.2. Verzekering . . . . . . . . . . . . 272

7.5.6. Conclusie onzekerheidsreductie . . . . . . . . . 274

7.6. Conclusie . . . . . . . . . . . . . . . . . . . 274

7.6.1. Expertise in het milieurecht . . . . . . . . . . . 274

7.6.2. Expertise en non-contentieuze besluitvorming . . . . . . 277

\section{Deel IV Expertise en de administratieve rechter}

Hoofdstuk 8 De functie van de administratieve rechter

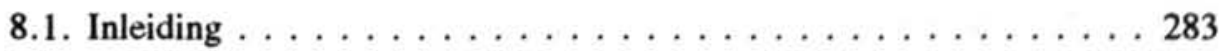

8.2. De contouren van het nieuwe bestuursproces . . . . . . . 286

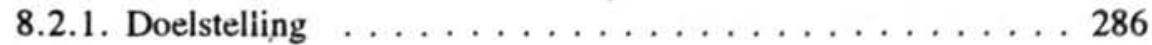

8.2.2. Knelpunten . . . . . . . . . . . . . . . 286

8.2.3. Karakteristieken . . . . . . . . . . . . . . 287

8.3. Nadere analyse van het nieuwe bestuursprocesrecht . . . . . . 290 
8.3.2.1. Twee posities . . . . . . . . . . . . 291

8.3.2.2. Eigen opvatting . . . . . . . . . 292

8.3.3. De rol van de non-contentieuze procedure . . . . . . . 297

8.3.3.1. Democratie en rechtsbescherming . . . . . . 297

8.3.3.2. Objectieve redelijkheidstoetsing . . . . . . . . . 297

8.3.3.3. Ongelijkheidscompensatie en rechterlijke discretie . . . . . . . . . . . . . . 304

8.3.3.4. Zelf in de zaak voorzien . . . . . . . . . 306

8.3.3.5. Publieke werking . . . . . . . . . . 309

8.3.3.6. Ex nunc of ex tunc . . . . . . . . . . 310

8.3.3.7. Opnieuw: zelf in de zaak voorzien . . . . . . 314

8.3.4. Herziening . . . . . . . . . . . . . 317

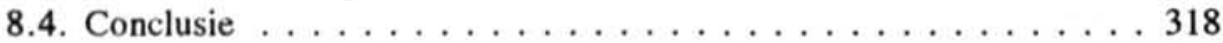

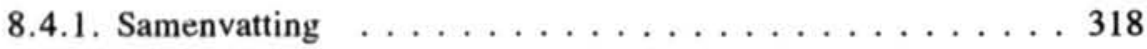

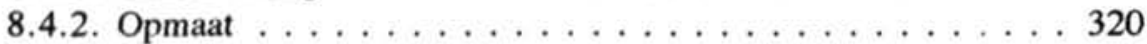

Hoofdstuk 9 De feitenvaststelling in het bestuursproces

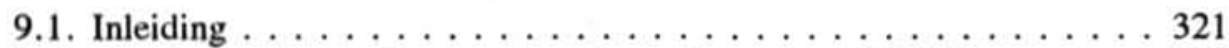

9.2. Enkele regels van de procesvoering volgens het WHRO1 . . . 321

9.2.1. Preliminaire zaken . . . . . . . . . . . . 322

9.2.2. Het vooronderzoek . . . . . . . . . . . . . 324

9.2.3. Het onderzoek ter zitting $\ldots \ldots \ldots \ldots \ldots \ldots \ldots \ldots$

9.2.4. De uitspraak . . . . . . . . . . . . . . . 327

9.2.5. Rechter of deskundige . . . . . . . . . . . . 328

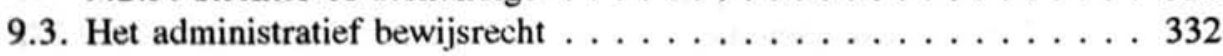

9.3.1. 'De waarheid' . . . . . . . . . . . . . . . 332

9.3.2. Vier aspecten $\ldots \ldots \ldots \ldots \ldots \ldots \ldots \ldots \ldots \ldots \ldots \ldots$

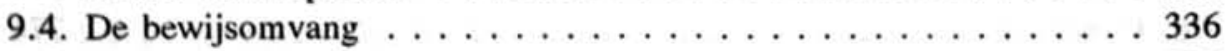

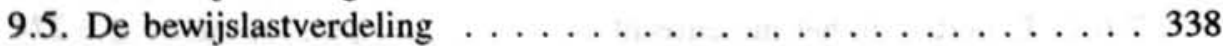

9.5.1. Vrije bewijsleer . . . . . . . . . . . . . 338

9.5.2. Bewijs door de rechter . . . . . . . . . . . . 338

9.5.3. Bewijs door partijen . . . . . . . . . . . . 340

9.5.3.1. Bestuursrechtelijke regels . . . . . . 340

9.5.3.2. Een vergelijking met de

9.5.4. Conclusie . . . . . . . . . . . . . . . . . . . . 347

9.6. De bewijsmiddelen . . . . . . . . . . . . 348

9.6.1. Preliminaire zaken . . . . . . . . . . . . . . . 348

9.6.2. De deskundigenverklaring . . . . . . . . . 350

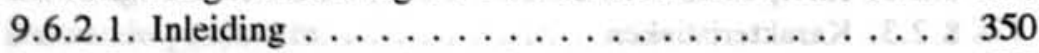

9.6.2.2. Ervaringen met het ambtsbericht $\ldots \ldots \ldots \ldots 351$ 
9.6.3. Naar een nieuwe adviescultuur? . . . . . . . . . . 355

9.6.3.1. Vaste-deskundigheid . . . . . . . . . . . 357

9.6.3.2. Ad-hoc deskundigheid . . . . . . . . . . 360

9.6.4. Conclusie . . . . . . . . . . . . . . . . 362

9.7. De bewijswaardering . . . . . . . . . . . . . 364

9.7.1. Rechterlijke overtuiging . . . . . . . . . . . . . 364

9.7.1.1. Normatieve uitgangspunten . . . . . . . . . 364

9.7.1.2. Kritische opstelling . . . . . . . . . . . 365

9.7.1.3. Onzekerheid . . . . . . . . . . . . . 367

9.7.1.4. Motivering . . . . . . . . . . . . . . . 369

9.7.2. Enkele beperkingen in de vrijheid van bewijswaardering . . . . . . . . . . . . 370

9.7.2.1. 'Methodologische kritiek' . . . . . . . . . . . 370

9.7.2.2. Formalisering van het bewijs . . . . . . . . 374

9.7.3. Afrondende opmerkingen . . . . . . . . . . 376

9.7.3.1. Samenvatting . . . . . . . . . . . . 376

9.7.3.2. Enkele slotopmerkingen . . . . . . . . . . . . 377

9.8. Afronding, conclusies en aanbevelingen . . . . . . . . . . . 379

9.8.1. Samenvatting . . . . . . . . . . . . . . 379

9.8.2. Een regeling van bewijsrecht? . . . . . . . . . 384

\section{Deel $\mathbf{V}$ conclusies en aanbevelingen}

Hoofdstuk 10 Normstelling en expertise

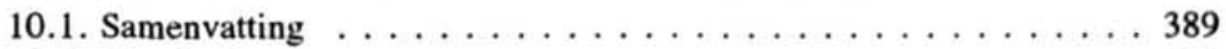

10.2. Conclusies . . . . . . . . . . . . . . . . . 401

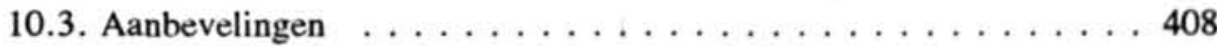

Literatuurlijst . . . . . . . . . . . . . . . . . . 419

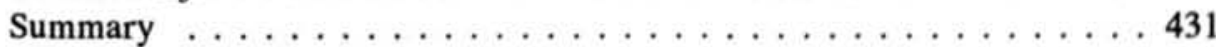

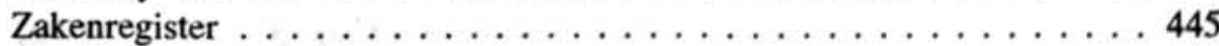

Curriculum vitae . . . . . . . . . . . . . . . . . . . 449 


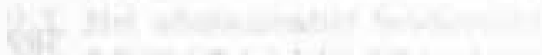

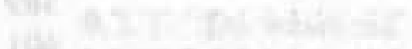

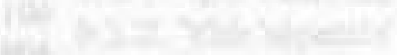

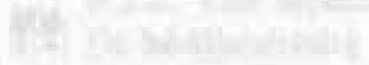

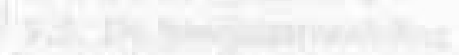

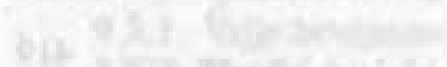

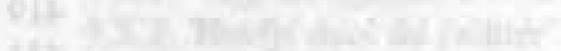

1172-2.

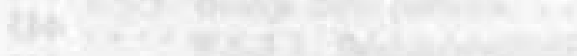

(1)

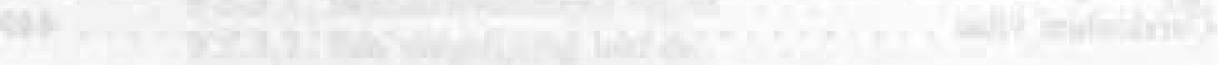

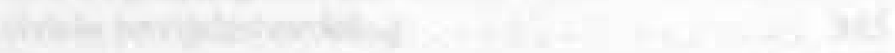

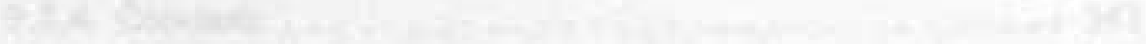

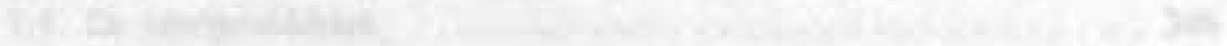
tran

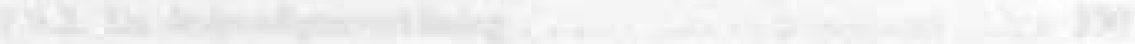

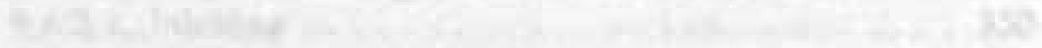

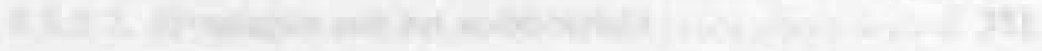




\section{Lijst van afkortingen}

\begin{tabular}{|c|c|}
\hline AA & Ars Aequi \\
\hline $\mathrm{AB}$ & Administratiefrechtelijke Beslissingen \\
\hline ABAR & Algemene Bepalingen van Administratief Recht \\
\hline $\mathrm{ABM}$ & Adviseur Beroepen Milieubeheer \\
\hline AGRvS & Afdeling Geschillen Raad van State \\
\hline $\mathrm{AM} v \mathrm{~B}$ & Algemene Maatregel van Bestuur \\
\hline AROB & Wet Administratieve Rechtspraak Overheidsbeschikkingen \\
\hline ARRvS & Afdeling Rechtspraak Raad van State \\
\hline Asw & Afvalstoffenwet \\
\hline a.w. & Aangehaald werk \\
\hline Awb & Algemene wet bestuursrecht \\
\hline Awbl & Algemene wet bestuursrecht eerste tranche \\
\hline Awb2 & $\begin{array}{l}\text { Algemene wet bestuursrecht tweede tranche (onderdeel van } \\
\text { Whrol) }\end{array}$ \\
\hline Awb3 & Voorontwerp Algemene wet bestuursrecht derde tranche \\
\hline AwbA & $\begin{array}{l}\text { Algemene wet bestuursrecht aanvullingsvoorstel (o.a afdeling } \\
3.5 \text { ) }\end{array}$ \\
\hline Bmer & Besluit milieu-effectrapportage \\
\hline BUPO & $\begin{array}{l}\text { Internationaal verdrag inzake beurgerrechten en politieke } \\
\text { rechten (ook wel IVBPR) }\end{array}$ \\
\hline BW & Burgerlijk Wetboek \\
\hline Cmer & Commissie voor de milieu-effectrapportage \\
\hline CRvB & Centrale raad van Beroep \\
\hline CTW & Commissie voor de toetsing van wetgevingsprojecten \\
\hline DGM & Directoraat Generaal Milieubeheer \\
\hline DROM & $\begin{array}{l}\text { Deregulering op het gebied van Ruimtelijke Ordening en } \\
\text { Milieubeheer }\end{array}$ \\
\hline ECOSOC & $\begin{array}{l}\text { Internationaal verdrag inzake economische, sociale en cultu- } \\
\text { rele rechten }\end{array}$ \\
\hline ECW & Evaluatiecommissie Wabm \\
\hline EG & Europese Gemeenschap \\
\hline EHRM & Europese Hof voor de Rechten van de Mens \\
\hline EK & Eerste Kamer der Staten Generaal (bijlagen/handelingen) \\
\hline EVRM & Europees Verdrag voor de Rechten van de Mens \\
\hline Gw & Grondwet \\
\hline HR & Hoge Raad der Nederlanden \\
\hline $\mathrm{Hw}$ & Hinderwet \\
\hline IMP-M & Indicatief meerjarenprogramma Milieubeheer \\
\hline
\end{tabular}


IVBPR Internationaal verdrag inzake burgerrechten en politieke rechten (ook wel BUPO)

Kew Kernenergiewet

LNV

m.e.r.

MER

m.nt.

$M \& R$

MvA

MvT

NEN

NJ

NJB

NJV

NMP

NNI

NTB

prft.

$\mathrm{Rb}$

RIVM

$R \& K$

RMTh

Rv

RvdW

RvS

$\mathrm{Sr}$

Stcrt.

Stb.

Sv

$\mathrm{tB} / \mathrm{S}$

TK

TvO

TwK

VAR

VROM

Wabm

Wbb

Wca

Wed

Wet A.B.
Ministerie van Landbouw, Natuurbeheer en Visserij

Regeling milieu-effectrapportage

Milieu-effectrapport

Met noot

Tijdschrift voor Milieu en Recht

Memorie van Antwoord

Memorie van Toelichting

Normen afkomstig van het NNI

Nederlands Jurisprudentie

Nederlands Juristenblad

Nederlandse juristenvereniging

Nationaal milieubeleidsplan

Nederlands Normalisatie Instituut

Nederlands Tijdschrift voor Bestuursrecht

Proefschrift

Rechtbank

Rijksinstituut voor Volksgezondheid en milieuhygiëne

Recht en Kritiek

Rechtsgeleerd Magazijn Themis

Wetboek van burgerlijke rechtsvordering

Rechtspraak van de Week

Raad van State

Wetboek van Strafrecht

Staatscourant

Staatsblad

Wetboek van Strafvordering

Wet Administratieve rechtspraak overheidsbeschikkingen, onder redactie van J.B.J.M ten Berge en F.A.M. Stroïnk

Tweede Kamer der Staten Generaal (bijlagen/handelingen) •

Tijdschrift voor het Openbaar bestuur

Tijdelijke wet Kroongeschillen

Vereniging voor administratiefrecht

Ministerie van volkshuisvesting, Ruimtelijke Ordening en Milieubeheer

Wet algemene bepalingen milieuhygiëne

Wet bodembescherming

Wet chemische afvalstoffen

Wet op de economische delicten

Wet Algemene bepalingen 


$\begin{array}{ll}\text { Wet RvS } & \text { Wet op de Raad van State } \\ \text { Wgh } & \text { Wet geluidhinder } \\ \text { Whrol } & \text { Wetsontwerp herziening rechterlijke organisatie eerste fase } \\ \text { Wlv } & \text { Wet inzake de luchtverontreiniging } \\ \text { Wm } & \text { Wet milieubeheer } \\ \text { Wm-m\&m } & \text { Wetsontwerp milieubeleidsplanning en milieukwaliteitseisen } \\ \text { Wm-var } & \text { Wetsontwerp Vergunningen en algemene regels } \\ \text { Wms } & \text { Wet milieugevaarlijke stoffen } \\ \text { Wob } & \text { Wet openbaarheid van bestuur } \\ \text { Wvo } & \text { Wet verontreiniging oppervlaktewateren } \\ \text { Wvw } & \text { Wegenverkeerswet }\end{array}$




\section{Deel I}

\section{Object, probleemstelling en opzet van onderzoek}




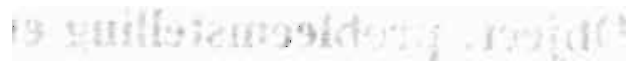

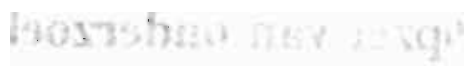

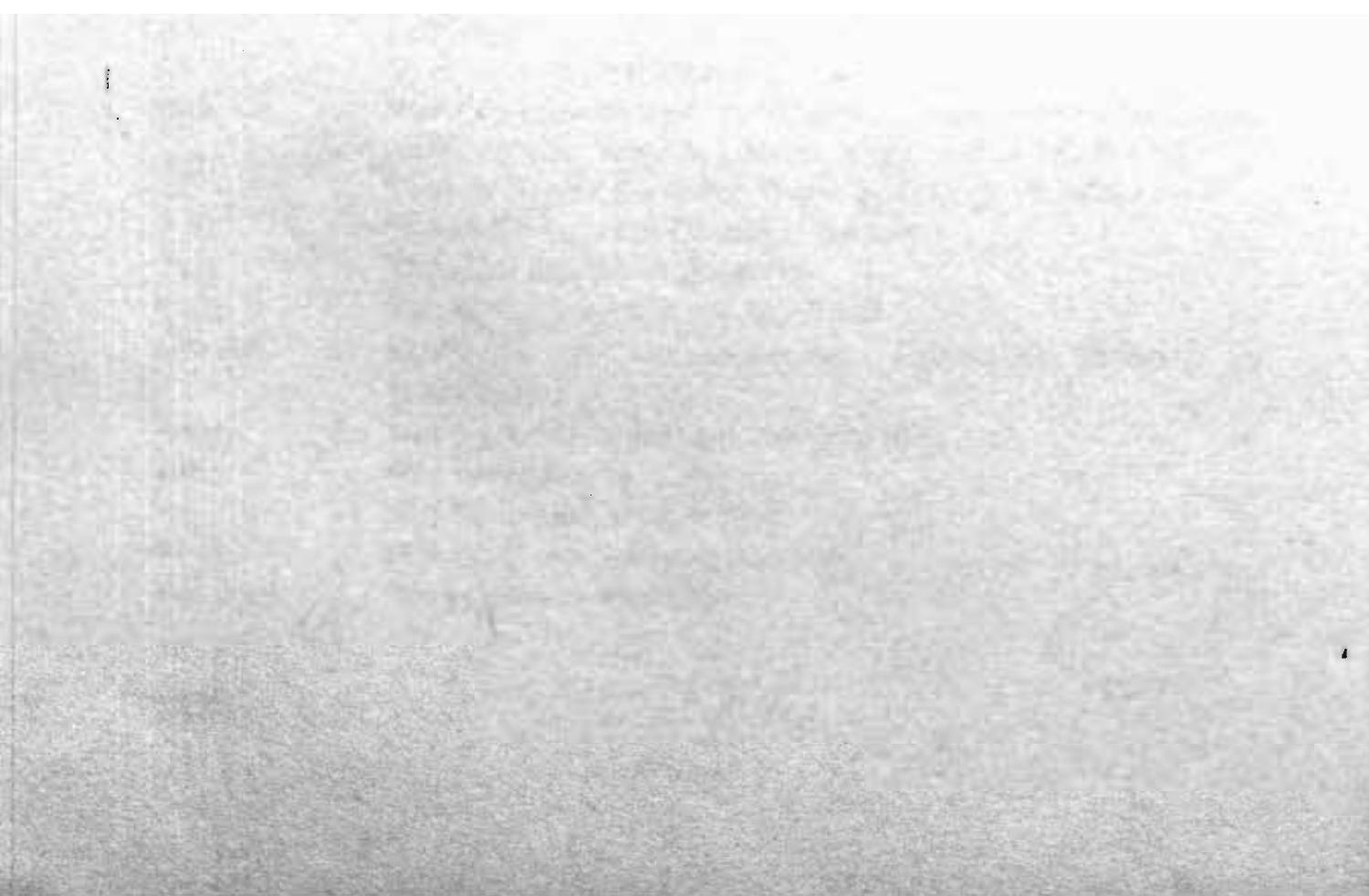




\section{Hoofdstuk 1 \\ Probleemstelling en domein van onderzoek}

\subsection{Onderwerp en aanleiding}

Vaak blijkt bij normstelling door de overheid technisch-wetenschappelijk onderzoek noodzakelijk om te komen tot een rechtens aanvaardbare beoordeling en afweging van betrokken belangen. Niet zelden beschikken overheidsorganen, burgers en rechters echter niet zelf over de voor normstelling benodigde technisch-wetenschappelijke expertise.' Deskundigen moeten worden ingeroepen om de besluitvorming (of controle daarop) tot een goed einde te brengen.

Problemen van normstelling en expertise doen zich in het bijzonder voor bij de milieuproblematiek. De zorg voor het milieu blijkt in toenemende mate een onderwerp te zijn geworden van specialisten. In de eerste plaats als het gaat om kennis over het milieu zelf. Voor een goed begrip van processen en samenhangen in het leefmilieu, alsook van de kwetsbaarheid van daarin voorkomende soorten moeten we tegenwoordig al snel aankloppen bij biologen, ecologen, toxicologen en andere deskundigen. Daarnaast worden ook de bronnen van milieuverontreiniging zoals specifieke procestechnieken en materiaalsoorten steeds ingewikkelder. Analyse daarvan is nodig om vast te stellen welke gevaren het milieu bij het gebruik van dergelijke technieken en materialen eventueel kan ondervinden. Daarbij komt dat het risico van onomkeerbare schade aan het milieu, zich bij de steeds nauwere en grootschaliger samenhangen in menselijke activiteiten allengs duidelijker doet gevoelen.

Tegen deze achtergrond heb ik besloten tot een studie naar de inbreng van technisch-wetenschappelijke deskundigheid bij het stellen van normen door het overheidsbestuur. In het bijzonder gaat het mij om de vraag welke juridische waarborgen daarvoor wenselijk zijn. Enerzijds heb ik daarbij gekozen voor een algemeen bestuursrechtelijk perspectief, hetgeen vooral tot uitdrukking komt in de structuur van deze studie (zie \& 1.3). Anderzijds heb ik willen aanknopen bij de vergunningverlening in het milieurecht. Juist daar is de problematiek van (ontbrekende) technisch-wetenschappelijke deskundigheid immers aan de orde van de dag. Dat maakt het milieurecht als een

1. In deze studie zullen de woorden deskundigheid en expertise als synoniemen van elkaar worden gebruikt. 
exempel van de problematiek van expertise en normstelling bij uitstek geschikt.

\subsection{Probleemstelling}

De probleemstelling van dit onderzoek luidt aldus:

Welke juridische waarborgen dienen in acht te worden genomen bij de inbreng van technisch-wetenschappelijke expertise bij het verlenen van milieuvergunningen?

In deze probleemstelling figureert de verlening van milieuvergunningen als exempel voor de problematiek van normstelling en expertise. De behandeling van de probleemstelling is er echter op gericht dat ook voor het bestuursrecht in het algemeen conclusies uit het onderzoek kunnen worden afgeleid.

In dat verband is het me niet te doen om de vraag hoe per se meer technischwetenschappelijke deskundigheid voor de besluitvorming (en de controle daarop) beschikbaar kan worden gemaakt. Met de vraag naar juridische waarborgen gaat het mij juist om de kwaliteit van bestuurlijke normstelling, gelet op de factor deskundigheid. Door het accent te leggen op juridische waarborgen hoop ik "kwaliteitseisen" voor het inbrengen en omgaan met expertise op te kunnen sporen. Deze benaderingswijze hangt nauw samen met twee veronderstellingen.

- In de eerste plaats stel ik voorop dat het (voor bestuurlijke besluitvorming) ontwikkelen, inbrengen en beoordelen van deskundigheid niet als een waarde-neutrale operatie kan worden gezien. Dit houdt nauw verband met het feit dat onzekerheid over deskundigheid in de wetenschap aan de orde van de dag is. Daarmee wordt beslissen (mede) op basis van technisch-wetenschappelijke deskundigheid beslissen in onzekerheid.

Tegelijkertijd is het niet zo dat waardegebondenheid en onzekerheid van wetenschappelijke uitspraken en toepassingen daarvan, de inbreng van deskundigheid in concrete besluitvormingssituaties op voorhand overbodig makt. Wel is het van belang om te bezien welke consequenties onzekerheid en waardegebondenheid voor de wijze van besluitvorming en daarbij te maken normatieve keuzes kunnen hebben.

- In de tweede plaats is mijn premisse dat moet worden voorkomen dat de juridische waarborgen voor de inbreng van deskundigheid ontaarden in een schijn van objectieve zekerheid van genomen beslissingen. Juridische ambtsdragers, zoals bestuursorganen en rechters moeten niet als "super- 
deskundigen" te werk willen gaan. Ook moeten de juridische waarborgen niet gestoeld zijn op de pretentie dat rechtens slechts die beslissingen aanvaardbaar zijn die kunnen bogen op een objectieve en een onomstotelijke technisch-wetenschappelijke grondslag. Alle juridische waarborgen ten spijt leidt beslissen in onzekerheid toch steeds tot (naar hun technischwetenschappelijke effect) onzekere beslissingen. Wat telt is het naar omstandigheden en naar de aard en hoedanigheid van de betrokken belangen geven van aanvaardbare beslissingen: "juridische zekerheid".

Het ligt voor de hand dat deze premisses in het onderzoek aan de orde komen. Teneinde zulks te verzekeren heb ik bij de aanpak van het onderzoek de idee van het rationeel beslissen voorop gesteld.

Rationeel beslissen vat ik in deze studie op als weloverwogen handelen, handelen op basis van goede redenen; dat wil zeggen redenen waaraan kritiseerbare kennis ten grondslag ligt. ${ }^{2}$

Dit idee van rationeel beslissen omvat, indien toegepast op het bestuurlijk handelen, drie aspecten.

- In de eerste plaats de veronderstelling dat het bestuur is gehouden tot het geven van beslissingen op een empirische grondslag.

- In aansluiting hierop de aanname dat het bestuur zijn kennis omtrent deze (empirische) feiten baseert op wetenschappelijke rationaliteit als methode van kennisvergaring en -ontwikkeling. ${ }^{3}$

- In verband hiermee op de veronderstelling dat deskundigheid kritiseerbaar moet zijn en zich niet als onaantastbare, absolute en eenduidige waarheid boven kritiek kan verheffen.

Met rationeel beslissen als heuristisch perspectief verplicht ik mij er in de eerste plaats toe om deskundigheid te bezien vanuit de context van wetenschappelijke rationaliteit. Mitsdien is een - bescheiden - epistemologische verkenning gepast. Langs die weg kan ik immers toetsen of mijn veronderstellingen inzake onzekerheid en waardegebondenheid van technisch-wetenschappelijke expertise steekhoudend zijn. Mocht dit zo zijn, dan is tevens een opstap gegeven om te bezien of, en zo ja, hoe niettemin toch rationeel kan worden beslist.

2. Vergelijk voor deze definitie Kunneman, H., Habermas' theorie van het communicatieve handelen: een samenvatting, Meppel 1985, p. 19.

3. Niet in die zin dat elke beslissing hernieuwd (en uitgebreid) wetenschappelijk onderzoek vereist, maar in de zin dat niet onder enkele verwijzing naar religieuze overtuigingen, voodoo of astrologie feiten worden vastgesteld. 
In de tweede plaats wil ik nagaan of de idee van rationeel beslissen niet alleen als heuristisch begrip dienst kan doen, maar ook ten grondslag kan worden gelegd aan juridische waarborgen inzake bestuurlijk handelen. In het bijzonder aan waarborgen voor de inbreng van technisch-wetenschappelijke deskundigheid.

$\mathrm{Bij}$ dat laatste gaat het niet slechts om een abstracte verkenning van grondslagen. Concrete juridische waarborgen voor rationeel beslissen met het oog op voor de te nemen beslissing relevante deskundigheid, zullen in kaart moeten worden gebracht. In het verlengde daarvan komen ook de relaties tussen bestuur, burgers, rechter en deskundige uitdrukkelijk aan de orde. In dat perspectief zijn verschillende vragen van belang, zoals:

- Wie draagt de verantwoordelijkheid voor de inbreng van deskundigheid? Kunnen "technische beslissingen" worden gedelegeerd aan deskundigen? Hoe moet worden geoordeeld over de feiten bij onenigheid tussen deskundigen? Mag van een deskundigen-advies worden afgeweken? Is het wenselijk dat rechters de bestuurlijke feitenvaststelling (al dan niet met behulp van deskundigen-adviezen) integraal toetsen c.q. hervaststellen? Hoe ver strekt de informatie-of onderzoeksplicht, c.q. de bewijslast van betrokken bestuursorganen, burgers en rechters? Bestaat er een aanspraak van burgers op deskundige bijstand?

- Wanneer is het noodzakelijk dat bestuur, burger of rechter technischwetenschappelijke adviezen inwinnen? Hoeveel kennis is nodig; hoever moet door worden gezocht (er van uitgaande dat onzekerheid onvermijdelijk blijft)? In hoeverre kan en mag van bestuur en rechter worden verlangd dat zij (als niet-deskundigen) de deskundige c.q. het technischwetenschappelijk advies (zelfstandig) controleren?

- Welke procedurele waarborgen zijn nodig ten einde een goede inbreng en een goede beoordeling van technische-wetenschappelijke expertise te garanderen? Welke ruimte moet - bij voorbeeld - worden geboden aan mogelijkheden tot contra-expertise?

- Hoe moeten bestuur en rechter zich overigens (materieel) rekenschap geven van onzekerheden en waarde-oriëntaties verbonden aan ingebrachte technisch-wetenschappelijke expertise? Is het aanvaardbaar (of onder omstandigheden zelfs noodzakelijk) dat bepaalde "veiligheidsmarges" worden toegepast?

Vooreerst moet ik echter verduidelijken wat in deze studie zal worden verstaan onder deskundigheid of expertise. Ik bracht hierboven al een zekere precisering aan door enkele malen te spreken van "technisch-wetenschappelijke expertise". Daarmee heb ik reeds een onderscheid met juridische expertise 
willen maken. Op voet van de vergunningverlening in het milieurecht is het mij in het bijzonder te doen om technisch-wetenschappelijke deskundigheid omtrent de gevolgen voor het leefmilieu veroorzaakt door vergunningplichtige activiteiten. Daarbij gaat het mij om specialistische kennis, niet om kennis die als "common sense" (algemeen) bekend is. ${ }^{5}$ Enerzijds gaat het om specialistische kennis over het leefmilieu; als geheel maar ook naar onderdelen (mens, dier en plant) in heden en in de toekomst. Anderzijds gaat het om expertise over vergunningplichtige activiteit zelf; de technieken en de gebruikte stoffen.

Voor de goede orde zij opgemerkt dat 'expertise' in deze studie een beperktere betekenis heeft dan 'rationaliteit'. Inzet is het rationeel omgaan met de factor deskundigheid. Rationaliteit verwijst daarbij naar de kwaliteit van de besluitvorming als geheel, deskundigheid of expertise duidt op (mogelijk) relevante specialistische kennis.

Bij de probleemstelling ga ik uit van vergunningverlening in het milieurecht. Een erg scherpe afbakening is daarmee nog niet gegeven. Mij gaat het echter in het bijzonder om de vergunningverlening zoals die plaatsvindt ingevolge de vergunningplicht van art. 8.1 Wm. Op het moment dat dit onderzoek begon was de (ingrijpende) wijziging van de Wabm, leidend tot de Wm, nog in volle gang. Per 1 maart 1993 is de Wabm, met de in werkingtreding van de regels inzake "Vergunningen en algemene regels"6 en "Milieubeleidsplanning en milieukwaliteitseisen"7, overgegaan in de Wm. Toch is bij het onderzoek van aanvang aan uitgegaan van de (te verwachten) Wm-tekst. De vergunningplicht ex art. 8.1 Wm biedt een aantrekkelijk aanknopingspunt omdat dit een toonaangevende vergunning in het milieurecht betreft, die juist voor de com-

4. Als een exempel in deze studie; d.w.z. als basis voor actualisering van en reflectie over de inbreng van expertise.

5. Het wordt immers uit een oogpunt van kritiseerbaarheid (zie het rationaliteitsconcept) pas echt interessant bij de vraag of specialistische kennis moet worden vergaard. Dan rijst de vraag wie die kennis moet leveren, hoeveel specialistische kennis nodig is en hoe de kwaliteit er van is te controleren.

6. Als wetsvoorstel: Uitbreiding en wijziging van de Wet algemene bepalingen milieuhygiëne en daarmee samenhangende wijzigingen van andere wetten (vergunningen en algemene regels voor inrichtingen; procedures voor vergunningen en ontheffingen; handhaving). TK'88/89, 21 087, nrs 1-2. Waar een specifieke verwijzing naar de wetshistorie nodig is zal ik spreken over $W_{m}-v a r$. Thans betreft het de materie van Hoofdstuk $8 \mathrm{Wm}$.

7. Als wetsvoorstel: Uitbreiding en wijziging van de Wet algemene bepalingen milieuhygiëne en daarmee samenhangende wijzigingen van andere wetten (milieubeleidsplanning en milieukwaliteitseisen; provinciale milieuverordening; totstandkoming algemene maatregelen van bestuur), TK'88/89, 21 163, nrs 1-2. Waar een specifieke verwijzing naar de wetshistorie nodig is zal ik spreken van Wm-m\&m. Thans betreft het de materie van Hoofdstuk 4 en $5 \mathrm{Wm}$. 
plexe gevallen bedoeld is. ${ }^{8}$ In het vervolg van deze studie zal ik gemakshalve spreken van de "Wm-vergunning". 9

Terwijl ik met de keuze voor de Wm-vergunning als exempel thans kan verwijzen naar geldend recht, is dat niet altijd het geval voor andere verwijzingen. Ik denk daarbij met name aan het wetsvoorstel "Algemene regels van bestuursrecht": de Algemene wet bestuursrecht (hierna, Awb). ${ }^{10}$ Ook het voorstel voor afdeling $3.5^{11}$ heb ik in mijn studie meegenomen. Hetzelfde geldt voor het wetsvoorstel "voltooiing eerste fase herziening rechterlijke organisatie" (hierna, Whro ${ }^{12}$ ). Bedoelde voorstellen zijn goed ontvangen ${ }^{13}$ en zullen naar verwachting in januari 1994 worden ingevoerd. Ten slotte is op sommige plaatsen ook reeds verwezen naar het voorontwerp voor de derde tranche van de Awb. ${ }^{14}$

Rest mij nog op te merken dat waarborgen die bij de beantwoording van de probleemstelling naar voren komen zullen worden vergeleken met de thans geldende - positiefrechtelijke - waarborgen. Op basis daarvan zal ik, zo nodig, proberen aanbevelingen te doen voor verbetering.

8. De eenvoudige gevallen zullen moeten voldoen aan bij AMvB te stellen regels (zie hoofdstuk 2).

9. Ook wordt wel gesproken van de "Integrale milieuvergunning". Echt integraal is deze echter niet, omdat verschillende milieuwetten (zoals de Wvo en de Kew) een eigen vergunningstelsel behouden.

10. Stb'92, 315: de zogenoemde "eerste tranche" - ingediend onder TK'88/89, 21221 nrs. 1-2. Bij verwijzing naar de toelichting/parlementaire behandeling van die tranche afgekort als Awb1.

11. Voluit: Wijziging van de Algemene wet bestuursrecht en enkele andere wetten in verband met de regeling van de procedure voor de voorbereiding en totstandkoming van besluiten en aanpassing van de Wet algemene bepalingen milieuhygiëne en enkele andere wetten aan de eerste tranche van de Algemene wet bestuursrecht, TK'91-92, 22 601, nrs. 1-3. Bij verwijzing naar de toelichting of parlementaire behandeling: AwbA.

12. Voluit: Wijziging van de Wet op de Rechterlijke Organisatie, de Algemene wet bestuursrecht, de Wet op de Raad van State, de Beroepswet, de Ambtenarenwet 1929 en andere wetten, alsmede intrekking van de Wet administratieve rechtspraak overheidsbeschikkingen; TK'92-93, 22495 , nrs 1-3. Voorzover het hierbij gaat om voorstellen tot wijziging of aanvulling van de Awb, zal ik deze aanhalen onder Awb2.

13. Zie voor een algehele impressie ondermeer, Berge, J.B.J.M. ten, F.A.M. Stroink, A.Q.C. Tak, B.W.N. de Waard en R.J.G.M. Widdershoven, Nieuw bestuursprocesrecht, Deventer 1992. Zie ook de NTB-nieuwsbrief Awb, NTB'92/4, p. 1-3.

14. Met een afwijkende - voorlopige - nummering. Commissie wetgeving algemene regels van bestuursrecht, Voorontwerp Algemene wet bestuursrecht, Derde tranche, 's-Gravenhage 1991. Bij verwijzing naar de toelichting: Awb3. 


\subsection{Opzet van het onderzoek}

Op basis van de in de voorgaande paragraaf genoemde probleemstelling wil ik in deze studie de volgende onderzoeksvragen beantwoorden.

1. Hoe manifesteert de problematiek van expertise en normstelling zich in het milieurecht?

Deze onderzoeksvraag dient twee doelen. Allereerst wil ik aan de hand van het milieurecht de actualiteitswaarde en juridische relevantie van het kernprobleem van deze studie aanschouwelijk maken. In de tweede plaats kan ik - voorzover nodig - aangeven welke milieurechtelijke normen uit een oogpunt van inbreng van expertise in het bijzonder van belang zijn.

Bespreking van deze onderzoeksvraag komt aan de orde in het tweede en derde hoofdstuk; welke samen met het onderhavige hoofdstuk het eerste deel van deze studie vormen.

2. Wat behelst rationeel beslissen, bezien met het oog op voor het nemen van een beslissing relevante technisch-wetenschappelijke deskundigheid?

Deze onderzoeksvraag is er allereerst op gericht na te gaan in hoeverre wetenschappelijke rationaliteit als basis van technisch-wetenschappelijke deskundigheid slechts benaderingen van de werkelijkheid kan verschaffen en daarbij in belangrijke mate door waarde-oordelen wordt bepaald. ${ }^{15}$ Het gaat hierbij om de "waarheid achter de deskundigen".

Op voet hiervan wil ik vervolgens bezien op welke wijze rationele beslissingen (toch) mogelijk zijn. ${ }^{16}$ Daarbij gaat het in de eerste plaats om "methodologische" vereisten te stellen aan het werk van de deskundige zoals onafhankelijkheid en de mogelijkheid van kritiek. Ook de inbedding van technisch-wetenschappelijke advisering in de besluitvorming, de procedurele vereisten en de verdeling van verantwoordelijkheden, komen daarbij aan de orde. Ten slotte ga ik in op het "gezag" van de deskundige c.q. de technisch-wetenschappelijke adviezen; zoals het omgaan met onzekerheden en met tegenstrijdige adviezen.

Bespreking van deze onderzoeksvraag vindt plaats in het tweede deel van deze studie (hoofdstuk 4).

3. In hoeverre is het bestuurlijk handelen onderworpen aan een juridische eis van rationeel beslissen en welke juridische waarborgen zijn (in het ver-

15. Deze wijze van vraagstelling wordt uiteraard geïnspireerd door de in de voorgaande paragraaf eerstgenoemde premisse.

16. Onder het motto: als de deskundigen geen waarheid kunnen onthullen, welke betekenis komt dan nog aan hun inbreng toe?! 
lengde daarvan) van toepassing op de inbreng van deskundigheid bij het geven van beschikkingen door het bestuur?

Allereerst wil ik bezien of de idee van rationeel beslissen ook kan worden onderscheiden als juridisch begrip, c.q. als bestuursrechtelijk postulaat. Daarbij neem ik de hierboven gekozen definitie van rationeel handelen en de uiteenzettingen uit het tweede deel van deze studie als uitgangspunt.

In het verlengde daarvan wil ik ingaan op concrete waarborgen in het geldende recht ten aanzien van de inbreng van deskundigheid in de noncontentieuze fase van de bestuurlijke besluitvorming. Daarbij kies ik eerst een algemeen bestuursrechtelijk perspectief om vervolgens te bezien of er op het punt van inbreng van deskundigheid ook typisch milieurechtelijke waarborgen zijn.

De gevonden waarborgen wil ik vervolgens vergelijken met de eisen van rationeel beslissen uit het tweede deel van mijn studie.

Bespreking van deze onderzoeksvraag komt aan de orde in het derde deel van deze studie (hoofdstuk 5, 6 en 7).

4. Welke eisen moeten worden gesteld aan de rechterlijke beoordeling van geschillen over bestuursbeslissingen waarbij de inbreng van deskundigheid een grote rol speelt?

Ging het bij de voorgaande onderzoeksvraag om inbreng van deskundigheid bij het nemen van bestuursbeslissingen, bij deze vraag gaat het om de rechter en de inbreng van technisch-wetenschappelijke adviezen.

Daarbij gaat het steeds om de betwisting van de bestuurlijke feitenvaststelling als grondslag van een aan het oordeel van een administratieve rechter onderworpen bestuursbeslissing ${ }^{17}$. In het kader van de bewijsvoering kan de deskundige onderbouwing danwel betwisting van de feitenvaststelling een belangrijke rol spelen.

In dat verband is het relevant te bepalen welke functie de administratieve rechter bij de beoordeling van bestuursbesluiten dient te vervullen. Op voet daarvan wil ik vervolgens bezien welke waarborgen een rol spelen bij de inbreng van deskundigheid bij de bewijsvoering ten processe.

Bij deze onderzoeksvraag zal het beroep tegen een beslissing op aanvraag van een Wm-vergunning uitgangspunt zijn. ${ }^{18}$

Bespreking van deze onderzoeksvraag komt aan de orde in het vierde deel van deze studie (hoofdstuk 8 en 9).

17. Soms ook indirect, zoals bij een klacht over willekeur of onzorgvuldigheid door - beweerdelijk onvoldoende acht te slaan op (c.q. onderzoek te plegen naar) bepaalde feiten of belangen.

18. Waar mogelijk zal echter een algemeen bestuursrechtelijke insteek worden gekozen - zoals bij de functie van de rechter en het bestuursrechtelijk bewijsrecht. 
5. Welke conclusies kunnen voor de beantwoording van de probleemstelling worden getrokken uit de bespreking van voornoemde onderzoeksvragen en welke aanbevelingen kunnen op voet daarvan voor het geldend recht worden gedaan?

Deze conclusies worden, met een korte samenvatting van eerdere bevindingen, opgetekend in het vijfde deel van deze studie (hoofdstuk 10).

Natuurlijk had de probleemstelling ook op een andere manier kunnen worden uitgewerkt. De door mij gemaakte keuzes ten aanzien van inhoud en opbouw van dit onderzoek werden bepaald door enkele concrete premisses (zie 1.2) en enkele (daarmee samenhangende) oogmerken. Zo heb ik de problematiek van expertise en normstelling primair vanuit drie domeinen willen problematiseren:

- vanuit de epistemologie; op zoek naar "ijkpunten" voor rationeel beslissen, in het bijzonder in situaties waar het omgaan met c.q. de inbreng van deskundigheid centraal staat.

- vanuit het milieurecht; als exempel (dat wil zeggen als basis voor actualisering en reflectie) van de problematiek van expertise en normstelling.

- vanuit het algemene deel van het bestuursrecht; speurend naar een juridische grondslag voor rationeel beslissen met het oog op de factor expertise en naar terzake concreet toepasbare (algemene) waarborgen.

In het onderzoek is vooral geprobeerd een brug te slaan tussen het eerste (vanuit het recht bezien, "externe") domein en het laatstgenoemde (vanuit het recht bezien, "interne", bestuursrechtelijke) domein. Dat vereist een zekere eenheid van vertoog. Dientengevolge zijn andere invalshoeken of vergelijkingen - zoals bijvoorbeeld die van de internationale rechtsvergelijking - buiten het onderzoek gehouden. Met drie onderzoeksdomeinen is de onderzoeksboog mijns inziens reeds op maximale spanning gebracht. 


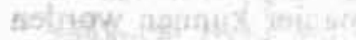

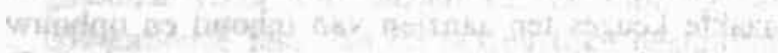

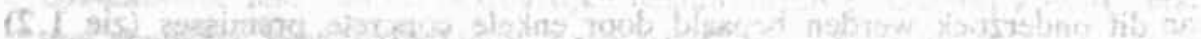

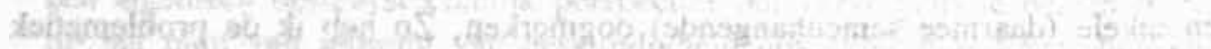

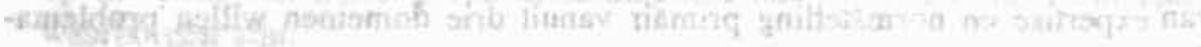

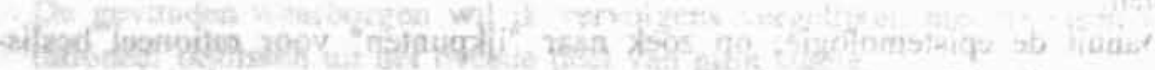

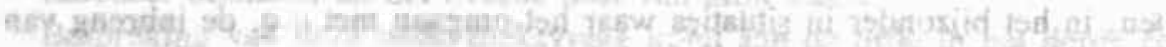

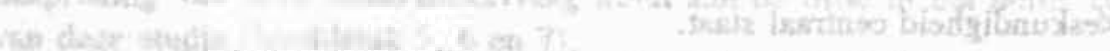

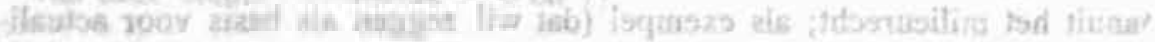

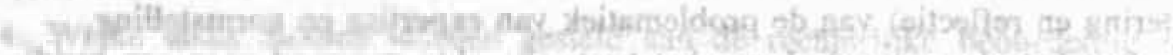

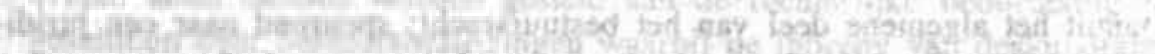

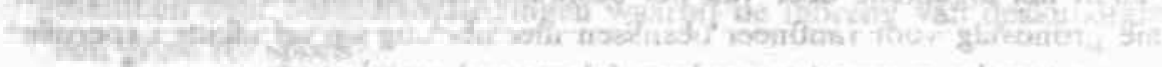

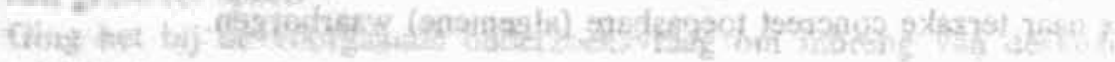

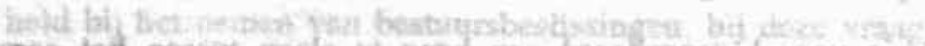

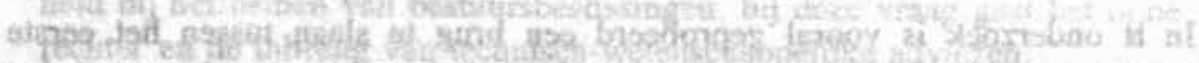

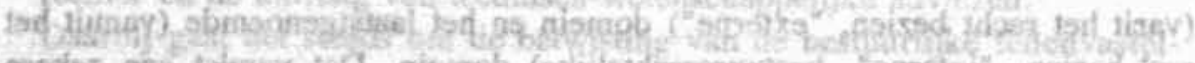

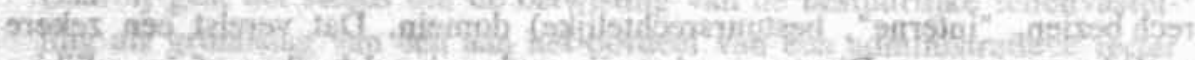

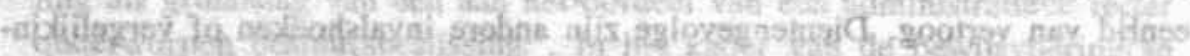

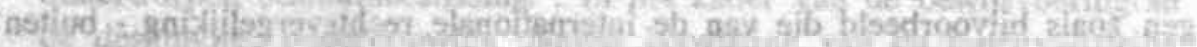

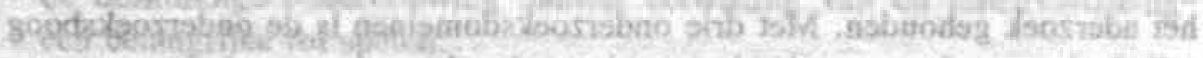

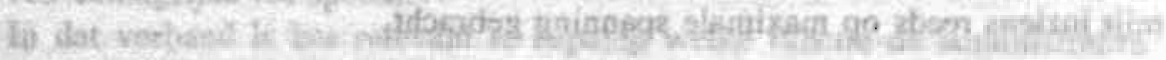

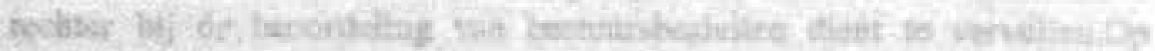

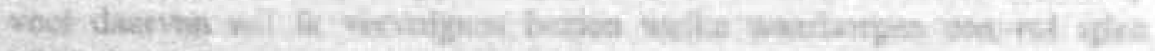

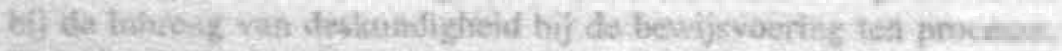

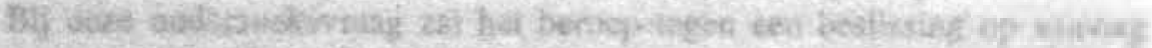

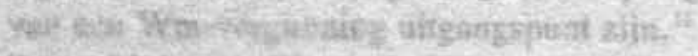

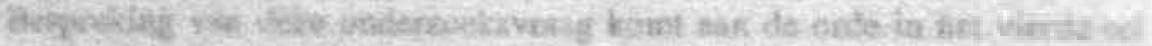

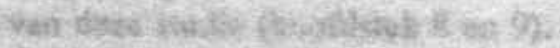

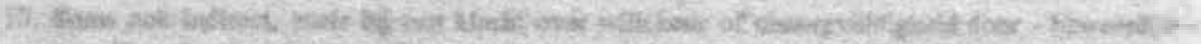

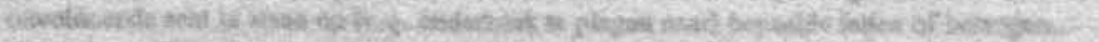

15. if

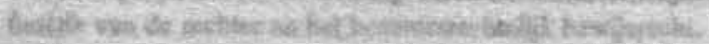




\section{Hoofdstuk 2}

\section{Normstelling in het milieurecht}

\subsection{Inleiding}

Art. $21 \mathrm{Gw}$ draagt aan de overheid de zorg op voor de bescherming en verbetering van het leefmilieu. In dat bestek geeft de overheid normen waarbij inbreng van technisch-wetenschappelijke expertise van groot belang kan zijn. Tot die normen behoren de bestuursbeslissingen tot verlening of weigering van $\mathrm{Wm}$-vergunningen. ${ }^{\prime}$ Bij vergunningverlening op grond van de $\mathrm{Wm}$ wordt niet alleen het bevoegd gezag maar ook de burger zeer concreet geconfronteerd met de invloed van technisch-wetenschappelijke inzichten op normstelling. Op voet daarvan hebben burgers een direct belang bij waarborgen voor een goede inbreng van deskundigheid in het besluitvormingsproces. Dientengevolge is goed voorstelbaar dat de rechter zich bij geschillen over Wm-vergunningen uitdrukkelijk moet bezinnen op de rol die de factor deskundigheid heeft gespeeld. Overigens zal de rechter wellicht ook zelf behoefte hebben aan deskundige-bijstand.

Bij dit alles moeten we uiteraard niet vergeten dat veel geschillen over Wmvergunningen betrekking hebben op beperkingen bij het verlenen van een vergunning (art. 8.11, tweede lid $\mathrm{Wm}$ ) en het aan een vergunning verbinden van voorschriften (art. 8.11, derde lid Wm). Zo kan de rol van technischwetenschappelijke expertise bij vergunningvoorschriften tot uitdrukking komen bij "middelvoorschriften"2 waarin (nauwkeurig) wordt voorgeschreven aan welke eisen de uitvoering van een activiteit moet voldoen. We moeten hier denken aan het voorgeschreven gebruik van bepaalde technieken, bepaalde materialen en specifieke veiligheidsvoorzieningen. Deze voorschriften kunnen een getalsmatig karakter dragen. De getalsmatige benadering is vooral manifest aanwezig bij de zogenoemde "doelvoorschriften". ${ }^{3}$ Het bestuur kan - bij voorbeeld - de maximaal uit een inrichting te emitteren hoeveelheid van een bepaalde afvalstof getalsmatig vastleggen. Het spreekt wel vanzelf dat ook bij de totstandkoming van dergelijke voorschriften technischwetenschappelijke expertise een rol zal spelen.

1. Voor de goede orde; het gat in deze studie primair om vergunningverlening. Het wijdsere begrip 'normen' wordt her en der gebruikt omdat het duidelijker refereert aan de totstandkoming van normen: de 'normstelling'.

2. Vergelijk art. 8.12, tweede lid Wm.

3. Vergelijk art. 8.12, eerste lid Wm. 
Zoals reeds in het eerste hoofdstuk werd gesteld is de rol van expertise bij de verlening van Wm-vergunningen de concrete focus in deze studie. De rol die expertise daarbij speelt kan echter pas goed begrepen worden als we vooreerst stilstaan bij het leefmilieu, waarop in art. $21 \mathrm{Gw}$ wordt gedoeld. Het leefmilieu vormt immers de "empirische context" voor de beslissing over aangevraagde $\mathrm{Wm}_{\mathrm{m}}$-vergunningen. In deze empirische context moeten de rechtsnormen die aan vergunningverlening ten grondslag worden gelegd, of die in concrete vergunningen worden neergelegd, tot gelding worden gebracht.

$\mathrm{Nu}$ zal duidelijk zijn dat het leefmilieu z'n eigen empirische kenmerken heeft, met "wetmatigheden" die inhoudelijk niet door een juridische reactie kunnen worden veranderd. Er van uitgaand dat vorm en inhoud van milieunormen op deze wetmatigheden moeten zijn afgestemd wil ik allereerst proberen enkele karakteristieken van het leefmilieu in kaart te brengen (zie 2.2). Vervolgens zal ik ingaan op de verschillende soorten milieunormen (zie 2.3). Ten slotte rond ik af met een korte conclusie (zie 2.4).

\subsection{Karakteristieken van de milieuproblematiek}

\subsubsection{Ontwikkeling van de milieuproblematiek}

De karakteristieken van de milieuproblematiek komen goed tot uitdrukking als we kennis nemen van de verschillende beleidsvisies die in de loop der jaren door of namens de overheid, als vertrekpunt voor de beteugeling van milieuproblemen, zijn uitgebracht. Daarin wordt ook duidelijk hoe lastig het is om de zorgplicht van art. $21 \mathrm{Gw}$ effectief gestalte te geven.

In het Nationaal Milieubeleidsplan 1990-1994 (kortweg NMP'90) constateert de regering dat na twintig jaar milieubeleid de resultaten "toch niet zodanig (zijn) als indertijd werd verwacht," "Sommige problemen zijn onderschat en er zijn ook nieuwe problemen bijgekomen". ${ }^{\text {s }}$ Veel beleid moet nog in concrete maatregelen worden omgezet, èn, zo constateert de regering: "Daarbij komt dat de huidige problemen veelal niet direct zichtbare, grootschalige en sluipende problemen zijn. Soms zijn de problemen een opstapeling van verontreinigingen uit vele bronnen". ${ }^{6}$

Dat laatste sluit naadloos aan bij de inzichten die ik vond in de Urgentie-nota milieuhygiëne van bijna twintig jaar (!) daarvoor. ${ }^{7}$ In deze nota merkt de regering op dat de grote veranderingen in het milieu vaak het gevolg zijn van

\footnotetext{
4. TK' $88 / 89,21$ 137, nrs. 1-2.

5. A.w. p. 48 .

6. Ibidem.

7. TK'71/72, $11906, \mathrm{nr} .2$.
} 
"meer geleidelijk verlopende, min of meer subtiele veranderingen in allerlei afzonderlijke elementen van het milieu,..." ${ }^{88}$ De effecten worden pas merkbaar als ze door cumulatie zijn versterkt. Volgens de regering kunnen alsdan de grenzen van het "natuurlijk herstelproces" worden overschreden, waardoor een voortschrijdende verslechtering van het milieu optreedt.

In dezelfde Urgentie-nota en de twee jaar daarna verschenen Normennota $1974^{\circ}$, staat een schets van de milieuproblematiek waarin het beginpunt maar liefst 6000 jaar terug wordt gekozen. Dat is het moment waarop de mens gaandeweg op een sedentaire leefwijze overschakelde. De verbetering van de levensomstandigheden, vooral in voedselvoorziening en veiligheid, wordt genoemd als een belangrijke oorzaak van een gestage groei in de populatie van de menselijke soort. Een groei die vanaf het begin van onze jaartelling een exponentieel karakter aanneemt, terwijl op dat moment ook een expansie van menselijke activiteiten wordt ingezet, die het begin van de uitputting van natuurlijke rijkdommen inluidt. Volgens de normennota begint de "opmars van de grote getallen"10 met de technisch-industriële- en de gezondheidsrevolutie van(af) de $17 \mathrm{e}$ en $18 \mathrm{e}$ eeuw. In de Urgentie-nota wordt in dat verband opgemerkt dat een eenmaal in gang gezette industriële ontwikkeling zich ontplooit als een zichzelf versterkend proces, waarin elke nieuwe ontdekking de springplank vormt voor meerdere daaropvolgende ontwikkelingen in verschillende richtingen." Menselijke activiteiten worden gedifferentieerder en complexer. Er ontstaan industriële centra en de verstedelijking zet zich in. Bijgevolg verliest het natuurlandschap terrein en vermindert het besef van natuurgebondenheid bij de mens. De $19 \mathrm{e}$ en $20 \mathrm{e}$ eeuw worden gekenmerkt door een onstuimige groei. In Nederland zet de economische groei zich na de Tweede Wereldoorlog "in verhevigde mate voort". ${ }^{12}$ Een sterke bevolkingsgroei en een verhoogde mobiliteit(sbehoefte) dragen bij aan exponentiële groei van produktie en consumptie. De gevolgen van deze ontwikkeling doen zich gaandeweg in het totale milieu gelden; niets blijft gespaard.

\subsubsection{Naar 'duurzame ontwikkeling'}

Hoewel deze schets uit het begin van de jaren zeventig aan duidelijkheid niet te wensen overlaat, is de overheid aan het einde van de jaren tachtig nog altijd bezig een zo helder mogelijk beeld van de processen achter de verslechtering van het milieu te verkrijgen.

8. A.w., p. 8.

9. TK'74/75, 13100 . hfst. XVIII. nr. 2.

10. A.w., p. 180.

11. A.w., p. 6.

12. Urgentie-nota, a.w., p. 7. 
In het rapport Zorgen voor Morgen, dat in 1988 verschijnt $^{13}$, bevat de onderbouwing voor de beleidsvoornemens van de rijksoverheid voor de jaren negentig; meer in het bijzonder voor het NMP'90. Het rapport geeft een integrale verkenning van de stand van het Nederlands milieu, mede met het oog op de te verwachten ontwikkelingen in het milieu op de lange termijn (1985-2010). Twee kenmerken in de ontwikkeling van de milieuproblematiek die daaruit naar voren komen, lijken mij voor een goed begrip van de - hedendaagse - milieuproblematiek essentieel.

In de eerste plaats is sinds de vorige eeuw, maar met name toch in de laatste decennia, sprake van een duidelijke schaalvergroting in de milieuproblematiek. In de vorige eeuw beperkten problemen zich veelal tot de lokale sfeer. Gaandeweg zijn daar echter de regionale schaal (met name de verslechtering van bodem-en landschapskwaliteit), de fluviale schaal (de verontreiniging van oppervlaktewater in stroomgebieden en randzeeën), de continentale schaal (de verontreiniging van de lucht over oceanen en continenten) en de mondiale schaal (de aantasting van de hogere delen van de atmosfeer) bijgekomen. ${ }^{14}$

In de tweede plaats wordt gewezen op het aspect van de tijdschalen of tijdfasen. Zo las ik bijvoorbeeld dat voor het $\mathrm{CO} 2$ probleem de aanlooptijd tussen de eerste "bovennormale" uitworp in het milieu en het moment van ongewenste effecten zo'n 150 jaar beslaat. De reguleringstijd vanaf de erkenning van dit probleem tot het uitvoeren van maatregelen omvat naar verluid tussen de 50 en de 100 jaar. De hersteltijd van de eerste maatregelen tot het moment dat aanvaardbare waarden zijn bereikt zal - volgens het rapport - nog 500 jaar vergen. ${ }^{15}$ Gelukkig gaat het niet bij alle problemen om dergelijke tijdspannes. ${ }^{16}$ De kwestie van de tijdschalen is verraderlijk; we onderkennen milieuproblemen vaak pas als de natuurlijke buffers reeds zijn overschreden, na een relatief lange tijd. Herstel van de oorspronkelijke situatie - voorzover nog mogelijk - zal dan vaak eveneens lange tijd vergen. ${ }^{17}$

In het NMP'90 borduurt de regering - als gezegd - voort op Zorgen voor Morgen. Zo wijst zij er op dat de toegenomen ernst van de milieuproblematiek vooral verband houdt met schaalvergroting en tijdschalen. ${ }^{18}$ Volgens de

13. Rijksinstituut voor Volksgezondheid en Milieuhygiẻne, 1988 RIVM Bilthoven, Alphen aan den Rijn, 1989.

14. A.w., p. 3-5, en overigens de uitwerking hiervan per hoofdstuk.

15. $\mathrm{Nu}$ is dit natuurlijk wel een mondiaal probleem en bestaan er thans geen effectief toepasbare saneringstechnieken. $\mathrm{Na}$ (ast) beperking van de verontreiniging zijn we dus primair afhankelijk van natuurlijk herstel.

16. Zie Zorgen voor Morgen, a.w., p. 7 .

17. A.w., p. 6-7.

18. A.w., p. 60. 
regering is hierdoor een grotere afstand ontstaan tussen veroorzakers en ondervinders of slachtoffers. Ook vergen merkbare verbeteringen in het milieu meer tijd. ${ }^{19}$

De regering wijst er op dat het draagvermogen van het milieu in de problemen dreigt te komen. Bijgevolg geraken natuurlijke ecosystemen maar ook menselijke activiteiten (zoals landbouw, wonen, recreëren, industrie en watervoorziening) in de knel. Als ik de regering hier goed begrijp acht zij het goed mogelijk dat deze "Verelendung" uiteindelijk - als een soort terugkoppelingsmechanisme - juist tot het herstel van het natuurlijk draagvermogen zou kunnen leiden. De regering meent echter dat de risico's voor de menselijke beschaving, alsmede voor het voortbestaan van natuurlijke soorten, in een dergelijk scenario te groot $\mathrm{zijn}$. $\mathrm{Zij}$ stelt daarom het uitgangspunt van een "duurzame ontwikkeling" voorop. Duurzame ontwikkeling is "een ontwikkeling die voorziet in de behoeften van de huidige generatie zonder daarmee voor toekomstige generaties de mogelijkheid in gevaar te brengen om ook in hun behoeften te voorzien". ${ }^{20}$ Daarvoor is echter wel een tijdige trendbreuk in de milieuproblematiek noodzakelijk. Aan afwenteling van de kosten van milieuverslechtering naar een ander land, een ander schaalniveau en een andere generatie moet een halt worden toegeroepen. ${ }^{21}$

In het NMP worden daartoe, tegen de achtergrond van een nadere analyse van de oorzaken van de milieuproblematiek, strategische doelstellingen en actie-punten - respectievelijk 59 en 220 in getal - ontwikkeld. Ik zie er vanaf hier de verschillende scenario's en oplossingen nader te bespreken. ${ }^{22}$

\subsubsection{Karakteristieken: ecologisch, technologisch-dynamisch}

De voorgaande schets van de ontwikkeling in het milieubeleid van de overheid, vormt een goede opstap tot de onderliggende karakteristieken van de milieuproblematiek. Inzicht in dergelijke karakteristieken acht ik noodzakelijk voor een goed begrip van de rol van expertise bij beslissingen over Wm-vergunningen.

19. Ibidem.

20. A.w., p. 42. Met dit uitgangspunt volgt de regering het identieke uitgangspunt van de World Commission on Environment and Development (de commissie Brundtland): "Our Common Future", 1987. Het is tevens een hoeksteen van het (latere) Verdrag van Rio van 1992.

21. "Het afwentelingsproces vindt zijn grond in de gedachte dat het milieu een vrij goed is, dat het milieubeheer niet in relatie hoeft te staan tot het eigen handelen en dat, zolang geen effecten optreden, gedragsaanpassingen niet nodig zijn.", NMP, a.w., p. 71.

22. Nog geen jaar na het verschijnen van het NMP'90 blijken "beleidsintensiveringen" nodig. Hiertoe verschijnt het "NMP-plus" (TK'89/90, 21 137, nr. 20-21). Deze nota gat uit van de zelfde grondgedachten en blijft derhalve buiten bespreking. 
Bröring c.s. noemen verschillende kenmerken van het milieubeleid ${ }^{23}$ : het ecologische, het nieuwe en vernieuwende, het technisch ingewikkelde karakter, alsmede de opvallende aanwezigheid van buitenwettelijke normen. Deze beleidskenmerken weerspiegelen mijns inziens twee karakteristieken van de empirische context van dat beleid. ${ }^{24}$

In de eerste plaats het ecologisch karakter van de milieuproblematiek. ${ }^{25}$ Het leefmilieu is een ecologisch systeem. Dat is het geheel van organismen die elkaar en de omgeving waarin zij leven op allerlei manieren beïnvloeden, c.q. in evenwicht houden. ${ }^{26}$

Ecologische processen zijn in de eerste plaats interactionistisch van aard; elke actie geeft een reactie. Voorts zijn zij multi-causalistisch; er is vrijwel altijd sprake van processen met meerdere oorzaken en meerdere gevolgen. Ten slotte speelt de totale context waarin een gebeurtenis zich voordoet een rol en niet alleen de kleine schaal van die individuele gebeurtenis zelf; het leefmilieu wordt gekenmerkt door een globaliserend perspectief. ${ }^{27}$ Volgens Callebaut - die voorgaande typeringen heeft geëxpliciteerd - staat het ecologisch karakter haaks op het westerse denken, dat uitgaat van het dualisme van natuur en cultuur. Dit denken is juist actionistisch (de mens handelt, de natuur "ontvangt"), uni-causaal (één oorzaak, één gevolg) en particulariserend (alleen het kleine deel van de wereld waarin het individu handelt is relevant). De westerse mens ervaart zichzelf als "onbewogen beweger". ${ }^{28}$ Een dergelijke analyse vond ik ook reeds in de Urgentie-nota ${ }^{29}$ : "steeds duidelijker dringt zich de gedachte op dat het de diep in ons huidige cultuurpatroon verankerde, anti-ecologische geaardheid van bepaalde vormen van menselijk handelen is die als een der grondoorzaken van de milieuproblematiek moet worden aangemerkt."

Het ecologisch karakter van de milieu-problematiek, doet ons inzien dat individuele rationaliteit tot collectieve irrationaliteit kan leiden. ${ }^{30}$ Een rationele

23. Bröring, Lambers, Scheltema, Bolt, Kroonberoepen Milieuhygiëne, Deventer 1985.

24. Ik heb niet de pretentie van uitputtendheid. Er zijn ongetwijfeld meerdere karakteristieken te onderscheiden, mede athankelijk van de probleemstelling waar men vanuit gaat.

25. Vergelijk het ecologische aspect als karakteristiek van het milieubeleid; Bröring c.s., a.w., p. 24 25.

26. Neuerburg, E.N., P.Verfaille, Schets van het Nederlands milieuhygiënerecht, Alphen aan den Rijn 1991, p. 23-24.

27. Zie Callebaut, W., Filosofische en maatschappelijke beschouwingen over ecologie, in: Goosens, M. en D. Vanderhallen (reds.), Ecologische vorming in het secundair onderwijs, K.U.Leuven 1982, p. 8-22.

28. Ibidem, i.h.b. p. 11.

29. A.w., p. 11.

30. Zie ook Callebaut, a.w., p. 14. 
analyse van milieuproblemen vereist inzicht in interacties tussen ecologische effecten mede met het oog op mogelijke schaaleffecten. ${ }^{3}$

Het ecologisch karakter van de milieuproblematiek is ook terug te vinden in het door de overheid in het milieubeleid gehuldigde uitgangspunt van een ecocentrische optiek. ${ }^{32}$ De mens is in die visie "slechts" een van de vele onderling gelijkwaardige soorten organismen. Elk organisme heeft zijn eigen milieu dat in meer of mindere mate wordt beïnvloed door organismen van andere milieus. ${ }^{33}$ Met deze benadering wordt gepoogd afstand te nemen van de voorheen geldende antropocentrische optiek, waarin de mens als de beslissende maat voor de kwaliteit van het leefmilieu centraal stond.

Als tweede karakteristiek van de milieuproblematiek onderscheid ik de technologische-dynamie. Ook dit sluit aan bij de analyse van Bröring c.s. Zij spreken immers over het nieuwe en vernieuwende en het technisch ingewikkelde karakter van het milieubeleid..$^{34}$ Gelet op de aard van de milieuproblematiek is wel zeker dat het milieubeleid gekenmerkt zal blijven door een permanente vernieuwing. ${ }^{35}$ De ontwikkeling van nieuwe kennis op (onder meer) ecologisch en toxicologisch gebied, alsmede in de sfeer van de industriële bedrijvigheid (produktieprocessen en produkten) zal steeds blijven bijdragen aan de vorming van nieuwe problemen.

Daarbij komt dat deze problemen er naar alle waarschijnlijkheid al evenmin eenvoudiger op zullen worden. De technische complexiteit van milieuproblemen is van een dergelijke aard dat sommige feiten niet of nauwelijks "objectief" of met "zekerheid" ${ }^{36}$ vaststelbaar zijn. ${ }^{37}$ Laat staan als het gaat om feiten in termen van "gevolgen van gevolgen van gevolgen.." van bepaalde handelingen.

Vernieuwing en technische ontwikkeling in de milieuproblematiek houden verband met het reeds in de Urgentie-nota genoemde verschijnsel van een zichzelf versterkend proces van ontdekkingen die weer nieuwe ontdekkingen uitlokken. ${ }^{38}$ Nieuwe procestechnieken, nieuwe stoffen, materialen en produkten; een permanent proces van innovatie. Een proces dat tevens effecten

31. Bröring c.s., a.w., p. 24-25, bespreken enkele soorten ecologische effecten, te weten cumulatieve, synergetische, bovensectorale en grensoverschrijdende effecten.

32. Bij mijn weten voor het eerst in de Urgentie-nota, a.w., p. 6.

33. Neuerburg/Verfaille, a.w., p. 24-25.

34. Bröring c.s., a.w., p. 26.

35. Ibidem.

36. Tussen aanhalingstekens; ook zonder lezing van Wittgensteins "Uber Gewissheit" is de relatieve strekking wel duidelijk.

37. Bröring c.s., a.w., p. 26.

38. Urgentie-nota, a.w., p. 6. 
zal hebben op de omvang van de bevolking en het welvaartsniveau, met alle daaraan verbonden (op zichzelf ook weer veranderende) gevolgen voor het leefmilieu.

Naast de voortdurende verandering in onze "exploitatie" van het leefmilieu zal ook ons inzicht in de ecologische processen aan een permanente verandering onderhevig zijn. Ons inzicht in de milieuproblematiek zal nimmer voltooid zijn; zelfs al zou zich in onze exploitatie van het leefmilieu geen verandering meer voordoen. Nieuwe inzichten zullen de aanpak van bestaande of dreigende milieuproblemen steeds blijven beïnvloeden. Tegelijkertijd betekent dit dat wij nimmer zekerheid zullen hebben over de oplossingen die ons vandaag voor ogen staan; morgen kunnen zij zijn achterhaald! Dit verklaart ook de constante stroom van buitenwettelijke normen als karakteristiek van het milieubeleid. ${ }^{39}$

\subsubsection{Verwetenschappelijking: milieu als 'complex belang'}

Het ecologische en technologisch-dynamische karakter van de milieuproblematiek ligt aan de basis van de behoefte aan technisch-wetenschappelijke expertise bij normstelling.

De normen voor de beoordeling van aanvragen voor een Wm-vergunning en normen zoals neergelegd in $\mathrm{Wm}$-vergunningen hebben slechts zin indien zij zijn gebaseerd op inzichten in (interdependente) ecologische processen en in de eigenschappen en risico's van stoffen, produkten en produktieprocessen, alsmede in de wijze waarop mensen daarmee omgaan. Daarbij spelen factoren van ruimtelijke schaal en tijdsfasering een grote rol. Het vergt tevens inzicht in de technologische en economische veranderingen die zich voltrek$\mathrm{ken}^{40}$ èn het besef dat onze inzichten in de milieuproblematiek steeds voorlopig zullen zijn.

De conclusie daaruit moet zijn dat indien de overheid door vergunningverlening ingevolge de $\mathrm{Wm}$ effectief inhoud wil geven aan de zorgplicht van art. $21 \mathrm{Gw}$, de inzet van technisch-wetenschappelijke expertise veelal onmisbaar zal blijken. Zo beschouwd kan men spreken van een verwetenschappelijking van de milieuproblematiek.

Deze verwetenschappelijking van de milieuproblematiek gaat gepaard met het besef dat beoordelingsfouten tot zeer ongewenste en soms zelfs tot volstrekt onomkeerbare negatieve - om niet te zeggen vernietigende - gevolgen kunnen

39. Vgl. Bröring c.s., a.w., p. 27-29.

40. Alsmede daaraan verbonden ontwikkelingen (bijvoorbeeld op demografisch terrein of op het gebied van de mobiliteit)). 
leiden. ${ }^{41}$ Het revolutionaire tempo en de grootschalige invloed van de hedendaagse technische innovatie hebben ons vatbaar gemaakt voor de risico's van grootschalige en irreversibele aantasting van het leefmilieu. Het onvoorstelbare - het einde van het leven zelf - is immers voorstelbaar geworden. ${ }^{42}$

Bij de beoordeling en afweging van de gevolgen voor het milieu van een voorgenomen activiteit zal mitsdien kritisch moeten gelet op de factor deskundigheid. Het milieubelang is een complex belang. Er is mitsdien veel aan gelegen dat we ons, (onder meer) bij vergunningverlening ingevolge de $\mathrm{Wm}$, rekenschap geven van de inbreng van technisch-wetenschappelijke expertise.

Het milieubelang is stellig niet het enig denkbare complexe belang waarbij de factor deskundigheid kritische aandacht behoeft. In het proces van "wetenschappelijke civilisatie" dat zich in vele samenlevingen voltrekt, zijn meerdere soorten belangen complex geworden. ${ }^{43} \mathrm{Ik}$ denk daarbij ondermeer aan (macro-)economische beslissingen of beslissingen inzake de volksgezondheid. De milieuproblematiek is echter bovenal een duidelijk exempel. Er zijn gegronde redenen om risico's van het ondeskundig wegen van het milieubelang goed in ogenschouw te nemen. Daarom staat de milieuproblematiek in deze studie (als exempel) centraal.

\subsection{Normstelling in het milieurecht: open en gesloten normen}

\subsubsection{Empirische context en juridische normen}

In deze paragraaf wil ik in het bijzonder stil staan bij het karakter van milieurechtelijke normen. Hoe wordt in milieurechtelijke normen verwezen naar de empirische context van het milieurecht? Deze verwijzingen vormen immers in de praktijk van regeltoepassing de punten waar de invloed van expertise zich kan doen gelden. Zo verwijst de term "milieuschade" in een (denkbeeldige) rechtsnorm naar een (te verwachten, c.q. te voorkomen) toestand

41. Dat is op zichzelf niets nieuws. Dergelijke consequenties kende en kent de mens ook op andere terreinen: beslissingen over het tijdstip van de oogst, beslissingen om een oorlog aan te gaan etc.

42. Zinsnede uit de kersttoespraak van H.M. Koningin Beatrix, kerst 1988.

43. Vergelijk Lohmar, U., Politik und Sachverstand, Zur freiheit parlamentarischer Entscheidung in der wissenschaftlichen Zivilisation, Aus Politik und Zeitgeschichte, bijlage bij Das Parlament. B42/87, p. 11-17. Met Lohmar ontleen ik de term wetenschappelijke civilisatie ("Wissenschaftlichen civilization") aan Schelsky. 
van het milieu. Bij toepassing van die norm in een concreet geval ${ }^{44} \mathrm{kan}$ onderzoek door experts naar die toestand geboden zijn. ${ }^{45}$

In deze paragraaf gaat het om het karakter van de normen met het oog op hun verwijzing naar de empirie. Daartoe schets ik eerst een abstract denkraam. Vervolgens werk ik dit concreet uit met een analyse van milieurechtelijke normen.

\subsubsection{Poreusheid, open omschrijvingen en gebreken}

Helaas is het de mens niet gegeven een complete, laat staan definitieve beschrijving van de empirische werkelijkheid te geven. Zo stelt Waismann ${ }^{46}$ dat empirische begrippen ${ }^{47}$ ter beschrijving van de empirische wereld onvermijdelijk "poreus" van karakter zijn. ${ }^{48}$

Wat we ook proberen, er is geen enkel empirisch begrip zo te preciseren dat een blijvend sluitende definitie ontstaat:"We tend to overlook the fact that there are always other directions in which the concept has not been defined. And if we did, we could easily imagine conditions which would necessitate new limitations". "Every description stretches, as it were, into a horizon of open possibilities: however far I go, I shall always carry this horizon with me". 49

Wij zijn, met andere woorden, slechts in staat tot het geven van "open omschrijvingen" van empirische begrippen. Aan een eenmaal gegeven omschrijving van een begrip kunnen immers altijd weer nieuwe kenmerken worden toegevoegd. ${ }^{50}$ Nieuwe kenmerken die leiden tot verdere begripsmatige differentiatie en daarmee mogelijk tot verdieping van onze kennis over een empirische context als geheel.

Derhalve zijn we er nooit zeker van of een bepaald object voldoet aan een door ons omschreven begrip, omdat de definitie daarvan nog incompleet is.

44. Als bevoegdheidsgrondslag of als basis voor aansprakelijkheids- of strafbaarstelling.

45. Hoe dit onderzoek er uit moet zien en wat er met de uitkomsten gebeurt hangt samen met de genoemde term en met de regels inzake toepassing van de rechtsnorm als geheel. Daarover gaat hfst. 3.

46. Waismann, F., Verifiability, in: Logie and language, Anthony Flew (ed.), Oxford 1968, p. 117 144. Waismann was een der "founding fathers" van de Wiener Kreis.

47. Door hem aangeduid als "empirical concepts".

48. Neem de omschrijving van het element goud. Deze lijkt (bijvoorbeeld in termen van spectraalanalyse) duidelijk. Maar wat als we een stof ontdekken die volkomen op goud lijkt (ook volgens spectraal-analyse), maar radio-actief blijkt (of beneden nul graden Celcius doorzichtig wordt)? Vgl. Waismann, a.w., p. 120.

49. Waismann, a.w., resp. p. 120 en p. 122. Als tegenstelling noemt Waismann de beschrijving van een partij schaak of de wiskunde.

50. Vaak voelen we ons wel tot precisering gedwongen, teneinde zaken uit elkaar te kunnen houden. 
De "lijst" met tests om uit te maken of een empirisch verschijnsel aan een bestaande omschrijving voldoet is dientengevolge eindeloos. Onze omschrijvingen van de empirische werkelijkheid zijn nooit compleet en nimmer definitief van karakter.

Definities zijn incompleet omdat, zelfs als we slechts uitgaan van de nu bestaande wereld, we toch aldoor nieuwe kenmerken aan onze omschrijvingen kunnen toevoegen. De ervaringswereld is onuitputtelijk. ${ }^{51 / 52}$ Het is ondoenlijk en ons ontbreekt eenvoudig ook de tijd om alle denkbare kenmerken (uit de bestaande ervaringswereld) te benoemen, laat staan om ieder verschijnsel steeds op al deze (bijkomende) kenmerken te onderzoeken.

Onze definities zijn voorlopig omdat we - bovendien - nooit klaar zijn met omschrijven aangezien zich altijd onvoorziene, nieuwe omstandigheden kunnen voordoen die ons dwingen tot preciseringen. Dit onvermogen is wat Waismann als de kern van het poreusheidsprobleem ziet. ${ }^{53}$ Terwijl incompleetheid de bekende ervaringswereld betreft, verwijst voorlopigheid naar de altijd aanwezige kans op onvoorziene gebeurtenissen. Dat kan een nieuwe ervaring zijn, waardoor we verschijnselen anders gaan zien, ${ }^{54}$ maar ook een ontdekking die onze interpretatie van verschijnselen (radicaal) verandert. ${ }^{55}$

Poreusheid is bij uitstek te verbinden met de karakteristieken van het leefmilieu als empirische context. Van de milieuproblematiek zullen wij, mede gelet op het ecologisch karakter, nooit een compleet, afgerond beeld krijgen. Zelfs als we de eigen evolutie van ecosystemen en onze (steeds weer) nieuwe ingrepen daarin negeren, zijn de verschijnselen (de organismen, processen, omgevingsfactoren en relaties daartussen) een absoluut onuitputtelijke bron van onderzoek.

Het technologisch-dynamische karakter van de milieuproblematiek sluit aan bij de "kern" van het poreusheidsprobleem. Het leefmilieu verandert, al dan

51. Waismann, a.w., p. 122. Hij wijst op de eindeloze kenmerken van de menselijke hand: vorm, omvang, kleur, weefsel, botopbouw, celstructuur ets. Daarbij komen nog de kenmerken van kenmerken: zoals bij botopbouw de vorm. chemische samenstelling, kleur, omvang etc. Waismann noemt ook nog het voorbeeld van de ontelbare posities die je kunt innemen om een tafel te bezien en te omschrijven, a.w., p. 124.

52. Iets anders is dat wij de wereld slechts kunnen uitleggen in de woorden die wij voor verschijnselen bedenken, zonder daarin ooit een "laatste woord" te bereiken; uiteindelijk beginnen definities naar elkaar te verwijzen.

53. A.w., p. 124.

54. Waismann, a.w., p. 124, vergelijkt dit met een blinde die voor het eerst ziende wordt.

55. Waismann, a.w., p. 124, vergelijkt dit met de ontdekking van elektriciteit (als natuurkundig verschijnsel). 
niet door toedoen van veranderende menselijke ingrepen. Niet is uit te sluiten dat er "morgen" weer nieuwe omstandigheden zullen zijn met nieuwe effecten of nieuwe interpretaties van (bestaande) effecten. De wetenschappelijke innovatie lijkt ontembaar en voortdurend liggen wij met onze tests achter op de (nieuwste) feiten. Veranderingen kunnen - conform het door Waismann gemaakte onderscheid ${ }^{56}$ - betrekking hebben op nieuwe kennis over het leefmilieu, nieuwe interpretaties van bestaande effecten en de achtergronden en bredere verbanden daarvan, maar ook (tegelijkertijd) op nieuwe technische vondsten die - eenmaal geëxploiteerd - geheel nieuwe effecten in het leefmilieu teweeg brengen.

Ook rechtsnormen zijn poreus. $\mathrm{Zij}$ bevatten immers verwijzingen naar feitelijke situaties waaraan een juridisch gevolg wordt verbonden. ${ }^{57}$ De "rechtstermen" waarmee naar de ervaringswereld wordt verwezen dragen de poreusheid, waarvan ik hierboven sprak, onvermijdelijk met zich mee. In dat verband denk ik - bij voorbeeld - aan de vraag of computergegevens net als elektriciteit zijn aan te merken als een goed in de zin van art. $310 \mathrm{Sr}^{58}$

Poreusheid van rechtstermen kan gebruikt worden om een zekere flexibiliteit in normstelling te bereiken. ${ }^{99}$ Ik denk - in de context van deze studie - met name aan rechtstermen die de voorwaarden of "toepasselijkheidscondities" voor bestuurlijke bevoegdheidsuitoefening vastleggen. ${ }^{60}$ Het gebruik van dergelijke rechtstermen (hierna "vage termen"61) duidt op een "beschrijvingsmoeilijkheid" voor de wetgever ${ }^{62}$; de wetgever wil de toepasselijkheidscondities bindend en concreet voorschrijven, maar moet erkennen dat dit gelet op de complexiteit en veranderlijkheid van de materie (de empirische context) te ingewikkeld is. Een goed voorbeeld vinden we bij art. 8.10, eerste lid Wm: De vergunning kan slechts in het belang van de bescherming van het milieu worden geweigerd. ${ }^{63}$

56. A.w., p. 124.

57. Een bevoegdheid, strafbaarstelling, aansprakelijkheid e.d.

58. Vgl. HR 23 mei 1921, NJ p. 564 (Het Electriciteits-arrest).

59. Zie ook Addink, G.H., De term inrichting, een vaag begrip in het kader van harmonisatie van milieuwetgeving, In: Steenbeek, J.G., M.C. Burkens en J.B.J.M. ten Berge (reds.), Bestuur en norm, Bundel opstellen opgedragen aan Prof, mr. R. Crince Le Roy, Deventer 1986, p. 17-32.

60. Wijk, H.D. van. Hoofdstukken van administratief recht, bewerkt door Willem Konijnenbelt, Culemborg 1988, p. 244 (hierna aangehaald als Van Wijk/Konijnenbelt 1988).

61. Van Wijk/Konijnenbelt, a.w., p. 243, spreekt over "vage normen" maar doelt dan op de gehele rechtsnorm.

62. Van Wijk/Konijnenbelt, a.w., p. 244.

63. Het criterium van art. $8.10 \mathrm{Wm}$ lijkt een meer normatieve strekking te hebben ("het belang van..") dan het criterium uit het oude art. $13 \mathrm{Hw}$ ("gevaar, schade of hinder buiten de inrichting"). M.i. is het echter meer een kwestie van grotere vaagheid. De interpretatie van vage termen dwingt overigens altijd tot bepaalde normatieve keuzes. 
Waismann wijst er op dat er een verschil bestaat tussen vaagheid en poreusheid. ${ }^{64}$ Een vaag begrip is volgens hem een verzamelbegrip, bedoeld om meerdere soortgelijke zaken in een term te vangen (zoals een "hoop", een "werk" of een "inrichting"). Bij andere begrippen is juist scherpte beoogt maar wordt dit oogmerk uiteindelijk steeds door poreusheid gefrustreerd. Waismann omschrijft poreusheid ook wel als "possibility of vagueness": een term kan scherp zijn bedoeld maar valt uiteindelijk toch door de mand - en blijkt dan eigenlijk een vage term die meerdere vergelijkbare begrippen omvat. ${ }^{65}$ Door met vage rechtstermen te werken wordt een poreusheid bewerkt die zoveel mogelijk die van de empirische context nabootst: door de vaagheid wordt de poreusheid ondervangen. ${ }^{66}$

Bij milieurechtelijke normstelling is de mogelijkheid om met vage termen poreusheid en daarmee soepelheid in normen te bereiken vooral interessant vanwege het reeds genoemde gevaar van grootschalige en irreversibele milieuschade. Met vage termen kan in twee richtingen openheid in de desbetreffende rechtsnormen worden bereikt:

In de eerste plaats kan geprobeerd worden om normen zo op te stellen dat nieuw onderkende gevaren van bestaande, genormeerde activiteiten onder de werking van die norm kunnen worden gebracht. In de tweede plaats is het zaak om nieuwe activiteiten, met het oog op (mogelijke) gevaren daarvan, onder de werking van een norm te kunnen brengen.

Op voet hiervan kunnen twee typen vage termen worden onderscheiden. Allereerst de vage term die een effect omschrijft en daarmee een aanduiding geeft van het te beschermen belang, zoals "gevaar, schade of hinder". Daarnaast de vage term die een activiteit omschrijft, zoals het begrip inrichting. ${ }^{6}$ Beide typen maken het (tot op zekere hoogte) mogelijk respectievelijk nieuwe effecten of nieuwe activiteiten onder het regime van een bestaande open norm te brengen. Vaak komen beide typen normen tegelijkertijd voor, zoals in art. 8.1 , eerste lid $\mathrm{Wm} .^{68}$

64. A.w., p. 120.

65. Als we althans uitgaan van de oorspronkelijke incomplete definitie.

66. De wens om vage termen niet te vaag te maken brengt mee dat er steeds een "horizon" in de omschrijving van een term ligt besloten. Daardoor kan poreusheid toch weer onbedoeld toeslaan.

67. Vgl. Addink, a.w., p.21, die onderscheidt tussen vage termen ter beschrijving van het object van bevoegdheid (personen, handelingen, zaken -i.c. de inrichtingen) en vage termen (of "vage normen") ter beschrijving van het doel of de optiek van de bevoegdheid.

68. Voorzover relevant: Het is verboden zonder daartoe verleende vergunning een inrichting: a. op te richten; ..... Uit art. 1.1 lid 3 jo lid $4 \mathrm{Wm}$ volgt dat wordt gedoeld op een inrichting die nadelige gevolgen voor het milieu kan veroorzaken. 


\subsubsection{Open publiekrechtelijke milieunormen}

Gelet op het gebruik van vage termen zijn in het hedendaagse publiekrechtelijke milieurecht verschillende "open rechtsnormen" aan te wijzen; normen met een uitdrukkelijk - beoogd - poreus karakter. Ik wil deze kort bespreken.

\subsubsection{Grondrechten}

Ik denk allereerst aan de rechtsnormen inhoudende grondrechten op een goed leefmilieu. Art. $21 \mathrm{Gw}$ is daarvan een voorbeeld, met "bescherming en verbetering van het leefmilieu" als bepalende vage term. De openheid van art. $21 \mathrm{Gw}$ brengt mee dat zowel voor bestaande als voor nieuwe activiteiten overheidsdaden kunnen worden verricht om de verbetering en bescherming van het leefmilieu te bereiken. ${ }^{\theta 9}$

Ook art. 12 ECOSOC, ${ }^{70}$ art. 8 EVRM,${ }^{71}$ art. 17 BUPO, ${ }^{72}$ alsmede art. 10 en $11 \mathrm{Gw}^{73}$ behelzen voor de kwaliteit van het leefmilieu relevante grond-of mensenrechten. In meerdere opzichten zijn deze voorschriften open geformuleerd. Allereerst beperken zij zich niet tot milieu-gevoelig handelen. In de tweede plaats is sprake van openheid omdat vage termen zoals "persoonlijke levenssfeer", "eerbiediging" en "onaantastbaarheid" nog in vele richtingen ongedefinieerd zijn gebleven. Met welke maten in een concreet geval zal worden gemeten is vooraf niet geheel en al te overzien en dientengevolge verplichten deze bepalingen tot aanhoudende waakzaamheid en zorgvuldigheid.

\subsubsection{Vergunningen}

Ook het vergunningstelsel van art. $8.1 \mathrm{Wm}$ heeft een open karakter. In de eerste plaats openheid naar object: de inrichting. Het inrichtingbegrip is de klassieke vage term van het milieurecht. Cup wijst erop dat in de loop der tijd, ondanks wetgeving en jurisprudentie, nog altijd sprake is van flink wat onduidelijkheden. ${ }^{74}$ Naast deze vaagheid omtrent de activiteit als het object

69. Zie voor het waarborg-karakter van art. $21 \mathrm{Gw}$ en andere "sociale grondrechten" Heringa, A.W., Sociale grondrechten, prft. 's Gravenhage 1989, m.n. Hfst. II, p. 73-114.

70. Erkenning van het recht op lichamelijke en geestelijke gezondheid.

71. Eerbiediging van het privé-leven.

72. Aantasting persoonlijke sfeer.

73. Resp. eerbiediging van de persoonlijke levenssfeer en onaantastbaarheid van het lichaam. Art. 11 is mede geïnspireerd op art. 2 van de Duitse grondwet. Vgl. hiervoor J.M.H.F. Teunissen, Een met voldoende waarborgen omgeven procedure...., Gemeentestem no 6887 en 6888 , m.n. p. 467.

74. Cup, P.C., Het begrip inrichting. Een rechtsonzeker begrip?, M\&R '86/6, p. 174-180. Cup legt vooral de nadruk op de nadelen van de onduidelijkheden en zoekt naar oplossingen daarvoor. Hij gaat niet in op de vraag of onduidelijkheid een aanvaardbare prijs is voor grotere flexibiliteit. Overigens is Cups verhandeling van vó́r de Wm. Vergelijk in verband met (art. 1.1, eerste lid van) de Wm, Addink, a.w., die vooral in gaat op de complicaties bij harmonisatie/integratie van milieuvergunningen. 
van normstelling, wees ik al op vage termen terzake van de effecten, c.q. het te beschermen belang, welke doorgaans zichtbaar worden als de criteria voor het verlenen of weigeren van een vergunning. Zo getuigt het criterium van art. 8.10, eerste lid Wm: "het belang van de bescherming van het milieu", van een grote vaagheid. De wetgever heeft hier het milieuhygiënisch nadeel - als weigeringscriterium - klaarblijkelijk ruim willen definiëren. ${ }^{75}$

Vergunningverlening is aantrekkelijk voor het leveren van "maatwerk". Enerzijds maken open weigeringscriteria het mogelijk om nieuwe of nieuw onderkende nadelen van reeds genormeerde activiteiten - door hantering van de open weigeringscriteria - mee te wegen. ${ }^{76}$ Voorts kunnen deze criteria op nieuwe milieubedreigende activiteiten worden toegepast. ${ }^{n}$ Maatwerk wordt ten slotte geleverd doordat de criteria op de specifieke (ruimtelijke) omstandigheden van het geval kunnen worden toegepast.

Uiteraard kan en moet bij verlening van een Wm-vergunning rekening worden gehouden met de wetenschap waarover wordt beschikt op het moment waarop een oordeel over een vergunningsaanvrage wordt gegeven. Na verlening ontstane inzichten of gebleken nadelen kunnen - althans wat de vergunning betreft - slechts nog worden meegewogen bij herziening of intrekking van de vergunning. ${ }^{78}$

\subsubsection{Zorgplichten}

De milieurechtelijke zorgplichtbepalingen die thans in art. $2 \mathrm{Wms}^{79}$ en art. $14 \mathrm{Wbb}^{80}$ zijn opgenomen, kennen een nog grotere openheid. ${ }^{81}$

75. Zulks met het oog op de integratic van de vergunningplichten voor inrichtingen o.g.v. $\mathrm{Hw}, \mathbf{W g h}$, Wlv, Asw en Wca, alsmede met het oog op het gestelde in art. 1.1, tweede lid Wm.

76. Voorzover deze nadelen onder de vage termen zijn te brengen.

77. Uiteraard moet de activiteit wel onder de limitatieve opsomming van categorieën van inrichtingen te brengen zijn (vgl. art. 1.1, derde en vierde lid Wm).

78. Zie art. $8.22 \mathrm{Wm}$.

79. "Ieder die beroepshalve een stof of een preparaat vervaardigt, aan een ander ter beschikking stelt, in Nederland invoert of toepast, en die weet of redelijkerwijs had kunnen vermoeden dat door zijn handelingen met die stof of dat preparaat gevaren kunnen optreden voor mens of milieu, is verplicht alle maatregelen te nemen die redelijkerwijs van hem kunnen worden gevergd, teneinde die gevaren zoveel mogelijk te beperken."

80. "leder die op of in de bodem handelingen verricht als bedoeld in de artikelen 8-13 en die weet of redelijkerwijs had kunnen vermoeden dat door die handelingen de bodem kan worden verontreinigd of aangetast, is verplicht alle maatregelen te nemen die redelijkerwijs van hem kunnen worden geworden gevergd, teneinde die verontreiniging of aantasting te voorkomen, dan wel indien die verontreiniging of aantasting zich voordoet, deze zoveel mogelijk te beperken en de gevolgen daarvan zoveel mogelijk te beperken of ongedaan te maken."

81. Vgl. voor een algemene beschrijving: Dresden. M.J. De Zorgplicht in de milieuwetgeving, M\&R'89/2, p. 50-67, en Verschuuren, J.M., Wettelijke algemene zorgplichten in het milieurecht, in: Backx, H.A.M. et al., Recht doen door wetgeving, Opstellen over wetgevingsvraagstukken aangeboden aan mr. E.M.H. Hirsch Ballin, Zwolle 1990, p. 419-430. 
Voor de zorgplichtbepalingen is een aanvullende rol weggelegd, waarbij een publiekrechtelijke, maatschappelijke zorgvuldigheidsnorm tot leven komt. ${ }^{82}$ Deze zorgvuldigheidsnorm kan in onvoorziene omstandigheden bestaande regels aanvullen. De zorgplicht van art. $14 \mathrm{Wbb}$ is hiervan een goed voorbeeld. Verbonden met de in artt. 8-13 Wbb genoemde handelingen kan deze bepaling aanvullen zowel indien ingevolge genoemde artikelen - bij AMvB nog geen nadere regels zijn gegeven, alsook als dit al wel is gebeurd. In het laatste geval zullen de regels immers toch nimmer alle denkbare verfijning bevatten; de poreusheid van die regels wordt dan door de zorgplicht afgedekt. ${ }^{83}$ Overigens zal veelvuldig inroepen van de zorgplicht een indicatie zijn om met nieuwe of gewijzigde algemene regels te komen. Voor de aanvullende werking van de zorgplicht is het uiteraard wel noodzaak na te gaan of de (overige) bestaande regels terzake niet uitputtend zijn bedoeld. ${ }^{84}$

De openheid van de genoemde bepalingen wordt met name bewerkstelligd door twee vage normen: het redelijk vermoeden van milieuverontreiniging en de redelijkerwijs te vergen maatregelen. Dresden ${ }^{85}$ wijst terecht op de uiterst belangrijke rol die kennis en deskundigheid spelen bij uitleg en toepassing van deze vage termen. Ik stel me voor dat de vage term "redelijkerwijs", in verband met de te vergen maatregelen, ook een belangenafweging impliceert: tot welke voorzieningen is iemand in het licht van betrokken risico's, gegeven de overige omstandigheden van het geval gehouden?

Vage termen zijn vooral relevant met het oog op de handhaving van de zorgplicht-bepalingen. Strafrechtelijke handhaving ${ }^{86}$ valt onder de werking van de Wed. In een proefproces inzake art. 14 Wbb voor de rechtbank Amsterdam $^{87}$ werd de vaagheid van deze bepaling op haar strafrechtelijke houdbaarheid getoetst. De Rechtbank stelde vast dat los van de vraag of is gehandeld in strijd met een in een AMvB bepaalde of te bepalen handeling, art.14 Wbb als vangnet-bepaling kan gelden. Het in casu bewezen geachte feit was volgens de Rechtbank ingevolge art. $14 \mathrm{Wbb}$ strafbaar en verdachte werd, bij gebreke van een strafuitsluitingsgrond, veroordeeld.

Bestuursrechtelijke handhaving van zorgplichtvoorschriften zou mogelijk zijn door toepassing van bestuursdwang of door oplegging van een dwangsom. Dresden ${ }^{88}$ wijst er op dat gelet op de aard van de zorgplicht, toepassing van

82. Dresden, a.w. p. 54 en p. 63 . Verschuuren, a.w., p. 420.

83. Dresden, a.w., p. 54-55.

84. Zo ook Dresden, a.w., p. 55. In zo'n geval neemt de wetgever het risico van poreusheid voor lief. Gelet op art. $21 \mathrm{Gw}$ en de dynamiek van de milieuproblematiek lijkt mij een kritische interpretatie aangewezen.

85. A.w., p. 59-61.

86. Respectievelijk in art. 65 en $66 \mathrm{Wms}$ en art. 1 onder 4 , onder b. Wed.

87. Rb. A'dam, 29 maart 1990, M\&R ' 90,58 , m.nt. A.M.Fransen.

88. A.w., p. 62. 
de dwangsom het meest in de rede ligt, al zullen hierop ongetwijfeld uitzonderingen bestaan. ${ }^{89}$ Addink $^{90}$ is van mening dat administratieve handhaving van de milieuzorgplicht niet goed mogelijk zal zijn, zulks vanwege de strikte eisen die de (voorzitter van) de Afdeling Rechtspraak stelt ten aanzien van het toepassen van bestuursdwang: duidelijke omschrijving van het illegale feit en duidelijkheid omtrent de reactie die van aangeschrevene wordt verwacht. Verschuuren meent dat deze eisen een administratieve reactie op normschending niet zullen uitsluiten, doch veeleer zullen meebrengen dat voor toepassing daarvan slechts bij grove onzorgvuldigheid (bij voorbeeld bij gevaar voor irreversibele schade) plaats zal zijn. ${ }^{91} \mathrm{Ik}$ heb meer in het algemeen aarzelingen bij de idee van bestuursrechtelijke handhaving van zorgplichtbepalingen. Gelet op het zeer open karakter van dergelijke bepalingen zou optreden terzake van schending van een zorgplicht mijns inziens slechts mogelijk moeten zijn op grondslag van een rechterlijke uitspraak dienaangaande.

Civielrechtelijk - ten slotte - is de (publiekrechtelijke) zorgplicht volgens Dresden $^{92}$ te beschouwen als een codificatie van de zorgvuldigheidsnorm van art. 6:162 BW. Onder verwijzing naar een zorgplicht zal een actie uit onrechtmatige daad kunnen worden gebaseerd op strijd met de wet.

De vage termen in de voorgestelde zorgplichtbepaling in het toekomstige hoofdstuk Afvalstoffen van de $\mathrm{Wm}^{93}$ werden door de Commissie voor de toetsing van wetgevingsprojecten (kortweg, CTW), mede met het oog op de strafbaarstelling, kritisch ontvangen ${ }^{94}$. Verschuuren is van mening dat de beoordelingslast voor normadressaten weliswaar groot lijkt maar dat dit bij nadere analyse toch meevalt. ${ }^{95}$ Daarbij wijst hij op de sterk toegenomen geïnformeerdheid van de burger over milieuproblemen (via media, politiek, rechtspraak en wetgeving) en op de goede mogelijkheden tot informatiever-

89. Bijvoorbeeld bij recidive of bij zeer ernstige onzorgvuldigheid, al dan niet in combinatie met de vrees dat de veroorzaker bereid noch in staat zal blijken gepaste maatregelen te nemen.

90. Addink, G.H., Milieurecht en privaatrecht. Publiek domein'89/5, p. 180-186, i.h.b. p. 181.

91. Vooral omdat slechts dan aan de door Addink bedoelde eisen kan worden voldaan. Zie Verschuuren, a.w., p. 425 .

92. A.w.

93. TK'88-'89, 21 246, nr.2, art. 1: Degene die zich van afvalstoffen ontdoet, deze inzamelt, bewaart, bewerkt, verwerkt, vernietigt of op of in de bodem brengt dan wel op andere wijze verwijdert, en die weet of redelijkerwijs had kunnen vermoeden dat door die handelingen het milieu in gevaar wordt of kan worden gebracht, is verplicht alle maatregelen te nemen die redelijkerwijs van hem kunnen worden gevergd, teneinde dat gevaar zoveel mogelijk te beperken.

94. Advies van 20 augustus 1990, CTW 90-6 en het CTW-jaarverslag '89-'90, TK'90-'91, 21800 VI, 24, p. 33-36. Vergelijk ook het kritisch commentaar van Addink, Publiek domein, a.w., m.n. p. 181-182.

95. Verschuuren, a.w., p. $423-424$. 
werving. Ook laten zorgplichten de mogelijkheid tot differentiatie, zodat niet van een ieder gelijke kennis wordt verwacht. Meerdere auteurs ${ }^{96}$ verwijzen terzake overigens naar de ervaringen met vergelijkbare regels in andere wetten, zoals art. $25 \mathrm{Wvw}^{97}$; vaagheid heeft daarbij - hoewel gekritiseerd in rechtspraak van de HR nimmer tot echte problemen geleid. ${ }^{98}$

Opmerking verdient dat vergelijkbare normen uit het in Duitsland in voorbereiding zijnde Umweltgesetzbuch uitdrukkelijk niet door straffen te handhaven bepalingen bevatten. Strafbaarstelling vereist naar de mening van de Duitse wetgever kennelijk nadere concretisering van normen. ${ }^{99}$

\subsubsection{Milieudelicten}

Ook in het strafrecht is de open milieunorm geen onbekende verschijning. Zo zijn de voorschriften van art. 173a en $173 \mathrm{~b}$ Sr zo geredigeerd ${ }^{100}$ dat thans nog onvoorziene activiteiten of effecten goed ingepast kunnen worden. Zowel de bedoelde gedragingen (met "een stof" en met effecten op tenminste één van de drie compartimenten van het milieu) als de effecten ("gevaar", "openbare gezondheid", "levensgevaar") maken deze artikelen immers geschikt voor een flexibel gebruik. ${ }^{101}$ Beide artikelen zijn nadrukkelijk op een antropocentrische leest geschoeid. ${ }^{102}$ Hendriks ${ }^{103}$ wijst er echter op dat termen als "openbare gezondheid" en "levensgevaar" wel uiterst vaag zijn, zeker als bedacht wordt dat blijkens de toelichting ook schade aan toekomstige genera-

96. Verschuuren, a.w., p. 424; Dresden, a.w., p. 64-65, Tonnaer, F.P.C.L., Het Nederlands milieurecht in ontwikkeling, Alphen aan den Rijn 1990, p. 233.

97. Luidende: Het is verboden zich op een weg zodanig te gedragen, dat de vrijheid van het verkeer zonder noodzaak wordt belemmerd of de veiligheid op de weg in gevaar wordt gebracht of redelijkerwijze is aan te nemen, dat de veiligheid op de weg in gevaar kan worden gebracht.

98. Dresden, a.w., p.64-65. Hij haalt hiervoor o.a. Remmelink aan die de bezwaren tegen art. 25 Wvw als "academisch" afdoet.

99. Zie hierover Van Buuren, P.J.J., Codificatie en vernieuwing van milieurecht in Duitsland en in Nederland, NJB' $92 / 12$, p. $377-383$, i.h.b. p. 382-383.

100. art. 173a Sr: Hij die opzettelijk en wederrechtelijk een stof op of in de bodem, in de lucht of in het oppervlaktewater brengt wordt gestraft: 1 . met ...[strafmaat]..indien de schuldige weet of ernstige reden heeft om te vermoeden dat daarvan gevaar voor de openbare gezondheid of levensgevaar voor de ander te duchten is: 2 . met... [strafmaat]...indien de schuldige weet of ernstige reden heeft om te vermoeden dat daarvan levensgevaar voor een ander te duchten is en het feit iemands dood ten gevolge heeft. Art. 173b is de culpose variant van 173a Sr.

101. Ik ga hier overigens voorbij aan andere voor het milieurecht relevante commune strafbepalingen, zoals: art. $142 \mathrm{Sr}$ (verstoring rust); art. 161quater en art. 161quinquies $\mathrm{Sr}$ (blootstelling aan ioniserende straling); art. 172 en art. $173 \mathrm{Sr}$ (vergiftiging drinkwater); art. $174 \mathrm{Sr}$ (verkoop schadelijke waren); art. 429 lid $4 \mathrm{Sr}$ (stof in oppervlaktewater); art. $431 \mathrm{Sr}$ (burengerucht).

102. Zie ook Fransen, A.M., in zijn noot bij RB A'dam 29 maart 1990, M\&R '90, 58.

103. L.E.M.Hendriks, Milieustrafrecht behoeft sanering, M\&R '88/9, p. 334-340. 
ties daarbij is inbegrepen. ${ }^{104}$ Dit punt is van belang met het oog op het lex certa-beginsel van art. $1 \mathrm{Sr}$; de burger moet met enige zekerheid op voorhand kunnen beoordelen wat de juridische gevolgen van zijn handelen zullen zijn. Centraal staat hier de eis dat de betekenis van de wettelijke terminologie "in de specifieke context (...) met voldoende helderheid en exactheid te bepalen valt". ${ }^{105}$ Succesvolle vervolging terzake van overtreding van deze artikelen blijkt overigens niet eenvoudig nu het strafrecht een betrekkelijk sluitend bewijs vergt van het bestaan van gevaar voor de openbare gezondheid of van levensgevaar. ${ }^{106}$ Evenals in de voornoemde zorgplichtbepalingen neemt het aspect van kennis of deskundigheid ("weet of ernstige redenen heeft om te vermoeden") in art. 173a en 173b Sr een belangrijke plaats in. Door dit aspect als bestanddeel op te nemen is een aanknopingspunt voor thans nog onbekende inzichten geconstrueerd.

\subsubsection{Open privaatrechtelijke milieunormen}

Het privaatrechtelijk milieurecht wordt bij uitstek gekenmerkt door open normen. Daarbij moeten we in het bijzonder denken aan overeenkomsten of convenanten ${ }^{107}$ en acties uit onrechtmatige daad. ${ }^{108}$

Het voert te ver om deze beide typen open normen hier afzonderlijk bespreken. Wel is het interessant om summierlijk aan te geven welke rol de factor deskundigheid speelt bij open normen in het privaatrecht. Daartoe biedt in het bijzonder de (ontwikkeling van) milieu-aansprakelijkheid uit onrechtmatige daad een goed kader. ${ }^{109}$

104. A.w., p. 335. Terecht stelt Hendriks dat zo beschouwd elke aantasting van het eco-systeem uiteindelijk de gezondheid kan aantasten en dus onder het regime van de genoemde artikelen kan worden gebracht. Kennelijk heeft de wetgever dit niet bedoeld, maar wat dan wel?

105. Aldus A.C. ' $t$ Hart in zijn noot onder HR 11 maart 1986, NJ 613.

106. Zie ook Groeneveld, E.R., Is de onafhankelijke deskundige in het strafproces uitgediend?, AA'89/11, p. 928-929.

107. Zie over het verschijnsel "milieuconvenanten" o.a. Rossum, E.R.C. van, en M.V.C.Aalders, Milieuconvenanten: zacht recht of nieuw recht?, M\&R'89/6, p. 242-249, alsmede, Aalders, M.V.C. en R.J.J. van Acht (reds.), Afspraken in het milieurecht, Zwolle 1992.

108. In het bijzonder wat betreft de overheid zouden we daar nog het gebruik van eigendomsrecht aan kunnen toevoegen: vergelijk in dat verband Maanen, G.E. van, Publiek domein; Het belang van de overheid bij bodemsanering, oratie R.U.Limburg, Deventer, 1990 en Van de vogelen des hemels en de stranden der zee, publiek domein en ander overheidseigendom, WPNR 6074, p. $970-977$.

109. Daarbij ga ik niet in op de bekende problematiek rondom de twee-wegenleer, zoals ook aan de orde in het windmill-arrest (HR 26 januari 1990. RvdW 36). Vgl. hierover (onder meer) Maanen, G.E. van, Publiek domein en twee-wegenleer, R\&K'90/3, p. 198-209; Tak, A.Q.C., Terugtocht van twee wegen, NTB'89/9-10, p.297-314. en Publiek domein, overheidscontract en rechterlijke wetshandhaving, NTB'90/9, p.265-270. Een interessant perspectief biedt ook Simon, Henk, Publiekrecht of privaatrecht, prft., Zwolle 1993, i.h.b. Hfst 6. 


\subsubsection{Onrechtmatigheid en wetenschap}

Mogen we uitgaan van de regel dat iemand slechts dan voor bepaalde schade verantwoordelijk kan worden gesteld als hij wist of kon weten dat zijn handelen of nalaten die schade tot gevolg kon hebben? ${ }^{110}$

Volgens Bier"11 is een aan onrechtmatigheid ten grondslag liggende "zorgplicht" afwezig indien het risico voor de veroorzaker "niet kenbaar was op het moment waarop het risico zich realiseerde". ${ }^{112}$ Braams komt tot een soortgelijke vaststelling vanuit het element toerekening. ${ }^{113}$

Aldus bezien is de stand van de wetenschap een belangrijke maatstaf voor aansprakelijkheid. Ongelukkigerwijs is de inhoud van deze maatstaf niet altijd even gemakkelijk te bepalen. ${ }^{114}$

In de eerste plaats is de grens tussen bekend en onbekend niet scherp. Er kan bij voorbeeld sprake zijn van meningsverschillen tussen deskundigen - iets dat zich vooral bij nieuwe activiteiten kan voordoen.

In de tweede plaats hebben we vaak te maken met een complex van risico's en niet met én overzichtelijk risico.

Ten slotte is er nog de complicatie van tijdschaal: soms gaat er lange tijd voorbij vooraleer een risico zich volledig ontwikkeld. ${ }^{115}$

Juridisch gezien lijkt het wijs uit te gaan van redelijkerwijs kenbare risico's: risico's waarover informatie redelijkerwijs beschikbaar is. ${ }^{116}$ Uiteraard is daarbij ook de onderzoeksplicht van de veroorzaker van belang. Bekendheid met een risico kan worden verondersteld indien de veroorzaker deze risico's zelfstandig had moeten onderzoeken. Dit geldt vooral bij activiteiten die notoir bijzondere risico's meebrengen en bij de doorvoering van nieuwe technische ontwikkelingen. ${ }^{117}$

110. Zie voor deze hoofdregel o.a. Braams, Een oude kennis, Over de rol van de "schuld" bij milieu-aansprakelijkheid, in: Koeman. N.S.J., W.J. Ouwerkerk en J.M. van Dunné (red.), Civielrechtelijke aansprakelijkheid voor milieuschade, Vereniging voor Milieurecht, 1987-4, Zwolle 1989, p.46-78, i.h.b. p. 52.

111. Bier, L., De zorgvuldige veroorzaker van milieuschade, in: Koeman, N.S.J., W.J. Ouwerkerk en J.M. van Dunné (red.), a.w., p. 79-96.

112. Bbidem, p. 84. Risico vat Bier op als "de kans dat een gevaar zich zal verwezenlijken en de mogelijke effecten bij deze verwezenlijking". Ernst van het risico komt overeen met "gevaarlijkheid" (a.w., p. 85).

113. Braams, W.Th., a.w., p. 52 e.v. Algemeen wordt aangenomen dat de elementen onrechtmatigheid en toerekening sterk verweven (kunnen) zijn; vgl., Braams a.w., p. 48-50.

114. Zie Bier, a.w., p. 87 e.v.

115. Zie ook 2.2.2.

116. Zie ook Bier, a.w., p. 87-88. Zij wijst er nog op dat het ergens ter wereld bekend zijn van bepaalde risico's wel wat anders is dan de beoordeling van een complex risico.

117. Bbidem, p. 89. 
Redelijkerwijs kenbaar impliceert niet dat het risico precies naar kans, aard en omvang kan worden bepaald. ${ }^{118}$ Voor aansprakelijkheidstelling is overigens ook de ernst van het risico van belang èn de voorzorgsmaatregelen welke hadden kunnen worden genomen.

In dat verband kan naast de stand der wetenschap ook de stand der techniek een rol gaan spelen. Om met Braams te spreken: naast kennen wordt het kunnen van belang. ${ }^{119}$ Daarbij zal de ernst van het risico moeten worden afgezet tegen "de moeite, de kosten, de praktische bezwaren en de te verwachten effectiviteit. ${ }^{120}$ Meer in het algemeen zal daarbij het maatschappelijk belang van de schadeveroorzakende activiteit tegen de geschade belangen van benadeelden moeten worden afgewogen; er moet een waardeoordeel worden geveld over de aanvaardbaarheid van risico's. ${ }^{121}$

\subsubsection{Van schuld naar risico}

Bezien vanuit zorgplicht en toerekening overheerst voor de milieu-aansprakelijkheid de gedachte van de 'fout-aansprakelijkheid'. Bekendheid met risico's lijkt een conditio sine qua non. Toch kunnen we met Braams spreken van een "pittige aansprakelijkheid" die in steeds sterkere mate is "ver-risicoiseerd". ${ }^{122}$ Zulks komt ook goed tot uitdrukking in het Natronloogarrest. ${ }^{123}$ In deze zaak plaatste een werkster van het dorpshuis te Kamerik een plastic zak met daarin een emmertje met een onbekende vloeistof aan de straatkant ten behoeve van de vuilnisdienst. Bij het ophalen en vervolgens samenpersen van het emmertje werd de inhoud in het oog van een vuilnisman gespoten, hetgeen tot blijvende schade leidde. De Hoge Raad overwoog dat het in strijd is met de zorgplicht om een emmertje met onbekende vloeistof voor afvoering door de vuilnisdienst neer te zetten, "tenzij men of wel weet of gegronde reden heeft om aan te nemen dat het om een vloeistof gaat die bij een aanraking met de mens geen gevaar oplevert, of wel de betreffende vuilniszak onder controle houdt en degeen die de zak aan wil pakken waarschuwt voor de aanwezigheid daarin van een emmertje met een mogelijk gevaarlijke vloeistof". Het feit dat men op het dorpshuis onbekend was met

118. Ibidem, p. 85. Bier verwijst hierbij na het - ook hierna nog te noemen - Natronloog-arrest (HR 8 januari 1982, NJ 614).

119. Braams (1989), a.w., p. 54 e.v. Zijn indruk uit de jurisprudentie is dat kennen en kunnen naadloos op elkaar volgen. Kennis lijkt neer te komen op "zoals het moet" (a.w., p. 57).

120. Bier, a.w., p. 84 .

121. Bbidem. Bier is overigens van mening dat indien niet eenduidig duidelijk is wat de beste aanpak tot voorkoming of beperking van nadelige gevolgen is, de veroorzaker een zekere beleidsvrijheid gegund moet worden (a.w., p. 92).

122. Braams (1989), a.w., resp. p. 58 en p. 63.

123. HR 8 januari 1982, NJ 614; ook wel bekend als het vuilnisman-arrest of het arrest dorpshuis Kamerik. 
de inhoud van het emmertje, c.q. de gevaarlijkheid daarvan, deed aan de ansprakelijkheid niet af. ${ }^{124}$

De benadering in het Natronloog-arrest pleit er mijns inziens voor om met Van Maanen, Spier en Sterk uit te gaan van een afzonderlijk aansprakelijkheidstype. ${ }^{125}$ In hun bespreking van de ontwikkeling in het aansprakelijkheidsrecht "van schuld naar risico", wijzen zij een analyse vanuit toerekening of onrechtmatigheid af. ${ }^{126} \mathrm{Zij}$ onderscheiden vervolgens een afzonderlijk type van aansprakelijkheid voor schade veroorzaakt door zaken: "een aansprakelijkheid die los staat van zowel het gedrag van de aansprakelijke persoon als van het (onrechtmatige) gedrag van een ander." 127 Onrechtmatigheid en schuld spelen bij dit type aansprakelijkheid geen rol. ${ }^{128}$ Het gaat om een 'kwalitatieve aansprakelijkheid', bij voorbeeld als bezitter van gevaarlijke stoffen. Deze bezitter draagt het risico voor de kwade kans dat de gevaarlijke stof schade aan anderen berokkend. Het is overigens niet gezegd dat bij dit type steeds van een zuivere risico-aansprakelijkheid moet worden gesproken. ${ }^{129}$ Soms lijkt dit, gelet op de scherpte van de desbetreffende gedragsnormen, wel het geval. Anderzijds kan het echter zijn dat de mogelijkheden van disculpatie zo ver reiken dat veeleer van schuld-aansprakelijkheid moet worden gesproken. ${ }^{130}$

De gedachte dat de aanwezigheid van ernstig gevaar reeds op zichzelf, na verwezenlijking van dit gevaar, basis voor aansprakelijkheid kan zijn (zelfs buiten eigen fouten, op louter "kwalitatieve" gronden $^{131}$ ), sluit ook goed aan bij het wetsvoorstel tot "Aanvulling van de boeken 3, 6 en 8 nieuw BW met regels betreffende de aansprakelijkheid voor gevaarlijke stoffen en ver-

124. Maanen, G.E. van, J. Spier en C.H.W.M. Sterk, Van schuld naar risico? Enkele opmerkingen over ontwikkelingen in het aansprakelijkheidsrecht, in: Raaijmakers, M.J.G.C., R van Rooij en J. Spier (reds.). Aansprakelijkheden, Opstellen rond het thema Ontwikkelingen in het aansprakelijkheidsrecht, bij gelegenheid van het 60 -jarig bestaan van het Nederlands Genootschap van Bedrijfsjuristen, Deventer 1990, p. 65-143, i.h.b. p. 125.

125. Zie vorige noot.

126. Ibidem, p. 68-69.

127. Ibidem, p. 74. Daarnaast zien zij nog 4 andere typen (zie p. $72-75$ en p. 140-143).

128. Ibidem, p. 140.

129. Ibidem, p. 68. Risico-aansprakelijkheid is een term die Van Maanen c.s. willen reserveren voor "aansprakelijkheid buiten eigen fout".

130. Ibidem, p. 75.

131. Braams spreekt in dit verband wel van "causaliteitsaansprakelijkheid"; zie Braams, W.Th, Ontwikkelingen in het Nederlands recht, preadvies, in: Braams, W.Th., A. van Oevelen en W.W.Sturms, Risico-aansprakelijkheid voor milieuschade, Vereniging voor Milieurecht'91-3, Zwolle 1992, p.1-58, i.h.b. p. 16-17 en p. 42. 
ontreiniging van lucht, water of bodem". ${ }^{132}$ Daarvan is vooral art. 6:175 BW dat ziet op de aansprakelijkheid voor gevaarlijke stoffen interessant. ${ }^{133}$

De vraag of, en zo ja, in hoeverre in art. 6:175 BW nu een (zuivere) risicoaansprakelijkheid wordt beoogd, laat ik hier verder rusten. ${ }^{134}$

De voorgestelde wetswijziging past in elk geval duidelijk in de tendens naar strengere aansprakelijkheidsstelling - in elk geval voor de beroeps- of bedrijfsmatige gebruikers van gevaarlijke stoffen. Naar mijn indruk is het toch de bedoeling met het voorstel de open norm van art. 6:162 BW voor gevaarlijke stoffen te objectiveren en bijgevolg de aansprakelijkheid te verscherpen. ${ }^{135}$ De bekendheidseis die zowel bij toerekening ("schuld") en onrechtmatigheid ("zorgplicht") van elementair belang is, is geobjectiveerd. Deze objectivering is het sterkst als de bekendheidseis is geformaliseerd doordat het een stof betreft die op de lijst van lid 6 van art. 6:175 BW is opgenomen. ${ }^{136}$ Daarbuiten moet nog worden bezien of en zo ja, in hoeverre de aangesprokene zich op onbekendheid zal kunnen beroepen.

In elk geval is in art. 6:175 BW sprake van een zelfstandige aansprakelijkheidsgrond. In dat opzicht lijkt het passend om met Van Maanen c.s. van een specifiek (kwalitatief) aansprakelijkheidstype te spreken. ${ }^{137}$

Uit een oogpunt van vergelijking met open publiekrechtelijke normen is het interessant na te gaan inhoeverre ook sprake is van een zekere objectivering of formalisering van het weten. Wat vergunningverlening betreft denk ik daarbij in het bijzonder aan de zorgvuldigheid bij feitenvaststelling en belangenafweging. Enerzijds ligt er de vraag of het criterium van de stand van wetenschap en techniek daarbij toepasbaar is. Anderzijds rijst de vraag of bij

132. Ingediend TK' $88-' 89,21202$ nrs. 1-2, nadien meermalen gewijzigd, Ik ga uit van de tekst zoals verschenen in EK' $92 / 93,21$ 202, nr 283.

133. Lid 1 daarvan luidt: Degene die in de uitoefening van zijn beroep of bedrijf een stof gebruikt of onder zich heeft, terwijl van deze stof bekend is dat zij zodanige eigenschappen heeft, dat zij een bijzonder gevaar van ernstige aard voor personen en zaken oplevert, is aansprakelijk wanneer dit gevaar zich verwezenlijkt. Onder degene die een bedrijf uitoefent, wordt mede begrepen elke rechtspersoon die de stof in de uitoefening van haar taak gebruikt of onder zich heeft. Als bijzonder gevaar van ernstige aard geldt in elk geval dat de stof ontplofbaar, oxyderend, ontvlambaar, licht ontvlambaar of zeer licht ontvlambaar, dan wel vergiftig of zeer vergiftig is volgens de criteria en methoden, vastgesteld krachtens art. 34 , derde lid, Wet Milieugevaarlijke stoffen, Stb. 1985, 639.

134. Zie hierover o.m. Van Maanen c.s., a.w., p. 114-115.

135. De openheid van art. 6:162 BW ligt natuurlijk vooral besloten in de zorgvuldigheidsnorm. Ook "inbreuk op een recht" en "doen en nalaten in strijd met een wettelijke plicht" zijn echter open aangezien de conerete inhoud van deze normen niet voor alle tijden vast ligt.

136. Dan is ook de zorgplicht een gegeven.

137. Nogmaals, zonder daarmee nu aanstonds te coneluderen dat het hier (steeds) om zuivere risicoaansprakelijkheid gaat; vgl. Van Maanen c.s., a.w., p. 75. 
"gevaarlijke activiteiten" bijzondere waarborgen voor kennisvergaring en extra voorzorgen voor bescherming van het milieubelang geboden zijn.

\subsubsection{Gesloten milieunormen: algemene regels}

De hiervoor genoemde open normen sluiten goed aan bij de poreusheid van de milieuproblematiek. Feit is echter dat in het publiekrechtelijk milieurecht juist de gesloten normen sterk in opkomst zijn. Ik denk daarbij in het bijzonder aan getalsnormen. De numerieke norm vertegenwoordigt immers op zichzelf een gesloten waarde. ${ }^{138}$ Deze norm is vooral bij het voorschrijven van maximale emissie-waarden aantrekkelijk.

Naast de voor een concreet geval verleende vergunning vinden we ook steeds vaker in voorschriften van algemene strekking numerieke en aldus gesloten normen. ${ }^{139}$ Op deze laatste categorie "algemene regels" wil ik hier nog wat nader ingaan.

In de nota milieuhygiënische normen $1976^{140}$ worden getalsnormen omschreven als een in kwantitatieve vorm uitgedrukte algemene regel met een bepaalde mate van bindendheid. ${ }^{141}$ In het IMP-Milieubeheer'85-'89 ${ }^{142}$ (kortweg IMP-M'85) en de aansluitende brief van de minister van VROM van 28 januari $1985^{143}$ wordt normstelling van algemene strekking verdeeld naar bronen effectgerichte normstelling. ${ }^{144}$

Bij effectgerichte normen moeten we denken aan "milieukwaliteitseisen", inhoudende grens-, richt- of streefwaarden. Het bevoegd gezag dient bij vergunningverlening steeds (dat wil zeggen behoudens overmacht) de relevante

138. Op zich zelf; uiteindelijk wordt de numerieke waarde weer aan een niet-getalsmatig omschreven empirisch begrip gekoppeld: daar ontstaat, onbedoeld, weer enige poreusheid. Zolang echter iedereen het over het empirische begrip eens is. is het voorschrift (numeriek) gesloten. Vgl. Waismann, a.w., p. 129: "Incompleteness (..) is the mark of empirical knowledge as opposed to a priori knowledge such as mathematics."

139. Ik spreek in het vervolg van gesloten normen ook al is duidelijk dat deze geslotenheid niet volkomen kan zijn (zie voorgaande noot). Ik stel - gemakshalve - het oogmerk van geslotenheid voorop.

140. TK'76/77, $14318, \mathrm{nr} .1-2$,

141. A.w., p. 6. De systematiek is in deze nota overigens niet erg helder. Vgl. Van Dooren, J.W.M. en L.A.Clarenburg. Normstelling in het milieubeleid, zoveel hoofden, zoveel zinnen, M\&R'79/7, p. 173-186. Voorts Janswoude, J.J.. Juridische aspecten van milieuhygiënische vergunningverlening door gedeputeerde staten, prft., Zwolle 1987. p. 85-93, m.n. p. 86 .

142. TK' $84 / 85,18602$, nrs. $1-2$.

143. TK' $84 / 85,18602, \mathrm{nr} .5$.

144. IMP-M'85, a.w.. p. 51. Effectgerichte normen betreffen de waarden voor de milieukwaliteit voor een bepaald gebied, terwijl de brongerichte normen waarden voor de bronnen van milieubelasting betreffen. 
grenswaarden in acht te nemen. Met een richtwaarde moet "slechts" rekening worden gehouden, omdat dit een kwaliteitseis betreft die pas op termijn moet worden gerealiseerd. Een streefwaarde is geen "eis" en dient er (slechts) toe het uiteindelijk beoogde kwaliteitsniveau - waarbij geen als nadelig te waarderen effecten van milieubelasting voor mens, dier en plant te verwachten zijn - zichtbaar te maken. ${ }^{145}$

In hoofdstuk $5 \mathrm{Wm}$ is voorzien in een integrale regeling van milieukwaliteitseisen. Op basis daarvan kunnen bij AMvB, ${ }^{146}$ milieukwaliteitseisen worden gesteld. Deze eisen zullen primair zijn gericht tot overheidsorganen. De AMvB in kwestie geeft zelf aan bij de uitoefening van welke bevoegdheden de in de AMvB vervatte eisen moeten worden betrokken. ${ }^{147}$ De desbetreffende AMvB geeft eveneens zelf uitsluitsel over de vraag of het bevoegd gezag de kwaliteitseisen in acht moet nemen of er "slechts" rekening mee moet houden. In het laatste geval kan van de eis in kwestie onder gewichtige omstandigheden - gemotiveerd - worden afgeweken. ${ }^{148}$

In art. $8.8 \mathrm{Wm}$ worden milieukwaliteitseisen in verband gebracht met de vergunningverlening. Zo wordt in het derde lid (onder b) van dit artikel geregeld dat van "milieukwaliteitseisen, voorzover de verplichting tot het in achtnemen daarvan bij of krachtens wettelijk voorschrift is vastgelegd" niet mag worden afgeweken. In het tweede lid van art. $8.8 \mathrm{Wm}$ is voorgeschreven dat "rekening moet worden gehouden" met "geldende (...) milieukwaliteitseisen, die krachtens wettelijk voorschrift zijn vastgesteld en niet zijn bedoeld in het derde lid onder b. ${ }^{149}$

De brongerichte normen, die in de brief van de minister omschreven worden als "regels met betrekking tot inrichtingen, toestellen, handelingen etc.", worden in het IMP-M'85 onderscheiden in emissie-eisen, procédé-eisen en produkt-eisen. $\mathrm{Ze}$ hebben rechtstreekse werking voor degenen die handelingen willen verrichten waarop die eisen toepasselijk zijn. ${ }^{150}$

145. Vgl. IMP-M'85, a.w., p. 108.

146. Art. 5.1. Wm. Daarnaast in voorkomende gevallen bij ministeriële regeling of provinciale verordening (resp. art. 5.4 en art. $5.5 \mathrm{Wm}$ ). Ik zal hierna slechts over AMvB's spreken.

147. Art. $5.2 \mathrm{Wm}$. Het kan naast vergunningverlening bijvoorbeeld ook gaan om de vaststelling van een bestemmingsplan. Drexhage, E.C., Twee nieuwe hoofdstukken voor de Wabm, Het voorontwerp voor een wet tot uitbreiding van de Wabm met regelen inzake milieubeleidsplanning en milieukwaliteitseisen (c.a.), M\&R '87/8, p. 258-265, m.n.p. 263 e.v., wijst erop dat het hier wel bevoegdheden moet betreffen waarbij milieubelangen mogen worden meegewogen.

148. Art. 5.1 lid $3 \mathrm{Wm}$. Zie ook Biezeveld, G.A., De Wabm gaat veranderen, M\&R'89/11, p. 442 452, m.n. p. 445 , alsmede Drexhage, a.w., p. 264 , alwaar hij voorts opmerkt dat dit onderscheid overeenkomt met het onderscheid "grenswaarde" - "richtwaarde".

149. Zie MvT-Wm-var, a.w., p. 72-73.

150. A.w., p. 109. 
De algemene brongerichte normen zijn vooral bekend geworden door de ingevolge art. $2 \mathrm{a} \mathrm{Hw}$, bij $\mathrm{AMvB}$ te stellen, "algemene regels" voor categorieën van inrichtingen. In het in 1983 verschenen DROM-rapport ${ }^{151}$ worden algemene regels voorgesteld als een belangrijke deregulerings-maatregel: "Het aantal vergunningverplichtingen moet zo snel mogelijk worden verminderd. Algemene regels die daarvoor in de plaats komen bieden meer zekerheid aan de desbetreffende bedrijfscategorieën en verminderen de procedurekosten in tijd en geld. Bovendien komt ruimte bij overheden vrij om de gevallen waarin een vergunning wel noodzakelijk is, efficiënter en sneller af te handelen. "152 In het IMP-M'85 staat dat aan een aantal condities voldaan moet zijn willen algemene bron-eisen de vergunningplicht kunnen vervangen. ${ }^{153}$ Zo moeten de voor regeling beoogde handelingen landelijk bezien "van groot milieuhygiënisch belang zijn en/of in voldoende aantal worden verricht" wil een dergelijke regeling doelmatig kunnen zijn. Voorts moeten categorieën van handelingen een voldoende mate van "homogeniteit" bezitten om algemeen geldende eisen mogelijk te maken. Ten slotte - en dit lijkt mij hier vooral belangrijk - moet het gaan om handelingen met een relatief geringe milieubelasting, of vormen van milieubelasting waarvoor min of meer algemeen geaccepteerde middelen ter voorkoming of beperking voorhanden zijn. $\mathrm{Na}$ de start met een project voor algemene regels ex art. $2 \mathrm{a} \mathrm{Hw}$, wordt in de $\mathrm{Wm}$ de lijn uit DROM voortgezet. ${ }^{154}$ Het voorstel kent drie typen van algemene regels voor bronnen. In de regeling van art. $8.40 \mathrm{Wm}$ blijft voor de desbetreffende inrichtingen de Wm-vergunningplicht achterwege. Art. 8.44 $\mathrm{Wm}$ voorziet in bij $\mathrm{AMvB}$ te geven algemene regels die slechts én aspect van de - overigens - vergunningplichtige inrichting betreffen. Ten slotte kunnen ex art. 8.45 Wm bij AMvB algemene regels als instructie-norm voor het tot vergunningverlening bevoegde gezag worden gegeven.

Teneinde het voorgestelde geheel van algemene regels van z'n starheid te ontdoen, is voorzien in een aantal ontsnappingsclausules. Zo kan het bevoegd gezag ingevolge art. 8.42, eerste lid $\mathrm{Wm}$ in een concreet geval nadere eisen stellen ten aanzien van een onder een algemene regel van art. 8.40 gebrachte inrichting. In art. 8.44, vierde en vijfde lid $\mathrm{Wm}$ is (met het oog op concrete gevallen) voorzien in een afwijkingsbevoegdheid en een bevoegdheid tot het stellen van nadere eisen ten aanzien van een algemene regel ingevolge art. 8.44 , eerste lid $\mathrm{Wm}$. In art. 8.45 , derde lid $\mathrm{Wm}$ is - ten slotte - voorzien in

151. Deregulering op het gebied van Ruimtelijke Ordening en Milieubeheer, TK'82/83, 17931 . nr. 4 .

152. DROM, a.w., p. 11, 12-13 (m.n. conclusie 1.).

153. A.w., p. 109; waarbij uitsluitend wordt gedoeld op emissie- en op procédé-eisen.

154. Met vooralsnog 26 AMvB's voor meer dan 200.000 inrichtingen in het verschiet, vgl. MvTWm-var, a.w., p. 38, en voorts, Brussaard W.. et al. (reds), Milieurecht, Zwolle 1991, p. 2526 en p. 115-116. 
de mogelijkheid om in een concreet geval een instructie-norm ingevolge art. 8.45 , eerste lid $\mathrm{Wm}$ op te vatten als minimumnorm en aanvullende eisen te stellen. Al deze afwijkingsbevoegdheden zijn overigens slechts toepasbaar indien de desbetreffende AMvB zulks uitdrukkelijk aangeeft.

Er zijn inmiddels voor en tegen de algemene regels voor bronnen, naast of in verband met de overwegingen uit het DROM-rapport, vele argumenten te berde gebracht. Van Dijk ${ }^{155}$ geeft hiervan een heldere en kritische analyse. Zo passeren rechtszekerheid en rechtsgelijkheid, kortere procedures, formalisering van een bestendige praktijk ${ }^{156}$ en het gewin aan tijd voor handhaving, aan de positieve kant van de balans de revue. ${ }^{157}$ Daartegenover stelt hij de centraliserende werking, het gebrek aan flexibiliteit, ${ }^{158}$ de weinig echt deregulerende werking, ${ }^{190}$ het verlies aan rechtsbescherming en het gevaar van het opkomen van informele procedures.

Een bijkomend voordeel van vergunningverlening lijkt mij dat, anders dan in het geval van algemene regels, zowel de aanvrager als overige belanghebbenden uitdrukkelijk worden betrokken bij de beoordeling en de (af)weging van het milieu-belang. Uitwisseling van inzichten en standpunten maakt het milieubelang in kwestie voor alle direct betrokkenen zichtbaar. Uit een oogpunt van "verinnerlijking" van de milieuzorg lijkt mij dat een pré.

Wat de afweging van voor- en nadelen betreft is de praktijk inmiddels op ons vooruit gesneld. Thans zijn (ex art. 2a Hw) reeds vele AMvB's tot stand gebracht. Veel van deze regels hebben inderdaad een numeriek karakter. De leesbaarheid ervan wordt overigens nogal gehinderd door de vele verwijzingen naar zogenoemde NEN-bladen, ${ }^{160}$ of naar technische normen van andere (technisch-deskundige) instellingen. ${ }^{161}$ Niettemin zullen regels van dit

155. Dijk, G.R.M. van, Wabm; wetsvoorstel VAR, Regelmaat '89, p. 114-117.

156. Gedoeld wordt op het tegenwoordige gebruik van handboeken bij vergunningverlening (vgl. het Handboek Milieuvergunningen).

157. Van Dijk zwijgt over de vraag of het milieubelang met de introductie van algemene regels (in de belangenafweging) aan "hardheid" wint.

158. Het is niet de bedoeling dat veel gebruik wordt gemaakt van de mogelijkheid tot afwijken of het geven van nadere regels.

159. Op p. 116 noemt hij de problemen van samenloop van algemene regels of van algemene regels met vergunningen, de overgangsproblemen (die zullen blijven vanwege de veranderende omvang en hoedanigheid van inrichtingen - die daardoor van het ene in het andere regime terecht kunnen komen), de complexe begrippen en definities (algemene regels zijn in ieder geval voor de "leek" niet of nauwelijks leesbaar) en de (incidentele) mogelijkheid tot het geven van nadere regels.

160. Technische normstellingen opgesteld door het Nederlands Normalisatie Instituut.

161. Vgl, voor deze praktijk van verwijzing naar technische normen: Overhoff, R.W., De Europese "Technologische gemeenschap", normalisatienormen en nationale wetgeving, Regelmat'88/1, p. 9-14. 
type ongetwijfeld een steeds belangrijker plaats in het milieurecht gaan innemen. Daarmee zal zich ook in het publiekrechtelijk milieurecht een steeds sterkere objectivering van de normstelling gaan voor doen. Net als in het privaatrechtelijk milieurecht gaat zulks gepaard met een zekere formalisering van "het weten"; algemene regels (voor bronnen en voor effecten) zullen immers gebaseerd moeten zijn op onderzoek overeenkomstig de eisen van de stand van wetenschap en techniek.

\subsection{Voortschrijdende normstelling: conclusie}

Het milieubelang is een complex belang. Dat was de conclusie aan het slot van $\$ 2.2$. Ons structurele gebrek aan inzicht in de comptexe empirische context van het leefmilieu, de dynamische ontwikkeling van de milieuproblematiek en het gevaar van zeer ingrijpende (grootschalige) en onomkeerbare schade, lagen daaraan ten grondslag.

Vanuit dat gezichtspunt is goed te begrijpen dat het milieurecht wordt gekenmerkt door een groot aantal open normen. Daarmee kunnen bij normstelling of handhaving van reeds bestaande normen, tot op zekere hoogte de nieuwste inzichten worden toegepast op de nieuwste milieuhedreigende activiteiten. Let wel, dit geldt slechts tot op zekere hoogte: geen enkele rechtsnorm zou zo vaag (en dus zo open) mogen zijn dat de voorgaande stelling gyeheel kan opgaan. Een volstrekt open norm zoals "Alles wat redelijkerwijs verboden is, is verboden!", neemt een loopje met de rechtszekerheid (en mondt vrijwel zeker uit in willekeurf).

In het voorafgaande is een aantal van die open normen geschetst: grond- en mensenrechten, regels inzake vergunningverlening, zorgplichtbepalingen, milieudelicten, overeenkomstenrecht en onrechtmatige daad. Het is een waar palet aan normen met vage bestandlelen; in beginsel geschikt om een effectieve bescherming van het milieu te waarborgen.

Tegelijkertijd bleek dat ook gesloten normen hun plaats hebhen binnen het milieurecht. In het bijzonder de "algemene regels", die thans sterk in opkomst zijn. Uit een oogpunt van rechtszekerheid en rechtsgelijklzeid zijn deze regels zeker nuttig. Ook kan ik mij voorstellen dat deze regels zinvol zijn als een vorm van "formalisering van expertise": waar bestendige inzichten bestaan in de aanpak van een categorie van potentieel milieubelastende activiteiten, is het praktisch dat deze inzichten in gesloten normen worden aangereikt. ${ }^{162}$ Overigens is hier een vergelijking met de regels vonr civielrechtelijke aansprakelijkheid voor schade, veroorzaakt door (activiteiten met) ge-

162. "Aanciken": mijn voorketr is dat do2e normen primair als instructicnomen worden gebnikt. 
vaarlijke stoffen, goed te maken. Ook daarbij zagen we immers een streven tot formalisering, te weten formalisering (of objectivering) van de bekendheidseis. ${ }^{163}$

Mijns inziens kan voor normstelling in het milieurecht worden gesproken van het paradigma van open en voortschrijdende normstelling. Openheid is een noodzakelijke voorwaarde voor effectieve bescherming van het milieubelang. In samenhang met de openheid van normen is de normstelling voortschrijdend van karakter. Nieuwe inzichten zullen steeds weer nopen tot herziening van geldende normen. Daarnaast zullen nieuwe activiteiten vragen om nieuwe normstelling. Het ecologisch en het technologisch-dynamische karakter van de milieuproblematiek plaatsen het milieurecht wat normstelling betreft in een betrekkelijk unieke positie.

De voorgaande stelling sluit naadloos aan bij de rol van het BW bij de bescherming van het leefmilieu. De onrechtmatige daad en de overeenkomst kunnen in concrete gevallen op voet van de meest recente inzichten en opvattingen worden "ingevuld".

Voor het publiekrechtelijk milieurecht ${ }^{164}$ kan allereerst worden gewezen op vergunningverlening (al dan niet in combinatie met de mer-plicht), als vorm van maatwerk. Daarin is sprake van openheid - de vage termen moeten worden toegepast - maar ook van voortschrijdende normstelling doordat bij elke nieuwe vergunning die wordt verleend (steeds) de meest recente inzichten en opvattingen kunnen worden meegenomen, waardoor de meeste recente vergunning een scherpere norm kan bevatten dan oudere gelijksoortige vergunningen.

Naar mijn mening is er in publiekrechtelijk opzicht (echter ook) meer principieel sprake van open en voortschrijdende normstelling. Ik denk daarbij in het bijzonder aan de milieuzorgplichten. Mij dunkt dat er sprake is van een ontwikkeling naar een algemene milieuzorgplicht. Naast art. $21 \mathrm{Gw}$, dat zich tot de overheid richt, zou zo'n - thans nog niet gecodificeerde - algemene milieuzorgplicht tot uitdrukking kunnen brengen dat een ieder zorg draagt voor de bescherming (en misschien ook de verbetering) van het leefmilieu. ${ }^{165}$ De idee van een algemene milieuzorgplicht vindt tevens zijn grond in de veronderstelling dat het "milieubewustzijn" inmiddels een peil heeft bereikt waarbij van burgers waakzaamheid bij milieugevoelige handelin-

163. Als de stof op de lijst van gevaarlijke stoffen staat, wordt bekendheid verondersteld.

164. Op het strafrechtelijk milieurecht ga ik hier niet meer in.

165. Dresden, a.w., pleit (in conclusie 6.9.) uitdrukkelijk voor codificatie. 
gen mag worden verwacht. ${ }^{160} \mathrm{Er}$ zou daarmee een goede aansluiting zijn met de ontwikkelingen in het privaatrechtelijk milieurecht; voor burgers onderling zou een algemene milieuzorgplicht kunnen dienen als een onderbouwing van aansprakelijkheidsstelling.

Hierboven bleek overigens reeds dat ik er geen voorstander van ben om zorgplichten bestuurlijk te handhaven, althans voorafgaand aan een rechterlijk oordeel over de beweerde schending.

Een algemene milieuzorgplicht versterkt de rol van het "ongeschreven milieurecht". Die rol is ook nu reeds nadrukkelijk te onderkennen. Bij invulling van vage termen in grond- en mensenrechten, weigeringscriteria voor vergunningverlening, criteria voor onrechtmatigheid en wat dies meer zij, wordt voortdurend een beroep gedaan op buitenwettelijke normen. Een in het milieurecht interessante categorie daarvan is die van de zogenoemde richtlijnen: ${ }^{16}$ circulaires, nota's, brochures en dergelijke, afkomstig van overheden, maar ook van (semi-)particuliere instellingen. Dergelijk richtlijnen blijken met name bij vergunningverlening van groot belang voor de uitleg van vage termen en het gebruik van beleidsvrijheid. ${ }^{168}$

Bij de ontwikkeling van dergelijke richtlijnen kan deskundigheid een belangrijke rol spelen. Het zelfde geldt uiteraard voor de toepassing van een open norm (bij voorbeeld bij vergunningverlening) op een concreet geval. In het volgende hoofdstuk wil ik ingaan op de vraag hoe deskundigheid als factor bij vergunningverlening in het spel komt en welke aspecten daarbij in het bijzonder de aandacht vragen. Daarbij zal de Wm-vergunning - als gezegd de rol van exempel blijven vervullen.

166. Zie ook Tonnaer, a.w., p. 14-16 en p. 231.

167. Vgl. hierover: Bröring, H.E., Juridisch onbestemde regels in het bestuursrecht: richtlijnen, NTB' $88 / 3$, p. $80-86$.

168. Vgl. de analyse van de TWK-praktijk in: Widdershoven, R.J.G.M., G.T.J.M. Jurgens, P.J.J. van Buuren en G.H. Addink. Bestuursrechtspraak in milieugeschillen, Zwolle 1991, en Brugge, T. ter, J. Veltman, H.E. Bröring, K.F. Schuiling en M. Scheltema, Kroongeschillen en het nieuwe bestuursprocesrecht. 


\section{Hoofdstuk 3 \\ Expertise en open normering}

\subsection{Inleiding}

In deze studie staat de kwaliteit van normstelling met het oog op de inbreng van expertise voorop. Zulks kwam ook tot uitdrukking in de probleemstelling, met name door de focus op "juridische waarborgen". In het eerste hoofdstuk werd in dat verband in het bijzonder een relatie gelegd met onzekerheid en waardegebondenheid van deskundigheid, c.q. het voorkomen van de schijn van objectieve zekerheid.

Met behulp van "rationeel beslissen" als heuristisch uitgangspunt, werd voorgesteld vervolgens voor een aantal aspecten van de expertise-problematiek te analyseren: de verantwoordelijkheid voor de inbreng van expertise, de noodzaak tot het inwinnen van expertise, procedurele waarborgen en de wijze waarop bestuur en rechter zich overigens rekenschap zouden moeten geven van onzekerheid en waardegebondenheid van deskundigheid. Een en ander ging vergezeld van de belofte te onderzoeken of "rationeel beslissen" ook als uitgangspunt van het bestuursrecht is te onderkennen.'

In het tweede hoofdstuk is getracht aanschouwelijk te maken hoezeer, gegeven de aard van de milieuproblematiek en de "milieuzorgplicht" van de overheid, expertise bij normstelling onmisbaar is. Door te verwijzen naar het ecologisch en het technologisch-dynamische karakter van milieuproblemen is geprobeerd aannemelijk te maken dat het hier een technisch zeer ingewikkelde materie betreft. Dit gegeven werd bepalend geacht voor het karakter van de belangrijkste milieunormen; openheid van normen en voortschrijdende normstelling waren daarbij sleutelbegrippen. ${ }^{2}$

In dit hoofdstuk wil ik regels inzake vergunningverlening analyseren op aanknopingspunten voor kennisvergaring c.q. de inbreng van deskundigheid. Mijn aspiratie gaat daarbij voorlopig niet verder dan te signaleren waar de noodzaak om expertise bij normstelling te betrekken naar voren komt. Daartoe zal ik in het bijzonder aandacht besteden aan de regels die de bevoegd-

1. Een epistemologische verkenning is niet alleen vanwege de veronderstelde onzekerheid en waardegebondenheid van deskundigheid, maar ook met het oog op een nadere definitie van "rationeel beslissen" gewenst. Zonder zo'n definitie valt er weinig te onderkennen.

2. Met deze beschrijving heb ik en passant een schets willen geven van het terrein dat in deze studie als exempel voor de beantwoording van de probleemstelling fungeert. 
heid tot vergunningverlening betreffen. Kwesties als de verantwoordelijkheid voor advisering, de gewenste mate van inzet van expertise, procedurele waarborgen en wat dies meer zij, komen pas in het derde deel van deze studie aan de orde, nadat het begrip rationeel beslissen nader is besproken (in deel II). In $83.2 \mathrm{zal} \mathrm{ik}$ in algemene zin ingaan op open normen en expertise bij vergunningverlening. $\S 3.3$ is vervolgens gewijd aan de Wm-vergunning. $\S 3.4$ vormt ten slotte de afsluiting van dit hoofdstuk en het eerste deel van deze studie.

\subsection{Openheid van normen inzake vergunningverlening}

\subsubsection{Open normen en vage termen}

Openheid van normen is de sleutel tot de expertise-problematiek, omdat openheid steeds weer noodzaakt tot kennisvergaring. Op voet van de bevindingen uit het voorgaande hoofdstuk is dit goed te begrijpen. Daarbij wees ik reeds op de centrale rol van vage termen die verwijzen naar de empirische context van de desbetreffende open norm. In elk concreet geval moet worden beoordeeld of het feitensubstraat in kwestie naar aard en hoedanigheid overeenkomt met de door de vage termen bedoelde toestand. Met hun vage termen weerspiegelen open normen de poreusheid van hun empirische context. Openheid is de sleutel om op maat van het individuele geval normen te kunnen stellen, c.q. te kunnen toepassen. Daarbij is het zaak flexibel te reageren op veranderingen in de empirische context ${ }^{3}$ en de nieuwste inzichten omtrent de verschijnselen en processen in die context.

Er zijn mijns inziens twee vormen van openheid van normen. In het voorgaande hoofdstuk benadrukte ik de vorm waarbij de openheid de beoordeling van de toepasselijkheid van de norm in kwestie betrof. Bij vergunningverlening schetsen de desbetreffende vage termen (inzake effecten of gevolgen van een vergunningplichtige activiteit - hierna zal het slechts nog om de effecten gaan) de condities waaronder de desbetreffende bevoegdheid mag worden toegepast. Om het (inmiddels tot het verleden behorende) voorbeeld van art. 13 $\mathrm{Hw}$ te gebruiken: als er sprake is van gevaar, schade of hinder (...) dan kan de vergunning worden geweigerd. Zolang de effecten van een (voorgenomen) activiteit niet als gevaar, schade of hinder zijn te kwalificeren mag de vergunning niet worden geweigerd.

Er kan echter ook sprake zijn van de openheid van een norm naar de keuzevrijheid van de normsteller - zodra zijn bevoegdheid tot normstelling vast-

3. Zoals de introductie van nieuwe produktie-technieken of nieuwe stoffen. 
staat. Om wat meer bij de tijd te blijven neem ik hier art. 8.10, eerste lid $\mathrm{Wm}$ als voorbeeld: indien sprake is van aantasting van het belang van de bescherming van het milieu, dan mag de vergunning worden geweigerd, het hoeft echter niet. De bevoegdheid tot weigeren is daar, maar de normsteller kan besluiten niettemin een vergunning te verlenen - dat is een zaak van beleid, c.q. belangenafweging. Bij deze belangenafweging zijn de vage termen in zoverre van belang dat zij een (zo concret mogelijke) omschrijving bieden van het belang dat de normsteller met de desbetreffende bevoegdheid kan beschermen.

\subsubsection{Beoordelingsruimte, beoordelings-en beleidsvrijheid}

Bestuurlijke discretie in beoordeling en beleid vormt de opmaat tot de inbreng van expertise. Tegelijkertijd zijn beide begrippen zoals hierboven reeds summierlijk naar voren kwam zeer verschillend. Vertrekkend vanuit de verschillen tussen beide begrippen wil ik nu nader ingaan op hun betekenis voor het omgaan met expertise.

Bij de beoordeling van de toepasselijkheid van een norm vervullen vage termen de rol van "toepassingscondities". ${ }^{4}$ Het gaat om de voorwaarden voor uitoefening van een bevoegdheid. Volgens Duk ${ }^{5}$ wijzen vage termen op "beoordelingsruimte". De wetgever gebruikt een vage term omdat hij geen scherpe en eenduidige termen kan bedenken die een voor alle gevallen passende norm in het leven roepen. Dat betekent niet dat de wetgever geen objectieve norm heeft willen geven. Het betekent slechts dat de vage termen van geval tot geval dienen te worden geïnterpreteerd. ${ }^{6}$ Omdat het echter objectieve normen betreft komt interpretatie van de vage termen neer op het nemen van een rechtsbeslissing. Over de juistheid van een genomen rechtsbeslissing heeft uiteindelijk de rechter het laatste woord. De "ruimte" van het bestuur bestaat erin dat het als eerste tot het nemen van de rechtsbeslissing - tot interpretatie - bevoegd is. Of deze beslissing juist is, is aan de rechter om - desgevraagd - te beslissen.

Dat laatste ligt volgens Duk anders als het om beoordelingsvrijheid gaat. Bij beoordelingsvrijheid is de beoordeling van toepassingscondities rechtens, met uitsluiting van ieder ander, aan het desbetreffende bestuursorgaan gelaten. ${ }^{7 / 8}$

4. Van Wijk/Konijnenbelt, a.w., p. 244.

5. Duk, W., Beoordelingsvrijheid en beleidsvrijheid, RMTh'88, p. 156-169, i.h.b. p. 161.

6. $\mathrm{Er}$ is natuurlijk ook wel zoiets als een algemene interpretatie van een bepaalde term. Voor toepassing op het individuele geval is het echter vaak nodig deze interpretatic aan te scherpen zodat het mogelijk wordt de specifieke omstandigheden van het geval te kunnen kwalificeren in termen van de vage termen (zie ook hierna).

7. Duk, a.w... p. 157. 
De rechter zou hier slechts moeten nagaan of het bestuur in redelijkheid tot de genomen rechtsbeslissing kon komen. ${ }^{9}$

Bij de beleidsvrijheid van het bestuur draait het om de keuze van het bestuur of en zo ja, welke rechtsgevolgen het te weeg wil brengen. Uitgangspunt is dat aan de toepassingscondities is voldaan: het bestuur kan een vergunning weigeren, maar hoeft dat niet te doen en als het bestuur tot verlening besluit kan het daarbij kiezen uit verschillende varianten (in termen van voorwaarden en voorschriften). De aanwezige beleidsruimte tot het nemen van een politiek geïnspireerde beslissing is daarbij uiteraard begrensd, bij voorbeeld door het specialiteitsbeginsel: een besluit mag niet (louter) strekken ter behartiging van andere belangen dan met het oog waarop de bevoegdheid in kwestie is gegeven. ${ }^{10}$ Binnen de rechtens gelaten beleidsruimte kan het bestuur op autonome (politieke) gronden of normen beslissen over de mogelijkerwijs in het leven te roepen rechtsgevolgen. In zijn artikel over de "zachte kern van het bestuursrecht" stelt Duk het aldus:" "Beleidsvrijheid is er alleen, voorzover de te nemen beslissing afhangt - niet van normen die aan "geschreven" of "ongeschreven" recht zijn te ontlenen, maar - van normen waarvan inhoud en draagwijdte vrijelijk kunnen worden bepaald door de bestuurder aan wie de bevoegdheid tot beslissen toekomt. Rechtens kunnen hier dus uiteenlopende beslissingen als "juist" gelden." In overeenkomstige zin stelt Brenninkmeij$e^{12}$ dat het bestuur de bevoegdheid heeft om daar waar de rechtsbetrekking tot de burger niet volledig bepaald is, de "open plekken" in te vullen. "De taak van de rechter is het doen van een uitspraak omtrent de inhoud van de rechtsbetrekking en dat kan plaatsvinden met inachtneming van de beleids-

8. Vergelijk art. 3:10 Awb, toepassing van de uitgebreide voorbereidingsprocedure is (ook) mogelijk "...indien het bestuursorgaan dat doelmatig oordeelt." Overigens wil de regering deze tekst volgens art. IC AwbA weer aanpassen.

9. Nicolaï, P., Beginselen van behoorlijk bestuur, prft, Deventer 1990 , p. 356 , wijst er op dat de rechter -blijkens marginale toetsing - soms een beoordelingsvrijheid aanneemt waar op het oog beoordelingsruimte in het geding is - zonder dat steeds duidelijk wordt hoe de rechter tot zijn opvatting komt. Volgens Van Wijk/Konijnenbelt, a.w., p. 244, bepaalt de rechter ook bij beoordelingsruimte "niet zelfstandig, vanuit het niets hoe de vage term moet worden uitgelegd, maar doet dat door te controleren of hij de door het bestuur gekozen uitleg verantwoord acht...". Daarmee zit de rechter al snel op een "marginaal spoor".

10. Dat het woordje 'louter' tussen haakjes staat, houdt verband met de vraag hoe precies of rekkelijk men het specialiteitsbeginsel wenst to hanteren. Vgl. Heldeweg, M.A. en E.A.Messer, Bestuurscompensatie en het specialiteitsbeginsel, RMTh' 90 , p. 147-166.

11. Duk, W., De zachte kern van het bestuursrecht, RMTh'78, p. 575.

12. Brenninkmeijer, A.F.M., in: Jurgens, G.T.J.M., T. ter Brugge en J.Veltman (red.), Bestuursrechtspraak ingevolge de Tijdelijke wet Kroongeschillen, verslag van het TwK-congres, $Z$ wolle 1991, p. 80. 
keuzes die het orgaan heeft gemaakt."13 Daarbij aansluitend kan gesteld worden dat het bij beleidsvrijheid gaat om het nemen van een beleidsbeslissing en niet om het nemen van een rechtsbeslissing. ${ }^{14}$

In verband met beleidsvrijheid van het bestuur wordt als pendant veelal gesproken over een marginale toets door de rechter. De aanduiding "marginale toetsing" heeft slechts zin als zij wordt gebruikt in de zin van "marginale redelijkheidstoetsing". Van een "marginale rechtstoetsing" is natuurlijk geen sprake; dat zou materieel op rechtsweigering uitdraaien. Om misverstanden zo vroeg mogelijk te voorkomen wijs ik er op dat zo door mij de term marginale toetsing wordt gebruikt, daarmee een marginale redelijkheidstoets, als onderdeel van een "volle rechtstoets", wordt bedoeld. ${ }^{15}$

Het is naar mijn mening niet juist om de eerder genoemde beoordeling, bij 'beoordelingsvrijheid' louter als rechtsbeslissing op te vatten en aldus op een lijn te plaatsen met beoordelingsruimte. Vrijheid van interpretatie maakt van het bestuur tot op zekere hoogte normsteller in eigen zaak. Vrijheid van interpretatie zou, in extremis, kunnen uitmonden in vrijheid van definitie. ${ }^{16}$ Alsdan kan het bestuur zelf de voorwaarden voor bevoegdheidsuitoefening bepalen, waardoor het ontegenzeggelijk in het spoor van de bevoegdheidsuitoefening zelf geraakt. Met de keuze van een bepaalde interpretatie bepaalt het bestuur of het bepaalde rechtsgevolgen in het leven zal gaan roepen: de beoordelingsvrijheid mondt aldus uit in beleidsvrijheid. In feite neemt het bestuur met de rechtsbeslissing ook een beleidsbeslissing waarin het bepaalt of een bevoegdheid zal worden toegepast: in een afweging van belangen wordt bepaald of het aantrekkelijk is de bevoegdheid aan te wenden. Anders dan Duk $^{17}$ ben ik daarom van mening dat aan beoordelingsvrijheid zeer wel een belangenafweging te pas kan komen. ${ }^{18}$ Daarbij acht ik het wel van belang hoe nauwkeurig de wetgever de vrij door het bestuur te beoordelen voorwaarden heeft omschreven. Hoe preciezer, des te geringer is de "beleidsvrijheid" van het bestuur. De rechtsbetrekking tot de burger is dan scherper omlijnd en de rechter zal meer houvast hebben bij zijn oordeel over

13. Ibidem. Overigens is dit citaat een redactionele optekening van door Brenninkmeijer gemaakte opmerkingen.

14. Zie Duk (1978), a.w., p. 575.

15. Het spreekt vanzelf dat ik de misleidende term "marginale toetsing" zo min mogelijk zal gebruiken.

16. Zodat het specialiteitsbeginsel zijn werking lijkt te verliezen.

17. Duk (1988), a.w.. p. 165.

18. Ik ga er vanuit dat Duk met de door hem (als hypothetisch) geschetste mengvorm (1988, a.w., p. 165-166), waarbij het relatieve over- of ondergewicht van een bepaald belang als toepassingsconditie is omschreven, niet overeenkomt met de hier door mij omschreven vermenging van vrijheden. 
de "redelijkheid" van de door het bestuur gegeven uitleg. Als het - bij voorbeeld - gaat om de vraag of de uitoefening van een bevoegdheid "gelet op de ernst van de situatie passend(er) is" dan zal het bestuur eerder aan beleidsbeslissingen toekomen, dan bij de voorwaarde dat sprake moet zijn van "schade aan het milieu". ${ }^{19}$

\subsubsection{De rol van expertise bij 'beoordeling'}

De noodzaak tot beoordeling van de voorwaarden of toepassingscondities voor bevoegdheidsuitoefening vloeit voort uit het legaliteitsbeginsel. Om bevoegd te zijn moet aan de (vage) toepassingscondities zijn voldaan. Dientengevolge is de feitenvaststelling in het concrete geval een bijzondere verantwoordelijkheid voor het bestuur.

Beoordeling van de toepassingscondities vergt (bij vage termen) interpretatie van deze condities èn kwalificatie aan de hand van de feitenvaststelling. De interpretatie van vage termen is nodig om een relatie te kunnen leggen met het feitensubstraat in een concreet geval. Door uitleg moet er duidelijkheid komen over de precieze betekenis van vage termen, in termen van empirische begrippen.

Bij kwalificatie gaat het erom of zich in het feitensubstraat verschijnselen voordoen die (in termen van hoedanigheid, hoegrootheid, frequentie, intensiteit, of wat dies meer zij) met dezelfde empirische begrippen worden aangeduid, als die bij interpretatie van de vage termen zijn "gevonden".

Het komt er op neer dat door uitleg van vage termen als het ware de bril wordt gegeven waardoor vervolgens de kwalificatie van de feitenvaststelling kan plaatsvinden. In complexe zaken gaat het echter veeleer om een meer procesmatige activiteit: in onderlinge wisselwerking wordt enerzijds de interpretatie van de vage term(en) aangescherpt terwijl anderzijds de analyse (en op voet daarvan de kwalificatie) van de feiten aan precisie wint. Naar mijn smaak is hierbij feitelijk sprake van een zekere samenloop al zal in juridische zin de interpretatie van de vage term(en) (desgevraagd) zelfstandig op haar juistheid moeten worden beoordeeld. Bijvoorbeeld: kan een Wm-vergunning worden geweigerd wegens stankhinder? Enerzijds moet de conditie "belang van de bescherming van het milieu" zodanig worden gepreciseerd dat daaruit iets over stankhinder is op te maken - bij voorbeeld door de oude term "hinder" te gebruiken. Anderzijds moet de voorziene stank worden onderzocht op de hinderlijkheid daarvan. Beide analyses verwijzen naar elkaar: kennis van

19. Wo kunnen deze kwestie ook beschrijven in termen van het koppel legaliteits- en specialiteitsbeginsel. Als sprake is van beoordelingsvrijheid zijn de toepassingscondities zo open geformuleerd dat het specialiteitsbeginsel, dat oneigenlijk gebruik van een krachtens het legaliteitsbeginsel aan het bestuur toekomende bevoegdheid moet voorkomen, zijn werking verliest (zie noot 16). 
het begrip stank is nodig voor gerichte interpretatie van hinder, kennis van het begrip hinder (als toepasselijke operationalisering van "belang van de bescherming van het milieu") is nodig voor onderzoek naar de hinderlijkheid van stank.

Omdat bij de beoordeling van toepassingscondities (via interpretatie en kwalificatie) de feitenvaststelling een cruciale rol vervult, is het nodig kennis te verzamelen over in kwestie zijnde feitensubstraat. Daarmee belanden we als vanzelf bij het zorgvuldigheidsbeginsel, zoals neergelegd in art. 3:2 Awb: " $\mathrm{Bij}$ de voorbereiding van een besluit vergaart het bestuursorgaan de nodige kennis omtrent de relevante feiten en af te wegen belangen." Het is goed mogelijk dat aan deze opdracht niet kan worden voldaan dan met inzet van expertise omtrent de in het geding zijnde feiten. Of inzet van deskundigheid nodig is, zal vooral afhankelijk zijn van de uitleg die gegeven wordt aan de aanduiding "de nodige kennis". Daarbij speelt ook de vraag of het bestuur gehouden is tot kennisvergaring op maat van de stand van wetenschap en techniek. In het verlengde hiervan komen we uit op de reeds in het eerste hoofdstuk aangestipte vragen over de verantwoordelijkheid, de mate van expertise en de procedurele waarborgen.

De beoordeling van toepassingscondities is met name ingewikkeld als het gaat om de bevoegdheid tot het aan een vergunning verbinden van voorschriften. Zo staat in art. 8.11, derde lid Wm voorop dat aan een vergunning "de voorschriften (worden) verbonden, die nodig zijn ter bescherming van het milieu." Het bestuur zou derhalve eigenlijk verschillende, alternatieve, voorschriften moeten "toetsen" aan deze bevoegdheidsvoorwaarde. Daarbij gaat het niet alleen om de vraag of de mogelijke voorschriften bijdrage aan bescherming van het milieu, maar ook om de vraag in welke mate zij dat (mede in onderling verband beschouwd) doen. ${ }^{20}$

\subsubsection{De rol van expertise bij 'beleid'}

Als beoordeling van de toepassingscondities heeft plaatsgevonden en vast staat dat daaraan is voldaan, is het mogelijk dat de bevoegdheid aan het bestuur een beleidsvrijheid laat. Beleidsvrijheid impliceert de plicht tot belangenafweging. Daarbij is én belang reeds aangewezen, te weten het belang waarvan de bescherming gestalte kan krijgen door uitoefening van de desbetreffende bevoegdheid. Vage termen vormen een belangrijke aanwijzing voor de omschrijving van dat "eigen belang". De belangenafweging strekt ertoe dat dit belang wordt afgewogen tegen andere relevante belangen. ${ }^{21}$ De uit-

20. Voorschriften mogen immers niet onnodig worden opgelegd.

21. Vgl. art. 3:4, eerste lid Awb1. 
komst van deze belangenafweging is een beleidskeuze door het bestuur waarmee de voorheen open rechtsbetrekking met een burger wordt ingevuld. Op die wijze vervult het bestuur tevens een rechtsvormende taak voor het individueel-concrete geval. ${ }^{22}$

Waar het bij beoordeling gaat om interpretatie en kwalificatie, gaat het bij beleid om het onderkennen van belangen enerzijds en het waarderen van belangen anderzijds. Zowel bij onderkenning als bij waarderen kan expertise een rol spelen. Ook dit ligt reeds in art. 3:2 Awb besloten nu daarin tevens wordt gesproken over het vergaren van kennis omtrent af te wegen belangen.

In het proces van onderkenning en waardering van belangen moeten verschillende vergelijkingen worden gemaakt.

- Allereerst moet de concrete bevoor- of benadeling van een belang worden vergeleken met de beoogde "toestand" van dat belang in algemene zin. Zo zal de concrete benadeling van het leefmilieu moeten worden vergeleken met (of zelfs afgemeten aan) de bestaande toestand en het wenselijk geachte beschermingsniveau. Omschrijving van het wenselijk geachte beschermingsniveau is mogelijk met verschillende soorten maatstaven, al dan niet in onderlinge samenhang toegepast. Ik denk daarbij onder meer aan een getalsmatige aanduiding van de beoogde milieukwaliteit, al dan niet in combinatie met een getalsmatig criterium in termen van maximaal toelaatbare overschrijdingen van de beoogde milieukwaliteit door toedoen van nieuwe activiteiten. Ook is denkbaar dat, mogelijk in combinatie met een algemene norm voor de beoogde milieukwaliteit een vage norm wordt gebruikt, zoals de eis dat bij nieuwe activiteiten de best toepasbare technische voorzieningen worden getroffen. ${ }^{23}$ Welk criterium ook wordt gekozen, zeker is dat de vergunningverlener zich ernstig op de hoogte moet stellen van allerhande technische gegevens aangaande de beoogde activiteit, zijn concrete effecten en de betekenis van die effecten in termen van de betrokken belangen.

- Voorts moeten we bedenken dat het niet per se gaat om een concreet en eenduidig uitgewerkt voornemen, maar dat meerdere uitvoeringen denkbaar zijn. Vooral als het gaat om aan een vergunning te verbinden voorschriften, zijn verschillende, alternatieve vergunningsvarianten te ontwikkelen. Deze moeten elk voor zich worden geanalyseerd op de zo juist

22. Er was eerst sprake van openheid van de norm naar rechtsgevolgen, met de beleidskeuze is de (nu in de vergunning neergelegde, geconeretiseerde) norm naar zijn rechtsgevolgen "gesloten".

23. Ik kom hierop nog terug in de volgende paragraaf. 
omschreven wijze. Daarna moet een onderlinge vergelijking worden gemaakt, waarbij als het ware per betrokken belang, per variant een "winsten verliesrekening" wordt uitgewerkt.

- Met deze (theoretische) alternatieve "winst- en verliesrekeningen" kan vervolgens de afrondende waardering gestalte krijgen. Daarbij worden de verschillende besluitvormingsopties vergeleken met het relatieve politieke gewicht van de betrokken belangen. In dat proces vindt de uiteindelijke beleidskeuze plaats. ${ }^{24}$

\subsubsection{Onzekerheid}

Bij de beoordeling van toepassingscondities en het maken van de definitieve beleidskeuze is de onzekerheid over de kennis omtrent de effecten van de (in verschillende varianten uitgewerkte) voorgenomen activiteit een belangrijke factor. Deze onzekerheid kan verschillende vormen aannemen.

- Allereerst denk ik aan de principiële onzekerheid, inhoudende dat onze inzichten van vandaag achterhaald kunnen zijn door onze inzichten van morgen. Deze onzekerheid hangt als het zwaard van Damocles boven al onze bevindingen. Het zou absurd zijn om uit principiële onzekerheid af te zien van het nemen van een besluit, laat staan om nieuwe activiteiten op die grond af te wijzen. ${ }^{25}$ Het negeren van principiële onzekerheid, omdat we de besluitvorming er nu eenmaal niet tot in eeuwigheid door kunnen laten verlammen, lijkt evenmin juist. Voorstelbaar is dat het bestuur zich tenminste bezint op de ervaring in het verleden met soortgelijke activiteiten. Daarbij kan het bezien of er indicaties zijn over de mate waarin de inzichten dienaangaande "in beweging" zijn en kan het zich bezinnen op de mogelijkheid tot het treffen van extra voorzieningen ("voor het geval dat"). In dat verband is van groot gewicht hoe kwetsbaar het te beschermen belang - in het algemeen - is. ${ }^{26}$

- Vervolgens denk ik aan praktische onzekerheid, dat wil zeggen onzekerheid omdat ook "hier en nu" geen volledig of eenduidig inzicht in de effecten van een voorgenomen activiteit is te verwerven.

24. Mijn uitgangspunt is beleidsvrijheid. De politieke keuzevrijheid is natuurlijk beperkter als er dwingende rechtsregels (c.q. normen) zijn die bepaalde opties bij voorbaat uitsluiten.

25. Nieuw inzicht kan (voorlopig?) uitwijzen dat een bepaald voornemen eigenlijk gunstiger effecten heeft dan reeds bestaande soortgelijke activiteiten.

26. Van sommige stoffen of activiteiten staat een zekere "gevaarlijkheid" in abstracte zin wel vast. Op voet daarvan is enige voorzichtigheid met die stoffen of activiteiten, afhankelijk van de hoedanigheid en het gewicht van andere belangen mogelijk wijs. 
Gebrek aan eenduidigheid kwam ook in het voorgaande hoofdstuk al - kort - aan de orde, toen ik refereerde aan de opmerkingen van Bier over het criterium van de stand van wetenschap en techniek. ${ }^{27}$ Als het bestuur besluit een bepaalde visie te volgen kan het toch verstandig zijn op enigerlei wijze rekenschap te geven van een alternatieve deskundige-analyse.

Onvolledigheid van inzicht kan zich op verschillende wijzen voordoen. Zo kan het zijn dat slechts een statistische analyse van de effecten mogelijk is, hetzij omdat de algemene theorie over de desbetreffende effecten geen precies begrip biedt van de relevante causale relaties, ${ }^{28}$ hetzij omdat de omgeving van de voorgenomen activiteit zo weinig constant is dat de effecten niet precies traceerbaar zijn. ${ }^{29}$ Ook kan de onvolledigheid van inzicht eenvoudig neerkomen op "niet weten". Dat wil zeggen dat over bepaalde dosis-effectrelaties eenvoudig niets bekend is, of althans niets over de samenloop van verschillende effecten van een voorgenomen activiteit in een concreet geval. ${ }^{30}$ Dit brengt het bestuur in een positie die wel wat weg heeft van die bij principiële onzekerheid: op basis van algemene ervaringsregels met soortgelijke activiteiten moet bezien worden of het wenselijk en mogelijk is om extra "veiligheidsmarges" in te bouwen. Dergelijke marges kunnen ook relevant zijn als deskundigen reeds zelf in hun bevindingen een zekere marge voor "meet- en rekenfouten" aangeven. ${ }^{31}$

Het bestuur zal bij het beoordelen van toepassingscondities en het maken van beleidskeuzes bovengenoemde onzekerheden niet mogen ontkennen, terwijl het zich er evenmin door mag laten verlammen. Wat de beoordeling betreft rijst de vraag hoeveel zekerheid vereist is. In het perspectief van de belangenafweging zal het bestuur de onzekerheid op een of andere wijze in de belangenafweging moeten verdisconteren. In het tweede deel van deze studie zal deze kwestie vanuit het begrip "rationeel beslissen" nader worden uitgewerkt.

27. Zie $\$ 2.3 .4 .1$.

28. Bekend is dat bij een bepaalde blootstelling een zekere verhoging van de kans op een bepaald gezondheidseffect optreedt - omdat zulks bij proefdieren of proefpersonen is gemeten, niet omdat duidelijk is hoe de stof in kwestie op het lichaam ingrijpt.

29. Weersomstandigheden, andere emissies, de veranderende natuurlijke omgeving, fysieke veranderingen (verplaatsingen van voertuigen, personen, woningbouw e.d.) - alles voorzover relevant voor de causale relaties in kwestie.

30. Ik doel hier niet op gebrek aan constantheid (zie vorige noot), maar op het feit dat er vaak hooguit kennis bestaat over laboratoriumsituaties, waarin het gaat om enkelvoudige dosis-effectrelaties. Inzicht in (constant) mogelijk op elkaar inwerkende processen. in een praktisch-concrete setting, vergt aanvullende kennis (zie ook hierboven $\$ 2 \cdot 3 \cdot 4.1$ ).

31. Vanwege onzuiverheid van apparatuur, de aard van de statistische analyse (extrapolaties), of omdat beschikbare gegevens op proefdieronderzoek zijn gebaseerd en bij toepassing op mensen een bepaalde veiligheidsmarge wordt toegepast. 
Overigens past hier nog de opmerking dat de belangenafweging zich uiteraard ook dient te voltrekken binnen de grenzen van het verbod van détournement de pouvoir, het willekeurverbod en de abbb. Naast de eerder genoemde formele zorgvuldigheidseis, ten dele weerspiegeld in art. $3: 2 \mathrm{Awb},{ }^{32}$ denk ik in het bijzonder aan art. 3:4 lid 1 Awb (de plicht tot belangenafweging) en art. $3: 4$, tweede lid 2 Awb (evenredigheid, willekeurverbod en materiële zorgvuldigheid). ${ }^{33}$ Op de betekenis van deze beginselen voor de expertise-problematiek kom ik in deel III van deze studie nog terug.

\subsubsection{Beoordeling en beleid als proces}

Ten slotte merk ik op dat de voorgaande bespreking van beoordeling en beleid de suggestie wekken dat het hier om twee, elkaar keurig opvolgende fasen van bestuurlijke besluitvorming gaat. Toch zou ik er hier op willen wijzen dat dit weliswaar ideaaltypisch gezien juist lijkt maar dat in de praktijk verschillende stappen in de besluitvorming samen kunnen opgaan en soms bepaalde stappen moeten worden herhaald. ${ }^{34}$

\subsection{De Wm-vergunning}

Hierboven ging het om de juridisch-technische verankering van de expertiseproblematiek bij vergunningverlening in het algemeen. In deze studie wil ik - als gezegd - de vergunningverlening ingevolge art. 8.1 Wm als exempel gebruiken. Mitsdien zal ik het hiervoor besprokene nu plaatsen in de context van de Wm-vergunning.

Om te beginnen moet ik wijzen op enkele uitdrukkelijk in de $\mathrm{Wm}$ opgenomen regels inzake beoordeling en belangenafweging.

Ik denk daarbij in de eerste plaats aan het eerste lid van art. 8.10 Wm: De vergunning kan slechts in het belang van de bescherming van het milieu worden geweigerd.

Deze hoofdregel schept enerzijds beoordelingsruimte en anderzijds beleidsvrijheid. In dat opzicht is de vergelijking met (het oude) art. $13 \mathrm{Hw}$ goed te

32. Ten dele; het bij de besluitvorming betrekken van belanghebbenden als doel op zichzelf (ter bevordering van een open gedachtenwisseling. i.v.m. de legitimatie van besluitvorming) lijkt daarin niet (duidelijk) besloten te zijn (zie daartoe afd. 3.4 en 4.1.2 Awb).

33. Zie ook de MvT-Awb1, p. 62-63 en p. 66-71.

34. Ik treed hier niet in een nadere vergelijking van verschillende modellen voor besluitvorming zoals (bij voorbeeld) te vinden bij Berge, J.B.J.M. en F.A.M. Stroink. Arob in vogelvlucht, Alphen aan den Rijn 1989, p. 106, Waard, B.W.N. de. Beginselen van behoorlijke rechtspleging, prft., Zwolle 1987, p. 136-138 en Nicolai, P., prft., a.w., p. 288-289. 
maken. De norm van art. $8.10 \mathrm{Wm}$ is uiteraard zeer algemeen. Dat moest ook wel, gelet op de status van "Integrale milieuvergunning". ${ }^{35}$ In art. 8.8 Wm zijn de zogenoemde "beoordelingsgronden" opgenomen. ${ }^{36}$ Blijkens de toelichting gaat het daarbij enerzijds om gronden die ook wel als weigeringsgronden in verschillende sectorale milieuvergunningsstelsels waren opgenomen (eigenlijk dus toepassingscondities) ${ }^{37}$ en anderzijds om gronden die de mate van beleidsvrijheid van het bestuur betreffen. ${ }^{38}$

In het eerste lid van dat artikel wordt een aantal zaken genoemd die het bestuur bij zijn beslissing op de aanvraag van een vergunning dient te betrekken, zoals (kort weergegeven): a. de bestaande toestand van het milieu; b. de gevolgen voor het milieu; c. voor het milieu ter plaatse te verwachten toekomstige ontwikkelingen; d. de relevante milieuplannen; e. ingebrachte adviezen en bezwaren; f. mogelijkheden tot voorkoming of beperking van milieuschade. Het is duidelijk dat het hier gaat om elementaire gronden, noodzakelijk om te komen tot een weloverwogen beslissing. Ook spreekt het vanzelf dat de gronden onder a., b., c., e. en f. tot de nodige kennisvergaring zullen dwingen. ${ }^{39}$

Het tweede lid van art. $8.8 \mathrm{Wm}$ betreft milieukwaliteitseisen waarmee het bevoegd gezag bij het nemen van zijn beslissing rekening heeft te houden; waarvan derhalve slechts gemotiveerd mag worden afgeweken. ${ }^{40}$ Volgens het derde lid dient het bestuur bepaalde plannen, milieukwaliteitseisen, algemene regels voor bronnen ("instructie-normen") en ministeriële aanwijzingen in acht te nemen. Duidelijk is dat de beleidsvrijheid die in art. $8.10 \mathrm{Wm}$ wordt gegeven daarmee sterk aan banden kan worden gelegd. Daaruit volgt dat ook een deel van het onderzoek, nodig om normen ten aanzien van het gewenste beschermingsniveau te expliciteren, in een aantal gevallen niet door het tot vergunningverlening bevoegde gezag behoeft te worden verricht. ${ }^{41}$

Tijdens de behandeling van het wetsvoorstel Wm(-var) is gesproken over de vraag of het wenselijk was om in art. $8.8 \mathrm{Wm}$ rechtstreekse aanwijzingen op te nemen over "het te bereiken beschermingsniveau". ${ }^{42}$ De minister achtte dit niet nodig "omdat het voorgestelde toetsingskader reeds diverse elementen bevat die - veel concreter dan op wetsniveau kan - inhoudelijk richting geven

35. Zie ook MvT Wm-var, a.w., p. 74.

36. Ibidem, p. 70.

37. Ibidem, met name de gronden onder a. en b. van het eerste lid.

38. Ibidem, p. 72, met name lid 2 en 3 van art. 8.8.

39. Voor d. (plannen) is dat eerder reeds (door anderen) geschied.

40. MvT Wm-var, a.w., p. 72. Zie ook hfst. 2.3.5.1.

41. Hetgeen niet betekent dat er geen feitelijk onderzoek resteert. Het "maatwerk" moet toch nog worden verricht.

42. TK'89/90, 21087, nr. 6, p. 54. 
aan de te nemen beslissing". ${ }^{43}$ De minister had daarbij vooral het oog op het bepaalde in het eerste lid onder $\mathrm{d}$. (plannen) en de relatie die in het tweede en derde lid van art. $8.8 \mathrm{Wm}$ wordt gelegd met plannen en/of milieukwaliteitseisen. Wel heeft hij op voet van deze gedachtenwisseling de regels inzake vergunningvoorschriften aangepast.

De hoofdregel voor het geven van vergunningsvoorschriften, neergelegd in art. 8.11, derde lid luidde oorspronkelijk: ${ }^{44}$ "Aan een vergunning worden de voorschriften verbonden, die nodig zijn ter bescherming van het milieu". Ook deze bepaling kwam sterk overeen met z'n (oude) tegenhanger uit de $\mathrm{Hw}$ (art. $17 \mathrm{Hw}$ ).

Deze regel is echter later ${ }^{45}$ aangevuld met: Voorzover door het verbinden van voorschriften aan de vergunning de nadelige gevolgen die de inrichting voor het milieu kan veroorzaken niet kunnen worden voorkomen, worden daaraan de voorschriften verbonden die de grootst mogelijke bescherming bieden tegen die gevolgen, tenzij dit redelijkerwijs niet kan worden gevergd.

In de toelichting bij de oorspronkelijke tekst ${ }^{46}$ werd de (korte) tekst van art. 8.11 , derde lid Wm getypeerd als een "samenvatting" van reeds in specifieke milieuwetten bestaande bepalingen waarin is vastgelegd "dat aan de vergunning voorschriften in het belang van (onderdelen van) het milieu verbonden moeten of kunnen worden". Van beleidsvrijheid lijkt hier slechts in beperkte mate sprake. Blijkens de toelichting is voor een "imperatieve formulering" gekozen om het gewicht van de vergunningvoorschriften te onderstrepen. Daarbij is het de bedoeling dat de "best toepasbare" voorschriften worden gekozen. Pas als er alternatieve voorschriften denkbaar zijn met gelijke effectiviteit, ontstaat er ruimte om rekening te houden met het belang van de aanvrager. ${ }^{47}$

De aanvulling van de tekst van art. 8.11, derde lid Wm is er - blijkens de Memorie van Antwoord - op gericht "dat zorg wordt gedragen voor een zo hoog beschermingsniveau als redelijkerwijs bereikbaar is". ${ }^{48}$ De regels die de grootst mogelijke bescherming bieden staan voorop; het bevoegd gezag $\mathrm{zal}$, indien in een concreet geval voor een lager beschermingsniveau wordt gekozen, aannemelijk moeten maken dat redelijkerwijs niet meer (van de aanvrager) kan worden gevergd. Erg veel scherpte wordt in de toelichting overigens niet bereikt. Enerzijds wordt het niveau dat met de best toepasbare

\footnotetext{
43. Ibidem.

44. Zie TK'88/89, 21 087, nrs. 1-2, p. 6 en nr. 3 (MvT), p. 75-77.

45. Bij gelegenheid van de MvA. TK' $89 / 90,21087$, nr.6, p. 54 en 58.

46. MvT, a.w., TK'88/89, 21087, nr.3, p. 75.

47. Ibidem.

48. Ibidem, p. 54.
} 
technieken kan worden bereikt als minimumniveau beschouwd. ${ }^{49}$ Deze norm gaat uit van de uit het oogpunt van milieubescherming meest effectieve technieken die tegelijkertijd verenigbaar zijn met een normaal renderende bedrijfsvoering. ${ }^{\text {so }}$ Anderzijds wordt gesteld dat de toepassing van de best bestaande technieken echter geenszins mag worden uitgesloten. ${ }^{51}$

Ik deel de opvatting van Van Buuren ${ }^{52}$ dat de aspiraties van de wetgever hier onvoldoende scherp tot uitdrukking worden gebracht. Enerzijds lijkt het hoogste beschermingsniveau (best bestaande technieken) voorop te staan en vormt toepassing van de best toepasbare technieken een - expliciet te motiveren - uitzondering. Anderzijds lijkt de norm van de best toepasbare technieken uitgangspunt, getuige ook een laatste citaat uit de Memorie van Antwoord: "De situatie van het milieu of de aard of omvang van de gevolgen voor het milieu die een bepaalde inrichting kan veroorzaken door bijvoorbeeld het vrijkomen van "zwarte-lijststoffen", kan zeker meebrengen dat niet kan worden volstaan met de best toepasbare technieken. ${ }^{n 3}$

\subsection{Conclusie}

\subsubsection{Samenvatting}

Open normen vergen dat normtoepassers zich bij voortduring rekenschap geven van de factor deskundigheid. Zulks houdt allereerst verband met de beoordeling van de toepassingscondities van open normen. Vage termen als voorwaarden voor normtoepassing moeten worden geïnterpreteerd en vervolgens moet worden bezien of de feiten van het concrete geval zijn te kwalificeren in termen van deze voorwaarden. Daarbij heeft het bestuur een - rechtstreeks uit het legaliteitsbeginsel voortvloeiende - verantwoordelijkheid voor de vaststelling van de feiten. Het ligt voor de hand dat in dit proces, waarbij interpretatie en kwalificatie hand in hand gaan, kennisvergaring een grote rol kan spelen.

49. MvA, a.w., p. 54 .

50. $\mathrm{Vgl}$. Brussaard, c.s., a.w., p. 21: het milieurendement wordt afgewogen tegen de bedrijfskosten. Vgl. voorts het Eindverslag (Wm-VAR), TK'90/91, 21 087, nr. 12, p. 25-27 en de Nota n.a.v. het eindverslag. TK'90/91, 21087 , nr. 13, p. 34: het gemiddelde rendement in de bedrijfstak. c.q. geen overmatige kosten gegeven de aard van de bedrijfstak.

51. MvA, a.w., p. 58. Dit zijn de meest effectieve methoden, waarvan ook bekend is dat ze technisch toepasbaar zijn. Zie Brussaard c.s., a.w., p. 21.

52. Buuren. P.J.J. van, Codificatie en vernieuwing van milieurecht in Duitsland en in Nederland, NJB'92/12, p. 377-383, i.h.b. p. 380-381.

53. A.w., p. 58. In de Nota n.a.v. het eindverslag (Wm-VAR), a.w.. p. 34, stelt de minister dat op het bestuur een bewijslast rust krachtens welke het aannemelijk moet maken dat redelijkerwijs het optimum werd bereikt. 
Vage termen zijn ook relevant in het proces van belangenafweging. $\mathrm{Zij}$ vormen een aanwijzing voor het 'eigen belang' met het oog op de behartiging waarvan in kwestie een bevoegdheid is gegeven. In het proces van belangenafweging zal dit eigen belang tegen andere 'vreemde belangen' moeten worden afgewogen - zoals de eigen belangen van betrokken burgers of andere algemene belangen; een en ander met inachtneming van het specialiteitsbeginsel. Onderkenning en waardering van belangen vergt kennisvergaring, enerzijds ter bepaling van de effecten van bevoegdheidsuitoefening op betrokken belangen, anderzijds bij de bepaling van de ernst van dit effect. Wat het laatste betreft zullen de effecten moeten worden afgemeten aan de huidige en de beoogde toestand of kwaliteit van dat belang, terwijl doorgaans ook een vergelijking tussen meerdere besluitvormingsopties zal moeten worden gemakt (een en ander voorafgaand aan de politieke afweging). Kennisvergaring is - kortom - een onmisbare schakel in het proces van belangenafweging.

Gegeven de complexiteit van milieuproblematiek gaat de noodzaak van kennisvergaring in veel gevallen gepaard met de noodzaak van raadpleging van deskundigen. Dat zal mitsdien ook gelden voor toepassing van art. $8.10 \mathrm{Wm}$. Daar hebben we immers te maken met de beoordeling van vage toepassingscondities en een afweging van belangen met de milieuproblematiek als empirische context. Een kleine verkenning wijst uit dat bij de Wm-vergunning, in het proces van beoordeling en belangenafweging, verschillende normen en beginselen een rol spelen. Deze normen en beginselen zijn voor de kennisvergaring op twee manieren van belang. Enerzijds onderstrepen zij de noodzaak van kennisvergaring en geven zij aan welke gegevens bekend moeten worden. Dit zien we in het bijzonder in de eisen van art. 8.8, eerste lid Wm en de notie van de "grootst mogelijke bescherming" van art. 8.11, derde lid Wm. Anderzijds zijn er normen die - net als we bij de onrechtmatige daad zagen - een zekere objectivering bewerkstelligen. De eisen van art. 8.8, tweede en derde lid $\mathrm{Wm}^{\mathrm{s}}$ impliceren een zekere mate van formalisering van deskundigheid en belangenafweging. De kwaliteitseisen, plannen en instructie-normen voor bronnen zijn - naar men mag aannemen - gebaseerd op (betrekkelijk recente) technische wetenschappelijke inzichten. ${ }^{55}$ Daarnaast impliceren ze een bepaalde belangenafweging. Tegelijkertijd mag niet worden vergeten dat vergunningverlening steeds weer neerkomt op maatwerk; steeds zullen de concrete omstandigheden van het geval terdege moeten worden vastgesteld. Dat alleen al vergt steeds een deskundige mate van kennisvergaring.

54. De milieukwaliteitseisen en de algemene regels voor bronnen.

55. Zoals bij voorbeeld blijkt in art. $5.1 \mathrm{Wm}$. 


\subsubsection{Vervolgens}

In het eerste deel van deze studie is ingegaan op de probleemstelling van het onderzoek en de relevantie van de problematiek van expertise en normstelling voor vergunningverlening in het milieurecht.

In het navolgende deel wil ik ingaan op de vraag wat rationeel beslissen inhoudt, gelet op het aspect van technisch-wetenschappelijke deskundigheid. In het eerste hoofdstuk gaf ik reeds aan dat het mij daarbij vooral gaat om de "waarheid achter de deskundigen". De problematiek van (principiële en praktische) onzekerheid, alsmede de gebondenheid aan waarde-oordelen staat daarbij centraal. Het is in het bijzonder de vraag of en zo ja, hoe het gegeven de (veronderstelde) onzekerheden en waardegebondenheid mogelijk is - niettemin - rationeel te beslissen.

De beantwoording van deze vragen zal primair vanuit een niet-juridische optiek geschieden. ${ }^{56}$ Op voet daarvan wil ik vervolgens in deel III van deze studie nagaan of "rationeel beslissen" ook als een juridisch uitgangspunt is te begrijpen. Daarnaast - en mogelijk tegen een zodanige achtergrond - wil ik

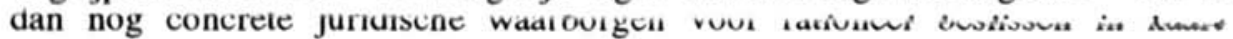
brengen. De aspecten die hierbij relevant zijn noemde ik reeds in het eerste hoofdstuk ( $\$ 1.2)$ : de verantwoordelijkheid voor kennisvergaring en feitenvaststelling, de noodzaak tot het inwinnen van expertise, de procedurele waarborgen en rekenschap van onzekerheid en waardegebondenheid.

Wat deze concrete waarborgen betreft zal in deel III de aandacht vooral uitgaan naar de non-contentieuze procedure. In deel IV zullen het perspectief van de contentieuze procedure en de controle op het rationeel beslissen aan de orde komen.

56. Maar primair uit een gemengd epistemologisch-bestuurskundigeoptiek. 


\section{Deel II}

Aanknopingspunten voor rationeel beslissen 


\section{Hoofdstuk 4 \\ Rationeel beslissen}

\subsection{Inleiding}

\subsubsection{Wijze van aanpak}

In hoofdstuk 1 heb ik een algemene definitie van rationaliteit gebruikt: rationeel handelen is weloverwogen handelen op basis van goede redenen, dat wil zeggen redenen waaraan kritiseerbare kennis ten grondslag ligt. In dit hoofdstuk wil ik deze definitie nader uitwerken teneinde na te gaan welke concrete eisen en aspecten aan de idee van rationeel beslissen verbonden zijn.

Snellen stelt in zijn Tilburgse oratie ${ }^{\prime}$ dat het openbaar bestuur constant moet opereren tussen vier aspiraties: die van politieke, van juridische, van economische en van wetenschappelijke rationaliteit. ${ }^{2}$ Elke aspiratie beschouwt hij als een autonome eigen-aardige "doeleindenstructuur". ${ }^{3}$ Op voet daarvan sluit hij uit dat een algemeen geldige rationele ordening van deze vier gezichtspunten tezamen kan worden ontwikkeld: coëxistentie is het hoogst haalbare. ${ }^{4}$

Ik denk dat deze onderscheiding in rationaliteitsaspiraties een nuttige functie kan vervullen voor de in dit hoofdstuk beoogde analyse. Een summiere typering van de door Snellen onderscheiden rationaliteiten lijkt daarom op z'n plaats: ${ }^{5}$

Politieke rationaliteit heeft als kern dat althans bepaalde problemen een collectieve aanpak behoeven, terwijl deze aanpak tevens bijdraagt tot bestendiging van eigen (individuele of collectieve) politieke macht. Zonder het laatste loopt men immers het risico dat gemaakte politieke keuzes niet kunnen worden doorgezet. Ook moet worden gewaakt voor de integriteit en een minimale mate van samenwerking binnen de samenleving, bijvoorbeeld door te voorkomen dat bij gelijke aanspraken aldoor dezelfde groep slachtoffer wordt van een - helaas vaak onontkoombare - ongelijke verdeling van (rechts)goederen.

1. I.M.Th. Snellen, Boeiend en geboeid, Ambivalenties en ambities in de bestuurskunde, Oratie KUB 1987, Alphen aan den Rijn 1987.

2. A.w.. p. 9.

3. Snellen, a.w., p. 2.

4. Ibidem. Bij gebrek aan tegenbewijs ben ik geneigd die stelling te volgen.

5. Tbidem, p. 3-5. 
Juridische rationaliteit wordt door Snellen verbonden met de instandhouding van het vertrouwen in het recht. Duidelijkheid en consistentie, eerbiediging van rechtsgelijkheid, rechtszekerheid en vrijheid van willekeur acht hij daarin essentieel.

Economische rationaliteit houdt verband met problemen van schaarste. De middelen waarover de overheid beschikt steken schril af tegenover de enorme veelheid aan behoeften en claims waarvoor een collectieve reactie noodzakelijk of wenselijk wordt geacht.

Wetenschappelijke rationaliteit betreft kennis omtrent gedragswijzen en mogelijkheden tot interventie in problemen in de samenleving. Het gaat Snellen hierbij overigens niet alleen om natuurwetenschappelijke kennis maar ook om de sociale wetenschappen, waaronder de beleidswetenschappen. Voorts wijst hij op de kritische functie van de wetenschap jegens de samenleving en tegelijkertijd op de paradigmatische beperktheid van de wetenschap. ${ }^{6}$

In deze studie gaat het om de rationaliteit van bestuursbeslissingen (c.q. het weigeren of verlenen van een Wm-vergunning). De rationaliteit daarvan wordt echter niet in algemene zin aan de orde gesteld, doch slechts in relatie tot de inbreng van deskundigheid. Het model van Snellen leent zich daarbij goed als handvat voor analyse.

Daarbij dient dan de wetenschappelijke rationaliteit van de bestuursbeslissing voorop te worden geplaatst. Deze aspiratie is van belang voor de beoordeling van de status van technische advisering door deskundigen bij het nemen van een bestuursbeslissing. ${ }^{7}$ Mijn aandacht gaat daarbij in het bijzonder uit naar de door mij (in hoofdstuk 1) veronderstelde onzekerheid en waarde-gebondenheid van expertise. ${ }^{8}$

In het voetspoor hiervan kunnen de overige drie rationaliteiten aan de orde komen. In het bestek van dit hoofdstuk zie ik vooral plaats voor de economische en de juridische rationaliteit. ${ }^{9}$

De economische rationaliteit acht ik in het bijzonder van belang voor de vraag wanneer het bestuur (op voet van art. 3:2 Awb) voldoende geinfor-

6. Snellen wijst ook op de "imperialistische tendenties" van ieder van deze rationaliteiten: de politiek elaimt het algemeen primaat, het recht stelt het kader te zijn voor alle belangenafweging, de wetenschap houdt al het niet-wetenschappelijke voor irrationeel en de economie ziet overal schaarste.

7. In hoofdstuk 1.2 stelde ik reeds voorop dat het mij in deze studie primair om wetenschappelijk verantwoorde advisering to doen is.

8. In welk verband de door Snellen genoemde "paradigmatische beperktheid" (zie boven) van belang is.

9. Of bepaalde zaken een collectieve aanpak behoeven en welke aanpak daarbij de juiste is, e.q. de politiek rationele, blijft buiten bespreking. 
meerd is. De vraag is dan met name welke inspanning het bestuur zich moet getroosten.

De juridische rationaliteit komt met name in deel III van deze studie nog uitdrukkelijk aan de orde. Toch meen ik dat het juist met het oog op de bevindingen op het vlak van de wetenschappelijke rationaliteit van belang kan zijn reeds in dit deel terzake enkele bevindingen te noteren.

\subsubsection{Opbouw van het vervolg}

Mijn analyse van het rationeel handelen volgens de hier geschetste benadering zal een beknopt karakter dragen. Dit is niet de plaats voor een uitgebreide verkenning en vergelijking van epistemologische en bestuurskundige theorieën. De onderbouwing van de navolgende bevindingen zal mitsdien strikt functioneel zijn tot het oogmerk na te gaan of en zo ja, hoe rationeel handelen mogelijk is.

De gekozen benadering voor analyse gaat uit van het handelen van het openbaar bestuur. Dat betekent uiteraard niet dat de idee van rationeel beslissen geen uitgangspunt hoeft te zijn voor de rechterlijke controle op dat handelen. Ook ten aanzien van de rechter kunnen de bevindingen uit dit hoofdstuk een rol spelen. Uitgangspunt is echter wel dat de rechter slechts controleert (en waar nodig corrigeert): de rationaliteit van het bestuurlijk handelen staat hier voorop. ${ }^{10}$

In $\$ 4.2 \mathrm{zal}$ ik ingaan op de (problemen van de) wetenschappelijke rationaliteit. Allereerst op de principiële onzekerheid en in het voetspoor daarvan op de waardegebondenheid van wetenschappelijke uitspraken. In $\S 4.3 \mathrm{zal}$ ik ingaan op de economische rationaliteit, die juist primair in het teken van de praktische onzekerheid staat. In $\S 4.4$ ga ik in op de juridische rationaliteit, waarbij ik zal proberen een aantal algemene vuistregels voor het omgaan met onzekerheid te geven.

In aansluiting op deze theoretische verkenningen wil ik in $\$ 4.5$ stilstaan bij enkele concrete, praktische problemen rond het omgaan met expertise. In $\S 4.6$ volgt dan een korte afronding van dit deel van deze studie.

10. Als rechterlijk ingrijpen feitelijk neerkomt op het nemen van een bestuursbeslissing (zoals bij zelf in de zaak voorzien), dan dient het hier besprokene ook daarvoor uitgangspunt te zijn. 


\subsection{Wetenschappelijke rationaliteit}

\subsubsection{De waarheid}

In deze paragraaf gaat het om de status van technische advisering door deskundigen. Uitgangspunt daarbij was (zie hoofdstuk 1.2) dat de deskundigen op wetenschappelijk verantwoorde wijze tot hun adviezen komen. ${ }^{11}$ Dat hield verband met de gedachte dat de uitspraken van deskundigen zijn gebaseerd op goede redenen, redenen waaraan kritiseerbare kennis ten grondslag ligt. Daarmee bevinden we ons in het domein van wetenschappelijke theorieën en wetenschappelijke theorievorming.

Het is met het oog op dat domein dat ik de veronderstelling heb geuit dat onzekerheid aan de orde van de dag is: onzekerheid over deskundigheid, direct terug te voeren op onzekerheid over wetenschappelijke theorieën en theorievorming. Ik heb daarbij het oog op de principiële onzekerheid die ik in hoofdstuk 3.2.4 ten tonele heb gevoerd. De praktische onzekerheid, die ik in dezelfde paragraaf opvoerde, blijft hier nu buiten bespreking. Praktische onzekerheid beschouw ik namelijk als een kwestie van schaarste in kennis; als menselijk onvermogen om de gehele werkelijkheid aanstonds in alomvattende theorieën te vatten. ${ }^{12}$ Het probleem van schaarste in kennis zal - uiteraard - bij de economische rationaliteit een rol spelen. Bij principiële onzekerheid gaat het om de vraag naar het gezag van wetenschappelijke theorieën. Anders gezegd naar het waarheidsgehalte van wetenschappelijke theorieën.

\subsubsection{Fundamentele onzekerheid: onderdeterminatie}

Lange tijd is wetenschap gezien als het ontdekken van de wetten der natuur. ${ }^{13}$ Dit ontdekken geschiedt door generalisatie van neutrale observaties. Door menselijke beoordeling vindt een extrapolatie plaats op basis van gedane waarnemingen en worden schattingen gemaakt omtrent nog niet waargenomen feiten. Daartoe is het uiteraard nodig speciale bekwaamheden en technieken te ontwikkelen, opdat de best mogelijke generalisatie wordt bereikt.

Aan de wetten die - aldus - langs inductieve weg worden ontdekt wordt reeds aanstonds een zekere waarheidsgetrouwheid toegeschreven. ${ }^{14}$ Door nieuwe

11. Zij hoeven niet zelf "wetenschapper" te zijn. Het is voorstelbaar dat een adviseur volstaat met het samenbrengen van onderzoeksresultaten van anderen (en op basis daarvan bepaalde uitspraken of aanbevelingen doet).

12. Voortvloeiend uit de poreusheid van ons begrip van de empirische werkelijkheid: een oneindige wereld van onderzoekbare fenomenen en hun onderlinge relaties.

13. Ik put voor mijn startpunt in deze uiteenzetting uit McMullin. E., Values In Science, presidential Address, Philosophy of Science Association (PSA) 1982, Vol. 2., 1983, p. 3-28.

14. De "context of justification" (de basis voor rechtvaardiging of aanvaarding van een theorie) valt a.h.w. samen met de "context of discovery" (de zoekfase of heuristiek die leidt tot introductie van de theorie). 
waarnemingen en verfijnder metingen vindt echter een continuë revisie van de eenmaal gevonden wetten plaats, waardoor een steeds hogere waarheidsgetrouwheid ontstaat. Fouten of andere ongewenste invloeden door menselijke beoordeling zullen gaandeweg van geringer betekenis worden, naarmate de ontworpen wetmatigheid in kwestie een steeds getrouwer beschrijving van de werkelijkheid geeft. Hoewel revisie tot in het oneindige zal doorgaan, zal een wetmatigheid uiteindelijk welhaast de status van feit bereiken. ${ }^{15}$

Helaas geeft deze inductieve methode geen handvat om de kloof tussen wetten en werkelijkheid te sluiten. Dit wordt wel het probleem van de "onderdeterminatie" genoemd. Hoeveel waarnemingsfeiten je ook hebt, in beginsel is er, logisch gesproken, een onbepaald aantal theorieën die daarop toepasselijk zijn. Derhalve is er nooit een adequate rechtvaardiging voor én bepaalde theorie. ${ }^{16}$ Verificatie van voorgestelde wetten is - anders gezegd - onmogelijk omdat daarvoor de beoordeling van een oneindig aantal, uit deze wet te deduceren, observaties noodzakelijk zou zijn. $\mathrm{Er}$ is - kortom - geen directe logische band tussen bewijsvoering en theorie. ${ }^{17}$

Wat natuurlijk wel kan is dat we een gedeelte van het oneindig aantal observaties verrichten. Naarmate het aantal observaties groeit is sprake van een toenemende inductieve confirmatie van de uitspraak in kwestie. Gegeven het probleem van onderdeterminatie zou er derhalve veel voor te zeggen zijn om het criterium verificatie in te ruilen voor het criterium confirmatie. Bijgevolg zou dan de wetenschappelijke aspiratie moeten worden verlegd van waarheid naar waarschijnlijkheid. ${ }^{18}$

Volgens Popper draagt echter ook de theorie van inductieve confirmatie niet bij tot het streven van de wetenschap om te komen tot groei in kennis. Het streven naar een hogere confirmatiegraad nodigt uit tot een kleinere empirische inhoud en bijgevolg is de kennistoename nogal pover. Bovendien blijft in de theorie van de inductieve confirmatie het aantal waarnemingen dat we verrichten altijd verwaarloosbaar klein ten opzichte van de oneindige verzameling van uit een uitspraak (in tijd en plaats) afleidbare observaties. De groei van de waarschijnlijkheid van een wet is derhalve altijd verwaarloos-

15. Vgl. McMullin, a.w., p. 9.

16. Aldus Prof. Th. Nickles, University of Nevada (Reno), In: Callebaut, W., (mod.), Taking the naturalistic turn, or how real philosophy of science is done, Chicago/London 1993. Aan elke denkbare theorie kan immers, gegeven één gelijkblijvend feitensubstraat, altijd "of..." worden toegevoegd. Zo is het aantal theorieën onbeperkt.

17. McMullin, a.w., p. 14.

18. Vgl. Koningsveld, Herman, Het verschijnsel wetenschap: een inleiding tot de wetenschapsfilosofie, Meppel 1982, p.96. 
baar. Popper merkt voorts op dat het inductie-criterium geen indicatie vormt voor het waarheidsgehalte van een theorie. Er zijn vele onware theorieën die door vele observaties worden bevestigd. ${ }^{19}$ Hoe waarschijnlijk een wet in het licht van vele confirmerende observaties ook mag lijken, deze waarschijnlijkheid mag nimmer met "bijna-waarheid" worden vereenzelvigd. In zekere zin is volgens Popper de onwetendheid van de mens het uitgangspunt; zelfs al verkondigt iemand de meest volmaakte waarheid, met zekerheid kunnen we dat niet weten. Er bestaat geen onfeilbaar criterium voor de waarheid, we kunnen er niet zeker van zijn dat we ons niet vergist hebben. ${ }^{20}$

In Poppers visie gaat het er dan ook niet om hoe de waarheid te funderen maar hoe onwaarheden kunnen worden uitgeschakeld. Theorieën die geen observeerbare verschijnselen verbieden zijn daarom in Poppers visie wetenschappelijk nogal schraal. Daartegenover ziet hij - als voorbeeld - in Einsteins relativiteitstheorie wel de mogelijkheid van een empirische test: "the theory is incompatible with certain possible results of observation-in fact with results which everybody before Einstein would have expected". ${ }^{21}$

Volgens Popper gaat wetenschap over beweringen en theorieën in plaats van over wetten. ${ }^{22}$ Uit theorieën (of "conjectures") moeten deductief zo riskant mogelijke voorspellingen worden afgeleid, welke vervolgens aan tests worden onderworpen. Als een uit een theorie deduceerbare voorspelling in strijd komt met een waarneming dan wordt de theorie daardoor gefalsificeerd. De toets van een theorie ligt aldus steeds in naar tijd en plaats bepaalde waarnemingen. Met een enkele waarneming kan aldus een theorie worden weerlegd ("refutation").

Blijft falsificatie uit dan neemt weliswaar het gezag van een theorie toe maar van verificatie van de theorie kan niet worden gesproken; anders dan de observatie is de theorie immers naar tijd en plaats universeel. Herhaaldelijk doorstaan van weerleggingspogingen maakt een theorie "aannemelijker"; een definitief bewijs is er echter niet bij - zelfs een theorie die jarenlang vele tests heeft doorstaan kan morgen door een enkele observatie worden weerlegd.

Testbaarheid is aldus een kernpunt in de popperiaanse visie: "Every genuine test of a theory is an attempt to falsify it, or to refute it. Testability is falsifi-

19. Koningsveld, a.w., p. 98. Voorbeelden zijn de wetten van Prolemaeus en Newton.

20. Popper, K.R., Rede uitgesproken als dank voor de toekenning van de Leopold Lucas Preis, opgenomen in: Schavemaker, c., H.Willemsen (red.). Over het weten van de mens, Alphen aan den Rijn, 1986, p. 163.

21. Popper, K.R.. Conjectures and refutations: the growth of scientific knowledge, New York (1962) 1965. p. 36.

22. MeMullin, a.w., p. 10. 
ability..", "One can sum up all this by saying that the criterion of the scientific status of a theory is its falsifiability, or refutability, or testability." 23

Ook aan Poppers falsificatie-procedure kleven echter problemen. De observaties waarmee een theorie wordt getest zijn namelijk weer aanvechtbaar. Uit de waarnemingsuitspraken over deze observaties kunnen immers weer voorspellingen worden gededuceerd die zelf weer falsificeerbaar zijn. Een regressie ad infinitum, c.q. een falsificatie van een falsificatie van een falsificatie (etcetera), dreigt en de hele procedure kan dus niet werken. ${ }^{24}$

Volgens Popper zijn echter slechts die waarnemingsuitspraken gezaghebbend die aansluiten bij de in de wetenschap als onproblematisch aanvaarde achtergrondskennis. ${ }^{25} \mathrm{Bij}$ elke waarnemingsuitspraak dienen dan ook tests worden aangegeven die het mogelijk maken de uitspraak te falsificeren. In de loop van het onderzoek zal de wetenschap dan zelf tot het oordeel moeten komen of er sprake is van uitspraken die tot weerlegging van de theorie kunnen strekken.

Niettemin blijft staan dat waarnemingsuitspraken als basis voor weerlegging van een theorie, na verloop van tijd toch zelf als onwaarheid kunnen worden ontmaskerd. Daarnaast wijst McMullin nog op een ander facet ${ }^{26}$ : "..scientists must often tolerate a certain degree of inaccuracy, especially in the early stages of theory-development. Nearly every theory is "born refuted'." Strikt falsificationisme zou vele theorieën ten onrechte een vroegtijdige dood injagen. Zo vormde de baan van Uranus lange tijd een anomalie in Newtons theorie dat alle planeten een elliptische baan rond de zon beschrijven. In plaats van deze anomalie op te vatten als een weerlegging, werd de hypothese genomen dat er een andere nog niet ontdekte planeet in het geding moest zijn die verantwoordelijk was voor de afwijkende baan van Uranus. Uiteindelijk werd Neptunus ontdekt en bleek de hypothese en daarmee de theorie van Newton (vooralsnog) houdbaar. ${ }^{27}$ In het verlengde hiervan heeft Lakatos er op gewezen dat pogingen tot falsificatie van een theorie steeds met nieuwe hulphypotheses kunnen worden afgeweerd; ware Neptunus niet gevonden dan was men wellicht naar een wolk kosmische stof gaan zoeken die de metingen

23. Popper (1962), a.w., resp. p. 36 en p. 37. Poppers "kritisch-rationalisme" komt eigenlijk neer op het aloude "trial and error".

24. McMullin, a.w., p. 10.

25. Ibidem.

26. A.w., p. 15.

27. Vgl. Koningsveld, a.w., p. 152-153. 
zou kunnen vertroebelen. Zou deze wolk onvindbaar blijken dan was wellicht een speurtocht naar een magnetisch veld ingezet, enzovoorts. ${ }^{28}$

Samenvattend moeten we allereerst vaststellen dat onderdeterminatie de verificatie van theorieën uitsluit, terwijl ook de inductieve confirmatie geen zekerheid biedt. Popper richt zijn aandacht op de enig nog haalbaar lijkende stelling, die tevens groei in kennis mogelijk maakt: zekerheid over wat onwaar moet worden geacht. De daartoe ontwikkelde falsificatie-procedure is echter al evenmin probleemloos. Enerzijds ontbreekt aan waarnemingsuitspraken een vaste empirische basis en anderzijds is het steeds weer mogelijk theorieën nader te verfijnen met aanvullende hypotheses zodat zij zich aan falsificatie onttrekken. Waarheid en onwaarheid zijn principieel onzeker.

\subsubsection{Waardeoordelen in de wetenschap}

De discussie over het gezag van waarnemingsuitspraken (die ter falsificatie van een bepaalde theorie worden opgeworpen) biedt een goed voorbeeld van de rol van waarden in de wetenschapsbeoefening. Popper stelt voorop dat aan zo'n waarnemingsuitspraak pas enig gezag toekomt als vast staat dat we van doen hebben met "a kind of statement that is especially easy to test. For it means that we are stopping at statements about whose acceptance or rejection the various investigators are likely to reach agreement". ${ }^{29} \mathrm{De}$ waarnemingsuitspraak wordt met andere woorden gedekt door consensus, c.q. door de onomstreden, onproblematische achtergrondskennis. Dan hebben we echter van doen met een waarde-oordeel als uiteindelijke toetssteen ${ }^{30}$ : opvattingen kunnen immers uiteenlopen en zelfs als dit niet zo is, is niets meer dan een gemeenschappelijke overtuiging beslissend.

Popper suggereert met de falsificatie-procedure een logisch dwingende confrontatie tussen theorieën en waarnemingsuitspraken. Tegelijkertijd echter stelt Popper dat waarnemingsuitspraken theorie-geladen zijn. ${ }^{31}$ Eigenlijk gaat het dus om een directe confrontatie tussen theorieën onderling: tussen een theorie die getest wordt en een theorie die onproblematisch wordt geacht. ${ }^{32}$ Welke theorie getest wordt en welke onproblematisch wordt geacht

28. Lakatos, I., Falsification and the methology of scientific Rescarch Programmes, in: Criticism and The Growth of knowledge, I.Lakatos en A. Musgrave (red.). Cambridge 1974, p. 100-101.

29. Popper, K.R., The logie of scientific discovery, London 1959, p. 104. McMullin, a.w., p. 1011.

30. Zie ook McMullin, a.w., p. 11-12.

31. Vgl. Koningsveld, a.w., p. 101.

32. Popper, The logic of scientific discovery, a.w., p. 111: The acceptance of basic statements is part of the application of a theoretical system." 
ligt volgens Popper besloten in de onomstreden achtergrondskennis. De wens van een logisch dwingende falsificatie is daarmee echter niet bereikt. ${ }^{33}$

We kunnen - kortom - vaststellen dat waarde-oordelen niet alleen van groot belang zijn voor het gezag van waarnemingsuitspraken, maar ook voor de theorie-keuze zelf.

Daarmee is de brug geslagen naar de wetenschapstheorie van Kuhn. In diens analyse van het wetenschappelijk bedrijf wordt een aantrekkelijke verklaring gegeven voor het feit dat onzekerheid en waardegebondenheid niet tot verlamming van wetenschappelijke activiteit behoeft te leiden.

In Kuhns visie is probleemoplossing de primaire oriëntatie van de wetenschap. Anders dan Popper neemt Kuhn dan ook aan dat de "normaal-wetenschappelijke activiteit" niet voortdurend in het teken staat van falsificatiepogingen. Integendeel: de normaal-wetenschappelijke praktijk staat juist in het teken van het behoud van uitgangspunten - en het streven daarbinnen zoveel mogelijk problemen ("puzzels") op te lossen. Volgens Kuhn zijn wetenschappers er gewoonlijk niet op uit om nieuwe theorieën te creëren en staan ze zelfs vaak intolerant tegenover nieuwe theorieën (van anderen). ${ }^{34}$

Een opmerkelijk verschil tussen de geschetste visie van Popper en de benadering van Kuhn wordt hiermee aanstonds zichtbaar. Popper heeft een normatieve theorie ontwikkeld waarin beschreven wordt hoe wetenschap zou moeten worden beoefend. Bij Kuhn gaat het om een descriptieve theorie; hij is er op uit na te gaan hoe de wetenschap feitelijk bedreven wordt.

Het centrale uitgangspunt van voornoemde normaal-wetenschappelijke praktijk duidt Kuhn aan als paradigma. Volgens Kuhn heeft het paradigma een cognitieve en een sociale dimensie. ${ }^{35}$ De cognitieve dimensie bestaat allereerst uit bepaalde standaard-uitdrukkingen en bewerkingen die binnen een bepaalde wetenschappelijke groep algemeen worden aanvaard. ${ }^{36}$ Voorts omvat het paradigma gemeenschappelijke meta-fysische overtuigingen en modellen. De modellen bepalen in sterke mate welke analogieën en metaforen binnen een bepaalde wetenschappelijke tak bij het ontwikkelen van oplossingen

33. Vgl. Kunneman. Harry, De waarheidstrechter. Een communicatietheoretisch perspectief op wetenschap en samenleving, Meppel 1986, p. 26-27.

34. Kuhn, T.S., The structure of Scientific Revolutions, Chicago 1962. Hier toegepaste vertaling (met naschrift 1969): T.S. Kuhn, De structuur van wetenschappelijke revoluties. Meppel 1987. p. 44 .

35. Kuhn, a.w., p. 234-241 (naschrift 1969).

36. Ibidem, p. 236: de zogenoemde "symbolische generalisaties". 
voor puzzels toelaatbaar zijn. ${ }^{37}$ Daarnaast kent elk paradigma bepaalde epistemologische waarden die relevant zijn voor de keuze van theorieën en de beantwoording van de vraag of in een bepaalde situatie wel of geen anomalie optreedt. Ten slotte zijn er de school- of navolgingswaardige voorbeelden ("exemplars": het paradigma in enge zin). Het gaat hierbij om de door Kuhn als erg belangrijk beschouwde voorbeelden van het professionele werk; typerende oplossingen voor typerende problemen uit de eigen tak van wetenschap. Het soort navolgenswaardige voorbeelden dat in handboeken een belangrijke rol speelt.

Theorieën maken de kans om als paradigma opgang te maken voorzover zij de belofte inhouden succesvol te kunnen worden ingezet bij de oplossing van, door de wetenschappers uit een bepaalde tak, belangrijk geachte problemen. Het paradigma ontleent zijn status aan de mate van "discoverability" die ermee in het vooruitzicht wordt gesteld. ${ }^{38}$ Het paradigma moet enerzijds een sterk probleemoplossend voorbeeld bieden en tegelijkertijd genoeg onvoltooide elementen bevatten waarbinnen aanhangers problemen kunnen oplossen. ${ }^{39}$

Daarmee ben ik meteen bij de sociale dimensie van het paradigma-begrip: het paradigma kan het onderzoek van een hele groep leiden. Het paradigma geeft aan welke feiten voor het onderzoek eigenlijk interessant zijn en welke niet; aldus wordt voor een bepaalde groep een onderzoeksterrein min of meer afgebakend. ${ }^{40}$

De onvoltooide elementen van een paradigma vormen de uitdaging om theorie en feiten met elkaar in overeenstemming te brengen. ${ }^{41}$ Geen enkel paradigma kan namelijk, als grondslag van onderzoek, alle problemen oplossen, doch houdt niettemin de belofte in dat de belangrijkste problemen ("puzzels") kunnen worden getackeld. Anomalieën tussen theorie en praktijk worden beschouwd als belangwekkende puzzels om tot verfijning of aanscherping van het paradigma te komen. Als het niet lukt om een anomalie de baas te worden dan is dit primair een gebrek van de wetenschapper in kwestie, niet van de paradigmatische theorie. ${ }^{42}$

Toch kan zich op een gegeven ogenblik een situatie voordoen dat de puzzeloplossende activiteit in een crisis geraakt. Voor menig anomalie is nog wel

37. Ibidem, p. 237.

38. Ibidem, p. 44.

39. Bbidem, p. 28.

40. Kuhn (a.w., hfst 8) vergelijkt een paradigma wel met een Gestalt. Het is zijns inziens zo coherent overtuigend dat wisselen van het ene naar het andere paradigma een mentale sprong vereist: paradigma's zijn incommensurabel.

41. Kuhn, a.w., p, 55.

42. Midem, p. 112. 
een verfijning te ontwikkelen. ${ }^{43}$ Als een anomalie echter duidelijk een expliciete en fundamentele generalisatie van het paradigma ter discussie stelt, de paradigmatische verfijningen steeds meer een ad hoc karakter krijgen en belangrijk geachte toepassingen van de paradigmatische theorie worden gehinderd door de anomalie, dan wordt de toekomst van het paradigma echt problematisch. ${ }^{44}$ Als zich in deze fase van diepgaande onzekerheid een alternatief paradigma aandient, dan is de crisis (en de mogelijkheid van een wetenschappelijke revolutie) daar. In het licht van de alternatieve theorie kunnen de anomalieën die eerder juist een indicatie vormden van het puzzeloplossend-potentiaal van het heersende paradigma nu als tegenvoorbeelden worden geanalyseerd. ${ }^{45}$

Hoewel op deze wijze de onrust binnen de wetenschappelijke groep groeit is er, gegeven het probleem van onderdeterminatie, geen logisch of wiskundig dwingende keuze te maken tussen de verschillende theorieën die in de toekomst de rol van paradigma moeten gaan vervullen. Daartoe zouden we over a priori premisses en vaststaande afleidingsregels moeten beschikken, hetgeen niet het geval is. Er is geen neutraal algoritme voor de keuze van theorieen. ${ }^{46}$

Volgens Kuhn speelt een aantal betrekkelijk algemeen geaccepteerde waarden een cruciale rol bij de keuze tussen verschillende (concurrerende) theorieen. ${ }^{47}$

In de eerste plaats noemt hij de voorspellende accuratesse. Een zekere mate van inaccuraatheid moet worden geaccepteerd ("nearly every theory is born refuted"), maar hoe hoger de voorspellende waarde des te overtuigender is de theorie..$^{48}$ Daarnaast noemt Kuhn de interne consistentie. Een theorie mag geen logische inconsistenties bevatten en er mag evenmin sprake zijn van een verstoring van de interne coherentie door een groot aantal ad hoc verklaringen voor specifieke problemen (anomalieën). Voorts is er de waarde van de externe consistentie. Het pleit voor een theorie als deze aansluit op andere theorieën en meer in het algemeen op bestaande algemene verwachtingspatronen in de desbetreffende tak van wetenschap. Positief is ook het eenheidsscheppende vermogen van een theorie. Als de theorie een gemeenschappelijke noemer biedt voor voorheen van elkaar losstaande fenomenen, is dit stellig een pré. Tenslotte noemt Kuhn de vruchtbaarheid van een theorie. Als een

43. Denk aan de hulphypotheses van Lakatos (4.2.2).

44. Kuhn, a.w., p. 116-117. De complexiteit van de theorie neemt sneller toe dan de nauwkeurigheid ervan en steeds duiken her en der nieuwe afwijkingen op.

45. Ibidem, p. 110-111.

46. Ibidem, p. 225.

47. Zie ook McMullin, a.w., p. 15-16.

48. McMullin, a.w., p. 15. 
theorie voorspellingen biedt welke eerder zelfs niet behoorden tot de te verklaren problemen, is dat een positieve waarde. Een theorie met de potentie om niet of ternauwernood ontwaarde problemen te onderzoeken is alleen al als een onderzoeksprogramma interessant (denk aan de eerdere "puzzels"). ${ }^{49}$

Ook voor deze waarden voor theorie-keuze ${ }^{50}$ geldt dat er geen algoritme is dat beslissend naar de ene of andere theorie verwijst. Wetenschappers zullen de mate waarin een theorie aan deze of gene waarde voldoet, alsook het (relatieve) gewicht van de onderscheiden waarden verschillend beoordelen. ${ }^{51}$ Misschien is dit juist een gunstig gegeven: er bestaat nu immers de vrijheid om theorieën met elkaar te confronteren en elkanders zwakke plekken bloot te leggen. ${ }^{52}$

Het kuhniaanse paradigma is als het ware de uitvergroting van Poppers onproblematische achtergrondskennis. ${ }^{53}$ De "Kuhniaanse wending"\$4 maakt echter duidelijk dat er geen logisch of empirisch dwingende keuze kan worden gemaakt tussen paradigmata. De opvolging van (paradigmatische-) theorieën biedt geen garantie meer voor het verder doordringen in de objectieve werkelijkheid; waarden maken immers de dienst uit. De vraag naar het bestaan van een onafhankelijk (objectief) gegeven werkelijkheid is irrelevant geworden..$^{55}$

De invloed van waarden op theorie-keuze impliceert het demasqué van de klassieke epistemologie. McMullin beschrijft de invloed van waarden op de wetenschap met een prikkelende metafoor: "Once the camels nose is inside, the tent rapidly becomes uncomfortable." Het is volgens hem de vraag of het door waarden uitgelokte relativisme nog een halt kan worden toegeroepen of dat de conclusie moet luiden dat wetenschap eigenlijk neerkomt op een contingente sociale consensus binnen de wetenschappelijke wereld?! ${ }^{56}$

49. Los van deze waarden zijn er ook nog algemenere wetenschappelijke waarden zoals die van reproduceerbaarheid van proefnemingen en nauwkeurigheid bij metingen.

50. Er is hier geen pretentie van volledigheid in het geding.

51. MeMullin, a.w., p. 16-17.

52. Dbidem, p. 17, zulks in het voetspoor van Popper.

53. Kunneman, a.w., p. 24 en p. 221.

54. Een term die Kunneman (a.w., p. 9-11) bezigt voor de aan Kuhn toe te schrijven breuk in de epistemologie met de "klassieke" traditie.

55. Kunneman, a.w. , p. 25.

56. McMullin, a.w., p. 20. 


\subsubsection{De wetenschap als 'sociale consensus'}

Er zijn verschillende reacties denkbaar op de idee van een ongebreideld relativisme in de wetenschap. Zo stelt Kuhn dat vaak wordt miskend dat (eerdergenoemde) waarden "de beproefde en gemeenschappelijke bezittingen (zijn) van de leden van een succesvolle groep". ${ }^{57}$ De bestendigheid van de eis van interne en externe consistentie is daarvan een goed voorbeeld. Ook acht hij het van groot belang dat er ruimte is voor afwijking door individuele onderzoekers, omdat daardoor in het proces van theorievorming de risico's van mislukking worden gespreid. Ten slotte moet niet vergeten worden dat wetenschappers uiteindelijk het puzzeloplossende vermogen van een theorie doorslaggevend achten. Volgens Kuhn ontwikkelt de wetenschap zich daarom ook als een biologisch proces; de meest recente theorieën hebben een groter puzzeloplossend vermogen dan de oudere theorieën. Kuhn is mitsdien overtuigd van de wetenschappelijke vooruitgang..$^{58}$

McMullin stelt voor onderscheid te maken tussen wetenschappelijke en nietwetenschappelijke waarden. Als van een waarde gezegd kan worden dat ze er op gericht is het waarheid-achtige karakter van de wetenschap te bevorderen dan betreft het een wetenschappelijke waarde. Voornoemde waarden voor theorie-keuze behoren tot die categorie. ${ }^{59}$ Daarnaast zijn er tal van niet-wetenschappelijke waarden die ter overwinning van het probleem van onderdeterminatie worden opgeworpen, zoals politieke, morele, sociale en religieuze overwegingen. McMullin erkent dat de lijn tussen wetenschappelijke en nietwetenschappelijke waarden soms moeilijk is te trekken. Dit komt goed tot uitdrukking in existentiële, meta-fysische of theologische waarden of overtuigingen. Hoewel de neiging sterk is deze waarden als niet-wetenschappelijk aan te merken, is niet uitgesloten dat ze juist worden ingeroepen vanuit de gedachte dat ze het waarheids-achtige karakter van de wetenschap ten goede kunnen komen (en dus losstaan van persoonlijke, psycho-sociale motieven). ${ }^{60}$

"Objectiviteit"61 van de wetenschap, ondanks de manifeste waardegeladenheid er van, wordt volgens McMullin - in het voetspoor van Kuhn - in de

57. Kuhn, a.w., p. 246.

58. Ibidem, p. 261-264.

59. McMullin, a.w., p. 5-6. Hij noemt ook nog andere ethisch-wetenschappelijke waarden, zoals openheid, integriteit en eerlijkheid. Daarnaast kunnen we nog denken aan meer elementaire regels zoals reproduceerbaarheid van proefnemingen en nauwkeurigheid bij metingen.

60. McMullin wijst in dit verband op enkele religieuze overwegingen in Newtons theorieên, a.w., p. 19-20. Denk ook aan Einsteins vermaarde stellingen: "Der Herrgott ist schwierig, aber boshaft ist Er nicht", en "Gott würfelt nicht".

61. Althans de stelling dat wetenschap meer is dan een contingente sociale consensus en werkelijk ons begrip van de wereld vergroot. 
wetenschappelijke praktijk zelf gerealiseerd. Het wetenschappelijke proces bestaat uit herhaling van proefnemingen, onderzoek naar theoretische (in)consistenties en onderzoek naar nieuwe theoretische mogelijkheden. Op de lange duur zullen de niet-wetenschappelijke waarden, die in individuele gevallen van wetenschapsbeoefening ongetwijfeld zullen doorwerken, dit proces niet overleven. ${ }^{62}$

Volgens Habermas is objectiviteit in de wetenschap, ondanks de invloed van waarden, nog wel degelijk haalbaar. ${ }^{63}$ Objectiviteit staat voor hem voor het instrumentele handelen, voor de herhaalbaarheid van experimenten met een stabiel experimenteel effect. ${ }^{64}$ Objectiviteit vindt $z^{\prime} n$ basis in intersubjectiviteit, omdat ons instrumentele handelen is gebaseerd op een gemeenschappelijke taal waarin wij ervaringsobjecten omschrijven, zonder ons daarmee dwingend te binden aan een bepaald paradigma. ${ }^{65}$ De geldigheid of waarheid van een theorie - die sinds de Kuhniaanse wending niet meer logischempirisch is te bepalen - moet in een op argumenten gerichte consensus tussen betrokkenen worden vastgesteld. ${ }^{66}$ Habermas ziet mogelijkheden voor vooruitgang in kennis indien theorieën voortvloeien uit een door argumenten gestuurd leerproces. ${ }^{6}$ Hoekstenen daarvan zijn de afwezigheid van handelingsdruk en de mogelijkheid van radicale kenniskritiek. Tussen betrokkenen moet sprake zijn van een ideale gesprekssituatie. Alsdan bestaat tussen betrokkenen een gelijke kans tot deelname aan het "discours" en tot het opperen van kritiek. ${ }^{68}$ Waarden vormen in Habermas' visie, geen bedreiging voor de wetenschap omdat ook daarover - in een discours - rationele overeenstemming kan worden bereikt. ${ }^{(9)}$

Mij dunkt dat we ons voor ogen moeten houden dat Habermas net als Popper een normatieve theorie poneert. De veronderstelling van rationaliteit is normatief ingebouwd in een theorie over argumenteren die een sterk idealistisch karakter heeft. De hele benadering steunt op het realiseren van de ideale gesprekssituatie.

62. McMullin, a.w., p. 20-23.

63. Ik put voor de uiteenzetting over Habermas' visie uit Kunneman, a.w., m.n. hoofdstuk 7.

64. Ibidem, p. 211. Eenieder die de proef op de voorgeschreven wijze uitvoert krijgt een zelfde effect.

65. Het is overigens de vraag hoe dit strookt met Kuhns incommensurabiliteits-postulaat (zie noot 40).

66. Kunneman, a.w., p. 221. Het bereiken van consensus lijkt bij Habermas minder fundamenteel te zijn dan de argumentatie (p. 224).

67. Ibidem, p. 222.

68. Bbidem, p. 219-224.

69. Didem, p. 232. 
Net als bij Popper komt bij Habermas overigens scherp de premisse van uniformiteit van de natuur ${ }^{70}$ tot uitdrukking. Bij Popper is die aanname noodzakelijk voor de werking van de falsificatie-procedure. ${ }^{71}$ Bij Habermas is de uniformiteitspremisse de grondslag voor objectiviteit. ${ }^{72}$ Meer in het algemeen is de uniformiteit van de natuur een uitgangspunt voor de beoefening der natuurwetenschappen. Een uniforme natuur stelt ons al voor genoeg onzekerheden.

\subsubsection{Conclusie wetenschappelijke rationaliteit}

$\mathrm{De}$ in het eerste hoofdstuk veronderstelde rol van onzekerheid en waarden in de wetenschap is met deze beknopte epistemologische verkenning duidelijk bevestigd. Terwijl Poppers model nog zekerheid over onwaarheid suggereert is met de Kuhniaanse wending de onzekerheid alom aanwezig en is de rol van waarden bij theorie-keuze manifest.

Dat wetenschap en de daarop gebaseerde uitspraken en adviezen van deskundigen niettemin van belang kunnen zijn voor (maatschappelijke) beslissingen, ligt mijns inziens in twee aspecten besloten.

In de eerste plaats behoeft de rol van waarden in de wetenschap niet negatief te worden beoordeeld. Integendeel: wetenschappelijke waarden blijken een zekere bestendigheid te bezitten èn laten tegelijkertijd de vrijheid voor wetenschappelijke innovatie. Dat het wetenschappelijk proces steunt op een sociale dimensie, waarbinnen het debat over waarden en theorieën permanent voortduurt, is misschien wel zijn grote kracht.

In de tweede plaats laten onzekerheid en waardegebondenheid ruimte voor een praktische en (maatschappij-)kritische oriëntatie van wetenschapsbeoefenaren. De praktische dimensie schuilt vooral in het streven naar probleemoplossing. De emancipatie van de mens door de bevrijding van onnodige materiële en immateriële dwang vormde reeds voor de logisch-positivisten de externe legitimatie voor de rationele wetenschap. ${ }^{73}$ De praktische oriëntatie van de wetenschap op het oplossen van problemen of puzzels komt natuurlijk bij uitstek tot uitdrukking in Kuhns perspectief van de normaal-wetenschappelijke praktijk.

70. De veronderstelling dat de natuur zich in eigenschappen en dus ook in "wetmatigheden" niet (gestaag) ontwikkeld (en dus verandert).

71. Als de natuur veranderlijk zou zijn rijst de vraag of een test nog concludent kan zijn.

72. Daarin speel het stabiele experimentele effect een grote rol. Dit kan bij fundamentele veranderlijkheid van de natuur niet worden gegarandeerd.

73. Koningsveld, a.w., p. 85; dwang door honger, ziekten, plagen, angsten, rampen e.d.. 
Men kan zich met Feyerabend ${ }^{74}$ te weer stellen tegen de idee dat er "objectieve" redenen zijn om aan te nemen dat de wetenschappelijke rationaliteit superieur is aan andere tradities. ${ }^{75}$ Ook zonder de wetenschap tot paradigma van rationaliteit te verklaren, zou ik met Kuhn (zie de voorgaande subparagraaf) willen vaststellen dat er naar de maatstaf van probleemoplossend vermogen van hedendaagse theorieën, sprake is van groei van wetenschappelijke kennis. In zoverre als deze groei vrucht is van een proces van onderlinge kritiek en ten goede kan komen aan de bevrijding van materiële en immateriële dwang is mijns inziens een doorslaggevende rechtvaardiging voor wetenschappelijke rationaliteit gegeven. ${ }^{76}$

Dit gezegd zijnde is het ook goed enkele voor het vervolg van deze studie relevante aspecten van wetenschappelijke kennisvergaring, kort op een rij te plaatsen.

- De wetenschap kan niet pretenderen de waarheid te ontdekken. Wetenschapsbeoefening levert slechts theorieën en hypotheses. De wetenschappelijke status van een theorie of uitspraak is afhankelijk van de testbaarheid ervan.

- De beoordeling van wetenschappelijke theorieën wordt op een essentiële wijze beïnvloed door waarde-oordelen. In verband daarmee is de sociale dimensie van de wetenschapsbeoefening essentieel. Deze dimensie moet ruimte bieden aan een open discours tussen wetenschappers - waaronder zij die voorstander zijn van nieuwe, afwijkende opvattingen en benaderingswijzen.

- De wetenschap kan, waardegeladen als zij is, een eigen koers ontwikkelen. Het nut van wetenschappelijk onderzoek ligt immers vooral in de toevoegende waarde van haar produkten voor de huidige samenleving en daarmee kan de samenleving haar eisen als onderzoekscriteria aan de wetenschap opdringen. De uitkomst hiervan kan zijn dat de wetenschapsbeoefening in dienst komt te staan van de instandhouding van de huidige samenleving (en de daarin geldende machtsverhoudingen). Habermas heeft in dit verband de vraag opgeworpen of de emanciperende functie van de wetenschap niet gaandeweg is ingeruild voor een op beheersing gerichte technologische doelstelling. Om de wetenschap ten dienste van de maat-

74. Feyerabend, Paul, Against method,: Outline of an Anarchistic Theory of Knowledge, London 1975.

75. Zoals magie, voodoo, astrologie, religie en wat dies meer zij.

76. Laat er geen misverstand over bestaan dat deze stellingname in dubbel opzicht een externe rechtvaardiging behelst: in de bevrijding van dwang èn in de bestrijding van dogma's. 
schappelijke gebreken te stellen ${ }^{77}$, is een permanente kritische analyse van de relatie maatschappij en wetenschapsbeoefening noodzakelijk. ${ }^{78}$

Deze drie aspecten kunnen een rol spelen bij het zoeken naar waarborgen voor de inbreng van technische expertise bij het nemen van bestuursbeslissingen. Eerst zal ik nu echter ingaan op de economische en juridische rationaliteit van bestuursbeslissingen.

\subsection{Economische rationaliteit}

\subsubsection{Onzekerheid}

In deze paragraaf staat onzekerheid centraal. Onzekerheid over zeer concrete problemen. Niet over universele theorieen (zoals in de voorafgaande paragraaf), maar over uitspraken aangaande de effecten van concrete voornemens waarover het bestuur een beslissing moet nemen.

Het gaat met andere woorden primair om de praktische onzekerheid. De principiële onzekerheid (uit de voorafgaande paragraaf) veronderstelt het bestaan van een theorie, een theorie met geldigheidsaanspraak. ${ }^{79} \mathrm{Nu}$ gaat het echter juist om het ontbreken van theoretische expertise over concrete problemen: over schaarste in kennis.

Praktische onzekerheid door schaarste in kennis is in de milieuproblematiek wijdverbreid. Uit verschillende milieu-studies blijkt dat "de grootste problemen van wetenschappelijke advisering niet zozeer te maken hebben met wat men weet, maar eerder met wat men niet weet." ${ }^{80}$ Dat gezegd zijnde rijst toch de vraag hoe, nog afgezien van de problematiek van de principiële onzekerheid, niettemin rationele beslissingen genomen kunnen worden.

Deze vraag rijst met name als we de rationeel-synoptische theorie van beslissen tot uitgangspunt nemen. Deze theorie berust op de volgende procedure: ${ }^{81}$

77. Armoede, honger, onderdrukking en uitbuiting, milieuverontreiniging: helaas zijn er nog problemen te over.

78. Vgl. Koningsveld, a.w., p.114-125.

79. Over alles is natuurlijk wel een theorie te bedenken. Vandaar de toevoeging "met geldigheidsaanspraak": theorieën die door betrokken wetenschappers terstond kunnen worden afgewezen, of die nog uiterst poreus zijn, vormen hooguit een maskerade van praktische onzekerheid.

80. Cramer,Jacqueline, Gebruik van ecologische gegevens in de besluitvorming. Amsterdam 1983, p. 18. Cramer gebruikt "voor al die vragen. waarop de wetenschap (nog) geen antwoord kan geven" de door Weinberg geintroduceerde term "transwetenschappelijk".

81. Zie Rosenthal, U., Rampen rellen gijzelingen, crisisbesluitvorming in Nederland, Amsterdam/Dieren 1984, p. 38-39. 
- de besluitvormer kent alle alternatieve mogelijkheden waaruit te kiezen valt;

- hij kent alle consequenties van elk der genoemde alternatieve mogelijkheden;

- hij plaatst al deze consequenties in een volgorde van voorkeuren;

- hij kiest die alternatieve mogelijkheid die tot de geprefereerde consequenties leidt.

Het zal duidelijk zijn dat bij praktische onzekerheid de eerste twee stappen in dit model tot grote problemen aanleiding geven. Allereerst is er slechts ontoereikende informatie. In de tweede plaats gaat het vergaren van kennis veelal met kosten gepaard; de rationeel-synoptische theorie zwijgt echter over de kosten die met de geschetste stappen gepaard gaan ${ }^{82}$.

\subsubsection{De bevredigende oplossing}

Een interessant alternatief voor de rationeel-synoptische theorie, juist met het oog op praktische onzekerheid, is Herbert Simons theorie van de bevredigende oplossing. Deze theorie kent drie stappen: ${ }^{83}$

- de besluitvormer haalt een aantal voor de hand liggende alternatieve mogelijkheden voor de dag;

- hij bepaalt min of meer wat hij met zijn beslissing wil bereiken (vaststelling van $z$ 'n aspiratieniveau);

- hij kiest het eerste de beste alternatief waarmee het aspiratieniveau gehaald wordt (de bevredigende oplossing).

Kernpunt in deze gedachtengang is dat mensen en menselijke organisaties gegeven hun beperkte geïnformeerdheid (of beperkte informatieverwerkende capaciteiten) slechts een beperkte rationaliteit kunnen opbrengen. Simon spreekt derhalve over zijn visie als "a theory of bounded rationality". ${ }^{84}$

Ter adstructie van zijn theorie maakt Simon een vergelijking met beslissingen te nemen in de loop van een schaakspel. Deze vergelijking is beslist het vermelden waard.

Bij een absoluut rekenkundig vermogen zouden alle mogelijke posities en combinaties van zetten voor het schaakspel in kaart kunnen worden gebracht. Een speler zou daaruit slechts nog de meest rendabele zetten behoeven te kiezen. In de praktijk is dit echter moeilijk te realiseren. Op een willekeurig

82. Ibidem.

83. Ibidem, p. 43.

84. Simon, H.A., Models of bounded rationality, Volume 2, Behavioral economics and business organization, Cambridge (USA), 1982, p. 401-494, i.h.b. p. 409. 
moment in een schaakspel zijn er gemiddeld zo'n 30 denkbare voortzettingen, waarop in totaal zo'n $10^{3}$ aan mogelijke reacties denkbaar zijn. Veertig zetten zouden in totaal een overzicht vergen van plusminus $10^{120}$ denkbare zetten. Het is duidelijk; hier is geen beginnen aan. Spelers moeten derhalve een strategie bedenken om ondanks hun beperkte informatie-verwerkende capaciteiten toch tot een bevredigend resultaat te komen.

Schaakspelers kiezen volgens Simon voor een strategie die kan worden aangeduid met de term "satisficing". ${ }^{85} \mathrm{Zij}$ overwegen niet alle mogelijkheden, doch ontwerpen en onderzoeken een beperkt aantal mogelijkheden, totdat één daarvan hen bevredigend voorkomt, welke zij dan kiezen.

De satisficing-strategie leidt (aldus) vanzelf tot de keuze van een bepaald alternatief. Dit lijkt mij echter slechts mogelijk als op enig moment ook een voorkeurvolgorde in de geselecteerde alternatieven wordt aangebracht: alleen dan kan het stoppen van de besluitvorming nadat het "eerste de beste" alternatief het aspiratieniveau overschrijdt, leiden tot de relatief beste beslissing. Mij dunkt dat een voorkeurvolgorde pas kan worden aangebracht nadat de geselecteerde alternatieven zijn onderzocht. Het aspiratieniveau is immers in eerste instantie slechts op vermoedens omtrent het haalbare gebaseerd. Simon $^{86}$ benadrukt de noodzaak van een dynamische optiek; als het aspiratieniveau niet wordt aangepast aan de bevindingen, bestaat de kans dat in het zicht van betere alternatieven toch een slechtere wordt gekozen - omdat de aspiraties "nu eenmaal" niet zo hoog waren gesteld.

Het is natuurlijk denkbaar dat geen van de in eerste instantie geselecteerde (voor de hand liggende) alternatieven aan het aspiratieniveau voldoet. Meerdere mogelijkheden doen zich dan voor. Allereerst kan onder handhaving van het aspiratieniveau een nieuwe selectie van alternatieven worden gemaakt - de eerste selectie was wellicht gewoon niet zo gelukkig. De procedure kan dan opnieuw beginnen. Ook is denkbaar dat het aspiratieniveau zodanig wordt aangepast dat én van de reeds geselecteerde alternatieven alsnog voldoet. ${ }^{87}$ Ten slotte is het mogelijk dat het aspiratieniveau wordt gehandhaafd maar dat geen nieuwe selectie wordt gemaakt. Er is geen twijfel over de juistheid van de selectie van te onderzoeken alternatieven en geen bereidheid (of mogelijk-

85. Simon, a.w., p. 412-418.

86. A.w., p. 453.

87. De suggestie is hier dat dit achteraf gebeurt. Bijstelling tijdens het onderzoek is bezwaarlijk omdat men nog niet weet welke mogelijkheden in de alternatieven besloten liggen (wellicht worden interessante, reeds geselecteerde alternatieven uitgesloten, voordat hun mogelijkheden ten volle zijn geopenbaard). 
heid) om het aspiratieniveau aan te passen: geen van de alternatieven is aanvaardbaar. ${ }^{88}$

De selectie van alternatieven geschiedt - zoals dat heet - op de grondslag van "ervaringskennis". ${ }^{89}$ Daarmee gewapend moeten alternatieven worden gezocht die de belofte inhouden dat zij tot een bevredigend besluit kunnen leiden. Hierbij passen twee opmerkingen.

In de eerste plaats dat dit zoekproces neigt tot een sjabloonmatige aanpak: eerder gekozen oplossingen zullen als eerste van stal gehaald worden - het probleemoplossend vermogen daarvan is immers bekend. Simon onderstreept dat het van groot belang is om methodes van selectie en evaluatie steeds te verbeteren; alleen zo kan het heuristisch vermogen bij besluitvorming worden verbeterd..$^{90}$

In de tweede plaats dat het aspiratieniveau reeds bij de selectie van alternatieven een zekere invloed zal hebben. Er wordt natuurlijk niet "ins Blaue hinein" geselecteerd. De wens een bepaald probleem op te lossen vormt doorgaans de basis voor de besluitvorming (bij voorbeeld de beoordeling van een vergunningsaanvraag - zie \$ 4.3.3). Er moet richting worden gegeven aan het selectie-proces. Het lijkt mij waarschijnlijk dat aspiraties van de besluitvormer hierbij als een "zoeklicht" fungeren"1 - zij het in een algemene (globale of ideaaltypische) zin. Grote precisering voorafgaand aan nader onderzoek vergroot immers de kans op uitsluiting op voorhand van interessante alternatieven. In negatieve zin zullen evident oninteressante opties kunnen worden uitgesloten. Zo zullen in een op winst gerichte onderneming de alternatieven die geen (enkele) belofte op winst inhouden, niet worden geselecteerd. In omgekeerde zin zullen beloftevolle alternatieven (zoals beslissingen die in soortgelijke gevallen hun winstgevendheid hebben bewezen) juist wel worden geselecteerd.

\subsubsection{Juridische beslissingen}

Hoe kan deze strategie nu worden gevolgd als het gaat om juridische beslissingen - bij voorbeeld bij de beslissing op een aanvraag van een Wm-vergunning?

\subsubsection{Juridische condities}

Daarvoor is het belangrijk te bedenken dat de bestuurlijke besluitvorming is onderworpen aan eigensoortige juridische condities. Essentieel daarin is dat

88. Dat impliceert natuurlijk ook een besluit: een besluit om niets te besluiten.

89. Rosenthal. a.w., p. 43.

90. Simon, a.w., p. 417-418. Men staat meer open voor nieuwe oplossingen.

91. In veel gevallen vloeit het probleem voort uit een aspiratie: het streven naar winst - de mogelijkheid om een bepaalde investering to plegen. 
er een concreet voornemen in de vorm van een aanvraag voorligt. Het probleem wordt als het ware van buitenaf opgelegd. Afwijkingen van de aanvraag zijn weliswaar mogelijk, maar dan gaat het toch al snel om marges. Belangrijk is voorts dat het bestuur op zijn wijze van besluitvormen en de inhoud van het genomen besluit door een rechter kan worden aangesproken. Het bestuurlijk handelen moet daarbij de toets aan het recht kunnen doorstaan. Wat het bestuur ook aspireert, steeds zal het de vraag moeten stellen of het daarbij binnen de grenzen van het recht blijft. In aansluiting daarop moeten we bedenken dat het aspiratieniveau van het bestuur in belangrijke mate door de wetgever wordt gedicteerd. De wetgever stelt de toepassingscondities voor bestuursbevoegdheden vast. Daarmee is bepaald aan welke voorwaarden voldaan moet zijn wil een bestuursorgaan van een bevoegdheid gebruik kunnen maken. Nu kan het zijn dat de wetgever daarbij enige discretie aan het bestuur heeft gelaten. Soms heeft het bestuur een belangrijke stem in de uitleg van de toepassingscondities. Deze beoordelingsvrijheid laat echter onverlet dat het bestuur binnen de grenzen van de marginale redelijkheidstoets moet blijven. Ook is denkbaar dat de toepassingscondities zijn gedicteerd, maar dat de vraag of een bevoegdheid wordt gebruikt weer vrij is gelaten. Deze beleidsvrijheid laat echter onverlet dat elke keuze die het bestuur uiteindelijk maakt moet passen bij de desbetreffende toepassingscondities en overigens de marginale redelijkheidstoets moet kunnen doorstaan.

Genoemde condities komen goed tot uitdrukking bij de Wm-vergunning. De beslissing op aanvraag is onderworpen aan een rechterlijke rechtmatigheidstoets. Toepassingscondities zijn van belang bij de bevoegdheid tot afwijzen van de aanvraag (art. 8.10, eerste lid $\mathrm{Wm}$ ), de bevoegdheid om de vergunning onder beperking te verlenen (art. 8.11, tweede lid Wm) en de bevoegdheid tot het geven van vergunningvoorschriften (art. 8.11, derde lid Wm). Bij al deze bevoegdheden staat (het belang van) de bescherming van het milieu als toepassingsconditie centraal. ${ }^{92}$ Zo het bestuur besluit een vergunning te weigeren of een vergunning onder beperkingen te verlenen of aan een vergunning voorschriften te verbinden, dan zal dit slechts mogelijk zijn indien zulks in het belang van (de bescherming van) het milieu (nodig) is. ${ }^{93}$

92. Bij het geven van voorschriften komt daar het bestanddeel van de noodzaak daartoe ("nodig zijn ter") nog bij.

93. Kortom: alleen het zonder beperking of voorbehoud verlenen van de vergunning (volstrekt i.o.m. de aanvraag) is een volstrekt vrije bevoegdheid. Zolang het bestuur de burger vrijheid laat te doen wat hij begeert is de bevoegdheid ongeclausuleerd. Dat laat natuurlijk onverlet dat er goede gronden kunnen zijn - bij voorbeeld met het oog op de belangen van derden - om juist wel te weigeren, danwel bij verlening beperkingen of voorschriften toe te passen. 


\subsubsection{De selectie}

Bezien we nu de eerste stap in de satisficing-strategie: de selectie. Op basis van de aanvraag zal het bestuur een selectie van voor de hand liggende alternatieven maken. Op basis van ervaringsregels zijn verschillende alternatieven te genereren. Uitgaande van de aanvraag zijn wellicht alternatieven naar locatie, wijze van uitvoering, methode en doelstelling te expliciteren. ${ }^{94}$ Daarnaast is eventueel een "nul-alternatief" (de uitgangssituatie met inbegrip van autonome ontwikkelingen) te selecteren.

Het is van belang dat de selectie niet te nauw wordt gemaakt. Beperking is natuurlijk noodzakelijk, maar voorkomen moet worden dat (mogelijk) interessante alternatieven op voorhand worden uitgesloten. In positieve zin moet het uitgangspunt zijn dat alle "redelijkerwijs in beschouwing te nemen alternatieven"95 worden onderzocht. Dit impliceert in negatieve zin dat alle "kennelijk ongeschikte" alternatieven buiten de selectie vallen. Voor de beoordeling van de geschiktheid of ongeschiktheid van alternatieven zijn twee ijkpunten van belang: het algemene aspiratieniveau en de inschatting van de veelbelovendheid in technische zin (naar ervaringskennis ${ }^{96}$ ).

Als gezegd ziet het bestuur zich bij de selectie van alternatieven in het kader van een Wm-vergunningsaanvraag geconfronteerd met een richtinggevend aspiratieniveau dat in belangrijke mate van buitenaf wordt gedicteerd. In negatieve zin geldt immers de algemene regel dat niet in strijd met het recht mag worden gehandeld. Alternatieven waarvan op voorhand gezegd kan worden dat deze in strijd zullen zijn met het recht vallen derhalve af: zij zijn kennelijk ongeschikt.

In dat opzicht vervullen de toepassingscondities een belangrijke rol. $\mathrm{Zij}$ stellen een specifieke grens aan het selecteren van alternatieven. Alternatieven inhoudende het weigeren van de vergunning of het (in enigerlei vorm) verlenen onder beperkingen kunnen slechts in overweging worden genomen indien zij hun grond vinden in de vrees voor aantasting van het milieubelang. Ook andere geschreven juridische beperkingen kunnen een rol spelen, zoals de wettelijk geregelde grenswaarden. ${ }^{97}$ Daarnaast is ook het ongeschreven recht van belang. Zo kunnen het vertrouwens-, het gelijkheids- en het rechts-

94. Vgl. voor deze en nog volgende alternatieven, Udo de Haes, H.A. en J.P.M. Bol, Voorspelling en beoordeling van effecten op het natuurlijk milieu, in: Nijkamp. P.. H.E. van de Veen en P. Winkel (reds.), Milieu-effectrapportering. Assen 1981, p. 120-137, i.h.b. p. 121-122.

95. Ik ontleen deze term aan de regeling voor de milieu-effectrapportage (kortweg mer - vgl art. 7.10 , eerste lid onder b. Wm). In Hoofdstuk 7 ga ik nader op de mer in.

96. Meer precies: aanwijzingen vanuit de ervaringskennis of een alternatief aan het algemene aspiratieniveau zal kunnen voldoen.

97. Een alternatief dat evident in strijd zal komen met zo'n grenswaarde, valt af. 
zekerheidsbeginsel er aanstonds toe leiden dat bepaalde alternatieven buiten selectie blijven. ${ }^{98}$

Aan de andere kant geeft het recht ook positief te duiden aanwijzingen over redelijkerwijs in beschouwing te nemen alternatieven. Heel specifiek kan dat gezegd worden van art. 8.8, eerste lid $\mathrm{Wm}$ dat uitdrukkelijk aangeeft dat het bestuur bepaalde zaken van feitelijke aard in ogenschouw moet nemen. ${ }^{90}$ Meer in algemene zin kan de regel van art. 3:4 Awb worden gezien als een aanwijzing aan het bestuur om een beslissing te nemen met de geringste last voor burgers, of - nog positiever gesteld - met het grootste netto-belangenresultaat. ${ }^{100}$ Dit brengt ook mee dat het bestuur acht moet slaan op suggesties van betrokkenen inzake te onderzoeken alternatieven. ${ }^{101}$ Zo zal moeten worden gezocht naar alternatieven die het belang van de aanvrager (zoals dat primair uit het in de aanvraag neergelegde alternatief naar voren komt) dienen. ${ }^{102}$ Hetzelfde geldt voor de belangen van derde-belanghebbenden. Overigens wordt in de toelichting bij art. 3:4, eerste lid Awb, gesteld dat alleen belangen die rechtstreeks bij het besluit zijn betrokken behoeven te worden meegewogen. Geen rekening behoeft te worden gehouden met belangen die in een "meer verwijderd verband door de beslissing kunnen worden getroffen. ${ }^{103}$

Ook de rechtens gelaten beleidsvrijheid is natuurlijk een positieve aanwijzing: het bestuur kan zelf beleidsvoorkeuren ontwikkelen. Belangrijk is daarbij echter wel dat deze beleidsvoorkeuren er niet toe mogen leiden dat (andere) redelijkerwijs in beschouwing te nemen alternatieven buiten beschouwing blijven. ${ }^{104}$ De beleidsvoorkeuren van het bestuur stimuleren mitsdien vooral tot uitbreiding van het aantal te onderzoeken alternatieven. Hier speelt ook het element van de rechterlijke toets weer een rol: uitbreiding van te onderzoeken alternatieven is niet bezwaarlijk; uitsluiting van een redelijkerwijs in beschouwing te nemen alternatief kan op onrechtmatig handelen uitdraaien.

98. Omdat keuze voor het alternatief (uiteindelijk - in beginsel) toch onrechtmatig moet worden geacht (wegens schending van opgewekt vertrouwen, discriminatoir karakter, of gebrek aan rechtszekerheid).

99. Zoals de autonome milieu-ontwikkeling (onder c.) en de meest milieuvriendelijke "variant" (onder e.).

100. Zie hierover hoofdstuk 6. Het zal duidelijk zijn dat art 3:4 Awb ook een beperkende rol speelt; alternatieven waarin een relevant belang eenvoudig wordt genegeerd kunnen (wegens kennelijke ongeschiktheid) buiten beschouwing blijven.

101. Dit volgt overigens ook uit art. 8.8, eerste lid onder $\mathrm{d} W \mathrm{~m}$.

102. Tenzij dit (in alle voor de aanvrager aanvaardbare varianties) aanstonds stuit op juridische restricties - in welk geval afwijzing in de rede ligt.

103. MvT-Awbl, a.w., p. 68. Blijkens deze toelichting moet daarbij gedacht worden aan "min of meer toevallige effecten die het bestuursorgaan niet zonder zeer verregaande informatieverzameling zou kunnen kennen."

104. De beleidsvoorkeuren moeten bovendien blijven binnen de grenzen die het specialiteitsbeginsel stelt. 
De eigen beleidsvoorkeur van het bestuur is overigens nog van belang voor een volgende stap, te weten het ontwikkelen van een voorkeursvolgorde in alternatieven - nadat deze zijn onderzocht.

Hierboven stelde ik dat de aspiratie als koersaanwijzing voor selectie een "algemene" (globale of ideaaltypische) vorm heeft - teneinde niet op voorhand alternatieven uit te sluiten. Voor het bestuurlijk handelen is duidelijk dat dit beeld niet helemaal opgaat. Voorzover dit niet opgaat is het primair het gevolg van denkwerk dat reeds door de wetgever is verricht. Deze heeft het aspiratieniveau reeds voor een "onbepaalde groep van gevallen" bepaald. Overigens zijn de criteria van de wetgever soms toch nog globaal: de toepassingsconditie van art. 8.10 , eerste lid $\mathrm{Wm}$ is natuurlijk nog betrekkelijk vaag - ook al is deze wel scherp bedoeld. ${ }^{105}$ Wat de ongeschreven aspiraties betreft hebben vele normen een vaag karakter. ${ }^{106} \mathrm{Bij}$ toepassing in het concrete geval verwerven zij scherpte.

Ik wijs er overigens op dat bij de selectie, met name als het gaat om de rechtens geldende restricties, sprake is van een prima facie beoordeling. Alleen (op voorhand) evident onrechtmatige varianten - of anderszins kennelijk ongeschikte alternatieven ${ }^{107}$ vallen buiten de boot. Ook beleidsvoorkeuren zullen doorgaans nog betrekkelijk algemeen of open geformuleerd zijn. Er moet weliswaar geselecteerd worden, maar tegelijkertijd moet uitsluiting van interessante alternatieven worden voorkomen.

Als gezegd moet het bestuur ook reageren op suggesties van belanghebbenden. In de openheid van de procedure, c.q. de mogelijkheid van inspraak, ligt een belangrijke waarborg dat alle redelijkerwijs in beschouwing te nemen alternatieven ook daadwerkelijk worden meegenomen. Het is echter de vraag of elk alternatief dat wordt aangedragen ook in beschouwing moet worden genomen. De vraag is daarbij toch in het bijzonder waar een alternatief redelijkerwijs niet meer in beschouwing behoeft te worden genomen. Afwijzing op basis van eigen bestuurlijke aspiraties is natuurlijk niet op zijn plaats. ${ }^{108} \mathrm{Wel}$ is denkbaar dat als voorshands aannemelijk is dat een alternatief in strijd met het recht zal blijken, het buiten beschouwing wordt gelaten. Ook kan het alternatief met name zien op de behartiging van een belang dat slechts in een zeer ver verwijderd verband bij de te nemen beslissing is

105. De rechter sanctioneert de scherpte doordat hij zijn eigen precieze interpretatie dwingend "voorschrijft".

106. Denk maar aan de eisen van art. 3:2-4 Awb.

107. De in technisch(-wetenschappelijk) opzicht twijfelachtige (d.i. niet veelbelovende) alternatieven.

108. Het bestuur kan zijn eigen (voorlopige) belangenafweging (al dan niet neergelegd in een beleidsregel) natuurlijk niet hanteren ter sereening van aangereikte alternatieven. 
betrokken. ${ }^{109}$ Ten slotte kan zich de situatie voordoen dat betwist wordt of het aangereikte alternatief "naar ervaringskennis" veelbelovend kan worden genoemd. Hier komt het aan op een technisch oordeei; houdt het gesuggereerde alternatief de belofte in dat daarmee het aspiratieniveau wordt bereikt? Zo kan een belanghebbende betogen dat het alternatief "weigeren" wel degelijk onderzocht moet worden, terwijl het bestuur van mening is dat daartoe onvoldoende grond bestaat nu er geen aanwijzingen zijn dat significante milieu-effecten te duchten zijn. De belanghebbende zal toch enigermate aannemelijk moeten maken dat het de moeite waard is om dit alternatief nader te onderzoeken. In deze discussie is het denkbaar dat de benadering van de "verwachte marginale meeropbrensten" een rol gaat spelen. Het onderzoek naar aanwijzingen voor milieu-effecten zou kunnen worden doorgezet totdat de verwachte verbetering van alternatieven in elk geval in evenwicht is met de marginale kosten van de extra onderzoeksinspanning. Probleem is echter dat op voorhand vaak moeilijk valt te voorspellen wat nu precies de verbetering van alternatieven zal zijn omdat het onderzoek nog moet plaatsvinden. ${ }^{110}$ In dat opzicht zou het bestuur toch kunnen verlangen dat op z'n minst aannemelijk wordt gemaakt dat het onderzoek een interessant alternatief zal opleveren. ${ }^{\prime \prime \prime}$

\subsubsection{Het onderzoek}

Als de redelijkerwijs in beschouwing te nemen alternatieven zijn geselecteerd, kan het onderzoek naar de feiten beginnen. Gelet op de geldende toepassingscondities zal het feitenonderzoek zich primair moeten richten op de effecten van het voorgenomen handelen op het milieu. Met het oog op de belangenafweging is het voorts - in het verlengde van dit feitenonderzoek nodig om na te gaan wat per alternatief de effecten op de andere betrokken belangen zijn. De vraag rijst hoe ver dit feitenonderzoek moet worden doorgezet.

Gegeven de beperkte tijd en de beperkte middelen die voor onderzoek beschikbaar zijn is dit een nijpende vraag. Het is daarom wenselijk om ook voor de geaspireerde nauwkeurigheid, omvang en diepgang van het onder-

109. "Betrokken", maar niet "getroffen": vgl. Bolt, H., de Awb en het begrip 'belanghebbende', NJB'93/15, p. 553-554.

110. Vgl. Simon, a.w., p. 417-419.

111. Belanghebbende zou bij voorbeeld moeten omschrijven welke test hij voorstaat, hoe die kan worden uitgevoerd en wat die test kan opleveren. Daartoe zou hij kunnen verwijzen naar onderzoek van deskundigen. In de procesrechtelijke context ligt deze kwestie overigens relatief eenvoudig: de belanghebbende moet zijn belanghebbendheid eerst aannemelijk maken. Wat zijn kritiek op de volledigheid van de feitenvaststelling betreft zal hij tenminste aannemelijk moeten maken op welke wijze zijn belang geraakt zou kunnen worden door feiten die het bestuur buiten beschouwing laat. 
zoek een soort van "stopregel" te vinden. Een positiefrechtelijke stopregel voor de vereiste ligt besloten in de regel van art. 3:2 Awb: het bestuur moet de nodige kennis verzamelen. In de toelichting op dit artikel wordt gesteld "dat bij elk specifiek besluit bepaald kan worden hoever de kennisvergaringsplicht reikt". ${ }^{112}$ Daartoe kunnen verschillende positieve aanwijzingen voor een onderzoeksplicht op een rij worden gezet, zoals de mate van beleidsvrijheid, het beroep van een belanghebbende op bijzondere omstandigheden of het omstreden zijn van bepaalde gegevens. ${ }^{113}$

Een aan art. 3:2 Awb te ontlenen "stopregel" veronderstelt naar mijn oordeel een zekere selectie. Door de precisering "nodige kennis omtrent de relevante feiten" is niet alleen ruimte voor een selectie in termen van redelijkerwijs in beschouwing te nemen alternatieven, maar ook naar redelijkerwijs in beschouwing te nemen effecten. Ook daar is een aspiratieniveau op zijn plaats. Ik zou menen dat dit aspiratieniveau in de eerste plaats wordt bepaald door de toepassingsconditie in kwestie. Vage termen zullen moeten worden geinterpreteerd. Zo zal interpretatie van "het belang van de bescherming van het milieu" in art. 8.10, eerste lid $\mathrm{Wm}$ helderheid moeten bieden over de nauwkeurigheid, diepgang en omvang van het onderzoek naar milieu-effecten. ${ }^{114}$ Daarnaast (en in verband daarmee) zou ik menen dat een evenredigheidsmaatstaf in het geding is ${ }^{115}$ : het onderzoek naar feiten en belangen moet zover reiken als nodig is met het oog op de bescherming van de belangen die bij de bevoegdheid(suitoefening) betrokken zijn. Met deze evenredigheidsmaatstaf gaat het er om "redelijke zekerheid"116 te verkrijgen over de mate waarin de betrokken belangen in het geding zijn. De eis van redelijke zekerheid zal daarbij inhoudelijk primair variëren met het gewicht en de kwetsbaarheid van de betrokken belangen. In samenhang daarmee is van belang of de effecten van een eventueel te nemen besluit op betrokken belangen al dan niet bekend of omstreden zijn. Voor elk concreet geval zal over de juistheid en volledigheid van de feitenvaststelling een bepaalde mate van zekerheid moeten worden bereikt. Opnieuw is het niet de bedoeling dat het bestuur hierbij een belangenafweging vooraf gaat plegen. Wel is het noodzakelijk dat als een rechtens relevant effect op een van de betrokken belangen

112. MvT-Awbl, p. 64. Vgl. ook M.H.Kobussen. Commentaar op art. 3:2, in: Ten Berge et al. (red.), Algemene wet bestuursrecht, a.w., E3.2.1-4 (ABR 11/40).

113. Kobussen, a.w., E 3.2.1-4/9, gaat op enkele van deze aanwijzingen nader in.

114. Soms kan men zich beperken tot alleen bepaalde milieu-effecten (stank, trilling, luchtverontreiniging), soms volstaat een algemene indruk ("enig effect is genoeg om te weigeren"), soms is het nodig lang door te zoeken ("we moeten zeker weten dat er echt geen risico's zijn - elk risico is te groot").

115. Zeker waar het gaat op (andere) betrokken belangen.

116. Ik ontleen deze term aan het procesrecht. Vgl. Ten Berge, J.B.J.M. en A.Q.C.Tak, Nederlands Administratief procesrecht, Zwolle 1983, deel I, p. 372-373. 
aannemelijk zou zijn, in het feitenonderzoek wordt getracht daarover uitsluitsel te krijgen. De eis die art 3:2 Awb stelt zal bij een rechterlijke toets (opnieuw) vooral een controle zijn op de vraag of het bestuur wellicht te weinig heeft gedaan. Als het bestuur meer uitzoekt dan strikt noodzakelijk, is dat geen probleem. ${ }^{117}$ Als echter wordt geklaagd over het feit dat een effect niet of nauwelijks is onderzocht, terwijl de rechter het aannemelijk acht dat dit effect voor én der betrokken belangen rechtens relevante gevolgen zou kunnen hebben, zal de feitenvaststelling moeten worden aangevuld.

Als de belangen groot (en kwetsbaar) zijn kan de wens van een hoge mate van zekerheid twee consequenties hebben die ik hier nog even specifiek wil noemen.

In de eerste plaats is denkbaar dat deze eis tot uitdrukking komt in de wens van strenge eisen aan de adequaatheid en accuratesse van de voorspelde effecten. De kans dat de werkelijkheid zal afwijken moet zo klein mogelijk worden gemaakt. Toegepast op art. 8.10, eerste lid $\mathrm{Wm}$ zou dit leiden tot de stelregel, dat het onderzoek niet mag stoppen als niet aanstonds blijkt van enig gevaar van aantasting van het leefmilieu. Er moet goed worden (door) gezocht, tot het risico op onvoorziene aantasting zeer klein is geworden. ${ }^{118}$ Evenzo zal bij alternatieve varianten van een eventueel te verlenen vergunning, een hoge mate van zekerheid moeten worden verworven over de adequaatheid en accuratesse van de voorspelde effecten.

Ook hier rijst de vraag of het criterium van de "verwachte marginale meeropbrengsten" een aanvullende rol kan spelen. Zelfs als levensbelang in het geding is gaat het niet aan om het onderzoek voort te zetten totdat "bijna absolute zekerheid" is bereikt. ${ }^{119}$ Het probleem van het genoemde criterium is echter - als gezegd - dat het maar de vraag is of het mogelijk is schattingen te geven van opbrengsten die nu juist onbekend zijn omdat het onderzoek (daarnaar) nog moet beginnen. Opnieuw moet de conclusie mijns inziens zijn dat als aannemelijk gemaakt kan worden dat nader onderzoek echt tot meeropbrengsten (in termen van vergroting van zekerheid) ${ }^{120}$ zal leiden, de stap daartoe gezet zou kunnen worden. In de finale analyse lijkt mij echter het

117. Tenzij dit tot termijnoverschrijding leidt.

118. Let wel: ik spreek over de kans op nog onvoorziene effecten. niet over de ernst van de voorziene effecten - en daarmee ook niet over de vraag of alsnog aan de toepassingsconditie is voldaan (dat is een zaak van kwalificatie die op het onderzoek volgt).

119. In de context van het milieubelang is dit bepaald geen exotische stelling. Nog daargelaten dat in veel gevallen van levensbelang juist zeer snel reageren op z'n plaats zal zijn.

120. D.w.z. informatie die invloed heeft op de reeds bereikte zekerheid omtrent de feiten in een mate die het nader onderzoek daarna rechtvaardigen: significante bevestiging of aanvechting van de onderzoeksresultaten van dat moment. 
criterium van de hoegrootheid van de betrokken belangen steeds doorslaggevend. Anders gezegd: er moet tenminste twijfel bestaan ${ }^{121}$ over het reeds bereikt hebben van redelijke zekerheid, willen verwachtingen over marginale meeropbrengsten nog relevant kunnen zijn. ${ }^{122}$

In de tweede plaats kan het naast de wens van een grote zekerheid omtrent de adequaatheid en accuratesse van een voorspelling, soms ook gaan om het streven naar een zo groot mogelijke zekerheid dat, indien de voorspelling niet juist blijkt, een bepaald (zwaarwegend) belang daarvan in elk geval niet de dupe zal worden. Bepaalde betrokken belangen kunnen zo zwaarwegend worden geacht dat zelfs de geringste aanwijzing van aantasting voldoende grond vormt om een bepaalde beslissing te nemen. Voorstelbaar is dat bepaalde milieu-effecten zo dreigend worden geacht dat de enkele aanwijzing dat er wel iets mis zou kunnen gaan voldoende reden zou kunnen zijn tot afwijzing van de desbetreffende vergunningaanvraag. Evenzo zou het reden kunnen zijn om snel te concluderen dat verlening van de vergunning slechts onder beperking mogelijk zal zijn. Nader onderzoek wordt slechts ondernomen als er wel zeer sterke aanwijzingen zijn dat daarmee mogelijk "alle twijfel" omtrent het gevaar van aantasting van het milieubelang kan worden weggenomen. Eigenlijk wordt hier gepreludeerd op de belangenafweging aan een bepaald belang wordt immers reeds op voorhand een bijzondere positie toegekend. Dat kan gebeuren doordat op enigerlei gezaghebbende wijze duidelijk wordt dat interpretatie van een toepassingsconditie onder het motto "safety-first" (of "no regrets") dient plaats te vinden. Overigens is ook denkbaar dat in de uiteindelijke keuze tussen onderzochte alternatieven wordt gezocht naar dit type zekerheid: het alternatief dat de minste risico's oplevert op ernstige milieu-effecten op het moment dat de voorspelling faalt, heeft dan een zekere voorkeur. ${ }^{123}$

Naast de stopregel welke ligt besloten in art. 3:2 Awb, en die een materiële strekking heeft, is in veel bestuurlijke procedures ook een formele stopregel van kracht: de termijnstelling voor het nemen van een besluit - al dan niet met de mogelijkheid tot termijnverlenging.

121. Of door de voorstanders van extra onderzoek worden opgewekt.

122. Deze benadering zet een premie op een goede heuristiek: het vermogen om uitspraken te kunnen doen over de to verwachten uitkomsten van nog te ondernemen onderzoek is een belangrijke vaardigheid in de discussie over al dan niet voortzetten van het onderzoek. Simon, a.w., p. 417-418, benadrukt het belang van goede evaluaties, opdat bij volgend onderzoek, een meer rendabele onderzoeksmethode wordt gevonden.

123. Hier rijst alweer de vraag hoe we kunnen inschatten welk alternatief, juist bij het falen van onze voorspellingen, de minste risico's geeft. Ervaringskennis zal hier algemene aanwijzingen moeten verschaffen. 


\subsubsection{De toetsing aan het aspiratieniveau}

De selectie van te onderzoeken alternatieven had de ervaringskennis als algemene basis. Richtinggevend voor de selectie van alternatieven waren de veelbelovendheid van alternatieven gelet op de belangen van betrokkenen en de voorlopige voorkeur van het bestuur (positieve selectie), terwijl daarnaast de "evidentie" van onrechtmatigheid van voorgedragen alternatieven een (negatief) selecterende rol speelde.

Als in het feitenonderzoek voor én of meer alternatieven redelijke zekerheid is bereikt ${ }^{124}$, kunnen deze vervolgens in volgorde van voorkeur worden geplaatst. Daarna kunnen de alternatieven achtereenvolgens aan het aspiratieniveau worden getoetst. Het eerste de beste alternatief dat deze toets doorstaat geeft een bevredigende beslissing, waarop het onderzoek (c.q. de besluitvorming) (voorlopig) kan worden afgerond. ${ }^{125}$

Het aanleggen van een voorkeurvolgorde geschiedt primair aan de hand van beleidsmatige voorkeuren van het bestuur. Welke voorkeuren het bestuur heeft zal soms vooraf reeds kenbaar zijn, aan de hand van plannen, beleidsregels, nota's, coalitie-afspraken, bestendig gebruik en wat dies meer zij. ${ }^{126}$

De volgende stap behelst een indringende toets van de onderzochte alternatieven aan de eisen van het recht; en wel in volgorde van de vastgestelde voorkeur. Het kan zijn dat alternatieven in hun uitgewerkte vorm alsnog in strijd met het recht blijken te zijn. ${ }^{127}$ Ook is overigens denkbaar dat bij onderzoek blijkt dat éen of meer alternatieven niet zo veelbelovend waren als wel werd verwacht - dat zal primair gevolgen hebben voor hun plaats in de rangorde van voorkeuren. ${ }^{128}$ Niet onbelangrijk is ten slotte nog, dat alternatieven natuurlijk niet alleen op strijd met het recht worden getoetst maar ook op hun doelmatigheid, hun bijdrage tot handhaving of gewin aan politieke steun en dergelijke. Ook toetsing op deze aspecten zal effect (kunnen) hebben op de voorkeurvolgorde. De toets aan het recht is bij uitstek zo belangrijk omdat onrechtmatigheid voor het besluit de doodsteek kan betekenen. Het bestuur doet er goed aan zich er rekenschap van te geven dat de rechter tot het verrichten van een rechtmatigheidstoets over het besluit kan worden

124. Als dat moeilijk blijkt is uiteraard denkbaar dat hangende het feitenonderzoek alternatieven worden aangepast.

125. Allereerst zijn er nog formele eisen, bij voorbeeld in de sfeer van de bekendmaking en motivering. Ook is denkbaar dat het slechts om een ontwerp-besluit gaat, dat eerst nog de inspraak in gaat.

126. Als er een uitdrukkelijke beleidsregel is, is het mogelijk dat daaraan onderzoek ten grondslag ligt dat de selectie van alternatieven en de wijze van onderzoek daarnaar, in belangrijke mate voorprogrammeert. Dat laat echter onverlet dat het bestuur steeds moet controleren of er in het concrete geval eigen-aardigheden in het geding zijn.

127. Nadere studie heeft uitgewezen dat bij voorbeeld een grenswaarde wordt overschreden.

128. Het kan ook betekenen dat omtrent het desbetreffende alternatief geen "redelijke zekerheid" wordt bereikt, zodat het buiten de toetsing blijft. 
geroepen. ${ }^{129}$ Een belangrijke eis lijkt mij gelegen in art. 3:4, tweede lid Awb: er mag geen onevenredigheid bestaan tussen met een besluit te dienen doelen en de voor belanghebbenden nadelige gevolgen daarvan. De negatieve strekking van dit voorschrift geeft precies aan hoever de rechtmatigheidstoets hier reikt. Het is mitsdien maar de vraag of het bestuur ertoe gehouden is om het grootste netto-belangenresultaat te verkiezen. De rechter zou het bestuur daarop slechts kunnen "aanspreken" als het gekozen alternatief, juist in het licht van andere alternatieven de onevenredigheidstoets niet doorstaat. ${ }^{130}$ Overigens is denkbaar dat het bestuur bij het bepalen van een volgorde van onderzochte alternatieven, ${ }^{131}$ het beperken van nadelige gevolgen expliciet tot doel stelt. Zodoende zal het eerste besluit dat de toets aan art. 3:4, tweede lid Awb doorstaat ook meteen het (relatief) minst belastende besluit kunnen zijn.

Zodra, uitgaande van de definitieve voorkeurvolgorde een alternatief deze toets doorstaat, kan het onderzoek stoppen. Of ook de andere alternatieven deze toets doorstaan is in beginsel irrelevant. Op die regel moet een uitzondering worden gemaakt als er twijfel zou ontstaan over de oorspronkelijke selectie van alternatieven. Zeer concreet kan dit zich voordoen indien alsnog een nieuw en aantrekkelijk alternatief wordt voorgesteld. ${ }^{132}$

In de voorgestelde benadering is het eerste alternatief dat de rechtmatigheidstoets doorstaat (uitgaande van een voorkeurvolgorde) meteen het relatief beste alternatief. Dit is alleen acceptabel als pas na het onderzoek het aspiratieniveau definitief wordt vastgesteld. Dit impliceert in de eerste plaats dat pas dan een voorkeursvolgorde wordt bepaald. ${ }^{133}$ Bovendien wordt de toetsing aan het recht (die bij de selectie alleen op evidente strijd plaatsvond) nu veel preciezer en kan deze met meer aandacht voor de specifieke kenmerken van elk der uitgezochte alternatieven geschieden.

129. Ik sluit niet uit dat het bestuur soms willens en wetens risico's neemt - bij voorbeeld met het oog op politicke verhoudingen. Als er problemen komen kunnen die doorgaans in de bezwaarschriftenprocedure worden gladgestreken.

130. De rechter voert dan in feite een vergelijkende toets uit: bij de "niet-onevenredigheidstoets" wordt tevens naar de alternatieven gekeken (en niet alleen naar het besluit zelf). In de praktijk worden natuurlijk toch vergelijkingen gemaakt, al is het maar omdat de appellant daartoe zelf de opstapjes geef. Toch mag de rechter niet uit het oog verliezen dat art. 3:4, tweede lid Awb1 niet tot "de meest evenredige beslissing" verplicht, maar onevenredigheid verbiedt; daartussen zit de beleidsmarge van het bestuur. Ik gebruik de term "aanspreken" (in de voorgaande zin in de tekst) met opzet: de rechter kan over de beste beslissing met het bestuur in discussie gaan, maar zijn toets behoort terughoudender te zijn.

131. Uiteraard na het onderzoek naar de alternatieven. Eerder is het geven van een voorkeurvolgorde toch een betrekkelijk speculatieve aangelegenheid - zeker als er meerdere tegengestelde belangen in het geding zijn.

132. Bij voorbeeld in de inspraak.

133. Toetsing aan het aspiratieniveau vindt plaats in volgorde van (positieve) voorkeur. 
Als slechts een alternatief met een lage voorkeur de toets aan het recht doorstaat kan dit een aanwijzing zijn dat de selectie van te onderzoeken alternatieven niet erg geslaagd is geweest en dat herbezinning op dit punt op z'n plaats is. ${ }^{134}$ Wellicht is het voor het bestuur aantrekkelijk om voorafgaand aan het vaststellen van een voorkeursvolgorde reeds de ("redelijk zekere") alternatieven aan het recht te toetsen. Dit voorkomt dat "voorkeurdiscussies" worden gevoerd over alternatieven die wegens onrechtmatigheid toch nimmer verkozen zouden mogen worden. ${ }^{135}$ Als bij die aanpak na de rechtmatigheidstoets slechts éen alternatief resteert, kan dat een belangrijke aanwijzing voor herbezinning op de selectie van alternatieven zijn. ${ }^{136}$

\subsubsection{Een juridisch bevredigende beslissing}

Een saillant gegeven in deze op de satisficing-strategie gebaseerde procedure, is dat niet is uitgesloten dat er - mede gelet op de beleidsmatige keuzecriteria - een beter alternatief kan zijn dan hetgeen waartoe besloten wordt. Het punt is echter dat wellicht ook dat betere alternatief nog weer is te overtreffen, maar dat zekerheid daarover pas is te verkrijgen in een eindeloze vergelijking van alternatieven. Zo'n vergelijking is niet alleen op praktische grond onwenselijk, maar wordt in juridische zin ook niet van het bestuur verlangd. De negatieve redactie van art. 3:4, tweede lid Awb en de vage norm van art. 3:2 Awb brengen mee dat het bestuur niet tot het absoluut, doch hooguit tot het relatief beste besluit gehouden kan worden.

De schets die in de voorgaande subparagrafen werd gegeven staat - zoals zo vaak bij theoretische modellen - toch wat af van de praktijk van alle dag. Mij dunkt dat de praktijk niet zelden een meer sjabloonmatig karakter zal vertonen: niet alleen de selectie, maar ook het onderzoek en de definitieve vaststelling van en toetsing aan het aspiratieniveau (met inbegrip van de voorkeurvolgorde), zullen in veel gevallen volgens tevoren gebaande paden verlopen. ${ }^{137}$ Als een vergunning een echte uitdaging inhoudt, met veel onbeken-

134. Het is geen specifieke aanwijzing voor weigering of juist voor blanco-toewijzing van de vergunning: alle alternatieven kunnen in beginsel worden geselecteerd. Wellicht echter heef het bestuur bij de eerste selectie nog niet aan weigering of blanco-toekenning willen denken (of aan enig ander alternatief). Niet beslissen is in de juridische context geen realistisch alternatief (tenzij er een "formeel gebrek" aan het licht treedt, bij voorbeeld onbevoegdheid).

135. Het klinkt wellicht vreemd dat het bestuur een onrechtmatigheidstoets uitvoert. Het is echter (voor correct besturen) de normaalste zaak van de wereld: belast met een rechtsvormende taak heeft het bestuur zich te bezinnen op de rechtmatigheid van zijn handelen. Anticiperenderwijs is het natuurlijk ook wijs vooraf de kansen bij de rechter in te calculeren.

136. Ook dan geldt natuurlijk dat er situaties zijn waar niettegenstaande beleidsvrijheid toch slechts één beslissing rechtmatig genomen kan worden.

137. Paden die zich in de bestendige praktijk hebben gevormd en/of die in beleidsregels en/of interne richtlijnen zijn neergelegd. 
de factoren en tegengestelde belangen, dan zal de besluitvorming allicht minder sjabloonmatig verlopen. Wat dan waarschijnlijk weer zal opvallen is, dat de besluitvorming veel meer geïntegreerd verloopt dan het gepresenteerde drie-stappen-model (selectie, onderzoek, toetsing) doet vermoeden. Na een eerste grofmazige selectie van "basis-alternatieven" zullen er gaande het onderzoek reeds alternatieven uitvallen èn zullen er nieuwe alternatieven, als varianten of verbijzonderingen van de eerdere basis-alternatieven onderwerp van onderzoek worden. ${ }^{138}$ Toetsing en herselectie zullen met andere woorden reeds in het onderzoek zelf plaatsvinden. Er vindt op die manier als het ware een toenemende precisering in onderzoek en voorkeuren plaats. Op zichzelf is zo'n geïntegreerde aanpak waarschijnlijk kostenbesparend: om na afwijzing van alle eerder geselecteerde alternatieven het hele proces weer opnieuw te moeten beginnen is waarschijnlijk erg omslachtig - nog afgezien van de problemen die dit zou kunnen geven met de formele stopregel: de beslistermijn.

Van belang is echter wel, dat het bestuur bij zijn eindbeslissing goed duidelijk moet kunnen maken welke alternatieven zijn onderzocht en waarom sommige alternatieven bij selectie, onderzoek of toetsing uit de boot vielen. Teneinde te waarborgen dat bepaalde alternatieven uitdrukkelijk worden uitgezocht, kan het natuurlijk wenselijk zijn toch bepaalde stappen te reguleren. De milieu-effect-rapportage biedt daarvan een goed voorbeeld. ${ }^{139}$

Ik meen dat de benadering van Simon in hoofdzaak ook in een juridische context kan worden toegepast. Elke stap heeft echter weer een typisch juridische inkleuring.

Wat de selectie betreft draait alles om de vraag welke alternatieven "redelijkerwijs in beschouwing moeten worden genomen". Daarbij speelt het aspiratieniveau als richtinggevende koers reeds een belangrijke rol. De toets daaraan is heeft een "prima facie" karakter: evident onrechtmatige of "technisch onhaalbare" alternatieven vallen af en algemene beleidsvoorkeuren dragen bij tot uitbreiding van het aantal alternatieven. Voor belanghebbende aantrekkelijke alternatieven moeten in overweging worden genomen. Voor een bestuurlijke belangenafweging tot beperking van te selecteren alternatieven is geen plaats. Het in deze fase ecarteren van beleidsmatig onwelgevallige alternatieven leidt al te gemakkelijk tot het negeren van bepaalde voor de belangenafweging relevante belangen.

Voor het onderzoek is "redelijke zekerheid" het parool. Kernpunten daarbij zijn de interpretatie van relevante toepassingscondities, het gewicht of de

138. Waarbij dit proces van verbijzondering steeds detailmatiger zal worden (tot aan de discussies over bepaalde filters, meetvoorschriften en wat dies meer zij toe).

139. Zie daartoe nader Hoofdstuk 7. 
kwetsbaarheid van betrokken belangen en de aannemelijkheid van meeropbrengsten van nader onderzoek.

Bij de toetsing biedt het definitief vastgestelde aspiratieniveau de opstap tot een voorkeursvolgorde en de stopregel: als na onderzoek (al dan niet na aanbrengen voorkeursvolgorde) een alternatief de toets aan het recht doorstaat is de besluitvorming in beginsel rond.

Wat - ten slotte - in het bijzonder opvalt is dat we in feite met een iteratief proces van doen hebben. Strikt methodisch omdat het aspiratieniveau zowel bij selectie als bij toetsing het uitgangspunt vormt - eerst in een meer algemene, daarna in zo precies mogelijke zin. In juridische zin is sprake van een iteratief proces doordat, bij de beoordeling van een $\mathrm{Wm}$-vergunningsaanvraag, eerst een ontwerpbesluit wordt gemaakt en pas na inspraak een definitief besluit wordt genomen. Inspraak kan er toe leiden dat het bestuur zich opnieuw in selectie, onderzoek en toetsing moet begeven. ${ }^{140}$

\subsubsection{Beperken van onzekerheid}

De theorie van de bevredigende oplossing is aantrekkelijk ingeval van onzekerheid over de gevolgen per alternatief, van onvolledige informatie over welke alternatieven er zijn, en van een complexiteit die groter is dan de actoren kunnen overzien of kunnen doorrekenen. Al deze onzekerheden kunnen bij concrete milieuproblemen in het geding zijn. Theoretisch gesproken zijn deze vormen van praktische onzekerheid allemaal op te helderen. ${ }^{141} \mathrm{De}$ kosten daarvan zouden in termen van tijd en geld echter de pan uit kunnen rijzen. Door te kiezen voor de theorie van de bevredigende oplossing wordt een rationele modus gevonden om onevenredige kosten en een onevenredige tijdsinvestering te voorkomen.

Daarmee is een theorie voor bevredigend beslissen in (praktische) onzekerheid gegeven. ${ }^{142}$ Het aldus trachten te "overwinnen" van onzekerheid dient echter gepaard te gaan met het streven onzekerheid te beperken. Simon noemt hiervoor vier concrete acties: ${ }^{143}$

- allereerst het bevorderen van zo goed mogelijke voorspellingen; te ondersteunen door methoden voor het opsporen van nieuwe gegevens en het verbeteren van modellen;

140. Vergelijk art. 8.8, eerste lid onder $\mathrm{d} \mathrm{Wm}$. Bij goed voorwerk is de meerinspanning gering. Ik zwijg nog over de mogelijkheid dat de rechter en daarna het bestuur (opnieuw) de procedure (moet) doorlopen.

141. Helaas wel met behoud van principiële onzekerheid.

142. Het is overigens niet mijn pretentie hier een afgeronde juridische theorie van de bevredigende oplossing te bieden.

143. A.w., p. 438-439. 
- voorts het scheppen van "buffers" voor het geval voorspellingen missers blijken te zijn; ik denk aan veiligheidsmarges, verzekeringen en compenserende maatregelen;

- daarnaast het streven naar vermindering van de gevoeligheid van de effecten van de activiteit voor externe effecten; in het geval van een beslissing over milieugevoelige activiteiten, het voorkomen dat de effecten van een activiteit ernstiger vormen aannemen door te reageren met effecten van andere activiteiten;

- tenslotte het vergroten van het aantal alternatieve handelingsopties, vooral als hoge risico's in het geding zijn.

\subsubsection{Conclusie economische rationaliteit}

Het probleem van praktische onzekerheid of schaarste in beschikbare kennis sluit een rationele beslissingswijze als voorzien in de rationeel-synoptische theorie van besluitvorming uit. Een dergelijke methode miskent de investering in tijd en geld die nodig zou zijn om de beoogde beslissingsprocedure te doorlopen.

Toch moeten er beslissingen worden genomen en Simons theorie van de bevredigende oplossing biedt daarvoor een handvat. Door een goede selectie van alternatieven en het stellen van een verantwoord aspiratieniveau (c.q de "stopregel") kan een rationele beslissing worden genomen. Rationaliteit komt in die benadering neer op: het middel ter vergroting van de kans op succes van een bepaald gedrag (of een bepaalde beslissing). ${ }^{144}$ In juridisch opzicht is deze theorie, zij het met enkele modificaties, goed toepasbaar. Selectie, onderzoek en toetsing vormen daarin de belangrijkste (logische) stappen. Respectievelijk gaat het daarbij om "redelijkerwijs in beschouwing te nemen alternatieven", "redelijke zekerheid" en het bepalen van een voorkeursvolgorde en een (precieze) toetsing aan het recht. In dat proces, dat in de praktijk meer sjabloonmatig, geïntegreerd en iteratief kan verlopen, kan de relatief beste keuze worden gemaakt. Uit de in dit verband in het bijzonder relevante, positiefrechtelijke maatstaven van art. 3:2 en art. 3:4, tweede lid Awb, valt op te maken dat het recht niet van het bestuur verlangt dat het op rationeel-synoptische grondslag tot zijn beslissingen komt. Het recht eist niet de absoluut beste beslissing: een bevredigende beslissing (de relatief beste) voldoet.

144. Vgl. Koch, K., Rationaliteit en rationeel gedrag: Definitie en hypothese, Acta Politica'76/3, p. $312-364$, i.h.b. p. $324-328$ en p. $335-338$. 


\subsection{Juridische rationaliteit}

\subsubsection{Onzekerheid}

Als het bestuur moet beslissen in onzekerheid, zoals bij de beslissing tot het al dan niet verlenen van een Wm-vergunning, verricht zij tevens een rechtsvormende taak. ${ }^{145}$ Het bestuur geeft immers rechtsnormen. Uit een oogpunt van juridische rationaliteit dient - aldus Snellen ${ }^{146}$ - het funderen van het "vertrouwen op het recht" daarbij als leidende aspiratie te worden beschouwd.

Hoe is dat vertrouwen echter mogelijk als de beslissing op een onzekere feitelijke grondslag is gebaseerd?

In het eerste hoofdstuk van deze studie ${ }^{147}$ merkte ik reeds op dat de juridische besluitvormingswaarborgen niet gestoeld moeten zijn op de eis dat rechtens slechts die beslissingen aanvaardbaar zijn die kunnen bogen op een objectieve en onomstotelijke technisch-wetenschappelijke grondslag. De bevindingen uit $\S 4.2$ maken evident duidelijk dat een dergelijke eis wetenschappelijk gezien overspannen zou zijn. De afwijzing van het rationeelsynoptische model van besluitvorming, in de voorafgaande paragraaf, ligt in het verlengde hiervan.

In het eerste hoofdstuk liep ik vervolgens op de zaken vooruit met de nogal globale positie, dat het er rechtens "slechts" om gaat om naar omstandigheden en naar aard en hoedanigheid van de betrokken belangen, aanvaardbare beslissingen te nemen. Aldus zou althans "juridische zekerheid" kunnen worden verschaft.

Juridische zekerheid in de zin van rechtszekerheid is stellig van groot belang als het gaat om het vaststellen van rechtsnormen op een onzekere feitelijke grondslag. Hiermee wordt een deel van de aspiratie tot vertrouwen op het recht bewaarheid. ${ }^{148}$ Juist als de onzekerheid over de feitelijke grondslag van een beslissing groot is, is het wenselijk dat burgers hun verwachtingen kunnen afstemmen op een juridisch gesanctioneerde vastlegging van een norm - zelfs als dit gepaard gaat met de wetenschap dat een dergelijke norm, bij gewijzigde inzichten, kan worden herzien. ${ }^{149}$

Vertrouwen op het recht bestaat echter niet bij rechtszekerheid alleen. Het gaat ook om de "minimale dosis redelijkheid in het optreden van de over-

145. Zie hoofdstuk 3.2.4.

146. A.w., p.4.

147. Meer precies, de tweede premisse onder 1.2.

148. Snellen, a.w., p. 4 , noemt rechtszekerheid ook expliciet.

149. Vgl. art. $8.22 \mathrm{Wm}$. 
heid". ${ }^{150}$ Die redelijkheid betreft (ook) de inhoud van te geven rechtsnormen; vertrouwen slaat ook op de legitimatie van de inhoud van rechtsnormen. Dat geldt in het algemeen ${ }^{151}$, maar stellig ook voor de wijze waarop het bestuur onzekerheid over de feitelijke grondslag bij het nemen van een beslissing meeweegt. Dat laatste is in het bestek van deze studie (gelet op het gestelde in de voorafgaande twee paragrafen) natuurlijk bij uitstek interessant. Daarom wil ik op de kwestie van de inhoudelijke legitimatie hier nog wat nader ingaan; eerst in algemene zin (en wel in \$ 4.4.2) en daarna met het oog op het afwegen van onzekerheid en daarmee verbonden waardengebondenheid (in \& 4.4.3).

\subsubsection{Legitimiteit}

Gelet op de centrale rol van het rationaliteitsbegrip in deze studie biedt Habermas een prikkelende stellingname inzake de vraag naar legitimiteit van rechtsnormen. Volgens hem is legitimiteit namelijk een zaak van rationele rechtvaardiging van het recht. ${ }^{152}$ Traditioneel vormden recht, moraal en politiek in Habermas' visie een samenhangend complex. Het ontstaan van het positieve recht heeft een breuk tussen recht en moraal teweeg gebracht. Het recht is verzelfstandigd. Enerzijds vormt het recht nu een aanvulling op de moraal; met name in de sfeer van de handhaving van normen. Anderzijds is het recht afhankelijk geworden van de politiek, waarbinnen het recht, danwel specifieke rechtsvormen, op instrumentele wijze wordt gebruikt. ${ }^{153}$

De opkomst van de rechtsstaat was een belangrijke stimulans voor de positivering van het recht. De binding van het recht aan de politiek lijkt er echter op neer te komen dat normen die volgens een voorgeschreven procedure door de bevoegde instanties worden gegeven, enkel daardoor, "recht" zijn. De vraag rijst daarmee hoe de inhoudelijke rechtvaardiging van het recht, de legitimiteit van rechtsnormen nog kan worden gegarandeerd. ${ }^{154}$

150. Snellen, a.w., p. 4. Ik beperk mij hier tot rechtsvorming door de overheid, zonder daarmee te willen beweren dat alle recht van de overheid komt!

151. Bij discretionaire bevoegdheden, maar ook daarbuiten (bij wijze van impliciete "hardheidsclausule").

152. Ter onderbouwing van Habermas' visie op het recht raadpleegde ik Wibren van der Burg, De rechtstheorie van Jürgen Habermas, R\&K'85/1, p. 6-26; Wibren van der Burg en Willem van Reijen, Inleiding, in: Jürgen Habermas, Recht en moraal, Kampen 1988, p. 7-47; Paul Cobben, Kan legitimiteit zuiver procedureel gegarandeerd worden? Een kritische beschouwing over Habermas' conceptie van de verhouding tussen moraal, recht en politiek, R\&K'89/3, p. 262 279: Peter Bal, Procedurele rationaliteit en mensenrechten in het strafproces, R\&K' $90 / 3$, p. 259-279.

153. Cobben, a.w., p. 263.

154. Ibidem, p. 264. 
Wat wetgeving betreft acht Habermas de democratische grondslag op zichzelf onvoldoende legitimatie. Het is daarbij nodig een normatieve rechtvaardiging te ontwikkelen voor het gepostuleerde primaat van het parlement. Volgens Habermas is parlementaire besluitvorming, voorzover deze voldoet aan het model van morele argumentatie, als een adequate procedure van rationele besluitvorming te beschouwen. ${ }^{155}$

Ook "wetstoepassing" door rechter en bestuur behoeft volgens Habermas een eigen morele argumentatie. Er moeten daartoe juridische besluitvormingsprocedures worden ontwikkeld die de inbedding vormen voor een moreel discours. ${ }^{156}$

Zie ik het goed dan komt Habermas' benadering er op neer dat de sociale gelding van een norm, althans op de lange duur, in elk geval niet mag berusten op macht alleen ${ }^{157}$. Voor de inhoudelijke legitimatie van een norm is een morele argumentatie noodzakelijk. In een dergelijk bestek ontlenen normen hun rechtvaardiging uit het (bij voorrang op alternatieve normen) door alle betrokkenen aanvaard kunnen worden. ${ }^{158}$ Dit houdt tevens in dat normen slechts binnen een bepaalde gemeenschappelijke context rationeel gerechtvaardigd kunnen worden. ${ }^{159}$

De morele argumentatie moet volgens Habermas overigens voldoen aan enkele algemene voorwaarden, zoals naleving van elementaire logische regels (bij voorbeeld de eis van consistentie), wederzijdse erkenning door de deelnemers aan het discours van elkaar ${ }^{160}$ en gerichtheid op rationeel gemotiveerde overeenstemming.

De laatste voorwaarde impliceert in hoofdzaak dat het discours niet wordt verstoord door machtsoverwicht of dwang. Alleen in een symmetrische verhouding tussen partners in argumentatie kan een ontwikkelde norm legitiem zijn. ${ }^{161}$ Slechts dan kunnen deelnemers de gevolgen van hun handelen gelijkelijk inzien en deze - in algemeenheid - gelijkelijk aanvaarden; zodat een rationeel gefundeerde instemming van betrokkenen ontstaat.

Uit deze korte schets komt naar mijn smaak opnieuw het beeld van een normatieve theorie naar voren. De rationele rechtvaardiging van het recht wordt normatief geconstrueerd door een rationele theorie van argumenteren te pos-

155. Ibidem, p. 264-265.

156. Ibidem.

157. Wat ook de basis daarvan mag zijn.

158. Dat wil zeggen, gelet op de voorzienbaar uit het algemene naleven van deze norm voortvloeiende gevolgen voor de belangen van iedere enkeling.

159. Cobben, a.w., p. 268.

160. Cobben, a.w., p. 269.

161. Ibidem. 
tuleren - zo ontstaat een beeld van wat recht behoort te zijn, maar waaraan veel rechtsnormen stellig niet zullen voldoen. Niettemin wordt op deze wijze toch een spiegel voorgehouden aan betrokkenen bij het proces van rechtsvorming. In die zin kan het redeneren vanuit een bepaalde aspiratie bijdragen aan kritische reflectie. De vraag rijst of Habermas' analyse daartoe een voldoende brede basis biedt.

Enkele schrijvers ${ }^{162}$ hebben mijns inziens terecht opgeworpen dat Habermas' benadering te zeer uitgaat van een louter procedurele garantie van legitimiteit: de enkele vorm van het discours lijkt doorslaggevend te zijn geworden.

Daar staat immers tegenover dat "het recht" sinds het ontstaan van de rechtsstaat is gericht op de verwezenlijking van bepaalde idealen. Juist deze idealen scheppen de voorwaarden voor een vrije op consensus gericht discours. Vanaf het intreden van de democratische rechtsstaat moet het recht tevens vanuit het democratisch ideaal worden begrepen. Bijgevolg wordt het kiesrecht algemener en democratiseren bedrijfsleven en wetenschap. ${ }^{163}$ Van der Burg ${ }^{164}$ en $\mathrm{Bal}^{165}$ wijzen in dit verband op de rechtstheorie van Dworkin. Dworkin stelt dat toepassing van het recht in een democratische constitutie een normatieve visie op democratie verlangt, waarin de rechten van burgers centraal staan. Volgens Dworkin moet de basis van deze visie gevonden worden in het gelijkheidsbeginsel, hetgeen vooral doorwerkt op de rechtspositie van minderheden. ${ }^{166}$ Bal ziet hier een duidelijk aanknopingspunt om het realiseren van mensenrechten tot richtsnoer te nemen van het morele discours. ${ }^{167}$ Op deze manier wordt ook een inhoudelijke basis voor de rationele rechtvaardiging (legitimatie) van rechtsregels gegeven.

Het intreden de verzorgingsstaat houdt verband met de behoefte aan een meer inhoudelijke, materiële basis voor de democratische rechtsstaat. Volgens Dworkin is in deze fase het gelijkheidsideaal, als een gelijk recht op respect en zorg tegenover de overheid het uitgangspunt. Niet slechts als een formele gelijkheid, maar een materiële, substantiële gelijkwaardigheid. De opkomst van de sociale grondrechten past in deze ontwikkeling, maar ook de horizontale toepassing van het gelijkheidsbeginsel - zoals bij arbeidsrechtelijke bescherming, huurrecht en consumentenrecht. ${ }^{168}$

162. Zoals Cobben, Van der Burg en Bal.

163. Van der Burg. R\&K, a.w., p. 18.

164. Dbidem.

165. A.w., p. 267.

166. Van der Burg, a.w., p. 18.

167. Met een dubbele functie: een maatstaf voor kritische beoordeling van de feitelijke situatie en een richtsnoer voor verbetering. Bal, a.w., p. 266-268.

168. Van der Burg. R\&K, a.w., p. 19. Hij volgt hierbij de visie van Dworkin. 


\subsubsection{Legitimatie bij beslissen in onzekerheid}

Tot zover een zeer beknopte procedureel-inhoudelijke onderbouwing van de inhoudelijke legitimatie van rechtsnormen. ${ }^{109}$ Deze kan nu dienen als achtergrond voor een aantal opmerkingen over het bij normstelling juridisch rationeel omgaan met onzekerheid inzake het betrokken feitensubstraat.

Daarvoor grijp ik even kort terug op de bevindingen uit $\$ 4.2$ en 4.3 . Achtereenvolgens gaat het om:

a. De wetenschap ontdekt geen waarheden. De theorie of hypothese is de belangrijkste wetenschappelijke eenheid. De testbaarheid daarvan is het criterium voor de wetenschappelijke status;

b. Beoordeling van wetenschappelijke theorieën wordt essentieel beïnvloed door waarde-oordelen. De sociale dimensie van de wetenschapsbeofening speelt daarbij (zowel voor bestendigheid als innovatie) een belangrijke rol;

c. Kritische aandacht is nodig voor de relatie wetenschap en maatschappij; ${ }^{170}$

d. De rationeel-synoptische theorie is een overspannen eis voor besluitvorming op onzekere feitelijke grondslag;

e. Rationeel beslissen in onzekerheid is mogelijk volgens de theorie van de bevredigende oplossing. Het recht biedt de grondslag voor het stellen van een aspiratieniveau als juridische "stopregel" voor het feitenonderzoek;

f. Bij beslissen in onzekerheid zijn onzekerheidverminderende acties op hun plaats. ${ }^{171}$

Voeg ik hierbij de eis van een procedurele en (minimale) inhoudelijke legitimatie van rechtsregels dan is mijns inziens voldoende achtergrond gegeven voor het expliciteren van een aantal vuistregels van belang voor een juridisch rationeel omgaan met onzekerheid en waardegebondenheid bij de inbreng van (wetenschappelijk) expertise bij normstelling:

\section{Bestuurlijke verantwoordelijkheid}

Niettegenstaande het technisch-complexe karakter van bepaalde beslissingen, dient de verantwoordelijkheid voor het nemen van een besluit steeds, naar procedure en naar inhoud bij de juridisch bevoegde instantie te liggen. Deze instantie voert primair de regie over de procedure. Het bevoegd gezag heeft uiteindelijk de verantwoordelijkheid om een rationeel bevredigende beslissing te nemen, dat wil zeggen zorgdragen voor de "nodige kennis" (redelijke zekerheid) en, ingeval van beleidsvrijheid, het streven naar de "relatief meest

169. Als onderdeel van de aspiratie om vertrouwen op het recht te funderen.

170. De punten a.,b. en c. vloeien voort uit $\$ 4.2$.

171. De punten d., e. en $f$. vloeien voort uit $\$ 4.3$. 
evenredige beslissing". ${ }^{172}$ Dit omvat keuzes inzake nauwkeurigheid, omvang en diepgang van het feitenonderzoek en keuzes omtrent het onderzoek naar alternatieve besluitvormingsopties. Omdat deze keuzes uiteindelijk berusten op waarde-oordelen kan het oordeel daarover eenvoudig niet aan de deskundige (als deskundige) worden gelaten. Voorzover het gaat om het feitenonderzoek terzake van de (relevante) toepassingscondities vloeit de bestuurlijke verantwoordelijkheid terzake ook voort uit het legaliteitsbeginsel: het bestuur moet zich vergewissen van zijn bevoegdheid. De verantwoordelijkheid voor het feitenonderzoek naar alternatieve besluitvormingsopties vloeit voort uit de plicht tot belangenafweging. Noch de bepaling van de eigen bevoegdheid noch de belangenafweging kan aan anderen worden gelaten.

Uiterste consequentie van de bestuurlijke verantwoordelijkheid voor de feitenvaststelling is dat het bestuur niet moet pretenderen als "superdeskundige" te beslissen. Zelfs als het bestuur uit deskundigen bestaat, kan die "eigendeskundigheid" niet als beslissende legitimatie van de feitenvaststelling worden aangevoerd. Deskundigheid, hoe groot ook, vermag geen oplossing voor onzekerheid te geven. Die "oplossing" vergt waarde-oordelen waarover slechts op voet van politieke legitimatie mag worden beslist. Het kan geen kwaad als een bestuursorgaan uit deskundigen bestaat. Het bevordert een kritische blik op de feitenvaststelling. Het gezag van de feitenvaststelling berust echter op een juridisch oordeel. Het zou niet goed zijn als daarover misverstanden zouden ontstaan. ${ }^{173}$ Het gaat - uiteindelijk - niet om de eigen-deskundigheid van het bestuur, maar om de feitenvaststelling zelf.

\section{De bevredigende beslissing}

De feitenvaststelling vereist niet dat wetenschappelijke onzekerheid volledig wordt geëlimineerd: rechtszekerheid vereist geen wetenschappelijke zekerheid. Rechtens is echter wel van belang dat naar omstandigheden en naar aard en hoedanigheid van de betrokken belangen, aanvaardbare beslissingen worden genomen. Dat is niet alleen een kwestie van het in formele zin bewaken dat een norm in een juridisch gesanctioneerde vorm wordt vastgelegd. Het gaat er in het bijzonder (ook) om dat in het normstellend handelen ten minste een "minimale dosis redelijkheid" verzekerd is. Juridische aanvaarding vereist (ook) een intrinsieke, normatieve basis. Als over het feitensub-

172. Ik gebruik hier nu een positieve maatstaf. Mede in het licht van rechterlijke controle (en de gewenste reikwijdte of diepgang daarvan) is uiteindelijk een negatieve regel (zoals art. 3:4 Awb) verkieselijk (zie ook deel III).

173. Bij voorbeeld doordat een bestuursorgaan zich uitdrukkelijk op zijn eigen-deskundigheid beroept. 
straat van een norm onzekerheid bestaat, is dat aanvaardbaar indien feitenvaststelling "to the best abilities" heeft plaatsgevonden.

Die maatstaf vergt van het bestuur geen rationeel-synoptische besluitvorming; een bevredigende beslissing voldoet. Als verantwoordelijke voor de feitenvaststelling, moet het bestuur bij de feitenvaststelling alle redelijkerwijs in beschouwing te nemen alternatieven aan een onderzoek onderwerpen. Voorzover over alternatieven redelijke zekerheid kan worden bereikt, kunnen deze aan het aspiratieniveau worden getoetst. Dat houdt in dat (in welke volgorde dan ook) de alternatieven aan het recht worden getoetst en een voorkeursvolgorde wordt bepaald.

De keuze voor deze aanpak bevestigt dat de uiteindelijk (in een vergunning) te stellen normen niet op een objectieve en wetenschappelijk onbetwistbare grondslag kan worden gebaseerd - maar wel op een rationeel en juridisch aanvaardbare grondslag. Mede op voet van de eerste vuistregel zal het bestuur er mitsdien goed aan doen ook geen wetenschappelijke zekerheid te pretenderen door als een "superdeskundige" over de feitenvaststelling te beslissen. Wel vergt de procedurele en inhoudelijke legitimatie van normstelling dat het bestuur toeziet op de openheid van besluitvorming (zie vuistregel 3 ) en "to the best of its abilities" de inhoudelijke verantwoordelijkheid neemt. Dat laatste impliceert allereerst dat voldaan wordt aan de hierboven besproken eisen van selectie, onderzoek en toetsing. Daarnaast zal het bestuur ("to the best of its abilities") de zorg moeten dragen voor de inbreng van deskundigheid, het uitvoeren van een marginale toetsing van ingebracht deskundigen-advies ${ }^{174}$ en het streven naar reductie van onzekerheid. ${ }^{175}$

\section{Openheid van besluitvorming}

Advisering en feitenvaststelling en belangenafweging moeten worden ingebed in een open procedure. Dat is allereerst een waarborg voor de controleerbaarheid van de wetenschappelijke juistheid en volledigheid van het besluit. Andere deskundigen moeten in beginsel de mogelijkheid hebben zich daarover uit te laten; mogelijk in de vorm van contra-expertise. Daarnaast moet de rol van onzekerheid en waarden tussen bij het besluit betrokkenen bediscussieerd kunnen worden. Procedurele waarborgen zoals openbaarheid, gemotiveerdheid en mogelijkheden tot inspraak en beroep zijn - kortom - essentieel. In dat verband moet overigens bezien worden of hierbij ook materiële waarborgen passen: bij voorbeeld in de sfeer van middelen voor burgers om deskundige bijstand in te roepen.

174. Het "uitfilteren" van kennelijk onredelijk, c.q onjuist advies.

175. Eisen die ook voortvloeien uit de eerste vuistregel. 


\section{Gangbare opvattingen en de kritiek}

Het feit dat een technisch-advies inhoudelijk aansluit bij "gangbare opvattingen" binnen de desbetreffende tak van wetenschap, is op zichzelf een positief criterium voor de validiteit van het advies. ${ }^{176}$ Zulks volgt ook uit de belangrijke rol van de sociale dimensie van de wetenschapsbeoefening.

Allereerst is het van belang er op te wijzen dat het criterium van "gangbare opvattingen" net als het criterium "naar de stand van wetenschap en techniek"177 suggereert dat een vaste norm kan worden gevonden, terwijl dit in de praktijk niet altijd het geval is. In de praktijk kan blijken dat er vele opvattingen zijn zonder dat er een dominante "leer"is aan te wijzen. Voorts is een kritische opstelling op z'n plaats zo gauw voor een empirische uitspraak een beroep wordt gedaan op "de" gangbare opvatting. Mogelijk is de gangbare opvatting sterk beïnvloed door maatschappelijke druk. ${ }^{178}$ De normsteller dient zich "to the best of its abilities" te vergewissen van de onafhankelijke signatuur van de bronnen van een empirische uitspraak - zoals een technischdeskundigen-advies. Daarnaast is het mogelijk dat er in de desbetreffende wetenschappelijke groep relevante afwijkende visies bestaan. ${ }^{179}$ Gelet op het complexe en kwetsbare karakter van milieubelangen zal het bestuur zich voor deze afwijkende signalen open moeten stellen - al is denkbaar dat andere betrokkenen (c.q. de deskundigen in kwestie) zelf althans aannemelijk zullen moeten maken dat hun visie (i.c.) relevant is. ${ }^{180}$

\section{Omgaan met waarden}

In het voorgaande kwamen twee soorten waarden aan de orde: wetenschappelijke- en niet-wetenschappelijke waarden. Voor het onderscheidend criterium wees ik op de vraag of een waarde er al dan niet toe strekt het "waarheidachtige" karakter van een wetenschappelijke uitspraken te bevorderen - zie $\S$ 4.2.4.

Wat de niet-wetenschappelijke waarden betreft past grote waakzaamheid. Als leidraad moet hier genomen worden dat deze waarden niet in het onderzoek naar de feiten thuis horen. Dat gezegd zijnde moet tegelijkertijd erkend

176. Zodanige eis sluit ook goed aan bij de tweede vuistregel: alwetendheid is niet vereist, "enkel" een beslissing "to the best of our abilities".

177. Beide aanduidingen zal ik hier als synoniem gebruiken.

178. Vanwege bepaalde belangengroepen of - minder aanwijsbaar - vanwege het feit dat het probleem waarover een gangbare opvatting bestaat stelselmatig vanuit een bepaalde (normatief gestuurde) invalshoek is bekeken (bij voorbeeld altijd vanuit een antropocentrische optiek).

179. Nieuwe afwijkende inzichten of afwijkende inzichten op grond van afwijkende onderzoeksmethoden of premisses.

180. Cramer, Jacqueline, a.w., p. 25, stelt dat het leveren van bewijs tegenover "de gangbare opvatting" juist vanwege de vele onzekerheden erg ingewikkeld is. De onzekerheid is een steun in de rug voor de "gangbare opvatting". De kwestie van de bewijslast komt in de volgende hoofdstukken nog uitdrukkelijk aan de orde. 
worden dat deze waarden een zekere invloed hebben op keuzes aangaande de nauwkeurigheid, diepgang en omvang van het feitenonderzoek. Zo is het oordeel over het gewicht van een bepaald belang mede van invloed op de mate van zekerheid die in het feitenonderzoek wordt nagestreefd.

In aansluiting daarop is het van belang acht te slaan op de rol van niet-wetenschappelijke waarden als premisses voor het feitenonderzoek. Feitenonderzoek wordt niet in een blanco-situatie ondernomen. De inhoud die aan een concrete toepassingsconditie of een concreet belang wordt toegedacht is een belangrijk uitgangspunt voor het feitenonderzoek. In het geval van een toepassingsconditie moet bij voorbeeld worden vastgesteld wat nu eigenlijk behoort tot de beschermingswaardige milieubelangen. Of in het onderzoek van een strikt antropocentrische of ecocentrische benadering wordt uitgegaan is dan van groot belang. Bij de beslissing over de vraag welke effecten in het (nader) onderzoek verwaarloosbaar zijn en welke niet, kunnen dergelijke premisses immers zeer sterk doorwerken. Vermits deze premisses en de geldende interpretatie van de toepassingsconditie overeenstemmen, lijkt mij een dergelijke niet-wetenschappelijke waarde in het onderzoek geen bezwaar. In tegendeel: waar in het feitenonderzoek aansluiting tussen feiten en de termen van een toepassingsconditie moet worden gevonden, is het van belang dat als het ware dezelfde taal wordt gesproken. ${ }^{181}$

Uiteraard spelen niet-wetenschappelijke waarden ook een grote rol als de feitenvaststelling getuigt van grote onzekerheden. Alsdan rijst de vraag of het gelet op de aard van de betrokken belangen verantwoord is om een aanvraag te honoreren. Ook kan er aanleiding zijn om met het oog op de betrokken belangen bepaalde veiligheidsmarges in te bouwen, of anderszins te voorzien in onzekerheidsreducerende maatregelen. ${ }^{182}$

Ten slotte kan zich nog de situatie voordoen waarin het bestuur wordt geconfronteerd met meerdere, onderling tegenstrijdige maar overigens in gelijke mate wetenschappelijk gezaghebbende adviezen. Gelet op de rol van wetenschappelijke waarden bij theorie-keuze is zo'n situatie goed denkbaar. De vraag rijst of het bestuur zich in een dergelijk geval ten faveure van de ene of andere wetenschappelijke waarde moet uitspreken of dat het, nu de wetenschap kennelijk geen eenduidigheid kan bieden, zijn keuze op een niet-weten-

181. Bij de kwalificatie. Let wel hiermee wordt geen oordeel uitgesproken of aan de toepassingsconditie is voldaan: het gaat er slechts om dit oordeel mogelijk te maken.

182. Als een bepaald alternatief wordt gekozen. mag worden aangenomen dat dit "redelijk zeker" is anders is de basis voor het besluit te zwak. Toch is dit slechts een minimumvereiste. De wens om het belang in kwestie, voor het geval de "redelijke zekerheid" toch door de feiten wordt achterhaald, te kunnen beschermen, kan aanleiding zijn tot aanvullende bescherming. 
schappelijk waarde-oordeel kan baseren. ${ }^{183} \mathrm{Mij}$ dunkt dat het laatste niet op zijn plaats is: het gaat er immers om dat een zo juist en volledig mogelijk inzicht in de feiten ontstaat. Waarde-oordelen die het ene of het andere belang begunstigen passen niet in die opdracht. Het bestuur zal (marginaal maar wel beslissend) moeten beoordelen welke visie het meeste gezag heeft. Daarvoor is een aantal parameters voorhanden. ${ }^{184} \mathrm{Ik}$ denk daarbij in het bijzonder aan de onafhankelijkheid of onpartijdigheid van de adviseur, de mate van gespecialiseerdheid van een adviseur en de mate van tegenspraak die op een uitspraak mogelijk is geweest (en hoe in welke mate de visie daartegen bestand bleek). In meer materiële zin kan ook het criterium van de gangbaarheid van de visie die aan een advies ten grondslag ligt een rol spelen. Zoals $i k$ in de voorgaande vuistregel al aangaf biedt gangbaarheid van een visie een goed aanknopingspunt, maar is niet zaligmakend. In dat opzicht kan het interessant zijn of ook een gangbare visie in het concrete geval tegenspraak nog altijd goed doorstaat. Openheid van besluitvorming (vergelijk de derde vuistregel) is ook in deze situaties essenticel.

Deze vijf "vuistregels" voor juridisch rationaliteit in technisch complexe beslissingen zijn nog betrekkelijk algemeen van karakter. In de volgende twee delen van deze studie zullen ze moeten worden geijkt aan (de ontwikkelingen in) het positieve bestuurs(proces)recht.

Alvorens daartoe over te gaan wil ik echter nog een aantal praktische aspecten van de inbreng van expertise kort de revue laten passeren. Ik wil daarmee aanschouwelijk maken hoe problematisch het rationeel beslissen in technische complexe aangelegenheden kan zijn.

\subsection{Enkele praktische kwesties}

\subsubsection{Accenten}

In deze paragraaf is het mij er om te doen aanschouwelijk te maken welke typische problemen verbonden zijn aan het omgaan met deskundigheid. Anders dan in de voorgaande drie paragrafen, waar de theoretische zijde van de problematiek van normstelling en expertise centraal stond, zal het nu vooral gaan om praktische accenten. Het spreekt vanzelf dat de theoretische inzichten uit het voorafgaande daarbij als achtergrond zullen fungeren. Aan

183. Bij voorbeeld: door welke benadering wordt het belang met het oog waarop het bestuur i.c. bevoegd is het meest beschermd. Maar misschien ook wel het omgekeerde: in welke visie kan het bestuur de aanvrager zo veel mogelijk tegemoet komen.

184. Het gaat hierbij eigenlijk ook om wetenschappelijke-waarden. Nu echter geen waarden van een "meta-niveau" (beslissend voor de keuze tussen grote theorieën), maar waarden inzake het gezag van op theoretische premisses gebaseerde uitspraken over concrete praktijkgevallen. 
het slot van deze paragraaf zal worden bezien of bijstelling of aanscherping van de bovenstaande "vuistregels" wenselijk is.

\subsubsection{Enkele kwesties}

\subsubsection{Wanneer expertise inwinnen?}

Wanneer moet het bestuur nu eigenlijk deskundigen-advies inwinnen? In een notedop: als het nemen van een beslissing kennis verlangt waarover het bestuur zelf niet beschikt. ${ }^{185}$

Intern zal het bestuur zich daarom moeten bezinnen op de voor normstelling relevante toepassingscondities en op de betrokken algemene en bijzondere belangen. Mede met behulp van allerlei "check-lists", "effecten-matrices" en "netwerk-analyses"186, alsmede eventuele richtlijnen ${ }^{187}$, is te bepalen wat er (grosso modo) aan kennis beschikbaar moet zijn.

$\mathrm{Er}$ is ook een externe kant. Het bestuur moet op zijn (gebrek aan) deskundigheid aangesproken kunnen worden. Dit kan uiteraard door burgers in inspraak en beroep. Ik acht het daarnaast, met name in de complexe milieuproblematiek, wenselijk dat onafhankelijke inhoudsdeskundige adviseurs bij elke procedure kunnen reageren. ${ }^{188}$

\subsubsection{Eenduidige kennis}

Van groot belang is voorts de vraag hoe bruikbaar de voor besluitvorming beschikbare kennis is.

Zo kan blijken dat er geen sprake is van eenduidigheid van opvattingen. ${ }^{189}$ Tegenspraak tussen deskundigen bleek bij voorbeeld bij de voorbereiding van het besluit tot aanleg van de Oost-Westbaan op de luchthaven Zuid-Limburg. Over de effecten van (nachtelijk) vlieglawaai liepen de meningen tussen deskundigen sterk uiteen. Van een gangbare opvatting kon niet worden gesproken. ${ }^{190}$ Ook kan er sprake zijn van onvolledige kennis. Mogelijk zijn de relevante causale relaties slechts statistisch of zelfs in het geheel niet te duiden. Niet zelden is ook de omgeving van een bepaalde activiteit onvoldoende constant.

185. We kunnen dit tot een probleem van filosofische proporties maken: wat als je niet weet dat je niets weet? Dan is een soort meta-niveau vereist. Op zeer praktische wijze wordt deze meta-stap hier in een intern en extern perspectief gezet.

186. Vgl. Udo de Haes, H.A., en J.P.M. Bol, a.w., p. 122-123.

187. In de door Bröring (NTB, a.w.) bedoelde zin.

188. Zoals ook is voorzien in art. 7.15 en art. 20.6 lid 2 onder b. Wm c.q. art. 3:23 Awb.

189. Vgl. \$ 2.3.4.4.

190. Zie hiervoor: Teunissen, J.M.H.F.. Het Plan van aanpak Schiphol: Rechtsbescherming gewaarborgd?, in: Tan. T.G., J.M.H.F. Teunissen en F.P.C.L. Tonnaer, Het plan van aanpak Schiphol, Zwolle 1991, p. 12-44, i.h.b. p. 26-27. 
Van Gunsteren stelt dat de wetenschap primair op de oplossing van paradigmatische puzzels is gericht en derhalve niet zozeer afbeeldingen van de werkelijkheid (in z'n alledaagse vorm) geeft, maar "als-dan-uitspraken" die slechts houdbaar zijn als een veelheid van andere factoren constant of buiten beschouwing worden gelaten. ${ }^{191}$ "Except in a controlled experiment, they (wetenschappelijke verklaringen, $\mathrm{MAH}$ ) seldom have predictive power". ${ }^{192}$ Udo de Haes en $\mathrm{Bol}^{193}$ wijzen er op dat het verkrijgen van gegevens over "ingreep-effectrelaties" erg problematisch kan zijn. ${ }^{194} \mathrm{Zij}$ stellen dan ook de vraag of kennis over milieuproblemen wel toereikend is voor het voorspellen van milieu-effecten en spreken in dat verband van de "armoede van de ecologie". ${ }^{195}$

\subsubsection{Schijnzekerheden}

Als er al een voor het concrete geval bruikbare theorie is, is het belangrijk te waken voor schijnzekerheden. In de voorgaande paragraaf (vuistregel 3 ) heb ik al gewezen op de noodzaak om eventuele afwijkingen van "de gangbare opvatting", mits althans betrekkelijk aannemelijk gemaakt, nader te onderzoeken. ${ }^{196}$ Een opvatting mag gangbaar zijn, heilig is zij stellig niet.

Ik denk in dit verband overigens ook aan het feit dat verschil in opvatting verband kan houden met verschil in opvattingen over de concrete uitgangspunten voor onderzoek, zoals bepaalde opvattingen over natuur en milieu. ${ }^{197}$ In de vijfde vuistregel gaf ik reeds aan dat het bestuur hier voorzichtig moet zijn. Het bestuur zal dergelijke (impliciete) waarderingscriteria moeten ijken aan de relevante politiek-juridische criteria. ${ }^{198}$

Naast deze problemen moet ook worden gewaakt voor schijnzekerheden door kwantificering. ${ }^{199}$ Reijnders wijst er op dat bij kwantificering van milieu-

191. Gunsteren. H.R. van. The Quest for control. A critique of rational-central-rule approach in public affairs, London 1976, p. 15.

192. Ibidem, p. 12.

193. A.w., p. 126.

194. Met als voorbeelden: probeer inzicht te krijgen in de gevolgen van de aanleg van een snelweg op de vogelstand, of de gevolgen van diepe grondwaterwinning op de vegetatie op korte en op lange termijn.

195. A.w., p. 126. De praktische onzekerheid ten voeten uit.

196. Mede gelet op de opmerking van Jacqueline Cramer, a.w., p. 25, dat de bewijslast voor "afwijkende visies" zeer zwaar is, kan ik mij voorstellen dat indien de belangen in kwestie groot èn kwetsbaar zijn, op het bestuur een zwaardere bewijslast zal moeten rusten (zie deel IV).

197. Bij voorbeeld in termen van een antropocentrische of een ecocentrische optiek. Vgl. in dit verband Brouwer, E., J.N.M. Dekker, G.H.E. Nieuwdorp en A.A.A. van der Schaaf (reds.), Strategieën voor ecologische normstelling, 's Gravenhage 1990, p. 62-67.

198. Uit wetgeving, beleidsregels en richtlijnen.

199. In verband met de voorspellende waarde van een theorie wordt kwantificering doorgaans ais een pré beschouwd. $\mathrm{Vgl}$. Kuhn, p. 210. 
risico's allerhande onzekerheden onzichtbaar blijven. ${ }^{200}$ In dat verband noemt hij vijf belangrijke bronnen van onzekerheid:

- in nieuwe technologie-intensieve systemen worden vaak componenten toegepast die zo nieuw zijn dat over de faalkansen en -effecten daarvan geen betrouwbare kwantitatieve informatie bestaat;

- betrouwbare kwantitatieve informatie over oude/bekende componenten ontbreekt vaak omdat geen goede statistieken zijn gemaakt;

- sommige bronnen van risico's, zoals sabotage, het gebruik van een inferieur materiaal, slecht onderhoud en slechte veiligheidsinspecties, zijn zeer slecht kwantificeerbaar;

- het denkraam van de risico-analytici is beperkt in die zin dat er altijd wel een aantal gevaren aan hun blikveld ontsnapt;

- de als regel theoretisch en empirisch zwakke basis onder modellen waarmee ongewenste gevolgen in effecten worden omgerekend. ${ }^{201}$

Er is - kortom - voor het bestuur alles aan gelegen een kritisch oog voor milieu-onderzoek te ontwikkelen. Dat begint al voorafgaand aan het nemen van een besluit. Op voet van Simons acties tot onzekerheidsreductie is het zaak om bij de voorbereiding meerdere alternatieven te ontwikkelen. Bij de vergelijking daarvan kunnen onzekerheden en normatieve elementen worden opgespoord, dan wel worden vergeleken. ${ }^{202}$ Ook achteraf is een kritisch oordeel op z'n plaats. Als aan evaluatie geen aandacht wordt geschonken, blijft kennisvergaring over milieu-effecten een zaak van "ad hoc opschrijven en overschrijven van nooit getoetste verwachtingen. "203

\subsubsection{De deskundige}

Of iemand deskundig is moet uiteindelijk worden vastgesteld in het wetenschappelijk discours; op tegenspraak derhalve. Het gaat uiteindelijk immers primair om de boodschap en niet om de boodschapper.

Niettemin is het voor het bestuur wenselijk om vooraf althans redelijk zeker te zijn van iemands deskundigheid. Bij een verkeerde keuze (en dito gebrekkig advies) loopt het bestuur ten slotte de kans dat de gehele procedure (of delen daarvan) moeten worden overgedaan.

De reputatie van een (beweerde) deskundige lijkt mij een belangrijke aanwijzing omtrent diens deskundigheid. Op de "expertise-markt" zal de mond tot mond reclame stellig een belangrijke rol vervullen. Reputatie kan ook een

200. Reijnders, L., Milieurisico's, in: Boersema, J.J., J.W. Copius Peereboom en W.T. de Groot (reds.), Basisboek milieukunde, Meppel. 1986, p. 439-446.

201. Ibidem, p. 439.

202. Het ene alternatief zal wellicht meer of minder, dan wel andersoortige onzekerheden kennen dan het andere.

203. Udo de Haes en Bol, a.w., p. 127. 
institutioneel karakter krijgen. Degene die deskundigheid zoekt kan zich namelijk ook richten tot algemeen erkende wetenschappelijke instellingen: instellingen waarvan bekend is dat zij (op onafhankelijke wijze) deelnemen aan het wetenschappelijke debat. De aldaar aanwezige deskundigen en deskundigheid zijn doorgaans mede door kritiek gevormd en ontwikkeld.

\subsubsection{Onafhankelijkheid}

In verband hiermee komt ook de kwestie van de onafhankelijkheid van deskundigen om de hoek kijken. Belangenverstrengeling kan grote invloed hebben op de uitgangspunten van onderzoek ${ }^{204}$, op voorkeuren voor bepaalde theorie-bepalende wetenschappelijke waarden en - last but not least - op de kans dat niet-wetenschappelijke waarden een rol gaan spelen. ${ }^{205}$

Opnieuw kan gesteld worden dat openheid en de mogelijkheid van kritiek er toe kunnen bijdragen dat dergelijke gevolgen van een afhankelijk adviseurschap worden geëlimineerd. Ook hier geldt echter het adagium "voorkomen is beter dan genezen". Reputatie en institutionele positie zullen hierbij (zie ook onder 4 . hierboven) belangrijke factoren vormen.

Onafhankelijkheid is ook een issue als het bestuur besluit dat interne, bij de eigen ambtenaren aanwezige expertise toereikend is. Kunnen de eigen deskundigen wel onafhankelijk zijn? Zal ongeacht de formeel onafhankelijke status van de ambtenaar, niet toch het politieke belang van de bestuurders een duidelijke stempel op de interne advisering drukken? Dit lijkt vooral een kwestie van een goede selectie en goede werkverhoudingen. Enig zelfbewust handelen kan echter zeker geen kwaad: als interne adviezen onjuist blijken krijgt het bestuur de deksel op de neus. Mitsdien is externe controle van groot belang: contra-expertise zou steeds mogelijk moeten zijn. Bij technisch complexe besluitvorming lijkt het wijs om de mogelijkheid van een advies door een vaste, doch onafhankelijke deskundige in de besluitvorming in te bouwen. In politiek gevoelige kwesties is overigens reeds de schijn van partijdigheid voldoende grond om actief extern advies in te roepen. Hetzelfde geldt voor het geval er aanwijzingen zijn dat er over de technische zijde van het onderwerp van besluitvorming veel wetenschappelijke discussie gaande is.

\subsubsection{Soorten adviezen}

Wat de vorm waarin een deskundige kan spreken betreft zou ik willen onderscheiden in twee soorten van adviezen.

204. Zie punt 2. hierboven; $m . n$. als het gaat over opvattingen over natuur en milieu.

205. Bewust of onbewust zwijgen over, of negeren van bij baas, vaste klant of geldschieter onwelgevallige wetenswaardigheden; of juist het overaccentueren van bepaalde gegevens omdat dit graag gehoord wordt. 
Onder het gerichte advies versta ik het gevraagd of ongevraagd op maat van het zich in een concreet geval voordoend probleemgeval verschaffen van advies.

Daartegenover stel ik - hoe kan het anders - het ongerichte advies. Bij ongericht advies gaat het om kennis die "grofmazig", meer in het algemeen gegeven wordt en derhalve doorgaans in algemenere termen verwoord is.

Tot deze groep zou men de losbladige edities, handboeken, wetenschappelijke werken, databanken, expertsystemen en wat dies meer zij, voorzover gericht op het verschaffen van technisch-wetenschappelijke kennis, kunnen rekenen. Bij veel van deze bronnen gaat het louter om het beschikbaar maken van "know-how" en niet echt om advies. Als er echter toch een onderliggend doel is, te weten het aanreiken van kennis en inzicht ten behoeve van het vaststellen van rechtsnormen, dan spreek ik van ongerichte advisering. We kunnen dan allereerst denken aan bloot technische advisering. Een voorbeeld bieden de zogenoemde NEN-bladen van het Nederlands Normalisatie Instituut. Ook is denkbaar dat deze ongerichte adviezen in een meer beleidsmatige jas zijn gestoken. Een belangrijke categorie daarvan is die van circulaires en nota's van overheidswege waarin terzake van de bevoegdheid van andere overheden wordt aangegeven hoe daarvan gebruik gemaakt zou kunnen worden. ${ }^{206}$ Het zal duidelijk zijn dat een circulaire inzake het gebruik van de beleidsvrijheid van art. 8.10, eerste lid Wm bij bepaalde voorgenomen activiteiten een aantal veronderstellingen bevat aangaande de uitleg van het criterium "belang van de bescherming van het milieu". Naast het bieden van zo'n handvat voor interpretatie kan het ook gaan om een aanduiding van de wijze waarop onderzoek naar bepaalde feiten zou moeten worden verricht of de wijze waarop beleidsvrijheid zou moeten worden benut. Het lijkt zaak bij dergelijke ongerichte adviezen de technische kenniscomponent goed te scheiden van de beleidscomponent, om vervolgens beide op hun eigen merites te beoordelen. ${ }^{207}$

Ik meen dat het onderscheid tussen gerichte en ongerichte adviezen om meerdere redenen relevant is. Allereerst benadrukt het onderscheid dat bij een geconstateerd gebrek aan eigen expertise niet per se een gericht advies behoeft te worden ingewonnen. Soms biedt een ongericht advies voldoende basis voor een zelfstandige afwikkeling van de besluitvorming.

206. De richtlijnen waarover Bröring (NTB, a.w.) spreekt.

207. Wat de technische-kennis betreft is het vooral zaak de onafhankelijkheid kritisch te bezien zeker als aan het advies een beleidsvisie is verbonden. 
Daartegenover staat dat het bij bepaalde beslissingen ook niet goed denkbaar is dat aan ongerichte adviezen zomaar voorbij wordt gegaan. ${ }^{208}$ Dat geldt zeker voor technische complexe problemen bij het verlenen van milieuvergunningen. In de praktijk blijken de ongerichte adviezen daarbij ook zo belangrijk $\mathrm{k}^{209}$, dat deze vorm van advisering in deze studie niet mag ontbreken.

\subsubsection{Afronding 'praktische kwesties'}

Ik heb het inmiddels al meerdere malen en op verschillende manieren gezegd: wetenschappelijke rationaliteit heeft een relativistisch karakter. Principiële onzekerheid en praktische onzekerheid zijn daarvan de oorzaak. ${ }^{210}$ Toch zijn er naar mijn stellige overtuiging goede gronden om wetenschappelijke kennis te betrekken bij technisch-complexe besluitvorming (zoals bij Wmvergunningen). ${ }^{211}$

Dat gezegd zijnde moeten we onderkennen dat feitenvaststelling met verschillende normatieve keuzes gepaard gaat. Wellicht is het goed die keuzes hier nog even kort op een rij te zetten en daarbij aan te geven welke opstelling bij iedere keuze van het bestuur mag worden verwacht.

- Een preliminaire stap is dat het bestuur - indachtig de eerste vuistregel zelf zal moeten nagaan welke bevoegdheid mogelijk in het geding is. Daardoor worden (wellicht nog nader te interpreteren) toepassingscondities expliciet. Ook kan vast komen te staan of een beleidsmatige keuze tussen alternatieve besluitvormingsopties gemaakt moet worden.

- In het onderzoek naar de feiten is het goed mogelijk dat een belangrijke rol is weggelegd voor niet-wetenschappelijke waarden. Een oordeel over de "hinderlijkheid" of "schadelijkheid" van een activiteit is bij voorbeeld sterk verbonden met het beeld dat de onderzoeker heeft van de verhouding mens en natuur. Het bestuur zal het feitenonderzoek indringend moeten controleren op dergelijke vooroordelen. ${ }^{212}$ Daarbij speelt - zoals ik reeds in de vijfde vuistregel stelde - een rol dat bepaalde premisses in

208. Ik denk hierbij vooral aan beslissingen over het al dan niet verlenen van milieuvergunningen. Ik kom daarop in het volgende hoofdstuk nog terug.

209. En m.h.o. de onathankelijkheid zo interessant.

210. De rol van de wetenschappelijke waarden is terug te veeren op het probleem van onderdeterminatie, c.q. op principiële onzekerheid. Het is goed te bedenken dat juist door toedoen van deze waarden voor het zelfde verschijnsel, uitgaande van dezelfde probleemstelling, tegelijkertijd meerdere wetenschappelijk evenzeer acceptabele - doch ondergedetermineerde - theorieēn kunnen bestaan. Het idee van "de stand van de wetenschap" wordt hierdoor sterk gerelativeerd.

211. Voortspruitend uit het (in beginsel) open en kritisch karakter van de wetenschap en de praktische successen ervan.

212. Een onderzoek dat nauw verbonden is met de vraag naar de onathankelijkheid of onpartijdigheid van de onderzoeker/adviseur. Vgl. de vijfde vuistregel. 
het onderzoek noodzakelijk kunnen zijn teneinde te kunnen beoordelen of aan de desbetreffende toepassingsconditie is voldaan. Als een toepassingsconditie het oog zou hebben op ecologische schade en in het feitenonderzoek komt slechts schade aan de gezondheid van de mens van de mens aan bod (of vise versa), dan is de kwalificatie van de feiten in termen van de toepassingsconditie onvoldoende voorbereid. Een onderzoek naar de ecologische schade door het kappen van een bos of het sterk inperken of uitroeien van een (plaatsgebonden) plant- of diersoort, gaat vanzelf met voornoemde premisses gepaard. Het is zaak dat duidelijk is welke vragen het bestuur precies wil beantwoorden.

- Ook is het mogelijk dat in het onderzoek sprake is van extrapolaties; bij voorbeeld door de "stap" van uitkomsten bij proefdieronderzoek naar mensen - meer in het bijzonder bij het vaststellen van vermenigvuldigingsof reductiefactoren bij het berekenen van risico's. Gegeven praktische onzekerheid zijn dergelijke noodgrepen in het onderzoek vaak onvermijdelijk. Het gaat hier om het geven van een wetenschappelijk oordeel dat door het bestuur "slechts" marginaal kan worden beoordeeld - "to the best of its abilities". Het bestuur zal moeten bezien of het onderzoek aansluit bij gangbare opvattingen en in welke mate rekenschap is gegeven van nieuwe inzichten. Uiteraard zal het moeten nagaan of het onderzoek of advies innerlijk consistent en begrijpelijk is; of onderbouwing en conclusie logisch op elkaar aansluiten, of wat er in het advies staat te begrijpen is, of er sprake is van (manifeste) meet- of rekenfouten en wat dies meer zij. Als deze toets wordt doorstaan heeft het bestuur zijn taak volbracht. ${ }^{213}$

- Beslissingen omtrent nauwkeurigheid, diepgang en omvang van het onderzoek kunnen worden geplaatst in het model van de bevredigende beslissing. Door selectie, onderzoek en toetsing langs de in $\$ 4.3 .3$ omschreven lijnen is zo'n beslissing te bereiken. Normatieve keuzes doen zich hier allereerst voor bij de vraag welke alternatieven redelijkerwijs in beschouwing dienen te worden genomen. Zo moeten inschattingen worden gemaakt inzake evidente onrechtmatigheid van bepaalde alternatieven, de mate van betrokkenheid van een bepaald belang ${ }^{214}$, de beleidsvoorkeuren van het bestuur zelf en ten slotte de inschatting of een alternatief technisch haalbaar is, dan wel of daarover "redelijke zekerheid" is te bereiken. Technische haalbaarheid plaatst het bestuur in een wat terughoudende positie. Snel mogelijkheden uitsluiten lijkt niet op z'n plaats. Bij het onderzoek is het primair van belang te beoordelen welke eisen daaraan ter

213. Inbedding van deze beoordeling in een open procedure is essentieel; daarover later meer.

214. Het is denkbaar dat iemand met het oog op zijn belang onderzoek naar een bepaald alternatief voorstelt, maar dat zijn belang zo ver verwijderd is dat dit redelijkerwijs niet in beschouwing behoeft te worden genomen. 
verkrijging van redelijke zekerheid over elk der alternatieven moeten worden gesteld. In de sfeer van de toetsing hebben we van doen met het recht en de beleidsvoorkeur van het bestuur als belangrijke normatieve elementen. Voorzover het om de toetsing aan het recht gaat moet het bestuur toetsen als ware het zelf rechter. Inzake de eigen beleidsvoorkeuren moet het bestuur de volle politieke (en daarmee ook juridische) verantwoordelijkheid voor zijn keuzes nemen.

- Bij het maken van beleidsmatige keuzes, c.q. het bepalen van een voorkeursvolgorde voor (redelijk zekere) alternatieven, kan de vraag rijzen of, gelet op het grote gewicht van bepaalde belangen, wellicht nog onzekerheidsreducerende maatregelen op hun plaats zijn. In het verlengde van een "safety-first" benadering kan worden besloten de kans op aantasting van het desbetreffende belang (niettegenstaande de redelijke zekerheid bij elk van de alternatieven) werkelijk zo gering mogelijk te doen zijn. De redelijke zekerheid biedt immers slechts een minimale zekerheid gelet op het gewicht van de betrokken belangen. Nu gaat het er om één belang in het bijzonder tegen aantasting te beschermen. Het bestuur kan daartoe alternatieven waarin extra veiligheidsmarges of veiligheidsmaatregelen worden gekozen hoog in de rangorúe píatsen. Voor een dergelijke keuze draagt het bestuur uiteraard de volledige verantwoordelijkheid. ${ }^{215}$

Bij al deze stappen is het steeds van belang dat het bestuur aanspreekbaar is door betrokkenen, en wel voorafgaand aan het nemen van een beslissing. Op dat moment zijn posities nog niet betrokken ${ }^{216}$ en kan goed overleg over de verschillende stappen plaatsvinden.

Het overzicht van stappen maakt duidelijk dat het maken van normatieve keuzes sterk met de feitenvaststelling is verweven. ${ }^{217} \mathrm{Ik}$ denk daarbij in het bijzonder aan de beslissing over de wenselijk nauwkeurigheid, diepgang en omvang van het feitenonderzoek en het verdisconteren van onzekerheden bij de belangenafweging. Naar mijn mening accentueert dit hetgeen ik in de eerste vuistregel heb gesteld: het bestuur moet de volle verantwoordelijkheid dragen voor de feitenvaststelling.

215. Soms is reeds wettelijk voorgeschreven dat het bestuur bepaalde belangen zo ver als redelijkerwijs mogelijk is moet beschermen. $\mathrm{Vgl}$. art. 8.11. derde lid Wm (het ALARA-beginsel, waarover meer in Hoofdstuk 7). In dat geval zal bij de toetsing aan het recht reeds een schifting in de alternatieven plaats vinden: bij vergelijkbare alternatieven blijtt in beginsel alleen de meest milieubeschermende over.

216. Of is er nog geen vrees voor "gezichtsverlies".

217. Vgl. Udo de Haes en Bol, a.w., p. 131. 
In het licht van die positie ben ik geen voorstander van een "organisatie van de feitenvaststelling" waarin willekeurig geselecteerde burgers of (willekeurig) geselecteerde deskundigen ${ }^{218}$ als panels tot een definitieve, eenduidige ("objectieve") vaststelling van de feiten komen; welke feiten dan vervolgens aan de bestuurlijke beslissing ten grondslag moeten worden gelegd. Ik stel mij voor dat dit een alternatief model volgens de satisficing-strategie zou kunnen zijn: de feitenvaststelling is bevredigend als het "forum" van mening is dat de feitenvaststelling voldoet. Dit zou een oordeel zijn dat ook ten overstaan van een rechter stand zou kunnen houden. De rechter zou zich er slechts van behoeven te vergewissen dat het forum op "willekeurige" wijze is samengesteld en dat de noodzakelijke formele condities voor een onafhankelijk en weloverwogen beoordeling door het forum vervuld zijn.

De feitenvaststelling impliceert, zoals ik hierboven reeds stelde, meerdere normatieve keuzes. Deze keuzes dienen "objectief" te verantwoorden te zijn en mogen geen alibi voor een verkapte belangenafweging gaan vormen. Mijn vrees zou echter zijn dat het forum als een vorm van (partieel) direct democratisch bestuur zou worden opgevat. Subjectieve opvattingen over het gewicht van bepaalde belangen zouden invloed kunnen hebben op de eisen die aan het onderzoek worden gesteld. Denkbaar is dat deze eisen op sommige punten zo hoog worden gesteld dat daaraan niet meer is te voldoen - waardoor effectief wordt gepreludeerd op de belangenafweging door het bestuur. In elk geval zou de selectie van te onderzoeken alternatieven al buiten het forum moeten worden gehouden. Binnen die selectie kan het bestuur immers op basis van eigen beleidsvoorkeuren alternatieven toevoegen; alternatieven die bij selectie door het forum wellicht buiten bespreking zouden blijven. Het oordeel van het forum zou zich dan reeds beperken tot de vraag of redelijke zekerheid is bereikt. Een flexibele reactie op bevindingen, in die zin dat hangende het onderzoek variaties op alternatieven worden ontwikkeld, kan niet worden verwacht. ${ }^{219}$

Een probleem is ook dat, anders dan het bestuur als feitenvaststeller, het forum veel minder makkelijk op zijn inhoudelijke oordeel is aan te spreken. Als een rechter meent dat het bestuur zijn eigen opvattingen over betrokken belangen in de feitenvaststelling op onoirbare wijze heeft laten prevaleren, kan hij het bestuur daar direct op aanspreken, c.q. zijn eigen oordeel daarvoor in de plaats stellen. Als het forum heeft geoordeeld, hebben we te maken met een soort oordeel uit een "black-box". Bestuur en rechter zouden hooguit wegens kennelijke willekeur kunnen oordelen dat het forum niet tot

218. Of een mengvorm van beide.

219. Het bestuur zou daar steeds expliciet door het forum op moeten worden aangesproken. Dat kan natuurlijk tot tal van onverkwikkelijkheden leiden: het forum ziet een alternatief dat goed kan worden onderzocht, maar het bestuur vindt dat het niet de moeite van het onderzoeken waard is. 
het gegeven oordeel kon komen. Zou immers een indringend oordeel worden gegeven dan lokt dit toch de kritiek uit dat in feite het bestuur of de rechter de dienst uitmaken en dat het oordeel van het forum geen eigen gezag heeft. Het resultaat zou zijn dat het forum de facto als adviesinstantie zou functioneren.

Overigens zou ik met een dergelijke advies-model, mits uitdrukkelijk beoogd, geen moeite hebben. Duidelijk is dan echter wel dat het bestuur uiteindelijk de feiten vaststelt.

Overigens verdient het opmerking dat, niettegenstaande de dominante invloed van het bestuur, bij gerichte advisering ook burgers richtinggevende kritiek op de koers van het onderzoek moeten kunnen geven. Bij de procedure voor de milieu-effectrapportage is dit reeds voorafgaand aan het milieu-effectrapport (kortweg, MER) mogelijk, bij het opstellen van de zogenoemde richtlijnen voor het MER. In een latere fase is ook kritiek op het MER mogelijk..$^{220}$

Ten aanzien van de vuistregels (in § 4.4.3) wil ik, gelet op de hiervoor besproken praktische kwesties, nog een viertal kanttekeningen maken:

- allereerst lijkt het mij van groot belang dat bij technisch-complexe besluitvorming telkens een vaste, doch onathankelijke deskundige in de gelegenheid wordt gesteld om zijn opvattingen kenbaar te maken. Mij dunkt dat daardoor aan de vergelijking tussen onderling tegenstrijdige (c.q. afwijkende) visies een waardevolle bijdrage kan worden geleverd. Daarmee sluit ik aan bij mijn opmerkingen bij de vierde en bij (het slot van) de vijfde vuistregel; ${ }^{221}$

- voorts wil ik nogmaals benadrukken dat kwalificaties als "de stand van wetenschap en techniek" of "gangbare opvattingen in de desbetreffende tak van wetenschap" kritisch moeten worden bezien. Daarmee wil ik niet afdoen aan de in vuistregel 4 gestelde regel dat het bestuur primair aan dergelijke kwalificaties kan refereren. Ik wijs er echter op dat er juist in de dynamische en complexe milieuproblematiek te veel onzekerheden, onduidelijkheden, verschillen van opvatting en schijnzekerheden zijn om klakkeloos op voornoemde kwalificaties van gezaghebbendheid te kunnen vertrouwen; ${ }^{222}$

- in het verlengde daarvan, dat het ontwikkelen van voldoende alternatieven, het onderzoeken van veiligheidsmarges en het inbouwen van evalua-

220. Zie art. 7.14, derde lid en art. 7.23, eerste lid Wm.

221. Een vaste deskundige kan als "specialist" een gezaghebbend oordeel geven over de verschillende visies op een bepaald gebied en het discours dat daarover gaande is.

222. Mijns inziens moet deze waakzaamheid (of argwaan) ook gevolgen hebben voor zowel het noncontentieuze als het contentieuze bewijsrecht (zie deel III en IV). 
ties, kortom: acties tot reductie van onzekerheid, van zeer groot belang zijn.

- niet op de laatste plaats, de keuze voor een "bestuurlijk model" bij de feitenvaststelling. Daarmee sluit ik aan bij de eerste vuistregel: het bestuur is verantwoordelijk.

\subsection{Conclusie}

Daarmee zijn we aan het einde van het tweede deel van deze studie. In de volgende twee delen hoop ik respectievelijk voor het non-contentieuze en het contentieuze bestuursrecht voort te kunnen bouwen op de vuistregels en bijkomende bevindingen uit het onderhavige deel.

Dit voortbouwen komt primair neer op een inventarisatie van positiefrechtelijke waarborgen. De voornoemde vuistregels en bevindingen dienen daarbij een kritisch doel. Als niet-positivistische, elementaire spelregels voor rationeel beslissen door bestuursorganen vormen zij een spiegel van referentiepunten voor het positieve recht.

Bij vergelijking kunnen verschillen aan het licht treden; variërend van tegenstellingen tot accentverschillen. Daarbij kan uiteraard een rol spelen dat in het positieve recht aan inhoud en vorm van juridische waarborgen, andere eisen worden gesteld of van andere intenties en ideeën wordt uitgaan dan in de voorafgaande uiteenzetting over de juridische rationaliteit. ${ }^{223}$

Mede met het oog daarop zal ik in het volgende deel dan ook aanstonds nagaan of de eis van rationeel beslissen ook als gepositiveerd rechtsbeginsel is te onderkennen.

223. Nota bene: de vuistregels uit dit hoofdstuk zijn vuistregels van juridisch rationeel handelen bij beslissen in onzekerheid. Dat wil zeggen juridische rationaliteit in het licht van daaraan voorafgaande bevindingen over (primair) wetenschappelijke en (secundair) economische rationaliteit. Dit volgt ook uit de plaatsing in \$ 4.4.3. 


\section{Deel III}

Rationeel beslissen in de non-contentieuze procedure 


\section{Hoofdstuk 5 \\ Rationaliteit en rechtmatig bestuur}

\subsection{Inleiding}

Dit deel gaat over het bestuursrecht voor de non-contentieuze besluitvorming. De idee van rationeel beslissen, zoals in hoofdstuk 1 geïntroduceerd (en in hoofdstuk 4 uitgewerkt), zal in dit deel grondslag vormen voor het onderzoek naar de juridische waarborgen voor de inbreng van expertise. Dit onderzoek zal in drie afzonderlijke hoofdstukken worden gepresenteerd.

In het onderhavige hoofdstuk gaat het om de vraag of de idee van rationeel beslissen als een positiefrechtelijk beginsel van bestuursrecht is te duiden.

In hoofdstuk $6 \mathrm{zal}$ ik ingaan op enkele specifieke juridische waarborgen voor de inbreng van expertise binnen het algemeen deel van het positieve bestuursrecht.

In hoofdstuk 7 bespreek ik - ten slotte - enkele specifieke milieurechtelijke waarborgen voor de inbreng van expertise.

Deze aanpak voorziet in een steeds concreter wordende analyse: eerst gaat het om de algemene uitgangspunten dan om concrete eisen uit het algemeen deel en tenslotte om de concrete eisen uit een bijzonder deel, te weten het milieurecht. De verlening van $\mathrm{Wm}$-vergunningen als exempel van deze studie zal mitsdien in het onderhavige hoofdstuk buiten beeld blijven, om vervolgens in hoofdstuk 6 weer enigszins en in hoofdstuk 7 ten volle in beeld te komen.

Als toegezegd zullen de onderzoeksresultaten uit dit deel waar mogelijk en wenselijk worden geconfronteerd met de bevindingen uit het voorgaande deel.

In het onderhavige hoofdstuk zal ik allereerst beknopt ingaan op de juridificering van het besturen $(\$ 5.2)$. Vervolgens zal ik kort stilstaan bij de betekenis van het democratisch primaat voor de rationaliteit van bestuur ( $\$ 5.3)$. Daarop (in \$ 5.4) zal ik het onderzoek naar rationaliteit als algemeen bestuursrechtelijk beginsel inzetten met een tweetal auteurs, te weten Van Male en Nicolaii. Daarop aansluitend zal ik ingaan op de rol van het willekeurverbod (§5.5). Ten slotte rond ik af met een conclusie $(\S 5.6)$. 


\subsection{De juridificering van het besturen}

\subsubsection{Drie dimensies}

Van der Hoeven onderscheidt drie dimensies in het algemene bestuursrecht. ${ }^{\prime}$ De dimensie van de legitimatie van de regeermacht, de dimensie van de instrumentatie van het regeren en de dimensie van de normatieve begrenzing. Aan de hand van een historisch perspectief zet hij uiteen hoe deze dimensies in de tijd op elkaar aansluiten.

De eerste dimensie is die van de legitimatie van de regeermacht; ook wel aangeduid als het recht op regeermacht. ${ }^{2}$ Oorspronkelijk was deze gezagsaanspraak vooral een persoonlijke aanspraak van de machthebber. Een principiële breuk trad op toen de macht werd onteigend en bij de gemeenschap zelf werd gelegd. De machthebber werd daarmee "ingeruild" voor een gezagsdrager: iemand die niet (eigenmachtig) regeerde voor en ten bate van zichzelf, maar iemand die regeerde voor en uit naam van de gemeenschap. ${ }^{3}$

Dat de eerste dimensie van het bestuursrecht niet slechts een politieke, maar ook een juridische betekenis heeft, vloeit voor Van der Hoeven voort uit het feit dat machthebbers en gezagsdragers door de historie heen steeds zochten en (zo mogelijk) verwezen naar rechtsnormen ter legitimatie van hun regeermacht. ${ }^{4}$

De tweede dimensie betreft de middelen van de machtsuitoefening. De keuze van de middelen van de machthebber - de organisatie en het instrumentarium dat hij gebruikt - is van groot belang voor de mogelijkheden om eigen doelen te realiseren. Rekening houden met de bereidheid van burgers tot "medewerking" is hierbij een belangrijke factor. Ook externe factoren, zoals geografie, techniek, economie en wereldbeschouwing, blijken echter bepalend te zijn voor de mate waarin machtsuitoefening mogelijk was en is. Normering van de instrumentatie werd noodzakelijk geacht om tot een geslaagde machtsuitoefening te komen. Deze normering werd belangrijker naarmate de middelen een grotere beheersing van de samenleving mogelijk maakten - en machthebbers de effectiviteit van deze middelen nog verder trachtten te verhogen. ${ }^{5}$

1. Hoeven, J. van der, De drie dimensies van het bestuursrecht: ontstaan en vorming van het Nederlandse algemene bestuursrecht. Alphen aan den Rijn 1989 (Geschriften van de Vereniging voor Administratief Recht: 100)

2. Ibidem, p. 11 .

3. Ibidem, p. 12-13. In extenso komt dit punt in de daaropvolgende hoofdstukken II en III nog naar voren.

4. Ibidem, p. 11-12.

5. Ibidem, p. 12 . 
Bij de normering van de instrumentatie gaat het primair om het welslagen van de machts- of gezagsuitoefening. In de derde dimensie, de normering van de machtsuitoefening, gaat het om de ontwikkeling van de rechtspositie van de burger tegenover het bestuur. ${ }^{6}$ Het belang daarvan wordt door Van der Hoeven als volgt verwoord: "Zolang legitimatie en instrumentering van gezag geen sluitstuk hebben in een rechtsnormering van de verhouding van het gezag tegenover de burger (om wie het in het bestuur ten slotte gaat), behouden zij een element van machtsonvolkomenheid dat onvermijdelijk een zekere willekeur insluit".?

Ik wil bij deze rechtsbeschermingsdimensie iets uitgebreider stilstaan omdat zich in de recente historie, juist hierin 'behoorlijke' ontwikkelingen hebben voorgedaan.

\subsubsection{Rechtsbescherming en het democratisch tekort}

Geruime tijd overheerste volgens Van der Hoeven de opvatting dat politieke verantwoordelijkheid voor een besluit een rechtsoordeel over dat besluit onnodig maakte. Het politieke oordeel was doorslaggevend omdat boven de rechtswaarde van een democratisch genomen besluit geen hogere rechtswaarde bestaanbaar was. Daarbij kwam dat een legitieme behartiging van het algemeen belang in beginsel prevaleerde boven (individualiseerbare) deelbelangen. Belangrijk was ook dat werd verondersteld dat het praktische en organisatorische vermogen van de volksvertegenwoordiging ook voor de controle op concrete beslissingen toereikend zou zijn. ${ }^{8}$

Machtsvorming, machtsuitoefening en controle op de macht vormden aldus én geheel.

Eén van de belangrijkste redenen die de hardnekkigheid van deze conceptie wellicht kunnen verklaren is volgens Van der Hoeven ${ }^{9}$ dat lange tijd werd aangenomen dat de volksvertegenwoordiging praktisch en organisatorisch geschikt was voor een effectieve controle op al het besturen. Waar het gaat om "macrobestuur", om algemene regelgeving, besluiten met gevolgen op grote schaal of besluiten die op grote schaal belangstelling genieten, lijkt dit ook goed te verdedigen.

Gaandeweg is echter het inzicht gegroeid dat een dergelijke vorm van politieke controle ongeschikt is voor "microbestuur", de overige veelal juist voor

\footnotetext{
6. Ibidem, p. 11 .

7. Ibidem, p. 20.

8. Ibidem, p. 15.

9. Ibidem, p. 17-19. Ik laat andere redenen. zoals de wens om andere (concurrerende) controleurs buiten de deur te houden en de mogelijke invloed van de "vierde macht", buiten bespreking.
} 
individuele of kleine groepen van individuele burgers relevante beslissingen en zelfs tot gebrekkige en willekeurige uitkomsten kan leiden.

Rechtsbescherming van de burger tegen het overheidsbestuur kon, kortgezegd, niet langer louter aan politieke controle worden overgelaten. ${ }^{10}$ Op voet van dat inzicht heeft de noodzaak van onafhankelijke rechterlijke controle op het micro-bestuur stap voor stap meer erkenning gekregen. ${ }^{11}$

Het proces van rechtsnormering van de machtsuitoefening heeft voor het micro-bestuur geleid tot een geheel aan regels die voor de totstandkoming van bestuursbesluiten een discursief verloop voorschrijven. Met name de bijzondere delen van het bestuursrecht, met eigen procedures inzake de voorbereiding van besluiten, inspraak en beroep, getuigen hiervan.

Tegelijkertijd is de juridificering van het besturen tot uitdrukking gekomen in, aan de groei van de rechterlijke controle verbonden beginselen, zoals het verbod van détournement de pouvoir, het willekeurverbod en de abbb. In het streven om dergelijke beginselen te codificeren in de Awb zie ik de wens om een effectieve rechterlijke (en dus juridische) controle grondig te verankeren. $^{12}$

\subsection{Democratie en rationaliteit}

Juridificering van het besturen laat uiteraard onverlet dat de democratie een essentiële karakteristiek (en waarborg) is van onze rechtsorde. Zoals ik in $\$ 5.5$ nog uiteen zal zetten vormt de democratisch gefundeerde politieke wil het hart van onze bestuurlijke motoriek. Het is in dat licht dat ik mij hier enkele opmerkingen veroorloof over de vraag of en zo ja, in hoeverre democratie bijdraagt aan de verwezenlijking van de rationaliteitseis. ${ }^{13}$

10. Ook over de geschiktheid van het parlement bij toetsing van de grondwettigheid van wetten zijn (inmiddels) twijfels gerezen, vgl. J. van der Hoeven. Toetsen aan de Grondwet. Hoe en door wie?, rede, NJB'91/19, p. 784-786; en Prakke, L.. T. Koopmans en J.M. Barendrecht, Toetsing, Preadviezen voor de NJV 1992, Zwolle 1992.

11. Het meest recent in de MvT bij het Whrol. p. 21 en p. 22-23.

12. De MvT bij de Awbl is hierover niet expliciet. Waar wordt gesteld dat het er om gaat "..de verworvenheden van de jurisprudentie in de wet vast te leggen.." (p. 9) wordt dit primair in functie geplaatst "..van de gezichtspunten kenbaarheid, eenheid en systematiek van het recht" (ibidem). Helaas blijft de kern van de zaak daarmee buiten beeld.

13. In deze studie ligt het accent op de juridische waarborgen voor rationaliteit. 
De relatie tussen democratie en rationele argumentatie tekent zich af in de typering van democratie als "government by discussion". ${ }^{14}$ Dit credo wijst naar het voor democratie kenmerkende mechanisme van openbare meningsvorming. Democratie als regeervorm gaat daardoor bij uitstek gepaard met de pretentie tot kwalitatief goede beslissingen te kunnen leiden. De meerderheidsregel past "naadloos" in dit systeem omdat daardoor de, voor openbare meningsvorming noodzakelijke, gelijkwaardige individuele (morele) autonomie van de burgers, voorop wordt gesteld. ${ }^{15}$ De meerderheidsregel geeft echter beslist geen uitsluitsel over waarheid of onwaarheid of over goed of kwaad, maar slechts over wat er moet gebeuren èn dat er iets gebeurt. ${ }^{16}$ Alleen in het democratisch proces, met een open ontwikkeling van openbare meningsvorming in een kritisch debat, ligt de aanspraak op een hogere rationaliteit van besluitvorming besloten.

Voorkomen moet worden dat in dit democratische proces verstoringen, zoals (misbruik van) machtsoverwicht, manipulatie van de publieke opinie, gebrek aan de noodzakelijke deskundigheid en het gevaar van "waan van de dag" de overhand krijgen. Zippelius wijst in dit verband naar de spelregels van de rechtsstaat: onpartijdigheid, wederkerige controle en de klassieke grondrechten (het recht van vergadering en betoging, vereniging en de vrijheid van meningsuiting). Deze regels zijn van directe betekenis voor het proces van openbare meningsuiting. ${ }^{17}$

Het democratische proces wordt aldus als een - discursief - rationeel proces door rechtsstatelijke waarborgen geschraagd. In termen van een dergelijke discursieve of relativistische rationaliteit lijkt de democratie eigenlijk niet zonder de waarborgen te kunnen die nu juist kenmerkend zijn voor het concept van de rechtsstaat. De aansluiting bij Habermas' theorie van een rationeel gestructureerde morele argumentatie is hier duidelijk. ${ }^{18}$ Democratie kan, mits daarin het open debat door rechts- en verzorgingsstatelijke eisen is gewaarborgd, een duidelijke bijdrage leveren aan een rationele besluitvorming.

14. Vgl. Pot, C.W. van der. Handboek van het Nederlandse Staatsrecht, bewerkt door A.M.Donner, Zwolle 1983, p. 146; alsmede de bewerking van dit standaardwerk door L.Prakke, Zwolle 1989. p. 161 .

15. En drukt uit dat geen enkele levens- of wereldbeschouwing hogere rechten heeft dan anderen. $\mathrm{V}$ gl. Zippelius, R., Zur rechtfertigung des Mehrheitsprinzips in der Demokratie, Aus Politik und Zeitgeschichte (bijlage bij Das Parlament. B42/87), p. 3-10 (m.n. p. 5 e.v.); alsook Lohmar, U, a.w.

16. De meerderheid heeft het dus ook niet bij het juiste eind omdat zij de meerderheid is; dan zou de (democratische) waarheid van vandaag - ceteris paribus - de (democratische) onwaarheid van morgen kunnen zijn. Vgl. Lohmar, U., a.w., p. 11: Zippelius, R., a.w., p. 3 e.v. (\$ II).

17. Zippelius p. 8

18. Zie 4.4.2. 
We moeten overigens niet vergeten dat de genoemde rechtswaarborgen tegelijkertijd een rol spelen bij de (zelf-)bestendiging van de democratische gezagsbasis. Daarin staat de overtuiging voorop dat inbreuken op vrijheden van burgers een zekere vorm van bewilliging door burgers vereisen. Nauw daarmee verbonden is het (emancipatoire) uitgangspunt van de gelijkwaardigheid en de autonomie van individuele burgers. Juist daarom zijn verschillende voor democratische besluitvorming noodzakelijk geachte juridische waarborgen, zoals de grondrechten, zo belangrijk. Het verdient te worden opgemerkt dat juridische waarborgen aldus tevens dienen ter voorkoming van de ontaarding der democratie. Terecht wijst Dworkin erop dat aanvaarding van het voor de democratie zo typerende mechanisme van collectieve besluitvorming (door - wisselende - meerderheden), invloed moet hebben op onze visie op het recht. Het recht, in het bijzonder de rechtsbeginselen, moet bescherming bieden voor het individu tegen een (utilitaire) doorvoering van collectieve overheidsdoelen (op basis van meerderheidsstandpunten). ${ }^{19}$

Waarborgen voor de openheid van het debat dienen uiteraard niet alleen de politieke en juridische rationaliteit maar ook de wetenschappelijke. Juist in het open debat kan de noodzaak tot de inbreng van deskundigheid, alsook het gezag van deskundigen-adviezen en de wijze waarop deze dienen mee te wegen bij het nemen van een besluit kritisch beargumenteerd worden. Zoals in de eerste "vuistregel" werd gesteld is het daarbij zaak dat de besluitvorming niet door deskundigen gedomineerd wordt. Het primaat van democratische besluitvorming dient overeind te blijven. ${ }^{20}$

\subsection{Rationaliteit als postulaat of evidentie}

Recente bestuursrechtelijke literatuur verschaft enkele interessante juridische aanknopingspunten voor de eis van rationeel beslissen. Twee daarvan wil ik hier achtereenvolgens beknopt belichten. In de volgende paragraaf zal ik daarna mijn eigen visie op de bestuursrechtelijke positivering van de idee van rationeel beslissen voorleggen.

19. Dworkin, R., Taking rights seriously, London 1978, p. 22, p. 31-33, p. 82. Zie ook $\$ 4.4 .2$.

20. Vgl. in dit verband overigens (naast veel andere literatuur) Polak, J.M., Uitbesteding van wetgeving, NJB'89, p. 1080. 


\subsubsection{Het rationaliteitspostulaat van Van Male}

Van Male merkt op dat het legaliteitsbeginsel van oudsher mede gegrondvest is op de fundamentele eis van weloverwogen overheidsbestuur. ${ }^{21}$ De gedachte dat de wet als geschreven rede rationaliteit belichaamt ${ }^{22}$ hield, volgens hem, verband met de veronderstelling dat de algemeenheid als kenmerk van wettelijke normen de rationaliteit daarvan zou verzekeren. Het proces van wetgeving waarborgt een goede discussie "waaruit - als vanzelf - de geschreven waarheid naar voren zou komen. Dit berustte op de romantische voorstelling dat wat gevonden werd, geen oordeel, maar een waardevrij inzicht, een ervaring zou zijn". ${ }^{23}$ De vergelijking met de natuurwetenschappen dringt zich hier op: de ratio in het recht wordt als in de natuurwetenschappen uitgedrukt in wetten. Het noodzakelijkerwijs algemene karakter van deze wetten sluit een regeling voor individuele gevallen uit; de wet heeft een universele gelding en is als zodanig vatbaar voor herhalde toepassing. ${ }^{24}$ In dat laatste ligt voor de burger uiteraard een belangrijke waarborg voor rechtszekerheid en rechtsgelijkheid besloten.

Onze hedendaagse rationaliteitsoptiek stelt - als gezegd - het discursieve element voorop. Van Male wijst er op dat rationaliteit van wetgeving zeker niet meer geldt als universele waarheid. Rationaliteit zou hier hooguit kunnen worden begrepen als afwezigheid van willekeur. ${ }^{25}$ Dit sluit aan op zijn stelling dat de thans geldende ongeschreven rechtsnormen (waaronder de algemene beginselen van behoorlijk bestuur), in een situatie van terugtred van de wetgever, dragers zijn geworden van de eis van weloverwogen, niet-willekeurig overheidsbestuur - waarvoor aanvankelijk slechts het legaliteitsbeginsel stond. In zijn visie bestond (en bestaat) er voor de rechtsstaat alle aanleiding om op het moment dat het juridisch rationaliteitspostulaat niet door de wet kan worden bereikt, het bestuur hieraan anderszins (door de abbb) te binden. ${ }^{26}$ Van Male beschouwt rationaliteit als een "structuurgegeven" van het administratief recht. ${ }^{27}$

\subsubsection{De evidente rationaliteit volgens Nicolai}

Nicolaï onderneemt in zijn proefschrift (ondermeer) een onderzoek naar de bouwstoffen of aanknopingspunten voor de onderkenning en articulatie van

21. Van Male, R.M., Beredeneerd besluiten. NTB'88/3, p. 73-79, i.h.b. p. 73.

22. Van Male, R.M., Rechter en bestuurswetgeving, prft., Zwolle 1988, p. 264. NTB'88/3, a.w., m.n. p. 73

23. Van Male, prft., a.w., p. 265.

24. Tbidem.

25. Ibidem, p. 266

26. NTB' $88 / 3$, a.w. p. 74 .

27. Jbidem, p. 75. 
regels van behoorlijk bestuur, c.q. de abbb. ${ }^{28}$ Het resultaat daarvan is een drietal categorieën van regels, te weten "evidente regels", "grondregels" en "fundamentele uitgangspunten". De eerste groep is met het oog op aanknopingspunten voor rationaal beslissen in het bijzonder interessant. Het betreft hierbij regels waarvan Nicolaï het, met het oog op te onzent aanvaarde rechtsinstituten, evident acht dat het bestuur deze bij de uitoefening van bevoegdheden naleeft. ${ }^{29}$

De eerstgenoemde evidente regel is die van de eis van een juiste feitelijke grondslag; beslissingen dienen op de realiteit en niet op fantasie of verzinsels te worden gebaseerd. ${ }^{30}$ Daarnaast noemt hij de eis van rationele argumentatie: aan elk bestuursbesluit dient een "rationele, logisch consistente en concludente, argumentatie" ten grondslag te liggen. ${ }^{31}$ In het verlengde van de eerstgenoemde regel ziet Nicolaï nog de eis van juiste informatie; de overheid mag uiteraard geen onwaarheden spreken. ${ }^{32}$

Het oogmerk of belang van elk van de genoemde drie "evidente regels" is het mogelijk maken van een zinnige discussie over de juistheid van het bestuurlijk besluit. Anders gezegd: als niet aan deze regels wordt voldaan is zo'n debat uitgesloten. Dit zelfde geldt mijns inziens ook voor de overige twee evidente regels die Nicolaï noemt, te weten: de eis van stelselmatigheid, zijnde de plicht criteria te ontwikkelen voor de wijze van bevoegdheidsuitoefening (c.q. het verbod van willekeur) en de eis van afweging van bij een besluit betrokken belangen. Wordt aan deze laatste twee regels niet voldaan dan ontstaat een "recht op grillen" en een "carte blanche" om naar believen belangen te desavoueren. In die context zou de conceptie van rechtsbescherming tegen overheidshandelen haar betekenis verliezen. ${ }^{33}$

Net als Van Male gaat ook Nicolaĩ in op het tanende gezag van de wet en de opkomst van het ongeschreven recht als nieuwe waarborg voor rationeel bestuur. ${ }^{34}$ Gelijk bij Van Male komt daarbij naar voren hoe parallel aan deze ontwikkeling ook sprake is van een herijking van de inhoud van het rationaliteitsbegrip; van absoluut (wetmatig, waarheidsonthullend) naar relativistisch (beoordelend, discursief).

28. Nicolaï, P., Beginselen van behoorlijk bestuur, prft., Deventer 1990, p. 413 e.v.

29. Ibidem, p. 413 en p. 414-417. Voor de omschrijving van de "grondregels" en "Fundamentele uitgangspunten", zij verwezen naar Hoofdstuk 13 van Nicolaïs proefschrift.

30. Vgl. het eerste door mij onderscheiden aspect van rationeel beslissen, als verwoord in $\$ 1.2$.

31. Nicolaï, prft., a.w., p. 414.

32. Ibidem, p. 415. Wel tekent Nicolaĩ aan dat onder bijzondere omstandigheden - zoals oorlog - een uitzondering op deze regel aanvaardbaar kan zijn.

33. Midem, p. 415-417.

34. Ibidem. p. 425-429. 
Door de terugtred van de wetgever voorzag de wet niet langer in de tegen willekeurig overheidsbestuur gezochte bescherming. Sterker nog, de terugtred gaf het bestuur meer mogelijkheden tot individuele concretisering van rechtsnormen. Nieuwe waarborgen werden gezocht om juist de toenemende bestuurlijke invloed op de vrijheid van individuen te kunnen compenseren. ${ }^{3 s}$ Juist op dat vlak kwamen vervolgens de abbb tot ontwikkeling. Nicolaï stelt vast dat het verlaten van het absolute primaat van de wet een breuk betekent met het eerdere uitgangspunt dat juist de wet bij uitstek de uitdrukking van menselijke rede vormde. Het algemene karakter van wetgeving waarborgde in die visie juist een abstractie van het toevallige, als onredelijk beoordeelde karakter van bijzondere belangen. ${ }^{36} \mathrm{De}$ opkomst van de ongeschreven beginselen acht Nicolaï echter goed te verklaren vanuit de hedendaagse visie op de overheid waarbij verlangd wordt dat zij ook de bijzondere belangen van burgers tracht te beschermen. ${ }^{37}$ Tegelijkertijd valt op hoe juist deze voor de bescherming van bijzondere belangen zo belangrijke beginselen goed aansluiten bij de hedendaagse conceptie van rationaliteit: relativistisch, op open argumentatie gericht.

\subsubsection{Tussenbalans}

Zowel in de visie van Van Male als in die van Nicolaï lijkt er nauwe aansluiting te bestaan tussen de klassieke juridische waarborgen (de wetmatigheidseis) en het klassieke, absolute rationaliteitsbegrip, alsook tussen de hedendaagse juridische waarborgen (naast de wet de beginselen) en het moderne, relativistische rationaliteitsbegrip.

Rationaliteit wordt door beide schrijvers gezien als een funderend juridisch uitgangspunt; respectievelijk een postulaat of een evidentie. Naar zijn hedendaagse inhoud stelt dit uitgangspunt het redelijk of weloverwogen handelen voorop, waarbij de nadruk ligt op de idee dat redelijkheid in een discursief proces moet worden bereikt.

Daarmee kunnen we aansluiten bij het perspectief uit het voorgaande hoofdstuk (met name \$ 4.4.2): juridische rationaliteit impliceert legitimatie van rechtsnormen door een open debat over de beoogde inhoud van die normen.

Voor de goede orde merk ik op dat de terugtred van de wetgever niet betekent dat alleen de ongeschreven beginselen een juridisch rationeel bestuursoptreden kunnen waarborgen. De wet vervult in dit verband wel degelijk een belangrijke rol. Zulks moge - ondermeer - blijken uit de vele wettelijke

35. Ibidem, p. 427.

36. Ibidem, p. 426-427. De algemene vorm was een waarborg voor onpartijdigheid en objectiviteit en vormde een goede toepassing van het rationeel geachte "als-dan"-schema.

37. Ibidem, p. 433-434. 
procedurevoorschriften voor besluitvorming welke juist een goede argumentatie moeten waarborgen; zoals bij regelingen voor inspraak, advisering en beroep. Ook geeft de wet waarborgen voor openheid (WOB) en vrije meningsuiting (art. $7 \mathrm{Gw}$ ). Tegelijkertijd worden in de Awb bestendige, uit de ongeschreven beginselen af te leiden "beslisregels" in de vorm van (al dan niet procedurele) wettelijke voorschriften neergelegd.

De analyses van Van Male en Nicolä bieden naar mijn mening toch nog onvoldoende aanknopingspunten voor status en reikwijdte van de idee van rationaliteit als bestuursrechtelijk "grondbeginsel". Met name de vraag naar de inhoudelijke begrenzing van de eis van rationeel beslissen blijft mijns inziens te veel in het vage. Mitsdien wil ik in de volgende paragraaf zelf een poging ondernemen om hierin meer scherpte aan te brengen.

\subsection{Het willekeurverbod als bestuursrechtelijk paradigma}

\subsubsection{Het algemeen belang en de burgerlijke vrijheid}

In de visies van Van Male en Nicolaï zijn de ongeschreven beginselen tot ontwikkeling gekomen om het "gat" te dichten dat door het tekortschieten van de wet is ontstaan. Dit "tekortschieten" hangt vooral samen met een sterke toename in de instrumentele mogelijkheden van de overheid, waardoor de overheid steeds nadrukkelijker kon penetreren in de privé-sfeer. ${ }^{38} \mathrm{De}$ wetgeving vervulde daarbij steeds meer een instrumentele rol. Voor het beeld van de wet als een geheel van imperatieve en objectieve regels kwam de idee van de wet als voertuig of vertrekpunt voor het effectueren van beleid in de plaats. ${ }^{39}$ De wet als waarborg verloor bijgevolg steeds meer gezag, juist op een moment dat extra waarborgen nodig werden geacht.

Deze ontwikkeling loopt parallel met de opkomst van de behoefte aan individuele rechtsbedeling. ${ }^{40}$ Gaandeweg groeide de overtuiging dat de overheid zich meer moest richten naar de rechtvaardigheid in individuele gevallen. De idee van "Normgerechtigkeit", van een binnen de wet opererende overheid moest wijken voor de wens van "Einzelfallgerechtigkeit", van het recht doen aan bijzondere belangen. "Bestuur op maat" werd noodzakelijk geacht voor

38. VgI, ook Van der Hoeven, Drie dimensies, a.w., p. 12.

39. Nicolai, prft. a.w. p. 433. Vgl, voorts $\$ 4.4 .2$ : legitimiteitsproblemen als gevolg van bet gebruik van de wet ats (procedureel) instrument van de meerderheid. In HR 14 april 1989, AAe'89/38, nr. 6. m.nt. Hirsch Ballin (Harmonisatit-wet), komt de vraag naar het rechtsgehalte van wetgeving in formele zin uitdrukkelijk aan de orde.

40. Dit punt wordt ook door Nicolä (prft, a.w., p. 431), in navolging van Peters (J. Peters, Algemene beginselen van behoorlijk bestuut, verordracht gehouden op de belastingtonsulentendag 197 ? Deventer 1971) naar voren getorach:. 
het verbeteren van de individuele ontplooiingsmogelijkheden van burgers. Zulks vergde echter een toename van het aantal discretionaire bevoegdheden en bijgevolg een terugtred van de wetgever.

Met de steeds effectievere inzet van overheidsmiddelen en de grotere behoefte aan individuele rechtsbedeling ontstond echter een spanning tussen de politieke wil tot machtsuitoefening enerzijds en het respect voor de individuele burgerlijke vrijheid anderzijds. Tegen deze achtergrond valt goed te begrijpen dat nieuwe waarborgen tot ontwikkeling kwamen en de democratische rechtsstaat evoluerde tot de sociale rechtsstaat of verzorgingsstaat. ${ }^{41}$ Twee tendensen in deze ontwikkeling acht ik hier in het bijzonder van belang.

- Allereerst denk ik aan de tendens om rechtsbescherming te zoeken bij de rechter. Falende politieke controle op het micro-besturen sterkte de roep om rechterlijke controle. Daarbij ging het niet alleen om aanvullende bescherming van burgerlijke vrijheden maar ook om een eigenbelang van de wetgever: de rechter kon er (indirect) op toezien dat het bestuur "gehoorzaamde" aan de wil des wetgevers. ${ }^{42}$ Voor de burger was rechterlijke controle echter juist aantrekkelijk vanwege de rechterlijke onathankelijkheid van de wil van de democratische meerderheid. Op deze manier kon een drempel worden opgeworpen tegen de willekeur van de meerderheid. ${ }^{43}$

Een gevolg van deze ontwikkeling is mijns inziens het ontstaan van een duale staatsrechtelijke structuur: regeermacht versus rechterlijke macht. ${ }^{44}$ Binnen de regermacht, gevormd door wetgever en bestuur, domineert het democratisch primaat als grondslag voor machtsuitoefening. De rechterlijke macht oriënteert zich in het bijzonder op de bescherming van bijzonde-

41. Oosting, M.. Beginselen van bestutr, oratie RUG 1980, Alpen aan den Rijn 1980, wijst erop dat de term verzorgingsstaat vooral een politicke ideologie tot uitdrukking brengt, terwijl de term sociait rechtsstaal vooral een juridische lading heeft (p. 3-4). Ondat ik beide elementen nauw verbonden acht, gebnik ik hier beids termen door elkaar.

42. Volguns Banda (Banda, P.H. . Administraticf procesrechi, in vergelijkend perspectief, prft. KUB 1989. Zwolle 1989) stond het administratief procescechl eerst in het teken van rechterlijke controle met hel aog op het algemeen belang (controle op wetmatigheid). Eigenlijk pas vrij recent is de bescherning van de rechtspositic van het individu voorop komen te staan. $\mathrm{Vgl}_{\mathrm{g}}$. Banda, p. 118 en p. 163. Vgl. ook het Whrol. MvT, a.w., p. 30-32. Reformatio in peius en het ultra petita gaan zjjn nog typische overblijfselto van het "onde" perspectief.

43. Hier konu de $\$ 4.4 .2$ en $\$ 5.3$ aangehaalde visie van Dworkin opnieuw naar voren: bet recht als waarborg van enkelingen, e.q. ininderheden tegen de (wil van de) meerderheid.

44. Vgl. voor een wat andere - en meer uilgewerkte - opzet: Koeman. N.S.J., De nogelijkheden van de burgerlijke rechter on hel bestutir uit onrechtnatige daad tol schadevergoeding te veroordelen, VAR-geschriften nr. 102, Alphen aan den Rijn 1989, p. 173-175. 
re belangen. Voor de rechter is het democratisch primaat echter wel een belangrijk gegeven; de wet is de primaire rechterlijke toetssteen. De ongeschreven beginselen zijn relevant als de wet bestuurlijke vrijheid laat of als onverkorte wetstoepassing tot willekeur leidt. ${ }^{45}$

- Voorts denk ik aan de tendens tot het ontwikkelen van inhoudelijke aanspraken voor de ontplooiing van individuele vrijheden. Ik denk daarbij in het bijzonder aan de sociale grondrechten. De ongeschreven (rechterlijke) waarborgen voor de individuele vrijheid van burgers voorzien in een "afwerende" bescherming tegen een ongebreidelde politieke machtsuitoefening. De sociale grondrechten dienen echter primair als een stimulans; een aanwijzing aan de overheid om bij (democratisch gelegitimeerde) machtsuitoefening het tot gelding kunnen brengen van individuele vrijheid voorop te stellen. ${ }^{46}$ Zo wordt het voor de individuele vrijheid essentiële belang van de materiële bevordering van vrijheid, gelijkheid en rechtszekerheid direct bij de vaststelling van de politieke agenda, bij de definiering van "het algemeen belang" ingebracht. ${ }^{47}$ Tegelijkertijd moet bedacht worden dat op deze wijze de overheidsbemoeienis met de samenleving en dientengevolge de druk op de individuele vrijheid juist weer groter is geworden. ${ }^{48}$

Beide tendensen hebben de spanning tussen politieke, democratisch gelegitimeerde machtsuitoefening en bescherming van individuele vrijheden in de laatste decennia sterk beïnvloed. Het is daarom zaak om deze relatie nu zelf te typeren. Daarvoor kies ik mijn vertrekpunt bij de regeermacht: politieke machtsuitoefening gericht op de behartiging van "het algemeen belang". Van daaruit zal ik gaandeweg met meer scherpte ingaan op de rol van de rechterlijke controle en de status en reikwijdte van de ongeschreven beginselen.

\subsubsection{De behartiging van het algemeen belang}

Het bestuur heeft tot taak het algemeen belang te behartigen. Het algemeen belang duidt niet op de concrete belangen van bepaalde (groepen van) personen maar op de kwaliteit van de besluitvorming als zodanig. Het bestuur handelt in het algemeen belang indien het algemene en bijzondere (groeps- en

45. Waar de Normgerechtigkeit het "tekort" aan Einzelfallgerechtigkeit niet meer kan billijken - de problematiek van de beginselen contra-legem. Vgl. Van Wijk/Konijnenbelt, a.w., p. 131 e.v..

46. Vgl. Nicolaï, prft., a.w., p. 429-430.

47. Eerder $(\$ 4.4 .2)$ kwam naar voren dat sociale grondrechten ook van belang zijn met het oog op het verzekeren van de voor een juridisch discours wenselijke formele èn materiële gelijkwaardigheid.

48. De sociale grondrechten zal ik hier niet nader bespreken. Zie daarvoor Heringa. prft., a.w. 
individuele) belangen onderling en tegen elkaar afweegt: "Een bepaald besluit (...) is als resultante van dit afwegingsproces 'in het algemeen belang' ". ${ }^{49}$

Krachtens het primaat van de democratie verplicht de taak het algemeen belang te behartigen het bestuur primair tot uitvoering van de wet. Zodra een wettelijke bevoegdheid beleidsvrijheid laat sluit Dommerings zienswijze nauw aan bij art. 3:4 Awb: de behartiging van het algemeen belang vergt alsdan een zorgvuldige belangenafweging. ${ }^{\text {so }}$

Nicolaï acht het onnodig om de plicht van de overheid om het algemeen belang te behartigen al te diepgaand te analyseren. ${ }^{51}$ Deze plicht behelst zijns inziens niet meer dan dat de overheid slechts de haar toevertrouwde gemeenschapsbelangen dient te behartigen. ${ }^{52}$

Ook de opvatting van Van der Hoeven nodigt - op het eerste gezicht - niet uit tot nadere analyse: het algemeen belang is in zijn optiek dat wat het bevoegd gezag oordeelt dat het is, terwijl dat oordeel rechtmatig is indien het niet met het recht in botsing komt. ${ }^{53}$

Wellicht moet met Tak worden aangenomen dat het algemeen belang slechts kan worden opgevat als "het evenwichtspunt van alle betrokken belangen" en niet "als inhoudelijk gevulde grootheid bestaat"..$^{.4}$ Volgens C.Drion ${ }^{55}$ hebben we het algemeen belang eigenlijk niet nodig als onderbouwing van de specifieke positie van de overheid. De overheid heeft tot taak bij elke beslissing een zorgvuldige belangenafweging te maken en daarmee is de kous af. Hij meent dan ook dat het gebruik van de term "het algemeen belang", zoals door Dommering voorgestaan (het proces waarin belangen worden afgewogen), hoewel er in die beperkte zin wat hem betreft mee te leven is, dogmatisch beschouwd geen toevoegende waarde bezit.

Toch meen ik dat die waarde er nu juist wel is omdat "het algemeen belang" verwijst naar de unieke positie van het overheidsbestuur. Een goed begrip van deze positie vergt dat niet alleen naar de juridische beperkingen aan het

49. Dommering, E.J., Algemene belangen in het burgerlijk recht, Deventer 1982, m.n. p. 2 e.v.

50. Ook interessant is of het bestuur bij gebonden bevoegdheden niet toch een "marginale" discretie heeft (als een impliciete of stilzwijgende hardheidsclausule). Ik ga op die gedachte hier niet nader in.

51. Ibidem. Hij bespreekt daar kort de visies van Donner, Van Wijk, Hirsch Ballin en Van der Hoeven.

52. Nicolaï, prft., a.w., p. 418-419.

53. Vgl. Van der Hoeven, De drie dimensies, a.w., p. 60.

54. Tak, A.Q.C., Normaal bestuur, in: Steenbeek, J.G.. M.C.Burkens en J.B.J.M.ten Berge (red.), Bestuur en norm, bundel opstellen opgedragen aan Prof. mr. R. Crince le Roy, Deventer 1986. p. 255-263, i.h.b. p. 255.

55. Drion, C., Grondslagen van de onrechtmatige overheidsdaad, R\&K'88/14, p. 333-363 (m.n. p. 350-353). 
overheidshandelen wordt gekeken, maar juist ook naar het eigen momentum achter het overheidshandelen.

Dit momentum vloeit voort uit de (voornoemde) wil tot machtsuitoefening. ${ }^{56}$ Deze wil komt in de geschiedenis van het bestuursrecht naar voren als de te beteugelen factor; een factor onder druk van voortschrijdende juridificering.

Kernpunt van de wil tot machtsuitoefening is de politieke wil, gevormd in een democratisch discours. Dat is de motoriek achter het overheidshandelen: alleen door politieke wil kunnen keuzes worden gemaakt. Bestuursorganen formuleren hun programma of agenda van doelstellingen en prioriteiten in het politieke discours. Primair is dit een politiek, democratisch gelegitimeerd proces.

In de sociale rechtsstaat zijn, ik wees daar (onder $\S 5.5 .1$ ) al op, ook positieve juridische stimuli tot ontwikkeling gekomen, die aan de politieke wil tot machtsuitoefening een juridische impuls geven. Ik denk daarbij met name aan de eerdergenoemde sociale grondrechten. Deze scheppen immers een zekere plicht voor de overheid en beïnvloeden aldus de politieke agenda-vorming. ${ }^{57}$ Ook de zogenoemde klassieke grondrechten kunnen stimuleren tot (politiek) actief optreden door het bestuur ${ }^{58}$ en hetzelfde geldt natuurlijk ook voor discretionaire (taken en) bevoegdheden. ${ }^{59}$

Met de politieke, democratische wil als primaat moeten bestuursorganen afwegingen maken tegen de achtergrond van een mix van politieke en juridische doelen en prioriteiten. Op de keper beschouwd draagt deze afweging een utilitair-opportunistisch karakter. De politieke wil tot machtsuitoefening behelst een utilitair streven naar optimale doelbereiking. Ook de diverse juridische impulsen dragen hier aan bij. Zo "verlangen" grondrechten een zo optimaal mogelijke realisatie van de zorg. Daarnaast sporen bepaalde rechtsbeginselen aan tot een utilitaristische optiek. De Planque spreekt - bij voorbeeld - over de eis dat bij elk besluit het gewicht van de met dat besluit te dienen doelen het gewicht van de door dat besluit te schaden belangen te

56. Hoewel uit het perspectief van de democratische rechtsstaat beter van gezagsuitoefening kan worden gesproken, doe ik dat hier niet teneinde het politieke karakter beter tot uitdrukking te laten komen.

57. Een goed voorbeeld is art. $21 \mathrm{Gw}$ (zorg voor de bescherming en verbetering van het leefmilieu). Zie ook Heringa A.W. en T. Zwart, Facelift van een oude dame?, De Grondwet 1983, NJB'83/8, p. 233-247.

58. Het onderscheid klassieke - sociale grondrechten is enigszins achterhaald. Gemakshalve houd ik hier de oude termen nog maar aan. Vgl. Koopmans, T., Compendium van het staatsrecht. bewerkt door J.E. Goldschmidt, A.W. Heringa en R.E. de Winter, Deventer 1992, $\$ 150$.

59. Ook van de ongeschreven beginselen kan een inhoudelijk stimulerende werking uitgaan. Ik denk hierbij met name aan het gelijkheidsbeginsel. Toch houd ik vast aan het uitgangspunt dat het hier toetsingsmaatstaven betreft. 
boven moet gaan. ${ }^{\infty}$ Een soort evenredigheidsgebod derhalve waarbij van het bestuur wordt verlangd dat elk besluit per saldo een positief resultaat heeft en dat elk besluit ten opzichte van zijn alternatieven het grootst mogelijke "netto belangenresultaat" sorteert. ${ }^{61}$

De belangenafweging is opportunistisch omdat in beginsel alle betrokken belangen afweegbaar zijn; geen enkel belang heeft a priori een groter gewicht dan andere belangen. Qua vertrekpunt is de politiek-bestuurlijke agenda maatgevend, al is het bestuur natuurlijk wel gehouden aan maatstaven van (minimale) wettelijke belangenbescherming, zoals bij grenswaarden. Opportunisme ligt ook besloten in het feit dat in de tijd, gemeten over een serie van elkaar opvolgende bestuursbesluiten, geen positief belangenresultaat is vereist. Een cumulerend algemeen nut zou overigens ook moeilijk zijn te meten. ${ }^{62}$

Politieke wilsvorming op democratische grondslag is een goede basis voor de behartiging van het algemeen belang - juist omdat het in aanzet een legitimatie biedt voor inbreuken op burgerlijke vrijheden. Niettemin kan juist het utilitair-opportunistische karakter van de wil tot machtsuitoefening een geduchte bedreiging vormen voor deze burgerlijke vrijheden.

Juridische inperking van de wil tot machtsuitoefening is derhalve van het grootste belang. In het verlengde van die noodzaak voorzien het legaliteitsbeginsel, het specialiteitsbeginsel, het verbod van willekeur en de abbb in essentiële juridische waarborgen.

Gegeven een discretionaire bevoegdheid is tegelijkertijd van groot belang dat deze juridische waarborgen ruimte laten voor het tot gelding brengen van de wil tot machtsuitoefening. Daarin ligt immers de democratische legitimatie en het politieke momentum tot behartiging van het algemeen belang.

60. De Planque, J.H.W.. De mogelijkheden van administratieve rechters en de Kroon om het bestuur tot schadevergoeding te veroordelen. in: Koeman. N.S.J. en J.H.W.de Planque, Overheidsaansprakelijkheid, administratieve en burgerlijke rechter, VAR-preadvies, Alphen aan den Rijn 1989 , p. 7-160, i.h.b. p. 12-13 en p. 17.

61. Ibidem. p. 12-13. In $\$ 4.3 .3 \mathrm{kwam}$ deze norm al even aan de orde. Ik wees er toen reeds op dat de norm niet zover reikt dat de rechter het bestuur ertoe kan "dwingen" om ook het besluit met het grootst mogelijke netto-belangenresultaat te nemen. De positieve norm die De Planque eerst schetst (kortgezegd: de voordelen moeten groter zijn dan de nadelen) lijkt mij wel toetsbaar. De rechterlijke invloed op het verkiezen van de "relatief beste variant" is beperkt.

62. Na elk besluit zou een rekenkundige balans van alle betrokken belangen moeten worden opgemakt en dit zo moeten worden verdisconteerd bij elk nieuw te nemen besluit waarbij een of meer dezelfde belangen betrokken zijn. Eigenlijk zouden we alle (denkbare) belangen op voorhand moeten kennen en ook belangen-eenheden voor onderlinge waardevergelijking moeten kennen. Vgl. mijn interventie op de VAR-vergadering van 21 april 1989, VAR-geschriften nr. 103, p. 2830 . 
Dit punt komt goed tot uitdrukking bij het willekeurverbod, waarin het respect voor het (vrije) politieke momentum in zekere zin zelfs uitgangspunt vormt. Dit beginsel wordt, samen met het evenredigheidsbeginsel en het materiële zorgvuldigheidsbeginsel, in hoofdzaak gecodificeerd in art. 3:4 Awb. ${ }^{63}$ Belangrijk is dat dit artikel gekenmerkt wordt door een negatieve redactie: "De ... nadelige gevolgen mogen niet onevenredig zijn in verhouding tot ...". Deze negatieve redactie houdt verband met de wijze waarop de rechter het bestuurshandelen aan deze maatstaf kan toetsen. Meer in het algemeen zal de rechter ${ }^{64}$ pas daar moeten ingrijpen waar de regeermacht van de meerderheid ontaard in een "willekeurige" bejegening van de rechten van de enkeling of minderheid. Ik chargeer natuurlijk enigszins: elke vorm van willekeurige bejegening van belangen is in strijd met het recht. De begrippen meerderheid en minderheid vervullen in de juridische praktijk op dit punt geen rol als criterium. Gelukkig maar, anders zou het uitbrengen van een stem ook instemming impliceren met alles wat de eigen kandidaat of partij vervolgens voorstelt! In elk geval geldt voor de rechter de leidraad dat hij de burgerlijke vrijheid moet beschermen zonder te vergeten dat het democratisch primaat voor de behartiging van het algemeen belang onmisbaar en intrinsiek waardevol is.

Zouden we slechts spreken van de plicht tot een zorgvuldige belangenafweging dan komt de unieke positie van het overheidsbestuur niet goed in beeld. De typische spanning in het bestuursrecht, meer precies de "beperkte reikwijdte" van juridische waarborgen in het licht van de democratische legitimatie van politieke wilsvorming, wordt dan onvoldoende onthuld. "Het algemeen belang" geeft inhoud aan de (discretionaire) bevoegdheden van het bestuur en verwijst naar de democratisch gefundeerde wil tot machtsuitoefening. ${ }^{65}$ Omdat behartiging van "het algemeen belang" tevens naar een in aanleg utilitair-opportunistische machtsuitoefening verwijst, roept het op tot waakzaamheid. De bescherming van burgerlijke vrijheid is immers een zaak van aanhoudende zorg.

\subsubsection{De centrale rol van het willekeurverbod}

In het hedendaags bestuursrecht impliceert de plicht tot behartiging van het algemeen belang een typisch beleidsmatige dynamiek van het overheidsbestuur; een dynamiek op basis van democratische wilsvorming binnen de grenzen van daarop toegesneden rechtswaarborgen. Op deze waarborgen wil ik

63. Dat is althans het oogmerk: MvT-Awbl, a.w., p. 69-71.

64. Althans in geschillen tussen burger(s) en overheid.

65. In feite de publiekrechtelijke tegenhanger van het privaatrechtelijke begrip "wil". 
hier nog afzonderlijk in gaan, als opmaat tot de vraag of het juist is om rationaliteit te beschouwen als een (funderend) beginsel van bestuursrecht.

De juridische waarborgen tegen de overheid plaatste ik reeds in het perspectief van het streven willekeurig overheidsbestuur te voorkomen of tegen te gaan. In dat verband zou ik willen spreken van het willekeurverbod in ruime zin. $^{66}$

Met Bakker en $\mathrm{Tak}^{67}$ ben ik van mening dat juist dit willekeurverbod de eigenlijke kern vormt van de beperking van de machtsuitoefening van het bestuur. Het is de grondslag of de genus ${ }^{68}$ van de algemene beginselen voor bestuur, rechtspraak en wetgeving en gaat, als algemene notie ${ }^{\boldsymbol{\theta}}$, zelfs vooraf aan het legaliteitsbeginsel. ${ }^{70}$ Het is passend dat in dit willekeurverbod zowel erkenning is te vinden voor de opkomst van het idee van individuele rechtsbedeling ${ }^{71}$ als respect voor de democratisch gevormde politieke wil tot behartiging van het algemeen belang. Daarbij heeft het willekeurverbod een open karakter waardoor, zoals Bakker en Tak ook aangeven, naar de maat van de heersende rechtsopvattingen specifieke eisen aan het overheidsoptreden konden en kunnen worden gesteld. Zij spreken daarbij over "uitbreiding" die door speciesbeginselen kan worden gegeven aan het willekeurbeginsel als genusbeginsel. ${ }^{72}$ In het gebruik van die term lees ik de bevestiging van de teneur die in het gehele betoog lijkt te overheersen: het willekeurverbod wordt niet begrepen als een louter formeel gebod terughoudend te zijn ten aanzien van toetsing van overheidshandelen, maar als fundamenteel beginsel met een materiële inhoud. De basis daarvan wordt door hen gelegd bij de overweging die in het Doetinchemse woonruimtevorderingsarrest ${ }^{73}$ wordt gebezigd: van een daad van willekeur is sprake indien de overheid "bij afweging van de in aanmerking komende belangen in redelijkheid niet tot een

66. Dus niet het willekeurverbod als toetsingscriterium; de "c-grond" in bij voorbeeld art. 8 lid 1 AROB. Het willekeurverbod in ruimere zin omvat dit criterium, maar wordt hier gebruikt als een "mantelbegrip" voor het intomen van overheidswillekeur en is derhalve -analytisch gezien- van vroegere datum.

67. Bakker, R.E., A.Q.C.Tak, De centrale rol van het willekeurverbod bij de toetsing van overheidshandelen, in: Heringa, A.W. en N. Verheij, Publiekrechtelijke bewegingen, Deventer 1990, p. 205-218.

68. Ibidem, p. 218.

69. Als rechterlijk toetscriterium kwam het pas later tot ontwikkeling.

70. Hetgeen Bakker en Tak in hun betoog niet alleen historisch en rechtstheoretisch maar ook met verwijzing naar het leerstuk van onrechtmatige wetgeving aannemelijk weten te maken.

71. Als door nadruk op individuele rechtsbedeling de wetgever terugtreedt (door het geven van discretionaire bevoegdheden) voldoet de wetmatigheidstoets niet meer. Het willekeurverbod (als een aan de nieuwe rechtsopvattingen aangepast criterium) voorziet dan in waarborging van individuele rechtsbedeling.

72. A.w., p. 218.

73. HR 25 februari 1949, NJ 558. 
vordering had kunnen komen, en dus afweging van die belangen geacht moet worden niet te hebben plaatsgehad".

Nadat Bakker en Tak de lijn van de toetsing door de burgerlijke rechter van bestuursdaden en daden van wetgeving nader hebben geanalyseerd, stellen zij vast dat het willekeurverbod als een algemene noemer is te beschouwen, "die al nagelang de aard van het overheidsoptreden zijn verfijning in de vorm van algemene beginselen van behoorlijk bestuur, algemene beginselen van behoorlijke wetgeving en algemene beginselen van behoorlijke rechtspraak" vindt. $^{74}$

Nicolaï ziet juist in het eerder genoemde evenredigheidsbeginsel, inhoudende dat burgers niet verder in hun belangen (c.q. vrijheden) worden aangetast dan strikt noodzakelijk is, een grondregel van het hedendaagse bestuursrecht en een bouwstof voor abbb. ${ }^{75} \mathrm{Hij}$ waarschuwt er voor het willekeurverbod te beschouwen als een bestuursrechtelijke behoorlijkheidsregel of een abbb. ${ }^{76}$

De "c-grond" van het willekeurverbod is volgens Nicolaï slechts een aanwijzing aan de rechter, inhoudende dat hij slechts mag ingrijpen indien het bestuurlijk oordeel omtrent de redelijkheid en billijkheid bij het nemen van een bepaald bestuursbesluit een marginale toets niet doorstaat. ${ }^{7}$ Aan het willekeurverbod wordt alleen een formeel-negatieve betekenis gegeven: de rechter moet met zijn toets terughoudend zijn, want hij mag niet op de plaats van de bestuurder terecht komen.

De inhoudelijke norm die Bakker en Tak aan het willekeurverbod verbinden moet volgens Nicolaï in de abbb zelf worden gevonden. In dit perspectief is het passend dat Nicolaï een afzonderlijk beginsel van redelijke en billijke belangenafweging onderscheidt. ${ }^{78}$ Dit beginsel vereist "dat het bestuur bij de belangenafweging in abstracto redelijke beleidsregels vaststelt en dat het in concreto van die beleidsregels afwijkt als de bijzondere belangen van de individuele burger daartoe billijkheidshalve nopen". ${ }^{79}$ Ook is het consistent dat hij vervolgens op zoek gaat naar de oorsprong of bouwstenen daarvan, welke hij vindt, c.q. postuleert, in de evidente regels, de grondregels en de fundamentele uitgangspunten. ${ }^{80}$ Daar postuleert hij - ondermeer - de 'evidente regels' inhoudende de eis van stelselmatigheid (het verbod van grillen, van

74. Bakker/Tak, a.w., p. 216.

75. Prft., a.w., p. $420-422$.

76. A.w., p. 239-240 en p. 323-324.

77. Nicolai, prft., p. 240 (en noot 89 aldaar), alsmede p. 323 . Misschien komt art. 8 lid 1 Wet AROB volgens Nicolaï neer op: a: het primaat van de wet; b: de plicht het algemeen belang te behartigen; e: de eis aan de rechter terughoudend te toetsen; $d$ : specifieke behoorlijkheidscriteria.

78. Prft., a.w., p. 368-369.

79. Tbidem.

80. Prft., a.w., Hoofdstuk 13. 
willekeur - in inhoudelijke zin) en de eis van afweging van belangen (redelijkheid en billijkheid), ${ }^{81}$ die door anderen, naar zijn oordeel ten onrechte, aan de bekende "c-grond" (het verbod van willekeur) worden verbonden ${ }^{82}$

Naar mijn mening is het niet juist om aan te nemen dat evidente regels en grondregels voorafgaan aan het willekeurverbod. Deze regels danken hun bestaansrecht aan een lange rechtsstrijd waarin de rechter een vooraanstaande en baanbrekende rol heeft vervuld. ${ }^{83}$ Daardoor heeft de spanning tussen democratische machtsuitoefening en de bescherming van burgerlijke vrijheden en daarmee de verhouding tussen regeermacht en rechterlijke macht een nieuwe inhoud gekregen.

De ontwikkeling van het willekeurverbod geeft uitdrukking aan deze strijd en typeert deze spanningsrelatie. ${ }^{84}$ Het komt mij dan ook juist voor om aan te nemen dat het willekeurverbod zelf de door Nicolaï bedoelde evidente regels en grondregels moet impliceren, en zo dus toch een materiële norm (als genus voor de abbb) inhoudt: ${ }^{85}$ daden van willekeur zijn niet toelaatbaar, c.q. onrechtmatig.

Het willekeurverbod is stellig meer dan een abbb. Veeleer is het een algemeen, fundamenteel rechtsbeginsel, dat in oorsprong slechts zag op het voorkomen van irrationeel handelen. De willekeur-norm is (echter) open van karakter door de open verbinding tussen de norm-inhoud met de ontwikkelingen in het ongeschreven recht. Nieuwe opvattingen over de verhouding tussen burger en bestuur of tussen regeermacht en rechter konden (en kunnen) daardoor in de willekeur-norm worden geïncorporeerd. ${ }^{86}$

Terugkijkend meen ik dat het voorkomen van overheidswillekeur reeds bij het intreden van de democratische rechtsstaat als streven aanwezig was in de notie van rationeel handelen (in de klassieke zin), waarmee het een basis vormde voor het legaliteitsbeginsel. De eis van een democratische legitimatie

81. Prft. a.w., p. 415-417.

82. Volgens Nicolaï impliceert de willekeurformule in het Doetinchemse woonruimtevorderingsarrest, juist door zijn negatieve strekking. de daaraan voorafgaande rechtseis van afweging van belangen, prft. a.w., p. 417.

83. Waarmee niet gezegd is dat niet ook de wetgever zich op bepaalde momenten "vooruitstrevend" heeft betoond.

84. Bakker en Tak, a.w., p. 210 , menen dat met het willekeureriterium de doorgang tussen Scylla en Charybdis is gevonden.

85. Nicolaï, prft., a.w., p. 413-413, spreekt over regels die evident zijn m.h.o. aanvaarde rechtsinstituten: "..regels, die in feite geen verklaring behoeven.." (p. 413). Daarmee koppelt hij deze (anders dan de "grondregels" en "fundamentele uitgangspunten") los van de door mij bedoelde spanningsrelatie.

86. Zoals de eis van een beleidsmatige afweging (of twee-fasentoetsing): vgl. ARRvS 11 december 1982, AB'82, 216 (Hoorn). 
vond een pendant in de politieke verantwoordelijkheid voor machtsuitoefening. In de sociale rechtsstaat ontwikkelde zich mede door de idee van de individualiserende rechtsbedeling ook een juridische verantwoordelijkheid. Op dat moment komt het willekeurverbod als noemer èn als toetsingscriterium tot ontwikkeling. De rechterlijke toepassing van het willekeurverbod leidt tot de eis van weloverwogen en behoorlijk beargumenteerd bestuurlijk handelen; parallel met de relativering van het rationaliteitsbegrip.

Tegelijkertijd blijkt dan dat het willekeurverbod een materiële basis is voor meer specifieke rechterlijke toetsingsmaatstaven: een onderbouw waarop zich als een bovenbouw, in de vorm van de abbb nieuwe specifieke eisen ontwikkelen. Essentieel is echter juist op dat punt dat de openheid van het willekeurverbod een eenzijdige openheid is. In formeel-negatief opzicht is deze openheid beperkt doordat de rechter alleen eisen kan stellen die uitgaan van het politieke primaat van het discretionair handelende bestuur. Zowel de inhoudelijke ontwikkeling van het willekeurverbod als de totstandkoming van abbb wordt hierdoor bepaald. ${ }^{87}$

Het willekeurverbod verwijst, meer dan de aanduiding "algemeen rechtsbewustzijn", naar de karakteristieke bestuursrechtelijke spanning tussen democratische machtsuitoefening en burgerlijke vrijheid. Bij de plicht van de overheid om machtsuitoefening te richten op de behartiging van het algemeen belang, geeft het willekeurverbod de uiterste grens van deze machtsuitoefening aan. Nieuwe ongeschreven rechtswaarborgen ontstaan onder invloed van wijzigingen of nuanceringen (verfijningen) in onze opvattingen over voornoemde spanningsrelatie. In dat opzicht zijn zij vrucht van rechtsculturele opvattingen over het voorkomen en tegengaan van overheidswillekeur. Dit komt naar mijn mening ook tot uitdrukking in de wijze waarop de moderne, discursieve rationaliteitsopvatting in verschillende abbb is terug te vinden. Een punt dat ik hieronder - tot slot - nog zal bespreken.

Hoewel het willekeurverbod als toetsingscriterium in de afgelopen decennia enigszins in de schaduw van de abbb is komen te staan, staat voor mij vast dat het willekeurverbod als het paradigma van het bestuursrecht kan worden aangemerkt. Het typeert dat de rechter zich, als het echt op een confrontatie met de wetgever aankomt, zoals in de Doetichemse woonruimte vordering en

87. Ik ga er vanuit dat door rechters ontwikkelde eisen in dit opzicht inhoudelijk een beperkte reikwijdte zullen hebben en niet dat de eisen pas bij toepassing worden beperkt. Dat laatste zou passen in Nicolaïs formeel-negatieve uitleg van het willekeurverbod. Zijn precisering van (bij voorbeeld) het beginsel van een redelijke en billijke belangenafweging getuigt echter ook reeds van een (in bedoeld opzicht) "inwendige" beperktheid. Prft., a.w., p. 368-369. 
Jater in bij het Landbouwspuitvliegen, ${ }^{88}$ bij gebreke van een wettelijke maatstaf, direct op het willekeurverbod beroept.

In dit verband is het van belang dat codificatie van het willekeurverbod (althans in hoofdzaak) in art 3:4 Awb niet ten koste gaat van de open verbinding daarvan met het ongeschreven recht. Eerder heb ik verklaard dat de voorstellen dienaangaande een belemmering zouden kunnen vormen voor de bestuursrechtelijke rechtsontwikkeling. Mijn vrees was dat codificatie primair gedienstig zou zijn aan de rechtszekerheid van bestuursorganen, terwijl voor burgers slechts verstarring in het vat zat. ${ }^{89}$

De MvT bij de Awbl biedt, anders dan de toelichting op het voorontwerp, ${ }^{90}$ gelukkig meer duidefijkheid: "Overigens wordt met het in de wet opnemen van de in de rechtspraak ontwikkelde regels niet beoogd een verdere ontwikkeling van het ongeschreven recht af te snijden." "De mogelijkheid blijft (...) bestaan dat de rechter een bepaald bestuurshandelen in strijd met het recht zal oordelen zonder dat hij daarbij kan aansluiten bij een in de Awb gecodificeerde regel. Hij zal zich dan evenals nu kunnen beroepen op een ongeschreven beginsel van behoorlijk bestuur of een ander rechtsbeginsel". ${ }^{91}$ Hier komt goed tot uitdrukking dat de in de Awb te codificeren beginselen "slechts" als minimumnormen moeten worden opgevat.

Naar mijn overtuiging behoeven we op termijn niet voor het gevaar van verstarring te vrezen. De typische taak die in de sociale rechtsstaat aan de rechter is toebedacht, waarborgt dat hij, als hij willekeur ontwart, zal optreden. Daarvoor is het paradigma sterk genoeg; wetsbepaling of geen wetsbepaling!

\subsection{Een algemene eis van rationeel bestuur?}

Aan het slot van $\$ 5.4 .3$ stelde ik dat de analyses van Van Male en Nicolaï onvoldoende aanknopingspunten gaven voor status en reikwijdte van de idee van rationaliteit als bestuursrechtelijk "grondbeginsel".

Wat de optiek van Nicolaï betreft gaat het inmiddels niet meer om onvoldoende aanknopingspunten, maar om een afwijzing. Het lijkt mij onjuist om een rationaliteitseis als evidente (rechts)regel te aanvaarden omdat het a

88. Res], HR 25 Cehruari 1949. NJ 558 m.n. Veegens en HR 16 mei 1986, AB 547 m.n. Van Buuren.

89. $\mathrm{Zis}$ mijn artikel "De prijs van sodilisatie". TyO'88, p. 391-394, dat overigens ook betrekking had op de codificatic van abhb.

90. Vgl. p. 22 punt 3 van het voorontwerp.

91. MvT, a.w., p. 9. Zie ook Nicolaï, prfi., a.w.. p. 537 . 
priorisch karakter daarvan voorbijgaat aan de paradigmatische rol van het willekeurverbod.

Bij de analyse van Van Male kan ik mij goed vinden in de stelling dat in de hedendaagse optiek rationaliteit hooguit als afwezigheid van willekeur is te begrijpen. Dat impliceert enerzijds aansluiting bij het relativistisch rationaliteitsbegrip en anderzijds sluit het aan op het paradigmatisch karakter van het willekeurverbod. Tegelijkertijd word ik achterdochtig als hij vervolgens spreekt over een "rationaliteitspostulaat", als een "structuurgegeven voor het administratief recht", dat nu het niet langer door het legaliteitsbeginsel wordt gedragen, door ongeschreven rechtsbeginselen tot gelding moet worden gebracht. Deze uitlatingen suggereren een a priorisch "rationaliteitsbeginsel", ${ }^{92}$ dat los staat van het willekeurverbod en zich naar inhoud en reikwijdte los daarvan ontwikkeld.

Toch kan dit niet bedoeld zijn. Ik zie geen juridisch normatieve grondslag voor een inhoudelijke ontwikkeling van zo'n autonoom beginsel. Dit ligt anders voor het willekeurverbod, dat aansluit bij (zich ontwikkelende) opvattingen over de, inmiddels veelbesproken, spanningsrelatie.

Ik vermoed dat ook Van Male dit probleem ziet. Wat de inhoud van het "rationaliteitsbeginsel" betreft stelt hij voorop dat de vraag wat rationeel is en wat niet, primair is overgelaten aan direct en indirect democratisch gelegitimeerde organen. ${ }^{93}$ Een gedachte die ik, indachtig het democratisch primaat goed kan volgen, maar dan wel slechts als aspiratie of uitgangspunt. Alles komt dan tenslotte aan op de toetsing. Volgens Van Male komt de rechter bij toetsing van het handelen van voornoemde organen aan de ongeschreven rechtsbeginselen, slechts een oordeel toe "over de vraag of iets irrationeel is, omdat (...) niet blijkt dat er belangen zijn afgewogen. Aan een minder grote (rechterlijke, MAH) terughoudendheid kleeft het gevaar, dat de rechter dieper ingrijpt in het wezen van de politieke prioriteitstelling, dan hij gelet op zijn staatsrechtelijke positie kan verantwoorden". ${ }^{94}$

In dat licht zie ik geen andere mogelijkheid dan voor de bestuursrechtelijke conceptualisering van de idee van rationeel beslissen uit te gaan van de spanning tussen democratische machtsuitoefening en burgerlijke vrijheid, en dus van het willekeurverbod als bestuursrechtelijk paradigma. Enerzijds wordt daarmee dan voortgebouwd op de materiële onderbouw van het willekeurverbod: waarbij de vraag naar de noodzaak van waarborgen in het belang van de bescherming van burgerlijke vrijheden voorop staat. Anderzijds moet worden

92. Van Male, prft, a.w., p. 348.

93. Prft., a.w., p. 348.

94. Ibidem, p. 349. 
gebleven binnen de formeel-negatieve begrenzing van het willekeurverbod; in erkenning van het democratisch primaat van de politieke machtsuitoefening.

Op deze basis zijn de opvattingen over rationeel beslissen met het oog op de vaststelling van complexe feiten (door inbreng van expertise) goed te verankeren.

$\mathrm{Nu}$ deze problematiek, getuige de uiteenzetting in hoofdstuk 4. , in termen van een relativistische, discursieve rationaliteitsopvatting kan worden benaderd, lijkt mij juridificering van op die leest geschoeide beslisregels in beginsel goed mogelijk. Dergelijke regels betreffen immers primair de randvoorwaarden voor een goed debat, waarbij open(baar)heid en toegankelijkheid van de besluitvorming, de afwezigheid van dwang en de gelijkwaardige positie voor de deelnemers bij het inbrengen van informatie, argumenten en opvattingen, alsmede bij de presentatie van een eenmaal genomen besluit een grote rol spelen. Meer specifiek denk ik voorts aan de inbreng en beoordeling van expertise en ten slotte naar de normatieve eindverantwoordelijkheid.

In het volgende hoofdstuk hoop ik aan te kunnen geven hoe een aantal van deze elementen, als uitvloeisel van de idee van een discursieve rationaliteit zijn neerslag heeft gevonden in het streven willekeurig overheidshandelen tegen te gaan - en derhalve in het willekeurverbod en de abbb als toetsingscriteria zijn te traceren. Ik denk daarbij (wat de abbb aangaat) ${ }^{95}$ in het bijzonder aan regels inzake de openheid en toegankelijk van de besluitvorming, de advisering, de afweging en de motivering.

Tot slot wil ik nog eens onderstrepen hoezeer het relativistische rationaliteitsidee aansluit op het willekeurverbod. Ik doel hier op het feit dat de beoordeling van de rationaliteit van besluitvorming primair neerkomt op het elimineren van irrationeel gedrag; willekeur als verbod van irrationaliteit. Twee aspecten zijn daarbij vooral van belang.

- In de eerste plaats het corrigeren van onjuiste veronderstellingen, rekenen meetfouten, niet-wetenschappelijke waarden (partijdige deskundigheid), het voorbijgaan aan relevante en gezaghebbende informatie, het onmogelijk zijn of niet toelaten van contra-expertise, gebleken of kennelijke onjuistheden of inconsistenties en - meer in het algemeen - een gebrek aan open(baar)heid en toegankelijkheid van de besluitvorming. Voor het voorkomen of bestrijden van overheidswillekeur zijn dit elementaire (om niet te zeggen - evidente) ongerechtigheden.

95. Omdat het nu om een precisering gaat ligt het m.i. voor de hand aan de abbb te denken. Als gezegd lenen de "fundamentele noties" van het willekeurverbod zich daar minder toe (daar gaat het immers om de "enormiteiten"). 
- In de tweede plaats denk ik aan een belangrijke conclusie uit het voorgaande hoofdstuk. Rationeel beslissen volgens het rationeel-synoptische model is een irreële eis. Bij het onderzoek naar en de beoordeling van besluitvormingsalternatieven kan van het bestuur in technische-wetenschappelijke zin geen zekerheid worden verlangd. Juridisch gezien is een bevredigende beslissing het optimum. In dat verband wees ik op het criterium van art. 3:2 Awb ("de nodige kennis omtrent relevante feiten") en op het tweede lid van art. 3:4 Awb. ${ }^{96}$ Het onderzoek naar alternatieven kan worden gestopt als het relatief beste alternatief is gevonden.

Deze beide aspecten sluiten goed aan bij de vuistregels uit het voorafgaande hoofdstuk. Het tweede aspect valt samen met de tweede vuistregel (bevredigend beslissen). In het eerste aspect liggen eisen van openheid en wetenschappelijkheid besloten zoals die ook in de derde, vierde en vijfde vuistregel zijn te vinden. Beide aspecten sluiten aan op de bestuurlijke verantwoordelijkheid voor de feitenvaststelling, c.q. bij de eerste vuistregel.

De vraag voor dit hoofdstuk was of de idee van rationeel beslissen als een positiefrechtelijk beginsel van bestuursrecht is te duiden. Het antwoord luidt wat mij betreft positief, met dien verstande dat de idee van rationeel beslissen geen zelfstandige grondslag heeft in het positieve bestuursrecht maar (slechts) door of op basis van het willekeurverbod tot gelding kan worden gebracht: de bestuursrechtelijke toets van de rationaliteit van bestuurlijke besluitvorming ligt uiteindelijk steeds in het willekeurverbod. ${ }^{97}$

96. MvT-Awbl, a.w.. p. 68: "min of meer toevallige effecten die het bestuur niet zonder zeer verregaande informatieverzameling zou kennen" worden als te ver verwijderd beschouwd.

97. De bestuursrechtelijke toets. Het gaat hier - als gezegd - niet om de algemene eis van juridischrationeel handelen. De eis van de legitimiteit van rechtsnormen wordt hier - uiteindelijk "slechts" besproken in de context van de waarborgen in de bestuursrechtelijke spanningsrelatie tussen algemeen belang en burgerlijke vrijheid. 


\section{Hoofdstuk 6}

\section{Bestuursrechtelijke eisen voor rationeel beslissen}

\subsection{Inleiding: de publiekrechtelijke legitimatie}

In dit hoofdstuk zal ik ingaan op specifieke juridische waarborgen voor de inbreng van expertise binnen het algemeen deel van het positieve bestuursrecht. Dit hoofdstuk vormt daarmee de spil tussen de algemeen theoretische optiek van het voorgaande hoofdstuk en de speurtocht naar milieurechtelijke waarborgen in het volgende hoofdstuk. De procedure van totstandkoming van bestuursbesluiten, oftewel de non-contentieuze procedure staat daarbij centraal.' Ik denk daarbij in het bijzonder aan de algemene procedures uit de Awb, die ik in $\$ 6.3$ zal bespreken. Alvorens daartoe over te gaan zal ik (in $\S 6.2)$ kort ingaan op de in dit bestek belangrijkste rechtsbeginselen. Aansluitend aan de bespreking van rechtsbeginselen en procedures zal ik (zeer) specifiek ingaan op de regels inzake gerichte en ongerichte advisering; respectievelijk in $\S 6.4$ en $\S 6.5$. In de laatste paragraaf (6.6) zal ik ten slotte enkele conclusies optekenen en waar mogelijk en wenselijk een vergelijking maken met de vuistregels uit deel II van deze studie.

Uitgangspunt van dit hoofdstuk is de bijzondere juridische betekenis van de non-contentieuze procedure. In het voorgaande hoofdstuk kwam reeds naar voren dat een typisch aspect van het besturen is gelegen in het democratisch primaat. Als het bestuur discretionair optreedt, past het de rechter om (desgevraagd) het bestuurlijk handelen met respect voor het democratisch primaat te toetsen.

Naast deze democratische legitimatie staat de publiekrechtelijke legitimatie. Terwijl democratische legitimatie de bevoegdheid tot handelen betreft, betreft publiekrechtelijke legitimatie de wijze van bevoegdelijk handelen; de machtsuitoefening volgens de regels van de non-contentieuze procedure. ${ }^{2}$

De basis voor de idee van publiekrechtelijke legitimatie is dat wetstoepassing naast (in)directe democratische legitimatie een nadere legitimatie behoeft: dat met name verzekerd moet zijn dat beslissingen in een open procedure tot stand worden gebracht, indien mogelijk en wenselijk in wisselwerking met

1. De contentieuze procedure komt aan de orde in deel IV.

2. Deze regels kunnen natuurlijk ook een democratische grondslag hebben - denk aan de regels uit de Awb. Het gaat er nu echter om dat het bestuur naar de wijze van besluiten legitimatie verwerft. 
degenen die het aangaat. ${ }^{3}$ De nog nader te bespreken juridische besluitvormingsprocedures van de Awb spelen hierin een zeer grote rol.

Legitimatie is een normatief begrip: legitimatie moet worden verworven. Democratische legitimatie tot besturen wordt krachtens wettelijke bevoegdheidstoekenning verworven ${ }^{4}$; de test van de legitimatie ligt in de vraag naar de bevoegdheid. Hetzelfde geldt voor de publiekrechtelijke legitimatie: pas als wettelijke (procedure-)regels en rechtsbeginselen zijn gerespecteerd, is de uitkomst, het bestuursbesluit, publiekrechtelijk gelegitimeerd.

Ook de betekenis van de publiekrechtelijke legitimatie is te vergelijken met die van de democratische legitimatie; opnieuw speelt daarbij de rolverdeling tussen rechter en bestuur. Democratische legitimatie komt er in de kern op neer dat de rechter de wettelijke bevoegdheidsverdeling als uitgangspunt neemt en door het bestuur krachtens discretionaire bevoegdheid gemaakte keuzes respecteert, tenzij deze keuzes (in ruime zin) "willekeurig" zijn. De aanspraak op formele rechtskracht ${ }^{5}$ en het vermoeden van rechtmatigheid als beginsel van bestuursprocesrecht ${ }^{6}$ vinden hun grondslag in de verwachting dat overeenkomstig de regels van de non-contentieuze procedure is gehandeld. De voor publiekrechtelijke legitimatie kenmerkende non-contentieuze regels kunnen overigens in een verschillend perspectief worden geplaatst. Bij sommige regels, zoals inspraakregels, staat de idee van burgerlijke participatie voorop. In zekere mate wordt hiermee ook de democratische legitimatie van het bestuurlijk handelen weer gesterkt. Weer andere regels hangen samen met het ideaal van individuele rechtsbedeling en behelzen waarborgen voor individuele burgers om voor hun positie op te komen (zoals het recht op informatie, het recht om gehoord te worden, het recht op een reactie op een gedaan verzoek etcetera). ${ }^{7}$ Ten slotte zijn er regels die samenhangen met de kwaliteit van de besluitvorming in meer objectieve zin, bij voorbeeld regels inzake de advisering, of inzake de wijze waarop een besluit wordt genomen (bij voorbeeld collegiaal). Ik zou niet willen betogen dat er in deze zin typen van regels zijn te onderscheiden. ${ }^{8}$ Vaak zijn aan specifieke regels wel elementen van verschillende perspectieven te onderkennen. ${ }^{9}$ Tegelijkertijd moe-

3. Zie ook $\$ 4.4 .2$.

4. En, in voorkomende gevallen, door juiste toepassing van de regels inzake delegatie en mandaat.

5. Als geen beroep tegen het besluit wordt ingesteld. wordt het besluit - niettemin - geacht rechtmatig te zijn genomen. Vgl. HR 16 juni 1986, AB 573 (Heesch/Van den Akker).

6. Vgl. Ten Berge. J.B.J.M. en A.Q.C.Tak. Nederlands administratief procesrecht, Zwolle 1983 , par. 115 en 879 . Op de rol van dit beginsel in het toekomstige bestuursprocesrecht kom ik nog terug in hoofdstuk 9.

7. In dit verband wordt ook wel gesproken van "preventieve rechtsbescherming".

8. Regels inzake participatie, inzake individuele rechtsbedeling, inzake de kwaliteit van besluitvorming.

9. Zoals participatie m.i. ook de individuele rechtsbedeling en de kwaliteit van besluitvorming kan dienen. 
ten we bedenken dat de non-contentieuze procedure op deze grondslag een betrekkelijk unieke set aan waarborgen bevat die tezamen de publiekrechtelijke legitimatie van bestuursbesluiten moeten schragen. Met deze waarborgen is de non-contentieuze procedure naar mijn smaak ook bij uitstek de plaats voor de feitenvaststelling. Juist daar liggen immers vele waarborgen voor een kwalitatief optimale feitenvaststelling.

Op voet van de idee van publiekrechtelijke legitimatie zullen in dit hoofdstuk verschillende waarborgen aan bod komen.

\subsection{Enkele rechtsbeginselen}

In het voorgaande hoofdstuk stelde ik het willekeurverbod (in ruime zin) bovenaan in een denkbeeldige hiërarchie van rechtsbeginselen. Daarmee gaf ik impliciet te kennen dat de ultieme test van de an het overheidsbestuur te stellen eisen in het ongeschreven recht is gelegen. Dat geldt niet alleen voor het willekeurverbod in ruime zin maar ook voor de meer gepositiveerde juridische waarborgen: het legaliteitsbeginsel, het specialiteitsbeginsel, het willekeurverbod (in enge zin) en de abbb zijn alle ongeschreven. Ook de komst van de Awb brengt daarin geen verandering. ${ }^{10}$ Tegelijkertijd beschouw ik de in de volgende paragraaf te beschrijven algemene, non-contentieuze procedures uit de Awb als een codificatie van uit de ongeschreven beginselen afgeleide besluitvormingseisen.

Binnen de ongeschreven kern van het bestuursrecht is het willekeurverbod het paradigmatische genusbeginsel. Met het oog op de problematiek van deze studie kortweg getypeerd als het verbod van irrationaliteit. Deze typering indachtig, is het aantrekkelijk het willekeurverbod en enkele daarvan afgeleide speciesbeginselen, voorzover relevant voor de expertiseproblematiek, nader in hun positiefrechtelijke vorm te "definiëren."

\subsubsection{Willekeur}

Inbreng van expertise betreft niet slechts het verwerven van advies, maar het gehele omgaan met de factor deskundigheid: het rationele beslissen (zie hoofdstuk 1). In dat perspectief heb ik het willekeurverbod (in ruime zin) in het voorgaande hoofdstuk mede als belichaming van de eis van rationeel be-

10. De in $\$ 5.5 .3$ noot 90 en 91 aangehaalde verwijzing uit de MvT-Awbl naar de rol van het ongeschreven recht sluit hier $\mathrm{m} . \mathrm{i}$. bij aan.

11. Aan het slot van het voorgaande hoofdstuk wees ik er op hoe uitgaand van het verbod van irrationaliteit verschillende met enkele vuistregels te vergelijken regels opdoemen. Nu is het zaak die regels scherp in beeld te krijgen. 
slissen gepostuleerd. De inhoud daarvan was tweeledig: de eis van een correcte feitenvaststelling in een discursief gestructureerde besluitvorming en het verbod van irrationeel handelen. Wat het eerste aspect betreft verwijs ik naar de hierna de te bespreken eisen van zorgvuldigheid en gemotiveerdheid van handelen. Wat het verbod van irrationeel handelen betreft beperk ik mij er toe te wijzen op een tweetal aspecten:

- allereerst de eisen te stellen aan het nemen van een bevredigende beslissing. In hoofdstuk 4 heb ik daarvoor het drie-stappen-model (selectie, onderzoek en toetsing) geschetst. In dit model moeten oordelen worden gegeven over de redelijkerwijs in beschouwing te nemen alternatieven en de mate van zekerheid die in het feitenonderzoek moet worden verworven. Tot het laatste punt behoort ook de zakelijke controle van eventuele adviezen op partijdigheden, (ongewenste) premisses, meet- en rekenfouten, ontbrekende gegevens, onbegrijpelijkheden, inconsistenties en wat dies meer zij. ${ }^{12}$ Vervolgens moeten alternatieven worden getoetst aan het recht. ${ }^{13}$ Bevredigend beslissen is een methode voor rationeel handelen. Met het oog daarop is het van belang dat de rechter indringend kan toezien op een goede beoordeling van elk van de voornoemde elementen.

- Op voet van de feitenvaststelling wordt een belangenafweging gemaakt. Het bestuur brengt een voorkeurvolgorde aan in de uitgewerkte alternatieven. In die fase kan de wens om bepaalde onzekerheden zo veel mogelijk uit te bannen, teneinde een bepaald belang zo zeker mogelijk te beschermen, een grote rol spelen. Een alternatief dat grotere veiligheidsmarges of buffers heeft, en aldus het minste risico voor het bij uitstek te beschermen belang meebrengt, kan hoog worden gerangschikt. De rechter zal die rangschikking kritisch kunnen beoordelen. Hierin reikt zijn maatstaf echter niet verder dan art. 3:4 Awb bepaald: de belangenafweging moet volledig zijn, het resultaat daarvan "niet onevenredig".

\subsubsection{Zorgvuldigheid}

Zorgvuldigheid met het oog op het discursieve karakter van de besluitvorming, impliceert zorg voor de openheid van besluitvorming. De procedure moet voor belanghebbenden (en belangstellenden) toegankelijk zijn en reële (materiële) kansen bieden tot deelname aan het debat.

12. Hier is sprake van een zekere overlap met het zorgvuldigheids- en motiveringsbeginsel. Naar hun materiële inhoud bezien, verlangen ook die beginselen een dergelijke controle.

13. Toetsing aan het recht vraagt geen normatieve keuze, maar wel een juiste inschatting van het gewicht van de "benadeelde belangen". Die inschatting is - bij voorbeeld - essentieel met het oog op de maatstaf van art. 3:4, tweede lid Awb. 
Openheid komt ten goede aan het verkrijgen van relevante informatie, alsook aan de mogelijkheid tot tegenspraak bij feitenvaststelling. In verband hiermee zijn met name het beginsel van "correcte bejegening" en het zorgvuldigheidsbeginsel van belang.

De benaming beginsel van correcte bejegening ontleen ik aan Nicolai. ${ }^{14}$ Het omvat onder meer het fair play beginsel en volgens Nicolaï ziet het met name op de volgende eisen:

- Een mededelingsplicht voor het bestuur ten opzichte van belanghebbenden, inzake ophanden zijnde beslissingen. Ook is het bestuur gehouden belanghebbenden te informeren omtrent (de inhoud van) rapporten en adviezen waarop door belanghebbende bestreden beschikking is gebaseerd. ${ }^{15}$

- Een waarschuwingsplicht zo een besluit (ingrijpende) nadelige gevolgen heeft voor een burger of diens procespositie beïnvloedt.

- De plicht om een burger in de gelegenheid te stellen tot herstel van verzuim in verband met een door hem gedane aanvrage tot het nemen van een bepaalde beslissing.

- De plicht tot een fatsoenlijke behandeling van burgers (fair-play): openheid, eerlijkheid en royaliteit. Open kaart spelen - en in geen geval informatie achterhouden, laat staan achterbaksheid.

- De plicht tot het overleggen met belanghebbenden, c.q. de plicht tot het bieden van de mogelijkheid van inspraak en de hoorplicht bij voor burgers ingrijpende beslissingen, zoals ook voorgesteld in art. 4:7 en 4:8 Awb. Niet onbelangrijk is natuurlijk dat het bestuur voorafgaand aan het overleg met betrokkenen nog geen definitieve keuze heeft gemaakt en dus nog werkelijk beïnvloedbaar is. ${ }^{16}$ Ook zal, als na het horen van betrokkenen nieuwe feiten of inzichten aan het licht komen, daarvan aan deze betrokkenen mededeling gedaan moeten worden en eventueel zelfs tot opnieuw horen moeten worden besloten. ${ }^{17}$

Op zichzelf vind ik het nuttig om deze eisen - met Nicolaï - te onderscheiden van de eisen welke voortvloeien uit het (formele) zorgvuldigheidsbeginsel. Maar toch valt niet te ontkennen dat de eisen van zorgvuldig onderzoek of

14. Prft., a.w., p. 327 e.v.

15. Vgl. ARRvS 9 maart 1978, AB'79, 55 m.n. v.d.V. Zie overigens de WOB (waaraan i.c. niet werd getoetst).

16. Alleen zo komt er iets van het open debat terecht. Een dergelijk criterium heb ik in de jurisprudentie echter niet uitdrukkelijk kunnen vinden.

17. Vgl. Nicolaï, prft., a.w.. p. 331-332. 
een zorgvuldige beslissingsprocedure dicht tegen de eisen van correcte bejegening aanliggen. ${ }^{18}$

De eis dat een besluit pas mag worden genomen na een zorgvuldig onderzoek naar relevante feiten en omstandigheden, is als een eis van het formele zorgvuldigheidsbeginsel algemeen aanvaard en (in algemene zin) opgenomen in art. 3:2 Awb. Belangrijke elementen van het zorgvuldigheidsbeginsel zijn het overleggen met, c.q. horen van betrokkenen en het (eventueel) inwinnen van adviezen. In verband hiermee is het uiteraard van belang dat het bestuur ingaat op commentaren van betrokkenen en op de inhoud van en commentaren op het advies. In samenhang met het laatste punt zij er nog op gewezen dat het bestuur ook inhoudelijk de zorgvuldigheid van de feitenvaststelling dient te bewaken. De (ook reeds hierboven, bij het willekeurverbod genoemde) controle op partijdigheden, (ongewenste) premisses, meet- en rekenfouten, ontbrekende gegevens, onbegrijpelijkheden, inconsistenties en wat dies meer zij, behoort daartoe.

Voor de openheid van besluitvorming, mede in termen van de toegankelijkheid van het proces van meningsvorming, zijn ook de bepalingen van Hoofdstuk 2 Awb (Verkeer tussen burgers en bestuursorganen) van belang. Het gaat hier om regels inzake bijstand en vertegenwoordiging door een gemachtigde (artt. 2:1 en 2:2), doorzending van door burgers verkeerd geadresseerde stukken aan bevoegde instantie (art. 2:3), het verbod van vooringenomenheid aan de zijde van het bestuur (art. 2:4) en regels ter zake van vertrouwelijkheid (art. 2:5). Aan deze regels ligt volgens de MvT een moderne visie over de verhouding tussen burger en bestuur ten grondslag. In de memorie wordt er op gewezen dat aan het begin van deze eeuw de heersende opvatting was dat het bestuur zich als boven de burger gestelde overheid kon presenteren: "Kon het bestuursoptreden de toets aan de wet doorstaan en werd het niet door de volksvertegenwoordiging veroordeeld, dan had de burger het in beginsel te aanvaarden." ${ }^{19}$ Daartegenover stelt de memorie dat naar huidige opvattingen de overheid niet zonder zich van de belangen en zienswijzen van burgers rekenschap te geven beslissingen "over burgers" kan nemen. Opgemerkt wordt dat de gecompliceerdheid van de hedendaagse bestuurstaak overigens ook noodzaakt tot een duidelijke inbreng van burgers; zonder dat is het vaak eenvoudig onmogelijk om goede beslissingen te nemen. ${ }^{20}$ De slotsom is dat overleg en goede communicatie onontbeerlijk zijn. Daarin past dat de relatie tussen bestuur en burger wordt beschouwd als: "..een rechtsbetrek-

18. Het beginsel van zorgvuldig onderzoek en van een zorgvuldige beslissingsprocedure worden door Nicolaï als afzonderlijke beginselen opgevoerd: prft, a.w., p. 332-341.

19. MvT-Awbl, a.w., p. 11.

20. Ibidem. p. 11-12. 
king waarin beide partijen in een wederkerige relatie staan, zodat zij rekening moeten houden met de positie en de belangen van de andere partij. "21

Daarbij wordt overigens wel opgemerkt dat "het bestuur in de eerste plaats (is) gebonden aan de regels van de wetgever en aan de resultaten van de politieke besluitvorming,...". Binnen de aldus bepaalde grenzen moet het bestuur zich ook rekenschap geven van de belangen en (daarmee verbandhoudende) zienswijzen van burgers. ${ }^{22}$

\subsubsection{Motivering}

Het motiveringsbeginsel wordt door Van Male rechtstreeks in verband gebracht met het oogmerk van een rationele besluitvorming. ${ }^{23}$ Van groot belang is dat een beschikking dient te rusten op een deugdelijke motivering, dat wil zeggen een kenbare en draagkrachtige motivering, van groot belang. Uiteindelijk is daarin immers een eerste aanwijzing te vinden voor het oordeel over de vraag of het bestuur op juiste wijze tot zijn beslissing is gekomen en het besluit op zichzelf getuigt van een juiste interpretatie van relevante wettelijke regels, van een juiste (goed onderbouwde) feitenvaststelling en van een begrijpelijke afweging van belangen. Aldus moet blijken of het bestuur op basis van een rechtens aanvaardbare argumentatie tot zijn beslissing is gekomen. ${ }^{24}$ Terecht worden in afdeling 4.14. Awb enkele regels voor de motiveringsplicht voorgesteld; zowel in materiële zin (een deugdelijke motivering) als in formele (met het oog op bekendmaking en inhoud).

Voor deze studie is de motiveringsplicht vooral ook van belang met het oog op het rationele debat over een te nemen beslissing. Als een kenbare motivering ontbreekt wordt het debat over de beslissing nodeloos gehinderd; argumenteren pro of contra is dan zinledig. De draagkracht van een motivering is niet alleen relevant uit een oogpunt van de juiste feitelijke grondslag, afwezigheid van strijd met (geschreven en ongeschreven) rechtsregels, ${ }^{25}$ maar ook omdat in de motivering moet worden gereageerd op hetgeen bij de voorbereiding van het besluit aan argumenten pro en contra naar voren is gekomen. ${ }^{26}$

21. Bbidem. p. 12.

22. Ibidem, p. 11-12. Impliciet komt hierin ook de door mij gepostuleerde publiekrechtelijke legitimatie tot uitdrukking.

23. Van Male, NTB 1988, a.w., p. 73.

24. Vgl. Nicolaï, prft.. a.w., p. 353(-358).

25. Waaronder die van niet-onredelijk (toegepast) beleid en logische consistentie van de aan het besluit ten grondslag gelegde overwegingen en tussen overwegingen en het besluit.

26. Van Male, NTB 1988. a.w.. p.77-78. Wat het laatste punt betreft wijst Van Male op ARRvS 29 november 1979, tB/S III. 154 en ARRvS 5 juli 1982, AB 565. 
Het motiveringsbeginsel zal samen met de andere hier genoemde beginselen een belangrijke rol vervullen bij het omgaan met expertise. Ik hoop dit zichtbaar te kunnen maken bij de bespreking van de gerichte en ongerichte advisering (in par. 6.4 en 6.5). Eerst wil ik ingaan op enkele in de Awb voorziene, standaard-besluitvormingsprocedures. Deze procedures zijn mijns inziens overigens ook zelf weer geënt op voornoemde beginselen - en wel met name op het zorgvuldigheidsbeginsel en het beginsel van correcte bejegening.

\subsection{Non-contentieuze procedures volgens de Awb}

\subsubsection{Inzet van de Awb}

Naast codificatie van beginselen door bepalingen met een inhoudelijk vrij algemene strekking (zoals de artikelen 3:2 tot en met 3:4 Awb), bleek het goed mogelijk om enkele concrete, uit ongeschreven beginselen afleidbare handelingsvoorschriften te codificeren. ${ }^{27}$ Op voet daarvan is in de thans voorziene opzet een drietal procedures ontwikkeld, en wel in Titel 4.1 (Beschikkingen), in Afdeling 3.4 (Openbare voorbereidingsprocedure) en in Afdeling 3.5 (Uitgebreide openbare voorbereidingsprocedure).

De procedure van Titel 4.1 is de, voor het verlenen van beschikkingen normaal verplichte procedure. ${ }^{28} \mathrm{Bij}$ de daarin voorziene regels voor het horen van belanghebbenden (in afdeling 4.1.2) gaat de wetgever er van uit dat deze belanghebbenden bij het bestuur bekend zijn. In de procedure van Afdeling 3.4. is het uitgangspunt dat er onbekende belanghebbenden in het spel zijn en dat "het voor het bestuur praktisch en theoretisch ondoenlijk (is) alle mogelijke belanghebbenden aan te schrijven". ${ }^{29}$ De procedure van Afdeling 3.5 is toegesneden op "de voorbereiding van besluiten waarbij de belangen van derden in sterke mate betrokken kunnen zijn". ${ }^{30}$ De procedures van Afdeling 3.4 of 3.5 gelden overigens niet slechts voor beschikkingen maar voor besluiten in het algemeen. Ook zijn de openbare procedures niet verplicht maar facultatief: zij worden gevolgd "indien dat bij wettelijk voorschrift of bij besluit van het bestuursorgaan is bepaald". ${ }^{31}$

27. Vgl. Buuren, P.J.J. van, Codificatie van administratief recht in de algemene wet bestuursrecht, NJB 21 mei 1988 speciaal.

28. Vgl. voor de verhouding tussen de Awb en andere wetgeving MvT-Awbl, a.w., p. 17-18.

29. MvT-Awbl, a.w... p. 75.

30. MvT-AwbA. a.w... p. 1.

31. Aldus art. 3.10 en art. 3:14, overeenkomstig de volgens het AwbA beoogde eindversie van de Awb. Het oorspronkelijke art. 3:10 Awb stelde: "indien dat bij wettelijk voorschritt is bepaald of indien het bestuursorgaan dat doelmatig oordeelt". In de MvT-AwbA (a.w.. p. 2) staat dat de facultatieve standaardregeling kan worden toegepast waar dat doelmatig wordt geacht. De ratio van de voorgestelde wijziging ontgaat mij (en wordt ook in de MvT-AwbA. a.w., p. 8 niet onthuld) - gaat het er misschien om de rol van de rechter bij de procedure-keuze in te tomen? 
Op de drie genoemde procedures (en hun verschillen) ga ik hieronder nader in. Ook op de bezwaarschriftenprocedure als bedoeld in art. 7:1 Awb. Deze is namelijk verplicht voorgeschreven in (bijna) alle gevallen waarin tegen een besluit beroep bij de administratieve rechter openstaat. Een belangrijke uitzondering op deze regel wordt gevormd door besluiten die met toepassing van de procedure van Afdeling 3.5 zijn voorbereid. ${ }^{32}$ De verhouding tussen de voorbereidingsprocedures en de bezwaarschriftenprocedure verdient, voor een goed inzicht in de bestuurlijke besluitvorming, uitdrukkelijk de aandacht. De procedures van administratief beroep, goedkeuring, spontane vernietiging en schorsing zal ik niet bespreken. ${ }^{33}$

\subsubsection{De algemene standaard-procedure ${ }^{4}$}

De standaard-procedure van Titel 4.1 bestaat uit regels voor de aanvraag (Afdeling 4.1.1), voor de voorbereiding (Afdeling 4.1.2) en voor de beslistermijn (Afdeling 4.1.3) bij het geven van beschikkingen. ${ }^{35}$ Hier zijn vooral de bepalingen inzake de plicht van de aanvrager tot het verschaffen van gegevens (art. 4:2-6) en de bepalingen inzake het horen van aanvrager en/of belanghebbenden (art. 4:7-8) van belang.

\subsubsection{Gegevensverschaffing}

Art. 4:2 lid 2 Awb verplicht de aanvrager tot het verschaffen van gegevens en bescheiden die voor de beslissing op de aanvraag nodig zijn en waarover hij redelijkerwijs de beschikking kan krijgen. Deze bepaling betreft de noncontentieuze bewijslastverdeling. ${ }^{36}$ Daarin staat de regel van art 4:2 $\mathrm{Awb}^{37}$ tegenover de regel van art. 3:2 Awb: de actieve onderzoeksplicht van het bestuur. ${ }^{38}$ Uit de jurisprudentie blijkt duidelijk dat de aanvrager informatie

32. Aldus art. I H AwbA, dat strekt tot uitbreiding van art. 6.3.1 a (7:1) Awb met een nieuw onderdeel terzake (d).

33. Resp. Afd. 7.2 Awb, IA.2.1, IA.2.2 en IA.2.3 Awb.

34. Eigenlijk gaat het om "standaard-voorschriften", maar ze laten zich m.i. goed als procedure lezen.

35. Afdeling 4.1.4 Motivering, zal volgens het Awb3 worden aangepast tot een nieuwe Afdeling 3.6 Awb3. a.w.. p. 56-58. In deze tekst wordt uitgegaan van de nieuwste nummering: Afdeling 3.7.

36. Zie hierover o.m. Nicolaï, prft., a.w., p. 333-335.

37. Reeds door Kan. J.M., Bewijzen in het administratief recht, RMTh.'66, p. 519-541, i.h.b. p. 537. omschreven als de regel dat de aanvrager van een beschikking de plicht heeft "zijnerzijds alle gegevens te verschaffen, die de overheid nodig heeft om tot een verantwoord oordeel te kunnen komen".

38. Die aansluit op de regel van de Commissie van Maarseveen. VAR-geschriften LXXII, Alphen aan den Rijn 1974, in het concept voorstel van een Wet Algemene Bepalingen van Administratief Recht: "De overheid dient uit eigen beweging de nodige kennis te vergaren omtrent de belangen, die bij een te geven beschikking betrokken zijn". 
dient aan te reiken die inwilliging van zijn verzoek rechtvaardigt en dat hij (dus) niet kan verwachten dat het bestuur zelf steeds alle kennis vergaart. ${ }^{39}$

De MvT bij art. 4:2 lid 2 Awb stelt dat het gaat om de verstrekking van die informatie "die het bestuur meestal niet of veel moeilijker langs andere weg kan verkrijgen." ${ }^{40}$ Daartoe wordt van aanvrager verlangd dat hij althans de informatie verschaft waarover hij redelijkerwijs de beschikking kan krijgen. Welke gegevens dat precies zijn is in de Awb niet exact aan te geven en mitsdien verwijst de MvT naar de bepalingen dienaangaande in bijzondere wetten. ${ }^{41}$

Heel uitdrukkelijk wordt in de MvT gesteld dat art. 4:2 lid 2 Awb ook een grens stelt aan de gegevens die het bestuur van de aanvrager kan verlangen. ${ }^{42}$ Dit blijkt allereerst door de beperking tot informatie die "nodig" is om op de aanvraag te kunnen beslissen. Daarnaast is een belangrijke beperking gelegen in de eis, die gegevens en bescheiden te verstrekken waarover aanvrager "redelijkerwijs de beschikking kan krijgen". Of het redelijk is om van de aanvrager te verwachten dat hij bepaalde informatie verzamelt is bij voorbeeld afhankelijk van de moeite die het kost. Als het bestuur slechts met moeite aan bepaalde informatie kan komen terwijl de aanvrager hierover "veel gemakkelijker" kan komen te beschikken, dan ligt er een taak voor de aanvrager. ${ }^{43}$ Ook de verhouding tussen het belang van de aanvrager en de moeite die hij moet doen om informatie te vergaren vormt een aanwijzing voor de reikwijdte van zijn informatieplicht.

De bestuurlijke onderzoeksplicht van art. 3:2 Awb krijgt overigens een "bijzonder accent" bij besluiten waarbij tegengestelde belangen in het geding zijn, of waarbij aan bestuurszijde sprake is van "een zekere vrijheid van beslissen". ${ }^{44}$ Voorts mag de informatie die de aanvrager verstrekt niet klakkeloos worden overgenomen. Als de gegevens niet onomstreden zijn doet het bestuur er goed aan zelf nader onderzoek in te stellen. ${ }^{45}$

In verband met de persoonlijke levenssfeer of met de bescherming van bedrijfs- of fabricagegegevens heeft de aanvrager, ingevolge art. 4:3 Awb, het recht om te weigeren bepaalde gegevens of bescheiden te verschaffen. Ik meen dat de hardheid van deze bepaling nog het best wordt getypeerd met

39. $\mathrm{Vgl}$ de opgave van Nicolaï, prft., a.w.. p. 334, noot 213.

40. MvT-Awbl, a.w.. p. 88.

41. Ibidem.

42. Ibidem, p. 89.

43. Dbidem. "Veel gemakkelijker" suggereert dat niet te snel een plicht voor de aanvrager moet worden aangenomen.

44. Ibidem, p. 64.

45. Ibidem, p. 63. Vgl. ook Berge, J.B.J.M. ten. et al. (res.), Commentaar Awb, deel art. 4.1.1.2, Goorden (ABR 8/66). 
het volgende citaat uit de MvT: "Betreft het een gegeven dat weliswaar in de privacysfeer ligt maar dat voor besluitvorming onontbeerlijk is, bijvoorbeeld omdat het bestuursorgaan anders de aanvraag moet afwijzen, dan zal het belang van het verstrekken van gegevens waarschijnlijk wel opwegen tegen het belang van privacybescherming". ${ }^{46}$ Overigens is in dit verband van belang dat het gelet op art. 2:5 Awb mogelijk is om onder vertrouwelijkheid gegevens en bescheiden aan het bestuur te doen toekomen. ${ }^{47}$

Ten slotte wijs ik nog op art. 4:5 Awb, dat een regeling geeft van het recht van het bestuur om te besluiten een aanvraag niet in behandeling te nemen. Zo kan het niet voldoen aan wettelijke voorschriften inzake het doen van een aanvraag (waaronder art. 4:2 Awb) aanleiding zijn tot een dergelijk besluit. Een drietal punten is hierbij met name van belang. ${ }^{48}$

Allereerst is in de regeling geen sprake van een plicht om in bepaalde gevallen een aanvraag niet in behandeling te nemen. Als de aanvrager in zijn informatie-plicht te kort schiet maar het bestuur anderszins de nodige informatie heeft verworven, kan het bestuur besluiten om de aanvraag toch in behandeling te nemen.

In de tweede plaats kan een besluit om een aanvraag niet te behandelen pas worden genomen nadat de aanvrager in de gelegenheid is gesteld om zijn "verzuim" te verhelpen (en wel binnen een door het bestuur te stellen termijn). Dit punt is vooral van belang omdat de aanvrager niet altijd weet welke gegevens en bescheiden het bestuur nodig heeft om een beslissing te kunnen nemen.

In de derde plaats voorziet het derde lid van art. 4:5 Awb in de verplichting tot bekendmaking van het besluit tot het niet in behandeling nemen van een aanvraag - zodat de aanvrager weet waar hij aan toe is.

\subsubsection{Het horen}

Art. 4:7 en 4:8 Awb vormen de ruggegraat voor de hoorplicht van het bestuur bij de voorbereiding van beschikkingen. Art. 4:7 Awb verplicht het bestuur er toe de aanvrager in de gelegenheid te stellen zijn zienswijze naar voren te brengen indien het bestuur voornemens is diens aanvrage geheel of gedeeltelijk af te wijzen. Art. 4:8 Awb regelt een gelijksoortige verplichting ten aanzien van belanghebbenden die de beschikking niet hebben aangevraagd.

De hoorplicht is beperkt tot de situatie dat de gegevens waarop de beslissing steunt de aanvrager of belanghebbende betreffen maar (art. 4:7 Awb) afwij-

46. Ibidem, p. 90.

47. Ik kom op deze kwestie in hoofdstuk 7 nog terug (i.v.m. art. $58 \mathrm{Wm}$ ).

48. Vgl. MvT-Awbl, a.w., p. 91-93. 
ken van de gegevens die de aanvrager heeft verstrekt, of (art. 4:8 Awb) niet door de belanghebbende zijn verstrekt. Als de afwijking in de gegevens slechts van geringe betekenis is (art. 4:7 lid 2 Awb) of als belanghebbende zelf niet aan zijn wettelijke plicht tot het verstrekken van informatie heeft voldaan (art. 4:8 lid $2 \mathrm{Awb}$ ), vervalt de hoorplicht. Bovendien kunnen art. 4:7 en art. 4:8 Awb onder omstandigheden als in art. 4:11 en art. 4:12 Awb genoemd, buiten toepassing worden gelaten. ${ }^{49}$

Afdeling 4.1.2 Awb wordt gezien als een uitwerking van het aspect van het zorgvuldigheidsbeginsel inhoudende "de verplichting tot het horen van belanghebbenden indien dat voor het vergaren van de vereiste gegevens nodig is"..$^{50}$ Raadpleging dient "vooral plaats te vinden wanneer het contact met de belanghebbende kan bijdragen tot goede vaststelling van de feiten". (...) "Dit betekent dus niet dat bij de voorbereiding van iedere beschikking de belanghebbende in de gelegenheid moet worden gesteld zijn zienswijze naar voren te brengen". ${ }^{51}$ Zo geldt voor het horen van de aanvrager dat deze slechts als er bij het bestuursorgaan twijfels bestaan over de juistheid van de verstrekte gegevens, of het bestuursorgaan beschikt over daarmee tegenstrijdige informatie, daadwerkelijk in de gelegenheid moet worden gesteld om zijn zienswijze te geven..$^{52}$ Ook in de toelichting bij art. 4:8 Awb wordt benadrukt dat de verplichting tot horen (als geregeld in Afdeling 4.1.2) een betrekkelijk beperkt karakter heeft. ${ }^{53}$

Dit komt ook goed naar voren in de toelichting op de Openbare (voorheen: uitgebreide) voorbereidingsprocedure van Afdeling 3.4: "Ook zal het bij zulke uitgebreide procedures eerder voor de hand liggen om het "horen" niet strikt te beperken tot het aspect van de vaststelling van gegevens over feiten en belangen, maar daarbij tevens aandacht te besteden aan bezwaren van belanghebbenden". ${ }^{54}$

In de procedure van Afdeling 4.1.2 Awb wordt een goede voorbereiding van de beschikking vooropgesteld en niet de denkbare (preventieve) rechtsbeschermingsfunctie van het horen. Voor deze "verwerende" functie wordt in de MvT verwezen naar de "toetsing van de beschikking achteraf, maar nog wel binnen het bestuur": ${ }^{55}$ de bezwaarschriftenprocedure nadat een besluit is genomen. Eventuele feilen in de naleving van de hoorplicht dienen in die fase

49. Ik ga op deze omstandigheden hier niet nader in.

50. MvT-Awb1, a.w., p. 94.

51. Midem, p. 95.

52. Ibidem. p. 98.

53. Midem, p. 100

54. Dbidem, p. 75.

55. Ibidem, p. 96. 
te worden hersteld, ${ }^{56}$ gelijk ook andere onvolledigheden en gebreken in het vergaren van de benodigde gegevens alsdan kunnen worden opgeheven. ${ }^{57}$

\subsubsection{De advisering}

De procedure van Titel 4.1 voorziet niet in specifieke regels voor advisering bij het geven van beschikkingen. Voor advisering bij besluitvorming door personen of colleges die daar krachtens wettelijk voorschrift mee zijn belast en die niet werkzaam zijn onder verantwoordelijkheid van het tot beslissen bevoegde bestuursorgaan, bevat Afdeling 3.3 Awb enkele specifieke regels. Daarnaast komt advisering nog aan de orde bij de codificatie van het motiveringsbeginsel, en wel in art. 3.6.4 en art. 3.6.5 Awb. Art. 3.6.4 Awb betreft het bij wijze van motivering verwijzen naar een uitgebracht advies. Indien het advies zorgvuldig tot stand is gekomen, ${ }^{58}$ is een dergelijke verwijzing mogelijk, mits het advies zelf de motivering bevat en belanghebbenden inhoudelijk in kennis zijn of worden gesteld van het advies. Art. 3.6.5 Awb schrijft voor dat een besluit dat afwijkt van een krachtens wettelijk voorschrift gegeven advies de redenen voor deze afwijking vermeld. ${ }^{\$ 9}$ Op de materie van deze beide artikelen ga ik hierna, in paragraaf 6.4. nog nader in.

\subsubsection{De openbare voorbereidingsprocedure}

In de regeling van de hoorplicht bij beschikkingen in Afdeling 4.1.2. wordt aangenomen dat belanghebbenden bij het bestuur bekend zijn. In de praktijk doet zich in veel gevallen de situatie voor dat er "onbekende derden" in het spel zijn waarvan het wenselijk is dat zij bij de voorbereiding van het besluit betrokken worden. Juist daarin voorziet de openbare voorbereidingsprocedure door een uitgebreide openbare kennisgeving (art. 3:12 Awb) en een daaropvolgende regeling voor terinzagelegging en wat dies meer zij (art. 3:11 Awb).

De hoorplicht in de openbare voorbereidingsprocedure is geregeld in art. 3:13 Awb. Insprekers kunnen hun "zienswijze" naar voren brengen en (zoals hierboven onder $\$ 6.3 .2 .2$. al werd gesteld) kan daarbij tevens aandacht wor-

56. Ibidem, p. $1022^{-. . e n ~ z a l ~ n i e t ~ z o n d e r ~ m e e r ~ h o e v e n ~ t e ~ l e i d e n ~ t o t ~ v e r n i e t i g b a a r h e i d ~ v a n ~ d e ~ b e s c h i k-~}$ king in kwestie".

57. Ibidem, p. 145. Op de functie van de bezwaarschriftenprocedure kom ik - als gezegd - nog afzonderlijk terug.

58. Waarvan het bestuur zich zal moeten vergewissen, in voorkomende gevallen op grond van art. 3:9 Awb1. Vgl. MvT-Awb1, a.w., p. 111.

59. Advisering door bij voorbeeld de milieu-inspectie valt, blijkens de toelichting op art. 4:20 Awbl (MvT-Awb1, a.w., p. 112) ook onder deze bepaling. Een terzake in de $\mathrm{Wm}$ voorziene specifieke bepaling (art. 13.20 onder $\mathrm{b} \mathrm{Wm}$ ) is in de voorstellen ex AwbA vervallen (vgl. art. II EEE, waar in het herziene hoofdstuk $13 \mathrm{Wm}$ een met art. 13.20. vergelijkbare bepaling ontbreekt). 
den besteed aan hun bezwaren. Dit bevordert het draagvlak onder de noncontentieuze besluitvorming. In de toelichting wordt opgemerkt dat bezwaren vooral dan aan de orde kunnen komen als er een ontwerp van het te nemen besluit aanwezig is. ${ }^{60}$ De procedure voorziet daar uitdrukkelijk in door telkenmale te spreken over "de aanvraag of het ontwerp". Volgens de toelichting kan "de hier geregelde uitgebreide hoorprocedure vooraf $(\ldots)$ bepaalde trekken van een bezwaarprocedure vooraf krijgen", overeenkomstig de inspraakprocedure bij milieubeschikkingen. ${ }^{61}$

In beginsel gaat de openbare voorbereidingsprocedure uit van de zelfde kring van inspraakgerechtigden als de procedure van Afdeling 4.1.2 Awb: te weten belanghebbenden (als omschreven in art. 1:2 Awb). Uitdrukkelijk wordt echter in art. 3:13 lid 2 Awb de mogelijkheid geopend dat ook anderen dan belanghebbenden (bij voorbeeld "een ieder") in de gelegenheid worden gesteld hun zienswijze naar voren te brengen. Daarmee kan het draagvlak van de beslissing, c.q. de publiekrechtelijke legitimatie ervan, nog weer verder worden verbreed. ${ }^{62}$

Ten slotte wil ik nog drie korte opmerkingen maken.

- Ten eerste: indien de procedure een besluit op aanvraag betreft, wordt de aanvrager in de gelegenheid gesteld te reageren op de zienswijzen die door de insprekers naar voren zijn gebracht (aldus art. 3:13 lid 4 Awb). Daarmee is een confrontatie tussen alle betrokkenen mogelijk - dat lijkt mij een goede zaak.

- Ten tweede: ook de openbare voorbereidingsprocedure bevat geen specifieke regels voor advisering. Daarvoor zij - opnieuw - verwezen naar de regels van Afdeling 3.3 Awb en Afdeling 3.7 Awb.

- Ten derde: toepassing van de openbare voorbereidingsprocedure vrijwaart niet van de verplichte bezwaarschriftenprocedure (vergelijk art. 7:1 Awb). De belangrijkste reden die ik daarvoor kon vinden ${ }^{63}$ is dat de openbare voorbereidingsprocedure soms "slechts" een aanvraag betreft. Anders dan indien een ontwerp voorligt, zullen bedenkingen dan mogelijk nog niet zo uitgekristalliseerd zijn - onbekend is immers nog welke precieze voorwaarden en voorschriften het bestuur aan het uiteindelijke besluit zal verbinden. Voor een differentiatie op dit punt - indien bij toepassing van Afdeling 3.4 een ontwerp-besluit voorlag, kan zonder bezwaarschriften-

60. MvT-Awbl, a.w... p. 75.

61. Tbidem.

62. Als "een ieder" kan inspreken staat het normatieve debat over de beslissing open voor een ieder die zich daarbij - om welke reden dan ook - betrokken voelt,

63. En wel in de MvT-AwbA, a.w., p. 4. 
procedure direct de administratieve rechter worden geadieerd - voelde de wetgever kennelijk niet.

\subsubsection{De uitgebreide openbare voorbereidingsprocedure(s)}

\subsubsection{Karakteristiek}

Oorspronkelijk werd de procedure van Afdeling 3.4 beschouwd als de uitgebreide voorbereidingsprocedure. In de loop van de behandeling van het wetsvoorstel Awbl werd duidelijk dat behoefte bestond aan een openbare procedure met een nog meer uitgebreid karakter. ${ }^{64}$ Daarbij werd met name gedacht aan de voorbereiding van besluiten waarbij de belangen van derden in sterke mate betrokken zijn; zoals bij milieuvergunningen. Daarbij was de behoefte aan afstemming tussen de regels inzake de voorbereiding van besluiten uit de Awb enerzijds en de milieuwetgeving anderzijds, een belangrijk motief voor het voorstel voor Afdeling 3.5 Awb: de Uitgebreide openbare voorbereidingsprocedure. ${ }^{65}$

Ten opzichte van Afdeling 3.4 Awb bevat Afdeling 3.5 Awb een aantal extra waarborgen. ${ }^{66}$ Zo bevat de uitgebreide procedure (anders of meer dan Afdeling 3.4) regels over het betrekken van andere bestuursorganen bij de voorbereiding; regels voor bevestiging van de ontvangst van een aanvraag; regels voor het ter inzage leggen, regels voor de mogelijke gedachtenwisseling over het ontwerp-besluit en regels inzake de termijnen voor het opstellen van een ontwerp en het nemen van een definitieve beslissing.

Een viertal verschilpunten acht ik in het bijzonder van belang.

Allereerst vervult het ontwerp-besluit in de uitgebreide procedure een centrale rol. Dit bevordert een gefaseerde en grondige beraadslaging.

Daarnaast geldt als uitgangspunt dat een ieder bedenkingen tegen het ontwerp besluit kan inbrengen. ${ }^{67}$ Aldus bestaat de mogelijkheid tot een brede uitwisseling van argumenten en opvattingen.

In de derde plaats valt op dat de advisering aan bod komt, zoals onder meer blijkt uit de aanwijzing van adviserende bestuursorganen, de toezending van het ontwerp aan (adviserende) bestuursorganen, de uitdrukkelijke verplichting om adviezen en rapporten die in verband met het ontwerp zijn uitgebracht

64. De Nota naar aanleiding van het Eindverslag. T.K.'90-91, 21 221, nr. 8, p. 7-8, getuigt hiervan.

65. MvT-AwbA, a.w., p. 1. De procedure van Afdeling 3.5 zal ik hierna - gemakshalve - omschrijven als de "uitgebreide procedure".

66. Zie MvT-AwbA, a.w., p. 3.

67. Zie art. 3:24 Awb. Ingevolge art. 3:26 Awb is weliswaar weer een inperking mogelijk, maar de situatie is toch spiegelbeeldig aan die in Afdeling 3.4 (art. 3:13 lid 1 en lid 2) Awb. 
met het ontwerp ter inzage te leggen, of daarvan een overzicht te geven, en de termijn voor advisering. ${ }^{68}$

Ten slotte denk ik aan het feit dat een beroep op de administratieve rechter tegen een besluit dat met toepassing van de uitgebreide procedure is totstandgekomen, niet door een bezwaarschriftenprocedure behoeft te worden voorafgegaan. ${ }^{\omega}$ De wetgever is van mening dat de mogelijkheid om in de uitgebreide procedure bedenkingen in te brengen tegen het ontwerp-besluit, en dus ook tegen voorgestelde voorschriften en wat dies meer zij, bij handhaving van het verplichte bezwaarschrift vaker tot een "herhaling van zetten" zal kunnen leiden en de procedure aldus onnodig zou worden verlengd. ${ }^{70}$

De regeling van de uitgebreide procedure omvat eigenlijk twee procedures. De paragrafen 3.5.2 tot en met 3.5.5 Awb betreffen de procedure op aanvraag. Paragraaf 3.5.6 Awb betreft besluiten tot wijziging of intrekking, danwel ambtshalve te nemen andere besluiten. Elementen uit deze procedures zal ik hieronder bespreken. ${ }^{71}$ Voor de goede orde merk ik op dat de wetgever met de uitgebreide procedure niet alleen een regeling voor de voorbereiding van milieuvergunningen, c.q. Wm-vergunningen wil geven. ${ }^{72}$ In de toelichting op dit punt wordt overigens slechts de procedure van de trajectnota uit de komende Tracéwet genoemd. ${ }^{73}$

\subsubsection{De procedures op hoofdlijnen}

Gelijk het wetsvoorstel begin ik met de procedure op aanvraag (paragraaf 3.5.2-5 Awb). Zodra de aanvraag is ontvangen wordt de datum van ontvangst genoteerd, ontvangt de aanvrager een ontvangstbewijs en ontvangen de betrokken andere bestuursorganen ${ }^{74}$ een exemplaar van de aanvraag (met bijbehorende stukken). ${ }^{75}$

68. Resp. art. 3:15, 3:19, 3:21 lid 1 en 3:23 Awb. Ook Addink, G.H., Uitgebreide openbare voorbereidingsprocedures in de Awb, NTB'92/9-10, p. 290-299, wijst er op dat Afdeling 3.5 een aanzienlijke uitbreiding en verbetering van de regeling inzake advisering geeft (vgl. p. 295).

69. Aldus art. IH AwbA dat strekt tot herziening van art. 7:1 Awb. Zie ook MvT-AwbA, a.w., p. 3.

70. MvT-AwbA, a.w., p. 4.

71. Deze bespreking is door de nieuwigheid van de voorstellen wat uitgebreider dan anders het geval zou zijn.

72. Art. II AwbA bevat wijzigingsvoorstellen voor de $\mathrm{Wm}$ die de afstemming tussen de $\mathrm{Awb}(\mathrm{A})$ en de $\mathrm{Wm}$ moeten bewerkstelligen. Overigens blijft er een aantal specifieke procedure-bepalingen binnen de WM in stand. Voorzover relevant komen deze in het volgende hoofdstuk nog aan de orde.

73. MvT-AwbA, a.w., p. 2.

74. Art. 3:15 onderscheidt "adviserende bestuursorganen" en "betrokken bestuursorganen".

75. Aldus art. 3:17 Awb. Art. 3:16 Awb verklaart Afd. 4.1.1. Awb van overeenkomstige toepassing op de besluiten die met toepassing van Afdeling 3.5 worden voorbereid. 
Een eventueel besluit om een aanvraag niet te behandelen (art. 3:18 Awb jo. art. 4:5 Awb) kan slechts genomen worden indien aanvrager binnen acht weken na ontvangst van de aanvraag om aanvulling is verzocht en daaraan binnen de door het bestuur gestelde termijn niet (of in onvoldoende mate) heeft voldaan. ${ }^{76}$

Het bestuursorgaan stelt zo spoedig mogelijk een ontwerp-besluit op, dat uiterlijk twee weken na ontvangst van de aanvraag aan de aanvrager en de betrokken andere bestuursorganen wordt toegezonden (art. 3:19 Awb). De hoofdregel is - volgens art. 3:28 Awb - dat zo spoedig mogelijk wordt beslist. De voor toezending van het ontwerp gestelde termijn kan echter (binnen acht weken na ontvangst van de aanvraag) worden verlengd, indien het een "zeer ingewikkeld of omstreden onderwerp" betreft - aldus het eerste lid van art. 3:29 Awb. Hierbij wordt gedacht aan technisch ingewikkelde zaken en aan zaken die bestuurlijk of juridisch ingewikkeld of omstreden zijn. ${ }^{77}$ Een besluit tot verlenging behoeft uiteraard een deugdelijke motivering en dient een termijn van verlenging te bevatten.

Uiterlijk twee weken na verzending van het ontwerp wordt daarvan mededeling gedaan door terinzagelegging en openbare kennisgeving (art. 3:19 Awb). Deze mededeling omvat (volgens art. 3:20 Awb) de zakelijke inhoud van de aanvraag, de strekking van het ontwerp, de mogelijkheden van inzage, wie op welke wijze en wanneer bedenkingen naar voren kan brengen en dat bedenkingen desgewenst anoniem kunnen worden ingebracht. Ook de terinzagelegging (art. 3:21 en 3:22 Awb) is met verschillende waarborgen omgeven die moeten bevorderen dat burgers zich goed kunnen informeren. Inzage is mogelijk gedurende vier weken vanaf de datum van terinzagelegging.

De adviserende bestuursorganen dienen (volgens art. 3:23 Awb) binnen vier weken na terinzagelegging hun advies aan het bestuursorgaan toe te zenden. ${ }^{78}$ Ingevolge art. 3:24 Awb geldt dezelfde termijn voor een ieder die tegen het ontwerp bedenkingen wil inbrengen. Gedurende die termijn bestaat ook voor een ieder de gelegenheid tot een "gedachtenwisseling" over het ontwerp, eventueel in het bijzijn van de aanvrager.

De idee van een "gedachtenwisseling" houdt blijkens de toelichting in dat ook zij die "niet aanstonds een negatief oordeel" hebben over het ontwerp, daarover van gedachten kunnen wisselen ten behoeve van hun "definitieve meningsvorming". ${ }^{79}$ In dit opzicht is er volgens de toelichting een belangrijk verschil met de procedure van Afdeling $3.4 \mathrm{Awb}{ }^{80}$ Zie ik het goed dan ligt

76. De (nog te noemen) ontwerp- en beslistermijn wordt bij toepassing van deze bepaling opgeschort, vgl. art. 4:15 Awb, alsmede MvT-AwbA, a.w., p. 10.

77. Aldus de MvT-AwbA. a.w.. p. 14.

78. Daarna behoeft het bestuursorgaan niet meer te wachten (MvT-AwbA. a.w., p. 12).

79. MvT-AwbA, a.w., p. 13.

80. Ibidem, p. 3 en p. 13. 
het verschil daarin dat in Afdeling 3.4 (ingevolge art. 3:13 lid 1 en lid 4) Awb1 welisuaar de mogelijkheid van een mondelinge uiteenzetting (met een eventueel weerwoord van de aanvrager) bestaat, maar dat de posities dan reeds zijn ingenomen. De toelichting bij art. 3:13 Awb spreekt in dat verband van ees "confrontatie van de aanvrager met (..) bezwaren en andere zienswijzen" ${ }^{8}$ (mijn cursiveringen). Niettemin lijkt mij de hier bedoelde nuance erg academisch, zeker als we bedenken dat de "confrontatie' van Afdeling 3.4 zich kan afspelen naar aanleiding van een aanvraag en dus alleszins denkbaar is dat meningen - hoewel wellicht polariserend als bezwaar gepresenteerd - nog ingrijpend kunnen veranderen.

Art. 3:26 Awb is het spiegelbeeld van art. 3:13 lid 2 Awb: de kring van "bedenking-f̧erechtigden" kan worden beperkt bij in art. 3:14 Awb bedoeld wettelijk vocrschrift of bestuursbesluit.

Het besluit op aanvraag wordt zo spoedig mogelijk, doch uiterlijk zes maanden na ontrangst van de aanvraag genomen - aldus art. 3:28 Awb. Een uitzondering op de exacte termijnstelling is mogelijk ingevolge eerdergenoemd art. 3:29 Awb: bij een zeer ingewikkeld of omstreden onderwerp.

Ingevolge at. 3:27 Awb vermeldt het bestuursorgaan bij de bekendmaking van het besuit zijn overwegingen omtrent de ingebrachte bedenkingen. Een soortgelijke bepaling terzake van de ingebrachte adviezen ontbreekt in Afdeling 3.5 Awb, omdat daarin reeds in Afdeling 3.7 Awb (Motivering) is voorzien.

Over de procedure tot wijziging of intrekking en ambtshalve andere te nemen besluiten (paragraaf 3.5.6 Awb - hierna "wijziging etc.") wil ik kort zijn.

Het ontwerp-besluit vervult ook in deze procedure een voorname rol. Van groot gewicht is echter ook de "voornemenprocedure". Van het voornemen tot wijzigirg etc. wordt op voet van art. 3:30 Awb schriftelijk kennis gegeven aan berrokken andere bestuursorganen en, bij een voornemen tot "wijziging of intrekking" aan degene tot wie het voorgenomen besluit is gericht. $\mathrm{Zij}$ worder in de gelegenheid gesteld binnen een nader door het bestuur te bepalen temijn hun advies of zienswijze naar voren te brengen - aldus lid 2 van art. 3:30 Awb. ${ }^{82}$ Indien het voornemen stoelt op een verzoek dan geschiedt de kennisgeving van het voornemen (inclusief de gelegenheid tot inspraak) ook aan verzoeker (aldus lid 3).

Als vervolgens het ontwerp wordt vastgesteld wordt daarvan mededeling gedaan overeenkomstig art. 3:19 lid 2 onder b. en c. Awb (aldus art. 3:30 Awb). Een terinzagelegging ontbreekt - zoals ook blijkt bij vergelijking

81. MvT-Aub1, a.w., p. 80-81.

82. Onder onstandigheden kan van de "voornemenprocedure" worden afgezien: vgl. voornoemd lid 2 en MvT.AwbA, a.w., p. 15. 
tussen art. 3:20 Awb en art. 3:31 Awb. Over de reden achter dit ontbreken zwijgt de toelichting. Mogelijk houdt het verband met de ingelaste voornemenprocedure. ${ }^{83}$

De termijn voor het inbrengen van bedenkingen is twee weken, gerekend van bet moment van de mededeling. In beginsel staat deze gelegenheid voor een ieder open - opnieuw kan echter een beperking worden aangebracht (art. 3:32 Awb verklaart hiervoor art. 3:26 Awb van toepassing). Over de mogelijkheid om naar aanleiding van het ontwerp nog advies uit te brengen (zoals in de procedure op aanvraag, volgens art. 3:23 lid $1 \mathrm{Awb}$ ) zwijgt de regeling. ${ }^{84}$

Het definitieve bestuursbesluit wordt zo spoedig mogelijk, doch uiterlijk zestien weken na de kennisgeving van het voornemen genomen, tenzij de voornemenprocedure niet is gevolgd, in welk geval de termijn acht weken bedraagt - aldus respectievelijk lid 1 en lid 2 van art. 3:33 Awb.

Daarmee zijn de procedures kortweg beschreven. Twee aansluitende voorstellen wil ik echter nog noemen.

In de eerste plaats de toevoeging van art. 3:44 Awb (in Afdeling 3.5 Awb over Bekendmaking en mededeling). Indien een besluit met toepassing van Afdeling 3.5 is voorbereid worden enkele extra regels voor de mededeling van het besluit gegeven. Het gaat onder meer om een termijnstelling, de wijze van mededeling, de inhoud van de mededeling, toezending op verzoek en inzage.

In de tweede plaats denk ik aan de toevoeging van een nieuw derde lid aan art. 4:5 Awb, inhoudende de mogelijkheid om een aanvraag niet in behandeling te nemen wegens het ontbreken van een samenvatting daarvan. Zo'n samenvatting dient dan met het oog op de omvang of ingewikkeldheid van de aanvraag noodzakelijk te zijn. De $\mathrm{MvT}^{85}$ stelt dat het ontbreken van een samenvatting in een dergelijk geval de beoordeling van de aanvraag "voor een breed, niet-deskundig publiek" bemoeilijkt. Of een samenvatting noodzakelijk is "wordt aan het redelijk oordeel van het besturursorgaan overgelaten ... bij die beoordeling zal het bestuursorgaan in beginsel uitgaan van het belang dat een algemeen publiek bij een samenvatting heeft". ${ }^{86}$ Het bestuursorgaan kan de aanvraag slechts aanhouden indien het de aanvrager in de

83. Al rjst dan de vraag hoe bet zjt als deze op voet van lid 2 van art. 3:30 Awb achterwege wordt gelaten.

84. En de tosliching. Gelet op de terminologit en de analogie met de procedure op annvrang acht ik het niet waarsehijnlijk dat de mogelijkheid voor "ten ieder" on "bedenkingen" legen het ontwerp in te brengen onk voor adviserende bestuursorganen onen staat.

85. A.w., p. 17.

86. Jbideml. 
gelegenheid heeft gesteld binnen een bepaalde termijn de aanvraag met een samenvatting aan te vullen. ${ }^{87}$

\subsubsection{Advisering}

$\mathrm{Nu}$ Afdeling 3.5 anders dan de andere procedures enkele specifieke regels voor advisering kent, wil ik daarop nog kort ingaan.

Art. 3:15 Awb regelt de aanwijzing van adviserende bestuursorganen en betrokken bestuursorganen. ${ }^{88}$ Adviserende bestuursorganen moeten in de gelegenheid worden gesteld om advies uit te brengen tot het nemen van een besluit. ${ }^{89}$ Aanwijzing geschiedt bij of krachtens het in art. 3:14 Awb bedoelde wettelijk voorschrift of het daar bedoelde besluit. Voor toepassing op de $\mathrm{Wm}^{90}$ wordt in art. II.B Awb art.1 Wm gewijzigd door "betrokken bestuursorganen" aldaar te definiëren als: adviseurs en andere bestuursorganen die overeenkomstig afdeling 3.5 van de Algemene wet bestuursrecht worden betrokken bij de totstandkoming van de in art 13.1 eerste lid bedoelde beschikkingen. In art. 8.7 lid $1 \mathrm{Wm}$ worden enkele adviesgerechtigden aangewezen, waaronder (onder a) de inspecteur van het staatstoezicht op de volksgezondheid.

In de procedures van Afdeling 3.5 Awb is sprake van adviezen in twee fasen van de besluitvorming.

Allereerst de adviezen die meewerken tot de totstandkoming van een ontwerp. In de procedure op aanvraag is deze advisering geheel ongeregeld. Er wordt slechts blijk van gegeven van "rapporten en adviezen" welke bij terinzagelegging aanwezig moeten zijn of waarvan althans een overzicht moet worden gegeven - aldus art. 3:21 lid 1 onder c. en d. Awb.

In de procedure tot wijziging etc. biedt (indien toegepast) de voornemenprocedure van art. 3:30 lid 2 Awb een moment van advisering voorafgaand aan het ontwerp.

$\mathrm{Na}$ het uitbrengen van het ontwerp komen in de procedure op anvraag de adviserende bestuursorganen in het spel en wel op voet van art. 3:23 Awb. In de procedure tot wijziging etc. ontbreken juist in die fase regels inzake advisering.

De regels inzake advisering zijn over het geheel genomen uiterst summier. Zo bieden de voorschriften geen uitsluitsel over de vraag of een adviserend

87. En hieraan niet binnen die termijn is voldaan.

88. Met Addink, a.w., NTB'92/9-10, p. 294, ben ik van mening dat de term adviserend bestuursorgaan niet erg geschikt is. Adviseur ware beter geweest.

89. Aldus art. 3:15 onder a. Awb.

90. Art. 8.6 en $13 / 1 \mathrm{Wm}$ (zoals gewijzigd bij art II ii en EEE AwbA) verwijzen voor de voorbereiding van beschikkingen naar Afd. 3.5. 
bestuursorgaan, bij de procedure op aanvraag, ook bij de totstandkoming van het ontwerp betrokken mag zijn. Ik neem aan dat de gedachte van de wetgever is geweest dat zulks maar in de bijzondere wetten moeten worden geregeld. Ook de positie van de adviseur, de waarborgen voor deskundigheid en onafhankelijkheid, de inrichting en procedure van het advies zullen mede om die reden ongeregeld zijn gelaten. Mede, omdat sommige aspecten natuurlijk al op andere plaatsen in de Awb zijn geregeld, zoals in Afdeling 3.3 Awbl (Advisering) en Afdeling 4.1.4 Awb (3.7 Awb) (Motivering).

Wel heeft de wetgever zich in Afdeling 3.5 uitdrukkelijk de zorg voor de geïnformeerdheid van de adviserende bestuursorganen aangetrokken. Op allerlei punten geeft de regeling daar blijk van: bij toezending van de aanvraag en bijbehorende stukken (art. 3:17 lid 3 Awb); bij mededeling van het verzoek tot aanvulling van de aanvraag of van het besluit tot niet in behandeling nemen daarvan (art. 3:18 lid 2 Awb); bij toezending van het ontwerp (art. 3:19 lid 1 Awb); bij toezending van adviezen van andere adviserende bestuursorganen (art. 3:23 lid $2 \mathrm{Awb}$ ); bij toezending van tegen het ontwerp ingebrachte bedenkingen (art. 3:24 lid $3 \mathrm{Awb}$ ); bij toezending van het verslag van een eventuele gedachtenwisseling over het ontwerp (art. 3:25 lid 3 Awb); bij mededeling van een besluit tot termijnverlenging (art. 3:29 lid 2 Awb); bij kennisgeving over een voornemen tot wijziging etc. (art. 3:30 lid 2 Awb); bij mededeling van een ontwerp tot wijziging etc. (art. 3:30 lid 1 Awb); bij toezending van de tegen het ontwerp tot wijziging ingebrachte bedenkingen (art. 3:32 lid 2 Awb); bij mededeling over het genomen (definitieve) bestuursbesluit (art. 3:44 lid 1 Awb). Met deze regels wordt in belangrijke mate tegemoet gekomen aan de ook in art. 3:7 Awb gestelde regel, dat het bestuursorgaan de adviseur de gegevens ter beschikking stelt die nodig zijn voor een goede vervulling van diens taak.

Ik stel vast dat Afdeling 3.5 Awb voor advisering voorziet in de regeling van enkele basale waarborgen. Nadere uitwerking is gelaten aan andere voorschriften in Awb of bijzondere wetten. Wel rijst bij mij de vraag of juist Afdeling 3.5 niet de plaats was geweest om enige zorg aan de deskundigheid van de burger te besteden. Men mag aannemen dat in de gevallen waarin Afdeling 3.5 wordt toegepast, in de optiek van het publiek niet zelden sprake zal zijn van omvangrijke en ingewikkelde kwesties (zelfs als de beslistermijn niet behoeft te worden verlengd). Toepassing van deze procedure bij de voorbereiding van beschikkingen op de aanvraag van een Wm-vergunningen staat daarvoor in belangrijke mate garant. Ik zie echter slechts twee "handreikingen": de gedachtenwisseling van art. 3:25 Awb en het (bij AwbA toegevoegde) derde lid van art. 4:5 Awb: de eis van een samenvatting. Ik ben daarvan niet onder de indruk. Beide kunnen ongetwijfeld een nuttige functie vervullen, maar schieten, als het er op aankomt toch tekort. Een gedachtenwisseling 
voegt misschien enige deskundigheid toe - maar kan van aanvrager en bestuursorgaan objectiviteit verwacht worden? De samenvatting biedt uiteraard een handzame introductie, maar daarmee niet noodzakelijk de benodigde kennis om de aanvraag op zijn effecten te beoordelen. Hetzelfde geldt naar mijn smaak voor het terinzageleggen van rapporten en adviezen.

$\mathrm{Er}$ ontbreekt dus nog iets: deskundige ondersteuning voor de burger. Hiervoor zijn verschillende voorzieningen denkbaar, zoals (financiële) bijstand bij individuele ondersteuning of de mogelijkheid van een gedachtenwisseling met een (vaste) onafhankelijke adviseur. ${ }^{91}$ Ik kan mij voorstellen dat de wetgever dit waarborgen vindt die slechts in bijzondere gevallen op hun plaats zijn, zodat regeling aan de bijzondere wetgever gelaten kan worden. Daaromtrent had ik dan toch graag (in de toelichting) een aanwijzing gevonden. Daarvan is noch in Afdeling 3.5 Awb, noch in Hoofdstuk 2 Awb (Verkeer tussen burgers en bestuursorganen) sprake. ${ }^{92}$ Voor wetgeving waarin de rechtsbetrekking of de wederkerige relatie tussen burger en bestuur voorop wordt gesteld $^{93}$ vind ik dat toch magertjes.

\subsubsection{De bezwaarschriftenprocedure}

Hoewel de bezwaarschriftenprocedure zich afspeelt nadat een besluit is genomen en mitsdien deel uitmaakt van de contentieuze procedure, ${ }^{94}$ wordt hieraan in de toelichting op de non-contentieuze procedures zo veelvuldig gerefereerd, dat een korte bespreking daarvan hier niet mag ontbreken. ${ }^{95}$ Ik merk daarbij op dat ik mijn - toch betrekkelijk fundamentele - kritiek op de bezwaarschriftenprocedure pas aan het slot van het navolgende uiteen zal zetten (te weten in $\$ 6.3 .5 .3)^{96}$

91. Eventueel in combinatie met de voorziene gedachtenwisseling van art. 3:25 lid 1 Awb. Eventueel kan het advies van het adviserend bestuursorgaan bij de gedachtenwisseling worden betrokken. Overigens moet de termijn voor bedenkingen dan de adviestermijn overschrijden.

92. In de algemene toelichting bij Hoofdstuk 2 (MvT-Awbl, a.w., p. 45-46) wordt de toenemende gecompliceerdheid van de bestuurstaak wel genoemd maar komt de wetgever niet verder dan de noodzaak van een "betere communicatie' te noteren.

93. MvT-Awbl, a.w., p. 11-13.

94. Zie Tak, A.Q.C., Verlengde besluitvorming?, NJB'89, 45/46, p. 1688 en Commentaar Awb, a.w., deel art. 6.3.la (ABR 4/92), R.J.G.M.Widdershoven.

95. Daarbij laat ik de regels van Hoofdstuk 6 Awb buiten beschouwing en concentreer ik mij op Hoofdstuk 7 Awb.

96. Ik voorkom graag dat al lezende het idee ontstaat dat ik mij kan vinden in de ideeẽn achter en de opzet van de in de Awb geregelde bezwaarschriftenprocedure. 


\subsubsection{Motieven}

De keuze voor een als regel verplichte bezwaarschriftenprocedure voorafgaand aan een (eventueel) beroep op de administratieve rechter (art. 7:1 Awb) wordt door verschillende motieven ingegeven.

Allereerst het motief dat ook reeds bij de bezwaarschriftenprocedure van de Wet AROB vooropstond: het voorkómen van een te veelvuldig beroep op de administratieve rechter. ${ }^{97}$ Door middel van de bezwaarschriftenprocedure kan het geschil reeds in een vroeg stadium worden beslecht. ${ }^{98}$

Daarnaast dient de bezwaarschriftenprocedure - volgens de toelichting - de rechtsbescherming, aangezien zij kan voorzien in een bevredigende afronding van de bestuurlijke besluitvorming. ${ }^{99}$ Aspecten die eerder te weinig aandacht kregen kunnen bij heroverweging alsnog in de beschouwing worden betrokken. ${ }^{100}$ In verband hiermee is van belang dat bij de heroverweging van het besluit mogelijk personen betrokken zijn die bij de voorbereiding van het bestreden besluit juist geen rol hebben gespeeld. ${ }^{101}$ Ook wordt in de toelichting nog opgemerkt dat de bezwaarschriftenprocedure, als deze er niet toe leidt dat van beroep op de administratieve rechter wordt afgezien, voorziet in een "zodanige voorbehandeling (...) dat een beter afgebakende en duidelijker afgewerkte zaak bij de rechter terecht komt". ${ }^{102}$

Ten slotte wordt gewezen op de algemeen bestuurlijke functie van de bezwaarschriftenprocedure. ${ }^{103}$ Gebreken in de organisatie van het bestuursorgaan dat de betreden beslissing heeft genomen, zouden door het onderzoek in de procedure, zichtbaar kunnen worden. Het uitdrukkelijk horen van belanghebbende en de betrokkenheid van anderen dan de besluitvormers bij het onderzoek kunnen "signalen" opleveren die aanleiding kunnen vormen tot verbeteringen in de organisatie. ${ }^{104}$

97. MvT-Awb1, a.w., p. 115-116. Zie ook Borman, J.A., Aspecten van de AROB-bezwaarschriftenprocedure, oratic, Deventer 1979, p. 7.

98. A.w., p. 115. zulks blijkt ook in studies als: Breeuwsma, C.M., c.s., Beeld van de Arob-bezwaarschriftenprocedure, Deventer 1982 en Breeuwsma, C.M., c.s., Arob-praktijken, Deventer 1984.

99. A.w., p. 115.

100. Ibidem, p. 145.

101. Ibidem, p. 115 en p. 150. Zie ook art. 7:5 Awb.

102. A.w., p. 116.

103. Ibidem, p. 115.

104. A.w., p. 116. 


\subsubsection{Procedure}

Tegen de achtergrond van deze motieven is de (verplichte) bezwaarschriftenprocedure gestructureerd. Een aantal elementen daaruit wil ik hier bespreken.

Bekend is inmiddels art. 7:1 Awb (zoals gewijzigd bij AwbA). Dit artikel schrijft voorafgaand aan een beroep op de administratieve rechter een bezwaarschriftenprocedure voor. Op deze regel wordt een aantal uitzonderingen gemaakt, waarvan ik de toepassing van de uitgebreide procedure van Afdeling 3.5 Awb reeds noemde.

Van elementair belang is de bestuurlijke hoorplicht zoals geregeld in art. 7:2 Awb. Voordat het bestuur op het bezwaarschrift beslist, dient het belanghebbenden in de gelegenheid te stellen te worden gehoord. Van deze mogelijkheid moet het bestuur de indiener van het bezwaarschrift en belanghebbenden die bij de voorbereiding van het bestreden besluit hun zienswijze naar voren hebben gebracht op de hoogte stellen (aldus lid 2). Voorafgaand aan het horen kunnen belanghebbenden - ingevolge art. 7:4 lid 1 Awb - nadere schrifturen en bewijsstukken indienen.

Tot de motieven voor deze hoorplicht behoort (opnieuw) de mogelijkheid om eventuele gebreken of onvolledigheid in de gegevens waarover het bestuursorgaan beschikt, te herstellen. ${ }^{105}$ Daarnaast kan bij het horen gezamenlijk naar een oplossing voor het gerezen geschil worden gezocht, en draagt het horen er toe bij dat de burger "overtuigd kan raken dat aan zijn bezwaren ernstig aandacht is besteed". ${ }^{106}$

Zie ik het goed dan is er in de bezwaarschriftenprocedure, anders dan bij de hoorplicht ingevolge Afdeling 4.1.2 Awb, ruimte om ook bezwaren, anders dan over de feitenvaststelling op te werpen. Ook is van belang dat de belanghebbenden niet alleen op het bestreden besluit maar ook op de voorbereiding daarvan kunnen ingaan. Zo wijst Teunissen er op dat de belanghebbenden in de gelegenheid moeten worden gesteld hun visie te geven over bij de voorbereiding betrokken adviezen. ${ }^{107}$ In het verlengde daarvan stelt hij vast dat belanghebbenden in kennis dienen te worden gesteld van (nog) in de bezwaarschriftenprocedure ingewonnen (nadere) adviezen - en uiteraard in de gelegenheid dienen te worden gesteld om ook hierop te reageren. ${ }^{108}$ In dat

105. MvT-Awbl, a,w., p. 145.

106. Mbidem.

107. Vgl. Commentaar Awb, deel art. 6.3.7 (ABR 6/41), J.M.H.F.Teunissen. Teunissen verwijst hierbij naar ARRvS 20 maart 1990, Gemeentestem nr. 6910.4 (Haps).

108. Ibidem; Teunissen beschouwt dit - terecht - als een beginsel van behoorlijk procesrecht. 
verband is het wenselijk dat burgers zich - desgewenst - op dergelijke nieuwe informatie kunnen beraden. Een schorsing van het horen, hangende deze voorbereiding en eventueel nader onderzoek aan bestuurszijde, ligt dan in de rede. ${ }^{109}$ In dit verband is ook art. 7:9 Awb nog van belang: nieuwe feiten of omstandigheden die na het horen bekend worden en die voor de op bezwaar te nemen beslissing van "aanmerkelijk belang" kunnen zijn, moeten aan belanghebbenden worden meegedeeld. Ook moeten belanghebbenden in de gelegenheid worden gesteld om over deze nova te worden gehoord.

Het is goed om er - met Teunissen - nadrukkelijk op te wijzen dat het horen de informatieverschaffing naar beide kanten (naar bestuur èn burger) dient. ${ }^{110}$ Niet alleen het bestuursorgaan heeft baat bij informatie, ook de burger. Met het oog daarop is in art. 7:4 lid 2 Awb de plicht om voorafgaand aan het horen bezwaarschriften en "alle verder op de zaak betrekking hebbende stukken" ter inzage te leggen, gecodificeerd. Alle aan de bestreden of de op bezwaar te nemen beslissing ten grondslag liggende stukken behoren daartoe."' Ook deskundigenadviezen behoren tot deze groep, onder omstandigheden zelfs interne adviezen. ${ }^{112}$

Het is wenselijk dat er bij het horen daadwerkelijk wordt gecommuniceerd. ${ }^{113}$ Belanghebbenden en het bestuursorgaan moeten met elkaar in gesprek raken over de bestreden beslissing en de daartegen ingebrachte bezwaren. Dit bevordert de mogelijkheid om tot een afronding van het geschil te komen. Het is dan ook aantrekkelijk als in een dergelijk gesprek alle belanghebbenden tegelijkertijd aanwezig zijn. Dit is dan ook als hoofdregel neergelegd in art. 7:6 lid 1 Awb.

Volgens art. 7:5 Awb kan het horen (mede) door het bestuursorgaan, dan wel de voorzitter of een lid daarvan geschieden. Gebeurt dit niet dan stelt dit artikel de eis dat zij die horen (in meerderheid) niet bij de voorbereiding betrokken zijn geweest.

Niet onbelangrijk is voorts art. 7:8 Awb dat bepaalt dat op verzoek van de belanghebbende door hem meegebrachte getuigen en deskundigen worden gehoord. De kosten van deze getuigen en deskundigen komen, ingevolge lid 2 van dit artikel, voor rekening van de belanghebbende. In dit verband moet

109. Zie ook Teunissen, ibidem. ABR 6/42 en ABR 6/66-67.

110. Ibidem, ABR 9/44.

111. In de MvT-Awb1, a.w. p. 149, wordt er op gewezen dat moet worden voorkomen dat bepaalde stukken pas ten overstaan van de rechter ter inzage worden gegeven: de bezwaarschriftenprocedure is dan niet ten volle gericht geweest op het beslechten van het geschil.

112. Vgl. Commentaar Awb, deel art. 6.3.9 (ABR 9/66-9/71), J.M.H.F.Teunissen.

113. Vgl. Commentaar Awb, deel art. 6.3.7 (ABR 9/44), J.M.H.F.Teunissen. 
allereerst worden opgemerkt dat de belanghebbende uiteraard ook - ingevolge voornoemd art. 7:4 lid $1 \mathrm{Awb}$ - deskundigenrapporten kan inbrengen. Anders dan een deskundige mee te brengen kan de belanghebbende, het bestuursorgaan of de hoorcommissie verzoeken om de deskundige over zijn rapport te horen. Als inwilliging van dit verzoek, juist omwille van de deskundigezorgvuldigheid, door bestuursorgaan of hoorcommissie wenselijk wordt geacht, ligt het voor de hand dat de kosten (van het horen) voor rekening van het bestuursorgaan komen. ${ }^{114}$

In dit verband wil ik wijzen op art. 8:75 lid $1 \mathrm{Awb}$, dat de mogelijkheid biedt tot verhaal van kosten welke voor het beroep bij de rechtbank redelijkerwijs moesten worden gemaakt, op de in het ongelijk gestelde partij. ${ }^{115}$ Blijkens de toelichting op dit artikel ${ }^{116}$ is het niet de bedoeling ook de kosten gemaakt in het kader van de bezwaarschriftenprocedure langs deze weg verhaalbaar te maken. Het belangrijkste motief daarvoor lijkt te zijn dat de bezwaarschriftenprocedure primair is gericht op bestuurlijke heroverweging: "De omstandigheid dat het bestuursorgaan aan de bezwaren van belanghebbende is tegemoet gekomen, behoeft geenszins te betekenen dat het primaire besluit onrechtmatig was. De bezwaarschriftenprocedure is ook, juist omdat zij verlengde besluitvorming in gang zet, zonder drempel. Er is geen recht verschuldigd. (...) Toekenning van een vergoeding van in een bestuurlijke voorprocedure gemaakte kosten zal daarom naar ons oordeel uitzondering moeten blijven". ${ }^{117}$ De Awb-wetgever houdt deze kosten mitsdien buiten de regeling van art. 8:75 Awb. Ten tijde van de produktie van het wetsvoorstel Awb2 was de uitspraak van het CRvB van 17 december $1991^{118}$ nog niet gewezen. In die uitspraak wordt uitdrukkelijk in de mogelijkheid van een kostenvergoeding voor kosten gemaakt in een bestuurlijke voorprocedure voorzien. ${ }^{119}$ Blijkens de Nota naar aanleiding van het eindverslag ${ }^{120}$ volhardt de regering ook in het vervolg van de parlementaire behandeling in haar visie; niettegenstaande de andersluidende conclusie uit het terzake ingestelde onderzoek van de Erasmusuniversiteit, de K.U.Brabant en de R.U. Limburg. ${ }^{121}$ Ik vind deze keuze van de regering, gelet op het contentieuze

114. Ibidem, art. 6.3.7, ABR9/50-51.

115. Mede op voet van HR 17 november 1989. AB'90, 81 m.nt. G.P. Kleijn (Velsen-De Waard). Vgl. MvT-Awb2, a.w., p. 151.

116. MvT-Awb2, p. 150-154, i.h.b. p. 153.

117. Midem, p. 153.

118. AB'92, 163 m.nt. HH.

119. Zie hierover (onder meer) Do Groot, G.R.J., Een proceskostenveroordeling in het ambtenarenrecht, NTB' $92 / 5$, p. 169-172.

120. TK' $92 / 93,22495$, nr. 10, p. 46-47.

121. Vgl. het in voorgaande noot genoemde stuk, alsmede de Brief van de minister van Justitie terzake, TK'92/93, 22 495, nr. 11. 
karakter van de bezwaarschriftenprocedure en de noodzaak om in die fase het beginsel van de "equality of arms" te respecteren, getuigen van een zeer ongelukkige visie. ${ }^{122}$

In art. 7:3 Awb worden enkele gronden genoemd op basis waarvan van horen kan worden afgezien. In de kern van de zaak gaat het bij al deze gronden om situaties waar het horen - beslist - geen bijdrage zou leveren aan een "zorgvuldige heroverweging en besluitvorming". ${ }^{123} \mathrm{Er}$ moet redelijkerwijs geen twijfel over mogelijk zijn dat horen overbodig zou zijn.

De beslissing op het (ontvankelijke) bezwaar behelst - volgens art. 7:11 lid 1 Awb - een heroverweging van het bestreden besluit. Dit behelst, zoals genoegzaam bekend, een hernieuwde afweging op recht- en doelmatigheidsgronden. ${ }^{124}$ Als de heroverweging daartoe aanleiding geeft - zo bepaalt het tweede lid van art. 7:11 Awb - dan herroept het bestuursorgaan de bestreden beslissing en neemt het voorzover nodig in plaats daarvan een nieuw besluit. $^{125}$

Het rechtsbeschermingskarakter van de bezwaarschriftenprocedure komt op twee manieren goed tot uitdrukking. In de eerste plaats doordat onderdelen van de bestreden beslissing die geheel los staan van de ingediende bezwaren niet in de heroverweging worden betrokken. ${ }^{126}$ In de tweede plaats doordat de mogelijkheid van reformatio in peius uitdrukkelijk wordt afgewezen: "het bezwaarschrift (mag) er niet toe leiden dat het bestuursorgaan de heroverweging gebruikt om een verslechtering van de positie van de indiener te bereiken die zonder bezwaarschriftenprocedure niet mogelijk zou zijn. Dat betekent dat het bestuursorgaan het besluit voorzover het door het bezwaarschrift wordt bestreden, moet heroverwegen en moet nagaan of dit tot een voor de indiener gunstiger resultaat dient te leiden". ${ }^{127}$ In de Nota naar aanleiding van het eindverslag heet het: "De vragenderwijs geformuleerde conclusie (...) dat een wijziging ten nadele van de belanghebbende niet of nauwelijks mogelijk is, gaat ons iets te ver". ${ }^{128}$ Daaraan voorafgaand stelt de regering: "Wij achten slechts een voor indiener van het bezwaarschrift "slechtere" beslissing mogelijk, indien het bestuursorgaan tijdens de bezwaar-

122. In overeenkomstige zin: Spelt. N. en Ph. Langbroek. Proceskostenvergoeding in de Algemene wet bestuursrecht. NJB'92/27, p. 852-854, en Vergoeding van proceskosten in het bestuursprocesrecht, NTB' $91 / 10$, p. 298-309, i.h.b. p. 306.

123. MvT-Awb2, a.w., p. 146.

124. MvT-Awbl, a.w., p. 153.

125. Eventueel is sprake van een gedeeltelijke herroeping, vgl. MvT-Awb1, a.w., p. 154 .

126. MvT-Awb1, a.w.. p. 153.

127. Ibidem.

128. A.w., p. 37. 
schriftenprocedure op de hoogte komt van feiten en omstandigheden die, had het die kennis langs andere weg verkregen, een ambtshalve wijziging van het primaire besluit ten nadele van de indiener van het bezwaarschrift zouden hebben gerechtvaardigd". ${ }^{129} \mathrm{Zie}$ ik het goed dan kan het bestuur alleen op grond van voor hem nieuwe feiten of omstandigheden de positie van de bezwaarde verslechteren, niet echter op basis van een herwaardering van belangen. Uit rechtsbeschermingsoptiek lijkt dat goed verdedigbaar; het bestuur heeft immers reeds een in beginsel definitieve beslissing genomen. In termen van de beoogde verlengde besluitvorming, c.q. volledige heroverweging acht ik het toch problematisch. Dat ook het rechtsbeschermingsperspectief niet geheel zuiver wordt doorgevoerd moge overigens blijken uit het feit dat van het bestuur wordt verwacht, dat het ook los van het door indiener in zijn bezwaarschrift aangevoerde - ambtshalve - dient na te gaan "of er andere feiten of omstandigheden bekend zijn die tot een wijziging ten gunste van de indiener van het bezwaarschrift nopen"..$^{130}$ Zo blijkt weer dat de bezwaarschriftenprocedure enerzijds trekken van een zelfstandige beroepsgang en anderzijds trekken van verlengde besluitvorming vertoont. ${ }^{131}$

Ten slotte wijs ik er nog op dat de Awb regels stelt ten aanzien van de beslistermijn (in art. 7:10 lid $1 \mathrm{Awb}$ : al na gelang ingevolge art 7:13 Awb wel of geen adviescommissie is ingesteld, binnen tien of zes weken na ontvangst van het bezwaarschrift), de motivering van deze beslissing (art. 7:12 lid 1 Awb) en de bekendmaking en mededeling er van (art. 7:12 tweede, derde en vierde lid Awb).

Bepaald niet onbelangrijk is dan nog te vermelden dat volgens art. 7:15 Awb voor de behandeling van het bezwaar geen recht is verschuldigd. Het eigen belang van het bestuursorgaan bij de bezwaarschriftenprocedure is daarvoor het dragende argument. ${ }^{132}$

\subsubsection{Kritiek}

Ik ben in het algemeen geen voorstander van de bezwaarschriftenprocedure als voorzien in de Awb. In mijn opvatting behelst de idee van publiekrechtelijke legitimatie dat in de non-contentieuze procedure een open debat over alle relevante aspecten van een voorgenomen of aangevraagd besluit kan plaatsvinden. Dat betekent dat burgers (desgewenst) zowel over de beoordeling van het relevante feitensubstraat als over de afweging van belangen met

129. Ibidem, p. 36.

130. MvT-Awbl, a.w., p. 153.

131. Zie Stroink, F.A.M., Inspraak vooraf of bezwaar achteraf?, in: Steenbeek, J.G., c.s. (red.), Bestuur en norm. a.w., p. 243-253, i.h.b. p. 245.

132. MvT-Awbl, a.w., p. 156. 
het bestuur van gedachten kunnen wisselen. Daarbij acht ik het van wezenlijk belang dat het bestuur zich - in die fase - op enig moment ook uitspreekt over zijn eigen opvattingen, en wel zodanig dat burgers, adviseurs en andere betrokkenen daarop met enige precisie kunnen reageren, in het vertrouwen dat het bestuur nog uitdrukkelijk openstaat voor herziening van zijn positie: ik denk hierbij met name aan de beraadslaging over het ontwerp-besluit. Op deze wijze kan er sprake zijn van "goed overleg". Als deze procedure is voltooid, met het nemen van een definitief bestuursbesluit, liggen de posities vast. Er is nog slechts ruimte voor correctie van een mogelijk onjuist besturen. Daartoe zal dan echter een geschil aanhangig gemaakt moeten worden, waarin het bestuursbesluit wordt getoetst aan het recht, voorzover de gronden van de grief dit verlangen. ${ }^{133}$

Het mag duidelijk zijn dat ik mij op voet van deze positie niet kan vinden in de idee van de bezwaarschriftenprocedure als verlengde besluitvorming. Voor de afronding van de non-contentieuze procedure (althans die van Afdeling 3.4 Awb en die van Titel $4.1 \mathrm{Awb}$ ) wordt daarmee doorverwezen naar een stadium waarin het bestuur formeel reeds een definitief besluit heeft genomen. Beperkt zich dit bij toepassing van Afdeling 3.4 nog tot het herstellen van fouten, gebreken en onvolledigheden, bij de procedure van Titel 4.1 (in het bijzonder bij de hoorplicht van Afdeling 4.1.2) wordt het maken van bezwaren (anders dan terzake van de feitenvaststelling) geheel doorgeschoven naar de contentieuze bezwaarschriftenprocedure - dat wil zeggen nadat het bestuursbesluit in beginsel definitief is genomen en het bestuur zijn positie aldus formeel heeft bepaald. Bovendien zet de procedure een premie op doorschuifgedrag: als gebreken in de non contentieuze besluitvorming toch wel weer (door het bestuur zelf) in de bezwaarschriftenprocedure kunnen worden gerepareerd, ${ }^{134}$ bevordert dat zorgvuldigheid langs het 'piep-systeem': pas als er bezwaar wordt gemaakt wordt er serieus op de zaak ingegaan, anders is de zaak rond. ${ }^{135}$

Hier op aansluitend - in de tweede plaats - bevinden we ons vanaf het moment dat een besluit is genomen en daartegen bezwaren worden ingebracht - als gezegd - in de contentieuze procedure: er is sprake van een geschil. Beslechting daarvan behoort als regel te worden opgedragen aan een onafhankelijke geschillen-beslechtende instantie, waarbij verschillende algemene

133. Bestuurlijk toezicht laat ik hier terzijde. Interessant is in dit verband Tak. A.Q.C.. Het moment X. TrO'90, p. 134-138.

134. Vgl. MvT-Awb1, a.w., p 102: het voorkomen van vernietigbaarheid.

135. Dat voldoet ook niet bij massaal af te geven beschikkingen. 
procesbeginselen worden gerespecteerd. ${ }^{136}$ De voorstellen tot herziening van de rechterlijke organisatie gaan (als regel) uit van rechtsbescherming bij de administratieve rechter in twee instanties. Dat is mijns inziens een goede regel. Het is niet nodig daar nog een bezwaarschriftenprocedure tussen te plaatsen. Sterker nog: dat is met het oog op de redelijke termijn zelfs ongewenst. $^{137}$

Wat de zeefwerking van de bezwaarschriftenprocedure betreft voorzie ik geen gemis bij afschaffing van deze procedure. Nu als regel twee administratiefrechterlijke instanties zijn voorzien, zal de eerste instantie naar alle waarschijnlijkheid deze functie kunnen overnemen.

Addink $^{138}$ stelt dat Afdeling 3.4 Awb meer gericht is op democratische beinvloeding, terwijl Afdeling $3.5 \mathrm{Awb}$ veeleer het karakter draagt van "preventieve rechtsbescherming". ${ }^{139}$ Begrijp ik hem goed dan ziet hij daarin ook de rechtvaardiging voor het al dan niet toepasselijk zijn van de bezwaarschriftenprocedure: als er inspraak is op hoofdlijnen (Afdeling 3.4), dan past daarop bezwaar achteraf; als er uitgebreide inspraak vooraf is (Afdeling 3.5), dan heeft bezwaar achteraf weinig zin. ${ }^{140}$ Hoezeer ik hem kan volgen in zijn typering van de beide afdelingen, zaak blijft dat "preventieve rechtsbescherming", alsook een bezwaarschriftenprocedure niet moeten worden verward met "echte" (repressieve) rechtsbescherming.

Betekent deze zienswijze nu dat er voor heroverweging van een bestuursbesluit door het desbetreffende bestuursorgaan geen plaats meer is? Geenszins; ik wil echter bepleiten dat die heroverweging in een eerder stadium plaatsvindt en daardoor weer deel uitmaakt van de voorbereiding van het besluit, en plaatsvindt in een context waarin het bestuur nog werkelijk openstaat voor heroverweging. De procedure van bezwaren of bedenkingen op een ontwerpbesluit, zoals of vergelijkbaar met de procedure van Afdeling $3.5 \mathrm{Awb}$, lijkt mij daartoe het meest geëigend. In dit opzicht behoeft naar mijn mening geen onderscheid te worden gemaakt tussen betrekkelijk gebonden, weinig complexe $^{141}$, mogelijk massaal aantal beschikkingen van ésn soort en ongebonden beschikkingen in zaken waarbij veel, zwaarwegende en tegenstrijdige belangen betrokken zijn. Stroink oppert dat de voorbereiding bij de eerste soort aan de hand van een aanvraagformulier kan verlopen, waarbij in de bezwaarschriftenprocedure de puntjes op de $\mathrm{i}$ worden gezet. Daartegenover

136. Vgl. Tak, A.Q.C., Verlengde besluitvorming, a.w., p. 1688.

137. Dbidem.

138. A.w., NTB'92/9-10, p. 296.

139. Vergelijk mijn perspectieven voor non-contentieuze regels in $\$ 6.1$.

140. Ibidem. p. 299.

141. Technisch, dan wel in termen van de veelheid van betrokken belangen. 
ziet hij bij de tweede soort beschikkingen de noodzaak van een vroegtijdige betrokkenheid van burgers, waardoor een bezwaarschriftenprocedure achterwege kan blijven. ${ }^{142}$ Hoewel ik mij een zekere differentiatie goed kan voorstellen, lijkt het mij toch zaak de gehele besluitvorming in de non-contentieuze fase af te werken. Als regel dient daarin steeds de mogelijkheid tot het inbrengen van bedenkingen tegen een ontwerp-besluit aanwezig te zijn. Bij werkelijk complexe of omstreden beslissingen zou daaraan voorafgaand, bij wijze van voorfase, toepassing kunnen worden gegeven aan art. 4:7 en 4:8 $A w b,{ }^{143}$ of aan de voornemenprocedure van art. 3:30 tweede lid Awb.

Ik ben van mening dat deze suggestie - die natuurlijk veel te laat komt - ook een aantal "rariteiten" in de huidige voorstellen elimineert.

Ik denk daarbij in het aan de eerder genoemde afwijzing van de mogelijkheid van reformatio in peius. Een afwijzing die in de contentieuze fase past, maar mijns inziens toch niet in de (verlengde) besluitvorming; gegeven het oogmerk van een volledige heroverweging.

Ook denk ik aan de eerdergenoemde regel voor de vergoeding van proceskosten. In de voorgestelde optiek kan ik daar niet mee uit de voeten. Als het geschil daar is, dient de gelijkwaardige procespositie te worden beschermd, c.q. bevorderd. Een goed geregelde mogelijkheid voor vergoeding voor in redelijkheid gemaakte kosten (tot een redelijk niveau) voor de contentieuze bezwaarschriftenprocedure past daarbij. In de door mij geschetste optiek kan ik mij echter goed voorstellen dat art. 8:75 lid 1, Awb niet voor kosten in de non-contentieuze procedure wordt toegepast. Dit houdt verband met de specifieke rolverdeling in die procedure. Dat de aanvrager zonder aanspraak op vergoeding, kosten maakt om gegevens aan te leveren, vind ik - binnen de grenzen van art. 4:2 Awb - alleszins te billijken. Voor belanghebbenden die bedenkingen hebben tegen een voornemen of ontwerp-besluit zou het moeten volstaan dat zij bij een non-contentieuze gedachtenwisseling over dit voornemen of ontwerp-besluit aannemelijk kunnen maken dat hun belang in het geding is of dat er een reële mogelijkheid bestaat dat de bestuurlijke feitenvaststelling (bij voornemen of ontwerp) onvolledig of gebrekkig is, dan zal dat voor het bestuur aanleiding moeten zijn om op dat punt zelfstandig nader onderzoek te ondernemen. Bij complexe besluitvorming stel ik mij voor dat

142. Stroink, F.A.M., Inspraak vooraf of bezwaar achteraf?, a.w., p. 253.

143. Toegepast op het ontwerp-besluit, teneinde onzorgvuldigheden (gebreken) te voorkomen. 
een soort standaard-regeling voor deskundige-ondersteuning ${ }^{144}$ een aantrekkelijke èn afdoende voorziening moet kunnen bieden. Als het bestuur serieuze twijfels niet oppakt, zal daarover, al dan niet aan de hand van een uitgebreider deskundigen-advies, voor de rechter kunnen worden geklaagd ${ }^{145}$.

Ook het getover met de vraag of steeds moet worden vastgehouden aan de regel van rechtspraak in twee instanties, is in mijn benadering uit de wereld. In een brief van 10 april $1992^{146}$ gaven de ministers van Justitie en Binnenlandse zaken nog te kennen dat bij het gevolgd zijn van de Uitgebreide openbare voorbereidingsprocedure, met het oog op de rechtszekerheid, met één instantie kan worden volstaan. De vraag rijst of deze redenering niet impliceert dat aan het (wel) gevolgd zijn van de bezwaarschriftenprocedure eveneens de consequentie wordt verbonden dat éen instantie volstaat. Ook dan is immers de rechtszekerheid in het geding, en ook dan kan gezegd worden dat het voorwerk voldoende uitgebreid is geweest. In de Memorie van Antwoord ${ }^{147}$ stelt de regering (gelukkig) dat de conclusie dat voorprocedures inwisselbaar zijn met een rechterlijke instantie, onjuist is - ook als sprake is van een zware voorbereidingsprocedure zoals die van Afdeling 3.5 Awb. Verderop in deze Memorie ${ }^{148}$ geeft de regering vervolgens aan dat nu de procedure van Afdeling 3.5 Awb de "inbreng van belanghebbenden en een zo breed mogelijk georiënteerde besluitvorming" kan verzekeren, "het niet onverantwoord" is in desbetreffende gevallen af te zien van een tweede feitelijke instantie. In de Nota naar aanleiding van het eindverslag ${ }^{149}$ wordt het toepasselijk zijn van een zware voorbereidingsprocedure gekwalificeerd als een "verzachtende omstandigheid"150 voor het afzien van rechtspraak in twee feitelijke instanties. Het gevaar voor te veelvuldig doorprocederen en de wenselijkheid van snel uitsluitsel over besluiten rond grote maatschappelijke belangen zijn - beweerdelijk - de belangrijkste motieven.

Ik kan met de gemaakte keuze, ook al zal over de structurele keuze bij een latere fase van de WHRO nog uitdrukkelijk worden beraadslaagd, toch niet erg gelukkig zijn. Er gaat naar mijn smaak toch teveel de suggestie vanuit dat de non-contentieuze en de contentieuze procedure een procedureel continuüm vormen - dat wil zeggen: zonder scherpe cesuur. Kern van de zaak is echter

144. Een uitdrukkelijk voorziene mogelijkheid tot raadpleging van een vaste- (dan wel "aangewezen"-)deskundige, al dan niet tegen een "balie-tarief", eventueel in de vorm van een "kort deskundigen-bericht".

145. Op dit punt kom ik hieronder nog terug.

146. T.K. $91 / 92,22495$, nr. 4.

147. TK' $92 / 93,22495$, nr. 6 , p. 21.

148. A.w., p. 27.

149. A.w., p. 11-16.

150. Bbidem, p. 15. 
dat het hier om wezenlijk verschillende zaken gaat. Tegen die achtergrond zou het argument van de voorprocedure geen rol mogen spelen bij de vraag naar de inrichting van de rechtspraak. Voorzover het die rechtspraak betreft ben ik overigens van mening dat juist bij kwetsbare of ingewikkelde geschillen de noodzaak van twee feitelijke instantie groot is. ${ }^{|5|}$

Rest mij hier nog een opmerking. Als er geen contentieuze bezwaarschriftenprocedure is voorgeschreven, zoals ik categorisch bepleit en zoals - positiefrechtelijk gezien - bij toepassing van Afdeling 3.5 Awb het geval zou zijn, dan zou in de non-contentieuze procedure (c.q. in de procedure van Afdeling 3.5) analoog aan art. 7:8 Awb bij het horen over het ontwerp wel moeten worden voorzien in de mogelijkheid om deskundigen mee te brengen. ${ }^{152}$ Ook zal een verzoek aan het bestuursorgaan om een deskundige te horen mogelijk moeten zijn - en serieus moeten worden beoordeeld. Weliswaar zouden andere belanghebbenden dan de aanvrager mijns inziens slechts hun belang hoeven 'stellen', het is toch wenselijk dat zij hun bedenkingen - desgewenst (met de grootst mogelijke kracht van argumenten) kunnen inbrengen.

\subsubsection{Algemeen commentaar}

Ik heb in het voorgaande reeds veel van mijn kruit verschoten, en kan daarom in mijn afsluitende opmerkingen bij deze paragraaf kort van stof zijn.

Ik ben van mening dat over het geheel genomen een betrekkelijk positief oordeel kan worden uitgesproken over de procedurele opzet in de non-contentieuze procedure, zoals voorzien in de Awb. De procedures vormen, door hun open karakter, c.q. de nadruk op de mogelijkheden voor betrokkenen om bij de voorbereiding van beslissingen te participeren, een belangrijke aanzet tot de gewenste publiekrechtelijke legitimatie van bestuurlijke besluitvorming.

Dat gezegd zijnde is tevens geïmpliceerd dat de vervolmaking van de publiekrechtelijke legitimatie uiteindelijk is gelegen in het gebruik dat van de procedures wordt gemaakt. Daarbij hebben we enerzijds nog te maken met de eisen die in bijzondere wetten (zoals de Wm) worden gesteld en anderzijds met een aantal algemene regels die in de Awb zijn neergelegd. Wat het eerste betreft zij verwezen naar het volgende hoofdstuk: aldaar zal een aantal specifiek milieurechtelijke waarborgen worden besproken. Wat de algemene regels uit de Awb betreft kan ik deels terugverwijzen naar de abbb die ik in $\$ 6.2$

151. In de ministeriēle brief van 10 april (a.w.) wordt (op p. 5) ook erkend dat bij ingewikkelde kwesties (waar Afd. 3.4a de aangewezen weg lijkt) de keuze voor twee rechterlijke instanties ook zeer wel denkbaar is.

152. In Afd. 3.5 zocht ik, bij het horen, c.q. de "gedachtenwisseling", tevergeefs naar zo'n bepaling. 
reeds kort heb besproken - met de uitdrukkelijke aantekening dat de Awb slechts het topje van de ijsberg laat zien. Slechts die uit de abbb afleidbare regels die thans in het positieve recht betrekkelijk algemeen aanvaard zijn werden gecodificeerd; ${ }^{153}$ de ontwikkeling van de ongeschreven rechtsbeginselen, en de toetsing daaraan, gaat buiten de Awb permanent voort.

Een aantal regels uit de $A w b$ is hier tot nu toe niet in detail uitgewerkt. Ik denk daarbij aan de regels die heel direct verband houden met advisering: de voorschriften uit Afdeling 3.3 Awb (Advisering) en de artikelen 3.6.4 en 3.6.5 uit Afdeling 3.7 Awb (Motivering). De reden daarvan is dat ik deze geïntegreerd met een aantal andere, specifiek op advisering toegesneden regels wil bespreken - en wel in $\S 6.4$ en $\S 6.5$.

Naast het positieve oordeel over de opzet van de non-contentieuze procedures uit de Awb, kom ik niet om een aantal (zeer) kritische aantekeningen heen.

Ik denk daarbij allereerst aan de vertroebeling in de besluitvorming door de rol van de bezwaarschriftenprocedure. De legitimerende werking van de noncontentieuze procedure wordt mijns inziens ontkracht doordat een aantal waarborgen niet worden gerealiseerd of althans onder grote druk kunnen komen te staan. Ik denk daarbij in de eerste plaats aan het doorschuiven naar de bezwaarschriftenprocedure, van de mogelijkheid om bezwaren anders dan over de feitenvaststelling te maken (art. 4:7 en 4:8 Awb). In de tweede plaats lijkt de bezwaarschriftenprocedure een soort bestuurlijke verzuimregeling: alles kan alsnog goed worden gemaakt. Maar vergeten wordt dat de bestuurlijke heroverweging niet meer in het teken staat van een open debat, c.q. goed overleg; er is immers een geschil. ${ }^{154}$ Ik heb hierboven aangegeven hoe, naar mijn mening, in de non-contentieuze procedure in elk geval bedenkingen tegen een ontwerp-besluit, en in bijzondere gevallen ook in een "voorfase", terzake van een voornemen, moeten kunnen worden ingebracht. De besluitvorming moet non-contentieus "rond" zijn!

In de tweede plaats mis ik aandacht voor de deskundigheid van de burger. Ik wees er reeds op dat ik mij kan voorstellen dat de Awb-wetgever dit meer een zaak vond voor bijzondere wetgeving; gelijk dat ook geldt voor de positie van specifieke (vaste) adviseurs. Toch vind ik het voor een wet waarin de gedachte van de wederkerige relatie, de "rechtsbetrekking" tussen burger en bestuur een zeer belangrijk uitgangspunt vormt, een gemiste kans dat dit punt

153. Overigens niet alle, denk bij voorbeeld aan het vertrouwensbeginsel.

154. Ik ga hier niet meer in op toepassing van art. 7:8 lid 1 Awb in het bestek van art. 3:25 lid 1 Awb. 
in het geheel niet aan de orde komt. In het algemeen deel van de toelichting, of de in algemene toelichting bij Hoofdstuk 2 (Verkeer tussen burgers en bestuursorganen) had hieraan aandacht moeten worden besteed.

\subsection{Gerichte deskundigen-advisering}

\subsubsection{Inleiding}

In deze paragraaf gaat het om de bestuursrechtelijke eisen welke aan de advisering worden gesteld. Meer in het bijzonder betreft het gerichte advisering door externe personen of instanties: personen of instanties die (formeel) onafhankelijk zijn van het bestuur. ${ }^{155}$ De eisen die ik bespreek gelden (thans) in het algemeen deel van het bestuursrecht. Het uitgangspunt wordt daarbij gevormd door de eisen uit het ongeschreven recht. Met het oog op de komst van de Awb zal ik per onderdeel van bespreking bezien in hoeverre de Awb op het desbetreffende onderdeel regels bevat.

De werken van Hoogendijk-Deutsch, ${ }^{156}$ Nicolai $^{157}$ en Kummeling ${ }^{158}$ bieden reeds zoveel stof op dit terrein dat het mij niet nodig lijkt hier het wiel opnieuw uit te vinden. Mijn uiteenzetting zal derhalve een betrekkelijk schematisch karakter dragen. ${ }^{159}$

Het is belangrijk om in het oog te houden dat de te bespreken positiefrechtelijke regels inzake advisering tijdsgebonden zijn. Mede door de vooraanstaande rol van het ongeschreven recht is elke inventarisatie van adviesregels onvoltooid en vergankelijk.

Daarbij beperk ik mij tot enkele, naar de huidige stand van de jurisprudentie, wetgeving en literatuur meest toonaangevende regels.

In de navolgende bespreking beperk ik mij (uiteraard) tot gerichte advisering door deskundigen. Ik ga mitsdien voorbij aan semi- (of quasi-)rechterlijk advies en representatie-advies. ${ }^{160}$ Voor de goede orde merk ik op dat ver-

155. Vgl. ook Kummeling. H.R.B.M., Advisering in het Publiekrecht prft. Den Haag 1988, p. 6. Afwezigheid van een hiërarchische band - dus (bij voorbeeld) geen adviezen van ambtenaren in eigen dienst.

156. Hoogendijk-Deutsch, S.V.. Advisering in het bestuursrecht (in het bijzonder aan de centrale overheid), VAR-geschriften LXXX. Alphen aan den Rijn 1978, p. 11-65. Daarnaast nog haar bespreking van het proefschrift van Kummeling in NJB'89/45-46, p. 1695-1697.

157. Nicolaï. P, Advisering in het bestuursrecht, RMTh. $81 / 6$, p. $511-531$, alsmede enkele delen uit zijn proefschrift, a.w., i.h.b. par. 271-275, par. 340 en par. 285.

158. Prft.., a.w.

159. De genoemde werken vormen daarbij het uitgangspunt.

160. Een verdeling die oorspronkelijk door Hoogendijk-Deutsch, VAR, a.w., p. 20-23, is gemaakt. 
gunningverlening het leidende perspectief vormt. De advisering richt zich daarbij op de feitenvaststelling. In dat bestek gaat het om advies van deskundigen met een prospectief karakter: "welke effecten zullen optreden?" Op de positie van getuigen (retrospectief, "welke feiten werden waargenomen?") ga ik niet in. Evenmin komt advisering over belangenafweging hier aan de orde. Ik ga voorts uit van de volgende driedeling: verwerving van het advies ( $\$ 6.4 .2)$, kritiseerbaarheid van het advies $(\$ 6.4 .3)$ en het gezag van het advies $(\$ 6.4 .4)$. Een en ander wordt afgerond met een conclusie $(\$ 6.4 .5)$.

\subsubsection{Verwerving van advies}

Twee aspecten acht ik bij het verwerven van advies in het bijzonder van belang. Allereerst de verantwoordelijkheid voor een goede feitelijke beslissingsgrondslag en de bevoegdheid of plicht tot het vragen van advies $(\S 6.4 .2 .1)$ en in de tweede plaats de formulering van een adviesvraag (\$6.4.2.2).

\subsubsection{Verantwoordelijkheid, bevoegdheid en plicht}

Het bestuur heeft bij ontbreken van eigen deskundigheid een eigen verantwoordelijkheid tot het inwinnen van advies. ${ }^{161}$ In aansluiting hierop wordt eveneens aangenomen dat het bestuur bevoegd is tot het inwinnen van advies. Dat volgt thans ook uit art. 3:2 Awb, maar was ook reeds eerder in de jurisprudentie erkend. ${ }^{162}$ Met Nicolai ${ }^{163}$ ben ik van mening dat de omvang van onderzoeksplicht niet moet worden gekoppeld aan de vraag of voldoende feitenkennis aanwezig is om de rechtmatigheid van het (voorgenomen) besluit te beoordelen. ${ }^{164}$ Een besluit mag pas worden genomen na een "zorgvuldig onderzoek van de feiten". Alle voor de belangenafweging relevante gegevens moeten door het bestuursorgaan worden vergaard. ${ }^{165}$

Bevoegdheid tot het vragen van advies wordt geacht te ontbreken als daartoe geen redelijk belang is aan te wijzen, als het verzoek om advies in redelijkheid niet tot het beoogde doel kan leiden of als er een geheel ander oogmerk in het geding is dan het (doen) verrichten van verantwoord onderzoek. ${ }^{166}$ Wat het laatste punt betreft wijst Kummeling ${ }^{16}$ op drie oneigenlijke functies van advisering: de ijskastfunctie, de alibi- of afschuiffunctie en de inkap-

161. Vgl (o.m.) ARRvS 23 december 1982, AB'83, 256.

162. Bij voorbeeld: CRvB 16 juli 1980, AB'81, 61 (Adviesverzoek door Kamer van Koophandel) en AGRvS 24 augustus 1988, AB 513, m.nt. BJ v/d N.

163. Prft., a.w., p.332 (alwaar hij in noot 207 nog verwijst naar zijn Kroniek in het NTB'89, p. 124).

164. Zoals geschiedde bij de in de voorlaatste noot aangehaalde uitspraak van de AGRvS.

165. Nicolaï, NTB' $89 / 4$, p. 124.

166. Nicolaï, RMTh, a.w. p. 513.

167. Prft. a.w.. p. 30. 
selingsfunctie. Toch is het naar zijn mening niet zo dat indien advies wordt gevraagd omwille van deze functies daarmee ook per se sprake is van oneigenlijk advies. ${ }^{168}$ Dit lijkt mij slechts aanvaardbaar indien het bestuur duidelijkheid schept over de eigen oogmerken, opdat duidelijkheid ontstaat over de status van het advies - na het verschijnen daarvan.

De eerder besproken problematiek van de bewijslastverdeling in het noncontentieuze bestuursrecht (zie $\$ 6.3 .2 .1$ ) is nauw verbonden met de voornoemde aspecten verantwoordelijkheid en bevoegdheid. Ik zal mijn eerdere opmerkingen over de bewijslast hier niet herhalen. Wel wil ik er ter aanvulling van het eerdergestelde nog op wijzen dat indien een verzoeker - op een "beslissend punt" - een aanbod doet tot het leveren van bewijs, het bestuur niet met voorbijgaan aan dit aanbod tot afwijzing van het verzoek kan beslui$\operatorname{ten}^{109}$

Voorzover het bestuur gehouden is tot het vergaren van kennis over feiten en af te wegen belangen, rijst de vraag wanneer er sprake is van een plicht tot het inwinnen van advies.

Volgens Hoogendijk-Deutsch ${ }^{170}$ is van een plicht tot op kennisvergaring gerichte advisering (in eerste aanleg) slechts sprake indien en voorzover er feiten in het geding zijn die niet van algemene bekendheid zijn. Hiervan is (nog) geen sprake voorzover het gaat om feiten "die van algemene bekendheid zijn en die hij (het bestuur, MAH) uit algemeen toegankelijke bronnen te weten kan komen, op algemeen bekende feiten berustende gevolgtrekkingen, algemene ervaringsregels". ${ }^{171}$

Voorts kunnen meer extrinsieke factoren een rol spelen bij het al of niet aannemen van een advies-plicht. ${ }^{172}$ Daarbij valt te denken aan het bestaan van een vaste adviseur of een vast adviesorgaan. In (de toelichting op) het desbetreffende instellings- of aanwijzingsbesluit kan een indicatie voor een adviesplicht bij bepaalde beslissingen zijn gelegen. Ook in de bestuurspraktijk kan een aanwijzing voor een adviesplicht liggen, bij voorbeeld als een bestuursorgaan bij een bepaald soort besluit steevast advies vraagt. Indien het

168. Hij noemt het voorbeeld van de ijskastfunctie in geval van grote commotie rond een voorgenomen besluit. De zorgvuldigheid kan hier z.i. vergen dat wordt getracht om. bij voorbeeld door advies te vragen, de besluitvorming in rustiger vaarwater te brengen.

169. Vgl. ARRvS 3 mei 1985, AB 72 m.nt. JHvV.

170. VAR, a.w., p. 26.

171. Ibidem, vgl. ook noot 24 op p. 26. De door Hoogendijk-Deutsch gemaakte onderscheiding tussen gebonden en vrije beschikkingsbevoegdheid is hier - nu het "slechts" gaat om op feitenvaststelling gerichte deskundigenadvisering - m.i. niet relevant.

172. Hoogendijk-Deutsch, VAR, a.w. noemt enkele hiervan op p. 26-29. Nicolaï, RMTh., a.w., bespreekt ze op p. 513 en Kummeling. a.w.. op p. 86-89. 
bestuur aankondigt advies te zullen vragen lijkt - in beginsel - eveneens een adviesplicht te zijn ontstaan.

Meer in het algemeen zal uit het beginsel van zorgvuldig onderzoek moeten worden afgeleid of een adviesplicht bestaat. Als het bestuur de voor de feitenvaststelling noodzakelijke deskundigheid ontbeert, dan is advies geboden. ${ }^{173}$ Ook kan de ingrijpendheid van een voorgenomen beslissing voor burgers of het omstreden karakter van de voorgenomen beslissing - zeker als betrokkenen een verzoek tot onderzoek hebben ingediend - een adviesplicht indiceren. Ten slotte zullen ook de kosten van advies en het (mogelijk) tijdverlies moeten worden meegewogen.

\subsubsection{Formulering van de adviesvraag}

Hoofdregel voor het formuleren van een adviesvraag is dat voorkomen moet worden dat de adviseur buiten het terrein van zijn eigen deskundigheid wordt gelokt. Ook moet er voor worden gewaakt dat een advies in dienst van de feitenvaststelling ontaardt in een beleidsadvies. Hoogendijk-Deutsch geeft hierbij het voorbeeld ${ }^{174}$ van een bestuursorgaan dat aan T.N.O. vraagt naar de "aanvaardbaarheid" van te verwachten geluidshinder. In omgekeerde zin moet het bestuur er voor waken dat de adviesvraag niet zo eng is geformuleerd dat daaruit onwerkbare of ontoelaatbare belemmeringen voor het onderzoek van de adviseur voortvloeien. Meer in het algemeen moet een adviesvraag "alle essentiële elementen van de te nemen beslissing (..) betreffen". ${ }^{175}$ Het bestuur moet er voor zorgen dat de adviesvraag duidelijk is en correspondeert met het doel ervan. ${ }^{176}$

Voor de vereiste diepgang van een advies is geen precieze algemene regel te geven. In het rapport ABAR uit $1984^{177}$ wordt gesteld dat de diepgang van het onderzoek sterk zal afhangen van "de urgentie van de te geven beschikking, en de grootte van de belangen die daarbij zijn betrokken, in verband met de kosten en de duur van een in aanmerking komend onderzoek en de resultaten die het zal kunnen opleveren". ${ }^{178}$ Volgens Nicolaï is er in zoverre sprake van een algemene eis dat "het onderzoek zich zal moeten uitstrekken

173. Er van uitgaande dat die feitenvaststelling onontbeerlijk is voor een verantwoorde besluitvorming.

174. VAR, a.w., p. 35 .

175. Kummeling,a.w., p. 173.

176. Nicolaï, RMTh. a.w.. p. 519.

177. Rapport ABAR 1984, Algemene bepalingen van administratief recht. vijfde geheel herziene druk, Alphen aan den Rijn 1984, p. 125-126. Tevens aangehaald door Nicolaï, prft, a.w., p. 336.

178. Hier speelt opnieuw het optimizing-probleem. 
tot de feiten en omstandigheden van het individuele geval". ${ }^{170}$ Ten slotte geeft hij nog een opsomming van punten die tezamen als een soort check-list bij de bepaling van de diepgang van onderzoek kunnen worden betrokken. ${ }^{180}$

Voor de verwerving van advies zijn hiermee de voor deze studie meest relevante elementen in kaart gebracht. ${ }^{181}$ Met Nicolaï moet worden geconstateerd dat behoudens de algemene onderzoeksplicht en de bewijslast (resp. art. $3: 2$ en art. 4:2 lid $2 \mathrm{Awb}$ ) in de Awb niet is voorzien in uitdrukkelijke codificatie van de overige regels die in het voorgaande naar voren kwamen. ${ }^{182}$

\subsubsection{Kritiseerbaarheid: voorzorg en controle}

Kritiseerbaarheid dient de kwaliteit van het advies. Twee aspecten wil ik daarvan bespreken. De voorzorgen vooraf, gericht op een zo volwaardig mogelijke beantwoording van de adviesvraag $(\$ 6.4 .3 .1)$, en de mogelijkheden tot controle achteraf $(\S 6.4 \cdot 3 \cdot 2)$.

\subsubsection{Voorzorgen}

Vooral de procedure van advisering is een belangrijke waarborg voor een volwaardig advies. De procedure dient bij te dragen aan de inhoudelijke kwaliteit van het advies, terwijl tevens wordt bij gedragen aan de controle op het resultaat.

Vooraleer ik de procedure nader bespreek wil ik eerst nog in gaan op de keuze van de adviseur.

Buiten de situatie dat de wet een adviseur aanwijst, moet de keuze van een persoon of instelling voor deskundigen-advies gebaseerd zijn op, hoe kan het

179. Nicolaï, prft.. a.w., p. 336, vgl. ARRvS 4 januari 1978. AB 190, m.nt. FHv/dB. Volgens Nicolaï kan massaliteit van te beslissen gevallen een uitzondering op dit uitgangspunt meebrengen. Waar de wet voorschrijft dat onderzoek op individuele maat plaatsvindt dient dit echter ook te geschieden, vgl. ARRvS 14 augustus 1978, tB/S III, p. 86 (algemeen advies van de welstandscommissie inzake dakkapellen).

180. Ibidem, p. 336-337: Is op alle relevante gegevens ingegaan: is bij alle daarvoor in aanmerking komende personen en instantie informatie ingewonnen; kan op informatie van anderen worden afgegaan (of is eigen onderzoek nodig): geeft de aard van het verzoek of de klacht van burgers aanleiding tot grotere diepgravendheid; zijn er stellingen van burgers of constateringen van het bestuur die beargumenteerd door (andere) burgers worden weersproken; is met het oog op nova nieuw onderzoek nodig; vergt tegenstrijdigheid tussen de conclusies van verschillende adviezen nader onderzoek? Bij al deze vragen geeft Nicolaĩ tevens jurisprudentie. Over de laatste twee vragen - die in mijn indeling niet zozeer op deze plaats thuis horen - kom ik (later) nog te spreken.

181. Op de keuze van de adviseur ga ik hierna nog in $(\$ 6.4 .3 .1$.$) .$

182. Ik constateer zulks hier (vooralsnog) zonder nader oordeel. Of er behoefte is aan verdere codificatie is een kwestie die ik later nog zal bespreken. 
ook anders, deskundigheid van die persoon of instelling. Richtsnoer is het beschikken over "specifieke kundigheid", een "des"kundigheid, waarbij we in het bijzonder moeten denken aan een adviseur wiens specifieke kundigheid op opleiding en ervaring berust. ${ }^{183}$ De Afdeling rechtspraak kwalificeerde deskundigen als personen die moeten worden geacht een gefundeerd eigen oordeel te kunnen vormen. ${ }^{184}$ Deskundigheid verwijst volgens HoogendijkDeutsch $^{185}$ overigens niet alleen naar vakbekwaamheid maar ook naar beroepseigenschappen die onpartijdigheid en objectiviteit van handelen moeten waarborgen; deskundigen moeten blijven binnen hun deskundigheid. De grenzen van deskundigheid moeten steeds nauwlettend in de gaten worden gehouden.

Ook de (voorzitter van de) Afdeling Rechtspraak verbindt deskundigheid nadrukkelijk met onafhankelijkheid. Dit bleek bij voorbeeld in een uitspraak van de voorzitter ${ }^{186}$ van de Afdeling Rechtspraak inzake de samenstelling van een welstandscommissie. ${ }^{187}$ Volgens de voorzitter van de Afdeling kwam in de commissie geen plaats toe aan partijdige, stemhebbende leden. ${ }^{188}$

Art. 2:4 Awb, dat het tegengaan van vooringenomenheid betreft, is in dit verband relevant. Kummeling wijst erop dat ook andere dan persoonlijke belangen een storende rol kunnen spelen. Art. 2:4 Awb zou daarom niet moeten zijn gericht op "persoonlijke belangen", maar op het waken tegen beïnvloeding door partijdige personen. ${ }^{189}$ Ook de Raad van State had op dit punt bedenkingen, ${ }^{190}$ waarna (slechts) de toelichting op het artikel is gewijzigd. ${ }^{191}$

Kummeling ${ }^{192}$ ziet het als een eis van zorgvuldig bestuur te voorkomen dat partijdige personen bij besluitvorming zijn betrokken. Zelfs als geen twijfel over de goede trouw aanwezig is, moet de schijn van vermenging van zake-

183. Hoogendijk-Deutsch. VAR, a.w., p. 21.

184. ARRvS 21 april 1983, AB 478. Vgl. Kummeling, prft, a.w., p. 92.

185. VAR, a.w., p. 30-31.

186. Vz ARRvS 24 augustus 1979, AB'80, 8.

187. Volgens art. 85 lid 3 Woningwet een "deskundig college".

188. Ik ga voorbij aan de vraag of een welstandscommissie (materieel) wel "deskundigen-advies" geeft, Vgl. Krijnen, G.J.A.M. en B.W.N. de Waard, Omgaan met welstandsadviezen, NTB'88/5, p. 155-163. In ARRvS 27 november 1984, AB'85, 354 wordt de eis van onafhankelijkheid gesteld ten aanzien van een medisch-deskundig advies.

189. Kummeling, prft., a.w., p. 249.

190. TK'88-'89, 21221, B, p. 31-32.

191. TK'88-'89, 21221, B, p. 31-32. alsmede de MvT, a.w., p. 55: persoonlijk wil zeggen "ieder belang dat niet behoort tot de belangen die het bestuursorgaan uit hoofde van de hem opgedragen taak behoort te behartigen".

192. Prft., a.w., p. 124. 
lijke en "persoonlijke" belangen worden voorkomen. ${ }^{193}$ Volgens Nicolail'194 kan een met het verwijt van de schijn van partijdigheid belast advies niet aan een bestuursbesituit ten grondslag worden gelegd - het bestuursbesiujt zou deze schijn als het ware overnemen. In haar oordeel over het functioneren van een adviescommissie ex att. 14 lid 3 Wet Arob geeft de Afdeling Rechtspraak blijk van een nauwere visie. ${ }^{195}$ Zolang het bestuur zich ervan verzekerd weet dat privé-helangen niet doorslaggevend waren, hetgeen kan blijken uit de stemverhouding, dan kan het bestuur zich toch op het advies baseren. Ik deel de kritiek die De Waard terzake heeft geutt ${ }^{196}$ : het is niet mogelijk om het proces van meningsvorming binnen een adviesinstantie achteraf volledig te reconstrueren. Motivering of stemmingsverhouding schieten tekort als indicator voor de (mate van) beïnvloeding door niet-zakelijke belangen. Het vertrouwen in de onpartijdigheid van de advisering dient voorop te staan.

De objectiviteit van de deskundige moet door en ten overstaan van het wetenschappelijke forum worden gewarborgd; beroepsgenoten van de deskundigen moeten tot de toetsing van de advies in staat zijn. ${ }^{167}$ De eis dat de deskundige adviseur in staat moet zijn om de voorgelegde vragen objectief en uit het relevante gezichtspunt te beantwoorden, ${ }^{198}$ ligt ook ten grondslag aan de in de Awb opgenomen bepalingen inzake advisering: "Wezenlijk is dat de deskundige in staat is tot het geven van informatie op een onpartijdige en objectieve wijze". 199

Dan kom ik nu bij de inrichting van de procedure. Hoogendijk-Deutsch stelt dat bij het deskundigen-advies de wijze van kennis vergaren goeddeels aan deskundigen kan worden overgelaten. ${ }^{200}$ Ook Kummeling ${ }^{201}$ meent dat tot sterke formalisering van de procedure voor deskundigen-adivies in het alge-

193. Vgl. HR 5 juni 1964. NI 405 (Gendringen/Koster) en ARRvS 16 juni 1983, tB/S III. 449 (Alithenaat-secretaris hoorzilting).

194. RMTh.. a.w., p. 526.

195. Zie ARRvS I juli 1983 in antekening bij ARRvS 16-6-1983, tB/S IIl, 449. Zie nok Kummeling, grft. a.w., p. 125 .

196. B.N.W. de Waard, prti.. a.w.. P. 34.5 s.v.

197. Vgl. Hoogendijk-Demisch. VAR. a,w., p. 21: de "Geheimwissenschaft". Voonts ook Krijnen/De waard, a.w... p. 158-159, die wijzen op het helang van de mogelijkheid on deskindigenadvies op zuiverheid (het mubreken van voloringenomienheden)te loetsen.

198. Vg1. Niçalai, grt.. 2.W., p. 352. met aldaar angehaalde jurisprudentic.

199. MvT-Awbl, a.w.. p. 71.

200. VAR, a.w.. p. 46. In dit verhand wijst zij er op dat terzake onk nauwelijks wetsbepalingen zijn te vinden , vgl. p. 46 , noot 50

201. Prfi.. a.w., p. 165. 
meen geen reden zal bestaan, een opvatting die ook in de toelichting bij de Awbl naar voren komt. ${ }^{202}$

Voor een schets van de procedure is het praktisch om aan te sluiten bij de door Kummeling onderscheiden stappen: a. de adviesaanvraag, b. het voorbereidend onderzoek, c. het onderzoek, d. de formulering van het advies, e. het uitbrengen van het advies. ${ }^{203}$

De adviesaanvraag (a.) kwam hiervoor al aan de orde. Wat de procedure betreft wil ik nog wijzen op de eis dat het advies tijdig wordt aangevraagd. Het bestuur moet het tijdstip zo kiezen dat er voor de adviseur voldoende tijd is om zijn taak naar behoren te vervullen. Deze regel vinden we ook in art. 3:6 Awb. ${ }^{204}$ Tevens wordt in dat artikel gesproken over een aan de adviseur te stellen termijn, ter voorkoming van onevenredige vertraging in de besluitvorming. ${ }^{205}$

Het voorbereidend onderzoek (b.) heeft het verzamelen van informatie als hoofddoel. Allereerst is hierbij van belang dat het adviesvragende bestuursorgaan actief meewerkt tot verschaffing van informatie. ${ }^{206}$ In art. 3:7 lid 1 Awb staat: Het bestuursorgaan waaraan advies wordt uitgebracht, stelt aan de adviseur, al dan niet op verzoek, de gegevens ter beschikking die nodig zijn voor een goede vervulling van diens taak. Kummeling ${ }^{207}$ wijst er mijns inziens terecht op dat het in het tweede lid van deze bepaling van toepassing verklaren van art. 10 WOB $^{208}$ een onnodige beperking vormt op de beschikbaarheid van informatie. Allereerst betreft (art. 10 van) de WOB primair het verkeer tussen bestuur en burgers en niet dat tussen bestuur en adviseurs. Voorts kunnen adviseurs al snel tegen de weigeringsgronden van art. 10 WOB aanlopen - in welk verband ik zelf in het bijzonder denk aan het beroep op technisch advies terzake van de milieu-effecten van "spits-technologie". ${ }^{209}$ Kummeling meent dat het beter zou zijn om - zonodig - een geheimhoudingsplicht aan de adviseurs op te leggen. Hoewel dit stellig een betere aanpak is, blijven er ook dan problemen bestaan, zoals de vraag hoe

202. A.w., p. 72.

203. Prft., a.w., p. 147. Hij tekent overigens aan dat deze stappen vaak door elkaar zullen lopen.

204. In overeenkomstige zin ARRvS 23 december 1982, AB'83, 256.

205. Zoals eerder gezegd stelt een probleem van zelfs maar een geringe complexiteit toch al een eindeloze horizon aan te onderzoeken problemen.

206. Nicolaï, RMTh, a.w., p. 519, spreekt van de plicht tot "actieve medewerking".

207. Prft., a.w., p. 175 en p. 250-251.

208. Inhoudende verschillende weigeringsgronden voor het op verzoek beschikbaar stellen van informatie.

209. Bij de nieuwste en meest gesofisticeerde technologie zal de c-grond (industriële vertrouwelijkheid) al snel een rol gaan spelen. 
belanghebbenden in zo' $\mathrm{n}$ geval, al dan niet op basis van eigen contra-expertise met de adviseurs, c.q. het bestuur, over het advies in debat kunnen gaan. Opmerking verdient nog de verruiming van art. 3:7 lid 1 Awb ten opzichte van het voorontwerp. De oorspronkelijke beperking tot "Het bestuursorgaan dat advies vraagt.." is ingeruild voor een ruimere redactie: "Het bestuursorgaan waaraan advies wordt uitgebracht..". Bedacht moet worden dat deze verruiming (slechts) is bedoeld om ongevraagd advies van een wettelijk ingestelde adviesinstantie, in overeenstemming met een daartoe bij wet verleende bevoegdheid, in te sluiten. ${ }^{210}$ De plicht tot actieve medewerking geldt dus niet alleen voor advisering bij de totstandkoming van (het voornemen tot) een ontwerp-besluit, maar ook daarna - zoals terzake van adviserende bestuursorganen uit Afdeling 3.5 Awb. ${ }^{211}$

Andere adviseurs, die te kennen geven in opdracht van belanghebbenden of op eigen initiatief hun bevindingen (contra-expertise) ter kennis te willen brengen aan het bestuur, doch daarvoor vooreerst nadere gegevens van of door bemiddeling van het bestuur behoeven, kunnen zich niet op de plicht tot actieve medewerking van art. 3:7 lid 1 Awb beroepen; zij zullen de weg van de WOB moeten gaan.

Kummeling wijst er nog op dat art. 3:7 lid 1 Awb niet lijkt te voorzien in een duidelijke regeling voor het verwerven van informatie die bij anderen dan het bevoegd gezag in kwestie moet worden gehaald. ${ }^{212} \mathrm{De}$ adviseur moet deze gegevens zijns inziens kunnen verwerven, tenzij dit met (hoge) kosten gepaard gaat. Alsdan lijkt overleg met het bestuur de aangewezen weg.

Naast actieve medewerking door het bestuur kan het nodig zijn dat de deskundige-adviseur belanghebbenden kan horen. Voorzover zulks niet wettelijk is voorgeschreven, zal dit horen in elk geval nodig zijn indien belanghebbenden beschikken over (persoonlijke) informatie welke onmisbaar is voor de beantwoording van de adviesvraag.

Eventuele problemen over het inzagerecht van adviseurs (met het oog op de beperkingen van de WOB), het opvragen van gegevens bij anderen dan het bevoegd gezag in kwestie of het horen van belanghebbenden, dienen in de fase van het voorbereidend onderzoek tot een oplossing te worden gebracht. Ten slotte zal aandacht moeten worden besteed aan betrokkenen die eigener

210. TK' 88 -' 89,21221 , B, p. 32.

211. In Afdeling 3.5 getuigen de vele voorschriften inzake door-en toezending van informatie ook van de plicht tot actieve medewerking.

212. Prft.. a.w.. p. 184 en p. 250. 
beweging informatie, bewijsmateriaal of een eigen zienswijze naar voren brengen.

Het onderzoek (c.) dient uiteraard zorgvuldig te geschieden. Art. 3:9 Awb schrijft voor dat het bestuur hierop ook toeziet. De methode van onderzoek moet kunnen leiden tot een zo objectief mogelijke vaststelling van feiten. ${ }^{213}$ Hierbij zullen zowel het te onderzoeken object als het doel van het onderzoek van belang zijn. Zo moet worden beoordeeld op welke wijze (en met welke "nabijheid") de feiten moeten worden bestudeerd - door bezichtiging, kijken, luisteren, meten, cijfermatige analyses of technisch onderzoek. ${ }^{214}$ Indien adviseurs zich verlaten op onderzoek van derden dan brengt de eis van zorgvuldigheid mee dat dit onderzoek verifieerbaar is; een schriftelijk verslag ervan lijkt daarvoor een eerste vereiste. ${ }^{215}$ Zeer belangrijk is ook de actieve houding van de adviseurs tijdens het onderzoek. $\mathrm{Zij}$ moeten zelf de benodigde informatie zoeken. Ook als zich niet aanstonds belanghebbenden melden kan het zijn dat er belangen zijn die bestudering behoeven. Als belanghebbenden worden geraadpleegd zal voorts grote zorgvuldigheid moeten worden betracht. Louter aanhoren wat een belanghebbende heeft te melden is onvoldoende; het gaat juist om een daadwerkelijke gedachtenwisseling. Daarbij is het wenselijk om belanghebbenden en betrokkenen te informeren omtrent hetgeen aan de orde is, en gegeven de stand van het onderzoek bekend is of de aandacht heeft. Een open communicatieve instelling draagt bij aan de kennisvergaring en het vertrouwen van de belanghebbenden in de advisering.

Ten slotte is uiteraard van belang dat de adviseur zich in zijn onderzoek laat leiden door voldoende actuele gegevens. ${ }^{216}$

Bij de formulering van het advies (d.) vraagt vooral de motivering van de conclusie van het advies de aandacht. Hoogendijk-Deutsch stelt in haar pre$\operatorname{advies}^{217}$ dat over de motivering van het advies in de jurisprudentie slechts terloops een opmerking wordt gemaakt: veel meer dan dat een uitvoerige motivering het vertrouwen in het advies ten goede komt is daar volgens haar dan ook niet uit af te leiden. Volgens Kummeling ${ }^{218}$ is het - ook thans nog maar de vraag of een advies gemotiveerd moet worden - van een ongeschreven plicht kan zijns inziens in ieder geval niet worden gesproken. Daar

213. Vgl. ARRvS 17 november 1977, AB'78, 97 m.nt. B. de Goede. Zie ook Nicolaï, prft., a.w., p. 336 .

214. Kummeling, prft, a.w., p. 186-187 en Nicolaï, prft., a.w., p. 336 geven van dergelijke keuzes een aantal op jurisprudentie gebaseerde voorbeelden.

215. Nicolaï, prft., a.w., p. 336.

216. Zoals ook bleek in ARRvS 27 maart 1979. AB 367 m.nt. S.V.Hoogendijk-Deutsch.

217. A.w., p. 42.

218. Prft., a.w., p. 194. 
staat echter tegenover dat een gebrekkig gemotiveerd advies volgens de jurisprudentie, niet zonder meer mag worden gevolgd. De algemene lijn is hier dat "het overheidsorgaan steeds moet nagaan of het advies is geformuleerd op een wijze die de juistheid van de conclusie aannemelijk maakt". ${ }^{210}$ Daaraan is in elk geval niet voldaan bij een geheel ongemotiveerd of te summier gemotiveerd advies. De Afdeling Rechtspraak formuleerde het aldus: $:^{220}$ "een beslissing kan niet worden gegrond op een advies, indien dit advies is geformuleerd op een wijze die niet sluitend is, kennelijk onjuiste feiten vermeld of anderszins door zijn bewoordingen aanleiding geeft tot twijfel omtrent de juistheid van de conclusie". Deze nadruk op de motivering - die eigenlijk doet vermoeden dat er wel een ongeschreven plicht bestaat, zij het indirect (als het advies wordt gevolgd) - staat niet alleen in functie van het bestuurlijk belang bij het bepalen van de juiste feitelijke grondslag voor besluitvorming, maar ook van het belang van belanghebbenden (en hun mogelijkheden tot contra-expertise). Het is reeds daarom dat codificatie van de motiveringsplicht van adviezen die ten grondslag liggen aan een bestuursbesluit aanbeveling verdient. ${ }^{221}$

Gelet op het voorgaande is het wenselijk dat het uitbrengen van het advies (e.) in schriftelijke vorm geschiedt. De mogelijkheid tot controle van het advies is immers doorgaans afhankelijk van de beschikbaarheid van een schriftelijk stuk. ${ }^{222}$ De eis van schriftelijkheid lijkt echter in de jurisprudentie niet te worden gesteld. ${ }^{223}$ Daar staat tegenover dat bij afwezigheid van een schriftelijk advies het bestuur de last draagt voor de bewijsvoering terzake van het geadviseerde. ${ }^{224}$

In dit verband onderstreept Kummeling terecht het belang van de openbaarheid van het uitgebrachte advies. ${ }^{225}$ Met name art. 8 en art. 9 WOB (actieve openbaarmaking) zijn terzake relevant - alsmede de weigeringsgronden tot openbaarmaking van art. 10 en art. 11 WOB. ${ }^{226}$

219. Kummeling, prft., a.w., p. 194-195.

220. In ARRvS 25 november 1985, AB'86, 259.

221. Alsook voor alle uitdrukkelijk door het bestuur gevraagde adviezen (zelfs als deze niet worden gevolgd) en alle adviezen van wettelijke adviseurs i.o.m. hun wettelijke taak. De formulering in de tekst sluit ook een ongevraagd advies dat door het bestuur wordt gevolgd bij de motiveringsplicht in.

222. Dit is ook een kwestie van economie; controle vergt anders een serie van gesprekken over hetzelfde advies met meerdere personen (bestuurders, belanghebbenden, rechters).

223. Vgl. Kummeling, prft., a.w., p. 197-198.

224. Vgl. Kummeling, ibidem. en tB/S in hun aantekening bij ARRvS 3-2-1981, tB/S III, 237 (genoemd in noot 272 bij Kummeling, a.w.).

225. Prft., a.w., p. 201-205.

226. Kummeling. prft. , a.w., p. 203-204, bespreekt enkele voorbeelden uit de jurisprudentie inzake het inroepen van weigeringsgronden. In deze studie wordt op de WOB niet nader ingegaan. 
Alle stappen overziend merk ik - tot slot van dit overzicht - nog op dat in de praktijk sommige stappen vaak niet te (onder-)scheiden zijn, c.q. door elkaar heen lopen. Dat geldt voor de voorbereiding van het onderzoek en het feitelijke onderzoek, maar ook voor de onderzoeksvraagstelling, die - onder omstandigheden - wellicht reeds bij de eerste verkenningen en uitkomsten aanscherping, uitbreiding of inperking behoeft.

\subsubsection{Controle op het advies}

Met voornoemde voorzorgen is de eerste stap tot het verkrijgen van een goed advies gezet. Aldus kunnen de openheid van de adviesprocedure en de verifieerbaarheid van de uitkomsten ervan in belangrijke mate worden gewaarborgd. Op basis daarvan kan, als het advies "binnen is", de daadwerkelijke toetsing van het advies plaatsvinden. Ik wil daarvan drie aspecten noemen: eigen verantwoordelijkheid, gebreken en de positie van belanghebbenden.

Met "eigen verantwoordelijkheid" doel ik op de plicht van het bestuur om een advies te toetsen. Hoogendijk-Deutsch stelde reeds: "Enige toetsing, zij het marginale, blijft (..) geboden", "Wanneer een normaal (deskundig) adviseur een advies als het uitgebrachte had kunnen geven, zal het bestuursorgaan dat daarop afgaat, geen onzorgvuldigheid bij de voorbereiding kunnen worden verweten". 227

De toetsing houdt direct verband met het uitgangspunt dat vaststelling en beoordeling van relevante feiten en omstandigheden geschieden onder verantwoordelijkheid van het bevoegd gezag. ${ }^{228}$ Klakkeloos overnemen van het advies miskent de eigen verantwoordelijkheid. ${ }^{229}$ Evenmin is het aanvaardbaar dat het bestuur zich van zijn verantwoordelijkheid ontdoet door zelfbinding aan het advies. ${ }^{230}$ Ook het ontbreken van specifieke deskundigheid terzake aan de zijde van het bestuur, ontslaat niet van de plicht om te toetsen. ${ }^{231}$

De toetsing zelf moet gericht zijn op de redelijkheid van de argumentatie en de zorgvuldigheid bij de totstandkoming. ${ }^{232}$

Het bestuur mag een besluit niet baseren op een advies dat niet naar samenstelling van de adviesinstantie, procedure van totstandkoming, gebruikte

227. VAR, a.w... p. 45.

228. Vgl. Nicolaï, RMTh., a.w., p. 515.

229. Nicolaï, prft., a.w.. p. 351. Zie voorts Vz ARRvS 25 juni 1979, AB'80, 306 en ARRvS 23 januari 1980, AB 564.

230. Vgl. ARRvS 11 november 1985, AB'86, 170.

231. Vgl. voor jurisprudentie terzake o.a. Kummeling, prft., a.w. p. 216-219, i.h.b. noot 80 op p. 218.

232. Vgl. CRvB 28 september 1979, AB'80, 455. 
gegevens en dragende overwegingen door het bestuur is getoetst. ${ }^{233}$ Het bestuur is gehouden daadwerkelijk gegevens die door de adviseur zijn gebruikt op te vragen en inzicht te verwerven in de gevolgde procedure. In art. 3:9 Awb vinden we de toetsingsplicht van het bestuur terug: het bestuur moet nagaan "of aan de conclusie van de adviseur naar inhoud of wijze van totstandkoming niet zodanige gebreken kleven, dat de te nemen beslissing redelijkerwijs niet of niet zonder meer op het advies mag worden gebaseerd".234

Deze visie sluit aan op de twee "toetsingsformules" die Kummeling in de jurisprudentie heeft ontwaard: ${ }^{235}$ "Het (bestuursorgaan) dient zich ervan te vergewissen of aan het advies een zorgvuldig onderzoek is voorafgegaan, of dit berust op een feitelijke grondslag en is geformuleerd op een wijze die de juistheid van de conclusie aannemelijk maakt." en "Indien het advies (...) is geformuleerd op een wijze die niet sluitend is, kennelijk onjuiste feiten vermeld of anderszins door zijn bewoordingen aanleiding geeft tot twijfel omtrent de juistheid van de conclusie, kan daarop niet zonder meer een (...) beslissing worden gebaseerd."

Indien een uitgebracht advies deugdelijk blijkt, mag het bestuur daarop zijn beslissing ("in redelijkheid") baseren. In geval van deskundigen-advies zal het bestuur daarmee zeer sterk staan tegenover bezwaar of beroep. ${ }^{236}$

Hoewel we moeten vaststellen dat het bestuur (ook) bij deskundigen-advies niet ontkomt aan toetsing, zal deze toetsing noodzakelijkerwijs een marginale zijn. Het bestuur wordt dus niet tot het (superdeskundige) uiterste gehouden: "de (mogelijkheid van) tekortkoming van de deskundige moet voor een ondeskundige kenbaar zijn". ${ }^{237}$ Het gaat er "slechts" om vast te stellen of de adviseur niet onzorgvuldig heeft gehandeld, argumenten heeft gebruikt die niet "in redelijkheid" gebruikt kunnen worden, het advies geen "kennelijke onjuistheden" bevat en de conclusie van het advies niet aannemelijk is.

Ten slotte merk ik op dat ook de organisatie van een open debat over de inhoud en de wijze van (al dan niet) toepassen van een advies, behoort tot de verantwoordelijkheid van het bestuur. Deze punten komen hierna nog aan de orde.

233. Nicolaï. RMTh, a.w.. p. 518 en (o.a.) ARRvS 19 december 1977. AB'78, 157 en ARRvS 2 mei 1978. AB 344.

234. MvT-Awb1, a.w., p. 74.

235. Prft.. a.w., p. 218.

236. Kummeling, prft., a.w., p. 216 en de aldaar genoemde jurisprudentie

237. Hoogendijk-Deutsch, VAR, a.w., p. 46. Zie ook Nicolaï, RMTh., a.w., p. 528 en Kummeling. prft., a.w., p. 219. 
In geval van een gebrekkig deskundigenadvies mag het bestuur de kwestie niet op eigen gezag afdoen. De oorspronkelijke adviseur moet opnieuw worden geraadpleegd, of er moet aan een (of meer) andere adviseur(s) een oordeel moeten worden gevraagd. ${ }^{238}$ Het ligt wel voor de hand dat bij (de eerste) twijfel over het advies, laat staan bij aanstonds manifeste gebreken het bestuur vooreerst in overleg treedt met de desbetreffende adviseur. ${ }^{239}$

Bij alle stappen in de adviesprocedure kan wel iets mis gaan. Nicolai ${ }^{240}$ wijst onder meer op een gebrek in de bevoegdheid van de adviseur, indien deze treedt buiten de grenzen van zijn deskundigheid en op de mogelijkheid van een gebrek in de samenstelling van een adviesinstantie, voorzover hierbij de schijn van partijdigheid niet wordt vermeden. Ook kunnen er gebreken optreden in de inhoud van het advies, door onzorgvuldigheid, zoals het ten onrechte niet bezichtigen van een pand of niet horen van belanghebbenden. Gebreken in de motivering van het advies zijn natuurlijk steeds problematisch aangezien zij de controle van het advies frustreren. ${ }^{241}$

Blijkt een advies te zijn gebaseerd op oude, inmiddels gewijzigde feiten of omstandigheden, dan kan ook dat een inhoudelijk gebrek opleveren. Hierbij past het indien het bestuur de adviseur verwittigt van de "nova". Een nieuw advies lijkt dan, voorzover de nova een deskundige beoordeling behoeven, op z'n plaats. ${ }^{242}$ Opmerking verdient hier de opvatting van de Kroon dat het voorbijgaan aan nova het bestuur niet aangerekend kan worden indien technische ontwikkelingen een tempo hebben dat door adviseur en bestuur eenvoudig niet kan worden bijgehouden. ${ }^{243}$ Toch zou ik hier niet veel voor voelen. Als het bestuur volgens zorgvuldig eigen onderzoek (waaronder toetsing van het uitgebrachte advies) te werk gaat en daarbij (mogelijk) relevante nieuwe feiten of inzichten op het spoor komt, die een deskundig oordeel behoeven maar niet in het advies zijn verwerkt, dan dient het deze aan de adviseur mee te delen. Deze kan dan beoordelen of zijn advies bijstelling behoeft. ${ }^{244}$

238. Tenzij het om niet-essentiële, ondergeschikte punten gaat. Vgl. Kummeling, prft., a.w., p. 224. i.h.b. de jurisprudentie genoemd in noot 119 en 121 aldaar.

239. Kummeling, prft., a.w., p. 220.

240. RMTh., a.w., p. 525 e.v.

241. Nicolaï, RMTh., a.w., p. 529.

242. Vgl. Kummeling, prft., a.w., p. 223. Alsmede ARRvS 23 december 1986, AB'87, 387 m.nt. RF en ARRvS 27 maart 1979, AB 367 m.nt. S.V. Hoogendijk-Deutsch.

243. KB van 28 juni 1985 , Gem.stem 6845,9 m.nt. Bomhof. Zie voorts Kummeling, prft., a.w.. p. 222-223.

244. In overeenkomstige zin Nicolaï, RMTh, a.w., p. 520. 
Blijft herstel van gebreken uit dan ligt vernietiging van een op dit advies gebaseerd bestuursbesluit steeds op de loer. Het zorgvuldigheidsbeginsel (en in mindere mate het motiveringsbeginsel) vormen in dit verband belangrijke toetsingscriteria. ${ }^{245}$

Tegen de hier bedoelde deskundigenadviezen staat, mede blijkens constante jurisprudentie, geen beroep op een administratieve rechter open. ${ }^{246}$ Het advies heeft immers geen zelfstandige juridische betekenis - in termen van een daaraan direct verbonden rechtsgevolg.

De positie van belanghebbenden is relevant met het oog op de gegevens die zij kunnen verschaffen en hun bijdrage aan een kritisch debat over de inhoud en toepassing van het advies. Verschillende procedurele waarborgen, zoals de mogelijkheid tot inspraak en de inzage in stukken (met name deskundigenrapporten), ${ }^{247}$ zijn hiervoor van belang - en werden reeds onder $\S 6.3$ besproken. Bezien vanuit rechtsbeschermingsperspectief moet een appellant gemotiveerd verweer kunnen voeren en dient hij derhalve beschikking te kunnen krijgen over gegevens die door derden (zoals een adviseur) zijn verstrekt tenzij deze vertrouwelijk zijn. 248

\subsubsection{Het gezag van het advies}

Vier punten zal ik onder de bovenstaande noemer bespreken. Allereerst (opnieuw) de eigen verantwoordelijkheid van het bestuur. $\mathrm{Nu}$ echter in het bijzonder de verantwoordelijkheid voor het weloverwogen omgaan met het (deugdelijke) advies. Vervolgens ga ik in op het "volgen" en het "afwijken" van uitgebrachte adviezen. Ten slotte wil ik een opmerking maken over de aansprakelijkheid voor de feitenvaststelling na deskundigen-advisering.

\subsubsection{Verantwoordelijkheid}

Het bestuur moet beoordelen welk gewicht het aan het advies zal toekennen. ${ }^{249}$ Het bestuur zal met het advies rekening moeten houden en kan adviezen derhalve niet zonder meer, stilzwijgend (laat staan stelselmatig) negeren. $^{250}$ Nicolai ${ }^{251}$ kwalificeert het advies als een "rechtsfeit". Een advies dat in overeenstemming met het recht kan worden geoordeeld kan niet door het bestuur als een irrelevant feit worden afgedaan. Indien bij het nemen van

245. En. voorzover toepasselijk. strijd met de wet. Vergelijk voorts (ook voor jurisprudentie terzake) Kummeling, prft., a.w., p. 226-227.

246. Vgl. Hoogendijk-Deutsch, VAR, a.w., p. 48: Kummeling, prft., a.w., p. 50.

247. Vgl. resp. art. 3:25 lid 1 en art. 3:21 lid 1 onder $c$ en d Awb.

248. Zie ARRvS 2 mei 1978. AB 344.

249. Vgl. Hoogendijk-Deutsch, VAR, a.w., p. 43.

250. Ibidem.

251. RMTh, a.w., p. 521 e.v. 
een bestuursbesluit voorbij wordt gegaan aan een (eerder) door het bestuur gevraagd advies, zal dit al snel leiden tot schending van het beginsel van zorgvuldig onderzoek en mogelijk zelfs tot willekeur. ${ }^{252}$

Vooraleer ik de eigen verantwoordelijkheid van het bestuur in termen van de vrijheid tot "volgen" en "afwijken" bespreek, wil ik nog stilstaan bij de situatie dat het bestuur meerdere, onderling afwijkende of zelfs tegenstrijdige adviezen ontvangt, zonder dat één daarvan, uit wetenschappelijk oogpunt, gebreken vertoont. Bij Kummeling ${ }^{253}$ komt naar voren dat ingeval van meerdere onderling afwijkende of tegenstrijdige adviezen "nader onderzoek" (bij dezelfde of andere adviseurs) is geboden. ${ }^{2.4}$ Mits goed gemotiveerd is het aanvaardbaar als vervolgens én van de (onderling afwijkende) adviezen wordt gevolgd. ${ }^{255}$

Voor een dergelijke keuze kunnen verschillende gronden worden aangevoerd. Om te beginnen kunnen procedurele verschillen een grond vormen om aan een bepaald advies de voorkeur te geven. ${ }^{256}$ Ook kan de specifieke deskundigheid van de adviseur meewegen: de ene deskundige kan, gelet op het specifieke karakter van het onderwerp, geschikter zijn dan de ander (de specialist gaat voor de generalist). ${ }^{257}$ Ten slotte is denkbaar dat het bestuur zich oriënteert aan hetgeen in de kring van deskundige "beroepsgenoten" gangbaar is. ${ }^{258}$ Toepassing van het laatste criterium dient mijns inziens, zeker op gebieden met een technologisch-dynamisch karakter, met grote voorzichtigheid te geschieden. In dat verband mag de rol van vaste (en dus weer gespecialiseerde) adviseurs, voor bestuur en rechter, niet licht worden onderschat. ${ }^{259}$

Een speciale situatie doet zich voor indien "strijdigheid" bestaat tussen een intern (ambtelijk)advies en een extern advies. De schijn van partijdigheid van het interne advies blijkt in dat vergelijk een handicap. In zo'n geval roept het volgen van het interne advies een extra strenge motiveringsplicht op, terwijl - omgekeerd - het volgen van het externe advies zelfs ongemotiveerd mogelijk lijkt. ${ }^{260}$

252. Kummeling, prft., a.w., p. 237.

253. Dbidem. p. 220 e.v.

254. Zie ook hiervoor bij gebreken. Vgl. voorts ARRvS 31 augustus 1979. AB'80, $302 \mathrm{~m} . \mathrm{nt}$. v/dV.

255. Vgl. ARRvS 3 januari 1985, AB'86, 61.

256. Vgl. ARRvS 9 oktober 1986, AB'87, 321.

257. ARRvS 23 januari 1987, AB 304 m.nt. JHv/dV.

258. Vgl. Schoonenberg, J. en H.D. Vleesch Dunois, het administratieve procesrecht volgens de Beroepswet, Amsterdam 1957, p. 164-168, i.h.b. p. 166.

259. Dit is wel wat meer dan een indruk. In het volgende deel komt het gewicht van vaste adviezen aan de rechter goed naar voren.

260. Vgl. ARRvS 3 maart 1986, Gem.stem 6841, 10 m.nt. J.Teunissen. 


\subsubsection{Het volgen van een advies}

Indien sprake is van een deugdelijk advies dan kan het bestuur, ingevolge art. 4:19 (3.6.4) Awb, bij zijn besluit volstaan met een verwijzing naar dit advies. Voorwaarde is wel dat het advies zelf de motivering bevat en het advies ter kennis van belanghebbenden is of wordt gebracht.

De eis van een deugdelijke motivering brengt mee dat bij verwijzing naar een advies, de eindconclusies van dat advies moeten worden gedragen door daaraan ten grondslag gelegde overwegingen. Het advies, in het bijzonder de motivering daarvan, moet getuigen van een rechtens aanvaardbare argumentatie. ${ }^{261}$

In het algemeen geldt dat het hestuur, vooral bij een deugdelijk deskundigenadvies, zeer sterk staat als het besluit dit advies te volgen. In een gerechtelijke (contentieuze) procedure kunnen belanghebbenden de uit zo'n advies overgenomen feitelijke grondslag voor een bestuursbesluit niet met succes bestrijden indien zij zich slechts op hun eigen oordeel beroepen; in die fase zal tenminste een deskundig tegenadvies (contra-expertise) moeten worden ingebracht. ${ }^{262}$

\subsubsection{Afwijken van advies}

Als de complexiteit van de feiten noopt tot het inwinnen van deskundigenadvies, is de bestuurlijke ruimte voor afwijken van een dergelijk advies zeer beperkt. Als regel geldt dan ook dat afwijken van deskundigen-advies alleen mag na contra-expertise. ${ }^{263}$ Zonder contra-expertise ontbeert het bestuur afdoende eigen deskundig inzicht om een deugdelijke motivering voor het van het advies afwijkende bestuursbesluit te verschaffen. Contra-expertise is derhalve beslist noodzakelijk; afwijken van deskundigen-advies zonder voorafgaand inwinnen van contra-expertise zou daarbij resulteren in schending van het zorgvuldigheidsbeginsel. ${ }^{264}$ Ook Kummeling volgt deze redenering. ${ }^{265}$ Met Nicolaï wijst hij er overigens op dat afwijken van een advies onder omstandigheden ook een plicht kan zijn. Een gebrekkig advies of de werking van het vertrouwens- of gelijkheidsbeginsel kunnen tot afwijking van het advies verplichten. ${ }^{266}$

Het is goed te begrijpen dat praktische beperkingen (tijd en geld) het bestuur in de verleiding kunnen brengen om toch maar zonder contra-expertise van

261. Nicolaï, prft., a.w., p.353. Kummeling. prft., a.w., p. 229. i.h.b. noot 145 en 146.

262. Ik loop vooruit op het volgende deel. Zie Kummeling, prft., a.w., p. 216 en de aldaar genoemde jurisprudentie.

263. Vgl. Hoogendijk-Deutsch. VAR, a.w.. p. 43, Nicolaï. RMTh, a.w., p. 523; Kummeling, prft., a.w., p. 232: CRvB 25-11-1977, AB'78, 292.

264. Nicolaī, RMTh., a.w., p. 525.

265. Prft., a.w., p. 232 e.v. Hij verwijst daarbij o.m. naar ARRvS 28 juni 1979. AB'80, 110.

266. Kummeling, prft., a.w., p. 237. Nicolaĩ. RMTh., a.w., p. 525 e.v. 
een advies af te wijken. Terecht wordt dit door Nicolaï afgewezen: "Wij zien niet in hoe een beroep op de "dringende tijd" een gebrek aan fundering, voortkomend uit een "ondeskundig" oordeel van het bestuur, zou kunnen opheffen". ${ }^{267}$

Met Nicolaï ben ik tevens van mening dat het bestuur (voorafgaand aan het inwinnen van contra-expertise, althans) voordat tot afwijking wordt besloten, eerst de oorspronkelijke adviseur in de gelegenheid dient te stellen om over de aan dit voornemen ten grondslag liggende overwegingen nader te adviseren. ${ }^{268}$ Daarmee kan tevens worden voorkomen dat er misverstanden in het spel zijn, zoals dat bepaalde premisses door het bestuur ten onrechte voor "blote feiten" worden gehouden of vise versa. ${ }^{269}$

Reeds Hoogendijk-Deutsch stelde voorop dat afwijken van (deskundigen) advies altijd moet worden onderbouwd met een deugdelijke motivering. ${ }^{270}$ In art. 4:20 Awb (3.6.5 Awb) is deze verplichting gecodificeerd, voorzover het gaat om afwijking van wettelijk verplichte adviezen. In het voetspoor van Kummelings bevindingen dienaangaande, ${ }^{271}$ ben ik van mening dat deze motiveringsplicht ook zou moeten slaan op afwijken van andere door het bestuur gevraagde adviezen.

In de motivering ("tot afwijken") dient bijzondere aandacht te worden besteed aan de punten waar advies en besluit uiteenlopen. Het bestuur moet uitdrukkelijk aangeven waarom wordt afgeweken. ${ }^{272}$ Ook ten aanzien van spontaan overlegde rapporten en deskundigen-adviezen van of in opdracht van (deskundige-)derden wordt wel een motiveringsplicht bij afwijken aangenomen. ${ }^{273}$ In het algemeen wordt bij afwijken door het bestuur van spontaan advies of van niet wettelijk verplicht, doch door het bestuur gevraagd advies, geen motivering in detail van het afwijken verwacht. Dat zou immers resulteren in een "ongerechtvaardigde druk". ${ }^{274}$ Op deze lijn wordt echter een uitzondering gemaakt indien het gaat om deskundigen-rapporten die een oordeel

267. RMTh, a.w., p. 523.

268. RMTh., a.w.. p. 523 e.v.

269. Juist in deze premisses (zoals opvattingen over de verhouding mens en natuur) zitten aanknopingspunten voor (afwijkende) beleidsmatige posities. Zie over de verwevenheid van "facts" en "values". Nicolaĩ, RMTh, a.w., p. 524 en Kummeling, prft. a.w., p. 233.

270. VAR, a.w., p. 55, aanbeveling 9.

271. Kummeling, prft., a.w., p. 237-238 (en noot 192).

272. Kummeling, prft., a.w., p. 240-241. Kummeling merkt op (p. 239) dat het een eis van behoorlijkheid is dat de adviseur van deze motivering op de hoogte wordt gesteld.

273. Zoals in ARRvS 1 juli 1985, AB'86, 241.

274. Kummeling, prft., a.w., p. 241. 
uitspreken aan de hand van kennis die het bestuur zelf niet bezit; dan is - integendeel - juist een diepgaande motivering vereist. ${ }^{275}$

Met het oog op de positie van belanghebbenden heeft Hoogendijk-Deutsch een in dit verband vermeldenswaardige aanbeveling geformuleerd: ${ }^{276}$ "In geval van deskundigen-advies dient een processuele mogelijkheid geopend te worden tot een contra-expertise, op verzoek van een belanghebbende bij wege van incident te verrichten door deskundigen die hij heeft aangewezen, of met wier benoeming hij althans instemt." Deze aanbeveling staat enigszins los van de kwestie van voorgenomen afwijken van deskundigen-advies. Tegelijkertijd verdient zij hier vermelding omdat er een algemeen appel tot het nemen - of althans faciliteren - van contra-expertise uit spreekt. Een appel dat ik zonder meer steun. ${ }^{277}$

\subsubsection{Zorgvuldigheid (en aansprakelijkheid)}

Het gezag van een advies moet niet alleen worden bezien vanuit de aan het advies te stellen eisen, maar ook vanuit de eisen te stellen aan de voorbereiding van het desbetreffende besluit.

Een belangrijk punt bij die voorbereiding is de vraag naar de nauwkeurigheid, omvang en diepgang van het onderzoek (waar het advies deel van uitmaakt). Deze vraag houdt - door het juridisch oog bezien - nauw verband met de eisen die voortvloeien uit het zorgvuldigheidsbeginsel.

In $\S$ 4.3.3.3 kwam de vraag naar een 'stopregel' voor nauwkeurigheid, omvang en diepgang (hierna, reikwijdte) van het onderzoek reeds aan de orde. Daarbij werd verwezen naar (de wettelijke termijnbepalingen en) art. 3:2 Awb. De kwestie van de reikwijdte van het onderzoek wordt in art. 3:2 Awb gecapteerd in het criterium van "de nodige kennis". In voornoemde paragraaf benadrukte ik twee aspecten die bij de toepassing van dat criterium van belang zouden kunnen zijn. Allereerst wees ik op de juridische toepassingsconditie voor de bevoegdheid in kwestie. Daarnaast sprak ik over het streven naar 'redelijke zekerheid' door een evenredige onderzoeksinspanning. Bij laatstgenoemd aspect wees ik op een aantal mijns inziens belangrijke factoren. In de eerste plaats attendeerde ik op het gewicht en de kwetsbaarheid van de betrokken belangen. Daarnaast noemde ik het meer of minder omstreden zijn van de kennis over de effecten van het voorgenomen besluit en de bekendheid of vertrouwdheid van betrokkenen met die kennis. Ten slotte besprak ik de kwestie van de marginale meeropbrengst: als aannemelijk zou

275. Ibidem.

276. Aanbeveling 8, p. 55 .

277. Getuige ook mijn eerdere opmerkingen over deskundige ondersteuning van burgers $(\$ 6.3 .4 .3$ en $\$ 6.3 .6)$. 
worden gemaakt dat verdergaand onderzoek een waardevolle vergroting van zekerheid omtrent de effecten zou opleveren, zou dat pleiten voor een extra onderzoeksinspanning.

Het is aantrekkelijk om deze overpeinzingen aan te leggen tegen de ook reeds in \& 6.4.2.2 (formulering van de adviesvraag) gepresenteerde'ABAR-formule' voor de reikwijdte van het onderzoek: de reikwijdte van het onderzoek zal sterk afhankelijk zijn van "de urgentie van de te geven beschikking, en de grootte van de belangen die daarbij zijn betrokken, in verband met de kosten en de duur van een in aanmerking komend onderzoek en de resultaten die het zal kunnen opleveren". ${ }^{278}$ Ook in deze formule staat het gewicht van de betrokken belangen ("grootte", "urgentie") als factor voorop. Daartegenover staat dat de bekendheid met of het omstreden zijn van (kennis over) de te verwachten effecten - de 'epistemologische factor', de kwestie van de onzekerheid - in de benadering geen rol speelt. Ook is opvallend dat de 'kostenfactor' als een zeer wezenlijk punt wordt gezien.

De 'ABAR-formule' biedt - kortom - een betrekkelijk praktisch perspectief voor het verwerven van de 'nodige kennis', c.q. van redelijke zekerheid. Dit perspectief is nog aan te vullen met andere praktische regels, zoals de - in het voetspoor van Nicolaï - eveneens in $\$ 6.4 .2 .2$ - genoemde regel dat in elk geval de feiten en omstandigheden van het individuele geval moeten worden onderzocht (en niet slechts de effecten die in het algemeen plegen op te treden). Ook zal het bestuur zich nadrukkelijk moeten oriënteren op de signalen die van buiten af (bij voorbeeld door belanghebbenden en deskundigen) worden gegeven.

Een en ander neemt niet weg dat ik toch wil benadrukken dat de 'epistemologische factor' bij de vraag naar de reikwijdte van het onderzoek wel degelijk een rol zal moeten spelen. Ik denk daarbij met name aan de wenselijkheid om uitdrukkelijk contra-expertise in te winnen als er over de van een voornemen te verwachten effecten onenigheid (b)lijkt te bestaan. Ook wil ik ten aanzien van de 'kostenfactor' het criterium van de aannemelijkheid van waardevolle vergroting van zekerheid door extra onderzoek benadrukken. Kritische toepassing van dit criterium is nodig teneinde te voorkomen dat het onderzoek zich aldoor op grotere diepten en in nieuwe vergezichten beweegt - zonder dat dit in vergroting van zekerheid resulteert.

Als niettegenstaande gedegen onderzoek geen redelijke zekerheid omtrent de effecten wordt verkregen, kan dat aanleiding zijn om op een verzoek afwijzend te beschikken. Zo vat ik ook de uitspraak op van de Centrale Raad van Beroep waarin wordt gesteld dat het beginsel van zorgvuldig onderzoek "niet zover (gaat), dat in een situatie dat ondanks gedegen onderzoek onvoldoende 
controleerbare informatie werd verkregen, de gevolgen hiervan voor risico van het desbetreffende bestuursorgaan komen". ${ }^{279}$ In dit geval viste de burger achter het net. Nicolai ${ }^{280}$ meent dat de Centrale Raad hier een algemene regel beoogt te stellen, die hij vervolgens afwijst omdat naar zijn mening de vraag voor wiens risico de door de Centrale Raad bedoelde gevolgen behoren te komen, telkens op maat van de bijzondere omstandigheden van het geval moeten worden beoordeeld. ${ }^{281}$ Mijns inziens vat Nicolaï de door de Centrale Raad gedane uitspraak te algemeen op. Naar mijn mening speelde in deze zaak twee aspecten een rol: het tekortschieten van de burger in het verstrekken van de nodige ('controleerbare') informatie en het feit dat een voor de burger begunstigend besluit wordt gevraagd. Ik zou me goed kunnen voorstellen dat de Centrale raad overigens goed met de door Nicolaï geformuleerde regel zou kunnen leven. Deze regel sluit in dat er omstandigheden kunnen zijn waarin het niet verwerven van redelijke zekerheid omtrent de feiten, bij het nemen van een beslissing in het voordeel van de betrokken burger zou kunnen werken. ${ }^{282}$ Ook is goed voorstelbaar dat het eveneens in $\$ 4.3 .3 .3$ genoemde uitgangspunt van 'safety-first' (de 'no-regrets-policy') van invloed zal zijn op de conclusie die aan het niet verwerven van redelijke zekerheid moet worden verbonden. ${ }^{283}$

Als in het onderzoek ter voorbereiding van een besluit wel redelijke zekerheid wordt bereikt en op basis hiervan een (laten we zeggen) positief besluit wordt genomen, is er nog altijd geen absolute zekerheid. In hoofdstuk 4, in het bijzonder in de tweede vuistregel, heb ik getracht duidelijk te maken dat dit ook niet van het bestuur kan worden verwacht.

Consequentie van die visie moet zijn dat indien nadat het positieve besluit is genomen, inzichten aan het licht komen die duidelijk maken dat een ander, wellicht zelfs negatief besluit genomen had moeten worden, dit niet vanzelf meebrengt dat het bestuur bij het positieve besluit onzorgvuldig en mitsdien onrechtmatig heeft beslist - waarbij ik er (voor alle duidelijkheid) van uit ga dat de inzichten bij een extra onderzoeksinspanning wellicht aanstonds bekend hadden kunnen zijn. In een dergelijk geval zou het niet juist zijn aanstonds te spreken van een gebrekkige beschikking, die grondslag voor aan-

279. CRvB 14 september 1988. RSV'89, 95.

280. Prft., a.w., p. 337.

281. Ibidem.

282. Een evident geval hiervan is uiteraard het besluit af te zien van de toepassing van een administratief correctie- of sanctie-middel

283. Waarbij denkbaar is dat deze benadering in het concrete geval ook tot een specifieke invulling van 'redelijke zekerheid' kan leiden: een kleine aanwijzing van mogelijk gevaar zou - bij voorbeeld - kunnen worden gezien als voldoende (redelijke) zekerheid om afwijzend te beschikken inzake het voornemen. 
sprakelijkheidstelling vormt. ${ }^{284}$ Immers: indien het onderzoek van het bestuur voorafgaand aan het positieve besluit in de woorden van de Centrale Raad gedegen was, is er - in dat opzicht - geen sprake van een gebrekkig besluit en mitsdien al evenmin van enige aansprakelijkheid terzake. Of het onderzoek gedegen was zal daarbij ondermeer aan de hand van bovengenoemde criteria moeten worden bezien. ${ }^{285}$

\subsubsection{Conclusie gerichte advisering}

De meeste regels die ik hiervoor besprak behoeven geen nadere evaluatie. Voor een aantal regels echter lijkt het mij aantrekkelijk deze af te zetten tegen de vijf vuistregels uit deel II van deze studie.

Achtereenvolgens gaat het om de volgende regels:

1. De eigen verantwoordelijkheid van het bestuur voor de feitenvaststelling sluit - zoals dat heet - naadloos aan bij de eerste vuistregel (bestuurlijke verantwoordelijkheid). Dit geldt zowel voor de plicht van het bestuur om daadwerkelijk zelf te beslissen als voor de regie van het onderzoek. Deze regie behelst onder meer de zorg voor een redelijke en zorgvuldige feitenvaststelling en de daarmee verbonden controle op inhoud en wijze van totstandkoming van het advies.

In het voorgaande werd duidelijk dat het hierbij gaat om een marginale toets: heeft de adviseur gehandeld als een behoorlijk en zorgvuldig adviseur, betreft het een "normaal" deskundigen-advies? De redelijkheid van de gebezigde argumenten en de zorgvuldigheid in de keuze en het gebruik van methoden en technieken zijn bij deze marginale toets de belangrijkste aspecten. Het is niet de bedoeling dat het bestuur pretendeert het advies als een superdeskundige te kunnen sanctioneren. Het gaat er om (dat naar de omstandigheden van het geval) een redelijk vertrouwen in de te nemen beslissing mogelijk wordt gemaakt.

In het verlengde hiervan is het begrijpelijk dat bij gebleken gebreken in het advies de overheid het advies niet zelf afdoet, maar daarover de oorspronkelijke en/of een nieuwe adviseur raadpleegt.

Dat de deskundige als deskundige moet worden aangesproken, en dus niet met een adviesaanvraag moet worden opgezadeld die hem er toe zou kunnen verleiden uitspraken te doen die buiten het bereik van zijn deskun-

284. Vgl. HR 24-2-1984, AB 399 m.nt. Van Eijden (St. Oedenrode-Driessen) en HR 20-9-1986. AB'87, 70 m.nt. Van der Burg (Hoffman-La Roche).

285. Als de termijnen voor bezwaar en beroep zijn verstreken zal dat traject (overigens) verder geen soelaas meer kunnen bieden. 
digheid liggen, valt eveneens samen met de strekking van de eerste vuistregel.

2. Het bestuur is gehouden alle essentiële elementen bij de feitenvaststelling te betrekken, c.q. alle feiten en omstandigheden van het individuele geval. De diepgang van het in te stellen feitenonderzoek moet zijn afgestemd op de urgentie van het te nemen besluit en de grootte van de betrokken belangen, een en ander bezien in relatie tot de kosten en de duur van het onderzoek en de daarvan te verwachten resultaten. Met het laatste zitten we op het terrein van de tweede vuistregel (de bevredigende beslissing). Het is nu eenmaal niet mogelijk alle feiten volkomen te doorgronden. Daarom moet een bevredigende aanpak worden gekozen, gebaseerd op een redelijke afweging van belangen en een redelijke inschatting van de te verwachten onderzoeksresultaten. Opmerkelijk is hier dat de benadering van de verwachte marginale meeropbrengst nadrukkelijk een rol lijkt te spelen.

3. Aan de deskundige-adviseur moet een zekere vrijheid worden gelaten ten aanzien van de te volgen procedure. Essentieel is dat het advies kan bijdragen aan een zo "objectief" mogelijke vaststelling van de feiten (zie ook 1.). Aan de vrijheid van de deskundige moet echter in zoverre een beperking worden gesteld dat deze zijn resultaten controleerbaar maakt. Dat wil zeggen dat een schriftelijke presentatie voorzien van een deugdelijke motivering de voorkeur verdient. Dit sluit aan bij de derde vuistregel (inzake openheid). Controleerbaarheid en meer in het algemeen de mogelijkheid om kritiek te leveren staan of vallen immers bij een inzichtelijke presentatie. Daarnaast is het wenselijk dat de deskundige de belangrijkste onzekerheden in zijn advies expliciet maakt. Deze zijn immers voor het nemen van de bestuursbeslissing van groot gewicht en moeten weer in debat gebracht kunnen worden.

Meer in het algemeen is voor de toetsing van adviezen van belang dat belanghebbenden zich daarover kunnen uitlaten. $\mathrm{Zij}$ behoeven zich daarbij uiteraard niet 'marginaal' op te stellen. Tegelijkertijd geldt dat zij om twijfel te zaaien toch met sterke argumenten moeten komen, zeker als het een deskundigenadvies betreft dat de bestuurlijke toetsing heeft doorstaan. Eerder ( $\$ 6.3 .5 .3)$ stelde ik dat de burger in de non-contentieuze procedure niet tot een door deskundigen onderbouwde argumentatie moet worden verplicht. Ik ben aan die stellingname gehecht, maar de stand van het positieve recht maakt wel duidelijk dat een regeling voor deskundige ondersteuning - althans bij besluitvorming in complexe problemen - geen overbodige luxe is. 
4. De in de vierde vuistregel genoemde "gangbare visie" blijkt het bruggehoofd om bij tegenstrijdigheid van adviezen toch tot een eenduidige interpretatie van de (verwachte) feiten te komen. Naast en in verband met de "gangbare visie" blijkt de mate van gespecialiseerdheid van de adviseur een zeer sterk argument voor keuze tussen adviezen. Vaak is het de specialist die geacht wordt te weten wat de gangbare visie "anno nu" eigenlijk inhoudt. Goed voorstelbaar is dat een dergelijk oordeel is voorbehouden aan een vaste adviseur. Deze wordt in besluitvormingstechnische zin geacht gespecialiseerd genoeg te zijn om als een technisch-wetenschappelijke "alter-ego" een finaal oordeel te kunnen geven.

Op praktische gronden lijkt mij een dergelijke selectie in tegenstrijdige adviezen aanvaardbaar. Twee kanttekeningen zijn echter noodzakelijk.

In de eerste plaats zal het bestuur zich m.i. steeds rekenschap moeten geven van een "worst case scenario". Acceptatie van én bepaald advies, op de enkele grond dat dit is gebaseerd op gangbare opvattingen, impliceert dat daarnaast een afwijkende visie staat, die weliswaar niet "gangbaar" is, of van een gespecialiseerde of vaste deskundige afkomstig, maar evenmin aantoonbaar onjuist is. Als deze visie een somber beeld schetst over de bij het bestuursbesluit te beschermen belangen, acht ik het denkbaar dat dit het bestuur motiveert tot het nemen van onzekerheidreducerende maatregelen, c.q. de keuze voor een alternatief met het laagst mogelijke risico.

In de tweede plaats moet de positie van de vaste-adviseur met waarborgen voor onafhankelijkheid zijn voorzien. Er bestaat toch de kans dat iemand of een instelling die telkenmale met gezag adviseert over het gezag van de adviezen van anderen, bestuurlijke of wetenschappelijke voorkeuren ontwikkelt die de onpartijdigheid van de oordeelsvorming belemmeren.

5. De deskundige moet op zijn deskundige merites worden geselecteerd. Zijn onpartijdigheid vormt daarbij een essentieel gegeven. Onpartijdigheid wordt welhaast als ideaaltypisch kenmerk gebruikt: de deskundige is iemand die niet op grond van eigen denkbeelden oordeelt maar op basis van objectieve, althans onafhankelijke kennis of deskundigheid. Bij de vijfde vuistregel (omgaan met waarden) neemt onpartijdigheid een belangrijke plaats in. Daarbij wordt erkend dat ook de deskundige zich op waarden beroept. Dit lijkt aanvaardbaar zolang het hier wetenschappelijke waarden betreft. In de vijfde, maar ook in de derde vuistregel (openheid van procedure) wordt benadrukt dat advisering moet zijn ingebed in een open procedure waardoor kritiek op advisering mogelijk is. Aldus is controle op niet-wetenschappelijke ("partijdige") waarden mogelijk en kan ook een discours plaatsvinden over de relevantie van gehanteerde wetenschappelijke waarden. 


\subsection{Ongerichte advisering}

\subsubsection{Inleiding}

In \$ 4.5.2.5 heb ik twee vormen van advisering onderscheiden: gerichte en ongerichte. Het gerichte advies, dat op maat van een in een individueel geval voorliggend voornemen tot besluitvorming wordt opgemaakt, ten behoeve of ter beïnvloeding van het in casu bevoegde gezag, kwam hierboven aan de orde. Het ongerichte advies typeerde ik als "grofmazige kennis" die niet specifiek voor een bepaald individueel geval van besluitvorming is gegeven maar die van een algemeen karakter is. In dat verband heb ik twee vormen onderscheiden. Een vorm die kan worden benoemd als wetenschappelijke kennisoverdracht, omdat daarmee geen ander oogmerk dan een dergelijke wijze van kennisoverdracht in het geding is, en een vorm die kan worden aangeduid als normatieve (of beleidsgerichte) kennisoverdracht, nu daarmee uitdrukkelijk een bepaalde wijze van uitoefening van discretionaire bevoegdheden wordt voorgestaan. In verband met deze laatste categorie heb ik - in navolging van Bröring ${ }^{286}$ - de term richtlijnen gebruikt. Bröring wijst op de verwantschap tussen richtlijnen en deskundigen-adviezen ${ }^{287}$ èn op het feit dat richtlijnen allerminst als een "juridisch nihil" kunnen worden afgedaan. Bezien in het licht van het formele zorgvuldigheidsbeginsel en het motiveringsbeginsel kan een bestuursorgaan - volgens Bröring - onder omstandigheden niet zomaar aan een richtlijn voorbij gaan. Aangezien het formele zorgvuldigheidsbeginsel voorschrijft dat van alle voor het te nemen besluit relevante gegevens kennis moet worden genomen, en richtlijnen "doordachte argumenten" kunnen bevatten voor de wijze waarop de bevoegdheid in kwestie - adequaat - kan worden uitgeoefend, ligt het voor de hand dat het bestuur zich van de richtlijn rekenschap geeft. ${ }^{288}$ De rol van het motiveringsbeginsel is wellicht nog groter en sterkt ook het vergelijk met het deskundigenadvies. Hoewel als hoofdregel geldt dat het bestuur een eigen verantwoordelijkheid heeft en dientengevolge niet kan volstaan met verwijzing naar een richtlijn, ${ }^{289}$ blijkt uit de jurisprudentie dat indien het bevoegd gezag aanhaakt bij een richtlijn, een summiere motivering volstaat. ${ }^{290}$

286. Bröring, H.E., Juridisch onbestemde regels in het bestuursrecht: richtlijnen., NTB, a.w.

287. Ibidem, p. 84 .

288. Bröring verwijst in dit verband naar ARRvS 2 februari 1982. AB'83. 240.

289. Bröring, a.w., p. 83-84 en de aldaar aangehaalde uitspraken.

290. Vgl. ARRvS 26 februari 1982. AB 364. Er moet natuurlijk toch op de omstandigheden van het individuele geval worden ingegaan. Als er omstandigheden zijn die mogelijk tot afwijken van de richtlijn nopen of door belanghebbenden kritiek op de (inhoud van de) richtlijn is gegeven. zal de motivering natuurlijk al weer uitgebreider moeten zijn. 


\subsubsection{Motieven}

Het is allereerst interessant na te gaan welke de motieven tot het geven van richtlijnen kunnen zijn. In de Utrechtse studie "Bestuursrechtspraak in milieugeschillen"291 worden drie motieven onderscheiden. ${ }^{292}$ Allereerst wordt het deskundigheidsmotief genoemd. Hierbij staat voorop dat de bevoegde bestuursorganen veelal niet in voldoende mate beschikken over de (in het milieurecht) voor het nemen van besluiten onmisbare technisch-wetenschappelijke kennis. Door het geven van een richtlijn kan voorzien worden in een op specifieke bevoegdheden gerichte "technisch-wetenschappelijke voorlichting". Naast dit motief onderscheiden de auteurs ook nog het standaardiserings- en het beleidsmotief. Het standaardiseringsmotief behelst het streven om een grotere voorspelbaarheid in vergunningverlening (in het bijzonder in soorten van voorschriften) te bewerkstelligen, terwijl tevens een verkorting van de besluitvormingsduur worden bereikt. Het beleidsmotief staat volgens de Utrechtse studie in het teken van het voorkómen van een, door decentrale spreiding van bestuursbevoegdheden mogelijk gemaakte, onnodige verscheidenheid van normen. Voorzover het om richtlijnen van de rijksoverheid gaat kan ook het streven voorop staan om minimumnormen te geven, die door decentrale bestuursorganen tenminste zouden moeten worden aangehouden. ${ }^{293 / 294}$ Vaak is sprake van een zekere verwevenheid van de genoemde motieven. Zulks blijkt ook uit de voorbeelden die in het Utrechtse rapport worden genoemd, zoals de richtlijn Ammoniak en Veehouderij en het Handboek Milieuvergunningen. Overigens moeten we bedenken dat zelfs als slechts het deskundigheidsmotief in het geding wordt gebracht aan de richtlijn toch keuzes inzake premisses en dergelijke ten grondslag zullen liggen. ${ }^{295}$ Het normatieve element is natuurlijk a fortiori in het geding als het standaardiserings- of beleidsmotief voorop staat.

\subsubsection{Richtlijngevers}

In het licht van de motieven tot het geven van richtlijnen is ook de richtlijngever (als bron) interessant. Het Utrechtse rapport biedt een aantal voorbeelden, die goed aangeven hoe breed de samenwerking op dit punt kan zijn. Zo

291. Widdershoven et al., a.w.

292. Ibidem, p. 118-121.

293. Zo wordt de Richtlijn Ammoniak en Veehouderij als een minimumnorm beschouwd. Vgl. AGRvS 19 april 1990 AB 464 m.nt. FM en AGRvS 23 mei 1991 . AB 679 m.nt. FM, alsmede Michiels, F.C.M.A., De Wet milieubeheer, Zwolle 1992, p. 87-90, i.h.b. p. 89.

294. De studie richt zich hier sterk op de rijksoverheid als richtlijngever. Natuurlijk is ook denkbaar dat bepaalde belangenorganisaties (alleen of samen met de overheid) richtlijnen geven, waarbij het oogmerk niet (slechts) het tegengaan van "onnodige verscheidenheid" is, maar (mogelijk ook) het ontzien van bepaalde belangen.

295. Zie \$ 4.5.2.2. 
is de brochure Veehouderij en Hinderwet (de versies 1971 en 1976) vrucht van samenwerking tussen de (toenmalige) ministeries van Volksgezondheid en Milieuhygiëne, Landbouw en Visserij, de Vereniging van Nederlandse Gemeenten en het Landbouwschap. De richtlijn Ammoniak en Veehouderij is afkomstig van het ministerie van VROM en het ministerie van Landbouw en Visserij, terwijl het (achtergronds)onderzoek werd verricht door het centrum voor Milieukunde van de RUL. Het Handboek Milieuvergunningen is afkomstig van de Hinderwet en bouwtoezichtvereniging, het Directoraat Generaal Milieubeheer (VROM) de Vereniging van Nederlandse Gemeenten, het Inter Provinciaal Overleg-Milieuzaken, terwijl voorts aan het handboek wordt meegewerkt door diverse advies- en ingenieursbureaus en ambtenaren (van lokale overheden en van de milieu-inspectie). ${ }^{296}$ Aan werkgroep VI van de Coördinatiecommissie uitvoering Wvo (CUWVO), verantwoordelijk voor het uitbrengen van richtlijn inzake voor de Wvo relevante soorten van emissies, wordt niet slechts deelgenomen door vertegenwoordigers van rijks-, lokaleen functionele overheden (departementen, gemeenten, waterschappen) en door een onderzoeksbureau (het Instituut voor afvalstoffenonderzoek), maar ook door branche-organisaties, zoals de Vereniging van Nederlandse Ondernemingen, de Vereniging Nederlandse Chemische Industrie en de Federatie voor Metaal- en Electrotechnische Industrie. ${ }^{207}$ Uit het oogpunt van technisch-wetenschappelijke expertise bestaat waarschijnlijk goede grond voor de betrokkenheid van dergelijke branche-organisaties. Niettemin moet worden opgemerkt dat uit het oogpunt van onpartijdigheid en objectiviteit een kritische toets van de gegeven richtlijnen (naar inhoud of wijze van totstandkoming) op z'n plaats lijkt.

\subsubsection{Juridisch gezag}

Onder de vigeur van het oude Kroonberoep werd het juridisch gezag van richtlijnen, voorzover afkomstig van de rijksoverheid, verzekerd doordat in het administratief beroep uiteindelijk toch de visie van de Kroon, oftewel diezelfde rijksoverheid, de doorslag gaf. ${ }^{298}$ Zo was de mogelijkheid van centraliserend beleid met behulp van richtlijnen volop aanwezig. ${ }^{209}$ Met het intreden van het regime van de Tijdelijke Wet Kroongeschillen (TWK) ${ }^{300}$ bestond de verwachting dat de beoordelings- en beleidsvrijheid van (decen-

296. Widdershoven et al., a.w., p. 117, 118, 122.

297. Ibidem, p. 47 en p. 117.

298. De richtlijnen waren in feite beleidsregels voor de Kroon als hoogste bestuurlijke geschillenbeslechter.

299. Zeker gelet op het beroepsrecht van de inspectie milieuhygiëne (als "rijksheer in de regio"). Vgl. Bröring, H.E. C. Lambers. M. Scheltema en H. Bolt. Kroonberoepen milieuhygiëne, Deventer 1985.

300. Wet van 18 juni 1987 , Stb. 317. 
trale) bestuursorganen door het wegvallen van dit centralistische, pseudorechtsprakelijke toezicht, sterker tot uitdrukking zou kunnen komen.

Hierboven (in \$ 6.5.1) gaf ik al aan dat Bröring de richtlijnen beschouwt als doordachte argumenten waarvan het bevoegd gezag zich op grond van het zorgvuldigheids- en motiveringsbeginsel terdege rekenschap moet geven.

In de Utrechtse studie wordt voorop gesteld dat aan een richtlijn juridisch gezag kan toekomen door zelfbinding. ${ }^{301}$ Daarnaast wordt er op gewezen dat de bestuurlijke vrijheid zijn begrenzing vindt in de redelijkheid: "het bestuur moet binnen een min of meer geobjectiveerde invulling van wat een toelaatbare mate van milieubelasting is, blijven". ${ }^{302}$ In die benadering is de inhoudelijke overtuigingskracht van een richtlijn in belangrijke mate bepalend voor het juridische gewicht ervan. Twee "dimensies" van richtlijnen spelen daarbij in het bijzonder een rol. De eerste dimensie is die van de wetenschappelijke legitimatie van richtlijnen die zijn gebaseerd op een technischwetenschappelijke onderbouwing, waaromtrent bij (milieu)deskundigen overeenstemming bestaat. Juist dat laatste geeft aan de door wetenschappelijk onderzoek onderbouwde gegevens een zekere objectiviteit, zij het dat daarbij wel sprake zal zijn van bepaalde marges van toelaatbare milieuhinder. ${ }^{303}$ Van een richtlijn die op technisch-wetenschappelijke gronden een "volledige, als enig juiste oplossing te kwalificeren, norm" geeft zal slechts zelden sprake zijn. ${ }^{304}$ Naast de wetenschappelijke legitimatie is voor het gezag van een richtlijn ook van belang dat deze in de bestuurspraktijk zijn kwaliteit heeft bewezen. Daarmee komen we uit bij de tweede dimensie; de maatschappelijke acceptatie van een richtlijn als grond voor het gezag ervan. Indien een richtlijn in de praktijk zijn kwaliteit bewijst, groeit ook de overtuiging in de juistheid van de richtlijn, niet alleen in de juistheid van de wetenschappelijke onderbouwing maar ook van de op basis daarvan (in de richtlijn) gemaakte keuzes. Naar de mening van de auteurs kan voor veel van de ten tijde van het Kroonberoep gehanteerde richtlijnen worden gesteld dat zij maatschappelijk geaccepteerd zijn. ${ }^{305}$

Het juridisch gezag van richtlijnen verlangt niet alleen een analyse van de inhoudelijke overtuigingskracht, maar ook van de bestuurlijke vrijheid. In het Utrechtse onderzoek wordt de stelling gehuldigd dat bestuursorganen bij veel van de milieurechtelijke bevoegdheden niet slechts over beleidsvrijheid doch

301. De richtlijn wordt beleidsregel. A.w., p. 123.

302. Ibidem.

303. Mbidem, p. 106 en p. 123-124.

304. Midem, p. 124 (en p. 106-107).

305. Ibidem, p. 124 en p. 302 
ook over beoordelingsvrijheid beschikken. De vage termen in verschillende milieuwetten zouden - mede bezien in hun context - niet slechts duiden op een zekere beoordelingsruimte maar ook op een zekere vrijheid van beoordeling. ${ }^{306} \mathrm{Bij}$ lezing van de terzake relevante passages uit het rapport werd ik niet aanstonds overtuigd. De verwijzingen naar Duk, Van Wijk/Konijnenbelt, Bomhof, Van der Tak, Janswoude en Tonnaer kwamen mij daarbij niet erg steekhoudend voor, omdat deze schrijvers ofwel geen duidelijk onderscheid maken tussen beleidsvrijheid en beoordelingsvrijheid, ofwel spreken over wetsaanduidingen die in milieuwetten niet als zodanig zijn opgenomen. ${ }^{307}$

In het algemeen kan gesteld worden dat het onderscheid tussen beoordelingsruimte en beoordelingsvrijheid niet (altijd) scherp is te maken. Vooral als wettelijke criteria in termen van een algemeen belang zijn omschreven (zoals "de bescherming van het belang van het milieu") kan de indruk ontstaan dat beoordelingsvrijheid in het spel is. ${ }^{308}$ Toch zou ik hiertoe niet snel willen concluderen. Mijns inziens getuigt een aanduiding als "het belang van de bescherming van het milieu" veeleer van een beschrijvingsmoeilijkheid. Anders gezegd: het toepassingscriterium voor de desbetreffende bevoegdheid, c.q. het terrein van de specifieke overheidszorg in kwestie, wordt ruim gesteld. Het gaat derhalve niet om een criterium dat (op zichzelf) de bevoegdheid geeft om de hoegrootheid of gewichtigheid van dat belang af te wegen tegen andere belangen - dat laatste is een zaak van beleidsvrijheid, die we weer op zich moeten bezien. Ik ben dan ook geneigd in het milieurecht ten aanzien van de toepassingscondities van bevoegdheden "slechts" een (ruime) beoordelingsruimte aan te nemen. Formeel zie ik voor de rechter geen belemmering om in deze een beslissend, kritisch oordeel aan te leggen.

Volgens Konijnenbelt ${ }^{309}$ zal de rechter zich in technisch ingewikkelde geschillen ook bij beoordelingsruimte beperken tot de vraag of de door het bestuur gegeven beoordeling redelijk verantwoord is te achten. Dit is mijns inziens vooral een gevolg van rechterlijke onzekerheid, niet van een juridische gehoudenheid. Het is echter voorstelbaar dat een rechter juist in inhoudelijke overtuigende richtlijnen een aanknopingspunt ziet om zijn onzekerheid te overwinnen en bijgevolg scherper te toetsen. ${ }^{310}$

306. Ibidem, p. 88-92.

307. Zie voor de verwijzingen. ibidem, p. 90-91.

308. Een dergelijke verwijzing naar het begrip "belang", duidt immers op een oordeel met een politiek karakter (een waardering), waarover een rechter slechts met terughoudendheid mag oordelen. Vergelijk ook Duk. RMTh 1988, a.w., p. 161-162.

309. Van Wijk/Konijnenbelt, a.w., p. 244.

310. Blijft de vraag of hij zomaar op een (ogenschijnlijk) overtuigende richtlijn kan bouwen of dat hij zich dan toch eerst moet laten adviseren; hierover meer in het volgende deel van deze studie. 
De AGRvS lijkt bij geschillen inzake de verlening van milieuvergunningen in elk geval niet uit te gaan van bestuurlijke beoordelingsvrijheid. Voorop staat dat de beslissing in het belang van de bescherming van het milieu moet zijn, ${ }^{311}$ en wel in dier voege dat sprake moet zijn van "juist" of aanvaardbaar" beleid aan de zijde van het bestuursorgaan. ${ }^{312}$ Het Utrechtse rapport typeert deze beoordeling als een "inhoudelijk-indringende toetsing". Opmerkelijk is dat de AGRvS waar het gaat om een waardering van de noodzaak tot het geven van vergunningvoorschriften, na aanvankelijk veelvuldig schending van het motiveringsbeginsel toe te passen, vanaf om en nabij april 1989 steeds vaker beslist tot strijd met een algemeen verbindend voorschrift (art. 2 lid 1 onder a TWK). ${ }^{313}$ Zeer kenmerkend is in dit verband overigens een tweetal citaten van staatsraad M.D. van Wolferen, die terecht in de Utrechtse studie zijn opgenomen: "De Afdeling ziet de kernbepalingen van de milieuwetten - ik noem als voorbeeld de artikelen 13 en 17 van de Hinderwet - niet als vage, open normen die veel ruimte laten voor vrije beleidskeuzes. Uit de aard van het milieuhygiënerecht vloeit voort dat deze bepalingen de opdracht bevatten om een uit technisch-wetenschappelijk oogpunt solide beschikking te geven. In deze opvatting wordt in feite een zo doelmatig mogelijke beslissing van het betrokken overheidsorgaan vereist" (mijn cursivering). En voorts: "Met behulp van de adviezen van de Adviseur Beroepen Milieuhygiëne onderzoekt de Afdeling of een beschikking aan de wettelijke kwaliteitseisen voldoet. Richtlijnen, circulaires en dergelijke documenten van de Rijksoverheid kunnen daarbij in het algemeen als maatstaf dienen, mits de Afdeling ervan overtuigd is dat de daarin vervatte normen technisch-wetenschappelijk voldoende onderbouwd zijn". ${ }^{3 / 4}$ De Afdeling lijkt aan het discretionaire karakter van de wettelijk toegekende bevoegdheden van bestuursorganen op het gebied van het milieu weinig of geen betekenis toe te kennen. In die conceptie is het grote gewicht dat de Afdeling aan richtlijnen toekent goed te plaatsen.

\subsubsection{Afwijken van een richtlijn}

De aldus geschetste optiek doet zich vooral gelden als een bestuursorgaan afwijkt van een richtlijn. Veelal wordt afwijken niet toegelaten. In de Utrechtse studie zijn verschillende voorbeelden uit de jurisprudentie opgenomen die haast de suggestie wekken dat indien niet letterlijk en exact overeenkomstig de (desbetreffende) richtlijn wordt beschikt, onmiddellijk vernieti-

311. Widdershoven et al., a.w., p. 139.

312. Dbidem, p. 129.

313. Ibidem, p. 94-101.

314. A.w., p. 100 en p. 127. Wolferen, M.D. van. Ervaringen van de Afdeling geschillen van bestuur als milieurechter, in: Damen. L.J.A en R. Uylenburg (red.), Rechtsbescherming in het milieurecht, Zwolle 1990, p. 12. Staatsraad Van Wolferen is tevens voorzitter van Kamer V. milieukamer van de RvS. 
ging van het besluit volgt. ${ }^{315} \mathrm{De}$ verwijzing naar het motiveringsbeginsel als grondslag voor vernietiging lijkt overigens de mogelijkheid in te sluiten dat mits zeer goed gemotiveerd, afwijken van een richtlijn toch mogelijk is: "In de motivering die ten grondslag ligt aan de afwijking zal moeten worden aangegeven waarom de wetenschappelijk onderbouwde, doordachte en gemotiveerde of de algemeen aanvaarde keuzes (van de richtlijn, MAH) niet zijn overgenomen". ${ }^{316}$ Duidelijk is dat het grote moeite kost de Afdeling te overtuigen van de alternatieve zienswijze. Onderbouwing van een dergelijke motivering met deskundigen-advies lijkt noodzakelijk - waarmee de vergelijking met afwijken van een gericht deskundigen-advies zich opdringt.

In het Utrechtse onderzoek komt naar voren dat er twee omstandigheden zijn waarin afwijken mogelijk is. ${ }^{317}$

Allereerst moet worden afgeweken als sprake is van een nieuwe richtlijn die zich nog niet kan verheugen in een op de bestuurspraktijk gebaseerde maatschappelijke acceptatie. De kwaliteit van de richtlijn zal, zowel wat wetenschappelijke onderbouwing als wat de in de richtlijn gemaakte keuzes betreft, nog in de bestuurspraktijk moeten worden bewezen. Daardoor ontbeert de richtlijn thans nog de overtuigingskracht die vereist is om er zonder meer op af te kunnen gaan. Aanvulling, bij voorbeeld met een deskundigen-advies, zou hierin verandering kunnen brengen. Ook is het mogelijk dat er nieuwe inzichten zijn waardoor een (bestaande) richtlijn geheel of gedeeltelijk op lossen schroeven komt te staan, of van zodanige bijzondere omstandigheden van het concrete geval dat de meest toepasselijke richtlijn (wegens afwijkende fundamentele premisses) niet adequaat is.

Meer in het algemeen brengt de eis van zorgvuldig bestuur - volgens de $\mathrm{AGRvS}^{318}$ - mee dat het bestuur "dient na te gaan of er zich geen omstandigheden voordoen, die afwijking van het in algemene zin geformuleerde beleid rechtvaardigen of daartoe noodzaken." In een andere zaak overwoog de $\mathrm{AGRvS}^{319}$ dat, gegeven de afstand tussen de inrichting en een voor verzuring gevoelig gebied, volgens de richtlijn Ammoniak en Veehouderij weliswaar geen noodzaak tot beperkingen bij vergunningverlening bestond, doch dat dit niet wegnam dat het bestuur, gelet op de toenemende ammoniakproblematiek, in het geval in kwestie zonder meer mocht oordelen dat een ver-

315. Widdershoven et al.. a.w.. p. 304 en p. 130-132 (met jurisprudentie aldaar).

316. Ibidem. p. 132.

317. Gelet op de restrictieve interpretatie van de AGRvS is het hier misschien beter te spreken van een plicht tot afwijken!

318. AGRvS 9 maart 1989. M\&R'90, 11 - het betrof hier de toepassing van ministeriële richtlijnen voor kolengestookte installaties.

319. AGRvS 19 april 1990, AB 464 m.nt. F.C.M.A.Michiels. 
gunning kon worden verleend - waarna vernietiging wegens strijd met het motiveringsbeginsel volgde. ${ }^{320}$

Hoewel er aldus - naar het oordeel van de AGRvS - toch enige ruimte tot afwijken van richtlijnen blijkt te bestaan, is deze ruimte wel zeer beperkt. ${ }^{321}$ De Utrechtse onderzoekers zijn van mening dat de AGRvS de discretionaire bevoegdheid van de diverse bestuursorganen op milieugebied tekort doet. ${ }^{322}$ Zou men meer ruimte laten aan het bestuur maar toch willen voorkomen dat decentraal bestuur vervolgens tot een te grote diversiteit aan normen en voorschriften leidt dan kan, volgens de Utrechtse onderzoekers, worden gepleit voor een wettelijke basis voor richtlijnen, waardoor een juridisch dwingende verhouding tot met de vergunningverlening tot stand wordt gebracht. ${ }^{323}$ In dat verband pleiten zij overigens voor een meer genuanceerde analyse van richtlijnen. Alleen de gevestigde richtlijnen, waarvan met redelijk grote zekerheid gezegd kan worden dat de kwaliteit ervan (na jaren van ervaring in de bestuurspraktijk) genoegzaam vaststaat, lenen zich naar hun opvatting voor een harde koppeling - zoals bij opneming in een instructie-AMvB. ${ }^{324}$ Voor de richtlijnen die nog aan verandering onderhevig zijn staan zij een minder strakke koppeling voor. ${ }^{325}$ Ten slotte merken de onderzoekers op dat zij voor "wetenschappelijke onderzoeksrapporten" een wettelijke basis niet noodzakelijk achten. De overtuigingskracht van de daarin opgenomen informatie zal zelf beslissend moeten zijn voor het gezag dat daaraan wordt toegekend. ${ }^{326}$

\subsubsection{Beoordeling}

Ik deel de kritiek van de Utrechtse onderzoekers op de opvatting van de Afdeling over discretionaire bestuursbevoegdheden in het milieurecht, althans voorzover het om beleidsvrijheid gaat. Wat de beoordeling van toepassingscondities ("vage termen") betreft, zie ik wel goede gronden voor een indringende rechterlijke toets. Ik kan mij mitsdien vinden in Van Wolferens eis van een "technisch-wetenschappelijk (..) solide beschikking" met als doel een zo "doelmatig mogelijke beslissing" te nemen, voorzover hierbij impliciet wordt uitgegaan van (uiteindelijk door de rechter te bepalen) beoordelingsruimte en

320. Vergelijk voor deze en vergelijkbare uitspraken. Widdershoven et al., a.w.. p.130-138.

321. In het Utrechtse onderzoek wordt overigens opgemerkt (a.w., p. 304) dat in de jurisprudentie van de Afdeling vanaf 1989, sprake lijkt te zijn van een ruimhartiger oordeel t.a.v. het afwijken van richtlijnen.

322. A.w., p. 322.

323. Ibidem. Een verhouding in termen van een eis tot in achtneming, of het rekening houden met.

324. Ibidem, p. 323.

325. Ibidem.

326. Ibidem. 
(door de rechter te ontziene) beleidsvrijheid. ${ }^{327}$ Wat die beleidsvrijheid betreft moeten we overigens nog voorzichtig zijn. De bevoegdheid om aan een Wm-vergunning voorschriften te verbinden is niet vrij. ${ }^{328}$ Alleen in combinatie met de mogelijkheid om de vergunning onder beperking te verlenen ontstaat er een zekere beleidsvrijheid. ${ }^{329}$

In het verlengde hiervan is de door de Afdeling gevolgde koers, waarbij richtlijnen eenvoudig als handvaten voor de interpretatie van vage termen worden beschouwd, goed te billijken. Dit sluit aan bij hetgeen ik in hoofdstuk 4 opmerkte over het nemen van een bevredigende beslissing. In veel gevallen zal selectie, onderzoek en toetsing van alternatieven sjabloonmatig verlopen. Daarvoor is echter allereerst van belang dat de richtlijn betrekking heeft op precies het soort besluit als in het concrete geval van het bestuur wordt gevraagd. Daarnaast zal de rechter moeten vaststellen of hij de toegepaste (of volgens appellant ten onrechte niet toegepaste) richtlijn (in casu) overtuigend en gezaghebbend acht.

Het oordeel over de overtuigingskracht of het juridisch gezag van een richtlijn vergt (in het licht van het voorgaande) een zorgvuldige analyse. Per richtlijn zullen rechter èn (daaraan voorafgaand het) bestuur de wetenschappelijke onderbouwing, de interpretatie van vage termen en de beleidskeuzes elk afzonderlijk in beschouwing moeten nemen.

Wat de beleidskeuzes betreft moet worden nagegaan of en zo ja, op welke wijze de richtlijn getuigt van een beleidskeuze of belangenafweging. Bij de beoordeling van de uitoefening van een beleidsvrije bevoegdheid kan de rechter deze keuzes, voorzover deze hem overtuigend voorkomen, als ijkpunt gebruiken. Hij dient daarbij echter wel te bedenken dat zijn toets in de kern "slechts" een willekeurtoets is. ${ }^{330}$

Voorts zal de rechter per richtlijn moeten nagaan of hij de daarin gemaakte beleidskeuzes goed kan scheiden van de technisch-wetenschappelijke inhoud van de richtlijn. Dit is van belang voor het de wetenschappelijke overtuigingskracht van de richtlijn - waarbij meer in het bijzonder de "objectiviteit" of onpartijdigheid van (het technische aspect van) de richtlijn in het geding is.

327. Ik ga er vanuit dat "zo doelmatig mogelijk" ruimte laat voor een door de rechter te respecteren belangenafweging.

328. Gelet op art. 8.11, derde lid $\mathrm{Wm}$ worden aan een vergunning voorschriften verbonden die nodig zijn ter "bescherming van het milieu". Deze vage term kan ik toch niet aanstonds als beleidsvrijheid duiden, al kan ik instemmen met de gedachte dat het vaak ook een kwestie van gradatie is.

329. Vgl. art. 8.11, tweede lid Wm.

330. In overeenkomstige zin Michiels, a.w. (1992), p. 90. 
Wat de technisch-wetenschappelijke kant van richtlijnen betreft is in de jurisprudentie stellig ondersteuning te vinden voor de stelling dat richtlijnen, als het om de wetenschappelijke onderbouwing gaat, kunnen worden beschouwd als een vorm van deskundigen-advies. Bij eerste beschouwing lijken richtlijnen een streepje voor te hebben op de gerichte deskundigen-advisering. Bij eerste analyse van de jurisprudentie van de AGRvS ontstaat immers alras de indruk dat een bestuursorgaan zich bij het nemen van een besluit aanstonds op een richtlijn kan baseren en qua motivering met een verwijzing daarnaar kan volstaan. Een zelfstandige toetsing door het bestuursorgaan van de wetenschappelijke onderbouwing van de richtlijn lijkt niet vereist te zijn.

Bij nadere analyse blijkt het juridisch gewicht van richtlijnen toch minder groot. In de jurisprudentie is namelijk toch ook een aantal eisen te vinden die in feite neerkomen op een zelfstandige toetsing door het bestuur van de richtlijn.

In de eerste plaats denk ik daarbij aan de eis dat de richtlijn een bestendig gebleken kwaliteit moet bezitten vooraleer een bestuursorgaan zich daarop summierlijk kan beroepen. In termen van de Utrechtse onderzoekers moet sprake zijn van een "gevestigde richtlijn": een richtlijn die steunt op een "objectieve" basis. De AGRvS heeft in haar jurisprudentie duidelijk gemaakt dat (relatief) nieuwe richtlijnen zeker niet een zodanig gezag hebben dat met een (enkele) verwijzing naar die richtlijn kan worden volstaan. De richtlijn zal zich in de praktijk bewezen moeten hebben, door bestand te zijn tegen tegenspraak, door ondersteunende rapporten van deskundigen of door bij evaluatie gebleken houdbaarheid. Is daarvan geen sprake dan zal bij twijfel over de adequaatheid van de richtlijn ${ }^{331}$ het bestuur een aanvullende onderbouwing moeten geven - en mitsdien al snel een aanvullend deskundig onderzoek moeten laten verrichten.

Zelfs als een richtlijn een gevestigd karakter heeft zal moeten worden nagegaan of er geen aanwijzingen bestaan voor nieuwe inzichten die de wetenschappelijke onderbouwing van de (gevestigde) richtlijn (geheel of gedeeltelijk) op losse schroeven zetten. De eerder aangehaalde jurisprudentie ${ }^{332}$ maakt genoegzaam duidelijk dat het bestuur moet nagaan of er geen omstandigheden zijn die tot afwijking van de richtlijn nopen.

331. Zoals in AGRvS 3 oktober 1988 (G05.86.0817.248.88), aangehaald in Widdershoven et al., a.w.. p. 133, waar ook "tegengestelde" uitspraken van deskundigen in het geding waren. Elke deskundig onderbouwde kritiek (bijv. op instigatie van een belanghebbende) is genoeg reden om te twijfelen.

332. Met name AGRvS 9 maart 1989, M\&R'90, 11. 
In deze lijn past het tevens dat het bestuur zal moeten nagaan of in het bijzondere geval redenen bestaan tot afwijking van de richtlijn - hetgeen wel iets anders is dan toetsing van de richtlijn zelf. Volgens het zorgvuldigheidsbeginsel zal het onderzoek naar de feitelijke grondslag voor besluitvorming zich in elk geval moeten uitstrekken tot de feiten en omstandigheden van het individuele geval. ${ }^{33}$ Veel richtlijnen hebben een opbouw die reeds zo flexibel is dat maatwerk redelijk goed kan worden gerealiseerd - waarbij komt dat veel richtlijnen zelf ook wijzen op "afwegingsmarges". Het blijft echter denkbaar dat in een bijzonder geval variabelen in het spel zijn die niet in de richtlijn konden worden meegenomen, of althans daarin anders zijn gewogen dan in het bijzondere geval met het oog op het belang van de bescherming van het milieu wenselijk is.

Langs de weg van deze stappen, die van het bestuur stellig een zorgvuldig handelen verlangen, komt toch een kritische toets van de richtlijn tot stand. Hoewel de eerste stap bij een eenmaal gevestigde richtlijn steeds gemakkelijker zal zijn, bestaat er nimmer zekerheid over de tweede en derde stap; gevestigdheid is derhalve geen afdoende waarborg voor kwaliteit.

Bij het oordeel over de gevestigdheid van een richtlijn alsook bij het oordeel over het gezag van een nieuwe richtlijn (die getuigt van nieuwe inzichten) blijft het naar mijn oordeel van belang dat het bestuur toetst of de richtlijngever vakbekwaam, onpartijdig en objectief is. Bij gerichte advisering is reeds de schijn van partijdigheid een "vernietigend" gebrek. Mij dunkt dat rechter èn bestuur dit aspect ook bij richtlijnen zwaar moeten wegen. ${ }^{334}$

Ook terzake van richtlijnen zijn "technisch-wetenschappelijke confrontaties" goed voorstelbaar - en dienen deze tot op zekere hoogte ook mogelijk te worden gemaakt. Zo kunnen er confrontaties optreden tussen richtlijnen en individuele deskundigen die in een gericht advies de richtlijn kritiseren. Evenzeer is denkbaar dat zich een confrontatie tussen meerdere onderling conflicterende richtlijnen voordoet.

Bij gerichte advisering kwam reeds naar voren dat soms een keuze tussen conflicterende deskundigen-visies moet worden gemaakt. Het primaire ijkpunt is dan de "geschiktheid" van de adviseur of richtlijngever. Schijn van partijdigheid is hierbij een belangrijke factor: in de keuze tussen onderling conflicterende richtlijnen, respectievelijk afkomstig van de (belanghebbende) industrie en van de overheid, zal de keuze doorgaans eenvoudig zijn. Daarnaast

333. Nicolaï, prft., a.w., p. 336.

334. Ook bij gevestigde richtlijnen. In een later stadium kunnen aan de zijde van de richtlijngever immers altijd belangenverstrengelingen aan het daglicht treden die de onpartijdigheid van de wetenschappelijke analyses in de richtlijn in twijfel trekken. De vraag rijst dan of in de richtlijn een zodanig duidelijk onderscheid tussen facts en values is gemaakt, dat de wetenschappelijke onderbouwing onpartijdig is gebleven. 
zal gespecialiseerdheid een belangrijke rol gaan spelen. ${ }^{335}$ Het is goed voorstelbaar dat het bestuur (en ook de rechter) bij de hier bedoelde confrontaties (uiteindelijk) sterk zal leunen op het oordeel van een vaste (onafhankelijke) adviseur - die als het ware oordeelt over het wetenschappelijk gezag van de gerichte en ongerichte adviezen. Hier zij herhaald dat dit zware eisen stelt aan de positie van die vaste adviseur.

Bij dit alles geldt dat het bestuur uitdrukkelijk de mogelijkheid tot contraexpertise moet openen. Dat wil bij voorbeeld zeggen dat bij de inzage-regeling van art. 3:21 Awb onder "rapporten en adviezen" ook richtlijnen moeten worden verstaan, opdat daarvan kennis kan worden genomen.

Mij dunkt dat de vergelijking tussen richtlijnen en (gerichte) deskundigenadvisering zeer wel kan worden gemaakt. Concreet betekent dit dat het bestuur ook bij richtlijnen, zonder super-deskundige te willen zijn, richtlijnen moet toetsen. In aansluiting hierop roep ik in herinnering dat, zoals ook wordt opgemerkt in de Utrechtse studie inzake milieugeschillen, de AGRvS sinds medio 1989 toch een meer kritische koers tegenover richtlijnen is gaan varen. ${ }^{336}$

\subsubsection{Conclusie ongerichte advisering}

Deze kan kort zijn aangezien ik tot de slotsom ben gekomen dat een overeenkomstige behandeling van gerichte en ongerichte adviezen uitgangspunt dient te zijn. Ik kan daarmee dus eigenlijk terugverwijzen naar de conclusie in $\S 6.4 .5$.

Toch wil ik - op het gevaar af in herhaling te vervallen, hier drie punten nog even onderlijnen. Deze punten houden verband met het gevaar dat aan richtlijnen een "schijngezag" wordt toegekend. Richtlijnen hebben immers de charme van een zekere compleetheid en eenduidigheid; wat is er voor bestuur en rechter nu aantrekkelijker dan een advies dat getuigt van een zekere breedte in onderzoek en afweging en tegelijkertijd en zekere concreetheid in voor de praktijk bruikbare normen?! De voor het nemen van een bevredigende beslissing elementaire stappen van selectie, onderzoek en toetsing zijn in vele richtlijnen al geheel uitgewerkt en worden aldus als kant en klare mal aangereikt. In een technisch-complexe problematiek verheugt een richtlijn zich derhalve al snel in dezelfde waardering als de wet in het klassiek-romantische beeld van wetgeving als uitdrukking van de maatschappelijke rationaliteit. Men hoede zich echter voor dergelijk schijngezag!

335. Hier zou een industriēle norm wel eens sterker kunnen staan, ware het niet dat de schijn van partijdigheid deze norm reeds kan hebben uitgesloten.

336. Zie $\$ 6.5 .5$. 
Allereerst - en principieel - is inhoudelijke toetsing een vereiste. Overeenkomstig de eerste en tweede vuistregel uit Deel II van deze studie ${ }^{37}$ moet actief worden getoetst, niet als een superdeskundige maar naar de maat van redelijkheid en zorgvuldigheid. Daarbij speelt ook mee dat moet worden ingegaan op de bijzondere omstandigheden van het concrete geval.

Op voet daarvan dient - in de tweede plaats - te worden bedacht dat een technisch complexe problematiek veelal ook een technisch-dynamische problematiek is - zoals blijkt in de milieuproblematiek. Het is dan riskant om zonder meer te vertrouwen op "gevestigde richtlijnen". Bestuur en rechter dienen zich echter rekenschap te geven van mogelijke nieuwe inzichten (al dan niet in richtlijnvorm).

In de derde plaats is het van belang te waken voor belangenverstrengeling zie ook de vijfde vuistregel. ${ }^{338}$ Juist in het feit dat richtlijnen geschreven kunnen zijn op het gebruik van discretionaire bevoegdheden schuilt het gevaar dat beleidskeuzes doorwerken in de wetenschappelijke onderbouwing. Het gevaar van een onaanvaardbare verwevenheid van facts en values zal bij de beoordeling van het gezag van een richtlijn - al dan niet in vergelijking met andere (gerichte of ongerichte) adviezen - een belangrijke rol moeten spelen.

\subsection{Conclusie}

\subsubsection{Samenvatting}

Hiermee zijn we aan het einde van een omvangrijk hoofdstuk. Het begin ervan lag bij de idee van de "publiekrechtelijke legitimatie". Daarmee wordt verwezen naar beginselen en regels die de non-contentieuze procedure reguleren en aldus het bestuur aan banden leggen. Tegelijkertijd verschaft - eenmaal verworven - publiekrechtelijke legitimatie het bestuur een sterke positie. Dit blijkt onder meer uit het vermoeden van rechtmatigheid dat in een administratief geschil voorop staat. ${ }^{339}$ Daarnaast schraagt de verwachting inzake deze legitimatie de formele rechtskracht van een onbestreden gebleven bestuursbesluit.

De publiekrechtelijke legitimatie is ook een vingerwijzing voor de feitenvaststelling. Het primaat voor de feitenvaststelling ligt in de non-contentieuze procedure; daar is deze vaststelling het meest op z'n plaats. Niet alleen leent deze procedure zich goed voor een open en brede gedachtenwisseling, ook kan de bestuurlijke verantwoordelijkheid voor de besluitvorming aldus tot

337. Bestuurlijke verantwoordelijkheid en Bevredigend beslissen.

338. Omgaan met (niet-) wetenschappelijke waarden.

339. Er wordt van uit gegaan dat het bestuur overeenkomstig genoemde beginselen en regels werkt. 
gelding worden gebracht. ${ }^{340}$ De rechter toetst desgevraagd en dient zich daarbij rekenschap te geven van het bestuurlijk primaat en de specifieke waarborging van de feitenvaststelling in de non-contentieuze procedure. ${ }^{341}$

Wat volgt, in $\S 6.2-6.5$ zijn concretiseringen van de publiekrechtelijke legitimatie, met bijzondere aandacht voor de bestuurlijke feitenvaststelling.

Eerst heb ik de waarborgen op een relatief hoog abstractieniveau besproken, te weten enkele relevante rechtsbeginselen. Deze verkenning (in $\S 6.2$ ) voert langs het willekeurverbod, correcte bejegening en zorgvuldigheid (onder de noemer openheid) en de motivering. Elk beginsel heeft $z$ 'n specifieke rol in de normering van de feitenvaststelling. Deze rol is ten dele te traceren in non-contentieuze procedure-voorschriften $(\S 6.3)$ en deels ook in regels voor (gerichte en ongerichte) advisering ( $\S 6.4$ en $\S 6.5$ ).

Met de komst van de Awb ontstaat een geheel nieuw palet van procedures (voor beschikken en besluiten), de algemene standaard-procedure van titel 4.1 (alleen voor beschikkingen), de Openbare voorbereidingsprocedure van Afdeling 3.4, de Uitgebreide openbare voorbereidingsprocedure van Afdeling 3.5 en de Bezwaarschriftenprocedure van Hoofdstuk 7. Bij de bespreking van deze procedures (in $\$ 6.3$ ) voerden een aantal aspecten de boventoon.

Allereerst de openheid van de procedures, die ik in het algemeen positief beoordeel. Moeite heb ik echter wel met de beperkte strekking van de hoorplicht van art. 4:7 en art. 4:8 Awb. Deze is namelijk niet bedoeld om in het algemeen bezwaren te vernemen, doch slechts op het voorkómen van ernstige (feitelijke) gebreken. De procedure van Afdeling 3.4 en 3.5 , waar bezwaren tegen de aanvraag danwel tegen een ontwerp-beslissing kunnen worden ingebracht, c.q. over bedenkingen een "gedachtenwisseling" kan plaatsvinden, spreekt mij veel meer aan.

In het verlengde hiervan heb ik overwegende bedenkingen aangevoerd tegen de verplichte bezwaarschriftenprocedure; een gewrongen "mixture" van rechtsbescherming en verlengde besluitvorming.

Ikzelf zie meer in een strikte scheiding tussen non-contentieuze besluitvorming en contentieuze geschillenbeslechting. In de besluitvormingsfase wordt over een voornemen, respectievelijk over een ontwerp beraadslaagd - in een sfeer waarin het bestuur nog open staat voor argumentatie - over feiten en over beleid. Als het besluit is genomen staan de posities vast: dit is de fase van de door een onafhankelijke rechter te beslechten geschillen.

340. Zie ook de eerste vuistregel. in combinatie met het gestelde in $\$ 4.5 .3$.

341. Meer hierover in deel IV. 
Als derde punt heb ik bij de procedures mijn zorg uitgesproken over het gebrek aan aandacht voor de deskundigheid van de burger. Ik vind het logisch dat specifieke regels voor advisering niet in de Awb worden opgenomen maar in regelingen waar de specifieke aard van de onderwerpelijke problematiek kan worden verdisconteerd. Dat laat echter onverlet dat ik de zorg voor de deskundigheid van de burger nu juist graag in de Awb tot uitdrukking gebracht zag. Benevens enkele vage verwijzingen in de toelichting bij de Awbl is hierover echter niets te vinden. Toch verlangt dit punt aandacht, mede in verband met de problematiek van de bekostiging van deskundigen-advisering.

Mijn standpunt luidt hier als volgt: in de non-contentieuze procedure (waaronder ik de bezwaarschriftenprocedure uitdrukkelijk niet begrijp) is een speciale kostenvergoedingsregeling voor deskundigenadvisering niet op zijn plaats. $^{342}$ Onder omstandigheden kan het wel nodig zijn faciliteiten te scheppen die het mogelijk maken dat burgers een onafhankelijke deskundige kunnen consulteren. Een dergelijke voorziening zou echter in daarmee verbandhoudende bijzondere regelingen moeten worden opgenomen; zoals in de Wm. ${ }^{343}$ Vervolgens zou de voorgestelde regeling voor proceskostenveroordeling, die nu slechts op de kosten in de gerechtelijke procedure ziet, overeenkomstig moeten worden toegepast op de contentieuze voorprocedure. ${ }^{344}$ Voor alle duidelijkheid: deze regeling zou dus tevens zien op redelijke kosten van de in redelijkheid ingeroepen deskundigenbijstand.

Vervolgens heb ik (in $\$ 6.4$ ) een analyse van specifieke regels voor gerichte deskundigenadvisering gegeven. De verwerving van advies (verantwoordelijkheid, formulering van de adviesvraag), de kritiseerbaarheid van een advies (voorzorgen, inrichting van de procedure, controle) en het gezag van het advies (verantwoordelijkheid, volgen en afwijken, aansprakelijkheid) kwamen daarbij aan de orde.

In mijn conclusie stelde ik een aantal elementen voorop, die ik bij nadere bespreking ook vergeleek met de vuistregels uit deel II van deze studie.

De eigen verantwoordelijkheid van het bestuur kwam naar voren als een hoeksteen van de advisering - en meer in het algemeen van de feitenvaststelling. Het bestuur is regisseur, bepaalt de diepgang en richting van het advies,

342. En evenmin een vergoeding voor getuigen of rechtsbijstand (advocaten, rechtshulpverleners).

343. Het spreekt vanzelf dat ik hierop in het volgende hoofdstuk terug zal komen.

344. Toe te wijzen door het bestuur. maar een onathankelijke beslis- of toetsingscommissie ware hier aan te bevelen. Uiteraard moet de administratieve rechter. als de burger in de voorprocedure zijn gelijk niet kreeg. maar in de gerechtelijke procedure wel, ook de kosten in de voorprocedure meenemen in zijn uitspraak tot kostenvergoeding. In $\$ 6.3 .5 .2$ (m.n. noot 117) komt naar voren dat de regering hier een andere visie huldigt. 
draagt zorg voor een behoorlijke kwaliteit van de advisering en beslist uiteindelijk over het gezag ervan.

Binnen dat bestek beziet het bestuur in hoeverre advisering kan bijdragen aan het nemen van een "bevredigende beslissing" - diepgang en richting van het advies zijn uitkomsten van een bestuurlijk afwegingsproces. Ook is dat bestek bepalend voor de marginale beoordeling van een deskundigenadvies, naar totstandkoming en inhoud.

Van bijzonder belang is de onpartijdigheid van het advies. Deze dient zo strikt als redelijkerwijs mogelijk is te worden gewaarborgd - zelfs de schijn van partijdigheid dient te worden vermeden. Van groot belang is daarbij opnieuw - de openheid van de procedure. Belanghebbenden (of meer in het algemeen betrokkenen) moeten zich over het advies kunnen uitlaten.

Ook de kenbaarheid en inzichtelijkheid van het advies dient te zijn gewaarborgd. Algemeen wordt aangenomen dat het bestuur aan de deskundig-adviseur vrijheid moet laten om het onderzoek naar behoren te verrichten. Zulks neemt echter niet weg dat het eindresultaat naar inhoud en wijze van totstandkoming aan de eisen van een goed ('normaal") advies moet voldoen. Ook zijn kenbaarheid en inzichtelijkheid vereist met het oog op het nadere debat over de belangenafweging (en het omgaan met praktische onzekerheden).

Ten slotte is er op gewezen dat bij tegenstrijdigheid in adviezen een keuze moet worden gemaakt. Dergelijke keuzes dienen zorgvuldig te worden gemakt en goed gemotiveerd te worden. In dat verband met deze kwestie werd gewezen op de noodzaak van een goede zorg voor de onpartijdigheid van vaste deskundigen.

Last but not least werd ingegaan op de ongerichte advisering (en wel in $\S 6.5$. De conclusies uit dat deel sluiten in belangrijke mate aan bij die terzake van de gerichte advisering. Een kritisch oordeel werd gegeven over het gevaar dat aan richtlijnen automatisch een "schijngezag" wordt toegekend. In verband daarmee is het belang van inhoudelijke toetsing, van een open oog voor nieuwe inzichten en het waken voor belangenverstrengeling nogmaals onder de aandacht gebracht.

\subsubsection{Accenten}

De waaier van aspecten van het omgaan met technisch-wetenschappelijke expertise is met de bevindingen uit dit hoofdstuk duchtig uitgebreid. Een aantal elementen behoeft niet nader te worden uit gewerkt omdat zij mijns inziens "slechts" strekken tot beschrijving van niet problematische regels. Voor een aantal punten geldt dat echter niet. 
Het lijkt mij praktisch om bij het vervolg van deze studie twee lijsten als leidraad te hanteren. De ene lijst bevat punten die nog een nadere uitwerking behoeven. Op die lijst staan de volgende punten:

- de zorg voor de deskundigheid van de burger, in het bijzonder in de noncontentieuze procedure bij het nemen van technisch-complexe beslissingen;

- de positie van "vaste-deskundigen" ten behoeve van het bestuur èn de rechter, met name met het oog op diens "voorsprong" bij tegenstrijdige advisering; $;^{345}$

- de wijze waarop onzekerheid over het feitensubstraat in de besluitvorming procedureel en inhoudelijk kan worden gereduceerd.

- de verhouding tussen non-contentieuze en contentieuze procedure op het punt van de feitenvaststelling, zulks in het licht van de publiekrechtelijke legitimatie van bestuursbesluiten, c.q. het bestuurlijke primaat voor de feitenvaststelling;

- de organisatie van de rechtsbescherming, in het bijzonder de vraag naar het aantal rechterlijke instanties in samenhang met het gevolgd zijn van de Uitgebreide openbare voorbereidingsprocedure of de verplichte bezwaarschriftenprocedure;

Deze "uitwerkingspunten" zullen in het volgende hoofdstuk en in het volgende deel van deze studie nader worden besproken - primair in de context van besluitvorming of geschillenbeslechting in het milieurecht.

De tweede lijst is die van de vuistregels uit Deel II. Dit zijn aandachtspunten die geen nadere uitwerking meer behoeven, maar die niettemin belangrijk genoeg zijn om bij het vervolg steeds en marge mee te nemen. Indien nodig zullen ze het vertrekpunt vormen voor kritische kanttekeningen. Voor de goede orde schets ik ze hier nog even:

- eigen verantwoordelijkheid van het bestuur voor feitenvaststelling;

- een bevredigende oplossing als maximale aspiratie; feitenvaststelling, c.q. diepgang en richting van het feitenonderzoek staan in dat teken. Bestuur noch rechter werpen zich bij toetsing van deskundigen-adviezen op als superdeskundigen;

- de openheid van besluitvorming of geschillenbeslechting dient steeds te zijn gewaarborgd, er moet ruimte zijn voor contra expertise;

345. In verband met deze eerste twee punten kan ook de vraag aan de orde komen of er behoefte bestaat speciale onafhankelijke deskundigen in de non-contentieuze procedure; deskundigen die eigener beweging de feitenvaststelling kunnen kritiseren. 
- er dient kritisch te worden gekeken naar "gangbare inzichten of opvattingen". Openheid voor nieuwe inzichten is van groot belang. Bij richtlijnen dient te worden gewaakt voor "schijngezag";

- de onpartijdigheid, c.q. deskundigheid van adviseurs of richtlijngevers dient steeds kritisch te worden beschouwd. Belangenverstrengeling is uit den boze. 


\section{Hoofdstuk 7 \\ Expertise in het milieurecht}

\subsection{Inleiding}

In dit hoofdstuk staat het verlenen van de Wm-vergunning weer centraal. De rol van expertise wordt daarbij nader verkend tegen de achtergrond van de algemene bestuursrechtelijke uitgangspunten zoals geschetst in de twee voorafgaande hoofdstukken. Meer in het bijzonder gaat aandacht uit naar de eerste drie kwesties op de lijst van "uitwerkingspunten" uit het voorgaande hoofdstuk.

Het gaat daarbij om de volgende punten: de zorg voor de deskundigheid van de burger, de positie van vaste deskundigen en de onzekerheidsreductie. In algemene zin zijn deze punten genoegzaam ingeleid. Wat rest is een bespreking ervan in de context van technisch-wetenschappelijk complexe en dynamische problematiek van het milieu.'

Tegelijkertijd behoeft deze context op zichzelf, met name als het gaat om procedurele eigenaardigheden, nader de aandacht. Daarbij denk ik in het bijzonder aan de regeling voor de milieu-effectrapportage. Het spreekt wel vanzelf dat de milieu-effectrapportage in een studie als deze meer uitgebreid aan de orde moet komen. Een substantieel deel van dit hoofdstuk zal daaraan dan ook gewijd zijn (zie § 7.2). Aansluitend zal ik dan in gaan op de genoemde uitwerkingspunten (en wel in $\$ 7.3,7.4$ en 7.5). In $\S 7.6 \mathrm{kom}$ ik dan tot een afrondende beschouwing.

\subsection{De regeling milieu-effectrapportage}

\subsubsection{Inleiding}

De milieu-effectrapportage ${ }^{2}$ is wel getypeerd als een vorm van een rationele besluitvormingsprocedure. ${ }^{3}$ Als deze kwalificatie juist is sluit de m.e.r.-procedure goed aan op de in deel I van deze studie geschetste noden bij besluit-

1. Het spreekt wel vanzelf dat deze kwesties juist in die context werkelijk belangrijk worden.

2. Kortweg m.e.r.; zoals geregeld in $\mathrm{Hfst}$. $7 \mathrm{Wm}$ (art. 7.1-7.43). Waar nodig wordt (tevens) naar de oude artikelnummers uit de Wabm verwezen.

3. Vgl. Evaluatiecommissie Wet Algemene Bepalingen milieuhygiëne (ingesteld bij besluit van de minister van VROM van 15 augustus 1985, Stert. 163, hierna te noemen: ECW), Advies nr.3. Naar een volwaardige plaats. Advies over de werking van de regeling milieu-effectrapportage uit de Wabm. p. 13. 
vorming met een grote technische complexiteit en dynamiek - zoals de milieuproblematiek. In dergelijke situaties is het immers van belang dat doelen worden geëxpliciteerd, mogelijke alternatieven voor doelbereiking worden geïnventariseerd, voor elk alternatief de gevolgen worden onderzocht en ten slotte de alternatieven onderling worden vergeleken en worden gerangschikt naar de mate van hun aantrekkelijkheid. De m.e.r.-procedure voorziet in deze stappen, zonder daarbij overigens een rationeel-synoptisch model te impliceren. Sterker nog: de genoemde stappen sluiten goed aan bij de in Hoofdstuk 4 geschetste "bevredigende beslissing" (selectie, onderzoek en toetsing). ${ }^{4}$ Volgens de ECW is de m.e.r.-procedure zo ingericht dat "deskundigheid, beschikbaarheid van kennis en gefundeerde afweging van alternatieven een centrale rol spelen".

Het oogmerk van de m.e.r.-regeling is van oudsher drieledig. Voorop staat de doelstelling om het milieubelang een volwaardige plaats in de besluitvorming te geven. ${ }^{6}$ Dit moet primair worden bereikt door de milieu-effecten van bepaalde voorgenomen activiteiten zichtbaar te maken. Dit impliceert niet alleen dat voldoende milieu-informatie beschikbaar moet komen maar ook dat is gewaarborgd dat deze informatie bij de voor het voornemen cruciale besluitvorming wordt meegewogen.

Naast deze hoofddoelstelling staan nog twee nevendoelstellingen: bevordering van een positieve "milieu-attitude" en stroomlijning van de besluitvorming.? Het laatste is goed te begrijpen vanuit het idee dat de m.e.r.-procedure moet bijdragen tot een rationeel geordende besluitvorming. Daarbij zou m.e.r.plichtigheid van een activiteit ertoe moeten bijdragen dat initiatiefnemers zich in een zo vroeg mogelijk stadium van hun planning rekenschap geven van het milieubelang.

Het centrale instrument van de m.e.r.-regeling is het milieu-effectrapport (MER). Dit is een openbaar document waarin de redelijkerwijs in beschouwing te nemen alternatieven en de te verwachten milieugevolgen van de voorgenomen activiteit in hun onderlinge samenhang en zo objectief mogelijk dienen te worden beschreven. ${ }^{8}$

4. Vgl. in dit opzicht ook art. 7.10, eerste lid onder b Wm: "..de alternatieven..., die redelijkerwijs in beschouwing dienen te worden genomen."

5. A.w... p. 13 .

6. Ibidem, p. 9.

7. Ibidem.

8. TK'80-'81, 16814, nr. 3 (MvT), p. 11. 
De milieu-effectrapportage is in 1987 ingevoerd. ${ }^{9}$ Het lijkt niet nodig de bestaande regeling hier uitgebreid te beschrijven ${ }^{10}$. Ik zal derhalve slechts op enkele aspecten van procedure en werkingssfeer ingaan - respectievelijk in $\S 7.2 .2$ en $\$ 7.2 .3$. Ik oriënteer mij daarbij primair op aspecten die in de evaluatie van de m.e.r.-regeling door de $\mathrm{ECW}^{\prime \prime}$ centraal staan - met inbegrip van de kritiek van de zijde van de Europese Commissie. ${ }^{12}$ In \$ 7.2.3.4 ga ik dan in op het regeringsverslag over de werking van de m.e.r.-regeling. ${ }^{13}$ Aldus hoop ik de voor het omgaan met expertise belangrijkste punten van de m.e.r.-procedure te kunnen belichten.

\subsubsection{Bestaande procedure}

De mer-procedure bestaat uit een zevental stappen.

\subsubsection{De voorfase}

De eerste stap wordt gevormd door de zogenoemde Voorfase: art. 7.12, eerste lid $1 \mathrm{Wm}$. In deze fase meldt de "initiatiefnemer" bij het bevoegd gezag dat hij een m.e.r.-plichtige activiteit wil ondernemen. Deze melding dient te geschieden in de vorm van een zogenoemde "startnotitie". In het Besluit startnotitie milieu-effectrapportage ${ }^{14}$ wordt aangegeven welke gegevens tenminste bij de melding moeten worden ingebracht. Zo moet aandacht worden besteed aan doel, aard, omvang en plaats van de activiteit, de genomen en nog te nemen overheidsbesluiten, alsmede - in globale zin - aan de verwachte gevolgen voor het milieu. Over het opmaken van de startnotitie vindt doorgaans informeel overleg plaats tussen de initiatiefnemer en het bevoegd gezag, meestal aan de hand van een concept startnotitie. Daarbij kan ook de Commissie voor de milieu-effectrapportage (hierna Cmer) ${ }^{15}$ betrokken zijn. Dit overleg ${ }^{16}$ is vooral van belang voor duidelijkheid over de doelstelling van het voornemen èn, in verband daarmee, voor de alternatieven welke uiteindelijk zullen moeten worden onderzocht: hoe enger de doelstel-

9. Wet van 23 april 1986, Stb. 211 en het Besluit m.e.r. van 20 mei 1987, Stb. 278. De m.e.r.plicht trad in werking op 1 september 1987.

10. Ik verwijs hiervoor naar Brussaard et al. (red.), Milieurecht, Zwolle 1991, \$2.2.4 - Milieueffectrapportage (Gilhuis).

11. Zie noot 3 .

12. Europese Commissie, brief van 25 april 1990.

13. TK'90-'91, 22 103, nr. 1.

14. Besluit van 28 juli 1987 . Stcrt. 122 (13 augustus 1987).

15. Zie art. 2.17 e.v. Wm. Deze onathankelijke commissie bestaat uit een presidium, een groot aantal leden (plusminus 200) en een secretariaat. Bij elke procedure wordt een werkgroep bestaande uit drie à vier terzake deskundige leden samengesteld, welke adviseert over richtlijnen en het MER (zie hierna).

16. Dat met name in het ECW-advies aandacht krijgt, a.w., p. 20-24. 
ling is geformuleerd des te geringer zal de ruimte zijn voor (het bestuderen van) alternatieven. ${ }^{17}$

\subsubsection{De vooroverlegfase}

De tweede stap wordt gevormd door de vooroverlegfase: art. 7.12 , tweede lid - 7.16 Wm. Deze fase moet leiden tot de richtlijnen voor het MER. De startnotitie wordt gepubliceerd teneinde een ieder in de gelegenheid te stellen in te spreken over het geven van richtlijnen. Daarnaast worden wettelijke adviseurs en de Cmer in de gelegenheid gesteld advies uit te brengen. Openbaarheid is de sleutel van deze fase.

De richtlijnen zijn van eminent belang omdat zij aangeven welke informatie op welke wijze in het MER aan de orde moet komen. Hierbij zal het gaan om aanwijzing van de te beschrijven alternatieven, de te beschrijven milieueffecten en eventueel ook de te gebruiken methoden en technieken van voorspelling en beoordeling van milieu-effecten. ${ }^{18}$

De richtlijnen vormen een essentiële aanvulling en precisering op de wettelijke aanwijzingen omtrent de inhoud van het MER - zoals ondermeer te vinden in art. 7.10 Wm. Twee punten zijn daarbij in het bijzonder van belang.

Allereerst vindt vaststelling van de richtlijnen - na advies en inspraak - plaats door het bevoegd gezag. Dit ligt in lijn met de primaire verantwoordelijkheid van het bestuur voor de feitenvaststelling. In de tweede plaats geven de richtlijnen een belangrijke afbakening van de inhoud van het op te stellen MER. Dit impliceert een inhoudelijke aanscherping van de wettelijke eisen waaraan een MER moet voldoen maar ook een selectie waardoor een begrenzing in het onderzoek naar alternatieven en daarmee verbonden milieu-effecten wordt bereikt. ${ }^{19}$ Aldus sluiten de richtlijnen aan bij het algemene aspiratieniveau, waarover ik in Hoofdstuk 4 sprak: het uitgangspunt voor de selectie van alternatieven.

De ervaring - zoals geschetst door de ECW - wijst uit dat met name de adviezen van de Cmer een belangrijke bijdrage vormen tot keuzes inzake inhoud en structuur van het op te stellen MER. ${ }^{20}$ Wat voorts opvalt is dat in de praktijk vooral de bepaling van het doel van de activiteit tot problemen leidt. Daar blijkt de Cmer vaak een ruimere doelomschrijving voor te staan dan initiatiefnemer en bevoegd gezag. In samenhang daarmee bepleit de

17. Thidem, m.n. p. 23.

18. Art. 7.15, tweede lid Wm (voorheen art. 410, tweede lid Wabm), zie voorts ECW, a.w., p. 24.

19. Het is goed mogelijk dat bij het opstellen van het MER blijkt dat er nog andere relevante(re) alternatieven zijn of nog andere relevante(re) milieu-effecten. Het feit dat de richtlijnen daar niet naar verwijzen belet niet dat hiervan een beschrijving wordt gegeven.

20. ECW, a.w., p. 28. 
Cmer vaak dat een groter aantal alternatieven meer in detail worden beschreven. ${ }^{21}$

\subsubsection{Het opstellen van het MER}

De derde stap in de m.e.r.-procedure is het opstellen van het MER: art. 7.10 -7.11 Wm. Het MER wordt opgesteld door de initiatiefnemer, die zich daarbij dient te richten naar de terzake geldende voorschriften en de door het bevoegd gezag gegeven richtlijnen. Het MER is in zoverre de kern van de m.e.r.-procedure, dat juist het MER de milieu-informatie moet opleveren die aan het milieubelang in de besluitvorming een volwaardige plaats moet doen toekomen. Het spreekt wel vanzelf dat, hoewel het MER door of in opdracht van de initiatiefnemer (als primair belanghebbende) wordt opgesteld, de inhoud daarvan "objectief" dient te zijn. ${ }^{22}$

Art. 7.10 Wm schrijft in hoofdlijnen voor welke zaken in het MER aan bod moeten komen. Het hart van dit artikel wordt gevormd door een viertal in het eerste lid gestelde eisen:

- onder b.: het geven van een beschrijving van de voorgenomen activiteit, van de wijze waarop zij zal worden uitgevoerd en van de redelijkerwijs in beschouwing te nemen alternatieven daarvoor. ${ }^{23}$

- onder d.: een beschrijving van de bestaande toestand van het milieu, voorzover aspecten daarvan door het voornemen of de alternatieven daarvoor zouden worden beïnvloed, alsmede van de ontwikkeling in dat milieu indien de voorgenomen activiteit noch de alternatieven daarvoor zouden worden verwezenlijkt. ${ }^{24}$

- onder e.: een beschrijving van de gevolgen voor het milieu, die de voorgenomen activiteit of de alternatieven daarvoor kunnen hebben.

- onder f.: een vergelijking van de onder $d$. beschreven ontwikkeling met de onder e. beschreven gevolgen.

Het is uiteraard essentieel dat in het MER voldoende interessante alternatieven aan bod komen. De richtlijnen zullen op dit punt van geval tot geval, door aanwijzing van te beschrijven alternatieven, duidelijkheid moeten verschaffen. Daarbij kan het om verscheidene soorten alternatieven gaan, zoals doelstellingsalternatieven, lokatie-alternatieven, uitvoeringsalternatieven en het nul-alternatief. ${ }^{25}$

21. ECW, a.w., p. 29-30.

22. Op de bewaking daarvan kom ik hieronder nog terug.

23. In relatie hiermee is het doel natuurlijk relevant: zie lid 1 onder a.

24. Het nul-alternatief: de autonome milieu-ontwikkeling.

25. Zie Brussaard, a.w., p. 91 (Gilhuis), zie ook Udo de Haes en Bol, a.w., p 121-122. 
In algemene zin geldt het "redelijkerwijs in beschouwing te nemen" als criterium voor de aanwijzing van alternatieven in de richtlijnen. Bij het geschil over de elektriciteitscentrale Amer-9 te Geertruidenberg moest de Afdeling Geschillen ${ }^{26}$ (onder meer) oordelen over de vraag of het bevoegd gezag zich in redelijkheid op het standpunt had kunnen stellen dat een bepaald alternatief (in casu kolenvergassing) gelet op het redelijkheidscriterium, in het MER als te beschrijven alternatief buiten beschouwing kon blijven. De Afdeling Geschillen stelde voorop dat het criterium "redelijkerwijs in beschouwing te nemen" met het oog op de wetsgeschiedenis niet te eng moet worden gekozen, omdat "niet op voorhand voor het milieu minder ongunstige alternatieven mogen worden uitgesloten". ${ }^{27}$ Meer concreet oriënteerde de Afdeling zich vervolgens op het advies van de Cmer, op enkele belangrijke beleidsdocumenten - te weten het Electriciteitsplan 1987-1996 en het Structuurschema Electriciteitsvoorziening 1975, alsook op de bestaande twijfels omtrent de haalbaarheid van het niet beschreven alternatief, om vervolgens te oordelen dat het kolenvergassings-alternatief buiten beschouwing kon blijven. ${ }^{28}$

Hoewel het hier geschetste uitgangspunt ("niet op voorhand minder milieuschadelijke alternatieven uitsluiten") streng is, is het daarop aansluitende rechterlijke toetsingscriterium ("het zich in redelijkheid op het standpunt kunnen stellen dat een alternatief niet kan worden aangemerkt als een alternatief dat redelijkerwijs in beschouwing moet worden genomen") betrekkelijk open. Binnen de geboden beoordelingsruimte kan het bestuur besluiten welke alternatieven het voor het bereiken van een bevredigende beslissing in beschouwing wil nemen. In de praktijk doen zich op dit punt weinig problemen voor. Misschien houdt dit verband met de rol van de $\mathrm{Cmer}^{29}$

Problematischer ligt de meer concrete eis van art 7.10, derde lid Wm, inhoudende dat in elk geval een beschrijving wordt gegeven van het alternatief waarbij de best bestaande mogelijkheden ter bescherming van het milieu worden toegepast - ook wel het meest milieuvriendelijke alternatief genoemd. De invulling hiervan in het MER blijkt in de praktijk nogal eens te wensen over te laten. ${ }^{30}$

26. AGRvS 1 oktober 1990, M\&R' $^{\prime} 1 / 4$, nr. 41 m.nt. Gilhuis.

27. Vgl. ook \$ 4.3.3.2: alleen uitsluiten bij "kennelijke ongeschiktheid".

28. Naar aanleiding van deze zaak en $\mathrm{VzCBB} 4$ januari 1991, M\&R'91/4, nr. 42 m.nt. Uylenburg en Jans, rees ondermeer de vraag of het Electriciteitsplan niet m.e.r.-plichtig zou moeten zijn. Zie Jurgens, Victor, Texaco: "Hoe m.e.r.-plichtig is de electriciteitsvoorziening anno 1991?", M\&R'91/4, p. 194-199.

29. Zie ook ECW, a.w., p. 28-30. Weliswaar zijn er juist bij de keuze van te beschrijven alternatieven - als hierboven gesteld - vaker verschillen van opvatting tussen Cmer en bevoegd gezag, maar ik sluit toch beslist niet uit dat het advies van de Cmer, ook i.v.m. latere beroepsprocedures, een grote rol speelt.

30. Zie ECW, a.w., p. 34. Ik kom hierop nog terug. 
In verband met de beschrijving en vergelijking waartoe art. $7.10 \mathrm{Wm}$ verplicht is het niet onbelangrijk dat hetzelfde artikel (in het eerste lid onder g.) verplicht tot opgave van de leemten in de onder d. en e. van hetzelfde lid bedoelde beschrijvingen ten gevolge van het ontbreken van de benodigde gegevens. Blijkens de toelichting bij dit onderdeel ${ }^{31}$ wordt met "gegevens" zowel gedoeld op "lacunes in de feitelijke gegevens over de toestand van het milieu als onvolkomenheden en onzekerheden in de gebruikte berekeningsmethoden en -technieken." Dit punt raakt direct aan de problematiek van de praktische onzekerheid, c.q. de "armoede van de ecologie", waarover ik eerder reeds sprak. Het is van groot belang dat leemten op het moment van besluitvormen zoveel (als redelijkerwijs) mogelijk (is) expliciet zijn gemaakt. $^{32}$

Uit het advies van de ECW blijkt ${ }^{33}$ dat de Cmer ook bij de totstandkoming van het MER steeds vaker wordt benaderd met het verzoek om het MER informeel te bekijken - als een soort van "informele voortoets". De ECW stelt vast dat de vraag rijst of de Cmer door hieraan toe te geven ${ }^{34}$ haar onpartijdigheid in het geding brengt. Volgens de ECW is dat echter - blijkens de toetsingsadviezen - niet het geval en kan daarentegen worden vastgesteld dat de informele voortoets de voortgang in de besluitvorming kan bevorderen. ${ }^{35}$

Ten slotte nog een opmerking over de kosten. Volgens de $\mathrm{ECW}^{36}$ blijven deze beperkt tot een half tot enkele procenten van de totale investeringskosten van het desbetreffende project. Voorts merkt de ECW op dat het daarbij deels gaat om kosten die zonder m.e.r.-procedure ook gemaakt zouden zijn, bij voorbeeld in het kader van de vergunningaanvraag. Ik vraag mij af of die laatste opmerking de kwestie niet versluiert. Uiteraard gaat het hier deels om kosten die anders (bij de vergunningaanvraag) ook zouden zijn gemaakt, maar wie draagt welke kosten? Meer principieel gaat het er toch eenvoudig om dat initiatiefnemers van activiteiten die belangrijke nadelige gevolgen kunnen hebben voor het milieu, een bovennormale bewijslast dragen - een verzwaarde toepassing van art. 4:2 tweede lid Awb derhalve. De juridische onderbouwing voor de verschuiving in bewijslast van bestuur naar initiatief-

31. TK'80-'81, $16814, \mathrm{nr} 3$ (MvT), p. 71.

32. Met het oog op de vraag of "redelijke zekerheid" (vgl. \$ 4.3.3.3) kan worden bereikt en of eventueel onzekerheidsreducerende maatregelen (vgl. \$ 4.3.4) kunnen worden genomen.

33. A.w., p. 37-38.

34. $\mathrm{Zij}$ het op een specifieke manier - slechts een deel van de desbetreffende Cmer-werkgroep bekijkt het MER en spreekt zich daarover slechts onder voorbehoud uit. ECW, a.w., p. 37.

35. Ibidem. p. 38-39. Op het punt van de objectiviteit kom ik nog terug.

36. A.w.. p. 38. 
nemer ${ }^{37}$ ligt naar mijn smaak in het feit dat de ongeschreven algemene milieuzorgplicht in sterke mate wordt geactiveerd door het gegeven dat een voornemen juist belangrijke nadelige milieugevolgen zou kunnen hebben. Op voet hiervan zal de initiatiefnemer voor meer kosten komen te staan dan zonder m.e.r.-plicht het geval zou zijn; maar daarvoor bestaat juridisch gezien "goede grond". De bewijslastverdeling doet overigens niet af aan de primaire verantwoordelijkheid voor de feitenvaststelling: die ligt bij het bevoegd gezag en komt in de volgende procedurestap goed tot uitdrukking.

\subsubsection{De aanvaardbaarheid van het MER}

De vierde stap in de procedure is de beoordeling van de aanvaardbaarheid van het MER: art. 7.17-7.26 Wm. De initiatiefnemer dient het MER, zodra dit zijns inziens gereed is, in bij het bevoegd gezag. Als het gaat om een Wm-vergunningplichtige activiteit zal het MER samen met de vergunningaanvraag worden ingediend. Het is aan het bevoegd gezag te beoordelen of het MER juist en volledig is. Juistheid is een zaak van het wetenschappelijk gehalte van het MER. Volledigheid betreft de vraag of het MER aansluit bij de wettelijke eisen (art. 7.10 en $7.11 \mathrm{Wm}$ ) en de gegeven richtlijnen. De toets die hier door het bevoegd gezag wordt uitgevoerd moet naar mijn oordeel uiteindelijk worden ingepast in de eis van art. 3:2 Awb: het ter voorbereiding van een bestuursbesluit vergaren van de nodige kennis omtrent de relevante feiten en de af te wegen belangen. In dat verband is het toch ietwat pijnlijk dat de ECW in haar advies constateert dat slechts in een enkel geval kan worden gesproken van een serieuze toetsing door het bevoegd gezag. ${ }^{38}$ Eén van de oorzaken daarvoor is volgens de ECW gelegen in het gebrek aan deskundigheid nodig om de specialistische analyses uit het MER te kunnen beoordelen. ${ }^{39}$ In het verlengde hiervan wijst de ECW er overigens op dat bij het bevoegd gezag wel een zekere beduchtheid bestaat "dat het door een negatief toetsingsadvies van de Cmer zal worden "teruggefloten"..$^{40}$ In de praktijk wordt de Cmer (dan) ook vaak door het bevoegd gezag benaderd met een verzoek tot het uitvoeren van een "informele voortoets". ${ }^{41}$

37. Beide rollen kunnen zeer wel samenvallen: ook daarop kom ik nog terug.

38. A.w., p. 39.

39. A.w., p. 39. Daarnaast kunnen betrokkenheid bij het opstellen van het MER of het bestaan van grote bestuurlijke belangen bij realisatie van het m.e.r.-plichtige project het bevoegd gezag weerhouden van grondige toetsing (ibidem, p. 40).

40. Ibidem, p. 40.

41. In de MvT bij het wetsvoorstel m.e.r. (TK'80-'81, 16 814, nr. 3, p. 73) wordt ook expliciet van deze mogelijkheid gewag gemaakt. 
Indien het bevoegd gezag tot het oordeel komt dat het MER niet aanvaardbaar (want onvolledig of onjuist) is, dan doet het daarvan mededeling aan de initiatiefnemer. Vervolgens zal deze niet-ontvankelijk moeten worden verklaard. ${ }^{42}$ Het is dan aan hem om tot aanvulling te komen. Volgens de ECW is niet duidelijk wie het MER moet aanvullen indien dit door het bevoegd gezag is aanvaard doch er bij inspraak en advies (zie de volgende stap) alsnog tekortkomingen aan het licht komen. ${ }^{43} \mathrm{lk}$ zou hier wel de stelling willen verdedigen dat indien het MER door het bevoegd gezag is aanvaard, het bevoegd gezag de verantwoordelijkheid voor de feitenvaststelling overneemt. De initiatiefnemer heeft aan zijn plicht tot het verstrekken van gegevens en bescheiden voldaan. ${ }^{44}$ Vanaf dat moment is het aan het bevoegd gezag om er overigens voor zorg te dragen dat de nodige kennis wordt vergaard (overeenkomstig art. 3:2 Awb). De initiatiefnemer houdt naar mijn smaak wel een informatie-plicht, zeker op het punt van nieuwe inzichten of nieuwe feiten of omstandigheden, maar het bestuur moet de kar nu trekken. ${ }^{45}$

\subsubsection{Inspraak, advies en toetsing}

De vijfde stap in de procedure is die van inspraak, advies en toetsing: art. 7.19-7.27 Wm. Openbaarheid is van het grootste belang in deze fase van de m.e.r.-procedure.

Allereerst gaat het om openbaarheid van het MER tegenover een ieder die daarvan kennis wenst te nemen (art. 7.20 en $7.21 \mathrm{Wm}$ ) en van de door het bevoegd gezag voor het MER (vooraf) gegeven richtlijnen (art. $7.22 \mathrm{Wm}$ ). In het verlengde hiervan kan een ieder opmerkingen over het MER schriftelijk of mondeling (op een hoorzitting) inbrengen (art. 7.23 Wm). Deze opmerkingen dienen overigens nadrukkelijk te zijn toegesneden op de volledigheid en de juistheid van het MER en niet op de aanvaardbaarheid van een positief besluit over het voornemen. In de praktijk blijkt kennelijk dat veel inspraakreacties zijn gericht op de formulering van het doel van het desbetreffende voornemen. ${ }^{46}$ Naast de inspraakmogelijkheid die aan een ieder wordt geboden worden ook wettelijke adviseurs (zoals een inspectie milieuhygiëne) in de gelegenheid gesteld hun visie op het Mer te geven (art. 7.25 Wm). Blijkens

42. TK'80-'81, 16814 , nr. 3 (MvT), p. 73. Meer concreet: art. 7.28, eerste lid onder b Go art. 7.18, eerste lid Wm. dat weer spoort met art. 4:5 lid 1 Awb - zij het dat de m.e.r.-regeling zwijgt over een gelegenheid die de aanvrager (i.c. initiatiefnemer) moet worden geboden om een aanvulling te geven.

43. A.w., p. 39.

44. Vgl. voor beschikkingen in het algemeen art. 4:2 lid 2 jo ant 4:5 lid 1 Awb.

45. Eigenlijk zag ik wel iets in het oorspronkelijk voorgestelde art. $41 \times$ Wabm (een "aanvullend rapport", vgl. TK'80-81, 16 814, nrs. 2-3). Dit is bij de Deregulering op het gebied van ruimtelijke ordening en milieubeheer (DROM). a.w... conclusie 87) "geschrapt".

46. ECW-advies, a.w., p. 42. Dit hangt uiteraard nauw samen met de kwestie van de alternatieven. 
de ECW-studie is de bijdrage van de wettelijke adviseurs, in vergelijking met de toetsing door de Cmer, niet groot. ${ }^{47}$

De toetsing van het MER door de Cmer wordt zeer belangrijk gevonden. Daarbij speelt mee dat dit bij uitstek deskundige en onafhankelijke oordeel wordt neergelegd in een toetsingsrapport dat ook weer openbaar wordt gemaakt. Hoewel het toetsingsrapport pas verschijnt na inspraak en advies door wettelijke adviseurs (zodat die reacties kunnen worden meegenomen, zie art. $7.26 \mathrm{Wm}$ ), waarborgt de openbaarheid ervan, al dan niet door tussenkomst van de pers, dat dit rapport in een volgend stadium van de procedure een rol kan spelen. ${ }^{48}$

Op basis van een concept-toetsingsrapport van de Cmer wordt reeds overleg gevoerd met het bevoegd gezag. Vaak is daarbij ook de initiatiefnemer aanwezig. Op basis van dit overleg kan het bevoegd gezag besluiten tot een bijstelling van het MER. ${ }^{49}$ Hoewel deze werkwijze op zichzelf de besluitvorming ten goede komt - er komt een kwalitatief beter MER en de verstandhouding tussen betrokkenen wordt er door bevorderd - signaleert de ECW twee, mijns inziens belangrijke bezwaren ${ }^{50}$ : het negatieve oordeel van de Cmer onttrekt zich aan de openbaarheid ${ }^{51}$ en de indruk kan ontstaan dat de Cmer medeverantwoordelijk is voor de feitenvaststelling.

De onafhankelijkheid van de Cmer komt bij uitstek tot uitdrukking als in een begeleidend schrijven bij het toetsingsrapport enkele op- of aanmerkingen worden gemaakt over de door het bevoegd gezag (in afwijking van het Cmeradvies) vastgestelde richtlijnen. De ECW vraagt zich af of dit wel juist is of dat hiertoe alsnog een wettelijke basis zou moeten worden geschapen. ${ }^{52}$ Mijn uitgangspunt in deze is dat het bestuur de verantwoordelijkheid draagt voor de feitenvaststelling. De primaire manifestatie daarvan is de beslissing inzake de richting en diepgang van het feitenonderzoek - in de context van de m.e.r.-procedure: het geven van richtlijnen. Ik zie er geen bezwaar in als op welk tijdstip in de beraadslaging dan ook, door wie dan ook, kritiek wordt geuit op de vastgestelde richtlijnen. Voorzover de Cmer daartoe overgaat lijkt het mij wel wijs dat dergelijke kritiek separaat van het toetsingsrapport wordt overgebracht. In het toetsingsrapport vormen immers de wettelijke eisen en de richtlijnen het primaire ijkpunt voor de juistheid en volledigheid van het MER. ${ }^{53}$

47. A.w., p. 42.

48. ECW-advies, a.w., p. 43-44. Bij voorbeeld in een beroepsprocedure.

49. ECW-advies, a.w., p. 44.

50. Bbidem.

51. De "buitenwacht" heeft geen zicht op de discussie over mogelijke zwakke plekken in het MER.

52. A.w... p. 43.

53. Een wettelijke regeling voor kritiek-achteraf zou m.i. hooguit ter bevestiging dienen. 
Meer in het algemeen zijn de toetsingsrapporten van de Cmer kritisch van toonzetting en gaan zij zeer uitgebreid in op het MER. Volgens de ECW is er mitsdien geen enkele indicatie dat de onafhankelijkheid van de Cmer in het geding zou zijn. ${ }^{54}$ Het toetsingsadvies van de Cmer vormt in bijna alle gevallen reden tot aanvulling of bijstelling van het MER. Meestal gaat het daar om het "opvullen van hiaten". Vaak richten de bezwaren van de Cmer zich op het "meest milieuvriendelijke alternatief" (art. 7.10, derde lid Wm). Op het plegen van aanvullingen is formeel geen toetsing door de Cmer voorgeschreven.

Voorts heb ik mij afgevraagd hoe ik precies de functie van deze stap in de procedure moet beoordelen. Het doel lijkt te zijn na te gaan of het MER wel voldoet. ${ }^{56}$ Inhoudelijk lijkt dat neer te komen op een herhaling van de voorgaande stap maar nu met andere actoren. Dat laatste is dan in zoverre van belang dat in de voorgaande stap het bevoegd gezag de verantwoordelijkheid heeft genomen voor de feitenvaststelling en nu daarop aanspreekbaar is. ${ }^{57}$ Maar in hoeverre is dat wat de Cmer in deze stap doet dan te vergelijken met hetgeen waartoe het bestuur bij de eerste stap geroepen is? Beide zijn immers gehouden het MER te beoordelen op juistheid en volledigheid. Ook lijkt deze beoordeling identiek als we bedenken dat de Cmer vaak om een informele voortoets wordt gevraagd. Juist vanuit het perspectief van de verantwoordelijkheid zie ik echter een significant verschil in beoordeling. De Cmer heeft primair tot doel bij te dragen aan de objectiviteit van de informatie uit het MER. ${ }^{58}$ Daarbij dient zij bij haar oordeel over de volledigheid van het MER in beginsel uit te gaan van de wettelijke eisen en de richtlijnen. ${ }^{59}$ Voor het bestuur staat de beoordeling in het teken van het nemen van verantwoordelijkheid voor de feitenvaststelling. ${ }^{\infty}$ In het licht van de beoordeling van de (mogelijk) betrokken belangen bestaat er voor het bestuur een zekere vrijheid om, met de wettelijke eisen als minimum, genoegen te nemen met een in het licht van de gegeven richtlijnen, onvolledig MER. ${ }^{61}$ Dit gezegd hebbend

54. A.w., p. 43.

55. Mbidem, p. 42.

56. Zie het ECW-advies, a.w., p. 20.

57. In beroep als de feitelijke grondslag van de genomen beslissing wordt aangevochten, maar m.i. ook als het gaat om het plegen van eventuele bijstellingen in het MER nadat dit door het bevoegd gezag is aanvaard (zie het slot bij de voorgaande stap).

58. ECW-advies, a.w., p. 41.

59. Ik gaf reeds aan dat ik begeleidende kritiek op de richtlijnen niet problematisch acht.

60 . Het zal zich moeten bezinnen op de vraag of de uitgezochte alternatieven "redelijk zeker" zijn en of het nodig zal zijn (aanvullend) nieuwe alternatieven te selecteren.

61. Een bepaald alternatief kan bij voorbeeld onuitgewerkt zijn gebleven in het licht van de bevindingen tijdens het opstellen van het MER. Zie overigens ook art. 7.18, tweede lid Wm. 
blijft nog de vraag of de opeenvolging van deze en de voorgaande stap de meest gelukkige is. Daarop kom ik hieronder nog terug.

In aansluiting op het voorgaande heb ik nog een afsluitende opmerking over de kwestie van de objectiviteit van de feitenvaststelling bij een m.e.r.-plichtig besluit. In het voorafgaande hoofdstuk werd duidelijk dat bij raadpleging van deskundigen-adviseurs, in het kader van de feitenvaststelling, zelfs de schijn van partijdigheid moet worden voorkomen. Bij m.e.r.-plichtige besluiten wordt het belangrijkste document voor de feitenvaststelling echter door een bij uitstek partijdige initiatiefnemer gemaakt. Kan dat allemaal zomaar? Ik denk van wel. Ook op dit punt is het goed om voor ogen te houden dat het bevoegd gezag de feiten vaststelt, en dat het dit (onder meer) ${ }^{62}$ doet door een zelfstandige beoordeling van het MER op juistheid en volledigheid en op basis van inspraak, advisering en toetsing. Hierboven wees ik er reeds op dat de toetsing door de Cmer eveneens geschiedt naar de maatstaven juistheid en volledigheid. Mij dunkt dat zo, mede gelet op de onafhankelijke status van de Cmer, in beginsel voldoende waarborgen voor onpartijdigheid van de feitenvaststelling zijn gegeven.

\subsubsection{Het besluit}

De zesde stap in de procedure is die waarin een besluit wordt genomen over de voorgenomen activiteit: art. 7.27-7.38 Wm. Een paar aspecten zijn hierbij in het bijzonder van belang: de blokkerende werking, de verruimde beslissingsbevoegdheid en de motiveringsplicht.

De blokkerende werking van de m.e.r.-plicht is neergelegd in art. $7.27 \mathrm{Wm}$. Een besluit waarvoor een m.e.r.-plicht geldt kan niet worden genomen dan nadat de voorgaande stappen van de m.e.r.-procedure geheel zijn doorlopen. In aansluiting op deze formele eis is voorts nog een materiële eis (negatief) geformuleerd: indien weliswaar een MER is gemaakt maar de gegevens daaruit "redelijkerwijs niet meer aan het besluit ten grondslag kunnen worden gelegd in verband met aanmerkelijke wijziging van de omstandigheden waarvan bij het maken van het MER is uitgegaan" kan het m.e.r.-plichtige besluit niet worden genomen.

In de m.e.r.-procedure rond de uitbreiding van vliegveld Beek deed zich hiervan een bijzonder voorbeeld voor. Bij opstellen van het desbetreffende MER was uitgegaan van voor uitbreiding van het vliegveld benodigde internationale overeenstemming over het gebruik van luchtruim in het BelgischNederlandse grensgebied. Op het moment dat het m.e.r.-plichtige aanwijzingsbesluit genomen zou moeten worden was echter nog geen sprake van

62. Niet uitgesloten is dat er naast een MER nog ander (nader) onderzoek wordt verricht. 
overeenstemming. Volgens de Raad van State ${ }^{63}$ was hier sprake van een aanmerkelijke wijziging van omstandigheden als bedoeld in art. 7.27, tweede lid Wm (toen nog art. $41 \mathrm{aa}$, tweede lid Wabm). Het vooruitzicht van internationale overeenstemming op termijn vermocht aan dit oordeel niet af te doen, nu voornoemd artikel de situatie op het moment waarop het m.e.r.-plichtige wordt genomen als ijkpunt heeft. ${ }^{64}$

Art. 7.27, tweede lid Wm onderstreept hoezeer het bevoegd gezag op het moment dat het besluit wordt genomen alle feiten en omstandigheden zelfstandig in ogenschouw moet nemen. Zulks ligt naar mijn smak ook besloten in art. $7.35 \mathrm{Wm}$. Het eerste lid van dit artikel stelt immers dat het bevoegd gezag bij het nemen van een m.e.r.-plichtig besluit rekening houdt "met alle gevolgen die de activiteit waarop het besluit betrekking heeft, voor het milieu kan hebben."

Daarmee ben ik aangeland bij het artikel dat een regeling geeft van de zogenoemde "verruimde beslissingsbevoegdheid". 65 Deze regeling wordt volgens de $\mathrm{ECW}^{66}$ in de praktijk "over het algemeen als onduidelijk ervaren." Ik wil er hier ook wat uitdrukkelijker bij stilstaan.

De hoofdregel voor de verruimde beslissingsbevoegdheid ligt besloten in het eerste lid van art. $7.35 \mathrm{Wm}$ : het bevoegd gezag dient rekening te houden met alle gevolgen die de activiteit waarop het besluit betrekking heeft voor het milieu kan hebben. Op deze wijze wordt - in beginsel - voorkomen dat bepaalde gevolgen voor het milieu, zoals deze in het MER zijn geëxpliciteerd, bij de besluitvorming buiten beschouwing blijven.

Het tweede lid van het artikel bevat echter een belangrijke uitzonderingsregel: de hoofdregel geldt niet indien de wettelijke regeling waarop het besluit berust zich daartegen verzet. Deze regel houdt in dat indien de sectorwet waarop het te nemen m.e.r.-plichtige besluit berust zich verzet tegen het meewegen van "alle gevolgen voor het milieu", de hoofdregel buiten spel blijft.

Mijns inziens behelst de uitzonderingsregel primair een (door het eerste lid noodzakelijk geworden) verwijzing naar het specialiteitsbeginsel. Het gaat daarbij om een formele kwestie: als bij een sectorale bevoegdheid slechts bepaalde milieu-gevolgen mogen worden afgewogen (en aldus sprake is van een uitdrukkelijke bevoegdheidsbeperking), vermag de m.e.r.-plichtigheid van een besluit daaraan niet af te doen.

63. TK'87-'88, 15880 , nr. 44. De Raad was ex art. 18 lid 2 Wet RvS om advies gevraagd.

64. Een ander voorbeeld van toepassing van art. 41 aa tweede lid biedt Hof Den Haag 15 februari 1990, BR'90, p. 447 (Blankenburg-tunnel).

65. Zie ook Brussaard et al., a.w., p. 93-94 (Gilhuis).

66. A.w., p. 46. 
Het is de vraag of de uitzonderingsregel ook een materiële beperking inhoudt. Daarvan zou sprake zijn indien de milieu-gevolgen (waartoe de afweging dient te worden beperkt) ook slechts op en in een door de sectorwet bepaalde wijze en mate mogen worden beschreven en afgewogen.

De hierboven aangehaalde zaak over de uitbreiding van vliegveld Beek is in deze relevant. Daar rees namelijk ook nog de vraag of bij het m.e.r.-plichtige aanwijzingsbesluit alleen de geluidsnormen van de luchtvaartwetgeving (de zogenoemde Kosteneenheden, Ke's), of ook de (in de luchtvaartwetgeving niet gehanteerde) decibel-benadering ${ }^{\sigma}$ moest worden betrokken. Zowel de Cmer als de Raad van State stelden dat de decibel-benadering bij het nemen van de onderhavige beslissing niet kon worden gemist. De Raad gaf hiervoor twee gronden aan. In de eerste plaats "is voor het beschrijven van de specifieke geluidshindergevolgen van nachtelijk vlieggeluid de in de luchtvaartwetgeving gehanteerde Ke-norm niet geschikt". ${ }^{68}$ In de tweede plaats zou de m.e.r.-regeling "haar functie verliezen" indien de wettelijke bepalingen van de luchtvaartwetgeving een "belemmering zouden vormen om alle geluidshinderaspecten te onderkennen en een volwaardige plaats te geven in het besluitvormingsproces." Dit laatste punt werd expliciet in verband gebracht met art. $41 \mathrm{j}$, eerste lid onder e jo art. $41 \mathrm{a}$ Wabm $(7.10$ jo art. 1.1 , tweede lid $\mathrm{Wm}),{ }^{69}$ alsmede met art. 4lai Wabm $(7.35 \mathrm{Wm}){ }^{70}$ Een en ander had tot gevolg dat voor de beschrijving van de geluidseffecten ook in decibellen moest worden gerekend èn dat het bevoegd gezag zich bij het nemen van het besluit rekenschap moest geven van grenswaarden in termen van decibellen.

Het advies van de Raad van State zwijgt over de formele beperking in art. 4lai Wabm $(7.35 \mathrm{Wm})$. De voornoemde uitzonderingsregel is ook niet aan de orde omdat geluidshinder in beginsel past binnen de reikwijdte van de in het geding zijnde bevoegdheid. Wat het materiële aspect betreft lees ik het advies aldus dat de hoofdregel van art. 4lai Wabm $(7.35 \mathrm{Wm})$ zoveel mogelijk voorop dient te staan. In beginsel dienen de (relevante) milieu-gevolgen ten volle te worden beoordeeld. Indien materiële normen of voorgeschreven berekeningsmethoden uit de desbetreffende sectorwet ongeschikt zijn om een volledige beoordeling van dit aspect te verwezenlijken, zal op andere wijze (met andere normen of andere methoden) gezocht moeten worden naar een adequate beschrijving.

67. Zoals bekend uit de i.c. niet toepasselijke Wgh.

68. Volgens deskundigen kunnen m.n. de effecten van (nachtelijke) piekbelastingen alleen met decibellen op zinvolle wijze worden beschreven: de Ke's drukken slechts een maximaal saldo van vlieglawaai over een bepaalde periode (doorgaans 1 jaar) uit.

69. Betreffende de inhoud van het MER: de gevolgen voor het milieu.

70. Alle govolgen moeten worden meegewogen. 
De wetenschap zal een belangrijke rol vervullen bij de vraag of bestaande sectorale normen garant staan voor een adequate afweging van een bepaald milieu-aspect. Een addertje onder het gras is natuurlijk dat de keuze voor een bepaalde sectorale norm de expressie kan zijn van een bepaalde belangenafweging. Impliciet wordt dan de wijze waarop een bepaald milieu-gevolg in het kader van de sectorwet moet worden (beschreven en) afgewogen, nader beperkt. Mij dunkt dat de Raad van State in de zaak "Beek" de hoofdregel van art. 4lai, eerste lid Wabm $(7.35 \mathrm{Wm})$ uitdrukkelijk als uitgangspunt wenst te nemen. Op voet daarvan wordt de uitzonderingsregel (van het tweede lid) eng geïnterpreteerd. De keuze voor een bepaalde sectorale norm mag geen belemmering zijn om het desbetreffende milieu-aspect volledig te onderkennen en een volwaardige plaats te geven in het besluitvormingsproces. ${ }^{71}$

Dat de uitzonderingsregel van art. 7.35, tweede lid Wm slechts een formele strekking heeft, en het materiële aspect (onderkenning en beoordeling van de relevante milieu-aspecten) onverlet laat, is ook te rijmen met een derde regel uit art. 7.35 Wm. Deze bijzondere regel, neergelegd in het derde (en vierde) lid van art. $7.35 \mathrm{Wm}$, behelst dat indien op de totstandkoming van het besluit hoofdstuk $13 \mathrm{Wm}$, c.q. Afdeling $3.5 \mathrm{Awb}^{72}$ van toepassing is, het bevoegd gezag kan beslissen dat de uitzonderingsregel buiten toepassing blijft. Door deze regel kan er "in de besluitvorming toch rekening worden gehouden met zogenaamde "witte vlekken" in bestaande competenties en cumulatie van milieugevolgen,.." ${ }^{73}$ Het derde lid van art. $7.35 \mathrm{Wm}$ betreft de situatie dat er voor de activiteit én besluit is aangewezen op de totstandkoming waarvan hoofdstuk 13, c.q. Afdeling 3.5 van toepassing is; het vierde lid de situatie dat het om meerdere dergelijke besluiten voor dezelfde activiteit gaat. In het laatste geval is er per activiteit in het Besluit-mer (hierna, Bmer) ${ }^{74}$ een besluit aangewezen waarop de regel van lid 3 moet worden toegepast. Deze regel komt er op neer dat "ongeacht de beperkingen die terzake in de wettelijke regeling waarop het besluit berust, zijn gesteld:" (a) alle voorwaarden, voorschriften en beperkingen kunnen worden opgenomen, die nodig zijn ter bescherming van het milieu, of (b) een besluit tot afwijzing van de voorgenomen activiteit kan worden genomen omdat deze "activiteit tot ontoelaatbare nadelige gevolgen voor het milieu kan leiden".

71. Ik vermoed dat deze interpretatie van de RvS de CRMH tot zijn kritische opmerking over de verruimde beslissingsbevoegdheid heeft gebracht - zie het advies naar aanleiding van het verslag van de werking van de m.e.r.-regeling. Den Haag. september 1991, p. 24.

72. Zie Art. II.FF AwbA, waarbij in art 7.35 (4lai) derde lid, aanhef, en vierde lid "Hoofdstuk 13" wordt vervangen door "afdeling 3.4A AwbA" (lees afdeling 3.5 Awb).

73. Brussaard, et al., a.w..p. 93 (Gilhuis).

74. Besluit van 20 mei 1987. Stb. 278. laatstelijk gewijzigd op 24 februari 1992, Stb. 107. In het Bmer worden mer-plichtige activiteiten èn besluiten aangewezen. 
Deze bijzondere regel is als een discretionaire bevoegdheid geformuleerd: het bevoegd gezag kan ook volstaan met toepassing van de eerst genoemde twee regels. $^{75}$

De relatie tussen de bijzondere regel en de materiële verruiming van de beslissingsbevoegdheid komt scherp in beeld bij een bezinning op de uitspraak van de Afdeling Geschillen betreffende de elektriciteitscentrale Amer9 te Geertruidenberg. ${ }^{76}$ Daarin gaat de Afdeling er vanuit dat geen scherpere normen mogen worden toegepast dan in de desbetreffende sectorale regels (in casu uit het Besluit emissie-eisen stookinstallaties) zijn vastgelegd, tenzij de aanvrager met scherpere normen instemt. In zijn noot bij deze uitspraak stelt Gilhuis dat de Afdeling terecht met geen woord rept over art. 4lai Wabm $(7.35 \mathrm{Wm})$. In casu betreft het weliswaar een geval als bedoeld in art. 41ai vierde lid Wabm $(7.35 \mathrm{Wm})$, maar de verruimde beslissingsbevoegdheid dient in casu op een ander dan het in casu bestreden besluit te worden toegepast.

Terecht wijst Gilhuis in zijn noot vervolgens op het feit dat bij de parlementaire behandeling is gesteld dat de verruimde beslissingsbevoegdheid slechts bedoeld was om ontoelaatbare cumulatieve effecten te onderkennen en mee te wegen en niet om op basis van andere wetten gestelde voorschriften aan te scherpen of te verzwakken. ${ }^{n}$ Volgens Gilhuis leidt een dergelijke interpretatie tot de gevolgtrekking dat de verruimde beslissingsbevoegdheid slechts voor vergunningen onder de Wabm (Wm) is weggelegd. Omdat het daarbij veelal om meerdere vergunningen voor dezelfde activiteit zal gaan zal de verruimde bevoegdheid dan inderdaad slechts voor cumulatieve effecten relevant zijn. Volgens Gilhuis zou dit meebrengen dat "de milieu-informatie die door m.e.r. wordt aangedragen (...) daardoor niet altijd volledig in de besluitvorming (kan) worden meegewogen". ${ }^{78} \mathrm{Hij}$ spreekt als zijn wens uit dat de Afdeling bij gelegenheid duidelijkheid schept over de te volgen interpretatie. ${ }^{79}$

Ik meen dat er voor de verruimde beslissingsbevoegdheid een ruimere toepassingsmogelijkheid is dan alleen voor besluiten die totstandkomen met toepassing van Hoofdstuk $13 \mathrm{Wm}$, c.q. Afdeling $3.5 \mathrm{Awb}$. In formeel opzicht beperkt de toepassing zich inderdaad tot die besluiten, omdat alleen daarvoor (krachtens de bijzondere regel) het specialiteitsbeginsel buiten werking is geplaatst. In materieel opzicht meen ik echter dat verruimde beslissingsbe-

75. Mij is over het gebruik van deze discretie geen jurisprudentie bekend.

76. AGRvS 1 oktober 1990, M\&R'91/4, 41 m.nt. Gilhuis.

77. Zie annotatie, a.w., Parlementaire geschiedenis, TK'80-'81 en TK'83-84, 16814 nrs 3 en 7, resp. p. 22-25 en p. 41-47.

78. Zie annotatie, a.w.

79. Ibidem. 
voegdheid ook buiten de in de bijzondere regel genoemde gevallen kan worden toegepast. Gelet op hetgeen de Raad van State in de zaak "Beek" adviseerde, mogen sectorale normen de functie van de m.e.r.-regeling niet frustreren door een belemmering te vormen voor de volledige onderkenning en volwaardige afweging van relevante milieu-gevolgen. Van zo'n belemmering is in elk geval sprake indien de sectornormen ongeschikt zijn voor de beschrijving van het milieu-gevolg in kwestie. Dat voorbijgaan aan sectorale normen er vervolgens toe zal kunnen leiden dat andere, nieuwe grenswaarden een rol gaan spelen is iets dat de Raad van State (in het licht van de hoofdregel) op de koop toe wil nemen.

In mijn interpretatie van de verruimde beslissingsbevoegdheid is - kortom sprake van twee dimensies.

Allereerst een materiële dimensie, gelegen in de samenhang tussen lid 1 en lid 2 van art. $7.35 \mathrm{Wm}$. Voorop staat dat alle milieu-gevolgen volledig worden beschreven en beoordeeld. Volledigheid vergt gebruik van daartoe geschikte normen en grenswaarden. Als sectorale normen echter ongeschikt blijken, zal het bevoegd gezag zich op andere normen en grenswaarden moeten bezinnen. Hier speelt mijns inziens mee dat we van doen hebben met een activiteit met (mogelijk) belangrijke nadelige gevolgen voor het milieu. Daarbij past een verhoogde waakzaamheid met het oog op de bescherming van het milieu. Daarin past niet dat een effectieve bescherming wordt belemmerd door voorschriften die naar de actuele stand van wetenschap en techniek tekortschieten als instrument tot beschrijving van de (relevante) milieugevolgen.

Impliciet is de verruimde beslissingsbevoegdheid derhalve een vorm van open normstelling naast de in Hoofdstuk II genoemde gevallen. Indirect wordt hier het ongeschreven milieurecht in stelling gebracht, waarbij grondrechten en (bestendige) maatschappelijke opvattingen een funderende rol spelen. Het ongeschreven milieurecht zal een leidraad zijn bij de bepaling van grenswaarden voor eventueel bij m.e.r.-plichtigheid nieuw te introduceren normen. ${ }^{80}$ In de tweede plaats is er de formele dimensie, primair gericht op het doorbreken van het specialiteitsbeginsel waar anders (door "witte vlekken" in de bevoegdheidsverdeling) niet alle gevolgen voor het milieu kunnen worden meegewogen. Deze formele dimensie is slechts van toepassing op een bijzondere categorie van besluiten, te weten die waarop de procedure van Hoofdstuk 13, c.q. Afdeling 3.5 Awb van toepassing is. Ik begrijp deze selectie

80. Hierin ligt besloten dat het eindresultaat kan zijn dat (per saldo) aan een activiteit (binnen de grenzen van het specialiteitsheginsel blijvend) meer beperkingen worden opgelegd dan op grond van de oorspronkelijke (doch uit "m.e.r.-oogpunt") ontoereikende normen (met hun eigen grenswaarden) het geval zou zijn geweest. 
aldus dat de wetgever in dit procedurele criterium eigenlijk een materiële kwalificatie voor de desbetreffende besluiten legt: dit zijn besluiten die desgewenst $^{81}$ in een integrale milieubescherming moeten kunnen voorzien. Bij de oorspronkelijke tekst van art. 4 lai Wabm heeft de wetgever waarschijnlijk reeds het oog gehad op de aanstaande introductie van de (integrale) Wmvergunning. Het voorstel om bij de introductie van art. $7.35 \mathrm{Wm}$ de tekst van het derde een vierde lid van art. 41ai Wabm te schrappen past in die lijn. Dit voorstel werd op aandrang van de kamer ingetrokken omdat naast de Wm-vergunning (die zelf voorziet in een integrale afweging van milieu-aspecten) ook besluiten meteen beperktere afwegingsruimte naar totstandkoming aan Hoofdstuk 13, c.q. Afdeling 3.5 Awb zijn gebonden. ${ }^{82}$

Rest nog de motiveringsvereiste van art. $7.37 \mathrm{Wm}$. Het is stellig niet zo dat de m.e.r.-regeling ook als beoogd effect heeft dat (structureel) scherpere milieunormen worden gesteld. Als gezegd gaat het primair om het doorzichtig maken van de besluitvorming, hetgeen onverlet laat dat beslissingen evenzeer als zonder m.e.r.-plichtigheid het geval kan zijn, in het nadeel van het milieubelang kunnen uitvallen. ${ }^{83}$

Belangrijk is echter wel dat het bevoegd gezag in zijn beslissing moet aangeven op welke gronden dit rust en de wijze waarop rekening is gehouden met de te verwachten gevolgen voor het milieu. Tevens moet melding worden gemaakt van hetgeen is overwogen omtrent de in het MER beschreven alternatieven en de inspraak- en adviesreacties op het MER. Met deze uitdrukkelijke verplichtingen heeft de burger (en desgevraagd ook de rechter) een beter handvat voor de beoordeling van de aanvaardbaarheid van het besluit.

\subsubsection{De evaluatie}

De zevende en laatste stap in de procedure is die van de evaluatie: art. 7.39-7.43 Wm. Indien voor een bepaalde activiteit een MER is gemaakt dient het bevoegd gezag wanneer die activiteit wordt ondernomen, of nadat zij is ondernomen, de gevolgen daarvan voor het milieu te onderzoeken (art. 7.39 Wm). ${ }^{84}$ Degene die de activiteit onderneemt is verplicht alle medewerking te verlenen en informatie te verstrekken die voor het onderzoek nodig is (art. $7.40 \mathrm{Wm}$ ). Van het onderzoek wordt een verslag gemaakt dat vervolgens in de openbaarheid wordt gebracht en dat wordt toegezonden aan de wettelijke

81. Het gaat om een diseretionaire bevoegdheid om de verruimde beslissingsbevoegdheid al dan niet toe te passen.

82. Zoals bij voorbeeld de Wvo-vergunning. Zie over dit punt: TK'88-'89 en '89-'90, 21 087, nr. 2 , p. 26 , nr. 5 , p. 49 , nr. 6 , p. 82 en nr. 7 , p. 6.

83. Zo ook Brussaard, a.w.. p. 96 (Gilhuis).

84. De opzet hiervoor moet - ingevolge art. 7.37, tweede lid $\mathrm{Wm}$ - samen met de termijn voor het onderzoek worden bepaald in het m.e.r.-plichtige besluit. 
adviseurs en de Cmer (art. $7.41 \mathrm{Wm}$ ). Art. $7.42 \mathrm{Wm}$ voorziet in een uitdrukkelijke vergelijking tussen de bevindingen uit het onderzoek en de gevolgen die bij het nemen van het besluit werden verwacht. Mocht blijken dat de feitelijke gevolgen in belangrijke mate nadeliger zijn dan de verwachte gevolgen dan neemt het bevoegd gezag - indien het dat nodig acht - "de hem ter beschikking staande maatregelen ten einde die gevolgen zoveel mogelijk te beperken of ongedaan te maken."

Volgens de ECW is nog niet goed te zeggen hoe de evaluatie-bepalingen functioneren omdat er nog te weinig evaluatie-programma's in uitvoering is genomen. Uit het ECW-onderzoek blijkt wel dat over de evaluatie in het MER meestal wel wat globale opmerkingen worden gemaakt maar dat het aan echt vooropgestelde evaluatie-programma's vaak ontbreekt. ${ }^{85}$ Dat is ongelukkig omdat een zekere scherpte in opzet (alsook in te controleren data) een conditio sine qua non is om tot een zinnige evaluatie te komen. Meer in het algemeen spreekt het nut van evaluaties welhaast vanzelf: het voorziet in een onderbouwing voor een eventuele correctie van het genomen besluit en het is een instrument ter lering inzake effect-voorspelling. Dat laatste is in het licht van de "armoede van de ecologie" stellig van groot belang. ${ }^{86}$

\subsubsection{Werkingssfeer}

Ten aanzien van de werkingssfeer van de m.e.r.-regeling zal ik mij strikt beperken tot de meest relevante regels. $\mathrm{Na}$ een korte inventarisatie van het positieve recht terzake zal ik nog kort ingaan op enkele kritiekpunten van de Europese commissie. De bevindingen van de ECW inzake de m.e.r.-werkingssfeer zal ik in $\S 7.2 .3 .4$, tegelijk met het regeringsverslag bespreken.

Nationaalrechtelijk uitgangspunt voor de werkingssfeer is art. $7.2 \mathrm{Wm}$ : de m.e.r.-plicht geldt voor "activiteiten die belangrijke nadelige gevolgen kunnen hebben voor het milieu", voorzover deze zijn aangewezen bij AMvB -te weten het Bmer. Er is geen sprake van een materiële toets van geval tot geval, de positieve lijst uit bijlage $\mathrm{c}$ van het Bmer is limitatief. ${ }^{87}$

Bij de samenstelling van die lijst speelden twee elementen een belangrijke rol. Allereerst waren er de richtsnoeren voor de selectie van m.e.r.-plichtige activiteiten. ${ }^{88}$ In de tweede plaats stond als beleidsuitgangspunt vast dat "de werkingssfeer van de m.e.r. wat betreft de particuliere industrie, in de eerste

85. ECW, a.w., p. 47.

86. In Hoofdstuk 4.3 kwam het belang van goede evaluaties. met het oog op de verbetering van selectie en onderzoek, ook reeds aan de orde.

87. Zie ook Brussaard, a.w., p. 81 (Gilhuis).

88. Zie TK' $80-' 81,16814$, nr. 3, p. $83-84$ (bijlage A. Richtsnoeren voor de selectie van m.e.r.plichtige activiteiten en besluiten). 
fase beperkt zou blijven tot grote industriële projecten". ${ }^{89}$ Niet onbelangrijk is overigens dat art. $21.6 \mathrm{Wm}$ bepaalt dat voorafgaand aan vaststelling van het Bmer, ter advisering een voordracht aan de Centrale Raad voor de milieuhygiëne, ${ }^{90}$ de Natuurbeschermingsraad en de Raad van Advies voor de Ruimtelijke Ordening wordt voorgelegd. Voorts wordt het ontwerp-Bmer openbaar bekend gemaakt en wordt een ieder in de gelegenheid gesteld zijn opmerkingen daarover schriftelijk bij de minister kenbaar te maken.

Als gezegd bevat het Bmer in bijlage c een positieve lijst met m.e.r.-plichtige activiteiten. De activiteit wordt in algemene zin omschreven. Vervolgens is het mogelijk dat deze activiteit slechts in bepaalde "gevallen" m.e.r.-plichtig is. Daarvoor worden bij bepaalde activiteiten dan zogenoemde drempelwaarden gegeven. ${ }^{91}$ Voorts wordt per activiteit aangegeven bij welk besluit het desbetreffende MER moet worden gemaakt. Dit is het zogenoemde "cruciale besluit"; het is immers goed mogelijk dat voor het ondernemen van een en dezelfde activiteit meerdere overheidsbesluiten moeten worden genomen. Volgens de richtsnoeren ${ }^{92}$ is daarbij steeds gekozen voor die besluiten waarbij één of meer wezenlijke alternatieven worden uitgesloten of afvallen, één of meer verplichtingen worden aangegaan die verplichtend zijn voor het doorgaan van de activiteit, of waarbij bepaalde "kaders, randvoorwaarden c.q. faciliteiten" worden vastgesteld die bepalend zijn voor de wijze waarop de activiteit gerealiseerd kan worden. ${ }^{93}$ De lijst van cruciale besluiten is zo samengesteld dat in de meeste gevallen een MER op project- of uitvoeringsniveau moet worden gemaakt. Op die niveaus is het doorgaans goed mogelijk in het MER alternatieve lokaties en uitvoeringswijzen te vergelijken. ${ }^{94}$ Daarnaast zijn er overigens ook nog MER's op beleids- of planniveau. ${ }^{95}$ In een aantal gevallen lenen deze zich goed voor bij voorbeeld kwesties als lokatiekeuze. In andere gevallen, met name bij rijksplannen en -nota's, worden de afwegingen zo algemeen dat de m.e.r. zijn scherpte kan verliezen. ${ }^{96}$

De m.e.r.-regeling bevat een aantal bepalingen die voorzien in een verdere uitbreiding of beperking van de m.e.r.-plicht.

89. TK'90-'91, 22 103, nr. 1, p. 19. Vgl. DROM, a.w., conclusie 80.

90. In de toekomst waarschijnlijk Raad voor het milieubeheer: zie TK'92-'93, 22 842, nrs. 1-2.

91. Met name waarden ten aanzien van de omvang van een activiteit: "tracélengte", "laadvermogen", "ruimte oppervlak", "verkeersaantrekkende werking". "wijziging waterstand" en dergelijke. Het gaat overigens niet steeds om kwantitatieve drempelwaarde, vgl. al dan niet doorsnijden van een nationaal park.

92. Zie noot 88 .

93. Ibidem.

94. Brussaard, a.w., p. 84 (Gilhuis).

95. Zoals het Provinciale afvalstoffenplan (bijlage c. 18.1) en het streek- of bestemmingsplan (bijlage c. 20) en voor rijksplannen en nota's (art. 3 Bmer).

96. Brussaard, a.w., p. 84 (Gilhuis), zie ook ECW, a.w., p. 53-55. 
Uitbreidingsmogelijkheden liggen besloten in art. $7.4 \mathrm{Wm}$ (de ministeriële spoedaanwijzing van een activiteit - in algemene zin, te volgen door wijziging van het Bmer), de mogelijkheid van een m.e.r.-plicht bij provinciale verordening (art. $7.6 \mathrm{Wm}$, voor activiteiten in bijzonder waardevolle of reeds ernstig verontreinigde gebieden) en de mogelijkheid van een m.e.r. op vrijwillige basis.

Beperkingsmogelijkheden liggen in het bijzonder besloten in art. $7.5 \mathrm{Wm} .{ }^{97}$ Het betreft hier:

- onder a.: de ontheffing op inhoudelijke gronden (in casu geen belangrijke nadelige gevolgen) ${ }^{98}$

- onder b.: de ontheffing in verband met herhaling of voortzetting van een activiteit waarvoor reeds een - nog altijd adequaat! - MER is gemaakt;

- onder c.: de ontheffing als bij b. voor dezelfde activiteit - indien reeds een nog steeds adequaat MER voorligt;

- onder lid 2: de ontheffing wegens het feit dat de voorbereiding van de activiteit of het cruciale besluit, op het moment dat de m.e.r.-plicht in werking treedt, ${ }^{99}$ reeds zover is gevorderd, dat het maken van een MER redelijkerwijs niet meer kan worden verlangd. ${ }^{100}$

De Europese commissie heeft bij brief van 25 april 1990 laten weten dat de m.e.r.-regeling niet volledig overeenkomt met EG-richtlijn inzake de m.e.r. ${ }^{101}$ Wat betreft de werkingssfeer van de m.e.r.-regeling gaat het daarbij volgens de commissie om de volgende gebreken.

- de EG-richtlijn kent twee bijlagen (I en II). Projecten van bijlage I dienen zonder drempelwaarde te worden onderworpen aan de m.e.r.-plicht. Op bijlage $\mathrm{c}$ van het Bmer bevinden zich enkele projecten als bedoeld in bijlage I, waarvan de m.e.r.-plicht afhankelijk is gesteld van een drempelwaarde;

- ingevolge art. 4, tweede lid, van de EG-richtlijn moet in nationale regelgeving worden voorzien in de mogelijkheid dat de projecten genoemd op bijlage II van de EG-richtlijn, onder bepaalde omstandigheden worden

97. Ik ga voorbij aan de regeling van art. $41 \mathrm{~h}$.

98. In de praktijk blijkt deze ontheffingsgrond problemen te geven vanwege de vraag welke diepgang aan het ontheffingsverzoek moet worden gegeven; soms lijkt het verzoek wel op een "mini-MER" (Brussaard, a.w., p. 86 (Gilhuis). ECW, a.w., p. 64-66).

99. Bij invoering, maar uiteraard ook bij wijzigingen van het Bmer.

100. Voor de interpretatie van deze ontheffingsgrond, met name van het tijdstip waarop een initiatiefnemer had te rekenen met in werkingtreding van de m.e.r.-plicht, zie AGRvS 26 augustus 1991, AB 608 m.nt. FM, M\&R'92/2, nr. 37, p. 114 m.nt. Jans.

101. EG-Richtlijn $85 / 337$ van 27 juni 1985, Pb EG 1985, LJ75. Overigens zij opgemerkt dat de verplichting uit art. 4 (eerste lid) van deze richtlijn (het onderwerpen van bepaalde categorieën activiteiten aan de m.e.r.-plicht, rechtstreeks werkend is: vgl. vz AGRvS 19 december 1991 , AB'92, 122 m.nt. FM. 
onderworpen aan een m.e.r.-plicht. Dit zou kunnen worden gerealiseerd door deze projecten, eventueel voorzien van een drempelwaarde (in algemene zin) onder de m.e.r.-plicht te brengen. Voor de overige projecten van bijlage II dient te worden voorzien in de mogelijkheid van een ad hoc aanwijzing. Dat laatste is in de huidige m.e.r.-regeling niet mogelijk; die kent immers slechts de spoedaanwijzing gevolgd door wijziging van het Bmer.

- volgens art. 2, derde lid, van de EG-richtlijn is ontheffing van de m.e.r.plicht slechts mogelijk in uitzonderlijke gevallen. Volgens de commissie voorziet art. 7.5 onder a $\mathrm{Wm}$ in een te ruimhartige ontheffingsmogelijkheid.

\subsubsection{Het regeringsverslag}

Ingevolge art. $21.2 \mathrm{Wm}$ zendt de minister drie jaar na de inwerkingtreding van de m.e.r.-regeling een verslag over de werking ervan aan de StatenGeneraal. Aldus is geschied op 6 mei $1991 .{ }^{102}$ Ten behoeve van dit verslag heeft de regering de ECW verzocht advies uit te brengen. ${ }^{103}$ In het verslag neemt een achttal aanbevelingen van de ECW een belangrijke plaats in. Ook de kritiek van de Europese commissie is er in verwerkt.

De regering stelt voorop dat de ECW in haar advies concludeert dat de m.e.r. een redelijk functionerend instrument is. ${ }^{104}$ Door de m.e.r.-regeling is bij de besluitvorming meer milieu-informatie aanwezig en volgens het advies wordt deze informatie ook meegewogen bij het nemen van een beslissing. Met het laatste is overigens niet gezegd dat daarmee het milieubelang een grotere rol is gaan spelen. De hoofddoelstelling van de m.e.r.-regeling ("een volwaardige plaats") wordt echter wel bereikt. ${ }^{105}$

Vervolgens analyseert de regering het functioneren van de m.e.r.-procedure. ${ }^{106}$ De belangrijkste opmerkingen daaruit loop ik hier even kort na.

- Wat de voorfase van de procedure betreft deelt de regering het belang dat de ECW hecht aan een goede startnotitie. In lijn met de (vierde) aanbeveling van de ECW zal in het Besluit startnotitie meer aandacht worden gevraagd voor de omschrijving van doel- en probleemstelling, alsmede voor de aanduiding van de ruimte voor besluitvorming. ${ }^{107}$

102. TK'90-'91, 22 103, nr 1.

103. Het eerder aangehaalde advies.

104. Regeringsverslag, a.w., p. 3-4. ECW, a.w., p. 81.

105. Doidem.

106. Tbidem, p. 5-18.

107. Ibidem, p. 8. 
- Ten aanzien van de vooroverlegfase heeft de regering geen concrete voorstellen. Zij onderschrijft de bevindingen van de ECW, in het bijzonder het grote nut van richtlijnen voor het verkrijgen van milieu-informatie, het grote belang van overleg tussen initiatiefnemer en bevoegd gezag, de inspraak en de advisering door de Cmer en de wettelijke adviseurs.

- Op het opstellen van het MER gaat de regering wat uitgebreider in.

In de eerste plaats reageert zij op de aanbeveling van de ECW inzake de vraag welke milieu-aspecten in het MER aan bod kunnen komen. Met het oog op de hieromtrent in art. $41 \mathrm{a} \mathrm{Wabm}{ }^{108}$ gegeven omschrijving, adviseerde de ECW om de reikwijdte van de m.e.r. uit te breiden tot termen uit het NMP en het NMP-plus in het kader van het streven naar een duurzame ontwikkeling. ${ }^{109}$ Bij de totstandkoming van de $\mathrm{Wm}$ is, zo stelt de regering vast, besloten om de omschrijving van de reikwijdte van de m.e.r. te schrappen, nu "milieugevolgen" voor het gehele toepassingsgebied van de $\mathrm{Wm}$ breder zijn omschreven. ${ }^{110}$ Daardoor zullen maatschappelijke opvattingen omtrent milieugevolgen in beschouwing kunnen worden genomen. Aspecten als "ruimte beslag, energieverbruik (...), grondstoffenverbruik, ketenbeheer en mobiliteitsbeperking" kunnen mitsdien, als hoofdelementen uit het streven naar duurzame ontwikkeling, bij de beschrijving van milieugevolgen in het MER worden meegenomen. ${ }^{\prime \prime \prime}$

In de tweede plaats richt de regering zich op de beschrijving van de alternatieven. De ECW heeft terzake aanbevolen ${ }^{112}$ om door een wijziging van de omschrijving van art. 7.10, derde lid Wm (het "meest milieuvriendelijke alternatief"), zodanig aan te passen dat duidelijker is wat er van de opsteller van het MER wordt verwacht. Aldus kan het gebrek aan aandacht voor dit alternatief, zoals gebleken bij het ECW-onderzoek, wellicht worden verholpen. De regering is van mening dat het wijzigingsvoorstel van de $\mathrm{ECW}^{113}$ in essentie het zelfde beoogt als de huidige bepaling terzake en neemt het voorstel van de ECW over. ${ }^{114}$ In het verlengde daarvan stelt de regering voor om met een extra lid van art. 7.10

108. De omschrijving van de term "gevolgen voor het milieu" is thans te vinden in art. 1.1, tweede lid $\mathrm{Wm}$. deze term komt (o.m.) terug in art. 7.10, eerste lid onder e $\mathrm{Wm}$ (het MER moet een beschrijving geven van de "gevolgen voor het milieu..").

109. ECW, a.w., p. 98 (aanbeveling 6).

110. Zie art. 1.1, tweede lid $\mathrm{Wm}$ en voorts TK'89-'90, 21 087, nr. 6, p. 42-43.

111. Regeringsverslag, a.w., p. 10-11.

112. ECW, a.w., p. 98 (vijfde aanbeveling).

113. In plaats van "Tot de (..) te beschrijven alternatieven behoort in ieder geval het alternatief waarbij de beste bestaande mogelijkheden ter bescherming van het milieu worden toegepast.". "Onder de te beschrijven alternatieven behoort in ieder geval het alternatief waarbij wordt aangegeven hoe nadelige gevolgen voor het milieu kunnen worden voorkomen, dan wel zoveel mogelijk beperkt voor zover zij niet kunnen worden voorkomen."

114. Regeringsverslag. a.w., p. 11-12. 
Wm te regelen "dat in daarvoor in aanmerking komende gevallen ook gezocht wordt naar mogelijkheden van compensatie van onvermijdelijke negatieve milieugevolgen". Bij wijze van voorbeeld noemt zij het inrichten van een gebied met dezelfde ecologische waarden als een gebied dat door een voorgenomen activiteit verloren zal gaan. ${ }^{.15}$

Ten slotte stelt de regering - in het voetspoor van de ECW - vast dat het omgaan met de m.e.r. als een leerproces is te beschouwen. Naarmate men vaker met het instrument ervaring heeft opgedaan, gaat men de milieuaspecten van een voornemen eerder in de planvorming betrekken. Gaandeweg zal de verinnerlijkingsdoelstelling van de m.e.r. beter worden gerealiseerd.

- Bij de beschouwing over de derde stap in de procedure, de beoordeling van de aanvaardbaarheid van het MER, is de aandacht voor het bevoegd gezag en de Cmer mijns inziens het meest interessant. De regering stelt vast dat het bevoegd gezag in veel gevallen reeds tijdens het opstellen van het MER wordt geraadpleegd. In dergelijke gevallen is de eindbeoordeling nauwelijks meer dan een formaliteit. Belangrijk is dat het bevoegd gezag in veel gevallen de specialistische expertise mist voor een gegrond eindoordeel. ${ }^{116}$ Dit probleem was volgens de regering reeds bij de invoering van de m.e.r.-regeling onderkend en reden voor de instelling van de Cmer. De regering is van mening dat de bevindingen voor het bevoegd gezag een uitdaging moeten zijn tot kwaliteitsverbetering in het eigen apparaat. ${ }^{117}$

De regering heeft kennis genomen van het feit dat de Cmer regelmatig door de opsteller van het MER wordt gevraagd om een "informele voortoets" - voorafgaand aan de beoordeling van het MER door het bevoegd gezag. Op de wenselijkheid hiervan en de vraag of de Cmer wellicht voorafgaand aan het bevoegd gezag het MER zou moeten toetsen, gaat de regering echter pas bij de bespreking van de vierde stap in.

- Bij die vierde stap, te weten inspraak, advisering en toetsing, komt de verhouding tussen bevoegd gezag en de Cmer uitdrukkelijk aan de orde. In de eerste plaats neemt de regering zich voor de onduidelijkheid omtrent het maken van aanvullingen op een MER, nadat die door het bevoegd gezag is aanvaard maar door de Cmer onvolledig of onjuist is geoordeeld, weg te nemen. ${ }^{118}$ Anders dan ik hierboven (onder \$ 7.2.2) suggereerde stelt de regering voor dat de initiatiefnemer de aanvulling maakt. De

115. Bbidem.

116. ECW, a.w.. p. 40. Regeringsverslag. a.w.. p. 13.

117. Regeringsverslag, a.w., p. 13.

118. Midem, p. 14. De regering refereert hier aan het in de dereguleringsoperatie gesneuvelde ontwerp-art. $41 \times$ Wabm. Zie ook mijn opmerkingen onder \$ 7.2.2.4 (hierboven). 
regering acht diens verantwoordelijkheid voor de aanwezigheid van (kwalitatief) voldoende informatie hiervoor afdoende grond. $\mathrm{Zij}$ wil aan de Cmer de bevoegdheid geven om in het toetsingsadvies expliciet aan te geven welke aanvulling er op het MER nodig is alvorens tot besluitvorming kan worden overgegaan. Het bevoegd gezag zal op basis van dit advies en van de inspraak, aangeven welke aanvullende informatie moet worden geleverd. ${ }^{119}$ Ik ben van mening dat de verantwoordelijkheden tussen initiatiefnemer en bevoegd gezag en tussen het bevoegd gezag en de Cmer hier niet scherp genoeg worden gescheiden. In $\$ 7.2 .3 .5 \mathrm{kom}$ ik hierop nog terug.

In de tweede plaats gaat de regering in op het samenvallen van de rol van initiatiefnemer en bevoegd gezag. ${ }^{120}$ In aanbeveling 3 stelt de ECW voor om voor m.e.r.-plichtige besluiten waarbij de initiatiefnemer tevens bevoegd gezag is, extra procedurele waarborgen in te bouwen. ${ }^{121}$ De $\mathrm{ECW}$ is van mening dat zowel bij de vaststelling van richtlijnen als bij de beoordeling van de aanvaardbaarheid van het MER de samenloop in voornoemde rollen problematisch is te achten. Een vermenging van belangen wordt als "principieel onjuist" gekenschetst: de taken van de actoren in een besluitvormingsproces behoren gescheiden te zijn. De doorzichtigheid van de besluitvorming, en de in het verlengde daarvan de acceptatie van de uitkomsten, zijn in het geding. De Cmer zou hier volgens de ECW een rol kunnen spelen, bij voorbeeld door het Cmer-advies inzake de richtlijnen en de Cmer-toets van het MER bindend te laten zijn. Bij wijze van nuancering overweegt de ECW alleen de Cmer-toets bindend te laten zijn - in de verwachting dat hierop bij de vaststelling van richtlijnen zal worden geanticipeerd. ${ }^{122}$ De regering betwijfelt of de door de ECW voorgestane oplossing wenselijk is, nu zich tot op heden geen problemen hebben voorgedaan. ${ }^{123}$ Wat betreft het voorstel om aan de Cmer een zwaardere (c.q. bindende) rol toe te kennen, is de regering van mening dat de onafhankelijkheid van de Cmer in het geding zou kunnen komen. Een negatief bindend-toetsingsadvies zou - zo stelt de regering - al snel kunnen worden uitgelegd als een negatief advies over de wenselijkheid van het voornemen. De regering acht het wijs om op het gesignaleerde punt waakzaam te blijven en over vijf jaar bij de volgende evaluatie dit punt opnieuw in beschouwing te nemen.

119. Ibidem, p. 15. Voorzover de aanvullingen essentiële informatie betreffen zal hierover opnieuw inspraak en toetsing plaatsvinden (ibidem).

120. Iets waarover ik in het voorafgaande gemakshalve steeds heb gezwegen.

121. ECW. a.w., p. 95-96.

122. Ibidem. De ECW noemt nog de mogelijkheid van bemoeienis van een hogere bestuursinstantie.

123. Regeringsverslag, a.w.. p. 15. 
Ten slotte gaat de regering in op de tweede aanbeveling van de ECW, die betrekking heeft op de volgorde van de derde en de vierde stap in de m.e.r.-procedure: "onderwerp het MER eerst aan advies en inspraak en laat het toetsen door de Cmer, alvorens het bevoegd gezag oordeelt over de aanvaardbaarheid ervan". ${ }^{124}$ De ECW is van mening dat bij een dergelijke gang van zaken een beter beeld ontstaat van de verschillende verantwoordelijkheden van de bij de m.e.r. betrokken actoren. Zij laat zich in haar aanbeveling (mede) inspireren door het gegeven dat thans reeds in veel gevallen van de Cmer een "informele voortoets" wordt gevraagd. De regering is echter van mening dat een wijziging van de procedure op dit punt niet voor de hand ligt. In de eerste plaats is in de uitgebreide beraadslaging over de procedure-volgorde, bij de totstandkoming van de m.e.r.-regeling, overwogen dat de $\mathrm{Cmer}$ in de gelegenheid zou moeten verkeren om bij het toetsingsadvies ook de reacties uit de inspraak te betrekken. In de tweede plaats is het steeds de bedoeling geweest om de m.e.r.-procedure zoveel mogelijk in te passen in de originaire besluitvormingsprocedure van het m.e.r.-plichtige besluit. Het voorstel van de ECW zou leiden tot een extra procedure-stap. ${ }^{125}$ Als derde overweging voor afwijzing van de aanbeveling stelt de regering dat wijziging van de volgorde van stappen geen stimulans zou vormen voor het bevoegd gezag voor het nemen van eigen verantwoordelijkheid. Daarbij zou de initiatiefnemer in plaats van het bevoegd gezag de Cmer als belangrijkste overlegpartner kunnen gaan beschouwen. ${ }^{126} \mathrm{Ik}$ kom ook op de kwestie in $\$ 7.2 .5$ nog terug.

- Wat de zesde stap in de besluitvorming aangaat, stelt de regering voorop dat het nimmer het doel van de m.e.r. is geweest dat alleen nog maar milieu-vriendelijke beslissingen worden genomen: "Het hoofddoel van m.e.r. is het milieubelang een volwaardige plaats te geven in de belangenafweging in de besluitvorming. Dit kàn tot meer milieuvriendelijke besluiten leiden. M.e.r. biedt daarvoor echter geen garantie". ${ }^{127}$

In de visie van de regering vindt de regeling inzake de verruiming van de beslissingsgrondslag nog altijd slechts in beperkte mate toepassing. Onder verwijzing naar het - hierboven reeds besproken - advies van de RvS in de zaak "Beek", stelt de regering dat bij de verruimde beslissingsbevoegdheid niet alleen sprake is van een bevoegdheid maar ook van een verplich-

124. ECW, a.w.. p. 94-95. Regeringsverslag, a.w., p. 16.

125. Het ECW-voorstel leidt er toe dat insprekers en adviseurs reeds voorafgaand aan inspraak of advies op de aanvraag of het ontwerp-besluit, op het MER moeten kunnen reageren. Bij de aanvraag of het ontwerp-besluit zou een door de Cmer getoetst en door het bevoegd gezag aanvaard MER moeten voorliggen.

126. Regeringsverslag, a.w., p. 17.

127. Ibidem, p. 17. 
ting: bij het besluit moet rekening worden gehouden met alle gevolgen voor het milieu ook - indien daar aanleiding voor is ${ }^{128}$ - met milieugevolgen die binnen de wettelijke norm liggen. ${ }^{129}$ De regering neemt zich voor de voorlichting terzake te intensiveren.

- Aan een oordeel over de zevende en laatste stap, de evaluatie, komt de regering niet toe. $\mathrm{Zij}$ deelt de bevinding van de ECW dat het nu nog te vroeg is om een gefundeerd oordeel te geven over de werking van de evaluatie. ${ }^{130}$

Op het punt van de werkingssfeer speelt de kritiek van de Europese commissie een belangrijke rol. Deze kritiek is ook door de ECW in ogenschouw genomen ${ }^{131}$ en was aanleiding tot haar eerste aanbeveling: De thans bestaande lijst voor m.e.r.-plichtige activiteiten dient te worden uitgebreid. Daarnaast dient een procedure te worden ontwikkeld voor een "korte-m.e.r.procedure", waarbij bijlage II van de EG-richtlijn als uitgangspunt wordt genomen. Voor de op die lijst genoemde activiteiten, voorzover niet aanstonds op basis van bijlage c. van het Bmer m.e.r.-plichtig, zou in eerste aanleg een soort "aangeklede startnotitie" moeten worden gemaakt. ${ }^{132}$ Op basis van deze notitie moet het bevoegd gezag vervolgens beoordelen of alsnog een volledige m.e.r.-procedure moet worden doorlopen of dat met de notitie kan worden volstaan. In lijn met deze aanbeveling zou de ontheffingsgrond van art. 7.5, eerste lid, onder a Wm ("geen belangrijke nadelige gevolgen voor het milieu") kunnen vervallen. ${ }^{133}$

De regering stemt in met de gedachte om de werkingssfeer uit te breiden. Dat de werkingssfeer in de tweede fase zou worden uitgebreid was immers bij de start van de m.e.r. al voorzien. ${ }^{134}$

Wat de verkorte m.e.r.-procedure betreft stelt de regering zich afwijzend op. De regering is van mening dat uit de huidige m.e.r.-procedure geen elemen-

128. Ik neem aan dat hier wordt gedoeld op het "ongeschikt zijn" van bestaande sectorale normen c.q. een "belemmering vormen" voor onderkenning van alle milieugevolgen.

129. Regeringsverslag, a.w., p. 18. Naar ik aanneem wordt hier met "binnen" gedoeld op een "scherpere" norm.

130. Ibidem. Ik laat de problematiek van aanbeveling 7 en 8 van de ECW, inzake respectievelijk de milieutoets bij beleidsplannen en de m.e.r.-plichtigheid van landinrichtingsprojecten hier buiten beschouwing. Zie regeringsverslag, a.w., p. 23-24 en p. 20-21.

131. ECW, a.w., p. 66-70.

132. Ibidem, p. 93.

133. Ibidem. p. 93-94.

134. De uitbreiding van de werkingssfeer zal zich concentreren op "industriële projecten", "infrastructurele projecten" en "olie- en gaswinning", regeringsverslag, a.w., p. 19. Een deel van de wijzigingen van het Bmer i.v.m. strijd met de EG-richtlijn werden reeds effectief bij wijziging van het Bmer van 24 februari 1992 (Stb. 107). Het voornemen uit de tekst is in de integrale herziening (voorstel van 14 augustus 1992, TK'91-92, 22 103, nr. 4) meegenomen (met een deel aan resterende EG-implementatie). 
ten geschrapt kunnen worden. In plaats van de korte m.e.r.-procedure zoekt de regering aansluiting bij de problematiek van de aanwijzing van een m.e.r.plicht voor individuele gevallen. Een regeling terzake lijkt noodzakelijk gezien de kritiek van de Europese commissie op het feit dat de Nederlandse regeling geen individuele aanwijzing kent - doch slechts de spoedaanwijzing van art. 7.4 Wm, met een categorisch karakter. De regering stelt voor ${ }^{135}$ om een m.e.r.-beoordelingsprocedure in het leven te roepen voor (in elk geval) de activiteiten als genoemd in Bijlage II van de richtlijn - voorzover niet reeds in bijlage c. ondergebracht. Indien een activiteit, "gezien de omstandigheden waaronder zij wordt ondernomen, belangrijke nadelige milieugevolgen kan hebben", kan tot een m.e.r.-plicht worden besloten. ${ }^{136}$ Het gezag dat bevoegd is om uiteindelijk over de toelaatbaarheid van de activiteit te beslissen, moet in deze procedure ook beslissen over de m.e.r.-plichtigheid. Zolang deze beslissing niet is genomen, kan het uiteindelijke besluit niet worden genomen. ${ }^{137}$ Thans ligt een wetsvoorstel voor ${ }^{138}$ waarin deze aanpak nader is uitgewerkt. Voor een nader bij het Bmer te bepalen groep van activiteiten zal een "sluimerende m.e.r.-plicht"139 in het leven geroepen worden. $\mathrm{Bij}$ de beoordeling van de m.e.r.-plichtigheid is - voorzover ik kon opmaken - geen plaats ingeruimd voor de Cmer.

In de ontwerp-regeling is uitdrukkelijk de mogelijkheid ingesloten dat een initiatiefnemer meedeelt zich vrijwillig aan de m.e.r.-plicht te zullen onderwerpen (art. 7.8a, derde lid Wm). Gilhuis wijst er op dat het voor initiatiefnemers van een aan m.e.r.-beoordeling onderworpen activiteit wel eens het beste zou kunnen zijn zich aanstonds aan een m.e.r.-plicht te onderwerpen. ${ }^{140}$ Allereerst moet de initiatiefnemer zich reeds inspannen om de nodige gegevens op tafel te leggen aan de hand waarvan het bevoegd gezag een oordeel kan vellen over de m.e.r.-plichtigheid (art. 7.8a, tweede lid Wm). Dit kost op zichzelf reeds tijd. Daarbij komt dan de beslistermijn (van zes weken - art. $7.8 \mathrm{~b}$, eerste lid Wm) voor het bevoegd gezag. Mocht het bevoegd gezag beslissen dat geen m.e.r.-plicht geldt, dan is dit besluit nog voor beroep vatbaar. ${ }^{141}$ In een veel later stadium kan dan duidelijk worden dat alsnog een m.e.r.-plicht geldt. Gilhuis vraagt zich af of het, dit alles consta-

135. Regeringsverslag, a.w., p. 24-27.

136. Ibidem, p. 25. De regering denkt hierbij onder meer aan de aard, omvang of ligging van de activiteit.

137. Ibidem. p. 26.

138. TK'91-'92, 22 608, nrs 1-3. Wijziging van de regeling van de milieu-effectrapportage in de wet algemene bepalingen milieuhygiëne. Hier wordt uitgegaan van het gewijzigd voorstel van wet TK'92-'93, 22 608, nr. 8.

139. MvT, a.w., p. 10.

140. Gilhuis, P.C., M.e.r.-plicht met twee snelheden, M\&R'92/11, p. 577.

141. Zulks ingevolge art. $20.5 \mathrm{Wm}$ in samenhang met art. $7.8 \mathrm{~b}$, zesde lid $\mathbf{W m}$. 
terende, niet wijs zou zijn de groep van activiteiten die een m.e.r.-beoordeling moet ondergaan zo klein mogelijk te houden. Dit zou kunnen door zoveel mogelijk activiteiten (uit bijlage II) onder de (reguliere) m.e.r.-plicht te brengen. Als dit gebeurt zal de lijst van bijlage c. van het Bmer meer "lichte" gevallen bevatten. In verband daarmee bepleit Gilhuis dat wordt gezocht naar mogelijkheden om de tijdsduur van de m.e.r.-procedure waar mogelijk in te perken. ${ }^{142}$ Ik kan instemmen met de teneur van Gilhuis' betoog, maar zou geen voorstander zijn van verschillende m.e.r.-procedures voor verschillende categorieën van m.e.r.-plichtigheid. Mij dunkt dat de richtlijnen voor het opstellen van het MER hier in de benodigde flexibiliteit kunnen voorzien, door de beschrijving van meer of minder alternatieven in meer of minder gedetailleerde mate voor te schrijven. ${ }^{143}$

Rest nog op te merken dat het wetsvoorstel tevens voorziet in het vervallen van de spoedaanwijzing van art. $7.4 \mathrm{Wm}$. In het regeringsverslag wordt ook reeds aangekondigd dat de inhoudelijke ontheffing van art. 7.5 , eerste lid onder a Wm kan worden geschrapt. ${ }^{144}$ In het voornoemde wetsvoorstel wordt ter onderbouwing van dit (in art I.B vervatte) voorstel nog opgemerkt dat van deze bevoegdheid "geen simpele en snelle toepassing mogelijk (is)" en de regering wil voorkomen dat omtrent de toepassing van deze bevoegdheid "misleidende verwachtingen" worden gewekt. ${ }^{145}$

\subsubsection{Conclusies}

Gaandeweg zijn zowel de procedure als de werkingssfeer van de milieueffectrapportage van de nodige commentaren voorzien. Ik volsta mitsdien hier met een aantal hoofdpunten.

- Om te beginnen de vraag naar de verdeling van verantwoordelijkheden.

In de eerste plaats lijkt het mij wijs dat aan de Cmer op geen enkele wijze een bindende rol in de procedure wordt toegekend. De Cmer adviseert: de vaststelling van richtlijnen en van het MER is een (primaire) verantwoordelijkheid van het bestuur. Ik houd daarmee ook strak de hand aan de eerste vuistregel uit deel II van deze studie. Deze benadering moet naar mijn smaak ook worden gehanteerd in die gevallen waar het bevoegd gezag tevens initiatiefnemer is. De openbaarheid van de richtlijnen, het MER, alsmede de adviezen van de Cmer beschouw ik als voldoende waarborgen voor een zorgvuldige feitenvaststelling. ${ }^{146}$

142. A.w.

143. Gilhuis, a.w., wijst hier ook zelf op. Ook de CRMH wijst in zijn advies, a.w., p. 15, op deze rol voor richtlijnen.

144. A.w., p. 22-23.

145. MvT, a.w., p. 3. Uiteraard wordt hier ook de kritick van de Europese commissie gememoreerd.

146. Waarbij de openbaarheid impliciet het risico van een beroep op de rechter levend houdt. 
In de tweede plaats ben ik - anders dan de regering ${ }^{147}$ - van mening dat aanvaarding van het MER door het bevoegd gezag dient mee te brengen dat indien bij inspraak, advisering en toetsing alsnog mocht komen vast te staan dat het MER "onvolledig of onjuist" is, het bevoegd gezag voor bijstelling of aanvulling verantwoordelijk is. Naar mijn mening is dit niet alleen formeel-juridisch de enig juiste gang van zaken, ${ }^{148}$ ook naar de initiatiefnemer toe lijkt mij dit de enig heldere presentatie. Bijgevolg leidt het er toe dat het bestuur zich terdege zal bezinnen op zijn oordeel over het MER.

Tegen die achtergrond rijst vervolgens de vraag naar de meest wenselijke volgorde van beoordeling van het MER. De ECW sprak zich uit voor omwisseling van de derde en vierde stap, zodat de toetsing door de Cmer vooraf gaat aan de toetsing door het bevoegd gezag. ${ }^{149}$ Dit voorstel komt neer op een formalisering van de "informele voortoets". Het spoort inhoudelijk ook goed met hetgeen ik hierboven heb gesteld: na toetsing door de Cmer kan de initiatiefnemer door het bevoegd gezag worden verplicht tot aanvulling of verbetering van het MER. Op het moment dat het bevoegd gezag zich akkoord verklaard met het gewijzigde MER (al dan niet nadat de Cmer ook de aanvulling of verbetering nog heeft getoetst) neemt het de verantwoordelijkheid voor de feitenvaststelling over. ${ }^{150} \mathrm{De}$ regering wijst de aanbeveling van de ECW af met twee - ook hierboven reeds genoemde - argumenten: door wisseling van de procedure-stappen is er geen goede aansluiting met de sectorale "moeder-procedure", ${ }^{151}$ en de wisseling van stappen is "geen stimulans voor het nemen van eigen verantwoordelijkheid door het bevoegd gezag". ${ }^{152}$ Aan het laatste punt voegt de regering nog toe dat er sprake is van een "toenemende ervaring" bij het bevoegd gezag met de aanvaardbaarheidstoetsing, dat het bevoegd gezag de mogelijkheid heeft om (externe) deskundigen in te schakelen bij de aanvaardbaarheidstoetsing, en dat een "globale beoordeling" door de Cmer kan worden gevraagd. ${ }^{153}$

147. Zie het regeringsverslag, a.w., p. 14-15.

148. Immers, het oordeel van het bestuur is formeel verbonden met het oordeel over de ontvankelijkheid van de aanvraag: art. 7.28 eerste lid onder b jo art. 7.18 eerste lid Wm.

149. ECW, a.w., tweede aanbeveling, p. 94-95.

150. Bij de door mij gesuggereerde scheiding van verantwoordelijkheden voor het aanpassen van het MER zal, bij handhaving van de huidige procedure-volgorde, bij het bestuur de behoefte aan een informele voortoets toenemen.

151. Uitgaande van het standpunt dat de Cmer in haar oordeel ook de inspraak- en adviesreacties moet kunnen betrekken.

152. Regeringsverslag, a.w., p. 16-17.

153. In een later stadium. te weten in de lijst van vragen en antwoorden. TK'91-'92, 22 103, nr. 2 , p. 11. 
Het standpunt van de regering vermag mij niet te overtuigen. Sterker nog, meer en meer krijg ik de indruk dat ingeval van m.e.r.-plichtigheid een uitgebreide "moeder-procedure", in twee onderscheiden stappen wenselijk is. Ik denk dan aan besluitvorming met een voornemen-fase en een ontwerp-fase. In de voornemenfase staat de aanvraag samen met het MER centraal. ${ }^{154}$ Hierop is inspraak en advisering mogelijk. Als deze reacties binnen zijn volgt toetsing door de Cmer. Daarop aansluitend geeft het bevoegd gezag (al dan niet na tussentijdse aanpassing van het MER) een eind-oordeel over het MER. Dit eindoordeel ligt ten grondslag aan het ontwerp-besluit, waarop opnieuw inspraak en advies mogelijk is. ${ }^{155}$ Mocht er op basis van de inspraak- of adviesreacties nog behoefte bestaan aan aanpassing van het MER dan is dit de primaire verantwoordelijkheid van het bevoegd gezag.

Deze procedure sluit goed aan bij het voorstel dat ik in $\S 6.3 .5 .3$ formuleerde en doet mijns inziens overigens recht aan het complexe karakter van de te nemen beslissing. ${ }^{156}$

De gedachte dat bestuursorganen zich nog kunnen laten adviseren inzake de aanvaardbaarheidstoetsing vind ik op zichzelf niet onaardig, maar voorafgaand aan een Cmer-toets wel wat zwaar. In mijn optiek ligt het veeleer voor de hand dat indien het bevoegd gezag - na voorafgaande toetsing van het MER door de Cmer - niet kan instemmen met de bevindingen van de Cmer, door het bevoegd gezag contra-expertise wordt ingewonnen. Op deze wijze kan de m.e.r.-praktijk aansluiten bij de adviseringspraktijk zoals die in het voorgaande hoofdstuk werd geschetst. ${ }^{157 / 158}$

- Een tweede punt dat in het bijzonder mijn aandacht heeft is dat van de verruimde beslissingsbevoegdheid. Ik acht dit onderwerp daarom zo relevant nu het in feite een vorm van open milieurechtelijke normering be-

154. Gelijk nu reeds het geval is gaat de voor- en vooroverlegfase (i.v.m. de richtlijnen) en de fase van het opstellen van het MER hier nog aan vooraf.

155. Gericht op de wenselijkheid van het besluit. De Cmer komt er dus ook niet meer aan te pas.

156. Ik ben niet zo onder de indruk van de stellingname dat procedures allemaal per se maar moeten worden ingekort. Een strakke opzet, met een zo kort mogelijk tijdsverloop is wat mij betreft akkoord, maar tegenover het schrappen van "stappen" sta ik - zeker bij complexe besluiten sceptisch.

157. Niet afwijken van een deskundigen advies dan na (hernieuwd-/contra-)deskundigenadvies.

158. Strikt genomen kan ook nu na de Cmer-toets door het bevoegd gezag contra-expertise worden ingewonnen. Ik ben daarvan echter geen voorbeelden tegengekomen. Het ongelukkige in de huidige constellatie is dat het bestuur zich al heeft uitgesproken en dan na een onwelgevallige Cmer-toets tegenadvies kan inwinnen. Mij dunkt dat het aantrekkelijker is indien het bestuur zich pas uitspreekt nadat het zijn twijfels over de Cmer-toets aan contra-expertise heeft onderworpen. 
treft. In algemene zin beoogt de regeling van art. $7.35 \mathrm{Wm}$ dat "witte vlekken' in de milieubescherming kunnen worden gedicht. In het verlengde daarvan brengt m.e.r.-plichtigheid mee dat het bestuur zich rekenschap moet geven van voortschrijdende normstelling: als bestaande sectorale normen niet adequaat zijn voor de beschrijving van de milieu-effecten is er in beginsel een plicht om andere normen en bijgevolg andere grenswaarden bij de beschrijving en besluitvorming te betrekken. Aanwijzingen voor het niet-adequaat zijn van bestaande sectornormen kunnen voortvloeien uit de technische beperktheid van deze normen. Zo kan er sprake zijn van nieuwe inzichten die een meer gesofisticeerde beschrijving van effecten mogelijk maken, of van nieuwe inzichten in de gevaren van de activiteit in kwestie. In het laatste geval verdient het opmerking dat de maatschappelijke opvattingen, c.q. het ongeschreven milieurecht, dan kan meebrengen dat deze inzichten in het MER en in de daaropvolgende besluitvorming aan bod moeten komen. Dat dit mogelijk is vloeit mijns inziens voort uit de strekking van art. $7.35 \mathrm{Wm}$ - zoals ook is bevestigd in de zaak "Beek" - en ligt uiteindelijk verankerd in de bijzondere potentiële milieugevoeligheid van de desbetreffende activiteiten. ${ }^{159}$

- In de derde plaats is de m.e.r.-regeling interessant vanuit het perspectief van het vinden van een "bevredigende oplossing" in de besluitvorming. Vanuit de wetenschap dat niet alle alternatieven en alle bijbehorende gegevens beschreven kunnen worden zullen keuzes gemaakt moeten worden ten aanzien van de diepgang en omvang van het feitenonderzoek. In feite begint dat al bij de keuze die de wetgever heeft gemaakt door alleen voor activiteiten die belangrijke nadelige gevolgen voor het milieu kunnen hebben m.e.r.-plichtig te maken. ${ }^{160}$ In het verlengde daarop is de vaststelling van de richtlijnen essentieel. In algemene zin wordt hiermee aangegeven op welke wijze aan de wettelijke eisen voor het MER moet worden voldaan en welke gegevens dit in elk geval moet opleveren. ${ }^{161}$ Op het kruispunt van wettelijke eisen en de richtlijnen is vooral de selectie van te beschrijven alternatieven van belang. ${ }^{162}$ Hierbij staat het criterium van het "redelijkerwijs in beschouwing moeten worden genomen", dat ik ook in $\$$ 4.3.3.2 hanteerde, centraal. In elk geval is voorgeschreven dat het nul-alternatief en het "meest milieuvriendelijke alternatief" in het MER wordt uitgewerkt. Na het opstellen van het MER laat de wet aan het

159. Ik kies hier overigens opzettelijk voor een "extensieve interpretatie". Mij dunkt dat ook de regering (zie regeringsverslag, a.w., p. 18) die voorstaat.

160. En daarmee aan een uitgebreider feitenonderzoek te onderwerpen (art. $7.2 \mathrm{Wm}$ en het Bmer).

161. Vgl. art. 7.15, tweede lid onder a. en b. Wm.

162. In samenhang met de doelomschrijving; zie m.n. art. $7.10 \mathrm{Wm}$. 
bestuur een zekere vrijheid van beoordeling. ${ }^{163}$ Daarbij komt dat het bevoegd gezag voorbij kan zien aan eventueel tekortschieten op ondergeschikte punten.

Ik acht het van groot belang dat de procedure gekenmerkt wordt door deze marges voor een bevredigende aanpak. Ik hecht daarbij in het bijzonder aan de bestuurlijke verantwoordelijkheid, waarmee toch impliciet erkent zij dat op verschillende punten normatieve keuzes gemaakt moeten worden - ook al gaat het om de feitenvaststelling. Dit zijn keuzes die overeenkomstig het in de eerste vuistregel (van Deel II) gestelde - niet aan deskundigen mogen worden overgelaten.

In verband met het streven naar een "bevredigende oplossing" merk ik voorts nog op dat in de m.e.r.-regeling enkele interessante aanknopingspunten zijn gelegen voor "onzekerheidsreductie". In de eerste plaats is het van groot belang dat art. 7.10 (in het eerste lid onder g.) Wm voorschrijft dat in het MER een overzicht wordt gegeven van de leemtes in de gegeven beschrijvingen ten gevolge van het ontbreken van de benodigde gegevens. Hierbij kan het gaan om het ontbreken van feitelijke gegevens (zoals meetresultaten), maar ook om onzekerheden over de uitvoering van de activiteit en over oorzaak en gevolg-relaties. ${ }^{164}$ Bewustheid van onzekerheid is van groot belang voor de uiteindelijke besluitvorming en de evaluatie van de activiteit, indien deze doorgang vindt. Uit een oogpunt van onzekerheidsreductie is het voorts zeer waardevol dat in het MER het "meest milieuvriendelijke alternatief" wordt uitgewerkt. Dit biedt het bevoegd gezag een goed aanknopingspunt voor het verdisconteren van onzekerheden. Ik heb mij in dit verband wel afgevraagd of het niet mogelijk (en aantrekkelijk) zou zijn om ook een "worst case scenario" als alternatief (of per alternatief) te laten beschrijven. Daarbij moet dan naar de actuele stand van kennis en inzicht een beschrijving worden gegeven van de meest negatieve schattingen omtrent de milieu-effecten van de voorgenomen activiteit. Zo zouden bepaalde praktische onzekerheden op een - vanuit het te beschermen belang - interessante wijze worden beschreven. Praktisch lijkt het mij echter moeilijk de initiatiefnemer hiertoe te verplichten; dat blijkt al uit de problemen rondom het "meest milieu-vriendelijke alternatief".

In algemene zin deel ik de conclusie van de ECW dat de m.e.r. een "redelijk functionerend instrument" is. Naar mijn smaak zou echter de verdeling van verantwoordelijkheden (tussen Cmer en bevoegd gezag) op een andere wijze geregeld moeten worden dan thans het geval is. Als de consequentie hiervan

163. "In het bevoegd gezag van oordeel is..." - art. 7.18, eerste lid Wm.

164. Handleiding Mer, Ministeries van VROM en LNV, Lelystad 1987, p. 55. 
is, dat de procedure met een stap verlengd moet worden, dan heb ik daartegen, gelet op het bij uitstek zwaarwegende besluitvormingsbelang, geen overwegende bezwaren. ${ }^{165}$

\subsection{Zorg voor de deskundigheid van burgers}

De zorg voor de deskundigheid van burgers was een van de "uitwerkingspunten" uit het voorgaande hoofdstuk. Ik stelde daarbij vast dat de Awb op dat punt niet geweldig veel te bieden had; dat ik begrip had voor het feit dat een eventuele regeling terzake aan "bijzondere wetgeving" was gelaten, maar toch betreurde dat deze zorg in het geheel niet als een mogelijk probleem werd gesignaleerd.

Naar mijn stellige overtuiging is het in zaken waarbij technisch-complexe belangen onderwerp zijn van besluitvorming, zaak dat daarbij waarborgen voor de deskundigheid van burgers in het leven worden geroepen. Zonder dergelijke waarborgen komt van een open debat over het voorgenomen besluit niet veel terecht. Naar de aard van de materie geldt dat zeker ook voor het verlenen van $\mathrm{Wm}$-vergunningen.

Vooropgesteld zij dat openheid en openbaarheid van bestuur in de non-contentieuze procedure een eerste vereiste is. In dit opzicht zal de Awb belangrijker worden als de voorgenomen opname van de WOB in de Awb wordt verwezenlijkt.

Voor niet-deskundige burgers zou beschikbaarheid van de voor vergunningverlening relevante stukken, zoals de aanvraag en eventuele adviezen, in een gepopulariseerde vorm van groot belang kunnen zijn. Hiermee wint de burger weliswaar niet direct deskundigheid (in) maar zijn vermogen om te beoordelen of en zo ja, in hoeverre zijn positie in het geding is en zich terzake teweer te stellen, wordt er stellig door verbeterd. In de Wm zijn slechts een tweetal verplichtingen tot het maken van gepopulariseerde versies te vinden.

In \$6.3.2.1 wees ik reeds op het feit dat uit art. 2:5 Awb voortvloeit dat de aanvrager zijn gegevens als "vertrouwelijk" kan aanmerken. Blijkens de toelichting op genoemd artikel ${ }^{166}$ brengt de geheimhoudingsverplichting zijdens het bestuur mee dat vertrouwelijke gegevens niet ter inzage gelegd

165. Mij is onbekend in hoeverre het bestuur naast of na de m.e.r.-procedure zelf nog nader informatio vergaart. Ik kan mij voorstellen dat dit het geval is, met name als het gaat om informatie over andere belangen dan het milieubelang. Voorzover hierover in het MER wordt gerept valt dit overigens ook onder de "uitgebreide motiveringsplicht" van art. $7.37 \mathrm{Wm}$.

166. A.w., p. 56-57. 
mogen worden. Met het oog op de positie van derde-belanghebbenden voorziet art. 13.6 Wm in de mogelijkheid dat de aanvrager een beroep doet op toepassing van art. 19.3-6 Wm. In art. $19.3 \mathrm{Wm}$ is voorgeschreven dat geheimhouding van een stuk dat in de besluitvorming openbaar gemaakt zou moeten worden, mogelijk is, mits een zogenoemde "tweede tekst" wordt verstrekt. ${ }^{167} \mathrm{Er}$ is mitsdien geen mogelijkheid tot vertrouwelijkheid zonder vervangend "tweede stuk". ${ }^{168}$ De Afdeling Geschillen heeft terzake van toepassing van art. 19.3 Wm uitdrukkelijk te kennen gegeven dat de nadelen van geheimhouding zoveel mogelijk dienen te worden beperkt: "De geheimhouding dient in elk geval een goede beoordeling van de aanvraag onverlet te laten". ${ }^{(\theta)}$ Volgens Jans, in zijn noot bij geciteerde uitspraak, volgt hieruit dat de Afdeling in zijn algemeenheid het belang van een goede beoordeling stelt boven de belangen die met geheimhouding zijn gediend: "het goed kunnen beoordelen van de aanvraag is (...) een ultieme randvoorwaarde, waarbinnen de vergunningaanvrager om geheimhouding kan verzoeken". ${ }^{170}$ Deze zienswijze komt mij aantrekkelijk voor en zal mijns inziens ook een leidend uitgangspunt moeten zijn bij de eisen te stellen aan een "tweede tekst".

In art. 7.10, eerste lid onder $\mathrm{h} W \mathrm{~m}$ is bepaald dat een (populaire) samenvatting van de inhoud van het MER wordt gemaakt. Een goed voorbeeld van hetgeen ik op het oog heb, is te vinden in art. I.F AwbA dat strekt tot wijziging van art. 4:5 Awb; inhoudende dat aanvrager door het bestuur kan worden verplicht tot het maken van een samenvatting. Deze verplichting, die bij verzaken tot niet-ontvankelijkheid van de aanvrager kan leiden, kan worden opgelegd indien "de aanvraag of een van de daarbij behorende gegevens of bescheiden omvangrijk of ingewikkeld is".

Meer in het algemeen moeten we naar mijn mening op basis van het beginsel van correcte bejegening ${ }^{171}$ aannemen dat het bestuur een zorgplicht heeft in het inhoudelijk toegankelijk maken van relevante stukken. Uit dit beginsel vloeit in elk geval voort dat de burger wordt geïnformeerd over de inhoud van rapporten en adviezen waarop een beslissing steunt. ${ }^{172}$ Meer in het algemeen vordert dit beginsel, naar mijn smaak, dat het bestuur er toe bijdraagt dat burgers een realistische inschatting kunnen maken van de gevolgen van een (gevraagd of voorgenomen) bestuursbesluit op hun rechts- of belangenpositie. In zekere mate dringt zich hier een vergelijking op met het verde-

167. Dit is strikt genomen meer een negatieve-populaire versie: dat wil zeggen een gekuiste versie.

168. Zie ook AGRvS 20 november 1989, M\&R'91/9, nr. 106 m.nt. Jans.

169. Ibidem

170. Ibidem.

171. Zie hierover $\$ 6.2 .2$.

172. ARRvS 9 maart 1978, AB'79, 55 m.nt. v.d. v. Zie ook Nicolai, prft. a.w.. p. 328. 
digingsbeginsel in de contentieuze fase. ${ }^{173}$ Ik stel overigens wel vast dat het beginsel van correcte bejegening minder ver reikt dan de gedachte van "equality of arms". Er is immers (nog) geen sprake van een geschil.

Populaire versies van relevante stukken kunnen de niet-deskundige burger wellicht tot het inzicht brengen dat zijn positie mogelijk in het geding is, voor een actieve beïnvloeding van de besluitvorming is meer nodig. Naar mijn oordeel is het nodig dat een burger zich in de non-contentieuze fase met een deskundige kan verstaan. Ook dat is naar mijn mening een consequentie van het beginsel van een correcte bejegening. In het voorgaande hoofdstuk (onder \& 6.3.4.3 en \& 6.6.1) wees ik er op dat een bescheiden voorziening passend kan zijn. Van de burger behoeft in de non-contentieuze fase geen bewijsvoering te worden verwacht. Een meer passieve deskundigen-ondersteuning lijkt mij mitsdien toereikend - maar ook stellig noodzakelijk. Mij dunkt toch dat een regeling moet worden ontwikkeld die er in voorziet dat belanghebbenden ${ }^{174}$ in de gelegenheid worden gesteld zich oriënterend met een onafhankelijke deskundige te verstaan. Als minimale variant denk ik aan de mogelijkheid dat een onafhankelijke deskundige aanwezig is bij de in art. 3:25 eerste lid Awb voorziene gedachtenwisseling. Een wat meer uitgebreide variant zou neerkomen op de mogelijkheid tot individuele consultatie. ${ }^{175} \mathrm{De}$ voor burgers - denkelijk - meest optimale variant, een vaste vergoeding voor een oriënterend consult bij een milieudeskundige naar eigen keuze, lijkt mij bovenmatig. De kosten (en procedures) die dit meebrengt lijken mij als regel te omvangrijk, terwijl er ook de verkeerde suggestie van uit zou kunnen gaan, te weten dat het reeds in de non-contentieuze procedure nodig is een eigen bewijsvoering te ontwikkelen.

Gaan we uit van een onafhankelijke deskundige dan lijkt het mij wenselijk dat hiervoor een bepaalde institutionele garantie wordt ontwikkeld. Ik zie hiervoor grosso modo twee modellen.

De eerste mogelijkheid is dat een vaste, onafhankelijke, regionaal gespreide organisatie van milieu-deskundigen met deze taak wordt belast. Deze organisatie zou als een soort van milieu-raadsman in de gewenste ondersteuning kunnen voorzien. Mijns inziens zou de huidige inspectie milieuhygiëne (waarover meer in de volgende paragraaf), mits werkelijk onafhankelijk (en

173. Vgl. hierover Waard, B.W.N. de, a.w., p. 245 e.v.

174. Of, ter keuze van de regelgever, een ieder. Het bekostigingsperspectief brengt me ertoe van het minimale uit to gaan: een voorziening voor althans diegenen die een "rechtsbeschermingsbelang" hebben. Overigens heeft hantering van een belanghebbendheidscriterium hier mogelijk weer een "conflictopwekkend" karakter.

175. Mondeling; in een meer uitgebreide variant zelfs uitmondend in een klein oriēnterend verslag. 
dus onder meer verzelfstandigd van het ministerie), deze taak op zich kunnen nemen. ${ }^{176}$

De tweede mogelijkheid is gebaseerd op de organisatie van de Cmer. ${ }^{17} \mathrm{Er}$ wordt een milieu-advies-instituut opgericht dat bestaat uit een landelijk presidium en een groot aantal milieudeskundigen als leden. Per geval wordt een lid gevraagd de ombudsfunctie waar te nemen. Door een nauwkeurige selec$t_{i}{ }^{178}$ en eventueel ook door eedaflegging (en dergelijke voorzieningen meer) moet worden gewaarborgd dat de individuele deskundigen onafhankelijk optreden.

Een nadere studie zou nodig zijn om de diverse varianten op hun mogelijkheden en aantrekkelijkheden te onderzoeken. Hier volsta ik met het signaleren van de noodzaak van een cliëntgerichte "milieu-adviesfunctie" en met het opperen van enkele mogelijkheden daartoe.

Vooralsnog ben ik geneigd het eerste model te propageren. De veelheid van procedures, maakt het aantrekkelijk de hier bedoelde "milieu-adviesfunctie" te laten vervullen door een strakker georganiseerd professioneel verband. ${ }^{179}$

\subsection{Vaste deskundigen}

\subsubsection{Inleiding}

In het voorgaande hoofdstuk heb ik, in het verlengde van de vierde vuistregel nog een tweede uitwerkingspunt opgeworpen. ${ }^{180}$ Dit punt behelst de vraag of het bij technisch-complexe besluitvorming aantrekkelijk zou zijn een onafhankelijke vaste deskundige te betrekken. Meer concreet kan daarbij worden gedacht aan een adviesrecht terzake van het door een bestuursorgaan uitgebrachte ontwerp-besluit.

De ratio van een dergelijke vaste, onafhankelijke adviseur ligt vooral in het specifieke karakter van het desbetreffende "probleemveld" - zulks in termen

176. Op de onathankelijkheid van de milieu-inspectie kom ik hieronder nog terug.

177. Zie art. 2.17-2.24 Wm, i.h.b. art. $2.21 \mathrm{Wm}$.

178. $\mathrm{Bij}$ de benoeming tot lid maar ook bij het van geval tot geval selecteren van de af te vaardigen persoon of personen.

179. Jaarlijks gaat het om duizenden procedures. Dat is wel wat anders dan de taakstelling waar de Cmer voor staat.

180. Een kritisch oog op de stand van wetenschap en techniek vergt een deskundige blik. Overigens is hiermee ook de vijfde vuistregel (omgaan met niet-wetenschappelijke waarden) in het geding. 
van de technisch-wetenschappelijke complexiteit of dynamiek. ${ }^{181}$ In dergelijke gevallen is feitenvaststelling een lastige aangelegenheid, die zich voor sommige bestuursorganen op z'n zachtst gezegd op de toppen van de tenen voltrekt. Het is mitsdien nuttig om over een vaste deskundige te beschikken die bij uitstek is gespecialiseerd in het desbetreffende kennisdomein, en die mitsdien een goed oordeel kan geven over de stand van wetenschap en techniek. Dit geldt in nog sterkere mate als bij het besluit vele belangen zijn betrokken en fouten in de feitenvaststelling grote - ernstige - gevolgen kunnen hebben.

Mijn vertrekpunt voor analyse is overigens uitdrukkelijk dat het bestuur in beginsel eigenmachtig tot feitenvaststelling in staat moet worden geacht - al zou het maar zijn in het vermogen om een door een externe deskundige gemaakt "effectrapport" als feitenvaststelling te autoriseren. ${ }^{182}$ Hieruit volgt dat de door mij bedoelde vaste-deskundige een onafhankelijke, ondersteunende taak moet hebben. Er van uitgaande dat het bestuur in beginsel op zijn feitenvaststellende taak is berekend, geeft de vaste-deskundige een oordeel over (om het maar in m.e.r.-termen te zeggen) de juistheid en volledigheid van concrete feitenvaststellingen. Aldus krijgt het bestuur, dat vooreerst zelfstandig de feiten vast stelt ${ }^{183}$ een nuttige spiegel voorgehouden. Op basis van het advies van de vaste deskundige kan de ontwerp-feitenvaststelling eventueel nog worden aangepast.

De voordelen van een dergelijk vast adviseurschap zijn ook door de wetgever al wel erkend, getuige bij voorbeeld de Cmer. Ik stel mij voor dat bij besluitvorming over alle Wm-vergunningaanvragen, dus zelfs als er geen m.e.r.plicht in het geding is, een vaste deskundige een nuttige functie zou kunnen vervullen. Daarvoor pleit naar mijn smaak dat met de komst van (meer en meer) algemene regels voor categorieën van inrichtingen, de Wm-vergunningplicht alleen nog voor de complexe inrichtingen (of de complexe aspecten van inrichtingen) van kracht zal blijven. Ik ben me er daarbij van bewust dat "complex" iets anders kan zijn dan "met mogelijk belangrijke nadelige gevolgen voor het milieu" - zoals het algemene m.e.r.-plichtigheidscriterium luidt. Toch blijft er een groep van Wm-plichtige inrichtingen die niet m.e.r.plichtig is, maar toch voldoende eigen-aardig (heterogeen) is of waarvoor

181. In deel I heb ik geprobeerd duidelijk te maken dat complexiteit en dynamiek in de milieuproblematiek hand in hand lijken te gaan.

182. Een kwestie van de eerste vuistregel: het bestuur is verantwoordelijk en moet die verantwoordelijkheid dus ook kunnen waarmaken. Is het bestuur hiertoe (structureel) niet in staat dan is dit reden tot versterking van het eigen apparaat of tot herverdeling van bevoegdheden.

183. $\mathrm{Zij}$ het op basis van gegevens van de vergunningaanvrager, van andere belanghebbenden en (eventueel) de bevindingen van een "ingehuurde" deskundige... 
geldt dat de inzichten in de daaraan verbonden effecten (of de aanpak daarvan) onvoldoende bestendig zijn. ${ }^{184}$ Juist voor die groep, waar maatwerk kennelijk noodzakelijk is, kan vaste deskundigheid een goede bijdrage leveren.

$\mathrm{Nu}$ gaat het hierbij om aantallen besluiten die vele malen boven het aantal m.e.r.-plichtige besluiten zullen liggen. Het beoogde vaste adviseurschap zou daarmee het organisatorisch vermogen van de Cmer (hoogstwaarschijnlijk) te boven gaan. ${ }^{185}$ Naar organisatorische opzet en aanwezige expertise zou een organisatie als de milieu-inspectie, met een hoofdinspectie en (daaronder) regionale inspecties, goed in het bedoelde profiel passen. Dat geldt echter niet voor de taakstellingen en de onafhankelijkheid van de inspectie.

Ik wil dat laatste punt hier met een kleine vergelijking tussen de Cmer en de milieu-inspectie nader adstrueren. Daarmee neem ik de Cmer impliciet als een voorlopig "standaard-model" voor een vast en onafhankelijk adviseurschap in de non-contentieuze besluitvorming. Na een vergelijking met de milieu-inspectie zal ik nog op de contouren van dit model terugkomen.

\subsubsection{Vergelijking Cmer - milieu-inspectie}

De onafhankelijkheid van de Cmer is gewaarborgd door de bepalingen van art. 2.17 en volgende $\mathrm{Wm}$. Benoeming en ontslag van (plaatsvervangende) voorzitter(s) en de overige leden van de Cmer worden geregeld in art. 2.19 Wm.

Voorop staat, volgens art. 2.19 eerste lid $\mathrm{Wm}$, dat de commissie bestaat uit "deskundigen op het gebied van de beschrijving, de bescherming en de verontreiniging en aantasting van het milieu en op het gebied van de overeenkomstig art. 7.2 en $7.6 \mathrm{Wm}$ aangewezen activiteiten". Deskundigheid staat voorop en impliciet vloeit daaruit reeds de vereiste van onafhankelijkheid van de leden van de Cmer voort. Van belang is hierbij voorts art. $2.21 \mathrm{Wm}$ : de voorzitter stelt na overleg met de plaatsvervangend voorzitters, per geval waarin advies moet worden uitgebracht over ontheffing of een MER, een werkgroep samen uit de leden van de $\mathrm{Cmer}$, die aan het bevoegd gezag advies uitbrengt. Het bevoegd gezag heeft geen invloed op de samenstelling van de werkgroep. ${ }^{186}$ Uitdrukkelijk stipuleert het tweede lid van art. 2.21 $\mathrm{Wm}$ dat de leden van de werkgroep niet rechtstreeks betrokken mogen zijn

184. Juist het gebrek aan homogeniteit van aard en bestendigheid in beschikbare relevante kennis maakt ze ongeschikt voor algemene regelgeving.

185. Vergelijk de (soortgelijke) opmerking die ik hierboven over de vaste-adviseur ten behoeve van betrokken burgers maakte.

186. Uit de jaarverslagen van de Cmer, 1984 en 1985, respectievelijk p. 17 en p. 4, blijkt dat hierover op een bepaald moment in de wetsgeschiedenis anders werd gedacht. 
geweest bij de activiteit waarvoor een MER moet worden gemaakt (of de alternatieven daarvoor). ${ }^{187}$ Hetzelfde geldt ook voor eventueel door de werkgroep in te huren externe deskundigen (aldus art. 2.21, vierde lid). ${ }^{188}$

De positie van de inspecteur milieuhygiëne vindt z'n grondslag in de Gezondheidswet (Gzw). ${ }^{189}$ Art. 38, eerste lid Gzw. stelt dat er éen hoofdinspecteur voor de milieu-inspectie bestaat. Ingevolge het tweede lid van dit artikel en art 4 van het Besluit tot vaststelling van de ambtsgebieden van de regionale inspecteurs van de volksgezondheid ${ }^{190}$ zijn er negen regionale milieu-inspecteurs. ${ }^{191}$

Krachtens art 38 eerste lid Gzw. zijn de minister van VROM en de Directeur-Generaal van het Directoraat-Generaal Milieubeheer bevoegd de hoofdinspecteur aanwijzingen te geven. Het tweede lid van dit artikel voorziet in de mogelijkheid dat de hoofdinspecteur aanwijzingen geeft aan de regionale inspecteurs. Aldus ontstaat een "getrapte aanwijzingsbevoegdheid. ${ }^{192}$ Omdat daarnaast sprake is van aan de inspecteurs bij wet geattribueerde bevoegdheden, ${ }^{193}$ rijst het vermoeden van een relatief onafhankelijke positie van de inspecteurs.

Nochtans moet - met Bröring ${ }^{194}$ - worden aangenomen dat de regionale milieu-inspecteurs "rechtens hiërarchisch ondergeschikt zijn aan de minister". ${ }^{195}$ Ook in feitelijke zin wordt het doen en laten van de milieu-inspectie sterk beïnvloed door het beleid van de minister van VROM. ${ }^{196}$

187. Zie ook het derde lid van art. $2.21 \mathrm{Wm}$.

188. Mijns inziens had de onafhankelijkheidseis wel wat scherper gesteld mogen worden: ook indirecte betrokkenheid zou prohibitief moeten zijn voor deelname aan een werkgroep.

189. Wet van 18 januari 1956 , Stb 51 .

190. Besluit van 20 januari 1964, Stb 25, gewijzigd bij besluit van 13 december 1985, Stb. 740 .

191. Zie hierover nader Bröring, H.E., et al., a.w., p. 14 e.v.

192. Omdat de milieu-inspectie eigenlijk een onderdeel is van het Staatstoezicht op de volksgezondheid spreekt art. $38 \mathrm{Gzw}$, over de minister van en de D-G. Volksgezondheid, doch hiervoor is bij de kabinetsformatie van 1982 een regeling getroffen. $\mathrm{Vgl}$. Bröring, Kroonberoepen, a.w., p. 175 en Heldeweg, M.A., Inspectie milieuhygiëne: rijksheer in de regio of kleine zelfstandige?, Bestuur'86/1, p. 26- 29.

193. Vgl. het advies en ambtelijk beroepsrecht o.g.v. art. $3: 23$ eerste lid jo art. $3: 15$ Awb jo art. 8.7 $\mathrm{Wm}$ en art. 20.6 tweede lid onder b Wm (zoals dit zal komen te luiden na invoering van de Awb).

194. Kroonberoepen, a.w., p. 175-178.

195. Ibidem. Attributie heft de ondergeschiktheidsrelatie niet op; onafhankelijkheid van inspecteurs is blijkens de MvT en de MvA bij art. $38 \mathrm{Gzw}$. juridisch slechts t.a.v. geneeskundige-inspecteurs bedoeld. $\mathrm{Vgl}$. Ambtenarengerecht Utrecht, 14 juni 1971, AB'72, 216 (Willem Amtzhoeve) en ARRvS 11 februari 1983, AB'317.

196. Heldeweg, Inspectie milieuhygiëne, a.w., p. 28-29. Bröring, Kroonberoepen, a.w., p. 178, lijkt op dit punt terughoudender. 
Deze ambtelijk-hiërarchische ondergeschiktheid van de milieu-inspectie spoort heel nadrukkelijk met haar taakstelling.

Kijken we (ter vergelijking) eerst weer naar de Cmer dan zien we dat deze laatste als doel heeft advies te geven inzake ontheffing van de m.e.r.-plicht en advisering inzake richtlijnen voor het MER en het MER (zelf) - vergelijk art. $2.17 \mathrm{Wm}$. Het oogmerk van deze advisering is beperkt. Bij een advies inzake het MER gaat het, als hierboven uiteengezet, om de toets van de juistheid en volledigheid. Mijns inziens kan de aard van de taakstelling van de Cmer mede worden afgeleid uit de aard van de commissie: het is een commissie van deskundigen op het gebied van de beschrijving en de bescherming van het milieu, op het gebied van de gevolgen van menselijke activiteiten in het algemeen voor het milieu, alsmede op het gebied van de aangewezen activiteiten. ${ }^{197}$ Waar de deskundigheid dat mogelijk maakt vergt hun taak dat de leden van de Cmer zich uitlaten over de gronden voor ontheffing, richtlijnen voor het MER en het MER (zelf).

Bij de milieu-inspectie is in de taakstelling, en bijgevolg in het advieswerk, sprake van een duidelijke beleidsmatige dimensie. Dit komt goed tot uitdrukking in de ratio's voor de "beleidsmatige toezichtsfunctie" van de inspectie, waarbinnen het advies- en beroepsrecht van de inspectie zijn te situeren. ${ }^{198}$ Naast de technische deskundigheid en de noodzaak van afstemming van beleid tussen lokale overheden en de centrale overheid, ${ }^{199}$ staat het motief van "de wenselijkheid van het tot gelding brengen van de medeverantwoordelijkheid van de centrale overheid voor de uitvoering van het milieubeleid". ${ }^{200}$ In het verlengde daarvan kan worden aangenomen dat 's rijks milieu-richtlijnen, niet alleen naar hun technische inhoud maar ook naar hun beleidsmatige optiek de advisering door de milieu-inspectie zullen beïnvloeden.

Het beleidsaspect in het werk van de milieu-inspectie treedt ook in de bevoegdheid tot het instellen van beroep tegen een beslissing op vergunningverlening op de voorgrond.

Anders dan de Cmer, die slechts de bevoegdheid tot advisering heeft, heeft de milieu-inspectie ook nog een ambtelijk beroepsrecht. Op de uitoefening van dit recht is de zogenoemde "Groen-licht regeling" van toepassing. Deze regeling is gebaseerd op de anwijzingsbevoegdheid ex art. 38 eerste lid

197. MvT, p. 80: de laatstgenoemde categorie zal ook het realiteitsgehalte van de beschreven alternatieven moeten kunnen toetsen (ibidem).

198. Bröring, Kroonberoepen, a.w., p. 16-17, onderscheidt voorts nog de interne adviesfunctie (t.b.v. de minister), de externe adviesfunctie (dienstverlening), de strafrechtelijke toezichts- en opsporingsfunctie en enkele "overige" functies.

199. De inspectie als "beleidsgericht intermediair", Bröring, Kroonberoepen, a.w., p. 16.

200. Ibidem, p. 17. Uit de MvA (Wabm), TK'79-'80, 14 311, p. 35, blijkt duidelijk dat dit motief niet alleen het beroeps- maar ook het adviesrecht schraagt. 
$\mathrm{Gzw}^{201}$, en houdt in dat een regionale-inspecteur die tegen een beslissing in beroep wil gaan, daarvoor toestemming nodig heeft van de minister van VROM. De minister stemt met een verzoek daartoe slechts in, indien de aangevochten beslissing het rijksbeleid terzake op onaanvaardbare wijze zou doorkruisen. ${ }^{202}$ Duidelijk is dat de inspecteurs hier effectief gebonden zijn aan de minister van VROM. ${ }^{203}$ Tegelijkertijd ligt het voor de hand dat van deze regeling een zekere reflexwerking uitgaat: ook het advieswerk wordt er door beïnvloed. ${ }^{204}$

Mij dunkt dat de milieu-inspectie gelet op haar taakstelling en afhankelijkheid van de minister van VROM, niet past in het standaard-model voor een vaste, onafhankelijke adviseur.

Naar mijn mening past het ook niet goed dat een vaste advies-instantie een eigen beroepsrecht heeft. Daarmee verschuift de taakstelling van een adviseur te zeer in de richting van het beleid. De adviseur gaat zich er dan immers op bezinnen of een bestuursbesluit wel voldoende tegemoet komt aan een door hem gegeven advies. Bestuurlijke afwegingen inzake onzekerheidsmarges in de feitenvaststelling kunnen dan - bij voorbeeld - een rol gaan spelen. Ook zal de adviseur al snel een beleid moeten gaan ontwikkelen aan de hand waarvan bepaald wordt of een zaak "beroepswaardig" is. Mijn vrees is dat een vaste adviseur zich daarmee weldra over het gewicht van bepaalde milieubelangen of -aspecten zal gaan uitlaten, of althans de schijn zal opwekken dat te doen. Een adviseur moet adviseren; and that's it! Als een advies van een vaste adviseur wordt genegeerd kan zulks bij het onderzoek in beroep ambtshalve of door toedoen van een appellant ter tafel komen. Alsdan zal de rechter, zo het beroep dit meebrengt, zich hiervan rekenschap moeten geven. Voorwaarde is wel dat het advies (actief) openbaar wordt gemaakt!

\subsubsection{Taakstelling en ratio}

Daarmee zijn we eigenlijk al op het punt aangekomen van de takstelling van een vaste adviseur. Mij dunkt dat advisering door een vaste adviseur bij Wmvergunningverlening, net als bij de Cmer, in termen van een toets op juistheid en volledigheid zou moeten plaatsvinden. Naar mijn smaak zou het vooral moeten gaan om een soort van "meta-advies": de stand van weten-

201. Bröring, Kroonberoepen, a.w., p. 185: Heldeweg, Milieu-inspectie, a.w., p. 28.

202. Ibidem.

203. Bröring, Kroonberoepen, a.w., wijst er - terecht - op dat de inspecteur ook zonder toestemming van de minister in beroep kan worden ontvangen. Intern moet hij dan echter wel rekenen met rechtspositionele gevolgen.

204. Al zou het maar zijn dat een advies dat niet strookt met het rijksbeleid, waarschijnlijk niet in beroep kan worden doorgezet. 
schap en techniek is immers de primaire toetssteen voor het advies. Dit brengt mee dat een vaste adviseur ook in het bijzonder gespitst zal moeten zijn op nieuwe inzichten. Als expert mag dat van hem ook worden verwacht. ${ }^{205}$

Tegelijkertijd meen ik dat een vaste, onafhankelijke adviseur in milieuzaken in zijn adviezen het streven naar de hoogst mogelijke milieubescherming zou moeten laten doorklinken. De toets van de volledigheid van de bestuurlijke ontwerp-feitenvaststelling brengt dit naar mijn smaak ook mee. In art. 8.11 $\mathrm{Wm}$ is immers ook tot uitdrukking gebracht dat bij vergunningverlening het Alara-beginsel uitgangspunt moet zijn. ${ }^{206} \mathrm{Mij}$ dunkt dat de vaste adviseur, zonder dat hij daardoor beleidsadviseur wordt, in zijn adviezen aandacht zou moeten besteden aan de vraag of het "meest milieuvriendelijke alternatief" in de feitenvaststelling aan de orde komt, of althans daaruit is te destilleren. ${ }^{207}$ Hoewel ik mij kan voorstellen dat een vaste adviseur juist terzake van het meest milieuvriendelijke alternatief enig aanvullend onderzoek verricht (of laat verrichten), is mijn uitgangspunt dat hij niet zelfstandig moet gaan doen aan alternatieve feitenvaststelling. Hier geldt wat mij betreft hetzelfde als ik opmerkte over de non-contentieuze bewijslast van burgers: als de ontwerpfeitenvaststelling gebrekkig is volstaat het de gebreken aan te wijzen, dat wil zeggen aannemelijk te maken dat er gebreken zijn. De verantwoordelijkheid van het bestuur voor de feitenvaststelling brengt mee dat ze zich bezint op "aannemelijke kritiek".

Deze taakstelling sluit naar mijn smaak goed aan bij de ratio's voor het vaste, onafhankelijke adviseurschap. ${ }^{208}$ Toch is het goed de mogelijkheid van een vast-adviseurschap nog eens uitdrukkelijk te vergelijken met twee alternatieven.

\subsubsection{De oplossing in de markt}

Allereerst rijst de vraag of het niet mogelijk is de gezochte ("meta"-)expertise uit de markt te betrekken; dat wil zeggen bij commerciële en niet-commerciële milieu-adviesbureaus of -instanties ("consultants" en wat dies meer zij). In feite praten we dan over vaste contra-expertise en niet over vast-adviseurschap: er wordt wel steeds een advies gevraagd over de ontwerp-feitenvaststelling, maar niet steeds aan dezelfde adviseur. Bestuursorganen, die deze markt van milieu-expertise ook regelmatig opgaan voorafgaand aan het ont-

205. Indachtig de vierde vuistregel.

206. Ik sprak hierover reeds in hoofdstuk 3.3. In $\$ 7.5 \mathrm{komt}$ dit beginsel nogmaals ter sprake.

207. Inhoudelijk sluit dit vrij nauw aan op de Cmer.

208. Contra-expertise door een gespecialiseerde expert ter ondersteuning van het bestuur bij de feitenvaststelling in technisch-complexe besluitvorming. 
werp-besluit ten behoeve van het onderzoek naar de feiten en belangen, zouden het ontwerp-besluit in deze benadering ook telkenmale ${ }^{209}$ kunnen voorleggen aan een (andere) adviseur uit de markt, met het verzoek dit te toetsen op juistheid en volledigheid.

Een voordeel hiervan is dat voorkomen wordt dat een vaste deskundige zich als het ware ontwikkelt tot monopolist, zonder wiens instemming de feitenvaststelling in elk geval niet zal worden geaccepteerd door de rechter. ${ }^{210}$

Hoewel ik meen dat we zeer waakzaam moeten zijn voor dergelijke vormen van monopolisme, zie ik toch overwegende bezwaren tegen het marktmodel. Allereerst vrees ik dat de waarborgen voor de onafhankelijkheid van dit vaste advies niet voldoende hard kunnen zijn. Zelfs als daarvoor (landelijke) voorselectie worden gemaakt, ${ }^{211}$ is het steeds het bestuur dat de deskundige voor het vaste-advies aanwijst (en dat ervoor betaalt ${ }^{212}$ ). Last but not least is natuurlijk denkbaar dat een deskundige die op enig moment wordt gevraagd een vast advies te geven, op een ander moment in de markt is om het bestuur, voorafgaand aan het ontwerp-besluit te assisteren bij het onderzoek naar feiten en belangen. Daarmee dreigt, zeker bij besluiten van groot bestuurlijk gewicht, toch altijd een zekere belangenverstrengeling.

Naast deze bezwaren tegen vaste-adviezen vanuit de markt, meen ik dat de gevaren van monopolisme ook afgewogen moeten worden tegen de voordelen van een organisatorische bundeling van expertise.

In de eerste plaats moet bedacht worden dat het vaste-advies toch een eigensoortig karakter heeft. Enerzijds door het meta-karakter ervan: de stand van wetenschap en techniek moet als toetssteen worden aangelegd (en dat is meer dan alleen nagaan wat de "gangbare opvattingen" zijn, maar omvat ook kennis van "afwijkende" of nieuwe inzichten). Anderzijds doordat de volledigheidstoets ook een bezinning vereist op het normatieve kader van de feitenvaststelling (en de besluitvorming als geheel). Wat dat laatste betreft; mij lijkt het vanzelfsprekend dat een wettelijke adviseur (als hier bedoeld) zich niet alleen oriënteert op wettelijke normen maar ook op pseudo- of buitenwettelijke technische normen (zoals die uit richtlijnen). Dit veronderstelt dat de vaste adviseur naast aandacht voor de stand van wetenschap en techniek ook aandacht heeft voor voortschrijdende technische normstelling in het milieurecht. Een vaste organisatie lijkt meer op een dergelijke taak berekend; wat niet wegneemt dat ook zo'n organisatie regelmatig zelf externe adviezen zal

209. Dus niet alleen als de door het bestuur ten behoeve van de feitenvaststelling ingehuurde adviseur en het bestuursorgaan van mening verschillen (zie het voorgaande hoofdstuk).

210. Over dit gevaar bij advisering aan rechters kom ik in het volgende deel van deze studie nog te spreken.

211. Een soort van "onafhankelijkheidskeur" (samen met een "deskundigheidskeur" wellicht).

212. Hoewel dat wellicht met een landelijk systeem is te ondervangen. 
inwinnen. Dat laatste kan overigens ook juist in groter organisatorisch verband (meer) zin hebben, omdat op meerder plaatsen tegelijk geadviseerd moet worden. Extern advies inwinnen kan dan "uit", en draagt effectiever bij tot kennisontwikkeling.

Dat laatste (de groei in kennis) is ook van belang bij een tweede voordeel van een vaste-adviesorganisatie: deze instantie is als organisatie aanspreekbaar op z'n taakvervulling. Door zich uitdrukkelijk voor kritiek open te stellen door openbaarmaking van rapporten en publikatie van een jaarverslag (of themaverslagen) - iets dat ook wettelijk zou moeten worden geregeld wordt groei van kennis gestimuleerd en kan onafhankelijkheid worden gewaarborgd. Ik ben van mening dat onafhankelijkheid van het advies in het model van een vaste-adviesinstantie beter is gewaarborgd dan bij het model van vaste-advisering vanuit de markt. ${ }^{213}$

Ten slotte meen ik dat gegeven het beoogde meta-karakter van het advies en de plaats van het advies de vrees voor een al te rigide doorwerking ervan in de contentieuze procedure ongegrond is. Het advies is immers primair signalerend van aard en biedt dus geen kant en klare set van alternatieve voorwaarden en voorschriften - klaar om door de rechter als richtsnoer te worden toegepast. Doordat het advies wordt opgemaakt naar aanleiding van het ontwerp-besluit is het bovendien aan het bestuur om nog tot bijstellingen te komen of nader te motiveren waarom het blijft bij het ontwerp. Het vasteadvies is naar aard en moment van verschijnen veel meer dan het huidige ambtsbericht in milieuzaken (zie deel IV van deze studie) ingebed in het proces van voorbereiding van een besluit.

\subsubsection{Een vast advies aan de rechter}

Daarmee zijn we bij een tweede alternatief: afzien van vaste-advisering in de non-contentieuze procedure en vaste-advisering beperken tot advisering aan de rechter. In het bestuursprocesrecht kan immers goed worden voorzien in een vast-adviesrecht van een onafhankelijke instantie: een onafhankelijk advies aan een onafhankelijke instantie.

Ik ben van deze gedachte geen voorstander omdat er te zeer de idee van de contentieuze procedure als "verlengde besluitvorming" in doorklinkt. Voor mij staat voorop dat de non-contentieuze procedure zelf een afgerond geheel moet zijn, met een afgerond resultaat. Daarbij houd ik het er op dat het primaat van de feitenvaststelling dient te liggen bij het bestuur èn in de noncontentieuze procedure. Feitenvaststelling dient daar te geschieden waar de politieke verantwoordelijkheid wordt genomen op basis van een afweging van

213. Wat mij betreft zou er ook een periodieke (parlementaire) controle van zo'n adviesinstantie moeten plaatsvinden. 
belangen in de context van praktische onzekerheden. Een context bovendien die zich bij uitstek leent voor een open uitwisseling van opvattingen en argumenten. Juist in die context kan het vaste-advies een zeer nuttige rol vervullen.

Bezien we het genoemde argument vanuit de contentieuze "kant", dan zijn er evenzeer overwegende bezwaren aan te wijzen. Allereerst is daar een zeer praktisch argument: als slechts in de contentieuze fase is voorzien in een vast-advies, zou dat wel eens een geschilopwekkende invloed kunnen hebben. Zij die in de feitenvaststelling nog niet geheel tevreden gesteld zijn - misschien wel juist omdat zij menen dat deze "partijdig" is - gaan in beroep om nog een onafhankelijk advies te vernemen. Duidelijk mag zijn dat juist in de non-contentieuze procedure zo'n element van onafhankelijkheid aanwezig moet zijn. Voorts zie ik met name in de contentieuze procedure het gevaar van een al te dominante rol van een vast-adviseurschap. Anders dan menig bestuursorgaan ontbeert de rechter een ambtelijk apparaat dat hem de kritische reflexie geeft die ook ten aanzien van een onafhankelijk advies geboden is. Daarbij is juist in de contentieuze fase de druk groot om zo mogelijk het geschil volledig te beëindigen. Als in de non-contentieuze fase geen onafhankelijk advies is gegeven is de neiging al snel groot om op basis van een vastadvies aan de rechter tot een integrale hertoetsing en hervaststelling van de feiten over te gaan. Daarmee zou de rechter de facto het primaat van het bestuur in de feitenvaststelling gaan doorkruisen. Niet hervaststelling van de feiten maar een toetsing van de bestuurlijke feitenvaststelling is echter aan de orde. ${ }^{214}$ De rechter heeft zich te beraden op de zorgvuldigheid en "nietonredelijkheid" van de feitenvaststelling. Daarbij zal hij zich - desgevraagd kunnen beroepen op het vast-advies uit de non-contentieuze-procedure. ${ }^{215}$

\subsubsection{Conclusie}

Volgens de vierde vuistregel uit het tweede deel van deze studie is contraexpertise van groot belang in technisch ingewikkelde feitenvaststelling. In het voorgaande hoofdstuk kwam ik op voet daarvan tot de gedachte van het vaste-adviseurschap. Mij dunkt dat zo'n vast-adviseurschap bij Wm-vergunningverlening zeer wel op z'n plaats is. Daartoe zou naar mijn smaak in de $\mathrm{Wm}$ een vaste-adviseur aangewezen moeten worden, die overeenkomstig art. 3:23 Awb jo art. $8.7 \mathrm{Wm}$ advies kan uitbrengen. Organisatorisch ware te overwegen de milieu-inspectie om te bouwen tot de hierbij beoogde onaf-

214. Ik zou wel haast van "natoetsing" willen spreken.

215. Nota bene: ik zie er geen bozwaar in dat de rechter, als er een vast en onafhankelijk noncontentieus advies is. terzake van de in beroep opgeworpen bestrijding van de feitenvaststelling nog een gericht vast-advies ontvangt. 
hankelijke organisatie, nader te regelen in Hoofdstuk $2 \mathrm{Wm}$ (Adviesorganen). ${ }^{216}$ Ook is denkbaar dat de Cmer wordt uitgebouwd tot een organisatie met regionale vertakkingen (of althans taakverdelingen) en met een substantiële, vaste groep medewerkers.

Ik acht het niet problematisch om de hier bedoelde organisatie tevens te belasten met de adviesfunctie ten behoeve van particulieren. Dat advies is er immers "slechts" op gericht zichtbaar te maken welke de gevolgen zullen zijn van het ontwerp-besluit en of het ontwerp gemeten aan de stand van wetenschap en techniek wellicht feilen vertoont. Daarbij is geen sprake van een bijzondere adviseur-cliënt-relatie. Inhoudelijk zie ik dan ook geen doorkruising van het werk als vaste-adviseur. ${ }^{217}$

\subsection{Reductie van onzekerheid}

\subsubsection{Inleiding}

In Hoofdstuk 4 wees ik op het belang van reductie van onzekerheid.

Simon geeft daartoe een aantal strategieën aan: ${ }^{218}$

- het bevorderen van de kwaliteit van voorspellingen;

- het aanhouden van "buffers", c.q. veiligheidsmarges, verzekeringen en compenserende maatregelen;

- het "isoleren" van (milieugevoelige) activiteiten (ter voorkoming van reacties met externe factoren);

- het vergroten van het aantal alternatieve handelingsopties.

Mij dunkt dat deze strategieën ook in juridische normering tot uitdrukking kunnen komen. Sterker nog, ik meen dat op een aantal punten in het milieurecht reeds elementen van deze strategieen als waarborg of instrument aanwezig zijn - soms in de vorm van wettelijke regels, soms ook in een meer beginselmatige vorm. Een aantal daarvan wil ik hieronder kort belichten

\subsubsection{Het onderzoek}

De (ook hiervoor reeds) besproken waarborgen inzake de openheid van de feitenvaststelling (de mogelijkheid van contra-expertise) en de oriëntatie op de stand van wetenschap en techniek (en het onderzoek naar afwijkende of

216. In dit scenario zou voor het beleidsmatige toezicht desgewenst een alternatief ontwikkeld moeten worden.

217. In tegendeel zou kunnen worden opgeworpen dat dit adviseren van burgers de waakzaamheid van de adviseur juist bevordert.

218. Zie Hfst. 4.3.4. 
nieuwe inzichten), vormen - in algemene zin - de basis voor het aan normstelling voorafgaande onderzoek naar de feiten. Ook de controle na normstelling, zoals bij voorbeeld de in de m.e.r.-regeling voorgeschreven evaluatie van het MER (art. 7.39 e.v. Wm) kan er toe bijdragen dat het proces van selectie, onderzoek en toetsing (zoals in hoofdstuk 4 geschetst) beter verloopt.

De door Simon eerstgenoemde strategie voor onzekerheidsreductie wordt met dergelijke waarborgen stellig gediend. Tegelijkertijd vraagt de strategie van kwaliteitsverbetering in voorspellingen om een nog bredere oriëntatie.

Binnen de samenleving als geheel zou de kennis omtrent milieu-effecten verder tot ontwikkeling moeten worden gebracht en worden verspreid onder betrokkenen of geïnteresseerden. Hier ligt stellig (ook) een overheidstaak; te weten de bevordering van het (wetenschappelijk) onderzoek in de "milieuwetenschappen". Daarnaast wijs ik op de plicht van de minister van VROM er voor zorg te dragen dat ten minste eens in de vier jaar een beschrijvend rapport wordt opgesteld over de toestand van het milieu in Nederland. Deze verplichting - neergelegd in art. 4.2, eerste lid Wm - draagt bij aan de ontwikkeling en verbreiding van expertise over milieuproblemen. Dat zelfde zou ook gezegd kunnen worden van de door mij voorgestelde vaste, onafhankelijke adviesinstantie. Ik noemde (in \$ 7.4) reeds de mogelijkheid van zo'n instantie om onderzoekingen te laten ondernemen (bij voorbeeld naar bepaalde soorten effectvoorspelling).

Het vergelijken van alternatieven kan er toe bijdragen dat een beter zicht ontstaat op de risico's van de voorgenomen activiteit. Ook wordt hierdoor een beter aanknopingspunt voor de belangenafweging verkregen. Dat geldt in het bijzonder indien er (zoals bij de m.e.r.-procedure is voorgeschreven) een "meest milieuvriendelijk alternatief" wordt beschreven; daarmee is een goede opstap voor een kosten-baten analyse gegeven. De vraag rijst of wellicht ook speciale aandacht zou moeten worden besteed aan het opstellen van een "worst case-scenario", waarbij de "meest milieu-onvriendelijke mogelijkheden"219 (per alternatief) worden geëxpliciteerd. ${ }^{220}$ De strategie tot het vergroten van het aantal alternatieve handelingsopties wordt voorts gediend, indien het doel van een activiteit zo ruim wordt geformuleerd, dat een uit milieuhygiënisch oogpunt werkelijk breed spectrum aan alternatieven ontstaat. Op dat moment kunnen brede afwegingen worden gemaakt. Dit is een punt dat bij de m.e.r.-procedure goed tot uitdrukking komt. De omschrijving van

219. Waarbij zo mogelijk ook geëxpliciteerde onzekerheden worden verdisconteerd.

220. Ik gaf al aan van een verwezenlijking hiervan in het kader van de m.e.r.-procedure niet veel te verwachten (als het nu al zo moeilijk is in het MER het "meest milieuvriendelijke alternatief" beschreven te krijgen). 
het doel van de voorgenomen activiteit was daarbij regelmatig een bron van discussie. Ook herinner ik hier nog eens aan de casus over de elektriciteitscentrale Amer 9 te Geertruidenberg, en de vraag of in het MER ook het alternatief van kolenvergassing had moeten worden meegenomen. Uit strategisch oogpunt is het aantrekkelijk indien de formulering van de doelstelling het mogelijk maakt om uit het oogpunt van milieugevoeligheid werkelijk verschillende alternatieven te kunnen uitwerken. Dit pleit op zichzelf ook voor de mogelijkheid om reeds op beleidsniveau milieu-effecten goed te onderzoeken. ${ }^{221}$ Uiteraard is het daarbij van belang dat de idee van een "duurzame ontwikkeling" in de besluitvorming meespeett, zodat alle milieu-aspecten, ook die welke zich (pas) op lange termijn of (slechts) op grote schaal doen gelden, worden verdisconteerd.

Last but not least wijs ik er op dat het zonder meer van belang is onzekerheden in (het onderzoek naar) de feitenvaststelling zo veel mogelijk te expliciteren. In de m.e.r.-regeling is dit - zoals we reeds zagen - ook voorgeschreven. 222

\subsubsection{Beginselen}

Twee milieurechtelijke beginselen acht ik van groot belang voor het omgaan met onzekerheid bij het afwegen van belangen: het ALARA-beginsel en het voorzorgsbeginsel. Het eerste beginsel beoogt aantasting van het milieubelang te voorkomen dan wel te minimaliseren, het tweede beginsel beoogt de kans op schade aan het milieubelang te minimaliseren.

\subsubsection{Het ALARA-beginsel}

Het ALARA-beginsel, ${ }^{223}$ zoals neergelegd in art. 8.11 derde lid $\mathrm{Wm},{ }^{224}$ heeft een hoog beschermingsniveau als vertrekpunt. Uitgangspunt is immers het (door middel van voorschriften) voorkomen van nadelige gevolgen voor het milieu of (het geven van voorschriften die) de grootst mogelijke bescherming bieden tegen nadelige gevolgen. Slechts indien verwezenlijking van dit

221. Afgezien van de vraag of dit daarna op uitvoeringsniveau opnieuw in de vorm van een MER dient te geschieden.

222. In art. 7.10 eerste lid onder g. Wm.

223. Dat ook reeds onder $\$ 3.3$ aan de orde werd gesteld.

224. Art. 8.11 derde lid $\mathrm{Wm}$ luidt: Aan een vergunning worden de voorschriften verbonden, die nodig zijn ter bescherming van het milieu. Voor zover door het verbinden van voorschriften aan de vergunning de nadelige gevolgen die de inrichting voor het milieu kan veroorzaken, niet kunnen worden voorkomen, worden aan de vergunning de voorschriften verbonden, die de grootst mogelijke bescherming bieden tegen die gevolgen. tenzij dat redelijkerwijs niet kan worden gevergd. Dit beginsel is van overeenkomstige toepassing verklaard op de verschillende algemene regels: vgl. art. 8.40, derde lid, art. 8.44, tweede lid en art. 8.45, tweede lid Wm. 
uitgangspunt in redelijkheid niet kan worden gevergd, kan met een minder vergaande bescherming genoegen worden genomen. ${ }^{225}$

Wat de laatste betreft moet bedacht worden dat de "tenzij dat redelijkerwijs niet kan worden gevergd"-clausule anderzijds niet mag resulteren in een te laag milieubeschermingsniveau. Wat dat aangaat kent de $\mathrm{Wm}$ een systeem van effectieve milieubescherming - verankerd in de weigeringsgrond van art. $8.10 \mathrm{Wm}$, mede in relatie tot art. $8.8 \mathrm{Wm}$ (alwaar onder meer een relatie wordt gelegd met de beleidsplanning en de milieukwaliteitseisen).

Juist in de vergelijking tot het beginsel van de best toepasbare technieken en het beginsel van de beste bestaande technieken blijkt hoe het ALARA-beginsel een extra buffer kan meebrengen.

- Het ALARA-beginsel, zoals verwoord in art. 8.11, derde lid Wm, ${ }^{226}$ voorziet mogelijk in een hoger beschermingsniveau dan het beginsel van de beste bestaande technieken, omdat ten aanzien van laatstgenoemd beginsel nog de eis wordt gesteld dat de techniek in kwestie ten minste een keer (succesvol) toegepast moet zijn; ${ }^{227}$

- Het verschil tussen het beginsel van de best toepasbare (of uitvoerbare) technieken en het ALARA-beginsel is nog groter. De best toepasbare technieken zijn de meest effectieve technieken voorzover deze voor een normaal renderend bedrijf uit economisch oogpunt aanvaardbaar zijn. Uitgangspunt is dat economische belangen en milieubelangen (in beginsel) van gelijk gewicht zijn. Het ALARA-beginsel heeft een scherper vertrekpunt doordat een hoog beschermingsniveau voorop staat en slechts krachtens toepassing van de "tenzij..redelijkerwijs"-clausule een bedrijfseconomische calculatie in beeld komt. Dit verschil kan bij vergunningverlening in een extra "buffer" resulteren. Daar staat weer tegenover dat toepassing van het ALARA-beginsel bij een slecht renderend bedrijf in theorie, juist door toepassing van de "tenzij..redelijkerwijs"-clausule, zou kunnen resulteren in een aanmerkelijke verlaging van het beschermingsniveau. ${ }^{228}$ Daarmee zou het beschermingsniveau kunnen dalen beneden het peil dat volgens het beginsel van de best toepasbare technieken zou gelden, aangezien voor de vaststelling van dat (laatste) peil wordt uitgegaan van een "nor-

225. In overeenkomstige zin: Meijden, Dick van der, As low as reasonably achievable, M\&R'91/1, p. 12-19 (i.h.b. p. 17: "voorkomen of de grootst mogelijke beperking tenzij dat redelijkerwijs niet kan worden gevergd").

226. Ik ga nu uit van die tekst en neem enige afstand van het "gegoochel" in de toelichtingen (zie \$ 3.3, waarin ook wordt verwezen naar de kritiek van Van Buuren).

227. Zie ook Van der Meijden, a.w., p. 16, die concludeert dat er voor het beginsel van de beste bestaande technieken geen rol meer weggelegd is.

228. Mits niet beneden de absolute grenzen van art. 8.10 jo art. $8.8 \mathrm{Wm}$. 
maal renderend bedrijf". Met het oog op dit laatste punt zal het beginsel van de best toepasbare technieken als vangnet moeten blijven bestaan. ${ }^{229}$

Zo beschouwd kan toepassing van het ALARA-beginsel (onder omstandigheden) resulteren in een extra "buffer"; dat wil zeggen in een streven naar een zo hoog mogelijk beschermingsniveau. Gegeven bestaande praktische onzekerheden in de feitenvaststelling wordt daarmee - naar de stand van wetenschap en techniek - althans het maximale gedaan om nadelige effecten te keren. Mocht onverhoopt blijken dat de nadelige effecten te gunstig werden geprognosticeerd, dan is in relatieve zin (ten opzichte van het uitgangspunt van de beste bestaande technieken of de best toepasbare technieken) het meest optimale uitgangspunt genomen ${ }^{230}$ - al is dat allerminst een garantie dat de gegeven voorschriften de feitelijke effecten adequaat zullen kunnen "afdekken".

\subsubsection{Het voorzorgsbeginsel}

In de Verklaring van Rio over milieu en ontwikkeling ${ }^{231}$ is het voorzorgsbeginsel opgenomen als principe 15:232 "Om het milieu te beschermen zullen staten op zo groot mogelijke schaal de voorzorgbenadering toepassen. Daar waar ernstige of onomkeerbare schade dreigt, zal het ontbreken van onomstotelijke wetenschappelijke zekerheid niet worden gebruikt als argument voor het uitstellen van rendabele maatregelen om milieuschade te voorkomen".

Het voorzorgsbeginsel is als voortvloeisel van de "no-regrets policy", ook in verschillende andere internationale "milieuverdragen" te vinden. ${ }^{233}$

Nollkaemper ${ }^{234}$ stelt in zijn analyse van het recht inzake grensoverschrijdende waterverontreiniging, dat het voorzorgsbeginsel verder strekt dan de algemene zorgvuldigheidsnorm uit het internationale recht. De algemene

229. Vgl TK'89-90, 21 087, nr 6, p. 61, en Van der Meijden, a.w., p. 15.

230. Met als exceptie de situatie waarin (wegens bedrijfsrendementen lager dan gemiddeld in de desbetreffende bedrijfstak) het "minimumbeschermingsniveau" volgens de best toepasbare technieken moet worden toegepast.

231. VN-conferentie over milieu en ontwikkeling, 3-14 juni 1992, Zie hierover de parlementaire behandeling: TK'90-'91, 22 031, nrs. 1-12.

232. Naast een 26-tal andere beginselen. Zie daarover o.m. Waller-Hunter, J.H., De VN Conferentie over milieu en ontwikkeling, M\&R $92 / 11$, p. 578-590.

233. Zoals in het Verdrag van Wenen ter bescherming van de ozonlaag, Trb.'85, 144, art. 2, eerste en tweede lid (en in het daarbij behorende protocol van Montreal betreffende stoffen die de ozonlaag aantasten, Trb.' 88 , nr. 11), alsmede in het verdrag van Helsinki, inzake de bescherming en het gebruik van grensoverschrijdende waterlopen en internationale meren, art. 2 lid 5 onder a (besproken in het in de volgende noot genoemde artikel).

234. Nollkaemper, A., Progressie en stagnatie in het internationale regime voor grensoverschrijdende waterverontreiniging, M\&R'93/1, p. 11-23. 
norm vordert dat staten maatregelen nemen teneinde voorzienbare risico's te voorkomen; het voorzorgsbeginsel vordert maatregelen, ook als de risico's niet volledig voorzienbaar zijn, wegens het ontbreken van wetenschappelijke zekerheid. De vraag die dan echter rijst is: "hoeveel onzekerheid dwingt tot preventie". ${ }^{235}$

Ik zou menen dat het voorzorgsbeginsel, mede op voet van de Verklaring van Rio, een rol kan spelen bij vergunningverlening ingevolge de $\mathrm{Wm}$ - maar dan in indirecte zin, te weten bij de totstandkoming van algemene regels en milieukwaliteitseisen, welke op grond van art. $8.8 \mathrm{Wm}$ voor vergunningverlening van belang kunnen zijn. Het voorzorgsbeginsel plaatst de belangenafweging die bij de totstandkoming van deze regels wordt verricht in de context van de wetenschappelijke onzekerheid. De aard of het gewicht van de belangen die door bepaalde (categorieën) activiteiten geschaad zouden kunnen worden, zal bij de afweging tegen het met deze activiteiten te dienen doelen, mede bepalend zijn voor de vraag bij welke mate van onzekerheid preventieve maatregelen gerechtvaardigd zijn. Als de beschermenswaardige belangen groot zijn, zoals bij bescherming van leven en ecosystemen, en er aanwijzingen zijn dat deze belangen mogelijk (onomkeerbaar) bedreigd worden, kan dit grond zijn de normen - bij wijze van voorzorg - scherp te stellen.

\subsubsection{Het voorkomen van missers}

Onzekerheid bij feitenvaststelling is "a fact of life" bij het nemen van een besluit over vergunningverlening. Dat wil zeggen dat we moeten accepteren dat we - kort gezegd - "to the best of our abilities" tot beslissingen moeten zien te komen. Bij het nemen van besluiten betekent dit dat we ons in een open proces van besluitvorming kritisch rekenschap moeten geven van de stand van wetenschap en techniek, van mogelijkheden tot reductie van onzekerheid - als hiervoor besproken. ${ }^{236}$ Alhoewel we niet tot het onmogelijke zijn gehouden, past het ons anderzijds wel om vooraf rekening te houden met de mogelijkheid dat ons handelen anders uitpakt dan we hadden verwacht. In het voorzorgsbeginsel zit deze gedachte reeds duidelijk ingebakken. We kunnen haar echter nog verder doortrekken. Dat een besluit "to the best of our abilities" is genomen, neemt niet weg dat we waarborgen kunnen inbouwen om eventuele "missers" achteraf te corrigeren.

Binnen de Wm is deze gedachte op twee plaatsen heel duidelijk uitgewerkt.

235. A.w., p. 21.

236. Een en ander in de context van een zorgvuldige en redelijke (althans niet willekeurige) besluitvorming. 
In de eerste plaats wijs ik daarbij op de evaluatie-plicht ingevolge art. 7.39 e.v. Wm. Deze regeling houdt in dat het bevoegd gezag dat een m.e.r.-plichtig besluit heeft genomen, na de start van de desbetreffende activiteit onderzoekt welke milieu-effecten feitelijk optreden. Als uit dit onderzoek blijkt dat de activiteit feitelijk "in belangrijke mate nadeliger gevolgen voor het milieu" heeft dan bij het nemen van het (m.e.r.-plichtige) besluit werd aangenomen, dan neemt het bevoegd gezag - volgens art. $7.42 \mathrm{Wm}$ - alle naar zijn oordeel noodzakelijke maatregelen om die gevolgen zoveel mogelijk te beperken of ongedaan te maken.

In het regeringsverslag inzake de m.e.r.-procedure wordt opgemerkt dat het thans nog niet mogelijk is om het gebruik van de m.e.r.-evaluatieregeling goed te evalueren. ${ }^{237}$

Voorts is hier de "actualiseringsverplichting" ingevolge art. $8.22 \mathrm{Wm}$ van belang. Dit artikel verplicht het bevoegd gezag om regelmatig te bezien in hoeverre verleende vergunningen nog adequaat zijn. Als "blijkt" dat de verleende vergunningen in het licht van "de ontwikkelingen op het gebied van de technische mogelijkheden tot bescherming van het milieu" kunnen of, in het licht van "de ontwikkelingen met betrekking tot de kwaliteit van het milieu" moeten worden beperkt, gaat het bevoegd gezag over tot wijziging van de beperkingen waaronder de vergunning is verleend of tot wijziging, aanvulling of intrekking van de vergunningvoorschriften - aldus het tweede lid van art. $8.22 \mathrm{Wm}$. Men kan gerust spreken van een betrekkelijk imperatieve bevoegdheid. Niet onbelangrijk is daarbij dat ingevolge het vierde lid van art. 8.22 Wm, bij het actualiseren van vergunningen het ALARA-beginsel moet worden toegepast. Daarmee is ook voor de actualisering het uitgangspunt gelegen in het streven naar een hoog beschermingsniveau, c.q. naar het voorkomen van nadelige gevolgen voor het milieu. ${ }^{238}$

Geheel of gedeeltelijke intrekking van een vergunning is (onder andere) mogelijk als een inrichting ontoelaatbaar nadelige gevolgen voor het milieu veroorzaakt en actualisering van de vergunning (als bedoeld in art. $8.23 \mathrm{Wm}$ ) geen soelaas biedt. Michiels ${ }^{239}$ wijst er op dat het woordje "ontoelaatbaar" weliswaar doet vermoeden dat hier sprake is van een plicht, maar dat hier, mede in het licht van het rechtszekerheidsbeginsel, ${ }^{240}$ slechts sprake is van een bevoegdheid.

237. A.w., p. 18.

238. Zie ook Van der Meijden, a.w., p. 18.

239. Michiels, a.w. (1992), p. 62-63.

240. En door het gebruik van het woordje "kan" in de aanhef van art 8.25. 
Op de merites van deze bevoegdheden ga ik hier niet nader in. Opnieuw volsta ik ermee te wijzen op de mogelijkheden om in te spelen op onzekerheden bij feitenvaststelling.

\subsubsection{Verzekering en compensatie}

Ten slotte nog een korte opmerking over twee andere instrumenten die juist met het oog op onzekerheid bij de feitenvaststelling van waarde kunnen zijn.

\subsubsection{Compensatie}

In de eerste plaats doel ik op de in het Regeringsverslag inzake de m.e.r.procedure in het vooruitzicht gestelde regeling in verband met de "compensatie van onvermijdelijke negatieve milieugevolgen". ${ }^{241}$ De vraag rijst of onzekerheid over de milieu-effecten van een bepaalde activiteit bij de vraag naar aard en omvang van de compensatie mag meewegen - resulterend in een wat "ruimhartiger" compensatie. In algemene zin lijkt dat een kwestie van de inhoud van de evenredigheidmaatstaf die terzake zal moeten worden ontwikkeld. Meer precies zal het de vraag zijn of onzekerheid over de feitenvaststelling in de beoordeling van de verhouding tussen de (last van de) compensatie(maatregelen) en de (verwachte) mate van onvermijdelijke milieuschade een rol mag spelen. De vraag rijst echter of de precisering "onvermijdelijk negatieve milieugevolgen" impliceert dat over het intreden van bedoelde milieugevolgen een zeer grote zekerheid moet bestaan.

Ten aanzien van deze norm spelen overigens twee andere, meer algemene vragen nog een rol. Allereerst of bepaalde gevaren, zoals bedreiging van menselijk leven, wel vatbaar zijn voor compensatie in de door de regering bedoelde zin. In de tweede plaats de vraag of het compensatie-instrument, hoewel ongetwijfeld goed bedoeld, niet zal resulteren in het afwentelen (c.q. afkopen) van de risico's uit onzekerheid. Ik pretendeer niet hier pasklare antwoorden op deze vragen te kunnen geven. ${ }^{242}$

\subsubsection{Verzekering}

Een bekend algemeen middel van onzekerheidsreductie is ten slotte nog de verzekering. Als iets mis kan gaan, dan is er in beginsel de mogelijkheid een verzekering aan te gaan voor de daaruit mogelijk voortvloeiende schade. Op die manier kan het nadeel wellicht nog enigermate worden opgeheven.

In de context van milieuschade zou nog een bijkomend effect kunnen optreden: verzekeringsmaatschappijen zullen hun eigen risico's zo veel mogelijk willen indekken. Bijgevolg zal de verzekeraar aan de ondernemer van potentieel milieuschadelijke activiteiten scherpe eisen opleggen (naar de stand van

241. A.w., p. 12.

242. Daarvoor is het regeringsvoornemen naar mijn smaak ook nog te vaag. 
wetenschap en techniek alsmede naar de stand van milieukwaliteitseisen), deze van tijd tot tijd actualiseren en voorts inspecteren of de voorschriften worden nageleefd. . $^{243}$

Een belangrijk punt is natuurlijk of de verzekeraar bereid zal zijn het verzekeringspakket uit te breiden tot milieuschade uit onvoorziene oorzaak, c.q. voor onvoorziene milieuschade. ${ }^{244} \mathrm{Het}$ is maar de vraag of ophoging van de premie (al dan niet) in samenhang met hantering van een maximum uitkeringsbedrag voor "onvoorziene milieuschade" hierin verandering zou kunnen brengen.

In de $\mathrm{Wm}$ is in art. 8.15 een bepaling opgenomen die er toe strekt dat in bepaalde (bij AMvB te regelen) gevallen waarin inrichtingen ernstige nadelige gevolgen voor het milieu kunnen veroorzaken, voorschriften kunnen worden gegeven welke de houder van de inrichting verplichten om (a) financiële zekerheid te stellen voor de naleving van andere krachtens de vergunning voor hem geldende verplichtingen, of (b) financiële zekerheid te stellen ter dekking van zijn aansprakelijkheid voor door zijn inrichting veroorzaakte milieuschade. ${ }^{245}$

De onder (a) bedoelde zekerheidstelling biedt de overheid een verhaalsmogelijkheid indien zij kosten moet maken wegens niet-naleving van voorschriften door de houder van de inrichting. Hierbij wordt gedacht aan een bankgarantie, borgtocht of fondsvorming. ${ }^{246}$ Voor onzekerheidsreductie is dit niet echt interessant omdat daarbij nu juist de gegeven voorschriften voorwaardelijk bestanddeel (of toepassingsconditie) zijn en het al dan niet intreden van "onvoorziene effecten" strikt genomen geen rol speelt. ${ }^{247}$

De onder (b) bedoelde zekerheidsstelling betreft de aansprakelijkheid van de houder van de inrichting tegenover derden die milieuschade lijden. De bedoe-

243. Het is natuurlijk denkbaar dat die inspectie is vervat in het onderzock dat plaatsvindt als er iets daadwerkelijk is misgegaan. In die aanpak rekent de verzekeraar op zijn vermogen tot "controle achteraf" en/of op het anticiperend handelen van de verzekerde (die niet wil riskeren dat niet wordt uitbetaald wegens niet-naleven van de voorwaarden).

244. Vgl. Tonnaer, a.w., p. 224.

245. Op grond van art. 8.40 derde lid, art. 8.44 tweede lid en art. 8.45 tweede lid Wm kunnen deze verplichtingen ook aan houders van niet-vergunningplichtige inrichtingen worden opgelegd.

246. Vgl. Warendorf, F.C.S., Verplichte financiële zekerheidsstelling voor de nakoming van overheidsvoorschriften. M\&R'88/7. p. 254-262.

247. Dit zou anders kunnen worden indien een (algemeen) zorgplichtvoorschrift van toepassing zou zijn. dat ten aanzien van onvoorziene effecten niet is nageleefd. Het is echter de vraag of een dergelijk voorschrift de toets aan het rechtszekerheidsbeginsel (en het verbod van détournement de pouvoir) zou kunnen doorstaan. Ook is natuurlijk nog denkbaar dat niet-naleving van een voorschrift een bij vergunningverlening onvoorzien(baar) nadelig effect tot gevolg heeft. 
ling is dat hiertoe een milieuaansprakelijkheidsverzekering wordt afgesloten. Op dit moment is nog niet duidelijk op welke wijze aan het bepaalde in art. $8.15 \mathrm{Wm}$ (bij $\mathrm{AMvB}$ ) uitvoering zal worden gegeven. ${ }^{248}$

\subsubsection{Conclusie onzekerheidsreductie}

Met deze globale analyse wordt reeds aanstonds duidelijk hoe er (althans in aanzet) in het milieurecht verschillende waarborgen (of instrumenten) zijn voor onzekerheidsreductie.

Met enige ruimhartigheid kunnen we de bovengenoemde waarborgen classificeren naar de verschillende strategieën die Simon schetst (zie § 7.5.1).

Onder "verbetering van de voorspellingen" noemde ik de algemene procedurele waarborgen, de periodieke rapportage van de minister over de toestand van het milieu, en de eventuele rol van een onafhankelijke vaste milieuadviesinstantie.

Ten aanzien van de wenselijkheid van "buffers" zijn verschillende categorieën van waarborgen genoemd. Wat betreft de gestrengheid van voorschriften wees ik op de rol van het ALARA- en het voorzorgsbeginsel. Met het oog op de mogelijkheid van bijstelling wees ik op het evalueren en actualiseren van vergunning(voorschriften). Ten slotte wees ik nog op het nemen van de concrete schade-beperkende of opheffende waarborgen zoals compensatie en verzekeren.

Over het "isoleren" van een potentieel gevaarlijke activiteit heb ik hier geen nadere opmerkingen gemaakt. Het ligt overigens voor de hand dat juist in dat opzicht met het zoneringsinstrument wordt gewerkt. ${ }^{249}$

Wat betreft de categorie "ontwikkelen van alternatieven" verwees ik naar de in de m.e.r.-procedure neergelegde plicht om meerdere alternatieven uit te werken en in het MER te presenteren.

\subsection{Conclusie}

\subsubsection{Expertise in het milieurecht}

De rol van expertise bij de beslissing op aanvraag van een Wm-vergunning was de insteek voor dit hoofdstuk. Daarbij had ik mij voorgenomen in elk geval in te gaan op een drietal "uitwerkingspunten" uit het voorafgaande hoofdstuk. Tegelijkertijd moest een substantieel deel van dit hoofdstuk wor-

248. Vgl. over dit instrument, uit de parlementaire geschiedenis (o.m.): VAR-MvT, p. 78-79. VARMvA, p. 61-66, VAR-Nota n.a.v. het eindverslag Tk'90-91, 21 087, nr. 13. p. 37-43.

249. Vgl. over milieuzonering o.m. Brussaard et al, a.w., p. 412 e.v. In verband met zonering is ook de problematiek van de "risico-beheersingsnormen" nog interessant. Bespreking daarvan voert hier n.m.m. te ver. Vgl. hierover onder meer de Nota Omgaan met Risico's, TK'88-'89, 21137 , nr 5 (e.v.). 
den ingeruimd om de m.e.r.-procedure te bespreken. Deze procedure paste immers niet in het algemeen bestuursrechtelijke perspectief van hoofdstuk 6 , en is tegelijkertijd van eminent belang voor de verlening van een belangrijk aantal Wm-vergunningen.

Uit de bespreking van de m.e.r.-procedure heb ik (in \$ 7.2.5) een aantal conclusies getrokken. Allereerst door in te stemmen met de ECW en de regering dat de m.e.r.-procedure is te beschouwen als een "redelijk functionerend instrument". Meer specifiek heb ik vervolgens enkele opmerkingen gemaakt over de verdeling van verantwoordelijkheden, de verruimde beslissingsbevoegdheid en het vinden van bevredigende oplossingen.

Wat de verantwoordelijkheid betreft wil ik, indachtig de eerste vuistregel uit deel II van deze studie, vooral toch de verantwoordelijkheid van het bevoegd gezag voor een optimale feitenvaststelling onderstrepen. Dat brengt mee dat aan de adviezen van de Cmer op geen enkele wijze een bindende betekenis moet worden gehecht: de Cmer adviseert, het bevoegd gezag beslist! Voorts zou het moeten betekenen dat na aanvaarding van het MER door het bevoegd gezag, dit zelfde bevoegd gezag de primaire verantwoordelijkheid draagt voor eventuele aanpassingen van het MER of andersoortige aanvullingen ten behoeve van de feitenvaststelling. Het spreekt overigens vanzelf dat de initiatiefnemer hier (overeenkomstig art. 4:2, tweede lid Awb) medewerking dient te verlenen. Van groot belang is dat ik er met de ECW voorstander van ben dat, gegeven de verantwoordelijkheid van het bevoegd gezag, de Cmer adviseert vooraleer het bevoegd gezag zich over het MER uitspreekt. Dat dit zou meebrengen dat de non-contentieuze besluitvorming twee inspraak-momenten zal kennen zie ik niet als een probleem. Integendeel; gegeven het kennelijke gewicht van de te nemen beslissing, lijkt het mij zeer wel op z'n plaats om afzonderlijk over voornemen en MER, en vervolgens over het ontwerp-besluit inspraak te organiseren.

De verruimde beslissingsbevoegdheid heb ik uitgebreid belicht. Ik hoop dat duidelijk is geworden dat ik deze bevoegdheid graag zie als een mogelijkheid tot (relatief) open normstelling. Ik zou zelfs wel zo ver willen gaan om hier de criteria voor de actualiseringsplicht van art. 8:22 $\mathrm{Wm}^{250}$ te hanteren als ijkpunt voor de vraag of de verruimde beslissingsbevoegdheid in materieel opzicht $^{251}$ kan worden toegepast. Mij dunkt dat ook de regering, blijkens haar uiteenzetting in het regeringsverslag over de m.e.r.-regeling, een vorm van open (en dat wil ook zeggen, voortschrijdende) normstelling voorstaat.

250. Ontwikkelingen op het gebied van de technische mogelijkheden tot bescherming van het milieu en de ontwikkeling met betrekking tot de kwaliteit van het milieu.

251. Kortom: in afwijking van sectorale normen (maar binnen de grenzen van het specialiteitsbeginsel). 
De m.e.r.-regeling is wat mij betreft een goed voorbeeld van een regeling waarin de idee van het vinden van "bevredigende oplossingen" voorop staat. In het bijzonder blijkt dat in de selectie van m.e.r.-plichtige activiteiten, de vaststelling van richtlijnen, het criterium voor te beschrijven alternatieven en de beoordeling van het MER door het bevoegd gezag. Niet onbelangrijk vind ik ook de plicht om een overzicht te geven van leemtes in kennis. Dat is een belangrijk gegeven voor de belangenafweging, zoals we bij de kwestie van onzekerheidsreductie hebben kunnen zien.

De zorg voor de deskundigheid van burgers gaat mij na aan het hart. Deze zorg vormde de oorsprong tot de vragen die ten slotte aanleiding vormden tot het schrijven van dit boek. ${ }^{252}$ In hoofdstuk 6 gaf ik te kennen dat deze zorg er toch wat bekaaid af kwam. Raadpleging van de Wm en de Awb heeft dit beeld bestendigd, omdat er naast het instrument van de populaire versie geen openingen zijn voor deskundigen-ondersteuning in de non-contentieuze fase. Juist omdat er echter zo veel belang ligt in een open proces van besluitvorming, is er mijns inziens veel aan gelegen de zorg voor de deskundigheid van burgers ter harte te nemen. Van open beraadslaging komt immers weinig terecht als burgers niet weten welke vragen zij moeten stellen omdat ze niet weten welke problemen mogelijk op hen afkomen. Effectieve zorg voor deskundigheid van burgers lijkt mij overigens geen overdreven zware last, als we bedenken dat burgers in de non-contentieuze fase niet gehouden zijn tot ingewikkelde bewijsvoering: het volstaat indien zij serieuze vraagtekens plaatsen bij de effecten van een voorgenomen activiteit. Als die vraagtekens voldoende "aannemelijk" zijn, heeft het bestuur vervolgens zijn onderzoek daar maar toe uit te strekken. ${ }^{253}$ Mijn concrete voorstel is om een organisatie van onafhankelijke milieu-raadslieden in het leven te roepen. Deze raadslieden zouden bij gelegenheid van de gedachtenwisseling als bedoeld in art. $3: 25$, eerste lid Awb vragen kunnen beantwoorden. Ook zou kunnen worden gedacht aan mondelinge consulten. ${ }^{2.4}$

De idee van een organisatie met milieu-raadslieden sluit op zichzelf goed aan bij mijn voorstel inzake vaste, onafhankelijke milieu-adviseurs ten dienste van de besluitvorming over aanvragen van Wm-vergunningen. Hierbij is het uitgangspunt niet zozeer de specifieke zorg voor de deskundigheid van bur-

252. Eerst ging het alleen om de deskundigheid van burgers, toen tevens om die van het bestuur, daarna ook om die van de rechter, en ten slotte om de deskundigheid in het algemeen (en het omgaan met principiēle en praktische onzekerheden).

253. Ik spreek van "aannemelijke" vraagtekens, om duidelijk te maken dat van burgers niet per se antwoorden of conclusies verwacht mogen worden. Een serieuze vraag is voldoende voor een serieus onderzoek.

254. Aan het laatste denk ik met name bij m.e.r.-procedures. 
gers, ${ }^{255}$ als wel de directe zorg voor een adequate inbreng van deskundigheid in de non-contentieuze procedure. In deel II van deze studie is in de vierde vuistregel aangegeven dat de stand van wetenschap en techniek daarbij een ijkpunt kan zijn. Daaraan voegde ik echter wel toe dat we moeten bedenken dat deze stand wellicht moeilijk is te bepalen en dat we open oog moeten houden voor van gangbare opvattingen afwijkende inzichten. Ook als we er van uitgaan dat het bevoegd gezag op het punt van de feitenvaststelling op zijn taak is berekend, is het in een complex en dynamisch terrein als de milieuproblematiek wijs om door inzet van vaste, onafhankelijke adviseurs de inbreng (of het niveau) van expertise te waarborgen. Ik denk daarbij aan een onafhankelijk instituut voor milieu-advies met regionale vertakkingen. Aan dat instituut verbonden adviseurs zouden in de non-contentieuze fase adviezen kunnen geven inzake het verlenen van Wm-vergunningen. Oogmerk is daarbij commentaar te geven op de juistheid en volledigheid van de bestuurlijke (ontwerp-) feitenvaststelling (zonder daarbij alternatieve feitenvaststellingen aan te bieden). Juistheid en volledigheid zijn daarbij enerzijds te verbinden met "de stand van wetenschap en techniek" en anderzijds met de wettelijk voorgeschreven verplichting om te streven naar een hoog beschermingsniveau. Ik heb mijn voorstel vergeleken met eventuele alternatieven, zoals onafhankelijke advisering uit de "markt", en beperking van onafhankelijke advisering tot de contentieuze procedure, maar acht deze alternatieven minder geschikt.

Ten slotte ben ik ingegaan op de reductie van onzekerheid. Een noodzakelijk onderwerp nu de onvermijdelijkheid van onzekerheid bij feitenvaststelling in Deel II van deze studie is vastgesteld.

Ik geloof niet dat het nodig is om vlak nadat ik op dat punt mijn conclusies heb gereleveerd (zie \$ 7.5.6) nog al te uitgebreid op dit punt terug te komen. Ik hoop dat duidelijk is geworden dat er in het milieurecht (en in het bijzonder toch in de $\mathrm{Wm}$ ) verschillende elementen van onzekerheidsreductie zijn aan te wijzen. Tot een uitgebreide en omvattende analyse en beschrijving daarvan is het helaas nog niet gekomen. Zo'n onderneming gaat naar mijn smaak ook het bestek van deze studie te buiten. Ik hoop dat mijn inventarisatie op z'n minst de relevantie van dit onderwerp duidelijk heeft kunnen maken.

\subsubsection{Expertise en non-contentieuze besluitvorming}

Hiermee is het einde bereikt van het derde Deel van deze studie. Onder de noemer "rationeel beslissen in de non-contentieuze procedure" is een waaier aan onderwerpen aan bod gekomen. Het is niet mijn bedoeling om deze on-

255. Waarbij mijn voorstellen neerkomen op de mogelijkheid van een cliëntgericht advies. 
derwerpen hier nog eens kort op een rij te zetten. Wel wil ik proberen om te schetsen wat de algemene idee is die, naar ik hoop, uit het derde Deel naar voren is gekomen. De lezer kan dan toetsen of "we nog op én lijn zitten".

Uitgangspunt voor het derde Deel van was gelegen in de vijf vuistregels die in Deel II van deze studie zijn uiteengezet: 1. Bestuurlijke verantwoordelijkheid; 2. Bevredigend beslissen; 3. Openheid van besluitvorming; 4. Stand van wetenschap en techniek; 5 . Omgaan met waarden. Deze regels waren bedoeld voor rationeel beslissen in het bijzonder in technisch-complexe situaties.

In het eerste hoofdstuk van Deel III stond de vraag centraal of in het positieve bestuursrecht de idee van rationeel beslissen als regel of beginsel aanwijsbaar was; bijvoorbeeld in de vorm van een "rationaliteitspostulaat" of een "evidente rationaliteit". De conclusie was dat tegen de achtergrond van een utilitair-opportunistisch overheidsbestuur, rationaliteit alleen in de context van het "willekeurverbod in ruime zin" als juridische eis was te traceren. Datzelfde willekeurverbod vervulde in het bestuursrecht de rol van leidend paradigma. Als zodanig was het ook de oorsprong van andere, in de loop der tijd tot wasdom gekomen beginselen; zoals de abbb. In de context van het proces van feitenvaststelling werd het verbod van willekeur (in z'n ruime, paradigmatische betekenis) opgevat als een verbod van irrationaliteit. Daarin werd een tweetal aspecten onderkend: enerzijds de plicht tot het tegengaan of corrigeren van onjuistheden bij feitenvaststelling, in samenhang met de plicht tot openheid van besluitvorming. Anderzijds de afwijzing van een rationeelsynoptische visie op besluitvorming. In deze twee aspecten was een aantal vuistregels uit het voorgaande Deel van deze studie te herkennen. Tegelijkertijd wierpen zij hun schaduw vooruit naar meer concrete, positieve juridische waarborgen.

Deze meer concrete, positiefrechtelijke waarborgen waren inzet van het zesde hoofdstuk. Daar ging het er om na te gaan welke regels en beginselen voor het omgaan met expertise van belang waren en deze te vergelijken met de opgestelde vuistregels. Vooraleer daartoe over te gaan werd er op gewezen dat het in hoofdstuk 6 (en 7) ging om de publiekrechtelijke legitimatie van het bestuurshandelen. Deze legitimatie is vereist naast de eis van een democratische legitimatie van het bestuur. In aansluiting op de eis van een legitieme bevoegdheidsgrondslag komt aan het bestuurlijk handelen slechts enig rechtsgezag toe indien bij de wijze van bevoegdheidsuitoefening overeenkomstig bepaalde publiekrechtelijk regels en beginselen is gehandeld. De aanspraak op formele rechtskracht en het vermoeden van rechtmatigheid als beginsel van bestuursprocesrecht vinden onder meer hun grondslag in de 
verwachting dat het bestuur deze regels respecteert. Tegelijkertijd brengen de democratische en de publiekrechtelijke legitimatie mee dat de rechter zich heeft toe te leggen op toetsing achteraf. Hij dient zich te onthouden van politieke keuzes (hij ontbeert democratische legitimatie) en dient uit te gaan van het feitenvaststellende primaat van het bestuur (als uitvloeisel van de publiekrechtelijke legitimatie).

Dat alles gezegd zijnde werd, aansluitend op de bevindingen aan het slot van hoofdstuk 5, een aantal beginselen geëxpliciteerd dat in het bijzonder van belang leek voor het omgaan met expertise. Tegen die achtergrond zijn allereerst de non-contentieuze procedures uit de Awb en vervolgens de gerichte en ongerichte deskundigen-advisering besproken. Op voet van die bespreking werd een aantal algemeen-bestuursrechtelijke conclusies getrokken en een vijftal nadere "uitwerkingspunten" geformuleerd. Drie van deze vijf punten kwamen in hoofdstuk 7, naast een bespreking van de m.e.r.-regeling, aan de orde. De conclusies daaruit staan hierboven opgetekend.

Ik kan er niet omheen dat mijn visie op de rolverdeling tussen bestuur en rechter, op het vlak van de feitenvaststelling en aansluitende belangenafweging bij technisch complexe beslissingen in dit Deel reeds goeddeels is vastgelegd. In mijn perspectief brengen democratische en publiekrechtelijke legitimatie mee dat het primaat in de besluitvorming bij het bestuur ligt. Ik kan het ook eenvoudiger zeggen: het bestuur beslist en de rechter toetst!

Niet alleen met het oog op de (politiek geïnspireerde) belangenafweging, maar ook met het oog op de feitenvaststelling is de non-contentieuze procedure de aangewezen plek. De rechter toetst desgevraagd "slechts" of de belangenafweging of de feitenvaststelling overeenkomstig, althans niet in strijd met het recht hebben plaats gevonden: that's all. De toon voor het vierde Deel van deze studie is daarmee al in belangrijke mate gezet. ${ }^{256}$

256. Vgl. met name het vierde uitwerkingspunt uit de conclusie van hoofdstuk 6 (de verhouding noncontentieuze en contentieuze procedure). 


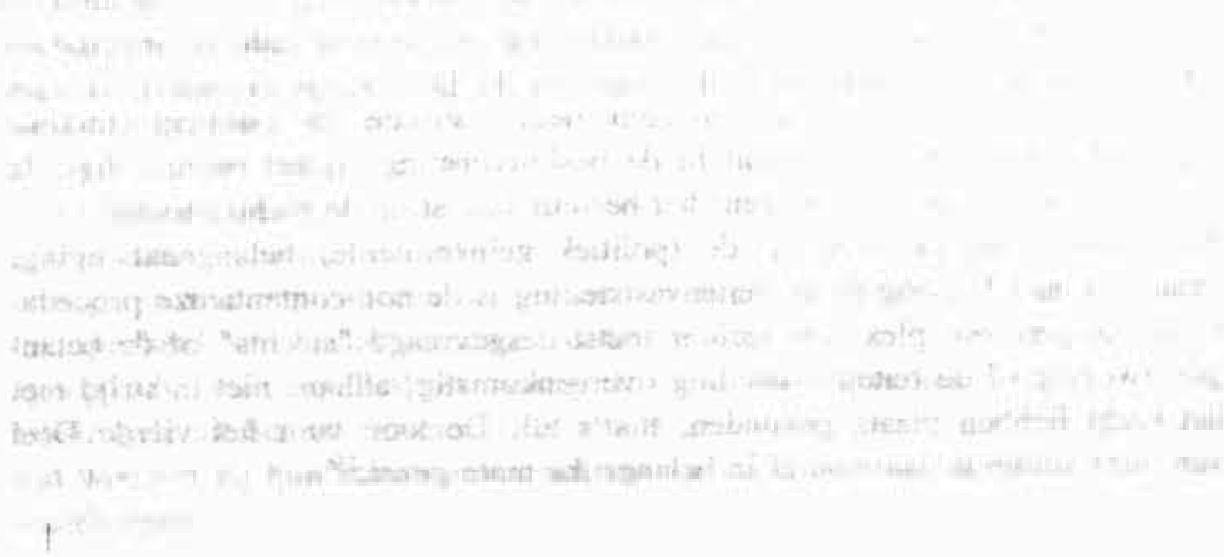

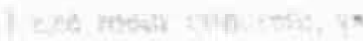

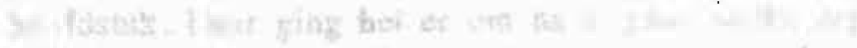

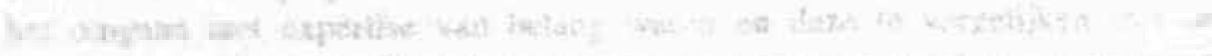

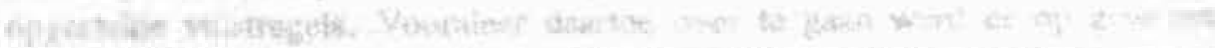

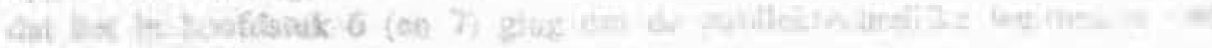

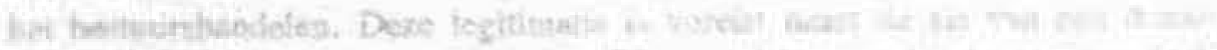

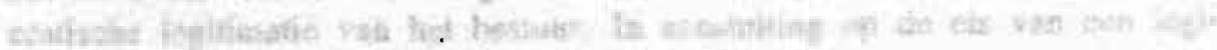

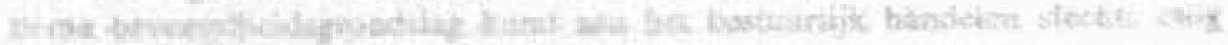

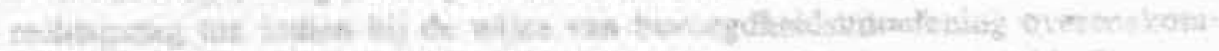

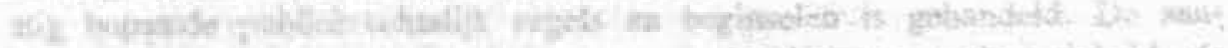

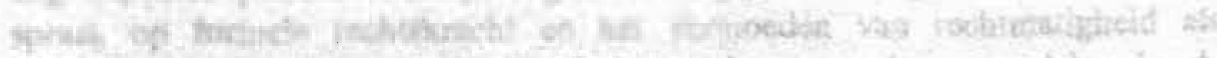

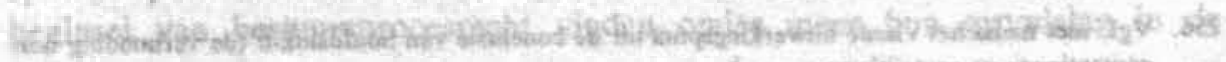

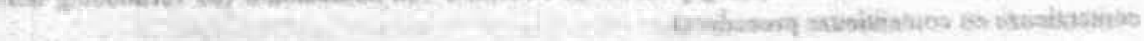




\section{Deel IV}

Expertise en de administratieve rechter 



\section{Hoofdstuk 8 \\ De functie van de administratieve rechter}

\subsection{Inleiding}

In deze studie ligt het accent op de waarborgen voor de inbreng van expertise in de non-contentieuze procedure. Deze waarborgen houden ten nauwste verband met de eisen van een democratische en publiekrechtelijke legitimatie van bestuursbesluiten. Uit de aard van deze eisen vloeit mijns inziens voort dat de non-contentieuze procedure, vooral bij technisch complexe beslissingen, ook bij uitstek de plaats is voor de feitenvaststelling en het verdisconteren van daarmee samenhangende onzekerheden (in de belangenafweging). Dat gezegd zijnde is het zaak de waarborgen voor non-contentieuze besluitvorming tot hun recht te laten komen. Dit roept de vraag op naar de waarborging van deze waarborgen.

Langs verschillende wegen kan deze controle worden verwezenlijkt. Twee belangrijke wegen zijn de toetsing door de rechter en toezicht vanuit de volksvertegenwoordiging. In dit deel van deze studie wil ik mij beperken tot de rol van de rechter, in het bijzonder de rol van de administratieve rechter.

Aandacht voor het beroep op de administratieve rechter tegen onjuist besturen brengt mee dat we ons moeten richten op de regels van het contentieuze bestuursproces. In dit proces staat voorop dat er sprake is van een geschil. Daar ligt het principiële verschil met de regels voor de non-contentieuze procedure(s), die de totstandkoming van een bestuursbesluit betreffen. In contentieuze sfeer zijn we op het punt dat het bestuursbesluit met al zijn rechtsgevolgen is gegeven, doch én of meer belanghebbenden of betrokkenen (hierna beroepsgerechtigden') van mening zijn dat het bestuur dit besluit (zo) niet had mogen nemen. In het bijzonder zal het in dit hoofdstuk gaan om de betwisting, c.q de beoordeling van de feitenvaststelling door het bestuur, dan wel om de feitenvaststelling door de rechter zelf.

Het ware denkbaar geweest om in dit deel van deze studie de vraag de behandelen of en zo ja, in hoeverre in het contentieuze proces (met name op

1. De term betrokkenen gebruik ik omdat in het non-contentieuze proces ook anderen dan belanghebbenden, bij voorbeeld geïnteresseerden of adviseurs, aan de procedure deel kunnen nemen. Het is denkbaar dat zij aan deze deelname vervolgens een beroepsrecht (anders dan als belanghebbende) ontlenen (vgl. art. 20.6, eerste lid onder c. Wm). 
het punt van de feitenvaststelling) moet worden gesproken van een rationele wijze van procesvoering. Daarmee zou een zekere analogie met het voorgaande deel ontstaan. In hoofdstuk 5 zagen we dat rationaliteit slechts in het kader van het willekeurverbod in ruime zin leidraad kon vormen voor concrete eisen voor het bestuurlijk handelen (inzake expertise).

In vergelijkbare zin zou het fair-trial-beginsel, zoals neergelegd in art. 6 EVRM en art. 14 BUPO, voor het contentieuze proces het algemenere, juridische kader kunnen vormen voor het idee van rationeel handelen. Vervolgens zou in de analyse van regels voor rationeel rechterlijk handelen aandacht kunnen worden besteed aan (overige, meer specifieke) eisen van behoorlijke rechtspleging ${ }^{2}$ en de concrete (wettelijke) regels van procesrecht. Een dergelijke analyse ware nog aan te vullen met een interne rechtsvergelijking tussen straf-, civiel- en bestuursprocesrecht en mogelijk nog met regels en beginselen uit buitenlands procesrecht. Het zal aanstonds duidelijk zijn dat deze opzet reeds op zichzelf in een proefschrift kan resulteren. ${ }^{3}$ Voorts is het nastreven van een analoge structuur geen opzichzelfstaand oogmerk van deze studie. Ik vrees bovendien dat het eigen-aardige karakter van het bestuursprocesrecht, mede gelet op de typische waarborgen voor de non-contentieuze besluitvorming - c.q. de rol van de democratische en publiekrechtelijke legitimatie - onvoldoende tot uitdrukking zouden komen.

Overigens zal in dit deel van deze studie wel worden uitgegaan van de veronderstelling dat in het fair-trial-beginsel, alsmede in verschillende speciesbeginselen (zoals het decisiebeginsel, het verdedigingsbeginsel, het onpartijdigheidsbeginsel en het motiveringsbeginsel ${ }^{4}$ ), impliciet (inderdaad) veronderstellingen van een rationele procesvoering besloten liggen. Voorzover daaraan in het vervolg, bij de beoordeling van procesregels of de procespraktijk, behoefte bestaat zal ik alsnog naar (alsdan te expliciteren) concrete spelregels voor een rationele procesvoering verwijzen.

De bespreking van het contentieuze bestuursproces wordt - kortom - geplaatst in de context van het belang van een juist verloop van het non-contentieuze proces. Zulks vereist een meer principiële analyse, en wel van de functie van het contentieuze proces. In dit hoofdstuk zal ik juist op dat punt ingaan.

In dit deel van deze studie zal steeds worden gerefereerd aan het thans voorliggende wetsvoorstel voor de herziening van de rechterlijke organisatie

2. Vgl. De Waard, B.W.N., prft., a.w.

3. Overigens is met het in de voorgaande noot genoemde proefschrift van De Waard al een belangrijke bijdrage an deze analyse geleverd.

4. Vergelijk De Waard, a.w... p. 122. 
(hierna Whrol). ${ }^{5}$ Het oogmerk om de hiermee samenhangende wetswijzigingen (voor de eerste fase) reeds per 1 januari 1994 in werking te laten treden en de brede ondersteuning voor de hoofdlijnen van het voorstel ${ }^{6}$ is hiervoor de reden. De thans geldende regelingen worden slechts nog aangehaald waar dit als vergelijk gedienstig kan zijn.

Een belangrijk novum van het Whrol is de introductie van het beroep in eerste aanleg bij de arrondissementsrechtbank. De integratie van administratieve rechtsgangen beperkt zich in deze eerste fase van het Whrol tot deze eerste instantie; in hoger beroep is weer sprake van meerdere instanties. Ik wil mij in dit deel van deze studie beperken tot de bespreking van het beroep tegen beschikkingen gegeven op aanvragen voor milieuvergunningen, ingevolge art. $20.1 \mathrm{Wm} .^{7}$ Opmerkelijk is daarbij aanstonds dat juist voor dit type beschikking de (nieuwe) Afdeling bestuursrechtspraak in eerste en enige aanleg als administratieve beroepsinstantie is aangewezen. ${ }^{8}$

In afwijking van de hoofdstructuur van het Whrol is hier derhalve geen sprake van twee administratiefrechtelijke instanties. Koeman kritiseert deze keuze uitdrukkelijk ${ }^{9}$ en stelt - mijns inziens zeer terecht - dat deze keuze niet gehandhaafd kan blijven. In $\S 6.3 .5 .3$ beschreef ik reeds hoe de regering onder andere voor "kwetsbare geschillen", waaronder milieuzaken, volhardt in het maken van een uitzondering op de hoofdregel. Ik ben geneigd met Koeman aan te nemen dat hier sprake is van een (voorlopige? ${ }^{10}$ knieval voor de Raad van State.

In dit hoofdstuk bespreek ik de functie van het contentieuze bestuursproces en de uitgangspunten van het Whrol. In de navolgende paragraaf zal ik daartoe de contouren van het voorliggende wetsvoorstel schetsen. In de daaropvolgende paragraaf zal ik de voorstellen op enkele onderdelen, juist met het

5. Wijziging van de Wet op de rechterlijke organisatie, de Algemene wet bestuursrecht, de Wet op de Raad van State, de Beroepswet, de Ambtenarenwet 1929 en andere wetten, alsmede intrekking van de Wet administratieve rechtspraak overheidsbeschikkingen, TK'91-'92, 22 495, nrs. 1-7 (Wetsvoorstel Herziening Rechterlijke Organisatie 1e fase: Whrol). De hierin voorgestelde uitbouw van de Awb duid ik zonodig aan met Awb2.

6. Vgl. de bijdragen aan het themanummer van het NJB over het uniform bestuursprocesrecht (NJB'91/36), alsmede Berge, J.B.J.M. ten. F.A.M. Stroink. A.Q.C.Tak, B.W.N. de Waard en R.J.G.M. Widdershoven (reds). Nieuw bestuursprocesrecht, Deventer 1992 en Bernd van der Meulen, Nieuw bestuursprocesrecht, NTB'92/1, p. 11-20.

7. Zoals gewijzigd bij WHRO (4E 10B).

8. Art. $20.1 \mathrm{Wm}$ jo art. $36 \mathrm{WRvS}$.

9. Koeman, N.S.J., Het nieuwe bestuursprocesrecht, NJB'91/36, p. 1454-1458, i.h.b. p. 14551456; alsmede in Uniform bestuursprocesrecht en de herziening van de rechterlijke organisatie: enkele beschouwingen vanuit de rechtspraktijk, NTB'91/10, p. 293-297 (i.h.b. p. 295-296).

10. Besloten is om in de derde fase van het WHRO (WHRO3) te bezien of terzake van de geschillen waarbij nu is voorzien in beslechting in én instantie, alsnog beslechting in twee instanties in te voeren (MvT. p. 12.) 
oog op de functie van het bestuursprocesrecht, becommentariëren. In het volgende hoofdstuk zal ik ingaan op de regels voor het rechterlijk onderzoek naar de feiten en de rol van de deskundige in het contentieuze proces.

\subsection{De contouren van het nieuwe bestuursprocesrecht}

Inmiddels is het Whrol al onderwerp geweest van uitgebreide beschrijving en debat." Ik acht mij mitsdien ontslagen van de plicht om hier een omvattende schets te geven. Een aantal uitgangspunten die zicht geven op de functie van de administratieve rechtsgang, zoals deze in het Whrol naar voren komen, wil ik echter niet onvermeld laten.

\subsubsection{Doelstelling}

Blijkens de doelstellingen van het Whrol beoogt de regering allereerst de "juridische kwaliteit en het gehalte van de rechtspraak" in stand te houden en te verbeteren. ${ }^{12}$ Daartoe wijst zij drie wegen aan: voorzieningen ter verbetering van de eenheid van recht en rechtspraak, concentratie van rechtsmacht en rechtspraak in twee instanties. In de tweede plaats wordt een grotere "clientgerichtheid van de rechtspleging" nagestreefd. Daartoe is verbetering van de toegang tot de rechter en het sneller beschikbaar komen van uitspraken gewenst. ${ }^{13}$ Ten slotte beoogt de regering "evenwicht in de structuur van de rechterlijke organisatie", zulks in termen van een evenredige verdeling van mensen en middelen binnen de rechterlijke organisatie. ${ }^{14}$

Genoemde doelstellingen wil de regering in drie onderscheiden fasen tot stand brengen. De verwezenlijking van de eerste fasen is voorzien per 1 januari 1994.

\subsubsection{Knelpunten}

In de eerste fase staat de herstructurering van de bestuursrechtelijke rechtsbescherming voorop. Verschillende knelpunten in het stelsel van de bestuursrechtelijke rechtsbescherming vragen daarbij volgens de regering thans om aandacht. Allereerst is het stelsel "in hoge mate verbrokkeld en daardoor ondoorzichtig en ontoegankelijk". ${ }^{15}$ In dat verband valt op dat de uitspraakbevoegdheden van administratieve rechters vaak zo beperkt zijn dat de procedure een vervolg krijgt bij de burgerlijke rechter. Voorts acht de regering het

11. Vergelijk de in noot 6 genoemde bijdragen. Zie voorts ook Tak, A.Q.C., De algemene wet bestuursrecht, het nieuwe bestuursprocesrecht, Zwolle 1992.

12. MvT, p. 10.

13. Bbidem.

14. Ibidem.

15. Bbidem, p. 18-19. 
stelsel onevenwichtig en inconsistent, in termen van aantallen instanties, de geografische spreiding van gerechten en de samenstelling van kamers van colleges in verhouding tot de zwaarte van de zaken. ${ }^{16}$ In de derde plaats voorziet het stelsel niet in een bewaking van de rechtseenheid, hetgeen de regering vooral bezwaart als het gaat om de uitleg van regels van internationaal recht, de toepassing van abbb en meer in het algemeen de ontwikkeling van algemene leerstukken in het bestuursrecht. ${ }^{17}$ Ook de groeiende (over)belasting van administratieve rechters baart de regering zorgen. ${ }^{18}$ Ten slotte stelt de regering vast dat het huidige stelsel niet op alle punten in overeenstemming is met de eisen van art 6 EVRM en art. 14 BUPO. Dit manco moet worden verholpen; "Wij wijzen er (..) op, dat het rechtsstatelijke uitgangspunt dat elk bestuursrechtelijk geschil aan een rechter moeten kunnen worden voorgelegd, met zich brengt dat ook omtrent geschillen die niet door art. 6 van het EVRM worden bestreken het oordeel van een rechter moet kunnen worden ingeroepen". ${ }^{19}$

In het wetsvoorstel wordt terecht gesteld dat een in historisch opzicht belangrijke knoop thans wordt doorgehakt. Het antwoord op de vraag of de beslechting van bestuursrechtelijke geschillen nu een zaak is voor de administratie of voor de rechter wordt nu over de gehele linie beantwoord met: de rechter. Voor bestuursorganen blijft wel een functie behouden in bezwaarschriftprocedures en in administratief beroep, maar hier gaat het uitdrukkelijk om "voorprocedures die voorafgaan aan een mogelijk beroep op de rechter". ${ }^{20}$

\subsubsection{Karakteristieken}

Deze keuze leidt tot een stelsel-voorstel met verschillende karakteristieken. ${ }^{21}$

In bepaalde opzichten stemmen deze karakteristieken overeen met die van het klassieke bestuursprocesrecht. Toch is er een aantal verschillen, die vooral te maken hebben met de veranderde inzichten over het doel van het bestuursrechtelijk geding. Hoewel van meet af aan de toetsing van de rechtmatigheid van het bestuurshandelen daarbij inzet was, ${ }^{22}$ was de oorspronkelijke doelstelling vooral de "handhaving van het objectieve publiekrecht". ${ }^{23}$ De rechterlijke rechtmatigheidstoetsing diende primair het algemeen belang. Op voet

16. Ibidem, p. 19-20.

17. Ibidem, p. 20-21.

18. Ibidem, p. 21.

19. Ibidem.

20. Ibidem, p. 23.

21. Ibidem, p. 35-38.

22. Ibidem, p. 31 .

23. Ibidem. 
daarvan kon de rechter buiten de grenzen van het beroepsschrift treden en - zelfs te nadele van de appellant - correctief optreden. ${ }^{24}$ Gaandeweg is de rechtmatigheidstoetsing steeds nadrukkelijker in het teken van een rechtsbeschermingsdoelstelling komen te staan. De burger diende beschermd te worden tegen onrechtmatig eenzijdig optreden van de overheid. In dat verband zag de rechter het als zijn taak in de procesvoering te voorzien in enige "ongelijkheidscompensatie" ten behoeve van de burger-partij. ${ }^{25}$

Deze ontwikkeling, waarin het bestuursproces van een "contentieux objectif" meer en meer de vorm van een "contentieux subjectif" heeft aangenomen, ${ }^{26}$ heeft, zo blijkt, vooral ook gevolgen voor de rol van de rechter. In beide "soorten" procedures kan de rechter zich actief opstellen. Deze activiteit is echter geheel verschillend gericht. In het contentieux objectief vult de rechter rechtsgronden en feiten aan en bepaalt hij zelf de omvang van het geschil teneinde een effectieve controle van het objectieve recht te bewerkstelligen - zelfs als dit ten koste van de appellant gaat. In het contentieux subjectief staat de partij-autonomie voorop: het object van geschil wordt door de partijen bepaald. De rechter is in dat opzicht lijdelijk, maar in andere opzichten wel actief voorzover hij zich daartoe uit overwegingen van ongelijkheidscompensatie geroepen voelt.

De regering kiest ervoor om de rechtsbeschermingsfunctie de primaire doelstelling van het bestuursprocesrecht te laten zijn. ${ }^{27}$ Elementen van het bestaande bestuursprocesrecht die slechts de handhaving van het objectieve recht beogen, kunnen derhalve worden geschrapt. ${ }^{28}$ De regering haast zich overigens om er op te wijzen dat handhaving van het objectieve publiekrecht wel degelijk van enige betekenis blijft. Zo komt elke correctie van onrechtmatig overheidsoptreden, ook als deze in een contentieux subjectif plaatsvindt, ten goede aan de handhaving van het objectieve recht. Nadere concrete adstructies van dit punt ontbreken echter helaas. ${ }^{29}$ Wel wijst de regering er op dat de ontwikkeling in het rechtsbeschermingsdenken haar eindpunt zou kunnen vinden in een situatie vergelijkbaar met de van het burgerlijk procesrecht, waarbij de "rechtsbetrekking" (ex nunc) tussen partijen de inzet van de procedure wordt. Thans echter acht de regering de tijd nog niet rijp om die gedachte in het bestuursprocesrecht te introduceren: vooralsnog zal het be-

24. Het zogenoemde ultra petitum gaan en de reformatio in peius. Vgl. Banda, P.H., a.w., hoofdstuk 5 en MvT-Whrol, p. 33.

25. Als zwakkere tegenover een "grote" overheid. MvT. p. 31.

26. Vgl. Banda, a.w.. Hoofdstuk 5 .

27. MvT, p. 35.

28. Zoals het ultra petitum gaan.

29. MvT, p. 35-36. De regering spreekt over het vinden van een nieuw evenwicht en over het algemeen belang van een spoedige afdoening van geschillen. maar daarmee is niet zo veel gezegd over het precieze doel van het bestuursproces. 
stuursprocesrecht blijven draaien om een rechtmatigheidstoetsing ex tunc van een besluit in de zin van art. 1:3 Awb. ${ }^{30}$

Daarmee heb ik ook al de eerste karakteristiek van het nieuwe bestuursprocesrecht genoemd: de rechtmatigheidstoetsing ex tunc van een besluit. Op dit punt is er (dus) niets nieuws onder de zon. ${ }^{31}$ Wel is nieuw dat de administratieve rechter nu (over de hele linie van zaken) de mogelijkheid krijgt om zelf in de zaak te voorzien. De regering presenteert dit als een "redresseren" van een insteek uit het contentieux objectif. ${ }^{32} \mathrm{Ze}$ voegt er aan toe dat de rechtsbeschermingsgedachte een effectieve en efficiënte afdoening van het geschil verlangt. Waar dit mogelijk is zou de rechter zelf in afdoening van het geschil moeten voorzien. Daarbij kan hij ex nunc te werk gaan; dus met medeneming van na het instellen van het beroep opgekomen feiten en omstandigheden. De rechter zou alleen dan in de zaak zelf mogen voorzien als "rechtens maar én beslissing mogelijk is". ${ }^{33}$

Omdat in het bestuursproces het besluit centraal blijft staan zal de "klassieke" karakteristiek van een korte beroepstermijn ook typerend zijn in het nieuwe bestuursproces.

De derde "klassieke" karakteristiek van het bestuursproces, het "zoeken naar de materiële waarheid" zal eveneens behouden blijven. Door de keuze voor de rechtsbeschermingsfunctie zal de wijze waarop de rechter zich hierbij opstelt wel enige wijziging ondergaan. ${ }^{34} \mathrm{Zo}$ zal de rechter zich moeten conformeren aan de door appellant voorgelegde omvang van het geschil. ${ }^{35}$ Ook de mogelijkheid van reformatio in peius 'in strikte zin' verdwijnt. ${ }^{36}$ Wel behoudt de rechter de mogelijkheid om rechtsgronden en feiten aan te vullen, voorzover hij daarbij blijft binnen het object van geschil. Volgens de regering is deze bevoegdheid een voortvloeisel uit de idee van ongelijkheidscompensatie. ${ }^{37}$ Ook blijven de regels van materieel bewijsrecht zoals ze waren. De regering merkt op dat in een stelsel waar de rechter ambtshalve feiten kan aanvullen, aan een wettelijk stelsel van materieel bewijsrecht eigenlijk nauwelijks behoefte bestaat. Wel dient (met name) de stelplicht van partijen naar redelijkheid en billijkheid te worden verdeeld. Naast een algemene bepaling

30. MvT. p. 33-35.

31. Dat blijkt ook als we de nieuwe karakteristieken vergelijken met de oude: zie MvT, p. 36-38 en p. 32-33.

32. Dat het besluit centraal staat is immers een kenmerk van het contentieux objectif. Met de mogelijkheid van 'zelf in de zaak voorzien' kan de rechter ex nunc het geschil beslechten.

33. MvT, p. 36. Zie ook Tak, a.w. 1992, p. 14.

34. MvT, p. 36-38.

35. Ibidem, p. 36. Voorts art. 8:69, eerste lid Awb.

36. Ibidem. De toevoeging 'in strikte zin' is essentieel!

37. MvT, p. 37. 
(in art. 8:69 Awb) inzake de grondslag voor het rechterlijk oordeel, zijn in de wetsvoorstellen echter geen bepalingen van bewijsrecht opgenomen. ${ }^{38}$ Meer in het algemeen bevat de nieuwe regeling vele instrumenten voor een actief-rechterschap. Zo is het de rechter die beslist over het al dan niet houden van een vooronderzoek (en over de eventuele omvang daarvan), over het volgen van procedures van vereenvoudigde afdoening of versnelde behandeling. ${ }^{39}$ De regering onderstreept dat in de meeste gevallen het onderzoek ter zitting een belangrijke plaats inneemt; zij acht het van belang dat zo mogelijk de hurger zijn "day in court" wordt geboden. ${ }^{40}$ Ten slotte is het nog van belang te wijzen op het uitgangspunt van de "eenheid van het bestuursrechtelijk geding". Er bestaat geen mogelijkheid van een afzonderlijk appel tegen beslissingen van de rechter voorafgaand aan diens eindoordeel. ${ }^{41}$

Als vierde en laatste karakteristiek noemt de regering het oogmerk van laagdrempeligheid van het bestuursprocesrecht. De geringe hoogte van de griffierechten $^{42}$ en het niet voorschrijven van verplichte procesbijstand (bij het geding in eerste aanleg) passen in dit streven.

\subsection{Nadere analyse van het nieuwe bestuursprocesrecht}

\subsubsection{Inleiding}

In de voorgaande paragraaf kwamen de hoofdlijnen van het regeringsvoorstel aan de orde. In deze paragraaf wil ik nog wat nader ingaan op de functie van het bestuursproces. In verband daarmee, wil ik ook de verhouding tussen de non-contentieuze procedure en het bestuursproces aan de orde stellen. Bij deze bespreking zullen enkele concrete elementen uit het voorgestelde nieuwe bestuursproces nader belicht worden. Het gaat daarbij om punten die met name betrekking hebben op de mate van vrijheid van de rechter in zijn beoordeling van en beslissing in het geschil. Ik denk daarbij in het bijzonder aan de afbakening van het geschil, de gevraagde voorzieningen, het aanvullen van rechtsgronden en feiten en de toetsing ex tunc of ex nunc. Met het oog op de rechterlijke feitenvaststelling zal ik ten slotte nog kort ingaan op de herziening van rechterlijke uitspraken. Meer in het algemeen is de nu volgen-

38. Het bewijsrecht komt in dit hoofdstuk later nog kort aan de orde. In het volgende hoofdstuk staat het centraal.

39. Tak, a.w. 1992. p. 15-16.

40. MvT, p. 37-38.

41. MvT, p. 37.

42. De vraag rijst wat er nog is van deze karakteristiek in het licht van de voorstellen tot verhoging van griffie-gelden, zoals voorgesteld in de Tweede nota van wijzigingen (TK'92-'93, 22 495, nr 12, p. 62-64)?! 
de bespreking primair bedoeld als een opmaat voor het navolgende hoofdstuk (over het onderzoek naar de feiten en de rol van de deskundige).

\subsubsection{De functie van het bestuursproces}

\subsubsection{Twee posities}

De regering ziet de rechtsbescherming als primaire functie van het nieuwe bestuursproces. Handhaving van het objectieve bestuursrecht is niet langer een zelfstandig doel in het proces. Hierachter staat waarschijnlijk de opvatting dat rechtspraak weinig geschikt is als instrument voor bestuurlijk toezicht. Zo ontbeert uitoefening van het toezicht - bij voorbeeld - elke systematiek omdat het volstrekt afhankelijk is gemaakt van een klacht van een belanghebbende. ${ }^{43}$

Volgens Tak is het voorgestelde stelsel op het punt van zijn doelstelling echter onvoldoende doordacht. Alhoewel de rechtsbescherming als doelstelling wordt genomen, blijft het bestuursbesluit inzet van de rechtsstrijd en niet de rechtsverhouding tussen bestuur en burger. ${ }^{44}$ Ook de uitspraak (c.q. de rechtsmacht) van de rechter is op het overheidsbesluit als object van geschil gericht. Bijgevolg is ook de rechterlijke uitspraak (zoals een vernietiging of het zelf in de zaak voorzien) eigenlijk een bestuursdaad. Een bestuursdaad met een werking "erga omnes"; voor alle betrokkenen, niet alleen voor de partijen in het geschil. Als de rechter (her)beslist doorkruist hij mitsdien in één beweging de wettelijke attributie van bestuurstaken en de typische noncontentieuze waarborgen van het bestuurlijk handelen. ${ }^{45}$ In de visie van Tak zou thans reeds radicaal gekozen moeten worden voor het uitgangspunt van subjectieve rechtsbescherming. Inzet is daarbij de rechtsverhouding tussen burger en bestuur. Deze verhouding wordt vrij van de "handhaving van het objectieve recht", ${ }^{46}$ beoordeeld naar het "moment $\mathrm{X}$; d dat is het moment waarop het (non-contentieuze) bestuurlijke besluitvormingsproces tot een einde is gekomen. De uitspraak van de rechter zou het bestuursbesluit onaangetast moeten laten. Geen vernietiging of zelf voorzien, maar slechts op de

43. Vgl. Verheij, N., Een klantvriendelijke rechter, in: Ten Berge et al. (red), Nieuw bestuursprocesrecht, a.w.. p. 131-149, i.h.b. p. 136, alwaar hij tevens verwijst naar het dienovereenkomstige standpunt van M. Scheltema (Administratieve Rechtsgangen, Algemeen deel 1.2.2).

44. Tak, a.w. 1992, p. 14 en p. 16-21. Deze visie komt ook - meer uitgebreid - tot uitdrukking in zijn bijdrage De ongewenste discussie. in: Ten Berge et al. (reds.) Nieuw bestuursprocesrecht, a.w., p. 67-84.

45. Tak, a.w. 1992, p. 17; De ongewenste discussie, a.w., p. 82-84.

46. Dus vrij van ultra petita gaan, reformatio in peius en wat dies meer zij: zie Tak, a.w. 1992, p. 19. 
individuele rechtspositie van de appellant toegesneden uitspraken, zoals een buiten-toepassing-verklaring of een schadevergoeding. ${ }^{47}$

In de Memorie van Antwoord bij de Whrol gaat de regering nogmaals in op deze problematiek. ${ }^{48}$ Daarmee reageert zij op een opmerking van de zijde van de PvdA-fractie, inhoudende "dat de uiterste consequentie van de keuze voor rechtsbescherming als primaire doelstelling van het bestuursprocesrecht zou zijn, uit te gaan van de rechtspositie van de appellant. In deze benadering zou het individuele rechtens te beschermen belang van appellant het object van het bestuursprocesrecht moeten zijn". ${ }^{49}$ In een mijns inziens wat duistere passage volhardt de regering in haar opvatting dat de keuze voor het rechtsbeschermingsperspectief niet "eo ipso" tot een ruimere bevoegdheid en een ander toetsingskader ${ }^{50}$ voor de administratieve rechter behoeft te leiden. De regering sluit opnieuw niet uit dat in de toekomst wel voor een dergelijke benadering wordt gekozen, met als uiterste consequentie dat "het formele onderscheid tussen burgerlijke en administratieve rechtspraak" zou komen te vervallen. ${ }^{51}$

Zie ik het goed dan is de regering van mening dat het - thans in elk geval nog aantrekkelijk is om een op het bestuursbesluit gerichte rechtsbescherming te bieden, naast een rechtsgang bij de burgerlijke rechter waar de rechtsverhouding tussen partijen ex nunc kan worden beoordeeld. ${ }^{52}$

\subsubsection{Eigen opvatting}

Ik kan ten volle instemmen met de keuze voor subjectieve rechtsbescherming als doelstelling van het bestuursproces. Naar mijn smak zou in beginsel elke rechtstreekse aantasting van burgerlijke belangen door het overheidsbestuur toegang tot de administratieve rechter moeten geven. ${ }^{53}$ Aldus zou niet langer het besluit (in de zin van art. 1:3 Awb) de enige ingang tot het bestuursproces zijn.

47. Beslissingen die op zichzelf aanleiding kunnen geven tot een bestuurlijke heroverweging van het reeds genomen besluit. Vgl. Tak, a.w. 1992, p. 20-21: De ongewenste discussie, a.w., p. 83-84.

48. MvA, p. 33-34.

49. Ibidem, p. 33.

50. Bedoeld wordt dat de rechter i.p.v. ex tunc dan ook ex nunc zou mogen toetsen, gelijk de burgerlijke rechter doet. MvA. p. 34.

51. Ibidem.

52. Ik vraag mij af of het wel zuiver is om te zeggen dat in het burgerlijk proces ex nunc wordt geoordeeld. Zo makt toch (bij voorbeeld) de jurisprudentie inzake het kostenverhaal terzake van bodemverontreiniging duidelijk dat de kwestie steeds is na te gaan of een verontreinigende handeling, naar de wetenschap van het moment van gedraging (omtrent de gevaren van dumping èn de "betrokkenheid" van de overheid), onrechtmatig is ?!

53. Ook de dreiging van een belangenaantasting zou de rechter bevoegd (en de eiser ontvankelijk) kunnen doen zijn. 
De vraag rijst of het in dat perspectief wenselijk is om de rechtsverhouding tussen bestuur en burger tot object van geschil te nemen, in plaats van het bestuurlijk handelen zelf.

Ik ben geneigd die vraag ontkennend te beantwoorden voorzover het gaat om "belangen-aantastingen" die het rechtstreekse gevolg zijn van besluiten wier totstandkoming is gebonden aan een specifieke non-contentieuze procedure. Dergelijke non-contentieuze procedures ontlenen immers hun ratio aan het bijzondere karakter van de desbetreffende bestuursbesluiten. Het is met het oog op dat karakter dat via de non-contentieuze procedure publiekrechtelijke legitimatie wordt gezocht. In $\S 6.1$ wees ik reeds op twee in dit verband belangrijke aspecten: het streven naar inhoudelijke democratische legitimatie en het streven naar rechtsbescherming met het oog op het streven naar (een optimale) individuele rechtsbedeling. Deze aspecten zijn vooral van belang bij besluiten waarbij het bestuur eenzijdig, erga omnes ingrijpt in de belangen van (groepen van) burgers. ${ }^{54}$ Juist bij dit type besluiten is het naar mijn mening goed om met het oog op de hierboven gestelde vraag (naar het object van geschil) een aantal zaken nader in overweging te nemen.

Vanuit het perspectief van het bestuur lijkt mij, in het bijzonder bij de bedoelde categorie besluiten, de eenheid van het bestuursbesluit van groot gewicht. Het bestuur zal het wenselijk vinden om op een doelmatige wijze, doeltreffende beslissingen te nemen. In dat perspectief is het wenselijk, dat binnen een relatief korte termijn na het nemen van een besluit vaststaat of dit besluit, met inbegrip van de rechtstreekse gevolgen die het voor de posities van belanghebbenden heeft, al dan niet rechtsgeldig genomen is. De koppeling van een (relatief korte) termijn aan de rechtsgeldigheid van het besluit voor allen, is daarbij essentieel. Aldus wordt de eenheid van het besluit, en daarmee de doelmatigheid van bestuur effectief gemaakt. Anders gezegd: het zou bestuurlijk uiterst onhandig zijn als elk besluit steeds onder dreiging zou staan van op individuele belangenposities toegesneden acties, die zouden kunnen leiden tot op individuele belangenposities toegesneden uitzonderingen en (mogelijk) tot een schier eindeloze reeks van herzieningen van het oorspronkelijke besluit.

Toch dwingt dit argument naar mijn mening niet tot de keuze voor het bestuursbesluit als object van geschil.

We moeten allereerst bedenken dat ook als de rechtsverhouding tot object van geschil wordt genomen, de eenheid van het besluit goed kan worden bewaakt. In formele zin spreekt dit ook vanzelf, omdat in die optiek de rechter het bestuursbesluit niet mag aantasten. De vrees dat door rechterlijke,

54. Let wel, ik begin mijn analyse met een veel bredere groep:"alle bestuurshandelingen". 
relatieve onverbindendverklaring, ${ }^{55}$ het bestuursbesluit materieel wordt uitgehold en aldus van zijn eenheid wordt beroofd, is eenvoudig te pareren: na de rechterlijke beslissing kan het bestuur - als het aan die eenheid van besluit(vorming) zo gehecht is, eenvoudig herbeslissen.

In de tweede plaats moeten we bedenken dat het aspect van de zekerheid binnen redelijke termijn over de rechtsgeldigheid van een bestuursbesluit ook via een specifieke verjaringsregeling kan worden ondervangen. Zo is een regeling denkbaar waarbij rechtsvorderingen uit hoofde van beweerde onrechtmatigheid van bepaalde categorieën bestuursbesluiten, na relatief korte tijd verjaren. Aldus heeft het bestuur dan alras de gewenste zekerheid. Ik beweer overigens niet dat zo'n regeling eenvoudig zal zijn; met name de problematiek van opgewekte verwachtingen lijkt mij ingewikkeld.

Vanuit het perspectief van de justitiabele moeten we acht slaan op de aspecten van inhoudelijke democratische legitimatie en rechtsbescherming als onderliggende doelstellingen van de non-contentieuze procedure. Deze aspecten dreigen te worden doorkruist als in een rechterlijke uitspraak specifieke materiële uitzonderingen op het bestuursbesluit worden gemaakt (zoals de onverbindendverklaring voor eiser), zonder dat herbeschikken is gegarandeerd.

Wat het aspect van de inhoudelijke democratische legitimatie betreft hebben we van doen met de aspiratie om in een open discours te komen tot het meest wenselijke besluit. De gedachte is dat inspraak een noodzakelijk deel is van de fundering voor de rechtskracht van het bestuursbesluit. Daarbij geldt als premisse dat het bestuur zich bij het nemen van het besluit ook uitdrukkelijk oriënteert op de inspraakreacties. Men kan stellen dat ook de eenheid van het non-contentieuze discours in het geding zou kunnen komen, als niet ook in het contentieuze proces het besluit centraal blijft staan. Het oogmerk om door uitwisseling van alle relevante feiten en argumenten tot een beslissing te komen, zou worden uitgehold indien via relatieve onverbindendverklaringen op dit eindresultaat weer uitzonderingen kunnen worden gemaakt. Dit bezwaar lijkt echter evenmin essentieel, nu toch ook hier de mogelijkheid van herbeslissen - en dus het heropenen van het discours - aanwezig is. Toch is er voor de justitiabele een zeker nadeel: dat wordt herbeslist is onzeker. Dat betekent dat de justitiabele afhankelijk is van de vraag of (op een eventueel verzoek) een procedure tot herbeslissen zal worden gestart.

Het rechtsbeschermingsaspect is nauw verbonden met het streven naar de meest optimale individuele rechtsbedeling. Hier ligt de aspiratie voor om in de besluitvorming zoveel mogelijk de posities van belanghebbenden te res-

55. Dat wil zeggen ten aanzien van eiser onverhindend, wegens onrechtmatigheid jegens eiser. Vgl. Tak, a.w. (1992), p. 20-21. 
pecteren. In "kwantitatieve" zin is dit te duiden als het streven naar minimalisering van belangenaantasting. In "kwalitatieve" zin impliceert het de wens om de belanghebbenden zoveel mogelijk in natura recht te doen. Deze aspiratie reikt overigens verder dan de rechterlijke toetsing, zoals moge blijken uit art. 3:4, tweede lid Awb: de rechter kan zich nu eenmaal niet inlaten met een speurtocht naar de meest optimale individuele rechtsbedeling. Dat is des bestuurs. Hooguit zou de rechter vanuit een marginaal redelijkheidsoordeel onder omstandigheden kunnen concluderen dat een bepaalde kans op een meer optimaal resultaat niet gemist had mogen worden; maar daar houdt de rechterlijke polsstok wel op. Dit gezegd zijnde lijkt het mij wel degelijk aangewezen de aspiratie van de meest optimale individuele rechtsbedeling serieus te nemen. Het zou niet aangaan om bij het nemen van een besluit belangenaantastingen af te doen als nadelige effecten die zonodig door schadevergoeding kunnen worden vergoelijkt. Het gaat er, als gezegd, toch om belangenaantastingen te minimaliseren en recht te doen in natura. De eenheid van het bestuursbesluit is hierbij van belang opdat met inachtneming van de relevante rechtsregels tot een optimale rechtsbedeling kan worden besloten. Ook hier geldt mitsdien dat na rechterlijk ingrijpen herbeschikken verzekerd moet zijn. Zou zulks niet het geval zijn dan zou naar mijn smaak de rechtsbeschermingsfunctie van de non-contentieuze procedure, c.q. het streven naar optimale individuele rechtsbedeling in gevaar kunnen komen. Het beeld doemt dan op van door onverbindendverklaringen materieel uitgeholde besluiten, die niettemin door schadevergoedingen overeind gehouden worden. Uiteindelijk zou - naar ik vrees - het pad worden gëffend voor een schadevergoedingspraktijk. Een besluit dat eigenlijk geen enkele betrokkene aanstaat zou daarin van kracht kunnen blijven bij de gratie van een uitgebreide verrekening van de schade in de posities van individuele belanghebbenden.

Het argument van de eenheid van het bestuursbesluit, dat aldus langs meerdere sporen in het geding lijkt te zijn, vormt mijns inziens een zeer praktisch motief voor de keuze van het bestuursbesluit als object van het bestuursproces. Dit impliceert dan ook dat de administratieve rechter, anders dan Tak voorstaat, wel degelijk in staat zou moeten zijn een bestreden bestuursbesluit te vernietigen!

Dit betekent naar mijn oordeel niet dat impliciet toch voor een contentieux objectif zou zijn gekozen. Rechtsbescherming zal in dier voege subjectief van aard zijn dat eiser door het besluit rechtstreeks in zijn (rechtens te beschermen) belang moet zijn getroffen. ${ }^{56}$ Ook zullen zaken als ultra petitum gaan,

56. Met als achterliggend motto: "zonder geschil geen toetsing." Vgl. Van Wijmen. P.C.E., Harmonisatie van procesrecht bij integratie van rechtspraak, in: Handelingen Nederlandse JuristenVereniging 1991-1, p. 107-176, i.h.b. p. 115. 
reformatio in peius en gedektverklaring om reden van algemeen belang en ambtelijk beroep niet meer te pas komen. ${ }^{57}$

De rechterlijke uitspraak zou het bestuursbesluit niet onaantastbaar moeten laten. De individuele belangpositie van eiser mag cruciaal zijn voor de toegang tot de rechter en - in beginsel - voor de reikwijdte van het onderzoek, als aan het bestreden besluit een onrechtmatigheid kleeft dient het als geheel te vallen - ook als het daarbij gaat om schending van non-contentieuze regels. ${ }^{58} \mathrm{Ik}$ zie daarin geen doorkruising van het besturen. Een vernietiging wegens strijdigheid van het besluit met het recht, is een halt toe roepen aan iets dat het bestuur (om te beginnen) niet had mogen doen. Sterker nog: door het besluit ondanks onrechtmatigheid onaangetast te laten zou juist de noncontentieuze procedure kunnen worden doorkruist.

In dat verband ben ik van mening dat vernietiging van een onrechtmatig bestuursbesluit als voordeel heeft dat het bestuur zich niet achter de rechter kan verschuilen. Met in achtneming van de non-contentieuze waarborgen moet worden herbeslist. Het bestuur herneemt daarvoor de volle verantwoordelijkheid: tegenover belanghebbenden maar ook in breder politiek verband. Voor mij geldt - kortgezegd - de regel dat waarborging van non-contentieuze waarborgen impliceert dat na een uitgesproken vernietiging door het bestuur wordt herbeschikt, ${ }^{59}$ volgens de spelregels van de non-contentieuze procedure. Dit brengt overigens wel mee dat ik zeer sceptisch sta tegenover de mogelijkheid voor rechters om, na vernietiging, zelf in de zaak te voorzien ook als dit slechts zou mogen als geen beleidsvrijheid resteert. Ik kom op dit punt nog uitdrukkelijk terug.

Met het oog op de rechtsbeschermingsinsteek zou reformatio in peius afgewezen moeten worden. De regering spreekt - terecht - over een afwijzing van reformatio in peius "in strikte zin". ${ }^{\infty}$ Bij nadere toelichting merkt de regering op er geen bezwaar in te zien als de rechter ten nadele van appellant in de zaak voorziet, indien ook het (verwerende) bestuursorgaan in het licht van "in de procedure gebleken nieuwe feiten en omstandigheden bevoegd en verplicht zou zijn het bestreden besluit ten nadele van appellant te wijzigen". ${ }^{61}$ Een andere relativering is natuurlijk dat een appellant er altijd mee moet

57. Zie ook Tak, a.w. 1992, p. 19.

58. Anders Tak, a.w. 1992, p. 18, die waarborging van non-contentieuze waarborgen toch vooral als een zaak van politieke, bestuurlijke en maatschappelijke controle ziet.

59. Ik sluit overigens de mogelijkheid van een voor gedektverklaring niet uit, maar zie daarvoor alleen in zeer specifieke gevallen ruimte.

60. MvT. p. 36.

61. Ibidem, p. 142. Ik zou op dit punt wel wat terughoudender willen zijn. Ik kom daarop in de volgende subparagraaf terug. 
rekenen dat er een andere appellant is met tegengestelde belangen, die in beroep (net iets) meer succes heeft. ${ }^{62}$ Iemand die zich beklaagt over enkele, naar zijn smaak te zware voorwaarden in een verleende vergunning kan, aan het eind van het beroep geconfronteerd worden met vernietiging van de vergunning. Uit rechtsbeschermingsoptiek lijkt het mij voor de hand te liggen dat alsdan, desgevraagd, de mogelijkheid tot het toekennen van schadevergoeding wordt toegepast.

\subsubsection{De rol van de non-contentieuze procedure}

\subsubsection{Democratie en rechtsbescherming}

In het licht van het voorafgaande zal duidelijk zijn geworden hoezeer ik hecht aan de democratische- en rechtsbeschermingsfunctie van de non-contentieuze procedure. Met name de achterliggende aspiratie om te komen tot de meest optimale individuele rechtsbedeling is daarbij van belang. Waarborging van de regels van de non-contentieuze procedure kan naar mijn smaak goed samengaan met de keuze voor rechtsbescherming als primair doel van het bestuursproces. Als immers het besluit zelf inzet van rechtsstrijd is, en niet voor onaantastbaar wordt gehouden, is verzekerd dat een succesvol beroep er ook daadwerkelijk in zal resulteren dat met inachtneming van non-contentieuze regels een nieuw besluit genomen wordt. Dat feit is mijns inziens een belangrijke raison d'être voor het bestuursproces.

\subsubsection{Objectieve redelijkheidstoetsing}

In het voorgaande deel heb ik getracht het belang van de democratische en de publiekrechtelijke legitimatie duidelijk te maken. Daarbij kwamen ook de plaats en de omvang van de rechterlijke toetsing om de hoek kijken. Er bestaat - gelukkig - geen twijfel meer over dat het bestuursproces draait om een rechtmatigheidstoets. In het allerlaatste (ten onrechte officieel ongepubliceerd gebleven) voorontwerp Whro $1{ }^{63}$ wordt an het uitgangspunt van een rechtmatigheidstoets nog krachtig toegevoegd: "niet meer, maar ook niet minder". ${ }^{64}$ Niet meer verwijst naar de beperking in het rechterlijk oordeel op die punten waar rechtsregels ruimte laten voor de "opportuniteit van het bestuurshandelen". ${ }^{\text {s. }}$ De term opportuniteit wordt niet nader gedefinieerd maar lijkt in elk geval discretionair bestuur (in termen van beleid en beoordeling) te omvatten. Niet minder maakt duidelijk dat indien het recht normen

62. Vgl. Verheij. N., Een klantvriendelijke rechter. a.w.. p. 144.

63. Dat ook ten grondslag lag aan de bespiegelingen in Nieuw bestuursprocesrecht, a.w.

64. In de ontwerp-MvT p. 28.

65. Ibidem. 
voor het besturen stelt, het bestuurlijk handelen hieraan ook ten volle kan worden getoetst.

In dit beeld ontbeert de rechter daar waar rechtsregels zwijgen de legitimatie om te spreken. Dit lijkt in het bijzonder het geval te zijn voor de inhoud van de krachtens dicretionaire bevoegdheid, op grond van democratische legitimatie door het bestuur genomen besluit. Niettemin staat (zoals ik in Hoofdstuk 6 heb uiteengezet) de rechter - juist krachtens zijn onafhankelijke, geschilbeslechtende functie - toch steeds de marginale redelijkheidstoets als (met het willekeurverbod gegeven) rechtsmaatstaf ten dienste.

Mij dunkt dat het belangrijk is om te weten of de eisen van een publiekrechtelijke legitimatie (de non-contentieuze waarborgen) eveneens aan het bestuur een zekere "opportuniteit" laten, en welke consequenties dat heeft voor de "indringendheid" van de rechterlijke toets. Dit punt speelt met name waar het gaat om het inhoudelijke oordeel inzake feitenvaststelling.

In bijzonder opzicht moeten we aandacht schenken aan de normatieve keuzes bij de feitenvaststelling - waarover ik reeds sprak in $\S 4.5 .3$.

In de eerste plaats de bepaling van de in het geding zijnde bevoegdheid. Deze keuze heeft invloed op het feitenonderzoek omdat dit moet zijn afgestemd op de toepassingscondities van de desbetreffende bevoegdheid. Het spreekt wel voor zich dat de rechter in dit opzicht zonder terughoudendheid toetst.

In de tweede plaats hebben we van doen met de toets op vooroordelen in het feitenonderzoek. In dit verband wees ik op het feit dat de premisses van het onderzoek congruent moeten zijn met de toepassingscondities: aan de hand van het feitenonderzoek moet de kwalificatievraag kunnen worden beantwoord. Ook hier toetst de rechter indringend, aangezien hij het laatste woord spreekt over de uitleg van (vage) toepassingscondities en hij ook de bevoegdheid van het bestuur moet controleren. ${ }^{66}$

In de derde plaats bevat het feitenonderzoek (doorgaans) extrapolaties van wetenschappelijke aard, is het gebaseerd op theorieen die gekozen zijn op grond van wetenschappelijke waarden en volgt het onderzoek (op voet daarvan) juist de inzichten die de onderzoeker toonaangevend of gezaghebbend acht. Het bestuur moet aan de hand van een marginale toets de juistheid en volledigheid van het feitenonderzoek vaststellen - superdeskundigheid wordt niet vereist. Het is denkbaar dat de rechter - desgevraagd - eenvoudig doet wat het bestuur reeds heeft gedaan: marginaal toetsen. Als hij daarbij tot andere conclusies zou komen dan het bestuur, zou dat reden kunnen zijn om "correctief" op te treden. De vraag rijst echter of, met name bij complexe

66. In die visie past het niet dat het bestuur een zekere marge krijgt om zelf uit te maken of aan de toepassingscondities is voldaan. 
feiten, de rechter er niet goed aan doet om te volstaan met de vraag of het bestuur in redelijkheid kon menen dat het feitenonderzoek juist en volledig is geweest. Deze formulering impliceert een marginale redelijkheidstoetsing van het bestuurlijk handelen: het blijft echter zo dat het bestuur zich op dit punt niet in subjectieve, dat wil zeggen politiek gemotiveerde keuzes mag begeven. De rechter zal bestuurlijke subjectiviteit (een belangenafweging) bij de feitenvaststelling moeten afwijzen. Daarnaast zal hij een objectieve doch afstandelijke toets moeten uitvoeren: "kon een redelijk denkend persoon of orgaan in redelijkheid tot de conclusie komen dat..." Deze norm, ik zou willen spreken van een "objectieve redelijkheidstoets", is een relatieve norm: de rechter laat een marge voor "normale" verschillen in appreciatie.

In de vierde plaats moet een beslissing worden genomen over nauwkeurigheid, diepgang en omvang van het feitenonderzoek: de problematiek van de bevredigende beslissing en van art. 3:2 en 3:4 Awb. Op drie punten worden hierbij normatieve keuzes gemaakt:

- bij de selectie van te onderzoeken alternatieven gaat het om de vraag welke alternatieven redelijkerwijs in beschouwing dienen te worden genomen. In \$ 7.2.3.2 verwees ik naar een uitspraak van de Afdeling Geschil$l^{1} \mathrm{n}^{6}$ over het voorschrift van art. 7.10, eerste lid onder b Wm, dat deze problematiek binnen de context van de m.e.r. betreft. De Afdeling nam daarbij als (negatief) criterium: "het zich in redelijkheid op het standpunt kunnen stellen dat een alternatief niet kan worden aangemerkt als een alternatief dat redelijkerwijs in beschouwing moet worden genomen." Deze redactie behelst naar mijn mening een zekere opportuniteit aan bestuurszijde. Dit behelst geen ruimte voor subjectieve normstelling, maar wel voor het geven van een "objectief redelijkheidsoordeel". Ik wijs er op dat het hier bij niet alleen gaan op het element "redelijkheid" maar ook om het in redelijkheid op het standpunt kunnen stellen etc. Voorts valt in het criterium de negatieve strekking op. Het bestuur laat een bepaald alternatief buiten beschouwing en in plaats van de vraag te stellen of (in redelijkheid zou moeten worden geoordeeld dat) het desbetreffende alternatief redelijkerwijs in beschouwing had moeten worden genomen, kiest de rechter voor een optiek die veel meer vanuit de positie van het bestuur lijkt te zijn gekozen.

- bij het onderzoek moet naar de maat van de toepassingscondities en het gewicht van de betrokken belangen, redelijke zekerheid worden bereikt. Dit is natuurlijk bij uitstek een bewijsrechtelijke kwestie die door de rechter wordt gecontroleerd. Zoals ook in het volgende hoofdstuk nog 
naar voren zal komen $^{68}$ brengt het vermoeden van rechtmatigheid mee, dat het bestuur niet gehouden is volstrekte zekerheid te bieden. Redelijke zekerheid kan meer of minder zware eisen aan het bewijs stellen; als regel is het daarbij zo dat het bestuur op gerede twijfel zal moeten kunnen antwoorden maar dat lichte twijfel niet tot afkeuring van de feitenvaststelling vermag te leiden. ${ }^{\theta}$

- bij toetsing kunnen onzekerheden over de feitenvaststelling worden verdisconteerd. We bevinden ons daarmee echter reeds in de sfeer van de (subjectieve) belangenafweging. Ik laat dit punt mitsdien terzijde.

Duidelijk mag zijn dat alhoewel de feitenvaststelling toch een domein is waar het bestuur zich heeft te onthouden van een subjectieve belangenafweging, er op onderdelen wel degelijk sprake is van een zekere "beoordelings-opportuniteit". Kortgezegd betreft dit de toets inzake de juistheid en volledigheid van het feitenonderzoek, de toets inzake redelijkerwijs in beschouwing te nemen alternatieven en de kwestie van de redelijke zekerheid.

Ik meen dat er twee belangrijke, algemene overwegingen zijn die pleiten voor een zekere beoordelings-opportuniteit zijdens het bestuur.

In de eerste plaats denk ik aan de openheid van de non-contentieuze procedure. Een openheid in formele zin, ik denk daarbij aan de formele regels inzake openbaarheid en inspraak, en een openheid in materiële zin, waarbij ik denk aan het feit dat een gedachtenwisseling plaatsvindt vooraleer een definitief besluit genomen is. Bij een optimale naleving van non-contentieuze regels, kan een procedure plaatsvinden die gelijkt op het normatieve discours van Habermas - waarover ik sprak in \$ 4.4.2. Mij lijkt het zaak dat het bestuur zich daar waar bij de feitenvaststelling normatieve keuzes gemaakt moeten worden, oriënteert op dit open debat. Beoordelings-opportuniteit impliceert het geven van een redelijk oordeel omtrent voornoemde normatieve keuzes; op voet van hetgeen in het open, non-contentieuze debat is voorgevallen. Het bestuur moet een inschatting maken van het "evenwichts- of zwaartepunt" in de gedachtenwisseling over de genoemde normatieve keuzes. Anders dan op het punt van de belangenafweging gaat het daarbij niet om een subjectieve

68. Ik hoop dat de lezer mij op dit punt enig krediet gunt; ik zal mijn stelling hier beslist nog nader adstrueren.

69. "Absolute zekerheid" kan wel in het geding zijn bij een geformaliseerde bewijsvoering (-waardering) - vergelijk de bloedproef bij alcoholcontrole. Ook dat punt zal in hoofdstuk 9 worden besproken. 
keuze maar om de aspiratie van een "objectieve taxatie". ${ }^{00}$ Het bestuur moet uiteindelijk de verantwoordelijkheid nemen om de noodzakelijke conclusies uit het debat te trekken. ${ }^{71}$ Essentieel is dan wel dat het bestuur daarop weer aanspreekbaar moet zijn. Voorzover de rechter in die controle op het bestuur een rol speelt, ${ }^{72}$ zal hij zich er rekenschap van moeten geven dat de conclusies van het bestuur voortvloeien uit een open debat, waaraan de rechter zelf geen deel heeft gehad en dat inmiddels is afgesloten. Hij zal zich moeten baseren op verslagen en verklaringen omtrent hetgeen is voorgevallen. De vraag of het bestuur gelet op hetgeen in de non-contentieuze gedachtenwisseling is voorgevallen in redelijkheid kon komen tot de (bestreden) beslissing, zal daarbij de rechterlijke maatstaf moeten zijn. ${ }^{73}$ Daarmee sluit de rechter aan op de aspiratie van de objectieve norm en erkent hij tegelijkertijd dat de normatieve keuzes primair in de non-contentieuze procedure zelf thuishoren. Mocht de rechter tot de conclusie komen dat het bestuur een onjuiste taxatie heeft gemaakt en daarmee een onjuiste beslissing heeft gegeven, dan zal hij zich terdege moeten afvragen of het niet wijs is om de hernieuwde feitenvaststelling zich opnieuw in de non-contentieuze sfeer te laten voltrekken. Het is immers maar zeer de vraag of ten overstaan van de rechter een open debat over de feiten, vergelijkbaar met het non-contentieuze debat, gevoerd kan worden. Ik denk daarbij ondermeer aan overwegingen inzake de laagdrempeligheid van inspraak en het vooruitzicht van een definitieve beslechting van de zaak. ${ }^{74}$

In het verlengde hiervan is nog een tweede punt in het geding: de geëquipeerdheid van het bestuur. Alhoewel het bestuur geen superdeskundigheid moet pretenderen, moet het wel over de deskundigheid beschikken om althans de marginale toets van de volledigheid en juistheid van het feitenonderzoek te kunnen uitvoeren. Dat geldt ook ten aanzien van door het bestuur ingewonnen adviezen. Voor de rechter zal dit, zeker waar complexe en omstreden feiten in het geding zijn, veel moeilijker zijn. Terwijl het bestuur aan zijn oordeel een minimale dosis inhoudsdeskundigheid ten grondslag legt, ${ }^{75}$ zal de rechter - in meer complexe gevallen - toch een terughoudender, meer

70. Objectief wordt hier in de Habermasiaanse zin gebruikt: als een aspiratie tot consensus. Ik spreek van een aspiratie tot (deze) "objectiviteit" om te onderstrepen dat we doorgaans met een kunstgreep van doen hebben: consensus wordt doorgaans niet bereikt - en is in geen geval met absolute zekerheid vaststelbaar.

71. Het bestuur is immers geroepen om een norm te stellen.

72. Publieke en politicke opinie kunnen in dit opzicht natuurlijk ook van belang zijn.

73. Let wel ik doel hier nog altijd uitsluitend op de voorbesproken normatieve keuzes.

74. In de non-contentieuze procedure is ook in zoverre sprake van openheid dat er de zekerheid is dat het verloop en de uitkomsten daarvan nadien door de rechter getoetst kunnen worden.

75. En van het bestuur die (minimale) inhoudsdeskundigheid ook verwacht mag worden. 
formeel oordeel moeten aanleggen. Hij zal moeten oordelen als het onafhankelijke forum: kon het bestuur "in redelijkheid tot de conclusie komen dat..."

De non-contentieuze procedure is - kortom - bij uitstek "geschikt" voor de feitenvaststelling. Het bestuur is voor feitenvaststelling naar mijn mening bij uitstek verantwoordelijk. Bij diverse normatieve keuzes is een beoordelingsopportuniteit in het geding waarin het bestuur een zeker primaat voor de feitenvaststelling toekomt. Dit hangt samen met het specifieke karakter van de non-contentieuze besluitvorming, de gëquipeerdheid van het bestuur en de eisen die rechtens worden gesteld aan de toetsing van onderzoek naar de feiten en het bereiken van een bevredigende beslissing.

Bezien we de eisen die de Awb stelt ten aanzien van de feitenvaststelling, dan komen we allereerst uit bij de regel over kennisvergaring, te weten art. 3:2 Awb. Mij dunkt dat de open of vage formulering van de hoofdbestanddelen uit dit artikel - "de nodige kennis omtrent de relevante feiten" - wel degelijk een bepaalde mate van beoordelings-opportuniteit laat. Dat daarin het bestuur het primaat heeft valt daarin echter niet expliciet te lezen. ${ }^{76}$ Gelet op het vorenstaande zal duidelijk zijn dat ik die stelling niettemin zou willen verdedigen. Ik zou menen dat de rechter er mee zou moeten volstaan na te gaan of het bestuur in redelijkheid heeft kunnen menen dat aan de vereisten van art. $3: 2 \mathrm{Awb}$ is voldaan.

Een ander aanknopingspunt zou natuurlijk kunnen zijn om deze gedachte te verbinden aan een bepaling inzake de bestuurlijke verantwoordelijkheid voor de feitenvaststelling. Zodanige bepaling is in de Awb niet te vinden. Dat is ook wel te begrijpen omdat deze verantwoordelijkheid, zoals ik ook in $\$ 3.2 .3$ reeds stelde, voortvloeit uit het legaliteitsbeginsel en (bij beleidsvrijheid) uit de plicht tot het maken van een belangenafweging. De bevoegdheid tot handelen bestaat slechts indien aan de daarvoor geldende toepassingscondities is voldaan. Of dit het geval is zal moeten worden beoordeeld aan de hand van een feitenvaststelling. ${ }^{77}$ Overigens biedt het motiveringsbeginsel ook een concrete aanwijzing voor de bestuurlijke plicht - en verantwoordelijkheid - tot vaststelling van de feiten. Waar in art. 4:16 Awb (art. 3.6.1 Awb) wordt gesproken van een deugdelijke motivering, wordt daarmee op twee aspecten gedoeld. ${ }^{78}$ In de eerste plaats een juiste vaststelling van de

76. Kobussen. M.H.. in: Ten Berge et al (red.). Commentaar op de Algemene wet bestuursrecht, a.w.. E3.2.1-4 (ABR 11/40) lijkt dat te impliceren.

77. Deze beoordeling omvat de interpretatie van toepassingscondities en de kwalificatie van de feiten in (de vage) termen van de toepassingscondities.

78. Vgl. MvT-Awbl, p. 108. 
feiten en in de tweede plaats een dragende redenering die van deze feiten leidt tot de genomen beslissing. ${ }^{79}$

Ik zou niet per se willen aandringen op een bijzondere bepaling waarin de plicht, de eigen verantwoordelijkheid en de beoordelings-opportuniteit van het bestuur tot uitdrukking worden gebracht. Mij dunkt dat het door mij hier omschreven uitgangspunt ook in de bestaande codificatie, in het bijzonder in art. 3:2 en art. 3:4 Awb kan worden ingelezen.

Tot slot wil ik nog wel benadrukken dat dit uitgangspunt verder reikt dan de stellingname dat het bestuur zich steeds als eerste over de feiten dient uit te laten, ${ }^{80}$ en dat het op praktische gronden niet wijs zou zijn dat de rechter als vanzelf (desgevraagd) tot algehele hervaststelling van de feiten over gaat. ${ }^{81}$ De crux van mijn stellingname is dat het bestuur over een zekere inhoudelijke opportuniteit beschikt, welke meebrengt dat de rechter zich (ten aanzien van bepaalde normatieve keuzes) ${ }^{82}$ dient te laten leiden door een "objectieveredelijkheidstoets". A fortiori geldt dan dat van een ambtshalve hervaststelling van de feiten, zoals in het Duitse bestuursrecht krachtens het "Untersuchungsprinzip", in elk geval geen sprake kan zijn. ${ }^{83}$ Dat wil echter niet zeggen dat de rechter zich nimmer met feitenvaststelling zou mogen bezig houden. Als het bestuur bij de feitenvaststelling de grenzen van de "objectieve redelijkheid" te buiten gaat, zal de rechter moeten ingrijpen. Als het optreden van het bestuur doet vrezen dat bestuurlijke hervaststelling van de feiten niet op de door de non-contentieuze voorschriften beoogde wijze zal kunnen plaatsvinden, ${ }^{84}$ dan zal de rechter de klus toch zelf moeten klaren. Dit geldt uiteraard ook voor (evidente) misstappen waarbij een bepaalde correctie voor de hand ligt. ${ }^{85}$

79. De eigen verantwoordelijkheid moge overigens blijken uit art. 4:19 en 4:20 Awb.

80. Vgl. Teunissen. J.M.H.F., Toetsing ex nunc of ex tunc?. in: Nieuw bestuursprocesrecht, a.w., p. 113 (noot 5): de rechtsstatelijke taakverdeling tussen rechter en bestuur: "das Recht der Verwaltung zur Erstenscheidung".

81. Vgl. (ten aanzien van zelf voorzien) Verheij, Een klantvriendelijke rechter, a.w., p. 142.

82. Uit het voorgaande bleek al wel dat dit niet geldt ten aanzien van de keuze van de bevoegdheid. de uitleg van de toepassingscondities en het screenen van het feitenonderzoek op niet-wetenschappelijke premisses.

83. Vgl art. 86, eerste lid, Verwaltungsgerichtsordnung, vgl. Banda, prft., a.w., p. 83, Veltman, J. Het passeren van procedurele gebreken. Artikel 6.2.14 Awb in rechtsvergelijkend perspectief, NTB'89/2, p. 37-38 en Verheij. N., Een klantvriendelijke rechter, a.w., p. 142.

84. Het bestuur heeft er zo'n rommeltje van gemaakt dat bij betrokkenen het vertrouwen in een open debat (volstrekt) ontbreekt, of het bestuur heeft zich inhoudelijk onbekwaam betoond.

85. Anders gezegd: als de feitenvaststelling op het punt in kwestie onomstreden is (bij voorbeeld bij een kennelijke verschrijving, of het ontbreken van een feit van algemene bekendheid). 


\subsubsection{Ongelijkheidscompensatie en rechterlijke discretie}

De toetsing van het bestuursbesluit staat in het teken van de subjectieve rechtsbescherming. Dat betekent dat de klacht van een burger aanleiding is tot een procedure waarin wordt nagegaan of het bestuursbesluit (in zijn aantasting van het belang van eiser) legitiem, dat wil zeggen rechtmatig (genomen) is. Hierboven gaf ik aan dat door het besluit als object centraal te blijven stellen de mogelijkheid daar is om de rechtsbeschermingsaanspraken van non-contentieuze waarborgen,${ }^{86}$ te verzekeren. Als het belang van eiser door het besluit onrechtmatig wordt aangetast, valt het besluit en zal een nieuw besluit genomen moeten worden.

In het verlengde hiervan wordt het object van geschil bepaald door de eiser. Inzoverre geldt het uitgangspunt van de partij-autonomie. Dit gezegd zijnde ziet de regering in de idee van ongelijkheidscompensatie een aanknopingspunt dat de rechter tot verdergaand onderzoek kan brengen dan de klacht in eerste aanleg doet vermoeden. De rechter zal zich, uitgaande van de individuele belangpositie van eiser moeten bezinnen op de machtsongelijkheid tussen burger en bestuur. In het bestuursprocesrecht geldt, om met Verheij te spreken, het "calimero-principe": de rechter zal de burger enigszins tegemoet moeten komen. ${ }^{87}$ Mitsdien zal de rechter er niet voetstoots vanuit mogen gaan dat het beroepschrift van appellant de optimale neerslag is van hetgeen hij in het geschil hoopt te bereiken. ${ }^{88}$ Uitgaande van de best mogelijke interpretatie van de belangpositie, zal de rechter rechtsgronden en feiten kunnen aanvullen. ${ }^{80}$ Wat het aanvullen der feiten betreft, ligt het belang van rechterlijk activisme er in besloten dat niet alleen de juistheid maar ook de volledigheid van de bestuurlijke feitenvaststelling aan de orde kan zijn. Omdat van klager niet - onder alle omstandigheden - kan worden verwacht dat hij zich beroept op de onvolledigheid van de feitenvaststelling (dit vergt immers een kennis op het niveau van de stand van wetenschap en techniek), ${ }^{90}$ is het wenselijk dat de rechter hier aanvult. ${ }^{91}$ In het wetsvoorstel Whrol wordt wat de aanvulling van feiten betreft overigens uitdrukkelijk toegevoegd dat de

86. Zoals een hoorplicht bij "onwelgevallige beslissingen" - vgl art. 4:8 Awb1.

87. Verheij, N. Een klantvriendelijke rechter, a.w., p. 133-134: "Zij zijn groot en ik is klein."

88. De MvT-Whrol. p. 141, zegt het aldus: "Uit het ontbreken van bepaalde stellingen in het beroepschrift kan men immers niet zonder meer afleiden dat de appellant welbewust bepaalde gebreken niet aan de orde heeft willen stellen en derhalve in deze gebreken zou willen berusten."

89. De rechter zal appellant uitdrukkelijk moeten aanspreken op hetgeen hij wenst aan te voeren c.q. te bereiken - vgl. MvT-Whrol.p. 142.

90. Waaronder kennis over procestechnieken en dergelijke (die bijvoorbeeld in casu niet zijn bestudeerd maar toch relevant kunnen zijn).

91. Vgl. Verheij. Een klantvriendelijke rechter, a.w.. p. 145-146. Hij betrekt deze kwestie overigens ook nog op het deskundigen-advies aan de rechter. Ook daar kunnen "en passant" nieuwe feiten worden aangeroerd. 
rechter partijen in de gelegenheid moet stellen zich daarover in de procedure uit te laten. ${ }^{92}$ Dit lijkt mij een elementaire eis.

Het zal duidelijk zijn, dat alhoewel de keuze voor subjectieve rechtsbescherming een grotere partij-autonomie impliceert, en wel met name ten aanzien van de afbakening van het object van geschil, ${ }^{93}$ dit niet aanstonds behoeft te leiden tot volstrekte lijdelijkheid van de rechter. Sterker nog: ongelijkheidscompensatie zal, mede in verband met het streven de materiële waarheid te vinden, met zich meebrengen dat de rechter als een dominus litis zal opereren. ${ }^{94}$ Overigens beperkt zich het rechterlijk activisme niet tot aanvulling van rechtsgronden en feiten. Op het punt van de beslissingen ten aanzien van het procesverloop, is de rol van de rechter zeer groot. Verheij, Banda en Wulffraat-van Dijk ${ }^{95}$ wijzen uitdrukkelijk op het grote aantal discretionaire bevoegdheden waarover de rechter beschikt om het verloop van het onderzoek te bepalen. $\mathrm{Zij}$ plaatsen enkele vraagtekens bij de omvang van de rechterlijke discretie. Hoewel niemand zal betwisten dat de behoefte aan ongelijkheidscompensatie enerzijds en de variatie naar soorten geschillen die volgens het onderhavige procesrecht moeten worden beslecht, krachtige argumenten vormen voor rechterlijke discretie, is er toch ook enige zorg over de rechtspositie van procespartijen. Zo wijst Banda er op dat vele bevoegdheden niet of nauwelijks aan condities zijn gebonden, zoals het over de (wijze) van toepassing daarvan horen van partijen, terwijl het om zeer belangrijke beslissingen kan gaan - zoals het al dan niet oproepen en benoemen van getuigen en deskundigen ${ }^{96}$ en het al dan niet afdoen van het geschil zonder onderzoek ter zitting. ${ }^{97}$

Het zal duidelijk zijn dat de "kan-bepalingen" in de regels voor procesrecht aandacht behoeven. Eens temeer wordt duidelijk hoe belangrijk het is dat in een tweede rechterlijke instantie, althans in cassatie kan worden geklaagd over de wijze waarop de rechter in een concreet geval zijn bevoegdheden heeft gebruikt. ${ }^{98}$

92. Ibidem.

93. Zulks ligt verankerd in art. 8:69, eerste lid Awb, dat voorschrijft dat het beroepschrift de grondslag vormt voor de rechterlijke uitspraak.

94. Zie ook Tak, a.w., 1992, p. 15.

95. Verheij. Een klantvriendelijke rechter, a.w., p. 149; Banda. P.H., Het onderzoek door de rechter, a.w., p. 107-109: Marja Wulffraat-van Dijk, De onderzoeksbevoegdhedenvan de rechter in het nieuwe bestuursprocesrecht, in: Nieuw bestuursprocesrecht, p. 151-168.

96. Art. 8:46 en art. 8:47 Awb.

97. Banda, Het onderzoek door de rechter, in: Nieuw bestuursprocesrecht, a.w., p. 99-109, noemt nog een aantal andere discretionaire bevoegdheden (vgl. p. 108-109).

98. Banda, Het onderzoek door de rechter, a.w., p. 109 (noot 25) noemt, voor het geval het geschreven Nederlandse procesrecht zwijgt, naast een beroep op art. 6 EVRM ook het ongeschreven recht als grondslag voor aanwending van een rechtsmiddel. 


\subsubsection{Zelf in de zaak voorzien}

We lijken met de laatste opmerkingen enigszins te zijn afgedwaald van de relatie met de non-contentieuze procedure. Toch is dat maar schijn. Rechterlijke discretie kan ontaarden in een doorkruising van de non-contentieuze waarborgen. Dat gevaar dreigt in het bijzonder bij de rechterlijke uitspraak, indien deze een bestuursbeslissing inhoudt. ${ }^{99}$ Formeel gezien is er geen probleem. Als de rechter het bestreden besluit vernietigt, doet hij dat omdat het bestuur dit besluit niet had mogen nemen. Als hij het vervolgens bij vernietiging houdt, kan het bestuur op herkansing. Besluit de rechter na vernietiging zelf in de zaak te voorzien, dan is ook dat geen doorkruising van het bestuur, zolang de rechter slechts zelf voorziet als er rechtens nog maar én besluit genomen kan worden; bij terugverwijzing zou ook het bestuur zo moeten beslissen. ${ }^{100}$

Toch is het erga omnes door de rechter zelf voorzien naar mijn smaak problematisch. De vraag rijst wie er op toeziet dat de rechter zijn bevoegdheid op dit punt niet te buiten gaat. Het risico bestaat dat de rechter, teneinde een geschil tot een snel einde te brengen, alhoewel nog beleidskeuzes open staan, toch zelf voorziet. De druk hiertoe zal vooral groot zijn als partijen tot een schikking bereid lijken. Met name de instemming van het verwerende bestuursorgaan kan de rechter hier op het verkeerde pad brengen.

Terecht stelt Verheij dat de rechter hier niet al te snel op in moet gaan. Het is immers maar de vraag of het bestuur bevoegd is om eigen beleidsvrijheid af te schuiven ${ }^{101}$ en daarbij zou het ongewenst zijn indien de rechter door een verzoek gedwongen zou kunnen worden om een uitgebreid feitenonderzoek te ondernemen: "Het mag geen regel worden dat de rechter ingeval van bestuurlijke slordigheid het karwei zelf moet opknappen". ${ }^{102}$

Ook rijst de vraag of de rechter wel goed in staat is om te beoordelen of bij een vrije bevoegdheid, in een concreet geval nog beleidsvrijheid resteert. In extreme gevallen zal dit niet zo'n probleem zijn - dit zijn tevens de gevallen waar duidelijk is dat elke andere beslissing schending van het willekeurverbod zou inhouden. Het gaat dan om evidenties of om gevallen waar de rech-

99. Het punt waar met name Tak, a.w. 1992, p. 17. voor waarschuwt.

100. De uitspraakbevoegdheden bij gegrondverklaring van het beroep staan opgenomen in art. 8:72 Awb (en omvatten meer dan de hier genoemde uitspraakmogelijkheden).

101. Verheij, N., Een klantvriendelijke rechter. a.w., p. 140-143. Dit volgt uit het legaliteitsbeginsel: het bestuur mag niet autonoom over zijn bevoegdheden beschikken. Verheij staat echter een genuanceerde beoordeling voor (o.a. naar de mate van politieke gevoeligheid). Ik ben daar huiverig voor: het bestuur is geen solist in de besluitvorming. hooguit dirigent of regisseur - er zijn ook andere betrokkenen met eigen belangen.

102. Verheij, ibidem (met het risico van onaanvaardbare verlenging van de procesduur). 
ter slechts de beleidsopties behoeft te beoordelen die concreet door partijen worden voorgelegd. Tot het oordeel over wat 'echt niet' kan acht ik de rechter zonder meer bekwaam. In andere gevallen lijkt het mij voor de rechter toch problematisch om na te gaan of er binnen de grenzen van het recht nog alternatieve besluitvormingsopties bestaan - en dit is precies de voorvraag die bij het al dan niet zelf in de zaak voorzien aan de orde is. De rechter moet een beleidsmatige analyse aangaan, waartoe hij toch eigenlijk niet is geëquipeerd. Naar mijn mening is het oordeel over de onredelijkheid van een beslissing, vanuit het juridisch perspectief, makkelijker te geven dan het oordeel over de vraag of er toch nog meer 'redelijke beslissingen' in het vat zitten. Zolang de rechter zich bij het zelf voorzien beperkt tot genoemde extreme gevallen, lijkt er niets aan de hand. Het punt is echter toch dat de mogelijkheid van het zelf voorzien, z'n schaduw vooruit werpt; de rechter gaat hypothetiseren over het bestaan van (eventuele) andere beleidskeuzes binnen de grenzen die het recht stelt. Hij begeeft zich daarmee in een betuurlijke verkenning, terwijl hij daartoe niet gekwalificeerd is.

Het lijkt mij met het oog op deze bedenkingen wijs om ten aanzien van het zelf in de zaak voorzien, nog eens kritisch naar de voorwaarden te kijken.

- Primaire voorwaarde is die van feitelijke afwezigheid van beleidsvrijheid. ${ }^{103}$ Daar is in elk geval aan voldaan bij gebonden bevoegdheden. Gaat het echter om een (formeel) discretionaire bestuursbevoegdheid, dan mag in het concrete geval op grondslag van die bevoegdheid slechts nog één rechtmatig besluit mogelijk zijn: er moet sprake zijn van "Ermessensreduzierung auf Null". ${ }^{104}$

Ook Brenninkmeijer ${ }^{105}$ trekt de grens voor de mogelijkheid om zelf te voorzien daar waar de rechter zich zou moeten bewegen in het maken van discretionaire beleidskeuzes. In zijn NJV-preadvies meen ik echter enige nuancering van dit standpunt te bespeuren. Hij verwijst daar naar de stellingname van Hirsch Ballin, ${ }^{106}$ die uitgaande van de bevoegdheid van de rechter om ook de uitoefening van discretionaire bevoegdheden te toetsen stelt: "De rechter kan dus ook ... een omstreden administratieve rechtsbetrekking vaststellen, eventueel met inbegrip van het gebruik dat van discretionaire bevoegdheden moet worden gemaakt." Brenninkmeijer wijst erop dat de "voortgaande rechtsontwikkeling" Hirsch Ballin geen

103. MvT-Whrol. p. 36, Voorts o.a. Widdershoven et al., Bestuursrechtspraak in milieugeschillen. a.w.. p. 214-215. Hutten. D.J., Zelf in de zaak voorzien. In: nieuw bestuursprocesrecht, a.w., p. 195-207, i.h.b.p. 198.

104. Vgl. Teunissen, J.M.H.F., Toetsing ex nunc of ex tunc, a.w., p.111-129. i.h.b. p.113.

105. NJV-preadvies, a.w.. p. 49-50.

106. Hirsch Ballin, E.H.M., Handelingen NJV 1983-I. p. 63. 
ongelijk lijkt te geven en stelt vast dat deze zienswijze (ook in rechtsvergelijkend perspectief) op het punt van sancties zeer wel toepasbaar lijkt. $^{107}$

Waar Hirsch Ballin het woordje "dus" gebruikt word ik argwanend. ${ }^{108}$ Allereerst meen ik dat de rechter bij toetsing van een besluit toch een andere, meer afstandelijke positie kan innemen dan bij het zelf geven van een nieuwe beslissing (in plaats van de vernietigde bestuursbeslissing). Bij toetsing kan onvoldoende overtuigd zijn van de juistheid van het bestreden besluit (gerede twijfel), voldoende grond zijn voor gegrondverklaring van het beroep. ${ }^{109} \mathrm{Bij}$ het vaststellen van een nieuw besluit is naar mijn mening een meer indringende beoordeling noodzakelijk, uitmondend in meer positieve, op redelijke zekerheid gebaseerde overwegingen. ${ }^{110}$ Voorts brengt de stellingname van Hirsch Ballin mee dat de rechter een eigen oordeel van het gebruik van beleids- of beoordelingsvrijheid moet ontwikkelen."' Dit acht ik in zoverre dubieus omdat dan zonder democratische legitimatie keuzes worden gemaakt. Keuzes die bovendien de publiekrechtelijke legitimatie van de non-contentieuze procedure behoeven. De gevaren waar Tak op wijst ${ }^{112}$ worden nu reëel.

- In de tweede plaats - maar naar mijn smaak niet minder belangrijk - wordt zelf voorzien ongewenst geacht als sprake is van een problematische feitenvaststelling. Drie gevallen kunnen zich daarbij voordoen.

In de eerste plaats zal de rechter in veel gevallen niet zelf kunnen voorzien omdat hij daartoe feiten en omstandigheden moet beoordelen die in de procedure (in verband met het punt van geschil) geen rol hebben gespeeld. ${ }^{113}$

In de tweede plaats kan het zijn dat feiten nog niet volledig onderzocht zijn of dat ingewikkelde berekeningen moeten worden gemaakt. Volgens Hutten ${ }^{114}$ is dit echter veeleer een "pragmatisch" bezwaar, waar de rech-

107. A.w., p. 50.

108. Bij mijn weten heeft Piet Grijs het woordje "dus" ooit eens ergens omschreven als "aankondiging van een denkfout", al weet ik helaas niet meer waar.

109. Bij voorbeeld wegens schending van het motiveringsbeginsel.

110. Vgl. Ten Berge/Tak I, a.w., p. 347-349. Vgl. tevens § 4.3.3.

111. Toetsing leidt tot uitsluiting van de apert onredelijke gevallen, maar binnen de categorie "redelijke gevallen" kunnen zich nog vele aanvaardbare opties voordoen met sterk uiteenlopende (rechts)gevolgen voor betrokkenen.

112. Tak. a.w. 1992, p. 17.

113. MvT-Whrol, p. 146. Eerder wees ik ook op de stellingname van Verheij, inhoudende dat de rechter niet automatisch het karwei voor het (slordige) bestuur moet gaan opknappen.

114. Hutten, D.J., Zelf in de zaak voorzien, in: Nieuw bestuursprocesrecht, a.w., p. 195-207, i.h.b. p. 198-199. 
ter ook weer niet al te moeilijk over moet doen - de wens om een geschil (efficiënt) af te doen staat voorop. ${ }^{115}$

In de derde plaats denk ik aan het feit dat de feitenvaststelling gepaard gaat met bestuurlijke opportuniteit, zoals hiervoor in $\$ 8.3 .3 .2$ omschreven. Dit zal zich met name doen gelden bij beslissingen van een ingewikkeld karakter inzake kwetsbare belangen. Zo zou ik mij kunnen voorstellen dat de rechter in elk geval bij beslissingen waarbij Afdeling 3.5 Awb wordt toegepast een zekere terughoudendheid in acht neemt. In feite keren we daarmee terug bij het primaire beletsel dat ik hiervoor besprak: de bestuurlijke discretie - zij het dat het hier niet gaat om een subjectieve maar om een objectieve discretie.

Naar mijn oordeel moeten de feiten - in dergelijke gevallen - wel heel duidelijk en eenduidig liggen ${ }^{116}$ wil zelf voorzien een aanvaardbare optie zijn. Anders zal zelf voorzien mijns inziens moeten afstuiten op de bestuurlijke beoordelings-opportuniteit, c.q. het primaat van de non-contentieuze procedure.

Beide aspecten, beleidsvrijheid en feitenvaststelling, behoren naar mijn idee primair tot het domein van de non-contentieuze bestuurlijke besluitvorming. Daar ligt de primaire verantwoordelijkheid en daar moet de legitimatie van het besluit worden verworven. In het verlengde van de gesignaleerde problemen is een tweetal aspecten nog in het bijzonder van belang: de publieke werking van besluiten en de kwestie van het beslissen of toetsen ex nunc.

\subsubsection{Publieke werking}

Door bepaalde bestuursbesluiten kunnen meerdere personen tegelijkertijd rechtstreeks en onmiddellijk in hun rechtens te beschermen belangen worden getroffen. We hebben dan te maken met besluiten met een "publieke werking" ${ }^{117}$ of een werking 'erga omnes'. Zo zal het verlenen van een integrale milieuvergunning niet alleen rechtsgevolgen hebben voor aanvrager/houder en bestuur maar ook voor omwonenden. Daartegenover is bij beschikkingen op het gebied van de fiscaliteit of de sociale zekerheid deze publieke werking veel zwakker. Natuurlijk is daar aan de zijde van het bestuur nog altijd het algemeen belang in het geding, maar aan de zijde van de burger is er slechts één persoon die rechtstreeks en onmiddellijk in zijn rechtens te beschermen belangen wordt geraakt.

Vele procedures getuigen van de ongeschreven regel dat bij de totstandkoming van beschikkingen met publieke werking in elk geval voor belangheb-

115. Ibidem, p. 206-207 - tenzij het gaat om punten die niet in geschil zijn geweest.

116. Zie ook Teunissen, Toetsing ex tunc of ex nunc, a.w.. p. 128.

117. Ik ontleen deze term aan P.C.E. van Wijmen, a.w.. p. 153. 
benden inspraak mogelijk moet zijn. Hier is het rechtsbeschermingsmotief achter non-contentieuze procedures in het geding. Bij besluiten die een zeer grote publieke werking hebben, waaronder besluiten van algemene strekking, en bij besluiten met zeer ingrijpende en voortdurende effecten, staat soms zelfs beroep open voor een ieder. Daar speelt ook het democratische belang een rol. ${ }^{118}$ Deze invloed is niet alleen van belang met het oog op het discretionaire karakter van een bevoegdheid, maar ook met het oog op het onderzoek naar en de vaststelling van de feiten. Inspraak dient niet alleen de mogelijkheid om opvattingen naar voren te brengen, maar ook om informatie en inzicht te verschaffen. Hutten wijst er op dat de publieke werking van een besluit een belangrijke hinderpaal kan zijn voor zelf in de zaak voorzien. ${ }^{119}$ $\mathrm{Zij}$ acht dit een principiële belemmering omdat niet ter processe betrokken belanghebbenden geen invloed op de rechterlijke beslissing kunnen uitoefenen. Weliswaar kan de rechter deze belanghebbenden oproepen, maar het is de vraag of daarmee niet weer zoveel nieuwe "feiten, omstandigheden en argumenten" naar voren komen, dat zelf voorzien te hoog gegrepen is. ${ }^{120}$ Ik voeg daar aan toe dat niet-belanghebbenden, niet door de rechter kunnen worden opgeroepen. ${ }^{121}$ Hun invloed gaat in elk geval verloren.

\subsubsection{Ex tunc of ex nunc}

Het is de vraag of de rechter bij de beoordeling van de bestuurlijke feitenvaststelling ook acht mag slaan op nieuwe feiten, omstandigheden of inzichten, onvoorzienbaar op het moment dat de bestreden beslissing werd genomen (kortweg nova). ${ }^{122} \mathrm{Bij}$ een toetsing ex nunc mag de rechter nova wel meewegen, bij een toetsing ex tunc niet. Deze vraag wordt uiteraard pas relevant indien aannemelijk wordt dat nova reden zouden kunnen vormen tot het nemen van een andere beslissing als door het bestuur (in eerste aanleg) gegeven. ${ }^{123}$

118. $\mathrm{Vgl}$. de procedure van Afd. 3.5 Awb. Daarmee is overigens niet gezegd dat het democratisch belang bij een beperktere kring, te weten "belanghebbenden", geen rol speelt.

119. A.w., p. 198.

120. Ibidem. Soms kan bepaalde kennis alleen met medewerking van betrokkenen worden verworven. Feitenvaststelling kan - met het oog op zelf voorzien - ook problematisch zijn als het om gebonden bevoegdheden gaat.

121. Art. 8:26 Awb geeft daartoe althans niet de mogelijkheid. Wel kunnen zij nog als getuigen worden opgeroepen.

122. Ik zal hierna gemakshalve steeds over nova blijven spreken in plaats van over "nova of een novum".

123. Hetzij voor de rechter, hetzij voor betrokkenen. Zo had een verleende vergunning wellicht toch moeten worden geweigerd of een geweigerde vergunning had wellicht toch moeten worden verleend (en alle tussenliggende modaliteiten). 
De bescherming van het milieu lijkt vooral gediend met een ex nunc toetsing; dit vanwege het technologisch-dynamische karakter van de milieuproblematiek. Het zou - bij voorbeeld - zonder meer ongelukkig zijn als beroep tegen de verlening van een milieuvergunning ex tunc toetsend ongegrond wordt bevonden, terwijl duidelijk is dat in het licht van bepaalde nova de vergunning thans niet zou (mogen) worden verleend. Het is niet ondenkbaar dat eer de "achterhaalde" vergunning is herzien, toch reeds milieuschade zal zijn ingetreden. ${ }^{124}$

In een rechtsbeschermingsoptiek waarin de rechtsverhouding tussen partijen centraal wordt gesteld, lijkt een ex nunc-toetsing goed te passen, omdat het voor klager (en niet zelden ook voor verweerder) aantrekkelijk is als de rechter het geschil ook daadwerkelijk tot een einde kan brengen. ${ }^{125}$

De democratische legitimatie van het bestuur brengt mee dat de rechter zich juist terughoudend dient op te stellen tegenover de aan de bestuurlijke bevoegdheid tot het verrichten van bepaalde handelingen verbonden beleids- en beoordelingsvrijheid. Bij een toetsing ex nunc betrekt de rechter mogelijk nova welke door het bestuur niet konden worden meegewogen. Terzake van de vaststelling en afweging van deze nova wordt het bestuur door de rechter gepasseerd. ${ }^{126}$

Ook de publiekrechtelijke legitimatie kan aan toetsing ex nunc in de weg staan. Niet ten processe betrokken derden kunnen bij een rechterlijke toetsing ex tunc op ongelukkige wijze in het gedrang komen. Zo kunnen er derden zijn die van mening veranderen door toedoen van nova: "wat aanvaardbaar was, is dat nu niet meer", of "wat niet aanvaardbaar was, is dat nu wel", terwijl de rechter in de nova geen reden tot een ander oordeel ziet. Ook is de spiegelbeeldige situatie denkbaar: de desbetreffende derden zijn door de nova niet van mening veranderd (de nova zijn voor het (on)rechtmatigheidsoordeel niet relevant), terwijl het nu juist de rechter is die in de nova een reden ziet om anders te oordelen over de (on) rechtmatigheid.

Met name zijn hier de derden in het geding die niet procederen omdat zij (in elk geval in eerste aanleg) accoord gaan met het genomen besluit en die uiteindelijk niet accoord kunnen gaan met het in het licht van de nova (al dan niet gewijzigde) eindoordeel van de rechter. Juist als de slotsom van de rechter bij ex nunc toetsing is dat het beroep gegrond is, staan genoemde

124. Vgl. over dit milieubelang. Widdershoven et al, a.w., pp. 209-210.

125. Zie Teunissen, Toetsing ex tunc of ex nunc, a.w., p. 116 en p. 126-127, waar hij er nog op wijst dat een toetsing ex nunc ook past in de benadering van art. 6 lid 1 en art. 13 EVRM.

126. Ter Brugge, a.w., p. 58 ("door ex nunc te toetsen zou de rechter ...in strijd komen met de rechtsstatelijke eisen, zoals die tot uitdrukking komen in de taakverdeling tussen rechter en bestuur"). Ook Teunissen, a.w., p. 113, spreekt in dit verband over de rechtsstatelijke taakverdeling tussen rechter en bestuur ("das Recht der Verwaltung zur Erstentscheidung"). 
categorieën derden er het slechtst voor. Dit geldt a fortiori als de rechter vervolgens besluit zelf (ex nunc) in de zaak te voorzien. ${ }^{127}$

In de huidige praktijk staat de toetsing ex tunc voorop. ${ }^{128}$ Daarmee in overeenstemming is de lijn die Schreuder-Vlasblom uitzet. ${ }^{129} \mathrm{Zij}$ ziet de ex tunc benadering als een uitvloeisel van de zorgvuldigheidseis. ${ }^{130}$ De centrale vraag is immers steeds of het bestuur rekening heeft gehouden met alle relevante feiten, omstandigheden en inzichten, voorzover het deze kon of behoorde te kennen?

De zogenoemde "retrospectieve ex tunc-beoordeling" van de Afdeling Geschillen in milieuzaken, waarover in het Utrechtse rapport over bestuursrechtspraak in milieugeschillen wordt gesproken, ${ }^{131}$ sluit, als ik het goed begrijp, aan op de benadering van Schreuder-Vlasblom. In de benadering van de AGRvS in milieugeschillen staat de vraag voorop of de nova wel echte nova zijn of dat het gaat om feiten en omstandigheden die op het moment dat het bestuur het besluit nam reeds voorzienbaar waren. ${ }^{132}$ Dit is vooral duidelijk zichtbaar als na het nemen van een besluit een nieuwe - i.c. relevante richtlijn is gegeven en deze voortvloeit uit verschillende rapporten en studies, die op het moment dat het besluit werd genomen al bekend waren. Het gaat er met andere woorden om of de nova in de lijn der verwachtingen liggen, of ze "(sluimerend) aanwezig waren, danwel voorzienbaar hadden moeten zijn ten tijde van het nemen van de aangevochten beslissing". ${ }^{133}$ Enerzijds kan in deze benadering worden volgehouden dat het gaat om "nieuwe inzichten", nova die door goed onderzoek op tafel hadden moeten komen. Dat is niet meer dan de eis dat wordt beslist overeenkomstig de stand van wetenschap en techniek. ${ }^{134}$ Anderzijds - en dat ligt ook wel besloten in de term "retrospectief"- lijkt het er ook een beetje op dat de Afdeling een soort bewijs achteraf pleegt. Zo wordt de anwezigheid van nova gehanteerd als het bewijs voor de stelling dat het bestuur "destijds" een onjuiste beslissing heeft genomen;

127. Dat geldt ook voor de kwestie van de democratische legitimatie; bij beleidsvrijheid. Ik ga hier nog even voorbij aan de mogelijkheid van hoger beroep (voor belanghebbenden, dus niet alleen voor partijen!) of enig ander rechtsmiddel.

128. Widdershoven, a.w., p. 192, Ter Brugge, a.w., p. 58. Van Wolferen. M.D., Ervaringen van de Afdeling voor de Geschillen van Bestuur als milieurechter, In: Damen, L.J.A., en R.Uylenburg (red.), Rechtsbescherming in het milieurecht, Zwolle 1990, p. 12-13.

129. Schreuder-Vlasblom. M., Tussen Dominus Litis en knecht van twee meesters, NTB'91/3, p. 69-83.

130. A.w., p. 74-76.

131. Widdershoven et al., a.w., hfst. 9, i.h.b. p. 200-204.

132. Ibidem, p. 200 e.v., alwaar ook een aantal aardige voorbeelden uit de jurisprudentie zijn opgenomen.

133. Ibidem. p. 204.

134. Zonder dat dit impliceert dat deze "stand" zou getuigen van én prevalerende of gangbare visie. 
indien althans door verweerder wordt toegegeven dat hij in het licht van de nova nu een andere beslissing zou nemen, terwijl zich sedert het nemen van de "bestreden beslissing" geen relevante wijzigingen in feiten en omstandigheden hebben voorgedaan. ${ }^{135}$ Voorkomen moet worden dat deze benadering ontaardt in overspannen eisen aan het bestuur.

Michiels ${ }^{136}$ uit hierover zijn scepsis. In zijn optiek leidt deze toetsing tot de eis van een verplicht wantrouwen. ${ }^{137}$ Michiels is van mening dat de Afdeling Geschillen een evenwichtiger benadering volgt als zij overweegt: ${ }^{138}$ "De omstandigheid dat recent verrichte onderzoeken tot afwijkende resultaten zouden leiden kan - nu ten tijde van de bestreden beslissing niet was gebleken dat de algemeen aanvaarde technisch wetenschappelijke inzichten op dat punt waren gewijzigd - geen grond bieden voor de opvatting dat verweerders in redelijkheid niet konden uitgaan van de in de richtlijn opgenomen tabel met emissiefactoren" (mijn cursivering).

Ik zou geen voorstander zijn van een alomvattend wantrouwen van het bestuur jegens voorliggend onderzoek aangaande het feitensubstraat bij een concrete beslissing. Indachtig de vierde vuistregel uit Deel II van deze studie vind ik de aangehaalde overweging van de Afdeling Geschillen - op zichzelf beschouwd - echter wel erg kort door de bocht. Weliswaar hanteert de afdeling de door mij voorgestane (negatieve) "objectieve redelijkheidstoets"; maar naar mijn mening dient het bestuur er ten minste wel blijk van te geven te hebben nagegaan of er, ten tijde van het nemen van de bestreden beslissing, sprake was van afwijkende opvattingen. Van afwijkende opvattingen die gepaard gaan met gerede onzekerheid in het wetenschappelijke forum, opvattingen die de potentie hebben om een significante (en in casu relevante) wijziging in algemeen aanvaarde inzichten te veroorzaken, ${ }^{139}$ zal het bestuur zich op enigerlei wijze rekenschap moeten geven - in de feitenvaststelling en eventueel bij de belangenafweging. ${ }^{140}$ Het zal duidelijk zijn dat het zoeken van advies, danwel het betrekken van advies van een vaste, onafhankelijke adviseur bij de besluitvorming, hierbij van groot belang zal zijn.

135. Widdershoven, a.w., p. 200 en p. 201-202.

136. Michiels, F.C.M.A., Rechtsbescherming in het milieurecht, Vereniging voor milieurecht 19914 , p. $2-14$, i.h.b. p. $4-6$.

137. Hij leest dit o.m. in AGRvS 19 juni 1990. AB'91, 295 m.nt. FM (onder nr. 293): Rechtsbescherming in het milieurecht, a.w., p. 5.

138. AGRvS 29 juli 1991 (G05.90.0872), Michiels. Rechtsbescherming in het milieurecht, a.w., p. 5-6.

139. Ik denk aan de uitkomst van een empirische test die niet strookt met de (kern van de) gangbare opvatting en die niet aanstonds met een theoretische verfijning ("... of..") is in te passen.

140. In deze benadering blijft "het wetenschappelijke forum", doorgaans drager van de "gangbare opvatting". toch het ijkpunt - het gaat immers om de daar gevoelde onzekerheid. Dit ijkpunt lijkt mij essentieel willen we voorkomen dat het bestuur zich ter kennisvergaring zelf als deskundige moet gaan opstellen (contrair aan de eerste en tweede vuistregel). 
Alleen met een kritische instelling kan aan de zorgvuldigheid die van het bestuur mag worden verwacht worden voldaan. Deze benadering ligt ook in het verlengde van hetgeen ik in Hoofdstuk 6 overwoog ter zake van het gebruik van richtlijnen: steeds moeten deze naar herkomst (onafhankelijkheid) en naar inhoud (marginaal) worden getoetst - gelijk ook dient te geschieden bij gerichte advisering. Een onderzoek naar eventueel afwijkende opvattingen past daarbij. Het lijkt mij wenselijk dat de rechter nagaat of het bestuur van deze zorgvuldigheid blijk heeft gegeven. Dat alles zal echter, zoals ook uit de aangehaalde passage blijkt, kunnen geschieden binnen de "objectieve redelijkheidstoets".

Het lijkt mij wijs dat de regering, nu zij kiest voor het bestreden besluit als object van geschil, uitgaat van een rechtmatigheidstoetsing ex tunc. Overigens is ook de aanpak van het CBB, dat, als het bestreden besluit onrechtmatig is en zich nova voordoen, verweerder in staat stelt hangende het beroep de beslissing te herzien om vervolgens appellant te vragen of deze zijn beroep (tegen het nieuwe besluit) doorzet, nog altijd een toetsing ex tunc. Deze benadering doorkruist echter de non-contentieuze besluitvorming geheel. ${ }^{141}$ Michiels probeert nog een stapje verder te gaan. In zijn visie moet de rechter, als het bestreden besluit rechtmatig is maar zich nova voordoen die tot heroverweging van dit besluit lijken te nopen, een bevel tot heroverweging kunnen geven. ${ }^{142}$ Naar mijn smaak loopt de rechter dan op een geschil vooruit. Anders gezegd, hij maakt de rechtsverhouding tussen partijen ineens tot object van geschil. Dat lijkt mij niet wijs. Het bestuur zal ambtshalve of op verzoek van belanghebbenden, langs non-contentieuze weg tot heroverweging moeten komen. Weigert het bestuur te heroverwegen dan kan de rechter zich, als zich terzake een geschil voordoet, alsnog uitspreken.

Voor het zelf in de zaak voorzien, oftewel het herbeslissen door de rechter, meent de regering dat de rechter ex nunc moet beslissen. Dit uitgangspunt ligt in het verlengde van de wens dat de rechter het geschil volledig moet kunnen afdoen. Daarmee tracht de rechter zich als eerste en als laatste over nieuwe feiten en omstandigheden uit te laten. Opnieuw zou zulks slechts dan mogelijk zijn indien rechtens slechts nog én beslissing mogelijk zou zijn. De eerder aangehaalde bedenkingen (zal de rechter terughoudend zijn ten aanzien van belangenafweging en feitenvaststelling) doen zich hier weer gelden.

\subsubsection{Opnieuw: zelf in de zaak voorzien}

Het kernprobleem van zelf in de zaak voorzien is naar mijn smaak toch, dat het om een beslissing gaat die, juist door zijn positieve strekking, meer dan

141. Vgl. Widdershoven, a.w., p. 192-193 en p. 210-211.

142. Rechtsbescherming in het milieurecht, a.w., p. 6. 
het besluit tot vernietiging ${ }^{143}$ de rechter in verleiding brengt om beslissingen te nemen die slechts door het bestuur als uitvloeisel van non-contentieuze besluitvorming behoren worden genomen. ${ }^{14}$

Zelf voorzien kan resulteren in een ernstige doorkruising van de non-contentieuze waarborgen. De vraag die rijst is hoe de rechter op het rechte spoor kan worden gehouden.

De meest verregaande oplossing is natuurlijk om af te zien van de mogelijkheid tot zelf in de zaak voorzien. Alsdan zal bij vernietiging de opdracht aan het bestuur tot het nemen van een nieuwe beslissing, via het non-contentieuze spoor tot beëindiging van het geschil moeten leiden.

Hoewel dit mijns inziens de meest zuivere oplossing is, staat vast dat daarmee in vele gevallen een nodeloos lange weg wordt gevolgd. ${ }^{145}$

Een alternatief zou zijn om het zelf voorzien geheel in de vorm van een op de individuele belangpositie van eiser toegesneden uitspraak te gieten. De rechter zou, mits de onrechtmatigheid van het besluit zich slechts ten aanzien van eiser doet gelden, aan het bestreden besluit een op de individuele belangpositie van eiser toegesneden "clausule" kunnen verbinden. Ik denk hierbij aan een aanvullende voorwaarde maar ook aan een buiten-toepassing-verklaring ten aanzien van eiser. Voorwaarde is wel dat eiser hierom heeft verzocht of er blijk van heeft gegeven met de clausule te kunnen instemmen. ${ }^{146}$ Deze clausule, als onderdeel van het besluit, behelst de vestiging van een relatieve anspraak van de eiser. Deze aanspraak is van belang omdat het bestuur op voet van de genomen rechterlijke beslissing zou kunnen herbeschikken. Het enkele feit dat het bestuursbesluit is aangepast (en aldus de eenheid van het bestuurlijk handelen is aangetast) zou daartoe aanleiding kunnen geven. Het bestuur zou met het oog op algemene belangen of de belangen van (niet ter processe betrokken) derden, alsmede met het oog op eventuele nova een "in natura" voor eiser ongunstige beslissing kunnen nemen. ${ }^{147}$ De relatieve aanspraak van eiser brengt dan mee dat hij, in de mate waarin deze aanspraak is

143. Strikt genomen ook een bestuursdaad, vgl. Tak, a.w. 1992. p. 17.

144. Daar, en in het verschil aan zekerheid (gerede twijfel voldoet voor vernietiging, redelijke zekerheid is vereist voor het nemen van een beslissing - vgl Ten Berge/Tak I, a.w., p. 347 349), ligt naar mijn smaak het cruciale verschil met de vernietiging: de (negatieve) constatering dat het recht is geschonden behoeft geen non-contentieuze procedure.

145. Zeker bij financiēle kwesties, als het om een (kennelijk) foutieve berekening gaat die de rechter eenvoudig kan herstellen.

146. Dat laatste is cruciaal omdat eiser moet beseffen dat het einde van het verhaal kan zijn dat hij louter schadevergoeding krijgt - en geen voor hem in natura gunstiger herbeslissing. De partijautonomie moet hier tot uitdrukking komen.

147. Het bestuur moet beslissen zoals zij ook in gewone gevallen. zonder voorafgaand rechterlijk oordeel zou moeten doen. 
doorkruist, schadevergoeding kan vorderen. ${ }^{148}$ Met deze benadering kom ik in het spoor van Tak. ${ }^{149}$ Mijn uitgangspunt is echter anders. Voor de rechter is het bestreden besluit niet onaantastbaar: hij kan het bestreden besluit vernietigen en zal dat bij onrechtmatigheid in beginsel ook moeten doen. In specifieke gevallen, waar eiser daar om verzoekt, c.q. daarmee instemt, kan ik mij voorstellen dat de rechter zelf voorziet bij wijze van een relatieve voorziening.

Strikt genomen is het aldus niet nodig voor zelf in de zaak voorzien de eis te stellen dat in zijn totaliteit bezien rechtens geen andere beslissing meer open staat. De rechter voorziet slechts in de voor het belang van eiser wenselijke, uitdrukkelijke bescherming.

Daarmee staat deze benadering bloot aan de kritiek dat in feite toch de rechtsverhouding tussen burger en bestuur in het zelf voorzien tot object van geschil wordt. Toch lijkt mij dat niet juist. De rechtmatigheid van het besluit is de centrale kwestie. Indien en voorzover bij het nemen van het besluit geschreven of ongeschreven normen eisers individuele belangpositie (in casu, in bepaalde mate) beogen te beschermen, kan de rechter dit echter door een afzonderlijke declaratoire uitspraak tot uitdrukking brengen.

In deze zienswijze behoudt het bestuur in zoverre zijn primaat, doordat het de gelegenheid heeft het door de rechter aangepaste besluit te herzien. Gelet op het voortraject dat reeds is doorlopen lijkt een korte non-contentieuze procedure, met het oog op nog onbekende belanghebbenden en eventuele nieuwe feiten of omstandigheden, voldoende. ${ }^{150}$

Zelf voorzien op de wijze waarop de regering dit voorstaat, zou mijns inziens in elk geval verlangen dat er binnen de rechterlijke organisatie zelf waarborgen tegen "rechterlijk ontsporen" worden ingebouwd. Ik denk daarbij in de eerste plaats aan de mogelijkheid (voor belanghebbenden!) van de tweede rechterlijke instantie (hoger beroep of cassatie). Ik ben daarvan een groot voorstander. De argumenten van de regering om (onder andere) voor kwetsbare geschillen (vooralsnog) niet uit te gaan van twee instanties overtuigen mij geenszins.

148. Let wel, nova kunnen meebrengen dat eiser slechts aanspraak maakt op een onevenredige inbruk op zijn aanspraak - gelijk dit ook geldt voor de vergunninghouder die geconfronteerd wordt met wijziging van zijn vergunning wegens nieuwe inzichten. Overigens wil ik niet uitsluiten dat de eiser met de herbeslissing "in natura" beter af zou kunnen zijn dan met zijn relatieve aanspraak - vandaar dat zijn instemming essentieel is.

149. A.w., 1992, p. 16-21.

150. Ik zou me kunnen voorstellen dat in de Awb een aparte, korte "herbeschikkingsprocedure op rechterlijk beslissing" wordt opgenomen (die dan ook bij terugverwijzing kan worden toegepast). 


\subsubsection{Herziening}

Over de herziening kan ik kort zijn. In art. 8:88 Awb is de mogelijkheid tot herziening van een onherroepelijke uitspraak van de rechtbank of de president voorzien. ${ }^{151}$ Herziening kan plaatsvinden op grond van feiten en omstandigheden die hebben plaatsgevonden voor de uitspraak, bij de indiener van het verzoek tot herziening voor de uitspraak niet bekend waren en redelijkerwijs niet bekend konden zijn, en die, zo zij bij de rechtbank of president eerder bekend waren geweest, tot een andere uitspraak zouden hebben kunnen leiden. De uitspraak moet in het licht van de nieuw gebleken feiten of omstandigheden geen stand meer kunnen houden. ${ }^{152}$ Het gaat uitdrukkelijk om "nieuw gebleken feiten en omstandigheden" en niet om "nieuwe feiten of omstandigheden". Anders gezegd: het gaat om feiten en omstandigheden die na het doen van de uitspraak zijn ingetreden. Nieuwe feiten en omstandigheden zullen het bestuur wellicht tot herziening van een besluit kunnen brengen. Afwijzing van een daartoe strekkend verzoek kan grond zijn voor een nieuw beroep op de rechter.

In de toelichting op art. 8:88 Awb wijst de regering er op dat indien - bij voorbeeld - nieuwe wetenschappelijke ontdekkingen een causaal verband leggen dat bij het nemen van de rechterlijke beslissing niet aanwezig werd geacht, dat geen reden tot herziening kan geven. Het betreft dan immers een inzicht dat voor de uitspraak niet bekend was en evenmin behoorde te zijn. De regering erkent overigens wel dat het soms niet eenvoudig is om te beoordelen of iets een nieuw feit is of een nieuw bekend feit. In geval van twijfel ligt een herzieningsverzoek, of toewijzing daarvan niet in de rede. ${ }^{153} \mathrm{Bij}$ twijfel ligt een verzoek aan het bestuur tot herziening van het bestuursbesluit het meest voor de hand. ${ }^{154}$

Dat over de vraag of we met nieuwe feiten of nieuw bekende feiten van doen hebben, zeer wel twijfel mogelijk is, volgt ook uit het hierboven gestelde inzake de toetsing ex tunc of ex nunc. Met voorzienbaarheid als criterium (de controle op het "behoren te weten") is het bestuur gehouden tot een speuren op de horizon van de zich ontwikkelende technisch wetenschappelijke inzichten. Dat geldt a fortiori als mijn wens, dat het bestuur niet aanstonds genoegen neemt met de gangbare (of algemeen erkende) visie, toegepast wordt. ${ }^{155}$ We komen dan in een gebied waarbinnen het soms moeilijk te

151. Vgl. Tak, a.w. 1992, p. 135.

152. Mvt-Whrol.p. 160.

153. Ibidem.

154. Ibidem. De regering kiest uitdrukkelijk voor een beperkte ruimte voor de rechterlijke herziening.

155. Sommige uitspraken, zoals de eerder aangehaalde uitspraken van de AGRvS, getuigen daar m.i. van. 
zeggen is of we al met een nieuw inzicht of slechts met de aankondiging of aanleiding daartoe van doen hebben.

Gelukkig hoeven we ons daar juridisch niet geweldig veel zorgen over te maken. Teneinde van het bestuur niet het onmogelijke te eisen (doch louter een bevredigend besluit), stelde ik al voor dat toch ten minste sprake moet zijn van gerede onzekerheid omtrent een mogelijk op handen zijnde significante wijzigingen van de algemeen aanvaarde opvatting ${ }^{156}$ - terwijl het bestuurlijk oordeel hierover door de rechter naar de maat van "objectieve redelijkheid" wordt getoetst. Wat de rechtspraak betreft lijkt het mij evenmin wijs het onmogelijke te eisen. Een terughoudend gebruik van de herzieningsprocedure sluit daarop aan. Alleen als betrekkelijk zeker is dat het nieuw bekende feiten en omstandigheden betreft, past herziening van de rechterlijke uitspraak. Anders betreft het nieuwe feiten en omstandigheden en zal eventueel bestuurlijk herbeslissen moeten volgen.

\subsection{Conclusie}

\subsubsection{Samenvatting}

In dit hoofdstuk stond de functie van het bestuursproces centraal. Het belangrijkste punt was daarbij de verhouding tussen de non-contentieuze procedure en het contentieuze proces. Getracht is aannemelijk te maken dat de keuze voor de rechtsbeschermingsfunctie van het bestuursproces goed is te verenigen met het streven naar onafhankelijke waarborging van non-contentieuze waarborgen. Door het besluit als resultaat van non-contentieuze besluitvorming, als object van geschil centraal te stellen en vervolgens na te gaan of dit besluit gelet op de positie van eiser juridisch steekhoudende gebreken vertoont, kan de rechter een effectieve rechtmatigheidstoets volvoeren. Van belang is daarbij dat de rechter bij gebleken onrechtmatigheid van het bestreden bestuursbesluit, dit besluit ook kan vernietigen. Aansluitend kan dan door het bestuur worden herbeslist volgens de regels van de non-contentieuze procedure. De verzekering van een zodanige herbeslissing is een belangrijke waarborg voor het streven naar de meest optimale individuele rechtsbedeling. Voorts is benadrukt dat de rechter, indachtig het rechtsbeschermingsperspectief en gelet op het beginsel van ongelijkheidscompensatie, een op de individuele belangpositie van eiser toegesneden, actieve toetsing volvoert. ${ }^{157}$

156. Ik ga er gemakshalve vanuit dat die er is!

157. Ik doel op de mogelijkheid tot aanvulling van rechtsgronden en feiten: vgl. art. 8:69, tweede en derde lid Awb. 
De aandacht is - mede op voet van het voorgaande - in het bijzonder uitgegaan naar de reikwijdte van de rechterlijke toetsing en een aantal voor de vaststelling van feiten en de afweging van belangen cruciale bevoegdheden.

Een belangrijk punt was daarbij de "objectieve redelijkheidstoetsing". Getracht is duidelijk te maken dat benevens de marginale redelijkheidstoets voor de klassieke situatie waar het bestuur krachtens beleidsvrijheid belangen afweegt (de "subjectieve redelijkheid"), ook ten aanzien van de bestuurlijke feitenvaststelling een marginale toetsingsmaatstaf dient te worden toegepast. Het vertrekpunt is daarbij niet het recht van het bestuur om als eerste een oordeel over de feiten te geven maar - meer principieel - de bestuurlijke opportuniteit bij feitenvaststelling. De rechter zal daartegenover een "objectieve redelijkheidstoets" dienen aan te houden - hetgeen zich met name zal aftekenen waar het een complex feitensubstraat betreft. In het verlengde van deze marginale toets van "objectieve redelijkheid", past de rechter terughoudendheid bij de vraag of hervaststelling van de feiten (door hemzelf - in geval van bestuurlijke onregelmatigheden) wel in de rede ligt.

In het bijzonder is nog ingegaan op de rechterlijke bevoegdheid tot het zelf in de zaak voorzien. Allereerst werd gewezen op de algemene reserves: beleidsvrijheid (ten aanzien van de belangen maar ook ten aanzien van de feitenvaststelling), en de eenduidigheid en duidelijkheid van de feiten. Deze beperkingen worden ook door de regering in de Whrol wel genoemd.

Meer specifiek werd vervolgens nog ingegaan op de complicaties bij besluiten met publieke werking en de kwestie van het beslissen ex tunc of ex nunc. Het laatste punt werd vrij uitgebreid besproken nu dit voor de feitenvaststelling in een dynamische empirische context als die van het milieurecht bij uitstek relevant is. Ook kwam de toetsing zelf daarbij nog (uitgebreid) aan de orde. Wat die toetsing betreft is vooral de voorzienbaarheid van belang. In de uiteengezette zienswijze moet de rechter de eerste, tweede en vierde vuistregel aan het bestuur voorhouden. ${ }^{158}$ Ten aanzien van het zelf voorzien werden grote reserves geuit. ${ }^{159}$ Het feit dat de rechter daarbij ex nunc te werk gaat, versterkt deze twijfels nog eens. In elk geval lijkt een tweede rechterlijke instantie, ter voorkoming van al te ruimhartige toepassing van het zelf voorzien, mij noodzakelijk. Daarnaast werd geopperd om de bevoegdheid tot het zelf in de zaak voorzien te beperken tot het - slechts op verzoek of met instemming - treffen van (aan het bestreden besluit te verbinden) relatieve voorzieningen.

Ten slotte werd nog kort ingegaan op de herziening als rechtsmiddel.

158. Het bestuur is geen superdeskundige: het bestuur kijkt voorbij de algemeen aanvaarde inzichten.

159. Voor velen lijkt dit al een vanzelfsprekendheid. Mij dunkt dat de Afdeling geschillen in milieuzaken wel anders leert. Vgl. Stroink, F.A.M., A.Q.C. Tak en J.M.H.F. Teunissen. Een analyse van één jaar TwK-jurisprudentie, NJB'89/8, p. 253-257. 


\subsubsection{Opmaat}

De bevindingen uit dit hoofdstuk vormen in belangrijke mate opmaat tot het volgende hoofdstuk inzake de rol van de deskundige bij de (toetsing van de:) feitenvaststelling in het bestuursproces. Daarmee is niet gezegd dat kwesties als de rechterlijke terughoudendheid tegenover de bestuurlijke feitenvaststelling en de zorgvuldigheid inzake de feiten en omstandigheden, niet op zichzelf van belang zijn. Naar mijn smaak zijn ze dat wel degelijk. In het volgende hoofdstuk zal echter het perspectief zeer concreet gericht zijn op de roll van de deskundige bij de feitenvaststelling. In dat opzicht vormt de verkenning aan de hand van de functie van het bestuursproces een noodzakelijke onderbouw. 


\section{Hoofdstuk 9 \\ De feitenvaststelling in het bestuursproces}

\subsection{Inleiding}

Tegen de achtergrond van de uiteenzetting over de functie van het bestuursprocesrecht (in het voorgaande hoofdstuk) wil ik nu specifiek ingaan op de rol van technische expertise in het contentieuze bestuursproces. Mitsdien zal ik in dit hoofdstuk het blikveld beperken tot de beoordeling, door de rechter, van de bestuurlijke feitenvaststelling. Daarbij zal ik in het bijzonder ingaan op de verhouding tussen rechter, procespartijen en deskundige.

Vooraleer ik op de specifieke bewijsrechtelijke kwesties in ga, lijkt het mij wijs in enkele streken de bevoegdheden van rechter en partijen ten processe te schetsen - en wel in $\S 9.2$.

In $\$ 9.3 \mathrm{zal}$ ik enkele algemene opmerkingen maken over het administratief bewijsrecht. Daaropvolgend zal ik in afzonderlijke paragrafen ingaan op de bewijsomvang ( $\$ 9.4)$, de bewijslastverdeling ( $\S 9.5$ ), de bewijsmiddelen (§9.6) en de bewijswaardering ( $\$ 9.7)$. Dit hoofdstuk wordt afgesloten met een algemene conclusie in $\$ 9.8$.

Ook in dit hoofdstuk zal ik uitgaan van geschillen als bedoeld in art. 20.1 Wm. Zoals eerder betoogd (zie hoofdstuk 1) gaat het hierbij om geschillen omtrent bestuursbeslissingen bij de totstandkoming waarvan technisch-wetenschappelijke kennis een belangrijke rol speelt.

\subsection{Enkele regels van de procesvoering volgens het Whrol}

Ook in dit hoofdstuk staan de in de Whrol voorgestelde regels voor het bestuursprocesrecht centraal. De voor dit hoofdstuk belangrijkste regels voor de toetsing van de feitenvaststelling zal ik in een vijftal clusters kort aanhalen. Het gaat om enkele preliminaire zaken $(\$ 9.2 .1)$, het vooronderzoek ( $\$ 9.2 .2$ ), het onderzoek ter zitting $(\S 9.2 .3)$, de uitspraak $(\$ 9.2 .4)$ en de vereenvoudigde afdoening $(\$ 9.2 .5)$. $^{\prime}$

1. De procedure van de voorlopige voorziening (Titel $8.3 \mathrm{Awb}$ ) blijft buiten bespreking. Het maken van een vergelijking op het punt van de waarborgen met de gewone procedure gaat n.m.m. het bestek van deze studie te buiten. 


\subsubsection{Preliminaire zaken}

Ik denk hierbij aan een viertal preliminaire zaken die zijn geregeld in Titel 8.1. (Algemene bepalingen) van het Whrol: de procesingang, het vooronderzoek, de verplichtingen van partijen, alsmede de verplichtingen en vergoedingen van deskundigen.

De procesingang in milieugeschillen is neergelegd in art. $20.1 \mathrm{Wm}$. Het beroep dient in eerste en enige aanleg bij de Afdeling bestuursrechtspraak, overeenkomstig art. 36 WRvS. Dit artikel verklaart hoofdstuk 8 Awb, op enkele hier niet relevante voorschriften na, van overeenkomstige toepassing op het beroep bij de Afdeling bestuursrechtspraak. ${ }^{2} \mathrm{Ik}$ zal hier het accent leggen op de gewone procedure. ${ }^{3}$

Ingevolge art. 8:12 Awb kan de rechter aan een rechter-commissaris opdragen het vooronderzoek of een gedeelte daarvan te verrichten. Ik noem deze bepaling om verschillende redenen reeds voorafgaand aan de bespreking van de regels voor het vooronderzoek.

Allereerst geeft de bevoegdheid in kwestie aan hoezeer de rechter als dominus litis moet worden beschouwd. Het is de rechter die zelfstandig kan beslissen tot het instellen van een vooronderzoek. Partijen kunnen echter verzoeken dat een vooronderzoek wordt verricht. ${ }^{4}$ De rechterlijke discretie op dit punt is ontegenzeggelijk groot. Tegen de beslissing tot het al dan niet instellen van vooronderzoek is geen afzonderlijk beroep mogelijk, ${ }^{5}$ doch kan slechts bij een eventueel beroep tegen de eindbeslissing bezwaar worden gemaakt. Het is in dat verband nogal ongelukkig dat beroep tegen beslechting van geschillen ex art. 20.1 Wm (vooralsnog) uitgesloten is.

Ook is het van belang dat het vooronderzoek door een rechter(-commissaris) wordt geleid. Het is klaarblijkelijk niet de bedoeling dat anderen, bijvoor-

2. De uitgezonderde bepalingen betreffen het beroepsrecht voor de administratieve rechtsgang naar de Rechtbank (belanghebbenden, (uitgesloten) besluiten), het hoger beroep bij de Afdeling bestuursrechtspraak (zie art. 37 e.v. WRvS), de verdeling van de werklast tussen enkelvoudige en meervoudige kamers (bij de rechtbank prinuair de enkelvoudige kamer. bij het beroep bij de Afdeling primair de meervoudige kamer!) en het verwijzen van zaken tussen rechtbanken.

3. De versnelde behandeling van afdeling 8.2 .3 en de voorlopige voorziening en onmiddellijke uitspraak in de hoofdzaak (afdeling 8.3) blijven buiten bespreking. Bij de navolgende schets zal ik steeds spreken over de rechtbank. ook al gaat het bij milieugeschillen om de Afdeling bestuursrechtspraak.

4. Art. 8:12 is een "kan-bepaling". Het lijkt mij dat de regel uit de MvT-Whrol, p. 128, t.a.v. de rechterlijke bevoegdheden in het vooronderzoek, ook hier geldt: waar "kan" staat impliceert dit dat de rechter zowel ambtshalve als op verzoek van een der partijen tot vooronderzoek kan besluiten. De toelichting bij art. 8:12 Awb (MvT-Awb2. p. 109-110) suggereert dat het vooronderzoek veelvuldig zal worden toegepast.

5. MvT-Whrol, p. 127. 
beeld leden van de ondersteunende staf van de rechtbank, het vooronderzoek leiden. Dit lijkt mij een goede zaak. Wel is denkbaar dat anderen dan rechters onderdelen van het vooronderzoek uitvoeren, zolang de algehele leiding maar bij de rechter ligt. ${ }^{6}$ Dat lijkt mij een acceptabele benadering, zolang slechts ondergeschikte "klussen" worden gedelegeerd. Bepaalde onderdelen van het vooronderzoek, zoals het horen van partijen, getuigen en deskundigen, behoeven beslist de leiding van een rechter; hij alleen bepaalt wat echt relevant is en hij beoordeelt de gelijkwaardigheid van partijen.

De artikelen 8:27 tot en met 8:31 Awb bevatten regels ten aanzien van de verplichtingen van partijen tot verschijnen, het verschaffen van inlichtingen, het overleggen van stukken of verlenen van medewerking aan het vooronderzoek. Indien een partij niet voldoet aan de op haar rustende verplichting "kan de rechtbank daaruit de gevolgtrekkingen maken die haar geraden voorkomen." - aldus art. 8:31 Awb. Gelet op de verdeling van de bewijslast is deze regel uiteraard van groot gewicht. Blijkens de toelichting kan (een niet-verontschuldigbaar) verzaken zelfs resulteren in niet-ontvankelijkheid of gegrondverklaring van het beroep. ${ }^{7}$

Ingevolge art. 8:34, eerste lid Awb is de deskundige die zijn benoeming heeft aanvaard, verplicht zijn opdracht onpartijdig en naar beste weten te vervullen. Niemand is tegen zijn wil als deskundige inroepbaar. Als iemand echter zijn benoeming tot deskundige heeft aanvaard, is hij gehouden tot het onpartijdig en naar beste weten vervullen van zijn opdracht. Aflegging van een eed, zoals in het strafprocesrecht, ${ }^{8}$ wordt kennelijk niet zinvol geacht. ${ }^{9}$

In art. 8:36, eerste lid Awb staat dat een vergoeding uit 's Rijks kas wordt verstrekt aan door de rechtbank opgeroepen deskundigen, getuigen en tolken, zulks overeenkomstig het Besluit tarieven in strafzaken. Volgens het tweede lid van dit artikel geldt een zelfde norm voor getuigen of deskundigen opgeroepen of meegebracht door partijen. ${ }^{10}$

6. Vergelijk daartoe Van der Meulen, B.M.J., Nieuw Bestuursprocesrecht, NTB'92/1, p. 11-20, i.h.b. p. 15 .

7. Respectievelijk indien eiser of verwerend bestuursorgaan verzaakt: MvT-Whrol, p. 121, Tak, a.w. (1992), p. 93-96.

8. Art. 296 lid 1 ten eerste Sv.

9. Anders dan voor getuigen, waar die mogelijkheid wel openstaat (vgl. art. 8:33, vierde lid Awb) waarmee de dreiging van art. $207 \mathrm{Sr}$ geactiveerd wordt.

10. Eventueel in te brengen bij een proceskostenveroordeling ex art. 8:75 Awb. Een slimme partij probeert de rechter er toe te bewegen een bepaalde deskundige op te roepen. 


\subsubsection{Het vooronderzoek}

De rechter is in het vooronderzoek dominus litis; hij bepaalt of er behoefte is aan een vooronderzoek en zo ja, hoe dit verloopt. Beslissingen daarover dienen voor partijen natuurlijk wel controleerbaar en kritiseerbaar te zijn. "In dat licht moet ook de betrokkenheid van partijen bij bepaalde beslissingen (zoals het deskundigen-onderzoek van art. 8:47 Awb) worden geplaatst.

Binnen vier weken na verzending van het beroepschrift dient het desbetreffende bestuursorgaan de stukken samen met een verweerschrift bij de rechtbank in, aldus art. 8:42 Awb. De rechtbank kan appellant vervolgens in de gelegenheid stellen schriftelijk te repliceren, in welk geval verweerder de gelegenheid krijgt schriftelijk te dupliceren. Andere partijen kunnen, ingevolge art. 8:43, tweede lid Awb, tenminste eenmaal een schriftelijke uiteenzetting indienen. Op deze wijze komt gaandeweg het procesdossier tot stand.

De rechtbank kan partijen vervolgens oproepen om te verschijnen - al dan niet voor het verstrekken van inlichtingen. Ook kan de rechtbank partijen of anderen verzoeken schriftelijk inlichtingen te verschaffen of stukken in te zenden.

Voorts kan de rechtbank getuigen oproepen en kan zij een deskundige benoemen voor het instellen van een onderzoek. Ten slotte kan de rechtbank besluiten tot "onderzoek ter plaatse". ${ }^{12}$

Wat het deskundigenonderzoek betreft is bepaald dat partijen van het voornemen daartoe op de hoogte worden gesteld. De rechter "kan partijen in de gelegenheid stellen om hun wensen omtrent het onderzoek (..) kenbaar te maken", aldus het derde lid van art. 8:47 Awb. Deze redactie is minder "klantvriendelijk" dan de oorspronkelijke redactie die er in voorzag dat partijen zonder meer in staat waren hun visie naar voren te brengen. De beperking is voorgesteld bij de eerste Nota van wijziging. ${ }^{13}$ Blijkens de MvA vind de regering de oorspronkelijke tekst te rigide, nu de rechter daarin verplicht was om partijen in de gelegenheid te stellen hun wensen omtrent het onderzoek naar voren te brengen. Ook ziet de regering proceseconomische voordelen in omzetting van deze verplichting in een bevoegdheid. ${ }^{14}$ Toch rijst mijns inziens de vraag hoe zulks zich verhoudt tot de eerdere overwegingen uit de $\mathrm{MvT}^{15}$, waar vanwege het gewicht van het hier bedoelde deskun-

11. MvT-Whrol, p. 127.

12. Deze bevoegdheden zijn te vinden in art. 8:44-8:47 en art. 8:50 Awb.

13. TK' $92-93,22495$, nr.7.

14. MvA-Whrol, p. 54.

15. MvT-Whrol, p. 130-131. Met een uitdrukkelijke verwijzing naar de TwK-praktijk. 
digenonderzoek uitdrukkelijk wordt bepleit dat partijen hun wensen kenbaar (moeten) kunnen maken. Daar wordt het proceseconomische argument juist ten faveure van deze plicht gehanteerd. ${ }^{16}$ Mij overtuigt de voorgestelde overweging allerminst. ${ }^{17}$

$\mathrm{Na}$ het verschijnen van het deskundigenverslag kunnen partijen hun zienswijze daarop overigens nog schriftelijk naar voren brengen, aldus art. 8:47, vijfde lid Awb.

In de toelichting wordt opgemerkt dat de aan de deskundige te verstrekken opdracht in algemene bewoordingen kan zijn gesteld doch ook (in aanvulling daarop) "bijzondere te onderzoeken aangelegenheden" kan vermelden. ${ }^{18}$ Daartegenover kan er ook sprake zijn van een "standaard advies" met een "open adviesaanvraag". ${ }^{19}$ Hierbij wordt gedacht aan de bestendige praktijk om bij bepaalde geschillen (waaronder milieugeschillen) dergelijke deskundigen-adviezen te vragen. In de MvT stelt de regering dat een dergelijk advies reeds voordat partijen in de gelegenheid worden gesteld hun visie over de opdracht aan de deskundige te geven, worden gevraagd. Kennelijk gaat men er van uit dat nadere toespitsing van het onderzoek, op aandrang van partijen, binnen de open-adviesaanvraag altijd nog mogelijk is. Gegeven de voornoemde beperking in het derde lid van art. 8:47 Awb, valt echter te vrezen dat er in deze gevallen slechts nog achteraf commentaar kan worden gegeven. In het voorgaande hoofdstuk bleek al dat het wenselijk kan zijn dat de rechter zich - ook uit het oogpunt van ongelijkheidscompensatie - actief betoond bij het onderzoek naar de bestuurlijke feitenvaststelling; vooral waar het de vraag naar de volledigheid daarvan betreft. ${ }^{20} \mathrm{Ik}$ vrees echter dat een actieve opstelling van de rechter op dit punt al te snel kan leiden tot een praktijk van algehele (standaard-) hervaststelling van de feiten door de rechter. ${ }^{21}$ Ik zou mitsdien in alle gevallen aan het vooraf raadplegen van partijen willen vasthouden.

Verheij heeft mijns inziens terecht de vraag opgeworpen waarom de regeling van het vooronderzoek niet ook (uitdrukkelijk) aangeeft dat het partijen vrijstaat om hun stellingen te bewijzen door getuigen en deskundigen (zoals in art. 8:60, vierde lid Awb wel geregeld is voor het onderzoek ter zit-

16. Bij de eerste lezing hield de regering "haar poot stijf" tegenover kritiek van de Raad van State terzake - vgl. TK'91-'92, 22495 A. p. 84.

17. De aanleiding tot aanpassing zal, als we van de stukken uitgaan, moeten liggen in de vraag van de fractie van D'66 (Voorlopig verslag, TK'92-'93, 22 495, nr. 5, p. 27); maar die is zodanig open geformuleerd dat het "omgaan" niet echt goed is te verklaren.

18. MvT-Whrol.p. 131 (art. 8:47, tweede lid Awb).

19. Ibidem (art. 8:47. derde lid Awb2).

20. Juist daar - zo beschreef ik in het voorgaande hoofdstuk in \$ 8.3.3.3 - kan van appellant niet (altijd) verwacht worden dat hij voldoende geinformeerd is.

21. Zoals thans de facto bij de AGRvS in milieuzaken. 
ting). ${ }^{22}$ De voorgestelde opzet doet vermoeden dat de keuze voor het houden van een vooronderzoek ook betekent dat de rechter een groot deel van de bewijslast voor eigen rekening wil nemen. Natuurlijk wordt partijen niet belet om bij het indienen van stukken of het verschaffen van (schriftelijke) inlichtingen deskundigen-verklaringen toe te voegen of zich daarop te beroepen. Toch zou het aantrekkelijk zijn als ook in het vooronderzoek partijen uitdrukkelijk zouden worden uitgenodigd om - afgezien van het verzoek tot het verstrekken van door de rechter gevraagde inlichtingen - bewijs te leveren. ${ }^{23}$

\subsubsection{Het onderzoek ter zitting}

Partijen worden (na het vooronderzoek) uitgenodigd om ter zitting te verschijnen, tenzij na instemming van partijen wordt besloten af te zien van een onderzoek ter zitting - aldus art. 8:56-8:57 Awb. Er is geen verschijningsplicht, maar in de MvT wordt uitdrukkelijk gewezen op de meerwaarde van de mondelinge uitwisseling van standpunten naast de schriftelijke uitwisseling van stukken. ${ }^{24}$

Partijen kunnen - ingevolge art. 8:58, eerste lid Awb - tot tien dagen voor de zitting stukken indienen. Ook kunnen partijen worden opgeroepen teneinde ter zitting inlichtingen te verstrekken - art. 8:59 $\mathrm{Awb}^{25}$

De rechtbank kan op voet van art. 8:60, eerste lid Awb, getuigen, deskundigen en tolken benoemen. Bij aanvaarding van zijn benoeming is de getuige, deskundige of tolk verplicht aan een eventuele oproeping door de rechtbank gevolg te geven. Ingevolge het tweede lid van deze bepaling wordt in de oproeping melding gemaakt van de opdracht die de deskundige moet vervullen. Partijen worden geïnformeerd over de opgeroepen deskundigen en getuigen, alsmede over de feiten waarop het horen betrekking zal hebben of de opdracht die moet worden vervuld - aldus het derde lid van art. 8:60 Awb. Ook partijen kunnen getuigen en deskundigen meebrengen c.q. oproepen, mits daarvan uiterlijk én week voor de zitting aan de andere partijen mededeling is gedaan, zo stelt art. 8:60, vierde lid Awb. Het laatste voorbehoud dient ertoe een "overval" te voorkomen.

Volgens art. 8:62 Awb is de zitting als regel openbaar. Daarmee, alsook bij het maken van uitzonderingen op deze regel, is aansluiting gezocht bij art. 6 EVRM en art. 14 BUPO. ${ }^{26}$

22. Een klantvriendelijke rechter, a.w., p. 148, noot 27.

23. Waarbij de term "uitnodiging" beoogt te impliceren dat indien partijen daarvan afzien, dit niet ten nadele van hen wordt opgevat.

24. MvT-Whrol, p. 137.

25. MvT-Whrol,p. 138 - nu is er wel een verschijningsplicht.

26. MvT-Whrol, p. 139. 
Art. 8:63, eerste lid Awb bepaalt dat partijen aan de getuigen en deskundigen vragen kunnen stellen, tenzij de rechter tussen beide komt. Ook kan de rechter ambtshalve of op verzoek van een der partijen een confrontatie tussen verschillende getuigen en deskundigen, c.q. tussen (een der) partijen en getuigen of deskundigen organiseren. De rechter kan voorts naar aanleiding van getuigen- of deskundigenverklaringen aan partijen vragen stellen. Op grond van art. 8:64 Awb kan de rechtbank de zitting schorsen teneinde het vooronderzoek te hervatten. Ten slotte bepaalt art. 8:65 Awb dat het onderzoek door de rechtbank wordt gesloten, "wanneer zij van oordeel is dat het is voltooid". Duidelijk is opnieuw dat de rechter hier dominus litis is. Voorafgaand aan deze sluiting worden partijen overigens in de gelegenheid gesteld nog eenmaal het woord te voeren.

\subsubsection{De uitspraak}

In het voorgaande hoofdstuk refereerde ik reeds aan art. 8:69 Awb waarin uitdrukkelijk wordt gesteld dat de rechtbank haar uitspraak doet op de grondslag van het beroepschrift, de overgelegde stukken, het verhandelde tijdens het vooronderzoek en het onderzoek ter zitting. Ik zal daarop hier niet nader ingaan.

Van groot belang is art. 8:72 Awb dat betrekking heeft op de situatie waarin de rechtbank oordeelt dat het beroep gegrond is. In de toelichting op art. 8:70 Awb wordt uitdrukkelijk gesteld dat de rechtbank het beroep gegrond moet verklaren "indien zij het bestreden besluit op én of meer der aangevoerde gronden, danwel ambtshalve, onrechtmatig acht. ${ }^{27}$ In het voorgaande hoofdstuk wees ik er reeds op dat de rechtbank bij deze gegrondverklaring onder meer de mogelijkheid heeft om zelf een uitspraak te doen die in de plaats treedt van het vernietigde besluit (lid 4 van art. 8:72 Awb).

Naast de uitbreiding van de rechterlijke uitrusting op het punt van de schadevergoeding (waaronder vergoeding van vertragingsschade), is vooral ook de (eerder wegens z'n te beperkte strekking gekritiseerde) in art. 8:75 Awb geregelde mogelijkheid van een proceskostenveroordeling van belang.

Art. 8:77 Awb schrijft onder meer voor dat de schriftelijke uitspraak de gronden van de beslissing vermeldt, in het bijzonder, bij gegrondverklaring van het beroep, welke geschreven of ongeschreven rechtsregel of welk algemeen rechtsbeginsel geschonden wordt geoordeeld. De beroepsgronden zelf worden niet in het wetsvoorstel genoemd, omdat het evident wordt geacht dat de rechter aan het recht toetst. ${ }^{28}$ Dit lijkt mij een juiste optiek.

27. MvT-Whrol, p. 143.

28. Vgl. MvA-Whrol, p. 61. 
Ten slotte kan de rechtbank nog op het moment dat zij tot een eindoordeel tracht te komen, beslissen om het onderzoek te heropenen - aldus art. 8:68 Awb.

\subsubsection{Rechter of deskundige}

In het voorgaande ben ik steeds uitgegaan van de gewone procedure. ${ }^{29}$ Juist met het oog op de positie van de deskundige wil ik nog even stilstaan bij de mogelijkheid van vereenvoudigde behandeling (Afdeling 8.2.4 Awb). De rechtbank kan nog voordat zij partijen ter zitting uitnodigt besluiten om het onderzoek te sluiten. Een dergelijk besluit vindt zijn grond in de omstandigheid dat voortzetting van het onderzoek onnodig is vanwege de evidentie van: onbevoegdheid van de rechtbank, niet-ontvankelijkheid van het beroep, ongegrondheid van het beroep, alsmede gegrondheid van het beroep. ${ }^{30}$ Tegen de uitspraak bij vereenvoudigde behandeling staat volgens art. 8:55 Awb de mogelijkheid van verzet open. ${ }^{31}$

Een bijzondere vorm van vereenvoudigde afdoening is de vaste-deskundigenprocedure van art. 135-144 Beroepswet. Deze procedure wordt onder andere toepasselijk verklaard in art. 75 , tweede lid Ziektewet, ten aanzien van geschillen van geneeskundige aard omtrent de ongeschiktheid tot werken. In de vaste-deskundigenprocedure draagt de voorzitter in bepaalde geschillen van geneeskundige aard, een onderzoek op aan een vaste deskundige - aldus art. 135 Beroepswet. De vaste-deskundige dient op grond van art. 137 Beroepswet bij zijn onderzoek verschillende verplichtingen na te leven. Hij moet: kennis nemen van het dossier; de behandelende arts en de verzekeringsdeskundige in de gelegenheid stellen hem van hun oordeel te doen blijken; de betrokkene oproepen en hem onderzoeken. ${ }^{32}$ Vervolgens brengt hij van zijn bevindingen een rapport (inclusief een advies) uit aan de voorzitter. ${ }^{33}$ Daarna volgt in beginsel de vereenvoudigde afdoening. De voorzitter verklaart ingevolge art. 141 Beroepswet het beroep gegrond of ongegegrond, tenzij hij van mening is dat de zaak niet bij zodanige beschikking kan worden afge-

29. Ik zwijg verder ook over de rechtsmiddelen. Overigens heb ik de mogelijkheid van herziening van een onherroepelijk geworden uitspraak (Titel 8.4) reeds in het voorgaande hoofdstuk belicht.

30. Aldus art. 8:54, eerste lid Awb. Vgl. Tak, a.w. (1992), p. 100.

31. Met als hoofdvraag of inderdaad sprake was van kennelijke onbevoegdheid, niet-ontvankelijkheid, ongegrondheid of gegrondheid van het beroep.

32. Het laatste is niet van toepassing t.a.v. artsen die hun oordeel in de stukken hebben neergelegd en wier oordeel overeenstemt met dat van de vaste-deskundige. Vgl. Jaspers, A.Ph.C.M., en J Riphagen (reds.) Schets van het sociaal zekerheidsrecht, Deventer 1991, p. 306.

33. Vgl. Ten Berge/Tak II. a.w., p. 170-171. Noordam. F.M., Inleiding Sociale zekerheidsrecht, Deventer 1992, p. 282-283. 
daan. ${ }^{34}$ Tegen de uitspraak van de voorzitter staat ingevolge art. $142 \mathrm{Be}-$ roepswet slechts de mogelijkheid van verzet open. ${ }^{35}$

Beslist een voordeel van deze gang van zaken is dat vlot geprocedeerd wordt, zodat het deskundigenrapport snel volgt op de bestreden beslissing en - aldus - aan betrouwbaarheid wint. ${ }^{36}$ In art. 143 Beroepswet is, ter bevordering van snelle geschilbeslechting, zelfs de mogelijkheid geopend dat een onderzochte persoon aanstonds door een controlerend geneesheer naar een vastedeskundige wordt verwezen. Mocht vervolgens beroep worden ingesteld dan kan het reeds op voet van deze verwijzing uitgevoerde onderzoek door de vaste-deskundige als advies worden uitgebracht.

Het procesrecht volgens de Whrol kent geen specifieke vaste-deskundigenprocedure meer. Door echter voor bepaalde geneeskundige geschillen de versnelde behandeling voor te schrijven en te voorzien in een specifieke regel voor het onderzoek door geneeskundigen, in combinatie met de mogelijkheid van vereenvoudigde afdoening, kan materieel het zelfde resultaat bereikt worden als in de vaste-deskundigenprocedure. Een regeling als voorzien in art. 143 Beroepswet, waarbij de vaste-deskundige voorafgaand aan het beroep op de rechter wordt ingeschakeld, keert echter, voorzover ik kan zien, niet meer terug. ${ }^{37}$

Een concreet voorbeeld van de nieuw voorgestelde regeling biedt art. 75 Ziektewet (nieuw). Daarin wordt voor geschillen van geneeskundige aard (...) de versnelde behandeling van Afdeling 8.2.3 Awb voorgeschreven. ${ }^{38}$ Terwijl thans nog de mogelijkheid van hoger beroep - bij de CRvB - is uitgesloten, wordt dit in het nieuw voorgestelde art. 18, eerste lid onder b. Beroepswet wel mogelijk gemaakt. Op voet van art. 75 Ziektewet is op het hoger beroep eveneens de versnelde behandeling voorgeschreven. ${ }^{39}$

34. Bij voorbeeld als de vaste-deskundige rapporteert dat er niet-medische kwesties aan het geschil zijn verbonden, of bij gebreken in het onderzoek van de vaste-deskundige (verontachtzaming van de regels van art. 137 beroepswet).

35. Door aanpassing van dit artikel (c.q. wegneming van beperkingen aan de mogelijkheid tot het aantekenen van verzet) heeft de wetgever getracht de problemen zoals opgeworpen in de zaak Feltbrugge, EHRM, 29 mei 1986, NJCM-bulletin'86, p. 452. op te ruimen; Noordam, a.w., p. 283.

36. Ook is het een voordeel dat klager (en zijn werkgever) snel zekerheid heeft (hebben) omtrent zijn aanspraak. Vgl. Jaspers, et al., a.w., p. 305.

37. Toelichtingen op dit punt ontbreken - helaas.

38. Deel 5.2. Art. IIL Whrol. Daarbij wordt ook Titel 8.3 Awb (Voorlopige voorziening en onmiddellijke uitspraak in de hoofdzaak) buiten toepassing verklaard.

39. Zie ook MvT-Whrol, p. 251. Dit past binnen de regel van het nieuwe art. 21, eerste lid Beroepswet. Versnelde behandeling impliceert vooral verkorting van diverse termijnen; vgl. Tak, a.w. (1992), p. 102-103. 
Zowel in eerste aanleg als in het hoger beroep kan de zaak overigens ook buiten zitting worden afgedaan, indien deze zich leent voor toepassing van de vereenvoudigde afdoening. ${ }^{40}$

Het functioneren van de deskundige in deze procedures wordt in de voorziene opzet primair bepaald door het eerder besproken art. 8:47 Awb. Dit artikel voorziet in de mogelijkheid van benoeming van een deskundige door de rechtbank ten einde een onderzoek te verrichten. Partijen zijn ingevolge art. 8:30 Awb verplicht mee te werken aan zodanig onderzoek. Specifiek met het oog op de medische deskundige is in art. 8:48, eerste lid Awb bepaald dat deze bij de behandelende arts, de verzekeringsarts en de adviserend arts van het bestuursorgaan, inlichtingen kan inwinnen. ${ }^{41}$

Op voet van het schriftelijk uitgebrachte deskundigenadvies zal de rechtbank kunnen bezien of vereenvoudigde afdoening van het geschil mogelijk is.

Interessant aan de vaste-deskundigenprocedure is de toespitsing op een geschil van geneeskundige aard. De klacht betreft alleen het medisch oordeel met het oog op (bij voorbeeld) de geschiktheid om te werken. Het is voorstelbaar dat in een dergelijk geschil het oordeel van de vaste-deskundige een zeer grote rol speelt. In dat verband verdient het opmerking dat bij de voorbereiding van de huidige Beroepswet in 1955 werd voorgesteld om in de hier bedoelde geschillen van geneeskundige aard, vereenvoudigde afdoening mogelijk te maken door enkelvoudige kamers met medische specialisten - anders gezegd: "geneesheren-rechters". Deze combinatie werd echter niet wenselijk geacht: de geneeskundigen dienden zich tot advisering te beperken en de voorzitter werd bevoegd tot vereenvoudigde afdoening..$^{2}$ Geen "dualisme" derhalve maar een strikte scheiding tussen medisch advies en juridisch oordeel. ${ }^{43}$

Bij deze kwestie denk ik aan de eerste vuistregel uit Deel II van deze studie: het nemen van bestuursbeslissingen mag niet aan de deskundige gelaten worden. Het bestuur moet zijn verantwoordelijkheid nemen voor de toegedeelde bestuursbevoegdheden.

40. In de zin van Afdeling 8.2.4 Awb. Vgl. MvT-Whrol. p. 251; met de mogelijkheid om nadien verzet aan te tekenen (art. 8:55 Awb).

41. Tak, a.w. (1992), p. 98-99.

42. Vgl. Schoonenberg, J. en H.D. Vleesch Dubois, Het administratieve procesrecht volgens de Beroepswet, Amsterdam 1957, p. 388-389; Ten Berge/Tak II, a.w., p. 177-178.

43. Uiteindelijk gaat het om de uitleg van een juridische term "(on)geschiktheid tot werken", bezien moet worden of er werkelijk niet meer in geding is dan een geneeskundig geschil. Voorts is een onafhankelijk oordeel omtrent de werkwijze van de (vaste-)deskundige gewenst (nu ook dat handelen onlosmakelijk verbonden is met bepaalde waarderingen). 
Primair gaat het er in deze vuistregel om dat het geven van een (in potentie) bindend rechtsoordeel, zoals bij rechtsvorming door het bestuur, maar ook bij rechtsvaststelling door de rechter in een geschil, een eigen juridische legitimatie behoeft. Het geven van bindende rechtsoordelen impliceert immers het maken van een bindende keuze van inhoudelijke of procedurele aard, danwel het bindend waarderen van zodanige keuze. Deskundigen missen daartoe de legitimatie. Zelfs in beslissingen van volstrekt feitelijke aard kan hun deskundigheid daartoe geen grondslag vormen. Hun oordeel is immers op verschillende wijzen onderhevig aan onzekerheid: zij kunnen geen objectieve zekerheid verschaffen. In en naar aanleiding van het onderzoek van deskundigen moeten mitsdien keuzes worden gemaakt en waarderingen worden gegeven. ${ }^{4}$ In ons bestel is daartoe een juridische legitimatie vereist. Bij het bestuur moeten we daarbij in het bijzonder denken aan de politieke en publiekrechtelijke legitimatie. Bij de rechter, op wie de eerste vuistregel mijns inzien ook toepasselijk is, aan diens onafhankelijkheid.

Nu zou kunnen worden geopperd dat de eerste vuistregel er niet aan in de weg staat dat een combinatie van hoedanigheden wordt gekozen: het deskundige-bestuur, de deskundige-rechter. De charme hiervan zou zijn dat waar de deskundige vanwege waarde-oordelen moet zwijgen, alsdan het bestuur of de rechter kan spreken. Het voordeel lijkt dan dat een kritisch oog op de feitenvaststelling is verzekerd.

In de eerste vuistregel is echter ook uitdrukkelijk naar voren gebracht dat deskundigheid van het bestuur een voordeel kan zijn teneinde de minimaal noodzakelijke dosis kritisch vermogen te waarborgen. Deze deskundigheid zal echter geen op zichzelf staande bron van legitimatie van bindende rechtsoordelen kunnen vormen. Voor het juridisch gezag van een rechtsoordeel is zulks ook niet nodig. Zoals ook in de tweede vuistregel tot uitdrukking wordt gebracht is wetenschappelijke zekerheid geen vereiste voor juridisch gezag het is ons om juridisch bevredigende beslissing te doen, niet om wetenschappelijke schijnzekerheid. Voorkomen moet worden dat de (steeds onterechte) pretentie van wetenschappelijke zekerheid als grondslag van de feitenstelling gaat functioneren. Op die grond wees ik de gedachte af dat bestuur en (bij deze) de rechter zich als superdeskundigen profileren: deskundigen die zich op de waarheid beroepen en wier oordeel mitsdien wel gezaghebbend moet zijn.

In het licht van wetenschappelijke onzekerheid is het zaak dat bij de feitenvaststelling diverse juridische waarborgen in acht worden genomen: inhoudelijke (zoals de marginale toets van een uitgebracht deskundigenadvies) en procedurele (zoals de openheid van de besluitvorming). Van geval tot geval

44. $\mathrm{V}$ gl. de normatieve keuzes uit $\$ 4.5 .3$ en $\$ 8.3 .3 .2$. 
wordt, in termen van een bevredigende beslissing, gestreefd naar een optimale kennisrepresentatie. ${ }^{45}$ Inzoverre het verlangde rechtsoordeel normatieve keuzes inzake de feitenvaststelling impliceert dreigt bij de combinatie deskundige-bestuur en deskundige-rechter het technisch-wetenschappelijk en juridisch oordeel onontwarbaar vervlochten te raken. ${ }^{46}$ Het zijn van deskundige is - kortom - enerzijds niet toereikend en anderzijds een belemmering voor het geven van een rechtsoordeel (als rechter of bestuur, a fortiori bij technisch-complexe beslissingen).

Wat de organisatie van de rechterlijke macht betreft ben ik om die reden geen voorstander van specialistische rechters, in dier voege dat hun "accessoire" deskundigheid mede ter schraging van de legitimatie hunner beslissingen is bedoeld. Specialisatie in de praktijk, bij voorbeeld door opdeling in kamers, acht ik, evenzeer als ambtelijk-deskundige ondersteuning van bestuursorganen, aanvaardbaar. Hier betreft het echter veeleer het zoeken naar een verantwoord minimum, om althans een marginale inhoudelijke toets van uitspraken van "echte deskundigen" te kunnen volvoeren. ${ }^{47}$

In de Whrol is geen sprake van heroverweging op dit punt. Het oordeel van de deskundige is niet meer dan een advies, ingebed in het vooronderzoek, voorafgaand aan een nog te geven rechterlijk oordeel. De rechter dient te beoordelen of het deskundigenonderzoek voldoet aan de daaraan redelijkerwijs te stellen eisen. Weliswaar ontbreken daartoe nu voorschriften als in art. 137, tweede lid Beroepswet (inzake de raadpleging van andere betrokken geneeskundigen), maar dat zal de rechter niet behoeven te beletten om de deskundige op zijn onafhankelijkheid en procedure van onderzoek aan te spreken. ${ }^{48}$

\subsection{Het administratief bewijsrecht}

\subsection{1. 'De waarheid'}

Het juridisch bewijs betreft de vaststelling van feiten met het oog op bepaalde - daaraan verbonden of te verbinden - rechtsgevolgen ${ }^{49}$ Het juridisch bewijs

45. Naar de stand van wetenschap en techniek - m.i.v. aandacht voor niet-gangbare visies.

46. Zo zou de rechter-deskundige in zijn "deskundige-oordeel" kunnen anticiperen op een nog te geven juridisch oordeel.

47. T.b.v. het onderkennen van ernstige gebreken of onbegrijpelijkheden.

48. Art. 8:48 Awb geeft hem daartoe ook een opstap: als de medisch-deskundige de daar genoemde personen niet raadpleegt, niettegenstaande een verschil van opvatting. behoeft zulks naar mijn mening toch enige toelichting.

49. Enschedé, Ch.J.. Bewijzen in het strafrecht. RMTh'66, p. 488-518, i.h.b. p. 489. 
als correcte wijze van vaststelling van feiten, ${ }^{50}$ impliceert het voldoen aan juridische eisen voor de vaststelling van feiten.

Correcte bewijsvoering heeft in het bestuursprocesrecht tot doel door te dringen tot de "materiële waarheid"; tot datgene dat werkelijk is gebeurd of zal gebeuren. ${ }^{51}$ In de rechtsbeschermingsoptiek (van het Whrol) zal de rechter zich bij zijn onderzoek naar 'de waarheid' vooreerst moeten oriënteren aan de klacht van appellant. Dit wordt ook tot uitdrukking gebracht in art. 8:69, eerste lid Awb.

Tegen die achtergrond is het interessant een vergelijk te maken met het civiele bewijs, in het bijzonder met art. 176 eerste lid Rv: tussen partijen onbetwist gebleven feiten moeten door de rechter als vaststaand worden aangenomen. ${ }^{52}$

Volgens Schreuder-Vlasblom moet het verschil tussen het bestuursprocesrecht en het burgerlijk procesrecht (met het oog op de waarheidsvinding) niet worden overtrokken. ${ }^{53}$ Enerzijds geeft art. 176 eerste lid $\mathrm{Rv}$ de burgerlijke rechter immers de ruimte om zo nodig toch zelfstandig (onbetwiste) feiten vast te stellen, "zo vaak aanvaarding van de stellingen zou leiden tot een rechtsgevolg dat niet ter vrije bepaling van partijen staat." Anderzijds houdt de rechtsbeschermingsoptiek in het bestuursproces voor de rechter een aansporing in om zich zo mogelijk (inderdaad) te beperken tot de vaststelling van betwiste feiten. ${ }^{54}$

In het Whrol wordt de actieve rol van de rechter bij het vinden van de materiële waarheid bovendien nog uit een oogpunt van ongelijkheidscompensatie benadrukt. ${ }^{55}$ In voornoemd art. 8:69 Awb (tweede en derde lid) wordt dan ook uitdrukkelijk bepaald dat de rechter de rechtsgronden en feiten aanvult, c.q. kan aanvullen. Met Verheij ${ }^{56}$ meen ik dat de rechter (niet alleen de juistheid maar) vooral ook de volledigheid van de bestuurlijke feitenvaststelling zou moeten onderzoeken - voorzover zulks in het verlengde van

50. Ten Berge/Tak, p. 344-345.

51. Vgl. voor het bestuursprocesrecht Ten Berge/Tak, a.w., p. 354, Schreuder-Vlasblom, M., Tussen Dominus Litis en knecht van twee meesters. NTB'91/3, p. 69-82, m.n. p. 70 en de MvT-Whrol, p. 36-37. Een vergelijkbaar oogmerk geldt voor het strafrecht: zie (o.a.) Remmelink, J., Enige opmerkingen over de deskundige in strafzaken, Tijdschrift voor strafrecht, Deel IXXIV (1965), p. 75 en Enschedé, a.w., p. 517.

52. Vgl. ook Hoogendijk-Deutsch, S.V., Beginselen van behoorlijk bewijs in de administratieve rechtspraak, RMTh'92/7, p. 308-323, i.h.b. p. 316.

53. A.w., p. 79.

54. Zulks in lijn met het voorkómen van ultra petitum gaan, om nog te zwijgen van reformatio in peius.

55. MvT-Whrol, p. 37.

56. Een klantvriendelijke rechter, a.w., p. 145-146. 
eisers klacht ligt. Dat de administratieve rechter actief is en als dominus litis opereert vloeit overigens ook reeds voort uit het feit dat hij, na de schriftelijke voorfase van de procedure (geïnitieerd door het beroepschrift van appellant) het heft in handen neemt; hij voert de regie over het onderzoek. ${ }^{57}$

Een tweede punt dat het karakter van het juridische bewijs verregaand beinvloedt is dat van de contentieuze procedure zelf. De juridische eisen aan het bewijs hangen nauw samen met het feit dat het bewijs bijdraagt aan een dwingende beslissing met rechtsgevolgen. Deze dwingende beslissing moet worden genomen in een procedure die aan de eisen van een fair-trial (waaronder de eis van hoor en wederhoor) moet voldoen. Daarbij dient de bewijsvoering (ook) uit een oogpunt van de legitimiteit van de rechterlijk uitspraak zorgvuldig te zijn, en zal - last but not least - binnen een beperkte tijd beslist moeten worden..$^{58}$

Bewijsvoering, opgevat als het blootleggen van de materiële waarheid wordt - met andere woorden - niet slechts bepaald door inzichten van wetenschappelijke rationaliteit, maar ook door normatieve gezichtspunten ten aanzien van middelen en methoden van onderzoek. ${ }^{59}$ Overigens zullen deze normatieve gezichtspunten (zoals het beginsel van hoor en wederhoor, alsmede het beginsel van ongelijkheidscompensatie) uiteindelijk ook bijdragen zijn aan de rationaliteit van de bewijsvoering. ${ }^{\infty}$

In de volgende paragrafen zullen de verschillende normatieve gezichtspunten aangaande het bewijsrecht nog expliciet aan de orde komen.

In de derde plaats moeten we binnen het contentieuze bestuursprocesrecht onderscheid maken tussen het bewijs in het kader van de rechtmatigheidstoets van een bestuursbesluit en het bewijs in het kader van de rechterlijke uitspraak, in het bijzonder het zelf voorzien door de rechter in een nieuw besluit of het voor gedekt verklaren (het in stand laten) van een (bepaald deel van een) bestuursbesluit. ${ }^{61}$ Dit onderscheid is vooral van belang met het oog op de mate van zekerheid over het bewijs. Ik kom hierop bij de "bewijswaardering" nog terug.

57. Wulffraat-van Dijk, M.S.E. et al. Bestuursprocesrecht en burgerlijk procesrecht onder één dak, NJB speciaal'91/36, p. 1489-1493, i.h.b. p. 1491.

58. Vgl. Ten Berge/Tak, p. 372.

59. Dit geldt a fortiori in het strafprocesrecht, vgl. Melai, A.L., Getuigen en deskundigen als exclusieve informanten van de rechter, D\&D'74, p. 176-182.

60. Terwijl het punt van de tijdsdruk eigenlijk altijd speelt omdat onderzoek naar feiten immers eindeloos kan voortgaan. Het gaat er "slechts" om in een beperkt tijdsbestek goede keuzes te maken: opnieuw gaat het om een "bevredigende beslissing".

61. Ten Berge/Tak, p. 347-348. 


\subsubsection{Vier aspecten}

Hierna zal ik een schets geven van een viertal aspecten van het bestuursrechtelijke, vrije bewijsstelsel, ${ }^{62}$ te weten: de kwestie van de bewijsomvang, van de bewijslastverdeling, van de bewijsmiddelen en van de bewijswaardering. ${ }^{63}$

Op verschillende plaatsen in de navolgende tekst zal ik verwijzen naar het straf- of burgerlijk procesrecht. Ik beoog hier geen interne rechtsvergelijking, doch slechts een verduidelijking van bepaalde ontwikkelingen of suggesties.

Wat het strafprocesrecht betreft moeten we uiteraard steeds bedenken dat het punitieve karakter van de strafrechtspleging doorwerkt in het strafrechtelijk bewijsrecht; zoals bij voorbeeld blijkt uit het in aanleg negatief-wettelijk bewijsstelsel. ${ }^{64}$

Wat het burgerlijk procesrecht betreft blijft het, vooralsnog, de vraag of het uitgangspunt van de partij-autonomie daaraan niet (toch) een van het bestuursprocesrecht afwijkend karakter geeft; ook al staat de gedachte van het contentieux subjectif thans ook in het bestuursprocesrecht voorop. ${ }^{65}$

In het perspectief van het Whrol zou men de administratieve rechter mijns inziens als een lijdelijke doch actieve rechter kunnen typeren. Daaraan ligt allereerst de idee van een grotere partij-autonomie ten grondslag. Partijen bakenen zelf het object van geschil af en daaraan is de rechter gebonden. Actief kan de rechter zijn als het gaat om het onderzoek naar feiten en rechtsgronden, mede op basis van het beginsel van ongelijkheidscompensatie (dat ook in de voorstellen van het Whrol een belangrijke plaats inneemt). "Lijdelijk doch actief" suggereert een eenduidig profiel voor het rechterlijk functioneren. Toch ligt dat in de praktijk minder eenvoudig. Partij-autonomie heeft (naast afbakening van het object van geschil) in zoverre (nog) een bewijsrechtelijke dimensie, dat daarin ook de vrijheid van partijen besloten ligt om bepaalde stellingen van de wederpartij al dan niet aan te vechten. De rechter zal zich mitsdien moeten bezinnen op de vraag in welke mate hij partijen die vrijheid laat, danwel zichzelf - actief - met het bewijs inlaat. Wat de burger betreft zal hij zich daarbij tevens moeten laten leiden door het begin-

62. Die vrijheid wordt in de MvT-Whrol, p. 37, hoewel niet expliciet toch nadrukkelijk verondersteld.

63. Dit onderscheid ontleen ik aan Ten Berge/Tak, a.w.. p. 352-353.

64. De wet somt de bewijsmiddelen limitatief op en eist een bepaalde minimale bewijsvoering - zoals in art. 342 tweede lid Sv. (één getuige kan niet alleen het bewijs leveren). Overigens wordt het strafrechtelijk bewijsstelsel volgens sommigen ook steeds vrijer: vgl. Enschedé, a.w., p. 515-516.

65. In de MvT-Whrol, p. 38-40, begeeft de regering zich in een kleine vergelijking tussen bestuursprocesrecht en burgerlijk procesrecht. Naast tendensen tot harmonisatic signaleert zij toch ook nog significante verschillen (in vertrekpunten). 
sel van ongelijkheidscompensatie - wellicht wordt een stelling van het bestuur niet aangevochten omdat de burger daarvoor als partij te zwak is. Wat het bestuur betreft zal de rechter moeten bedenken dat deze partij eigenlijk slechts beperkt autonoom is. Behoudens zekere discretionaire bevoegdhe$\operatorname{den}^{66}$ is het bestuur gebonden aan de regels van het objectieve recht - ook in dat opzicht kan er reden zijn om juist extra actief te zijn. ${ }^{67}$

Last but not least stel ik mij voor dat het administratieve bewijsrecht eigenaardige trekjes vertoont vanwege de typische relatie tussen de non-contentieuze procedure en het contentieuze proces. Dat punt heb ik in het voorgaande hoofdstuk, toegespitst op de functie van het bestuursproces, proberen te belichten. Nu lijkt het zaak om in de volgende paragrafen de bewijsrechtelijke consequenties daarvan zichtbaar te maken.

\subsection{De bewijsomvang}

Welke feiten moeten in de procedure nu precies bewezen worden? Ten Berge en Tak hanteren hiervoor een helder uitgangspunt: in beginsel moeten alle ter discussie staande feiten welke de rechter aan zijn beslissing ten grondslag wil leggen, worden bewezen. Een uitzondering kan worden gemaakt voor feiten die naar de overtuiging van de rechter reeds voldoende vaststaan. ${ }^{68}$ Het spreekt wel vanzelf dat dit laatste in elk geval geldt voor feiten van algemene bekendheid en ook voor (algemene) ervaringsregels waarmee causale relaties kunnen worden gelegd tussen oorzaken en gevolgen. ${ }^{\oplus}$ Ook processuele feiten en andere feiten die de rechter uit eigen wetenschap bekend zijn behoeven niet bewezen te worden. ${ }^{70}$

Eerder wees ik er op dat de administratieve rechter op grond van art. 8:69, derde lid Awb de feiten kan aanvullen. Deze bevoegdheid draagt bij aan de mogelijkheid om toepassing te geven aan het beginsel van ongelijkheidscompensatie. De rechter zou zich echter niet over feiten moet uitlaten waarover

66. Ik denk in het bijzonder aan de beleids- en beoordelingsvrijheid. Ook de beoordelings-opportuniteit bij feitenvaststelling is hier echter relevant. Dit punt komt nog terug.

67. Mede met het oog op de positie van derden en de vraag naar de bevoegdheid. Vergelijk voor deze modaliteiten de interessante schets die Verheij geeft in: Een klantvriendelijke rechter, a.w., p. 132-137.

68. Ten Berge/Tak, a.w., pp. 349-350 en p. 352.

69. Ibidem. p. 350. Waarbij het ofwel gaat om het met behulp van ervaringsregels en bepaalde feiten achterhalen van een toedracht uit het verleden (zoals bij menig strafbaar feit) of om een "voorspelling" over wat er in de toekomst zal gaan gebeuren.

70. Hoogendijk-Deutsch, a.w.. p. 311. 
partijen nog geen visie hebben kunnen geven. ${ }^{71}$ Dit houdt uiteraard vooral verband met het verdedigingsbeginsel. Dit is mijns nauw verweven met het uitgangspunt van de partij-autonomie - zoals ook hierboven geduid. In de opvatting dat partijen vrij zijn te beslissen of zij een stelling willen aanvechten, ligt immers besloten dat zij steeds in de gelegenheid gesteld worden zulks te doen.

Binnen die randvoorwaarde èn uitgaande van de klacht van eiser, kan de rechter feiten aanvullen teneinde de juistheid en de volledigheid van de bestuurlijke feitenvaststelling te toetsen. Ook lijkt mij hierbij van belang dat de bestreden beslissing ook derden kan betreffen en dat het bestuur (mede in verband daarmee) slechts beperkte autonomie heeft. Daaruit volgt dat de rechter bij zijn oordeelsvorming steeds ook feiten in ogenschouw moet nemen die procespartijen niet kunnen of willen bewijzen. ${ }^{72}$ Ten slotte is het mogelijk dat uit het onderzoek door een deskundige nieuwe feiten ter tafel komen. Binnen de voornoemde randvoorwaarden (de feiten moeten relevant zijn met het oog op de voorliggende klacht en partijen moeten zich over deze feiten kunnen uitlaten) kan de rechter ook deze in zijn oordeel betrekken.

Feiten worden ingebracht met het in de procedure bestreden besluit zelf. Niettemin schrijft art. 8:42, eerste lid Awb voor dat het bestuursorgaan binnen vier weken na verzending van het beroepschrift een verweerschrift in moet dienen. Naast de motivering in het bestreden besluit liggen zo alras de nodige feiten op tafel. ${ }^{73}$ Naast het bestreden besluit en het verweerschrift is het beroepschrift van de appellant van belang. Daarin dient deze immers te adstrueren waarom er zijns inziens een gebrek kleeft aan de feitenvaststelling door het bestuur. Deze adstructie geeft een nader inzicht in de voor het geschil mogelijk relevante feiten - en vormt zou een aanknopingspunt voor het onderzoek door de rechter. Ten slotte kan - als gezegd - ook het onderzoek door een deskundige op voet van art. 8:47 Awb nog nieuwe feiten opleveren. ${ }^{74}$

71. Vgl. MvT-Whrol, p. 142.

72. Art. 8:26. eerste lid en art. 8:45, eerste lid Awb verschaffen de rechter uitdrukkelijk de mogelijkheid (informatie van) derden bij het onderzoek te betrekken.

73. Bij toepassing van Afd. 8.2.4 Awb (Vereenvoudigde behandeling) kan een verweerschrift (eventueel) achterwege blijven. Vgl. MvT-Whrol, p. 128.

74. Zoals bij de bespreking van de bewijsmiddelen nog zal blijken vervult in de praktijk van het huidige TwK-proces het ambtsbericht een zeer grote rol bij het onderzoek naar de feiten. 


\subsection{De bewijslastverdeling}

\subsubsection{Vrije bewijsleer}

Het vrije bewijsstelsel stelt de rechter voor de volgende keuze: hij kan de gehele bewijslast verdelen over partijen en dan bepalen welke partij wat moet bewijzen, of hij kan een deel of de gehele bewijslast aan zichzelf voorbehouden.

Hoe de rechter ook beslist, hij dient partijen in elk geval toe te staan om, zo zij dat wensen, bewijs te leveren voor of tegen bepaalde stellingen. ${ }^{75}$.

\subsubsection{Bewijs door de rechter}

De beslissing van een administratieve rechter om zelf (een deel van) de bewijslast te dragen is zeer wel te plaatsen in zijn actieve rol in het geschil. Actief optreden is vooral aangewezen indien het beginsel van ongelijkheidscompensatie dit wenselijk maakt. In aanleg brengt rechterlijke lijdelijkheid mee dat de rechter partijen vraagt bewijs aan te dragen voor de door hen opgeworpen stellingen. Als deze last voor een der partijen te zwaar is terwijl het anderszins onredelijk lijkt de bewijslast van de andere partij te verzwaren, kan de rechter, op voet van het streven naar ongelijkheidscompensatie een deel van de bewijslast voor eigen rekening nemen. Ook is denkbaar dat er feiten in het geding zijn die relevant zijn voor rechtsgevolgen die niet ter vrije bepaling van partijen staan - in het bijzonder met het oog op de beperkte autonomie van het bestuur. De rechter zou het bewijs van deze feiten op zich moeten nemen, maar opnieuw zou ik menen dat hij vooreerst partijen in de gelegenheid stelt zich hierover uit te laten. De gelegenheid zou hiertoe reeds in een vroeg stadium kunnen worden geboden ${ }^{76}$ waarna de rechter kan beoordelen of het wenselijk of noodzakelijk is dat hij zelf bewijs gaat vergaren.

In een dergelijke opzet kan de eigen verantwoordelijkheid van partijen voor hun procespositie als uitgangspunt van het bestuursproces stellig goed tot uitdrukking komen. ${ }^{7}$ Wel kan ik mij voorstellen dat de administratieve rechter eigenmachtig besluit of al dan niet een vooronderzoek zal worden ingesteld. Een dergelijk besluit dient toch vooral zijn rechters- belang; het scheppen van optimale condities voor een goede oordeelsvorming op en na de zit-

75. Ten Berge/Tak. a.w., p. 361. Zie ook art. 8:60, vierde lid Awb. Een regel die m.i. ook in het vooronderzoek zou moeten gelden.

76. Bijvoorbeeld als hij in het kader van een vooronderzoek van partijen oproept (en om inlichtingen vraagt) ex art. 8:44 Awb.

77. Niet in het minst omdat de rechter zich zelf er aldus toe dwingt de klacht van appellant zo scherp mogelijk in het oog te houden en niet aanstonds tot (integrale) hervaststelling van de feiten over te gaan. 
ting. ${ }^{78}$ Als echter tot een vooronderzoek wordt besloten, dan lijkt het mij juist dat de rechter eerst partijen hoort, alvorens te besluiten om eventueel getuigen of deskundigen bij het onderzoek te betrekken. ${ }^{70}$

Ik sluit niet uit dat ook twijfel over eigen technische-deskundigheid een belangrijke drijfveer kan zijn bij de rechterlijke beslissing om (een deel van) de bewijslast aan zich te trekken. Dit speelt vooral bij het leveren van bewijs door deskundigen. De rechter kan zich natuurlijk op het standpunt stellen dat partijen hem maar van hun gelijk moeten overtuigen. Als de rechter echter vreest dat juist hijzelf bij de waardering van het bewijs de zwakke schakel dreigt te worden, dan zou dat reden kunnen zijn om reeds aanstonds deskundigenbewijs in eigen hand te nemen. Toch meen ik dat hij - niettemin - eerst partijen in de gelegenheid zou moeten stellen bewijs te leveren. Mocht gaande het onderzoek de twijfel aan zijn eigen technisch oordeelsvermogen niet verdwijnen (of zelfs toenemen) dan kan hij immers alsnog een deskundigenonderzoek gelasten (op vragen die hij als rechter voor zich zelf tot klaarheid wil brengen).

Deze benadering zou mijns inziens ook passen als het erom gaat partijen, juist door een partij-onafhankelijk deskundigenonderzoek te stimuleren tot het bereiken van een compromis of schikking inzake de feitenvaststelling. ${ }^{80}$

Er kan met andere woorden voor de rechter goede grond bestaan om (een deel van) de bewijslast voor eigen rekening te nemen. Ongelijkheidscompensatie, de beperkte autonomie van partijen ${ }^{81}$ eigen beoordelingsvermogen en processtrategische motieven kunnen een dergelijk actief optreden - onder omstandigheden - zeker billijken. Voorop dient echter te staan dat de rechter nagaat in hoeverre partijen zelf tot het leveren van bewijs in staat zijn. Soms zijn zij er zelfs veel eenvoudiger toe in staat. Belangrijker is echter dat de eigen verantwoordelijkheid van partijen zo duidelijk tot uitdrukking komt. In dat verband denk ik vooral ook aan de bijzondere verantwoordelijkheid van het bestuur, die hieronder nog aan de orde komt.

78. Vgl. MvT-Whrol, p 126-127: komen tot een "behoorlijke instructie" van de zaak. Vgl. ook Tak, a.w. (1992), p. 91, het "zittingsrijp maken" van de zaak.

79. Nog afgezien van het feit dat de rechter, zo hij - bij voorbeeld - voornemens is een deskundige in te schakelen, partijen in de gelegenheid kan stellen (wat mij betreft:dient te stellen) daarover hun zienswijze naar voren te brengen (vgl. art. 8:47, derde lid Awb).

80. Ambtsberichten blijken niet zelden dit effect te hebben, zie hierna bij bewijsmiddelen ( $\$ 9.6)$.

81. C.q de vaststelling van feiten terzake van rechtsgevolgen die niet ter vrije bepaling van partijen (m.n. het bestuur) staan. 


\subsubsection{Bewijs door partijen}

In de toelichting bij het Whrol stelt de regering dat aan een wettelijk stelsel van bewijsrecht niet of nauwelijks behoefte bestaat. ${ }^{82}$ Dat neemt niet weg "dat de rechter, afhankelijk van onder meer de verhouding tussen partijen, de aard van het geschil en de in geding zijnde feiten, naar redelijkheid en billijkheid stelplicht en bewijslast over de partijen heeft te verdelen" ${ }^{83}$

Deze regel lijkt op het tweede deel van art. $177 \mathrm{Rv}$. Het eerste deel van die bepaling (kortweg: "wie stelt moet bewijzen"), waarop dit tweede deel, althans in het civiele bewijsrecht, een uitzondering vormt, wordt niet aangehaald. Elders in de toelichting ${ }^{84}$ neemt de regering nadrukkelijk afstand van art. $177 \mathrm{Rv}$. Daarmee lijkt de regering te kiezen voor een typisch bestuursrechtelijke insteek voor de bewijslastverdeling, al wordt niet expliciet gemaakt waardoor die insteek dan wordt gekenmerkt.

Hieronder wil ik proberen de contouren van een typisch bestuursrechtelijke regeling van de bewijslastverdeling in kaart te brengen. Daarbij zal ik nu - uiteraard - ingaan op de positie van de procespartijen. Daarna zal ik nog kort ingaan op de vergelijking tussen de bestuursrechtelijke en de civielrechtelijke regels voor de bewijslastverdeling.

\subsubsection{Bestuursrechtelijke regels}

Vooraleer ik over de criteria voor bewijslastverdeling tussen partijen iets meer zeg, wijs ik er op dat een bewijsopdracht geen plicht inhoudt, doch hooguit een risico dat, indien het bewijs niet wordt geleverd, dit tegen de partij in kwestie kan werken. ${ }^{85}$

Vanuit typisch bestuursrechtelijk perspectief bezien is het interessant na te gaan wat de invloed is van een tweetal klassieke beginselen voor de posities van partijen ten aanzien van de bewijslast. Ik doel hier op het vermoeden van rechtmatigheid van de bestreden bestuursbeslissing ${ }^{86}$ en het beginsel van ongelijkheidcompensatie. Het vermoeden van rechtmatigheid zou met name ten goede komen aan de positie van het verwerende bestuursorgaan, de ongelijkheidscompensatie zou primair de procespositie van de appellant dienen.

82. MvT-Whrol, p. 37 (m.n. in het licht van de rechterlijke bevoegdheid tot aanvulling van de feiten).

83. Tbidem.

84. Ibidem, p. 40.

85. Ten Berge/Tak, a.w., p. 359, alsmede art. 8:31 Awb.

86. Als zodanig ook in het voorontwerp-Whrol als grondtrek erkend. Zie MvT-voorontwerp Whrol, a.w., p. 29. Zie overigens Van Galen/Van Maarseveen. a.w., p. 54-58. 
De Raad van State heeft nadrukkelijk kritiek geleverd op de oorspronkelijke opvatting van de regering dat het vermoeden van rechtmatigheid als een typische karakteristiek van het bestuursproces is op te vatten. ${ }^{87}$ Met name meent de Raad dat de gevolgtrekking uit dit beginsel (de burger moet initiatief nemen tot het geschil - als geen beroep volgt wordt het besluit voor rechtmatig gehouden) niet typisch bestuursrechtelijk is ${ }^{88}$ Refererend naar de gangbare praktijk wijst de Raad er op dat ook het verwerend bestuursorgaan in de procedure (door schriftelijk verweer, overlegging van het dossier, verantwoording ter zitting op kritische - soms ambtshalve gestelde - vragen door de rechter) zijn zaak moet verdedigen. De regering stemt inzoverre in met deze kritiek, dat het vermoeden van rechtmatigheid in de toelichting op het Whrol niet (meer) als "grondtrek" van het bestuursprocesrecht wordt opgevoerd. Tegelijkertijd stelt de regering uitdrukkelijk dat "daarmee (..) niet gezegd (wil) zijn, dat het vermoeden van rechtmatigheid van het bestuurshandelen als zodanig niet meer zou gelden." Zij verwijst daarbij onder meer naar de regel dat het beroep geen schorsende werking heeft. De regering erkent slechts dat geen sprake is van een "exclusieve karakteristiek van alleen het bestuursprocesrecht". ${ }^{89}$

Is het nu zo dat het vermoeden van rechtmatigheid, eigenlijk verwijst naar de regel "wie stelt, moet bewijzen" - en wel zo, dat het allereerst aan de appellant is om zijn stelling aannemelijk te maken?

Ik denk dat deze stelling inzoverre opgaat dat inderdaad van de appellant mag worden verwacht dat hij in zijn beroepschrift de gronden vermeldt waarop zijn beroep berust. Er moet sprake zijn van een aanvechting van het bestuursbesluit, maar het gaat te ver om hierin ook daadwerkelijk een stelplicht te zien. ${ }^{90}$ De in art. 6:5 Awb neergelegde plicht om de gronden van het beroep in het beroepschrift te vermelden is veeleer te beschouwen als een ontvankelijkheidsvereiste. Deze impliceert overigens wel dat appellant zijn beroepschrift zodanig moet motiveren dat op voet daarvan twijfel over de juistheid van het bestuursbesluit kan rijzen. Als appellant (reeds) hier verzaakt, kan de rechter de zaak wegens kennelijke (niet-ontvankelijkheid of) ongegrondheid van het beroep via vereenvoudigde behandeling afdoen.

Als deze eerste 'horde' door appellant echter is genomen, zal het verwerend bestuursorgaan moeten komen met een adstructie van de gevolgde werkwijze en het op voet daarvan genomen besluit.

87. Vgl. TK’91-'92, 22 495, A, p. 33-34.

88. Ibidem.

89. Ibidem, p. 34.

90. Vgl. Hoogendijk-Deutsch, a.w.(1992), p. 315. 
Deze adstructie is mijns inziens te beschouwen als het voldoen aan een 'preprocessuele bewijslast'. Allewijnn" stelt dat deze preprocessuele bewijslast inhoudt dat het verwerend bestuursorgaan aannemelijk moet maken te hebben voldaan aan elementaire regels van formele zorgvuldigheid ${ }^{22}$ en deugdelijke motivering. Daartoe strekt naar ik aanneem ook de in art. 8:42, eerste lid Awb neergelegde plicht voor het bestuursorgaan tot het inzenden van een verweerschrift. ${ }^{93}$

We zouden kunnen stellen dat het bestuur aldus het bewijs zal moeten leveren van de feiten die het ter onderbouwing van het bestreden besluit aanvoert. Volgens Verheij" komt hier tot uitdrukking dat het credo "wie stelt moet bewijzen" vooreerst van toepassing is op het bestuur. Nog afgezien van het feit dat het hier bedoelde verweer afhankelijk van de inhoud van het beroep meer of minder uitgebreid zal zijn, ${ }^{95}$ ben ik meer geneigd hier te spreken van een 'adstructieplicht' dan van een bewijsvoering over hetgeen in de noncontentieuze procedure is gedaan, overwogen en beslist. ${ }^{96}$

In deze optiek vangt de eigenlijke bewijsvoering pas aan nadat appellant zijn beroepschrift heeft gemotiveerd en het bestuur (vervolgens) zijn besluit(vorming) heeft geadstrueerd. In het zojuist geschetste 'voorportaal' van de bewijsvoering is het beginsel van ongelijkheidscompensatie in zoverre van belang dat de appellant "zijn standpunt niet aanstonds hoeft te schragen met bewijsbare feiten", terwijl het bestuur daar in zijn adstructie al wel toe verplicht is. ${ }^{97}$ Niettemin staat vast dat in het voorportaal ook het vermoeden van rechtmatigheid geldt: in beginsel wordt uitgegaan van de rechtsgeldigheid van het bestreden bestuursbesluit. Aangenomen wordt dat het bestuur zijn taak juist heeft uitgevoerd. Het is daarom dat de appellant niet kan volstaan met het stellen van zijn belanghebbendheid, maar ook gronden tot (gerede) twijfel aan de bewijsrechtelijke overtuigingskracht van het bestuursbesluit moet aanvoeren.

In de fase van de bewijsvoering neemt de rechter een sleutelpositie in omdat hij beslist over de bewijslastverdeling. Het vermoeden van rechtmatigheid

91. Allewijn, D., Een nieuw procesrecht voor ambtenarenzaken, NJB-speciaal'91/36, p. 1469-1475, i.h.b. p. 1470.

92. Het voldoen aan procedure-voorschriften (regels voor inspraak e.d.).

93. Uiteraard valt deze plicht weg als het beroepschrift aanleiding geeft tot het uitspreken van kennelijke ongegrondheid of kennelijke niet-ontvankelijkheid. Vgl MvT-Whrol, a.w., p. 128.

94. Een klantvriendelijke rechter, a.w., p. 147.

95. Vgl. MvT-Whrol, a.w., p. 128.

96. Ik zie deze adstructie-plicht dan ook primair als een 'toesnijding' van de bij het bestreden besluit behorende motivering op de klacht van appellant.

97. Hoogendijk-Deutsch, a.w. (1992), p. 315. 
leidt daarbij niet tot de gevolgtrekking dat appellant, wil hij in zijn beroep slagen, in elk geval gehouden is bewijs te leveren voor de feitelijke onjuistheid van het bestreden bestuurshesluit.

Opnieuw speelt hierbij - in de eerste plaats - het beginsel van ongelijkheidscompensatie een rol. Dat brengt mee dat de rechter, zo eiser zijn stelling in elk geval aannemelijk heeft kunnen maken, te hulp kan schieten. Daarbij kan hij zichzelf over het leveren van het bewijs ontfermen (zoals in het voorafgaande geschetst). Ook is het mogelijk dat hij het bestuur opdraagt bewijs voor zijn stellingen te leveren. Voor het laatste kan meewegen dat het bestuur eenzijdig ingrijpt in rechts- en belangenposities van burgers. Daaraan kan worden toegevoegd dat het bestuur niet zelden beperkingen oplegt of handhaaft in activiteiten die de burger in beginsel in vrijheid zou moeten kunnen uitoefenen. Ik denk daarbij ook aan de redenering uit het Jacobssonarrest van het EHRM: ${ }^{98}$ voordat een bouwvergunning wordt verleend is reeds sprake van een (burgerlijk) recht om te bouwen - dat door het algemene bouwverbod werd beperkt. Het afwijzen of verlenen onder beperkende voorschriften van een bouwvergunning is dus steeds een beperking in burgerlijke vrijheid. In deze lijn lijkt dan goed verdedigbaar dat het bestuur, mits (gerede) twijfel over het bestuursbesluit is gewekt, een zwaardere bewijslast krijgt opgelegd. Omgekeerd kan het overigens zo zijn dat uit een wettelijk voorschrift voortvloeit dat belanghebbende (c.q. appellant) bepaalde feiten moet stellen en zonodig bewijzen. Dan ligt de beschermende werking van het beginsel van ongelijkheidscompensatie niet voor de hand. ${ }^{99}$

$\mathrm{Bij}$ dit alles moet overigens het vermoeden van rechtmatigheid niet uit het oog worden verloren. Ook als het bestuur een belangrijke bewijsopdracht krijgt toebedeeld, is het niet zo dat het gehouden zou zijn om (in het contentieuze proces ineens) alle twijfel omtrent de feitelijke juistheid van het betreden besluit te elimineren. ${ }^{100}$ Dat zou ook een overspannen eis zijn. ${ }^{101}$

De bewijslastverdeling voor het vervolg van het onderzoek beweegt zich - kortom - tussen het ongelijkheidsbeginsel (het voordeel van de gerede twijfel) en het vermoeden van rechtmatigheid (het voordeel van lichte twijfel). In

98. EHRM 25 oktober 1989, AB'90, 334.

99. Vgl. Verheij. Een klantvriendelijke rechter, a.w.. p. 147.

100. Van Galen en Van Maarseveen stellen in hun preadvies, a.w., p. 54-58, dat door het vermoeden van rechtmatigheid klager zich in een zwakkere positie bevindt: de rechter moet overtuigd worden van de onrechtmatigheid van het bestuursbesluit. Zonder dat faalt het beroep - twijfel kan derhalve in het voordeel van de overheid werken (kan, zie ook de interventie terzake van Punt en de reactie daarop van de preadviseurs). In termen van bewijslastverdeling is het nadeel voor klager overigens niet per se zo groot. Hij moet weliswaar de waarschijnlijkheid aandragen van een gebrek, maar de rechter kan hem vervolgens te hulp komen.

101. Ik denk hierbij weer aan de tweede vuistregel: de bevredigende beslissing. 
aansluiting op deze grondtrekken kunnen verschillende factoren invloed hebben op de bewijslastverdeling tussen partijen. Ten Berge en Tak sommen een aantal van die factoren op: ${ }^{102}$

- Wie stelt een bijzonder belang of recht te hebben zal dit moeten bewijzen. Als een der partijen zich op een bijzonderheid beroept, dat wil zeggen een afwijking van de normale gang van zaken of van de normale situatie dan ligt het voor de hand dat deze partij ook wordt gevraagd zulks te bewijzen. Ook kunnen er aanwijzingen zijn vanuit het rechtsstelsel of de bevoegdheid in kwestie. Zo zal ingeval van toepassing van een sanctie of het gebruik van een (ruime) discretionaire bevoegdheid, op het bestuursorgaan in kwestie al snel een zware bewijslast rusten.

- Ook de regel dat de bewijslast bij voorkeur dient te worden opgelegd aan die partij die daardoor het minst wordt bezwaard wijst vooral in de richting van het bestuur. Dat heeft immers, als het goed is, net met de vereiste zorgvuldigheid een eigen onderzoek verricht, waarmee deze last aansluit op de preprocessuele bewijslast van het bestuur. Ook kan deze regel van bewijslastverdeling worden toegepast als een der partijen zich gesteld ziet voor het bewijs dat iets niet van toepassing is, iets niet is gebeurd enz. Vaak is dergelijk bewijs moeilijk te leveren en dat kan dan pleiten voor het verleggen van de bewijslast.

- Voorts kan het - als gezegd - relevant zijn welke partij de schijn tegen zich heeft. Dit is een regel die hangende het onderzoek verschillende partijen kan aanwijzen als gegadigden voor het leveren van bewijs (op een en het zelfde punt). Het is immers denkbaar dat tijdens het onderzoek bewijs gaandeweg wordt geleverd. Als de ene partij een stelling aannemelijk weet te maken kan de rechter op basis daarvan besluiten de andere partij op te dragen nu maar te bewijzen dat het door eerstgenoemde partij beweerde onjuist is.

- Ook kan de rechter als aanknopingspunt nagaan ten gunste van welke partij het bewijs van een bepaald feit zou strekken, om aan deze partij vervolgens het bewijs terzake op te dragen.

- Ten slotte kan de rechter indien mocht blijken dat een bepaald feit niet te bewijzen is, dit - analoog aan de redenering bij het niet voldoen aan een bewijsopdracht - voor risico brengen van die partij door wiens onzorgvuldigheid het leveren van bewijs onmogelijk is geworden. ${ }^{103}$

102. Ten Berge/Tak I, pp. 364-367. Vgl. ook Hoogendijk-Deutsch, a.w. (1992), p. 316-318.

103. Ten Berge/Tak noemen het voorbeeld van de brief die (beweerdelijk) is verstuurd maar (beweerdelijk) niet is aangekomen. Het niet aangetekend versturen van de brief kan in het nadeel van de afzender werken (a.w. I, p. 367). 
Ten slotte kom ik nog even terug op de kwestie van de partij-autonomie. Hierboven heb ik betoogd dat de rechter partijen uitdrukkelijk in de gelegenheid moet stellen bewijs te leveren of zich over het bewijs uit te laten. Deze zienswijze heeft invloed op de toepassing die de rechter geeft aan het beginsel van ongelijkheidscompensatie. Het betekent namelijk dat de rechter niet (te) snel moet aannemen dat de burger-partij te zwak is om zijn eigen zaak te bepleiten. Met Hoogendijk-Deutsch ${ }^{104}$ ben ik van mening dat in steeds meer gevallen burger-partijen goed voor zichzelf kunnen opkomen. ${ }^{105} \mathrm{De}$ rechter zal zich daarvan rekenschap moeten geven. Hoogendijk-Deutsch wijst echter terecht op een opmerkelijk risico van deze emancipatie van de burger-partij in het bestuursproces. ${ }^{106}$ Hoe serieuzer de rechter de burger-partij zal nemen, des te vanzelfsprekender wordt het voor hem om indien deze partij een stelling van de wederpartij onbestreden laat of een eigen stelling niet met bewijs onderbouwt, aan te nemen dat wordt ingestemd met de stelling van de wederpartij en dat de eigen stelling onbewijsbaar is. Het gevaar is dan dat de rechter in zijn eigen onderzoek verder aan deze stellingen voorbijgaat. Met het oog hierop bepleit Hoogendijk-Deutsch "een wettelijk tot de rechter gericht verbod, aan een relevant bewijsaanbod zonder motivering voorbij te gaan". ${ }^{107}$ Een dergelijke regel zou de meer onderlegde burger-partij moeten scherpen in het doen van zodanig bewijsaanbod.

Een en ander laat uiteraard onverlet dat de rechter op andere gronden dan ongelijkheidscompensatie (beperkte autonomie der partijen, het eigen beoordelingsvermogen van de rechter, processtrategische overwegingen) kan beslissen zelf een belangrijk aandeel in de bewijslast op zich te nemen.

\subsubsection{Een vergelijking met de civiele bewijslastverdeling}

In hoeverre komen de uitgangspunten voor de bewijslastverdeling in het bestuursproces nu overeen met de desbetreffende civielrechtelijke regels - in het bijzonder met art. $177 \mathrm{Rv}$ (kortweg: "wie stelt moet bewijzen, tenzij uit redelijkheid en billijkheid een andere bewijslast voortvloeit").

Verheij stelt ${ }^{108}$ dat de regel van art. $177 \mathrm{Rv}$ in beginsel ook voor het bestuursprocesrecht werkt. Hij die zich beroept op de rechtsgevolgen van bepaalde feiten, moet het bewijs van die feiten verschaffen. Naar zijn mening wijst deze regel in beginsel naar het bestuur, tenzij uit de billijkheid anders

104. A.w.(1992), p. 315.

105. Al dan niet door zich van rechtsbijstand te verzekeren.

106. A.w.(1992), p. 315-316.

107. Tbidem, p. 316.

108. Verheij, Een klantvriendelijke rechter, a.w.. p. 147-148. 
volgt - bij voorbeeld omdat sommige feiten volgens wettelijk voorschrift door belanghebbende aannemelijk gemaakt moeten worden. Ongelijkheidscompensatie noemt hij slechts als grondslag voor het besluit van de rechter om zelf een deel van de bewijslast op zich te nemen. ${ }^{109}$

IJsselmuiden ${ }^{110}$ wijst er op dat achter het in art. $177 \mathrm{Rv}$ verwoorde uitgangspunt "wie stelt, moet bewijzen", twee ideeen schuil gaan, te weten dat van de gelijkwaardigheid partijen in termen van macht en kennis en dat van de afwezigheid van rechtsgevolgen van 's rechters uitspraak voor anderen dan partijen. Op beide aspecten valt zijns inziens in het belastingrecht en meer in het algemeen in het bestuursrecht, maar stellig niet zelden ook in het burgerlijk recht, af te dingen. Juist daarom mag van partijen naar redelijkheid en billijkheid een bijdrage aan de bewijsvoering worden verlangd. Daarbij speelt volgens IJsselmuiden ook de vraag "welke van beide partijen zich het gemakkelijkst toegang kan verschaffen tot de relevante benodigde feiten" een grote rol. ${ }^{111}$

Voor IJsselmuiden is na vergelijking tussen de werkwijze van de belastingrechter en de burgerlijke rechter op basis van het burgerlijk procesrecht en de werkwijze van administratieve rechters (in het algemeen), duidelijk dat zij allemaal uitgaan op vergelijkbare wijze te werk gaan bij de verdeling van de bewijslast. ${ }^{112}$

Blaauw wijst er in zijn preadvies voor de $\mathrm{NJV}^{113}$ op dat ook de burgerlijke rechter zich vrijer opstelt bij de bewijslastverdeling. ${ }^{1 / 4}$ Het uitgangspunt wie stelt, c.q. wie zich op een bijzondere (rechts)positie beroept, moet bewijzen, wordt door de rechter wegens het stelsel der relevante wettelijke regels, c.q. de zware bewijslast, gelet op de aard der materie, gecorrigeerd door hetzij de wederpartij met de bewijslast te confronteren, hetzij ambtshalve een deskundigen-bericht in te winnen. Volgens Blaauw wordt de regel van art. $177 \mathrm{Rv}$ in de praktijk door de Afdeling Rechtspraak zonder meer toegepast. ${ }^{115} \mathrm{Al}$ met al acht hij de overeenkomsten tussen het burgerlijk en het

109. Het is mogelijk dat ook in zijn visie dit beginsel in de billijkheidsgedachte opgaat (zoals ik hierboven eigenlijk heb betoogd). Wellicht acht hij verwijzing naar ongelijkheidscompensatie (mitsdien) overbodig.

110. Vgl. Usselmuiden, Th.S., Over eenheid van belastingprocesrecht en burgerlijk procesrecht, NJB-speciaal'91/36, p. 1484-1488, i.h.b. p. 1486.

111. Ibidem, p. 1486.

112. Ibidem. p. 1487. Usselmuiden vergelijkt eigenlijk drie rechters tegelijk: de burgerlijke rechter, de belastingrechter en de (overige) administratieve rechters.

113. Blaauw, J.H., De rechterlijke habitus in burgerlijke en administratieve zaken, in: Preadviezen NJV 1991, a.w., p. 177-225, i.h.b. p. 210 e.v.

114. Ibidem, p. 213-214, resp. HR 9 maart 1990. NJ 561 en HR 6 april 1990, NJ 573.

115. Mbidem, p. 214. 
bestuursrechtelijk bewijsrecht dusdanig groot, dat hij bepleit om de regels van het bewijsrecht uit het Wetboek van burgerlijke Rechtsvordering op overeenkomstige wijze toe te passen in het contentieuze bestuursproces - zulks door een en ander expliciet te regelen in de Awb. ${ }^{116}$

\subsubsection{Conclusie}

Ik betwijfel toch of het wijs zou zijn geweest om voor het bestuursprocesrecht de regel van art. $177 \mathrm{Rv}$ als uitgangspunt te nemen.

Het adagium "wie stelt moet bewijzen" voldoet in elk geval niet in het 'voorportaal' van de bewijsvoering. In die fase moet de appellant zijn beroep motiveren en moet het bestuur zijn gedrag adstrueren, maar met stelplicht of contentieuze bewijsvoering heeft dat toch weinig van doen.

Voor de echte bewijsvoering lijkt mij het "wie stelt moet bewijzen" ook maar in beperkte mate te voldoen. In veel gevallen zal dit credo opgaan voor het bestuur, omdat dit nu eenmaal eenzijdig en niet zelden ook beperkend ingrijpt in burgerlijke vrijheden. Daar staat echter weer tegenover dat het bestuur zeker niet gehouden is alle twijfel over het genomen besluit weg te nemen. Bezien vanuit de positie van appellant geldt in nog sterkere mate dat in veel gevallen geen bewijs voor de eigen stellingen behoeft te worden geleverd. De toepassing van het beginsel van ongelijkheidscompensatie brengt veelal mee dat het voor appellant volstaat om door aanzetten tot bewijs of louter door argumentatie (gerede) twijfel op te wekken omtrent de feitelijke grondslag van het bestuursbesluit. Vanaf dat punt kan de rechter beslissen om de bewijslast terzake op te leggen aan de wederpartij of zelf een deel van het de bewijslast op zich te nemen.

Meer in het algemeen moeten we bedenken dat de rechter een uiterst belangrijke rol speelt bij de bewijslastverdeling, met name door zelf werk te maken van (een deel van) de bewijslast. Daartoe kan hij zich geroepen voelen op grond van het beginsel van ongelijkheidscompensatie, maar ook op grond van beperkingen in de autonomie van partijen, ${ }^{117}$ eigen beoordelingsvermogen en processtrategische overwegingen. Met het oog op het verdedigingsbeginsel, bezien in samenhang met de partij-autonomie, heb ik uitdrukkelijk bepleit dat de rechter partijen in de gelegenheid stelt bewijs te leveren. Voorzover de rechter zelf bewijs levert, zal hij partijen in de gelegenheid moeten stellen zich daarover uit te laten. Indien de rechter aan het bewijsaanbod van een der partijen voorbij gaat, zal hij deze beslissing uitdrukkelijk moeten motiveren.

116. Ibidem, p. 214. Hij staat er daarbij voor open dat wellicht op onderdelen afwijkingen wenselijk zullen zijn.

117. In het bijzonder van het bestuur, met name ook met het oog op de bevoegdheid en de positie van derden. 


\subsection{De bewijsmiddelen}

\subsubsection{Preliminaire zaken}

Eerder stelde ik al dat het vinden van de materiële waarheid uitgangspunt is voor het bestuursrechtelijk bewijsrecht. In het verlengde hiervan zijn in beginsel alle middelen toelaatbaar. De regel van art. 179 lid 1 Rv ("Bewijs kan geleverd worden door alle middelen, tenzij de wet anders bepaalt") lijkt voor het contentieuze bestuursprocesrecht van overeenkomstige toepassing.

Ten Berge en Tak sommen in hun boek verschillende bewijsmiddelen op: ambtsberichten, plaatsopneming, resultaten van voorbereidend onderzoek, het tonen van voorwerpen en personen, verklaringen van personen, verklaringen van getuigen (c.q. derde-belanghebbenden), verklaringen van deskundigen en de beslissende eed. Zij merken overigens op dat deze lijst niet limitatief is, eenvoudig omdat het bestuurlijk procesrecht geen limitatief aantal toegelaten bewijsmiddelen kent. ${ }^{118}$ Hieronder wil ik - hoe kan het ook anders - in het bijzonder ingaan op de deskundigenverklaringen en in verband daarmee op het vooronderzoek als bedoeld in afdeling 8.2.2 Awb.

Vooreerst wil ik nog wijzen op de rol van het verdedigingsbeginsel. ${ }^{119}$ Dit beginsel dat ook wel bekend is door het er van afgeleide species-beginsel van hoor en wederhoor, ziet niet slechts op de idee van "equality of arms", ${ }^{120}$ maar ook op "quantity and quality of arms". Het gaat niet alleen om het evenwicht in de kansen op verdediging maar ook op goede en voldoende kansen op verdediging. ${ }^{121}$ Het gaat er vooral ook om dat partijen voldoende tijd en gelegenheid krijgen om hun zaak te bepleiten - hetgeen bij technisch complexe zaken a fortiori geldt.

Zulks betekent in elk geval dat de rechter partijen in de gelegenheid moet stellen bewijs voor hun stellingen te leveren. ${ }^{122}$ Daarnaast zou de rechter, tegen de achtergrond van het beginsel van ongelijkheidscompensatie, evenwicht kunnen bewaken door zelf een deel van de bewijslast op zich te nemen. Uitgaande van het verdedigingsbeginsel is het uiteraard volstrekt ontoelaatbaar dat gegevens buiten de procedure om ter kennis van de rechter worden gebracht. Partijen moeten van alle relevante gegevens kunnen kennisnemen,

118. A.w., p. 368-370. Het laatstgenoemde middel komt volgens Ten Berge/Tak in het administratiefrecht niet voor.

119. De Waard, B.W.N., prft., a.w.. p. 245-329.

120. Hetgeen op zichzelf reeds verder gaat dan hoor en wederhoor, denk aan de kennisneming van stukken e.d. Vgl. De Waard, a.w., p. 245-246.

121. Ibidem.

122. Zoals geregeld in art. 8:60, vierde lid Awb. Dit zou - als gezegd - ook reeds in het vooronderzoek mogelijk moeten zijn. 
zodat zij daartegen - zonodig - verweer kunnen voeren. ${ }^{123}$ Wat de verslagen van deskundigen betreft voorziet het vijfde lid van art. 8:47 Awb voor partijen in de (ongeclausuleerde) mogelijkheid om daarover hun zienswijze naar voren te brengen. Dit veronderstelt dat het verslag steeds aan partijen wordt toegezonden. Voorzover het gaat om het verstrekken van inlichtingen door partijen, voorziet art. 8:29 Awb in een regeling krachtens welke partijen kunnen weigeren inlichtingen te verstrekken of stukken te overleggen, alsook in de mogelijkheid voor partijen om mee te delen dat uitsluitend de rechtbank kennis zou mogen nemen van de inlichtingen of stukken. De rechter kan een daartoe strekkend verzoek bij gebreke van 'gewichtige redenen' afwijzen. Uiteraard kan een partij alsdan volharden in zijn weigering, maar dan dreigt toch de sanctie van art. 8:31 Awb. ${ }^{124}$

Als de rechter een beperking in de kennisneming gerechtvaardigd acht, opent dit de weg tot het doen van een uitspraak mede op grondslag van desbetreffende inlichtingen en stukken. De regering ziet voor de rechter een belangrijke taak om in dit verband "het evenwicht tussen partijen te bewaken". ${ }^{125}$ Toch betwijfelt zij kennelijk of dit een voldoende waarborg is. Daarom wordt in het vijfde lid van art. 8:29 Awb bepaald dat als de rechtbank een beperking van de kennisneming (te weten tot hemzelf en de partij die de inlichtingen of stukken moet verstrekken) gerechtvaardigd acht, zij slechts met instemming van de andere partij(en) mede op grondslag van die inlichtingen of stukken uitspraak kan doen. Toch vraag ik mij af of deze voorziening niet in belangrijke mate een wassen neus is. De partijen wier instemming hier gevraagd wordt, weten immers eigenlijk niet waarover zij oordelen. Mij dunkt dat het verdedigingsbeginsel hiermee nog altijd in het geding is. ${ }^{126}$ Mede in verband hiermee lijkt een restrictieve toelating van beperking in de kennisgeving op zijn plaats. Ook vraag ik mij af of niet overeenkomstig de regels voor de non-contentieuze procedure (vergelijk $\& 7.3$ ) tenminste een "tweede tekst" verlangd zou kunnen worden.

Het verdedigingsbeginsel brengt mee dat het bestuursproces dient te voorzien in een kritisch-rationele, open discussie over de door verschillende partijen gestelde feiten, argumenten en opinies. Anders gezegd: het verdedigingsbeginsel eist dat partijen in staat moeten worden gesteld om contra-expertise te leveren op door de wederpartij ingebrachte feiten. In geschillen over kwets-

123. Ten Berge/Tak, a.w., p. 368.

124. Indien een partij niet voldoet aan de verplichting te verschijnen, inlichtingen te geven, stukken te overleggen (..), kan de rechtbank daaruit de gevolgtrekkingen maken die haar geraden voorkomen. $\mathrm{Te}$ denken is aan (on)gegrondverklaring van het beroep. niet-ontvankelijkheid en veroordeling in de kosten en schades.

125. MvT-Whrol, a.w., p. 120.

126. $\mathrm{Vgl}$ ook Tak, a.w. (1992), p. 95. 
bare en technische complexe belangen zal de rechter zich daarbij uitdrukkelijk moeten bekommeren om het vermogen van partijen om hieraan ook materieel te voldoen. Teneinde de "equality in quantity and quality of arms" te realiseren zal de rechter - indachtig ook het beginsel van ongelijkheidscompensatie - eventueel zelf bepaalde feiten ter discussie moeten gaan stellen. ${ }^{127}$

Voorts wil ik er nog op wijzen dat in het bestuursproces formeel geen sprake is van een bepaalde hiërarchische verhouding tussen de verschillende bewijsmiddelen, noch van bewijsmiddelen met een beslissend karakter. De rechter is in beginsel vrij in zijn waardering van de bewijsmiddelen. ${ }^{128}$ Ten Berge en Tak wijzen er wel op dat de verplichtingen voor het bestuur of de burger om bij de totstandkoming van bepaalde beslissingen aan zekere formele procedure-voorschriften te voldoen, wel "een soort bijzonder bewijsrecht" meebrengen, waardoor de vrijheid van bewijslevering van partijen enigszins vermindert. ${ }^{129}$ Meer in het algemeen moeten we op voornoemd uitgangspunt uitzondering maken indien de toepasselijke bijzondere (wettelijke) voorschriften zulks meebrengen. ${ }^{130}$

\subsubsection{De deskundigenverklaring}

\subsubsection{Inleiding}

De deskundigenverklaring (van art. 8:47 Awb) heeft een belangwekkende voorgeschiedenis in de praktijk van het ambtsbericht.

Ten Berge en Tak omschrijven het ambtsbericht als "schriftelijke bescheiden, afkomstig van een overheidsorgaan (het zich verwerende of een ander orgaan) en betrekking hebbend op de zaak". ${ }^{131} \mathrm{Zij}$ wijzen er op dat onder de ambtsberichten een veelheid aan bewijsmiddelen schuil kan gaan, zoals processen verbaal, verklaringen van getuigen of van ambtelijke of externe deskundigen, onderzoeksresultaten en wat dies meer zij. ${ }^{132}$

In 1990 en 1991 zijn drie belangwekkende rapporten verschenen waarin het ambtsbericht onder het TwK-regime (ex art. 4, eerste lid TwK jo art. 32c

127. En zelf een deel van de bewijslast moeten opnemen. De aansluiting bij de voorgaande paragraaf zal duidelijk zijn.

128. Ten Berge/Tak, a.w., p. 370-371.

129. Ten Berge/Tak, a.w., p. 371. Ten aanzien van het bestuur kunnen we weer denken aan de "preprocessuele bewijslast".

130. Bij voorbeeld in de vorm van meet- en regelvoorschriften (zie ook bewijswaardering in $\$ 9.7$ ).

131. Ten Berge/Tak, a.w.. p. 368.

132. Ibidem. 
Wet RvS) een belangrijke of centrale rol vervult. ${ }^{133}$ De uitgebreidheid van de daaraan ten grondslag liggende onderzoekingen, alsmede van de verslaglegging daarvan maakt het niet nodig op deze plaats nog een uitgebreid exposé te geven van de betekenis van het ambtsbericht voor de rechtsbescherming in milieuzaken. ${ }^{134}$ Toch wil ik hier enkele hoofdlijnen uitzetten en van commentaar voorzien. Aansluitend kom ik dan uit bij de deskundigenverklaring in het algemeen.

Voor een goed begrip is het nodig een duidelijk onderscheid te maken tussen drie soorten ambtsberichten. In de eerste plaats kan worden gedacht aan het ambtsbericht als verzamelterm voor de op de zaak betrekking hebbende stukken die door het verwerende bestuursorgaan worden ingezonden. In de tweede plaats aan een ambtsbericht als deskundigenbericht. Deze beide stukken worden op verzoek van de voorzitter (ex art. 32c, eerste lid Wet RvS) in beginsel ${ }^{135}$ door tussenkomst van de minister (ex art. 32c, tweede lid Wet RvS) aan de voorzitter toegezonden. In de derde plaats is voorstelbaar dat de minister, niet zijnde partij bij een geschil, het wenselijk vindt om toch - met het oog op de "eenheid van beleid" - zijn visie op het geschil te geven. Dit is mogelijk op basis van art. 32c, derde lid Wet RvS.

In het navolgende wil ik bij wijze van voorgeschiedenis, stilstaan bij de ervaringen met het ambtsbericht als deskundigenbericht. Het ambtsbericht als verzamelterm voor de stukken van verweerder laat ik als partij-stuk buiten beschouwing. Dit valt in het Whrol onder de vigeur van art. 8:45, eerste lid Awb. Ook het ambtsbericht als beleidsvisie laat ik buiten beschouwing. Onder het Whrol lijkt voor dit ambtsbericht alleen nog ruimte te bestaan als de rechter daar op grond van art. 8:43, tweede lid Awb (uiteenzettingen door niet-partijen) de mogelijkheid toe biedt. ${ }^{136}$

\subsubsection{Ervaringen met het ambtsbericht}

Interessant is het om allereerst te wijzen op de zeer grote feitelijke invloed van het ambtsbericht. In de genoemde onderzoeken heeft men dit allereerst

133. Respectievelijk: Gaastra, A.F., F.C.M.A. Michiels en P.J.J. van Buuren. Gelet op het ambtsbericht, Zwolle 1990 (onderzoek naar de ambtsberichten van de adviseur ten behoeve van de Raad van State in geschillen omtrent bestemmingsplannen en planschadevergoeding); Brugge, T. ter, J. Veltman, H.E. Bröring, K.F. Schuiling en M. Scheltema, Kroongeschillen en het nieuwe bestuursprocesrecht, Deventer 1991 (evaluatie van de TwK); Widdershoven, R.J.G.M., G.T.J.M. Jurgens, P.J.J. van Buuren en G.H. Addink, Bestuursrechtspraak in milieugeschillen, Zwolle 1991 (evaluatie van de TwK op het gebied van het milieurecht).

134. Dat is immers de focus van deze bespreking.

135. In het navolgende zal blijken dat deze regel niet steeds opgaat.

136. Uylenburg, Rosa, Rechtsbescherming in het milieurecht, prft., Zwolle 1992, p. 229, stelt dat dit soort ambtsbericht in strijd is met de eisen van adequate rechtsbescherming. 
duidelijk willen maken aan de hand van een zogenoemde conformiteitsmethode. ${ }^{137}$ Zo werd voor milieugeschillen (in 1988-1989) een volledige conformiteit van $70 \%$ gemeten $^{138}$ (bij zelf voorzien $62 \%$ ). ${ }^{139}$ Als we gevallen met ontvankelijkheidsproblemen, procedure-fouten en schikkingen na het uitbrengen van het ambtsbericht buiten beschouwing laten, komen we van $70 \%$ zelfs op $80 \%$.

Voorzover er sprake was van verschillen konden deze goed worden verklaard uit "verschillen in takopvatting", ${ }^{140}$ het "perfectioneren door het ambtsbericht" $^{141}$ en de meer afstandelijke opstelling van de Afdeling geschillen. ${ }^{142}$

Mede aan de hand van case-studies blijkt hoe het ambtsbericht ten processe in verschillende functies voorziet. ${ }^{143}$ Allereerst vormt het ambtsbericht een belangrijke bijdrage tot inzicht in de feiten van het geval; zowel in termen van een beschrijving alsook in termen van een analyse en beoordeling (bijvoorbeeld van effecten). In dit opzicht bewijst het ambtsbericht heel nadrukkelijk zijn functie als deskundigenbericht. Daarnaast blijkt het ambtsbericht van waarde doordat het een schets van het relevante beleidskader geeft (wetgeving, beleidsregels, richtlijnen en dergelijke). ${ }^{144}$ In de derde plaats blijkt het ambtsbericht van groot belang voor de feitelijke afwikkeling van de procedure. Het ambtsbericht vormt kennelijk een leidraad voor het onderzoek (ter zitting), waarbij het een structuur biedt voor de (wijze van) vraagstelling en de facto als een soort discussiestuk functioneert. ${ }^{145}$

137. Hiertoe vergeleek men items (een aspect van een zaak dat in de uitspraak aandacht krijgt en waarover door de Afdeling Geschillen een oordeel wordt gegeven) uit ambtsberichten met overwegingen en dicta van uitspraken. Volledige conformiteit duidt op volstrekte overeenstemming, zowel met overwegingen als met het dictum van een en dezelfde uitspraak. Vgl. Widdershoven et al., a.w., p. 18 en p. 66.

138. Vgl. Widdershoven et al., a.w., Hfst. 3.

139. $\mathrm{Vgl}$. Hfst. 10. Uiteraard gaat het steeds slechts om die gevallen waarbij een ambtsbericht (terzake) was uitgebracht; in de door Widdershoven c.s. Onderzochte periode '88-'89 werd in $33 \%$ van de (steekproef)zaken geen ambtsbericht uitgebracht (a.w., p. 67).

140. Met name de kwestie ex tune ex nunc. alsmede de kwesties van reformatio in peius en ultra petita gaan. Widdershoven, a.w. p. 70 en p. 238. Deels leek dit punt van verschil weer te verklaren vanuit het feit dat in het onderzoek ook pre-TwK-ambtsberichten betrokken waren.

141. In het ambtsbericht werden - bij voorbeeld - vergunningvoorschriften t.b.v. de duidelijkheid geredigeerd, terwijl de Afdeling daaraan geen behoefte bleek te hebben. Widdershoven, a.w., p. 71 en p. 239.

142. Deze kiest voor een meer formele positie. Hetgeen niet tot andere conclusies hoeft te leiden maar wel een andere onderbouwing geeft (inhoudelijke versus juridische gronden). A.w., p. 72 en p. 240-241.

143. Vgl. Widdershoven, a.w., p. 55 e.v., Gaastra, a.w., Hfst. 6, Ter Brugge, a.w., p. 155-164.

144. $\mathrm{V}$ gl. Widdershoven, a.w., p. 56-57. Hier wordt ook benadrukt dat het hier thans om een voorlichtende functie gaat en niet meer om een poging om de eenheid van (rijks) milieubeleid te bevorderen.

145. Gaastra, a.w., p. 102-104. Ter Brugge, a.w., p. 160-161. 
Widdershoven c.s. wijzen erop dat het ambtsbericht een procesordenende functie vervult en dat het ook regelmatig voorkomt dat het ambtsbericht de bemiddeling tussen partijen mogelijk maakt. ${ }^{146}$

Met de opmerking dat het ambtsbericht naast de functie van technisch-wetenschappelijk deskundigenbericht ook de functie van "prejudicieel-advies" vervult ${ }^{147}$ raken Gaastra c.s. mijns inziens aan een belangrijk aspect van de betekenis van het ambtsbericht onder de TwK. Uit alle onderzoeken komt naar voren dat de ambtsberichten lijken bij te dragen aan een meer inhoudelijke toetsing van het voorliggende geschil. ${ }^{148}$ Overigens moet tegelijkertijd worden opgemerkt dat "non-conformiteit" tussen ambtsbericht en uitspraak zich vooral voordoet op het punt van de juridische en beleidsmatige items van het ambtsbericht. ${ }^{149}$

Dat het ambtsbericht zo'n belangrijke rol kan spelen wordt duidelijk als we ook de inhoud daarvan bezien. ${ }^{150}$ Het ambtsbericht bevat achtereenvolgens een (korte) beschrijving van de inrichting, een weergave van met wie gesprekken zijn gevoerd, welke bezwaren appellant heeft ingebracht, eventueel een overzicht van de voorgeschiedenis (eerdere procedures), een inhoudelijke beschouwing, een conclusie over de gegrondheid van het beroep (geen vernietigingsgronden) en eventuele suggesties voor het zelf voorzien.

In voornoemde inhoudelijke beschouwing treffen we (al na gelang de noodzaak daartoe) de volgende elementen aan: de feitelijke aspecten (welke feiten heeft de adviseur "ter plaatse" aangetroffen); de technisch-inhoudelijke aspecten (een analyse van de effecten); relevante richtlijnen; relevante milieuplannen; het eigen beleid van het bevoegd gezag; juridische aspecten (slechts summierlijk); eventuele nieuwe feiten en omstandigheden en nieuwe (of aanstaande) rechtsregels.

Het is duidelijk dat een ambtsbericht dat in zoveel informatie voorziet inderdaad al die functies kan vervullen die hierboven werden geschetst.

Belangrijk is dan echter wel van wie het ambtsbericht afkomstig is, hoe het totstandkomt en hoe het in de procedure is ingebed. Daarover wil ik ten slotte nog enkele opmerkingen maken.

146. Aan de hand van het ambtsbericht komen partijen nader tot elkaar. A.w., p. 57-59.

147. Gaastra, a.w., p. 95.

148. Ibidem, alsook p. 129, waar zij opmerken dat de Afdeling geschillen in dit opzicht afsteekt tegen de meer procedurele toetsing door de Afdeling rechtspraak - die zich ook weer veel minder bedient van ambtsberichten. Vgl. ook Ter Brugge, a.w., p. 160-161 en p. 280-281. Ik twijfel er niet aan dat er ook een verband is met de geringe erkenning van de AGRvS voor discretionaire bevoegdheden.

149. Het technische aspect blijkt zeer gezaghebbend: Ter Brugge, a.w., p. 160. Widdershoven, p. 73-74.

150. Ik doe dat aan de hand van Widdershoven. a.w., p. 39-46. 
Wat de herkomst van het ambtsbericht betreft, is in milieugeschillen met namen de positie van de Adviseur Beroepen Milieuhygiëne (ABM) van belang. In het voetspoor van de zaak Benthem ${ }^{151}$ besloot de minister dat met ingang van 1 januari 1988 de ambtsberichten op het gebied van de milieuwetgeving door de $\mathrm{ABM}^{152}$ zelfstandig worden opgesteld en door deze ondertekend rechtstreeks aan de voorzitter AGRvS worden toegestuurd. ${ }^{153}$ Doel van deze maatregel was om de onafhankelijkheid van het ambtsbericht boven alle twijfel te verheffen.

Beleidsmatig is de minister in de verhouding tot de Tweede Kamer gehouden deze door hem zelf geschapen onafhankelijkheid van de ABM te respecteren. Enerzijds kunnen we daarbij aannemen dat de minister bevoegd was dwingend de werkwijze van zijn ondergeschikte voor te schrijven. Staatsrechtelijk gezien is het echter onjuist dat de minister zelfstandig zijn ministeriële verantwoordelijkheid beperkt (als we er van uit zouden gaan dat zulks i.c. is geschied) - daartoe lijkt een expliciete uitspraak van de wetgever (als grondslag) toch meer geëigend. ${ }^{154}$ Tegelijkertijd kan de inbedding van de ABM in de departementale organisatie (te weten het Directoraat-Generaal Milieubeheer (DGM)) toch meebrengen dat aldaar bestaande beleidsmatige inzichten van grote invloed zijn op de inhoud van het ambtsbericht. Last but not least moet bedacht worden dat de minister gegeven zijn ambtelijk-hiërarchische positie kan ingrijpen in, en verantwoordelijk blijft voor het doen en laten van de ABM. ${ }^{155}$

De gekozen oplossing is derhalve bepaald niet smetteloos. In verband hiermee is door Widdershoven c.s. en door Ter Brugge c.s. ${ }^{156}$ het voorstel gedaan om de ABM nadrukkelijker te verzelfstandigen. Widdershoven c.s. zien dit overigens vooral als een stap ter voorkoming van de schijn van afhankelijkheid. ${ }^{157} \mathrm{Zij}$ menen - mijns inziens terecht - dat het feit dat de rechter formeel op geen enkele wijze is gebonden aan het ambtsbericht tot de conclusie noopt dat terzake van het ambtsbericht geen sprake is van strijd met art. 6 EVRM. Een en ander zolang partijen ter procedure zelf met behulp van deskundigen weerwerk kunnen bieden en de rechter voldoende kritisch met het ambtsbericht kan omgaan - bij voorbeeld door de mogelijkheid te hebben (andere) deskundigen in te roepen.

151. Europese Hof voor de Rechten van de mens 23 oktober 1985, AB'86, 1 m.nt. Hirsch Ballin.

152. Als hoofd van de afdeling beroepen milieubeheer.

153. Besluit van 12 september 1988 . Widdershoven, a.w., p. 34.

154. Vgl. Gaastra et al. p. 17-18; Widdershoven et al. p. 35-36.

155. $\mathrm{Vgl}$ ook art. IA.1.2.2 Awb: Delegatie wordt niet verleend aan ondergeschikten, omdat de ondergeschikte in een dergelijke verhouding de bevoegdheid niet zelfstandig kan uitoefenen (vgl. MvT-Awb3, p. 38).

156. Resp. Widdershoven p. 59-63 en p. 324-326; Ter Brugge, p. 300-302.

157. Widdershoven et al. p. 61-62. 
Deze (laatste) clausulering maakt duidelijk dat over de kwestie van de (on)afhankelijkheid van het ambtsbericht als deskundigenbericht heen een ander, zwaarwegend(er) uitgangspunt in het geding is: het verdedigingsbeginsel. Met het oog daarop past een opmerking over de totstandkoming van de ambtsberichten en de wijze waarop de ambtsberichten procedureel in de contentieuze procedure zijn ingebed.

"De ambtsberichten zoals die thans gegeven worden houden het gevaar in dat de rechterlijke taak in niet onaanzienlijke mate uitgeoefend wordt door de adviseur, zodat er onvoldoende waarborgen voor een eerlijk proces aanwezig zijn.", zo concludeert Brenninkmeijer in zijn reactie op de onderzoeken naar de rol van het ambtsbericht. ${ }^{158}$ Michiels ziet mede in deze stellingname reden om een aantal voorstellen te doen ten einde waarborgen terzake te creëren. ${ }^{199}$

Allereerst bepleit hij de verzelfstandiging van de ABM tot zelfstandige Rijksdienst. ${ }^{160}$ Daarnaast stelt hij voor dat de ABM zich onthoudt van advisering over formeel-juridische aangelegenheden. Voorts zouden de ambtsberichten automatisch aan partijen moeten worden doorgezonden, terwijl de rechter "op gemotiveerd en redelijk verzoek van partijen" de ABM uitnodigt ter zitting aanwezig te zijn. Ook zou de door de ABM gevolgde onderzoeksmethode in een reglement, dat voor een ieder toegankelijk is, moeten worden neergelegd. Dit reglement zou ondermeer regels moeten bevatten inzake hoor en wederhoor bij de totstandkoming van het bericht. Last but not least zou de rechter "bij serieuze kritiek op het ambtsbericht" eventueel advies van een andere advies-instantie moeten inroepen. ${ }^{161}$

\subsubsection{Naar een nieuwe adviescultuur?}

De bevindingen uit de verschillende hiervoor aangehaalde studies en de voorstellen van Michiels maken mijns inziens duidelijk dat de vorm van het deskundigenbericht in milieuzaken serieus aandacht behoeft. In het Whrol gaat de regering kort op deze ervaringen in. Haar conclusie is dat "er geen aanleiding is om de rechter voor te schrijven zijn deskundige informatie alleen in te winnen bij onafhankelijke instanties". De bestaande praktijk kan

158. Brenninkmeijer, in: Jurgens, G.T.J.M., et al., p. 49-65, i.h.b. p. 65.

159. F.C.M.A.Michiels, Rechtsbescherming in het milieurecht, in: Michiels, F.C.M.A. en G.J.M. Cartigny, a.w., p. 13.

160. A.w., p. 13. Overeenkomstig de rapporten van Widdershoven et al. en Gaastra et al. Hoewel ook Michiels meent dat het ambtsbericht op dit punt de toets aan art. 6 EVRM kan doorstaan, acht hij het wenselijk "dat partijen ook werkelijk het gevoel kunnen hebben eerlijk en onpartijdig bejegend te zijn." (a.w., p. 12.).

161. Ibidem. 
mitsdien worden gehandhaafd. ${ }^{162}$ Wel is het nodig waarborgen te scheppen voor de deugdelijkheid en niet-vooringenomenheid van de deskundige. Daartoe dient in de eerste plaats art. 8:34, eerste lid Awb: De deskundige (...) is verplicht zijn opdracht onpartijdig en naar beste weten te vervullen. Ook acht de regering het wenselijk dat het deskundigenbericht controleerbaar is. ${ }^{163}$ In de toelichting op art. 8:47 Awb wordt gesteld dat het grote belang van het deskundigenbericht het wenselijk maakt dat partijen niet alleen over het resultaat van deskundigenonderzoek hun visie kunnen geven maar ook over de formulering van de onderzoeksvraag. ${ }^{164}$ Als het echter praktijk is dat standaard-advies wordt ingewonnen, zoals in milieugeschillen, dan bestaat er volgens de toelichting geen bezwaar tegen dat het onderzoek reeds van start gaat vooraleer partijen daarover zijn gehoord. ${ }^{165}$ In de Nota van wijzigingen stelt de regering zich ten aanzien van de mogelijkheid tot "inspraak" vooraf - als gezegd - nog terughoudender op: de rechter kan partijen daartoe in de gelegenheid stellen.

De vraag rijst nu of het, gelet op de hierboven geschetste ervaringen en gelet op het verdedigingsbeginsel, wenselijk is om in milieugeschillen standaard een deskundigenbericht van een vaste adviseur te vragen.

In de eerste plaats lijkt het mij, indachtig wat ik eerder over de bewijslastverdeling heb opgemerkt, niet wijs dat een rechter standaard om deskundigenbericht vraagt. Laat hij eerst afwachten wat partijen hebben in te brengen en dan bezien of deskundigenbericht wenselijk is. Dat impliceert dat de rechter partijen in de gelegenheid stelt hun visie te geven op een onderzoeksvraag. Zulks past in de partij-autonomie, en biedt hen de gelegenheid eventueel zelf nog met (aanvullende) expertise op de proppen te komen.

In de tweede plaats is het de vraag het wel wenselijk is dat advies wordt ingewonnen bij een vaste-deskundige. Daarmee is het standpunt van de regering, dat er geen bezwaar bestaat tegen handhaving van de huidige praktijk in TwK-zaken, in het geding. Overigens maakt de regering een fijn verschil tussen "onafhankelijke instanties" en "onpartijdigheid van de deskundige": afhankelijkheid is geen bezwaar, onpartijdigheid is een vereiste. Over de verenigbaarheid van beide (zoals bij de $A B M$ ) laat zij zich niet uit.

162. MvT-Whrol (bij art. 8:34 Awb), p. 123. De regering erkent impliciet de niet-onafhankelijkheid van de ABM. Dat hoeft echter - vanwege de onathankelijkheid van de rechter - (formeel) geen probleem te zijn.

163. Bbidem.

164. MvT-Whrol, p. 131.

165. Bbidem. 


\subsubsection{Vaste-deskundigheid}

Als de tweede vraag (wel of geen vaste-deskundige) positief wordt beantwoord moeten de bovengenoemde voorstellen van Michiels kritisch worden bezien:

- Wat de zelfstandigheid van de adviseur betreft bepleit Michiels verzelfstandiging van de $\mathrm{ABM}$ tot zelfstandige rijksdienst. ${ }^{166}$ Ook in de eerder aangehaalde Utrechtse studie wordt deze visie gehuldigd. ${ }^{167}$ In een dergelijk geval zou het voor de hand liggen om niet langer te spreken over een ambtsbericht maar eenvoudig over deskundigenbericht. ${ }^{168}$

Bij handhaving van de figuur van een deskundigenbericht van een vastedeskundige lijkt onafhankelijkheid mij een eerste vereiste. Het is dan noodzakelijk de banden met de departementale organisatie volledig door te snijden. Mijns inziens is het de moeite waard dan te denken aan de figuur van een zelfstandig bestuursorgaan. Dit zou er immers in kunnen voorzien dat de ministeriële verantwoordelijkheid volstrekt, dat wil zeggen zowel beleidsmatig als rechtspositioneel, wordt weggenomen. Een instituut voor technische advisering in milieugeschillen zou in mijn ogen onder dagelijkse leiding van een directeur (te vergelijken met de huidige $A B M$ ) kunnen opereren. Verantwoordelijkheid voor het functioneren van het instituut zou kunnen worden afgelegd aan een afzonderlijke raad van toezicht. ${ }^{16\rangle}$ Uiteraard zou een dergelijk instituut de actieve openbaarheid (door publikatie van (samenvattingen van) adviezen en van jaarverslagen hoog dienen te houden, opdat over de inhoudelijke kant van de advisering tussen vakgenoten gedebatteerd kan worden. ${ }^{170}$

Anders dan bij de vaste-deskundige in de non-contentieuze procedure (zie hoofdstuk 7), zou ik bij een vaste-deskundige in de contentieuze procedure geen voorstander zijn van nadere inhoudelijke profilering, dan als technisch-deskundige sec. Dat hangt vooral samen met het feit dat de vaste-deskundige in het contentieuze proces, mijns inziens zou moeten afwachten welke concrete vraag aan hem wordt voorgelegd. Een breed

166. Michiels, a.w. (1992), p. 13.

167. Vgl. Widdershoven, a.w.. p. 62 (zie ook noot 42: de auteurs volgen hier Gaastra c.s., a.w., p. 135-137).

168. Ter Brugge et al., a.w.. p. 301, Brenninkmeijer, A.F.M., Het ambtsbericht als deskundigenbericht, in: Jurgens, G.T.J.M. et al., Bestuursrechtspraak ingevolge de TwK, Zwolle 1991, p. 49. 65 , m.n. p. 55 .

169. Bij voorbeeld bestaande uit enkele volksvertegenwoordigers. vertegenwoordigers van (lokale) overheden en van diverse belangenorganisaties, alsmede uit enkele algemeen erkende deskundigen.

170. Meer in het algemeen zou op dit punt een vergelijking met - bij voorbeeld - het Rijksinstituut voor Oorlogsdocumentatic (vgl. Gaastra et al. a.w.. p. 209) of het Gerechtelijk laboratorium kunnen worden gemaakt. 
advies zou mijns inziens niet passen in het voorgestane rechtsbeschermingsperspectief.

- In het verlengde hiervan kan ik mij vinden in de stellingname van Michiels dat een vaste-adviseur zich verre zou moeten houden van advisering over formeel-juridische aspecten. Dat gezegd zijnde moet wel worden bedacht dat ook een zich strikt technisch-oriënterende deskundige er niet omheen kan dat hij op onderdelen zal refereren aan algemeen verbindende voorschriften, plannen, beleidsregels of richtlijnen. Michiels wijst er in zijn preadvies voor de Vereniging van Milieurecht ook zelf op dat tussen het constateren van feiten en het aan de hand van richtlijnen en beleidsregels geven van een advies op basis van die feiten geen scherpe overgang bestaat. ${ }^{171}$ Het lijkt mij zelfs een zaak van behoorlijke advisering dat een adviseur aangeeft van welke regels (c.q. interpretatie van regels) hij is uitgegaan. Daarmee wordt immers de zo gewenste duidelijkheid geboden over de aan zijn onderzoek ten grondslag liggende premissen.

Overigens kan ik mij voorstellen dat er bij de rechter (ter instructie van de zaak) behoefte bestaat aan een juridisch-beleidsmatig advies. Desgewenst kan hij daartoe een deskundige inschakelen. Mij lijkt het echter wijs hiervoor een andere dan de vaste-deskundige als hier bedoeld in te schakelen. Overigens is het mijn gedachte, dat het juist door het inschakelen van een vaste-deskundige in de non-contentieuze besluitvorming - een deskundige die expliciet ook op het juridische- en het beleidsaspect in kan gaan - niet meer nodig zal zijn dat de rechter op dit punt hernieuwd om een algemeen advies vraagt. ${ }^{172}$

- De gedachte dat ambtsberichten aan partijen worden toegezonden (of ter inzage worden gelegd) heeft de kracht van een evidente noodzaak. ${ }^{173}$ Mij dunkt dat de in het Whrol voorziene regeling van art. 8:39, eerste lid Awb (doorzending van stukken door de griffier) hierop mede van toepassing is.

- De mogelijkheid van aanwezigheid van de vaste-deskundige ter zitting, verdient ten volle ondersteuning. In art. 8:60 Awb wordt bepaald dat deskundigen op verzoek van partijen kunnen worden opgeroepen. Hoewel de toelichting hieromtrent niets vermeldt, neem ik aan dat deze bepaling (in het bijzonder in lid 2 en lid 4) ook voorziet in de mogelijkheid tot oproeping van de deskundige die in het kader van het vooronderzoek, ex art. 8:47 Awb een deskundigenbericht heeft opgesteld. Het valt aan te nemen dat indien bij een geschil een "vaste-deskundigenrapport" nodig

171. A.w., p. 12.

172. Advies op een deelaspect lijkt nij zeer wel mogelijk, maar waarschijnlijk zal daarin -zoals ook thans veel gebeurt - door gerechtsauditeurs kunnen worden voorzien.

173. Vgl. Widdershoven et al., a.w.. p. 327. 
wordt geacht, tevens behoefte zal bestaan aan het instellen van een vooronderzoek. Strikt noodzakelijk is dit niet. Het is ook denkbaar dat zulks in het kader van art. 8:60, tweede lid Awb (waar ook wordt gesproken van een "opdracht die moet worden vervuld") geschiedt. De toelichting bij dit artikel had wat dit betreft wel wat duidelijker mogen zijn.

- Tegen de gedachte van een onderzoeksreglement bestaat mijns inziens op zichzelf geen bezwaar. Toch moeten we er wel voor waken dat zo'n reglement er niet toe leidt dat het onderzoek van de vaste-deskundige tot een pseudo-rechterlijke procedure wordt - met als gevolg dat partijen dit onderzoek als de all-round beoordeling van hun positie beschouwen. Ook bij Brenninkmeijer ${ }^{174}$ en Widdershoven ${ }^{175}$ proef ik een dergelijke vrees. Het lijkt mij van belang dat partijen terdege beseffen dat het (uiteindelijk) de rechter is die over het bewijs beslist. Daarbij komt dat hij het (uiteindelijk) is die er op moet toezien dat partijen, ook in bewijsrechtelijke zin, hun "fair trial" krijgen.

Wat mij betreft staat voorop dat aan het deskundigenonderzoek die eisen worden gesteld die daarbij intrinsiek het beste passen. In een concreet geval kan dat meebrengen dat beide partijen door de deskundige worden gehoord. ${ }^{176}$ Dat betekent echter niet dat de vereiste van hoor en wederhoor standaard voor het deskundigenonderzoek zou moeten worden voorgeschreven. Wel zou - zoals ik reeds hierboven stelde - nadien de mogelijkheid van partijen om contra-expertise te produceren aanwezig moeten zijn. De verwezenlijking van die waarborg is echter een zaak die de rechter zich ter harte moet nemen.

- De mogelijkheid om naar aanleiding van contra-expertise op het vastedeskundigenbericht, tot nader onderzoek over te gaan - de laatste suggestie van Michiels - verdient uiteraard alle steun. Art. 8:64, eerste lid Awb voorziet in de mogelijkheid tot heropening van het vooronderzoek, waartoe het onderzoek ter zitting wordt geschorst. In dit bestek is hernieuwde raadpleging van (andere) deskundigen mogelijk. Overigens stel ik mij voor dat de rechter bij benoeming van een deskundige in het kader van het vooronderzoek (ex art. 8:47 Awb) ook nader advies aan dezelfde of een andere dan de vaste-deskundige kan vragen. Ik acht een en ander vanzelfsprekend; de rechter moet in staat zijn op kritische wijze tot een definitieve feitenvaststelling te komen.

174. Brenninkmeijer, A.F.M., in: Jurgens et al., a.w., p. 57.

175. A.w., p. 326-327.

176. De ABM gaat hiertoe zeer veelvuldig over. Vgl. Widdershoven et al., a.w., p. 38-39. 


\subsubsection{Ad-hoc deskundigheid}

Het bovenstaande gaat uit van de bestendiging van een vaste-deskundige in het bestuursproces inzake milieugeschillen. Brenninkmeijer staat een nog verdergaande breuk met de huidige praktijk voor ogen. Hij wil niet alleen de onafhankelijkheid van advisering bevorderen door de band tussen deskundigadviseur en minister en departement te verbreken, hij wil tevens voorkomen dat "de huidige monocultuur in de advisering wordt voortgezet." In zijn optiek moet "De rechter (...) naar eigen goedvinden onafhankelijke deskundigen ad hoc opdracht geven advies uit te brengen over concreet voorgelegde vraagpunten". ${ }^{177}$

Zie ik het goed dan beoogt Brenninkmeijer met zijn voorstel vooral de positie van de rechter als dominus litis te beschermen. ${ }^{178}$ Advisering vanwege door de rechter uitverkoren deskundigen zou de rechter weer in een sterkere positie kunnen brengen; doorbreking van de "monocultuur" in het deskundigenbericht heeft - denkelijk - tot gevolg dat de rechter uitdrukkelijker kan bepalen wat wordt onderzocht of waarover wordt geadviseerd. De vrees dat de deskundige gaandeweg geneigd zal zijn zich uit te laten over kwesties die uitdrukkelijk aan de rechter zijn voorbehouden wordt reeds door het incidentele karakter van het adviseurschap ingetoomd. Het incidentele adviseurschap leidt er ook toe dat uitverkoren deskundigen waarschijnlijk sterker zullen leunen op de concrete rechterlijke opdracht. In het verlengde hiervan zou naar mijn mening, indachtig het verdedigingsbeginsel, ook de positie van de procespartijen versterkt worden.

De vraag rijst of kan worden verwacht dat de incidentele adviseur een advies kan geven dat enerzijds minder overheersend is dan het huidige ambtsbericht maar anderzijds goed genoeg om het de rechter mogelijk te maken als actieve rechter leiding te geven aan het onderzoek.

De omvattendheid van het huidige ambtsbericht als deskundigenbericht doet vermoeden dat het zijn gelijke niet kent. Aan de andere kant hebben de ontwikkelingen in de wereld van de (technische) milieu-advisering allesbehalve stilgestaan. Er zijn vele adviesinstanties en bureaus die bij grote of ingewikkelde "klussen" betrokken zijn (geweest). Ik denk aan advisering ten behoeve van milieubeleidsplanning, bedrijfsmilieuplannen en milieu-effect-rapportages. Daarenboven zijn er drie niet te verwaarlozen factoren die pleiten voor inzetten van ad-hoc-deskundigen:

- In de eerste plaats ligt het voor de hand dat in het bestuursproces de deskundige bewijsvoering in sterkere mate bij partijen komt te liggen. Zoals ik reeds hiervoor, bij de kwestie van de bewijslastverdeling met het

177. Brenninkmeijer, in: Jurgens, et al., a.w., p. 65 .

178. Vgl. ook Ter Bruggen et al., a.w.. p. 301: "...de positie van de rechter als dominus litis (moet) gewaarborgd (..) worden." 
oog op de partij-autonomie, als uitgangspunt ook heb bepleit. Het automatisme van onderzoek door een vaste-deskundige past daar niet goed bij. Volgens art. 8:60, vierde lid Awb bestaat voor partijen de mogelijkheid om - ter zitting - deskundigen mee te brengen of te doen oproepen. Het lijkt mij voor de hand te liggen deze bevoegdheid ook reeds voor het vooronderzoek te realiseren.

- In de tweede plaats denk ik aan de bewijslast van het verwerend bestuursorgaan. Het bestuur zou als regel overtuigende, deskundige informatie moeten kunnen overleggen, zeker als we er van uitgaan dat de milieuexpertise bij de overheid gaandeweg zal toenemen. Wat dat betreft komt het mij voor dat het ambtsbericht er vroeger ook toe diende onkundigheden bij lokale overheden "op te vangen". Volgens Bröring c.s., ${ }^{179}$ wordt als pluspunt van het kroonberoep, mede vanwege het ambtsbericht, aldoor weer het uitgebreide (integrale) feitenonderzoek genoemd. Toch mag dit argument geen stand houden. De overheid moet zich zo nodig eerst goed laten adviseren alvorens te beslissen - de burger is geen waker voor bestuurlijk toezicht. Wat ligt er dan meer voor de hand dan dat de overheid haar zaakjes op tafel legt en, indien appellant toch gerede twijfel weet te zaaien, nader adstrueert.

- In de derde plaats denk ik aan de rol van de - door mij voorgestane vaste deskundige in de non-contentieuze procedure. Mede op basis van door deze deskundige te geven adviezen neemt het bestuur uiteindelijk een definitief besluit. In verband hiermee denk ik aan een citaat uit de Groningse studie naar de Kroongeschillen: "Hierbij kan men zelfs de vraag opwerpen, in hoeverre het gewenst is dat de rèchter - bijvoorbeeld via een deskundigenbericht - met een nieuwe, meer volledige visie op de feiten wordt geconfronteerd: zou die visie niet reeds in het kader van de bestuurlijke besluitvorming bekend moeten zijn (zoals dat door voorprocedures kan worden bewerkstelligd)?"180 Deze vraagstelling kan mijns inziens worden opgevat als een pleidooi voor een terughoudende rol van de rechter bij feitenvaststelling - zoals ook in het voorgaande hoofdstuk bepleit.

In die visie zou een door de rechter te benoemen deskundige veeleer een deskundige op de achterhand moeten zijn. Een deskundige die slechts wordt ingezet als de rechter dit uit het oogpunt van ongelijkheidscompensatie, of met het oog op beperkingen in de partij-autonomie, zijn eigen bekwaamheid tot beoordeling, of processtrategische overwegingen wenselijk acht. Met het oog op de rechterlijke beoordelingsbekwaamheid speelt

179. A.w (1985).

180. Ter Brugge et al., a.w., p. 302. 
natuurlijk mee dat de rechter, gelijk ook het bestuur, geen "superdeskundigheid" moet (willen) pretenderen.

In het licht van deze argumenten ben ik er - met Brenninkmeijer - voorstander van deskundigenonderzoek op ad-hoc basis te organiseren. ${ }^{181}$

\subsubsection{Conclusie}

In het voorgaande heb ik mij beperkt tot de rol van het deskundigenbericht. Daarbij heb ik, vanwege de praktijk van het huidige ambtsbericht, het accent gelegd bij het vooronderzoek.

Het zal duidelijk zijn dat in het vooronderzoek nog andere bewijsmiddelen een rol spelen. Als we de relevante bepalingen uit Afdeling 8.2.2 Awb doorlopen komen we achtereenvolgens het verweerschrift, repliek en dupliek, schriftelijke uiteenzettingen van "andere partijen", (schriftelijke) inlichtingen van (anderen dan) partijen op verzoek van de rechter, getuigenverklaringen, deskundigenberichten en de bezichtiging tegen. Bewijsmiddelen zullen uiteraard ook in het onderzoek ter zitting nog een belangrijke rol spelen.

De rechter heeft, gegeven zijn discretionaire bevoegdheden in (met name) het (voor-)onderzoek, grote invloed op het daadwerkelijk aan bod komen van een bepaald bewijsmiddel. Hoe de rechter met bewijsmiddelen (dan wel het verzoek deze in te brengen) zal omgaan, hangt primair samen met de bewijslastverdeling en in het voetspoor daarvan met de bewijswaardering.

Wat de bewijslastverdeling betreft zou ik hier voorop willen stellen dat de rechter niet aanstonds het leveren van bewijs aan zich zou moeten trekken. Eerst is het aan partijen om zich over het bewijs uit te laten. In algemene zin volgt zulks mijns inziens uit de partij-autonomie. Als hem dit uit het oogpunt van ongelijkheidscompensatie of op andere gronden wenselijk voorkomt kan de rechter echter wel degelijk bewijs aan zich trekken, bij voorbeeld door een opdracht te geven aan een deskundige. Wat het laatste betreft speelt mee dat voor het bestuursproces als uitgangspunt geldt dat de rechter tracht de materiële waarheid te vinden. ${ }^{182}$

In het verlengde daarvan wijs ik er - nogmaals - op dat het uitdrukkelijk niet de bedoeling kan zijn dat de rechter ambtshalve tot hervaststelling van de feiten over gaat. Dorhout ${ }^{183}$ merkt op dat wat de feitenvaststelling betreft toch vooral het accent moet liggen bij de non-contentieuze procedure met de

181. Op dit punt is wellicht een discussie over een expertise-keurmerk denkbaar. Ik laat de wenselijkheid daarvan hier nu rusten.

182. MvT-Whrol, p. 36.

183. Dorhout, L., De Beroepswet, nu en straks, NJB-speciaal'91/36, p. 1461-1466. 
daaraan verbonden bezwaarschriftenfase: ${ }^{184}$ "Aldus worden de bestuurslasten gelegd waar zij horen, en is de rechter in het eventueel volgende beroep niet genoodzaakt een zo uitvoerige onderzoekstaak te verrichten als de praktijk (te) dikwijls laat zien. In beginsel zal hij de nodige gegevens reeds vinden in het dossier van de na tegenspraak en heroverweging gegeven beslissing op het bezwaarschrift". ${ }^{185}$ In het verlengde van mijn stellingname in het voorgaande hoofdstuk voeg ik hieraan toe dat een dergelijke benadering aansluit bij de veronderstelling dat het bestuur tot taak heeft in normatieve keuzes aangaande de feitenvaststelling beslissingen te nemen en ertoe is uitgerust om op voet daarvan in de non-contentieuze procedure tot rechtmatige beslissingen te komen.

Een en ander sluit aan bij het perspectief van de bewijswaardering. ${ }^{186}$ Daarin vormt het vermoeden van rechtmatigheid een belangrijk ijkpunt. Zolang geen sprake is van gerede twijfel over de juistheid van het bestreden besluit, is er geen grond dit als onrechtmatig te kwalificeren. Belangrijk is echter wel - teruggrijpend op de bewijslastverdeling - dat de rechter, zelfs als door appellant slechts "lichte twijfel" is gezaaid, vanwege ongelijkheidcompensatie of op andere gronden toch bewijs aan zich kan trekken. Het resultaat daarvan kan zijn dat - alsnog - gerede twijfel over het bestreden besluit wordt opgeroepen.

Kortom: de rechter zal zich met het oog op de partij-autonomie lijdelijk, maar met het oog op ongelijkheidscompensatie, zijn eigen beoordelingsvermogen en de beperkte autonomie van partijen (c.q. het bestuur) (mogelijk) ook actief moeten betonen. In het verlengde daarvan acht ik twee zaken in het bijzonder van belang:

- bij het geven van een opdracht tot deskundigenonderzoek zou de rechter ad hoc deskundigen moeten aanzoeken. Aldus wordt voorkomen dat zich een adviescultuur ontwikkelt als onder het bestaande ambtsbericht - waarbij het advies zich allengs tot (bijna) alle aspecten van het geschil gaat uitstrekken. Nadelen daarvan zijn dat de positie van de rechter als dominus litis in het gedrang kan komen, terwijl het de rechter ook uitnodigt tot een ambtshalve, integrale hervaststelling van de feiten.

- Indien een deskundigenbericht wordt ingewonnen dan acht ik de rechter uitdrukkelijk gehouden partijen uit te nodigen tot contra-expertise. ${ }^{187}$

184. Zijn betoog spitst zich toe op beschikkingen in de sociale zekerheid, maar lijkt mij tegelijk ook algemener van strekking.

185. Dorhout, a.w., p. 1463.

186. Waarover meer in de volgende paragraaf.

187. Dat gaat verder dan dat zij in de gelegenheid kunnen worden gesteld om te reageren (vgl. art. 8:47, vijfde lid Awb). 
Voorts zou de rechter zijn eventuele verwerping van de in contra-expertise door partijen aangevoerde argumenten uitdrukkelijk moeten motiveren opdat daarover in hoger beroep of in cassatie kan worden geklaagd. Hiermee neem ik ook afstand van de vaste-deskundigeprocedure zoals we die thans in de Beroepswet kennen. Daar is hoger beroep immers uitgesloten. In het Whrol is - zoals ook in $\$ 9.2 .5$ reeds bleek - reeds met deze "traditie" gebroken (tenzij sprake is van vereenvoudigde afdoening in welk geval 'slechts' verzet mogelijk is).

Ten slotte wil ik er nog op wijzen dat een door de rechter gevraagd deskundigenbericht niet alleen bewijsinhoudelijk de ongelijke positie van de burgerappellant enigszins kan compenseren, maar ook een zekere financiële (ongelijkheids)compensatie inhoudt. Rechterlijke deskundigenopdrachten komen voor rekening van de overheid, hetgeen meebrengt dat appellant zich mogelijk voor minder kosten gesteld ziet. ${ }^{188}$

\subsection{De bewijswaardering}

Bij bewijswaardering gaat het om de vraag of toereikend bewijs is geleverd en daarmee om het gezag van de bewijsmiddelen. Niet alleen de vraag naar het gezag van individuele bewijsmiddelen (ieder bewijsmiddel moet natuurlijk op zichzelve reeds betrouwbaar zijn), maar zeker ook de vraag naar het passende verband tussen meerdere op zichzelf redelijk betrouwbare bewijsmiddelen. Het gaat immers om een overtuigende toedracht, zoals in de elementaire eis van consistent bewijs.

Ik wil achtereenvolgens ingaan op de rechterlijke overtuiging en op enkele beperkingen in de vrijheid van waardering van bewijs. Ten slotte maak ik nog enkele concluderende opmerkingen over de rechterlijke oordeelsvorming.

\subsubsection{Rechterlijke overtuiging}

\subsubsection{Normatieve uitgangspunten}

Hoe komt de rechter, gehoord of gezien de bewijsmiddelen, nu tot het bewijs? Het Whrol bevat hiervoor geen regels. Tenzij we - zoals Allewijn suggereert $^{189}$ - art. 8:69 Awb mede als een bewijsrechtelijke regel opvatten.

188. Hierbij passen twee kanttekeningen; 1. als appellant tevens aanvrager is zal hij ingeval van MER-plichtigheid natuurlijk toch het benodigde onderzoek moeten bekostigen; 2 . natuurlijk kan ook art. 8:75 Awb (proceskostenveroordeling) voor appellant onder omstandigheden soelaas bieden.

189. A.w., p. 1469. 
Voor de bewijswaardering helpt die regel ons mijns inziens niet verder. Waardering van het bewijs is echter zeker geen vrijblijvende aangelegenheid. Een aantal normatieve uitgangspunten is voor de bewijswaardering in het bijzonder van belang.

Allereerst moet het bewijsrecht worden geplaatst in het perspectief van de eisen die aan het contentieuze proces (als geheel) worden gesteld - het fair trial-beginsel, waaronder het respect voor het verdedigingsbeginsel. Rechterlijke vrijheid bij de bewijswaardering zou deze waarborgen kunnen ondermijnen. Er is dus een goede reden om stil te staan bij de normering van de bewijswaardering. Uiteraard geschiedt dat hier in het bijzonder in relatie tot de verklaringen van deskundigen.

Daarnaast moeten we bedenken dat de bewijswaardering in het teken staat van het vermoeden van rechtmatigheid. Indien naar de mening van de rechter (aan het "einde" van de bewijsvoering; ook de rechter moet er een keer een punt achter zetten en een "bevredigende beslissing" nemen) niet tenminste gerede twijfel bestaat omtrent de bestuurlijke feitenvaststelling, zal het beroep terzake moeten falen. In verband hiermee moet worden bedacht dat de rechter in termen van gradaties van zekerheid tot zijn oordeel moet komen. Absolute zekerheid is onbereikbaar en mitsdien is het bestuur tot het verschaffen daarvan - ook tegenover de rechter - niet gehouden. ${ }^{190}$

\subsubsection{Kritische opstelling}

Juist omdat het vinden van de materiële waarheid inzet is van het administratieve bewijsrecht dient de rechter zich bovenal kritisch op te stellen tegenover de aangeboden bewijsmiddelen. Zo moet hij nagaan welke premisses en preconcepties van de werkelijkheid aan de conclusies van deskundigen ten grondslag liggen. Als de rechter ernstige twijfels heeft over het gezag van aangevoerde bewijsmiddelen zal hij van zijn kritische instelling blijk moeten geven door het verlangen van aanvullend bewijs van een der partijen of het inroepen van contra-expertise. ${ }^{191}$

Vooral indien in een bewijsmiddel een beroep wordt gedaan op nieuwe methoden past een kritische instelling van de rechter. Niet zelden worden dergelijke methoden door de ontdekkers of bedenkers ervan met groot en beslist enthousiasme als uiterst betrouwbaar en zeer verfijnd aangeprezen. ${ }^{192}$ Tegelijkertijd moet de rechter een open oog hebben voor nieuwe inzichten. Anders gezegd: ook gangbare methoden moet de rechter kritisch bezien, zeker

190. Nogmaals: toepassing van de tweede vuistregel, maar nu in de rechtspraak.

191. Een soortgelijke regel is bekend in het strafrecht. Vgl. Reijntjes, J.M., Strafrechtelijk bewijs in wet en praktijk, Arnhem 1980, p. 48.

192. Onwillekeurig denk ik hierbij aan een klassieker uit het Amerikaanse strafrecht, te weten de "neutronenactiveringsmeting". Vgl.Groeneveld, E.R., Is de onafhankelijke deskundige in het strafproces uitgediend, AA $89 / 11$, p. 925-926, i.h.b. p. 926, noot 15. 
als het gaat om geschillen in een empirisch zo dynamisch gebied als de milieuproblematiek. Het gevaar is dat de erkende reputatie van gangbare methoden het zicht op nieuwe en mogelijk betere methoden kan belemmeren. ${ }^{193}$

Een kritische opstelling is - kortom - vereist, maar wat de rechter in elk geval niet moet doen is zich opwerpen als een superdeskundige. De pretentie dat hij het deskundigenoordeel geheel zou kunnen overzien en controleren, c.q. daarover met de desbetreffende deskundige in debat zou kunnen gaan, is misplaatst. ${ }^{194}$

In plaats daarvan dient de rechter vanuit een juridisch perspectief de deskundige te bewegen tot het afleggen van verantwoording voor zijn bevindingen. ${ }^{195}$ Als aanknopingspunten daarvoor denk ik allereerst aan de mogelijkheid van een "formele toetsing": is de deskundige een "echte deskundige", voldoet het deskundigenonderzoek aan daaraan te stellen algemene methodologische eisen en is sprake van een begrijpelijke en draagkrachtige motivering bij de conclusies van de deskundige. Ook een "materiële toets" is denkbaar: wordt in de deskundigenverklaring uitgegaan van in de kring van beroepsgenoten gebruikelijke of gangbare theorieën, werkwijzen en zekerheidsmarges?

Bij veel van dergelijke vragen zal de rechter zich, bij twijfel, nader kunnen laten voorlichten. Omdat de rechter zich tot zijn juridische leest moet bepalen, zal zijn uiteindelijke oordeel over verklaringen van deskundigen niet technisch-inhoudelijk indringend kunnen zijn. Als gezegd: de rechter is geen superdeskundige. Dit geldt zeker bij technisch zeer complexe problemen. Mij dunkt dat een zekere mate van gespecialiseerdheid van de rechter hierin geen verandering brengt. Het vergroot waarschijnlijk de wetenschappelijke intuïtie, waardoor de rechter sneller op het spoor van mogelijke gebreken in de verklaring van een deskundige zal komen. Staan blijft dat het niet wijs lijkt dat een rechter zichzelf als deskundige opwerpt: hij moet zich beperken tot zijn juridisch oordeel. ${ }^{196}$

193. Dit punt geldt ook t.a.v. de verwijzing naar richtlijnen (als ongerichte adviezen). Niet zelden zal het aankomen op de keuze tussen bestendige en alom gerespecteerde richtlijnen en relatief onbekende, nieuwe richtlijnen.

194. Inhoudsdeskundig. maar ook in termen van de legitimatie die daarmee voor het eindoordeel wordt gesuggereerd (zie $\$ 9.2 .5$ ).

195. Van art. 8:34, eerste lid Awb zou gezegd kunnen worden dat het niet alleen tot de deskundige is gericht. maar ook de rechter verplicht tot kritische evaluatie. In overeenkomstige zin neemt Borst (W.L.. De bewijsmiddelen in strafzaken, prft. Leiden 1985. Arnhem 1985, p. 262) aan dat art. $296 \mathrm{~Sv}$ (de deskundigenverklaring is met redenen omkleed) zich tot de strafrechter richt.

196. Geen dualisme (zie \$ 9.2.5). 


\subsubsection{Onzekerheid}

Ook als een rechter zich terdege kritisch betoont, zal het niet mogelijk zijn bewijs te vergaren dat absolute zekerheid verschaft. Ik merkte al op dat het bestuur daartoe al evenmin gehouden kan zijn. Ook in de rechtspraak moet goed voor ogen worden gehouden dat elk bewijs bloot staat "aan het gevaar, ex post te worden ontmaskerd als bedriegelijk" ${ }^{197}$

Onzekerheid zit ingebakken in elke deskundige-verklaring. Het zou zelfs uiterst ongewenst zijn als een deskundige zou trachten die onzekerheden te maskeren. Onzekerheden zijn immers van belang voor de bestuurlijke belangenafweging. Het zou volstrekt onjuist zijn om een deskundigenverklaring te desavoueren vanwege het enkele feit dat daarin openlijk gewag wordt gemaakt van onzekerheden.

In strafrechtelijke hoek vond ik in dit verband een toepasselijke overpeinzing van Borst. ${ }^{198}$ Deze constateert dat in de rechtsgeleerde literatuur nog vaak wordt verondersteld dat de wetenschap kan uitmonden in volstrekt zekere uitspraken. ${ }^{199}$ Een dergelijk standpunt acht ook hij - mijns inziens terecht onhoudbaar, omdat het neerkomt op "het maskeren van de eigen onzekerheid met een aan anderen ontleende schijnzekerheid". ${ }^{200} \mathrm{Hij}$ stelt vast dat wetenschappelijke uitspraken altijd in min of meerdere mate een "benaderingskarakter" dragen. ${ }^{201}$

Net als in het civiele of het strafproces zal de administratieve rechter in het bestuursproces uiteindelijk moeten uitmaken welke mate van onzekerheid toelaatbaar is wil een verklaring nog als bewijs kunnen dienen. ${ }^{202}$ Daarmee komen we op het punt van de rechterlijke overtuiging.

De rechter zal niettegenstaande het benaderingskarakter van deskundigenverklaringen toch moeten beslissen ${ }^{203}$ of hij deze (of welke van deze) hij gezaghebbend acht. ${ }^{204}$ Volgens Borst moet de onmogelijkheid om absolute maat-

197. Citaat ontleend aan Enschedé, Ch. J., Bewijzen in het strafrecht, RMTh'66. p. 488-518, i.h.b. p. 499.

198. A.w., p. 261 . Ik ben me ervan bewust regelmatig te refereren aan strafrechtelijke bronnen. $\mathrm{Z}_{\mathrm{ij}}$ lijken zich nog het meest aan de problematick van rechterlijke overtuiging te hebben gewaagd. Uiteraard is de bewijswaardering in het strafproces een precaire zaak (vanwege de mogelijk punitieve consequenties van een veroordelend vonnis). Toch kunnen zich ook in het bestuursproces precaire gevallen voordoen - met het oog daarop zij de vergelijking gemaakt.

199. Ibidem.

200. Ibidem, p. 261-262.

201. Ibidem, p. 265. Gelet op mijn bevindingen uit hoofdstuk 4 kan ik hier zonder meer mee instemmen.

202. In overeenkomstige zin zal het bestuur dergelijke beoordelingen moeten geven in het noncontentieuze proces.

203. Indachtig art. $13 \mathrm{Wet} \mathrm{AB}$.

204. Wetenschapstheoretisch beschouwd zou hij onderling tegenstrijdige verklaringen evenzeer gezaghebbend kunnen achten. 
staven voor de bewijsbeslissing te ontwikkelen worden overbrugd door rechterlijke overtuiging. De rechterlijke beslissing moet - aldus - tevens een overbrugging geven voor de onmogelijkheid om volstrekt zekere wetenschappelijke oordelen te geven. ${ }^{205}$

In overeenkomstige zin stellen Ten Berge en Tak dat (in het bestuursproces) in de idee van de rechterlijke overtuiging een "midden" moet worden gevonden tussen innerlijke, subjectieve overtuiging enerzijds (als een beslist te smalle basis voor de bewijswaardering) en de eis van absolute zekerheid anderzijds (als een principieel overspannen eis). ${ }^{206}$ In het voetspoor van Punt stellen zij dat het gaat om de "redelijke zekerheid". 207 Met dit uitgangspunt kan vervolgens worden geprobeerd om al naargelang de aard van het proces en de daarmee verbonden gevolgen voor partijen gradaties van redelijke zekerheid aan te geven. Zo stellen zij dat in het strafproces de "grootst mogelijke zekerheid" moet worden bereikt. De rechterlijke overtuiging mag redelijkerwijze geen ruimte voor twijfel open laten. In het burgerlijk proces zouden partijen er in moeten slagen de rechter een redelijke mate van zekerheid te verschaffen. Voor het bestuursproces achten zij het onjuist om aan te nemen dat het slechts om voldoende waarschijnlijkheid zou gaan. Naarmate de betrokken belangen groter zijn zal de rechter meer zekerheid verlangen. ${ }^{208}$ Ook zal het uitmaken of de rechter toetst danwel zelf in de zaak voorziet. ${ }^{209} \mathrm{Ik}$ acht het zeer wel voorstelbaar dat in geschillen aangaande kwetsbare belangen, zoals (bepaalde) milieugeschillen, een grotere mate van zekerheid wordt verlangd vooraleer de administratieve rechter aan een bestuurlijke feitenvaststelling of betwisting daarvan, gezag toekent. Denkbaar is hier te differentiëren tussen de feitenvaststelling als geheel en de separate bewijsmiddelen. De bewijsmiddelen moetẹn een bepaalde (minimale) mate van betrouwbaarheid bezitten. De mate van onzekerheid waarvan zij getuigen zal - naar ik aanneem - in het totald beeld van de bewijswaardering meewegen. Binnen het bestuursproces dienyn de verschillende gradaties van redelijke zekerheid ten slotte te worden geijkt aan het vermoeden van rechtmatigheid. De in een bepaald geschil toepasselijke (c.q. vereiste) gradatie van redelijke zekerheid is allereerst een maatstaf voor de eisen waaraan de bestuurlijke feitenvaststelling moet voldoen. Hoe scherper die eisen worden gesteld hoe zwaarder het voor het bestuur zal zijn om het bestreden besluit

205. Borst, a.w., p. 265 (geparafraseerd).

206. Zie Ten Berge/Tak, a.w., p. 371.

207. Ibidem, p. 373. "Redelijke zekerheid" figureerde in deze studie reeds in de kwestie van de "bevredigende beslissing" (\$ 4.3).

208. Ibidem. Als voorbeeld noemen zij disciplinaire naatregelen jegens ambtenaren en de uitoefening van imperatieve bevoegdheden. Zoals ik reeds in $\$ 4.3 .3$ en $\$$ 8.3.3.2 stelde gaat het hier niet om een belangenafweging (subjectieve redelijkheid), maar om objectieve redelijkheid.

209. Ibidem (alsmede op p. 347-349). 
zodanig aannemelijk te maken dat een bewijsrechtelijk vermoeden van rechtmatigheid ontstaat. ${ }^{210}$ Voor de appellant blijft het "eenvoudig" zaak om gerede twijfel aan de rechtmatigheid van het bestreden besluit te bewerkstelligen. Overigens zal het niet zo zijn dat een zwaardere bewijslast voor het bestuur, het vanzelf eenvoudiger maakt om gerede twijfel te zaaien. Als het bestuur in het preprocessuele bewijs aannemelijk maakt dat een beslissing correct is, zal er doorgaans toch wel wat voor nodig zijn om twijfel te doen ontstaan. In $\$$ 6.4.4.2 signaleerde ik - bij voorbeeld - dat als het bestuur met (degelijke) deskundigenrapporten komt om zijn bewijs te verstrekken, de burger doorgaans niet kan volstaan met hartekreten - hoewel hij juist daarmee kan speculeren op rechterlijke hulpvaardigheid op voet van de ongelijkheidscompensatie.

\subsubsection{Motivering}

Rechterlijke overtuiging is, zo mag toch uit het voorgaande worden opgemaakt, in elk geval geen vrijbrief voor rechterlijke oordeelsvorming. Een "redelijke mate van zekerheid", gebaseerd op een kritische analyse van bewijsmiddelen is in elk geval vereist.

Wat er echter werkelijk in het hoofd van een rechter omgaat is vaak niet goed te achterhalen. Hoe een rechter "de overtuiging bekomt" is waarschijnlijk minder het domein voor de jurist en meer dat van de psycholoog. Juridisch gezien is het (wellicht) ook niet zo belangrijk of het richtsnoer van redelijke zekerheid op basis van kritische analyse voor de rechter ook werkelijk heuristische waarde heeft. Het is de "context of justification", de rationele reconstructie die juridisch uiteindelijk het meest relevant is. Met behulp van de motivering in de uitspraak moet blijken of de bewijswaardering getuigt van redelijke zekerheid op basis van kritische analyse.

Motivering van uitspraken behoeft mitsdien onze nadrukkelijke aandacht. Art. 8:67, tweede lid en art. 8:77, eerste lid onder b. Awb schrijven voor dat een uitspraak "de gronden van de beslissing" vermeldt. Wat daarmee wordt bedoeld, wordt in gene toelichting van regeringszijde opgehelderd. Ten Berge en Tak wijzen er op dat de plicht om de gronden van een beslissing in de uitspraak te vermelden meerdere doelen dient. ${ }^{211}$ In het bijzonder lijkt mij hier het oogmerk van het mogelijk maken van vertrouwen in de rechtspraak, het verschaffen van aanknopingspunten voor hoger beroep of cassatie en de voorlichtende functie aan het bestuur en de justitiabelen van belang. Daarmee is nog niet opgehelderd in welke mate met name het oordeel over de feiten nadere adstructie behoeft. Ten Berge en Tak wijzen er op dat juist op dat

210. Vgl. §9.5.2.1.

211. Ten Berge/Tak II, a.w., p. 99. 
punt de administratieve rechters zich niet bepaald openhartig tonen. ${ }^{212}$ Wetgever (vide art. 8:77 Awb) en rechter lijken zich te beperken tot de opgave van geschonden geachte toetsingsgronden. ${ }^{213}$ De beperkte bewijsrechtelijke motivering zou overigens, zoals Hoogendijk-Deutsch terecht opmerkt, verband kunnen houden met het feit dat de administratieve rechter "geen vernietiging van zijn uitspraken wegens ondeugdelijke motivering (heeft) te duchten", door "het nagenoeg ontbreken van de mogelijkheid van beroep in cassatie". ${ }^{214}$ Dit pleit in algemene zin voor de verwezenlijking van een adequate (en algemene) regeling van cassatieberoep. Meer concreet zou de rechter verplicht moeten worden om (in technisch ingewikkelde geschillen) in elk geval aan te geven waarom hij aan bepaalde bewijsmiddelen geen of minder waarde heeft toegekend. ${ }^{215}$

\subsubsection{Enkele beperkingen in de vrijheid van bewijswaardering}

Ik wil hier nog wat uitdrukkelijker ingaan op een tweetal zaken die aan het "bekomen van de overtuiging" (kunnen) zijn verbonden en die mitsdien de rechterlijke vrijheid (kunnen) beperken: de toetsing aan methodologische regels en de formalisering van het bewijs.

\subsubsection{1. 'Methodologische kritiek'}

In het voetspoor van de motiveringseis als onder $\S 9.7 .1 .4$ bedoeld, zal de rechter bij de toetsing van bestuurlijke feitenvaststelling of de eigen feitenvaststelling (ten behoeve van het zelf voorzien) moeten letten op algemene methodologische regels. Ik denk hierbij in het bijzonder aan de regels toepasselijk op het onderzoek dat door deskundigen wordt verricht.

Inspiratie voor dit punt put ik uit een strafrechtelijke zaak, te weten het Anatomisch correcte poppen-arrest. ${ }^{216} \mathrm{Nu}$ merk ik reeds aanstonds op dat in het strafproces steeds een hoge mate van zekerheid wordt verlangd. ${ }^{217}$ Dit scherpt natuurlijk de bereidheid om eisen te stellen aan de (motivering van de) bewijswaardering. Toch lijkt me een vergelijking hier relevant omdat in bepaalde gevallen van dreigende milieuschade een grote mate van zekerheid eveneens geïndiceerd lijkt. ${ }^{218}$

212. Ibidem, p. 100.

213. Vgl. de (impliciete) kritiek van Tak, a.w. (1992), p. 12.

214. A.w. (1992), p. 310.

215. Ik kan mij voorstellen dat alleen de afwijzing van serieus te nemen bewijsmiddelen wordt gemotiveerd. Op dit punt kom ik in $\$ 9.7 .2 .1 \mathrm{en} \$ 9.7 .3 .1$ nog terug.

216. HR 28 februari 1989, rolnr. 84.723, uittreksel NJB' 89 , nr 114.

217. Behalve wellicht juist bij het bewijs van de aanwezigheid van strafuitsluitingsgronden.

218. Ik denk aan beslissingen over kernreactoren, chemische industrie. DNA-manipulatie en dergelijke. 
In voornoemd arrest casseerde de Hoge Raad een arrest van het Hof waarbij een verweer inzake de betrouwbaarheid van de blijkens een deskundigenverslag gevolgde onderzoeksmethode ongemotiveerd verworpen was. Het betrof hier de methode waarbij minderjarigen werden verhoord aan de hand van anatomisch correcte (dat wil zeggen gelijkende) poppen, waarbij op basis van de respons van kinderen in een gesprek over deze poppen, werd vastgesteld of bij deze minderjarigen sprake was van seksuele mishandeling.

Barning en Nijboer ${ }^{219}$ menen uit het arrest van de Hoge Raad een uit vijf stappen bestaande richtlijn voor de rechterlijke motiveringsplicht bij de verwerping van een "methodisch verweer" (MAH) te kunnen afleiden: "Wat betreft het gebruik van deskundigenverslagen in de bewijsconstructie eist de Hoge Raad (...) in ieder geval dat een: (1.) ter terechtzitting gevoerd - grondig gedocumenteerd - verweer, dat de (2.) betrouwbaarheid aanvecht van (3.) een nieuwe onderzoeksmethode, (4.) waarop veel kritiek wordt geuit en dat (5.) door de verdediging onvolledig wordt geacht, uitdrukkelijk met redenen omkleed moet worden verworpen indien het desbetreffende bewijsmateriaal ondanks het gevoerde verweer toch wordt gebezigd". ${ }^{220}$ Het arrest lijkt een belangrijke breuk met de eerdere terughoudendheid van de Hoge Raad ten aanzien van de bewijsbeslissing. ${ }^{221}$ Volgens Barning en Nijboer is de feitenrechter ook terzake van deskundigenverklaringen gebonden aan "normen van algemeen methodologische aard." "Gelet op de betrokken belangen kan van alle officiële functionarissen en met name van de rechter worden gevergd dat zij kwalitatief niet met minder genoegen nemen dan met deskundigenonderzoek van onbesproken en uitnemende kwaliteit. ${ }^{222}$ De uitdrukkelijke motiveringsplicht bij een "deugdelijk" verweer terzake is een logisch sequeel op deze visie. In het Anatomisch correcte poppen-arrest lijkt de Hoge Raad er voorts - van uit te gaan dat hoewel er geen algemene regel is die stelt dat de verdachte ook buiten in de wet geregelde gevallen recht heeft op contraexpertise, niettemin ook dan de mogelijkheid tot het bieden van contra-expertise moet worden geboden, althans dat een redelijk onderbouwd verzoek daartoe niet zonder meer van de hand kan worden gewezen. ${ }^{223}$

De belangrijkste elementen uit het voorgaande zijn - mijns inziens - de uitdrukkelijke motiveringsplicht van de rechter en de hoofdregel van het bieden

219. Barning, L., J.F. Nijboer, Het anatomisch correcte poppenarrest, NJB'89/32, p. 1173-1177.

220. Ibidem.

221. Wellicht was de aard van de betrokken belangen voor de Hoge Raad aanleiding zich zo uitdrukkelijk over de feitenvaststelling uit te laten.

222. Barning en Nijboer, a.w., p. 1174. Onbesproken vind ik een ongelukkige term. Eigenlijk wordt kritisch besproken, c.q. getest en niet weerlegd, bedoeld. Hier komt tot uitdrukking dat in het strafproces (doorgaans) een hoge mate van zekerheid over de feiten vereist is.

223. Vgl. Barning en Nijboer. a.w., p. 1176. 
van de mogelijkheid tot contra-expertise ingeval van een redelijk onderbouwd verzoek daartoe. Beide zaken zijn goed te transponeren naar het bestuursproces. Hierboven merkte ik (in \& 9.7.1.2) reeds op dat van de administratieve rechter een kritische houding tegenover bewijsmiddelen, c.q. deskundigenverklaringen, verwacht mag worden. Daarnaast stelde ik reeds in $\$ 9.6 .1$, op voet van het verdedigingsbeginsel dat het verdedigingsbeginsel meebrengt dat partijen in de gelegenheid gesteld moeten worden contra-expertise in te brengen. ${ }^{224}$

De indruk ontstaat dat aan de rechterlijke feitenvaststelling gelijksoortige eisen gesteld gaan worden als thans - door rechters - aan de bestuurlijke feitenvaststelling worden gesteld. In Hoofdstuk 6 was de eis van een kritische instelling en de wenselijkheid van contra-expertise ook reeds nadrukkelijk aan de orde. Als dergelijke eisen ook voor het bestuursproces zelf gesteld kunnen worden zou dat een belangrijke erkenning zijn van het technisch complexe karakter van bepaalde bestuursgeschillen. Van daaruit is goed voor te stellen dat door alle betrokkenen extra acht moet worden geslagen op de naleving van methodologische eisen, zoals bij voorbeeld de eis van contra-expertise. Met deze optiek worden de rechtswaarborgen van burgers in belangrijke mate versterkt.

Het punt van de contra-expertise, dat ik hier reeds enkele malen naar voren bracht, is natuurlijk niet slechts relevant als een methodologisch vereiste. ${ }^{225}$ De overlap tussen methodologische eisen en rechtswaarborgen is, gelet op art. 6 lid 1 EVRM goed te signaleren. Zoals ook tot uitdrukking komt in de door Haentjes besproken Bönisch case van het Europese Hof voor de Rechten van de Mens, ${ }^{226}$ omvat het in art. 6 eerste lid EVRM neergelegde beginsel van een "fair trial" de eis van "equality of arms". 227 Laatstgenoemde eis lijkt ook van belang voor (het horen) van deskundigen. De rechterlijke plicht om, zo daartoe redelijkerwijs aanleiding bestaat, de mogelijkheid tot het

224. Met als toevoeging dat de rechter de poging tot tegenbewijs, op voet van ongelijkheidcompensatie, in eigen hand zou kunnen nemen. Eerder (in \$ 9.5.1 en \$ 9.6.4) betoogde ik overigens reeds dat de rechter eerst partijen de gelegenheid moet geven om bewijs te leveren.

225. Te weten de eis van testbaarheid, c.q. daadwerkelijk getest of althans gekritiseerd zijn van een wetenschappelijke uitspraak.

226. Haentjes, R.C.P., Deskundigen in strafzaken, contra-expertise, het Europees verdrag tot bescherming van de Rechten van de Mens en bijzondere wetten. NJCM-Bulletin, 85. p. 447458. Bönisch case: Commissie voor de rechten van de Mens, Zaak 8141/78, d.d. 4 december 1978, in Decisions and reports. Council of Europe nr. 16, p. 141 e.v. Europese Hof voor de Rechten van de mens, case 6/1984/78/122, Judgement. 6 May 1985.

227. Aldus ook de Waard, a.w. (prft), p. 247. Deze noent de Bönisch-case overigens i.v.m. de behoorlijkheidseis van onbevangenheid van bij het proces betrokken (getuigen en) deskundigen. a.w., p. 353 . 
verrichten van contra-expertise te bieden, valt - volgens Haentjes en ik volg hem daarin - rechtstreeks uit de Bönisch-case af te leiden. ${ }^{228}$

Het zal opnieuw duidelijk zijn dat de eis van een degelijke motivering van de afwijzing van een verweer c.q. beroep inzake de betrouwbaarheid van (al dan niet aan een richtlijn ten grondslag gelegd) deskundigenonderzoek, slechts dan werkelijk zinvol is indien de mogelijkheid van een hoger beroep c.q. een cassatie-beroep wordt geboden. De keuze van de regering om in "kwetsbare geschillen" slechts beroep in é́n instantie mogelijk te maken acht ik mede om die reden niet verdedigbaar. ${ }^{229}$

Sprekend over contra-expertise rijst de vraag wat er is van Neutebooms opmerkingen terzake van de wetenschappelijke foutenmarge. ${ }^{230} \mathrm{Bij}$ contraexpertise komt het zelden of nooit voor dat precies dezelfde uitkomsten worden gevonden. Het lijkt mede afhankelijk te zijn van de mate van nauwkeurigheid die van de test verlangd wordt, of binnen een bepaalde afwijkingsmarges al van tegenspraak of weerlegging gesproken kan worden. Anders gezegd: de mate van zekerheid die de rechter in de bewijsvoering verlangd zal maatgevend zijn voor de het omgaan met dergelijke marges. In het strafrecht zal enerzijds een grote mate van precisie verlangd worden, ${ }^{231}$ anderzijds moet de bewijslast, c.q. de uitvoerbaarheid van regels ook in het oog worden gehouden. ${ }^{232} \mathrm{Mij}$ dunkt dat in het bestuursrecht doorgaans grotere marges aangehouden kunnen worden. Een uitzondering op die regel zal zich echter (kunnen) voordoen waar het om bestuursrechtelijke handhaving gaat, waar bij normstellend handelen door het bestuur kleine marges reeds grote verschillen in mate van gevaar kunnen geven, of waar fundamentele rechten of waarden in het geding zijn.

228. Haentjes, a.w.. gaat in het bijzonder in op de vraag of contra-expertise in enkele bijzondere delen van het strafrecht, waaronder enkele milieuwetten, wel afdoende is geregeld. Hij stelt vast dat er vooral op het punt van monstername (extra-monsters, extra tests) gebreken zijn aan te wijzen.

229. Wel volg ik de regering in haar keuze om bij de "vaste-deskundigenprocedure volgens het Whrol" de mogelijkheid van hoger beroep te openen - vgl. \$ 9.2.5. Bij vereenvoudigde afdoening resteert slechts het verzet als rechtsmiddel. Voorshands lijkt het mij niet nodig om het oordeel in verzet over de gegrondheid van de 'kennelijkheid', ook nog eens in cassatie te laten toetsen op de motivering inzake het deskundigenbewijs.

230. Neuteboom, W., Bloedproef, contra-expertise en het schijvenstelsel, D\&D'86/5, p. 467-472.

231. Denk aan vervolging op grond van art. 26, tweede lid, Wegenverkeerswet (ademtest en bloedproef).

232. De problemen spelen vooral daar waar het recht "digitaal" uitsluitsel vraagt (meetresultaten worden groepsgewijs geordend en bij elke groep passen specifieke rechtsgevolgen thetgeen vooral bij geformaliseerd bewijs voor kan komen) terwijl de werkelijkheid analoog (in termen van vloeiende overgangen, van meer of minder) is "georganiseerd". 


\subsubsection{Formalisering van het bewijs}

De vrijheid van bewijswaardering kan in belangrijke mate worden beperkt door formalisering van het bewijs. ${ }^{233}$

Het motief voor formalisering van het bewijs is de gedachte dat de steeds toenemende technische-complexiteit van het bewijs de rechterlijke afhankelijkheid van deskundigen vergroot. Daardoor kunnen de rol van de rechter als dominus litis en de notie van de rechterlijke overtuiging in het gedrang komen. Niet alleen is de deskundigenverklaring in veel gevallen een onmisbare bouwsteen van het bewijs geworden, ook is het voor de rechter steeds moeilijker om de methoden en de uitkomsten van het deskundigenonderzoek te controleren. ${ }^{234}$

Een onmiskenbaar voordeel van formalisering van het bewijs is dat de rechter (toch weer) zicht krijgt op de totstandkoming van de deskundigenverklaring. Ook voor burgers is er een voordeel. Het bewijs wordt in belangrijke mate geobjectiveerd en wordt daarmee in veel grotere mate voorspelbaar gemaakt. Ook in het milieurecht zijn hiervan voorbeelden aan te wijzen. Ik denk - bij voorbeeld - aan de Besluiten inzake reken- en meetvoorschriften voor verkeerslawaai, geluidsbelasting binnen gebouwen en industrie-lawaai. ${ }^{235}$ Voor de administratieve rechter kunnen dergelijke regels houvast bieden bij de beoordeling van deskundigenverklaringen. Uiteraard lijkt het voor het geven van voorschriften van dit type wel vereist dat sprake is van voldoende bestendigheid in de wijze van analyse en beoordeling van (de ernst van) het onderhavige effect. ${ }^{236}$

$\mathrm{Er}$ is echter ook een belangrijke risico bij formalisering van het bewijs. Hoewel de rechter aan de ene kant geholpen is met een duidelijk richtsnoer, rijst de vraag of zijn verantwoordelijkheid voor controle op de juistheid en volledigheid van de feitenvaststelling er niet al te snel bij in zal schieten.

Ik doel daarmee in de eerste plaats op de controle op proefnemingen en de mogelijkheid van tegenspraak. Het gevaar dreigt dat na de enkele bewering dat berekeningen zijn uitgevoerd overeenkomstig de geldende meet- en rekenvoorschriften, de rechter het wel gelooft. Toch zou die houding neerkomen op een verlies aan rechtswaarborgen.

233. Het strafrecht biedt hier - opnieuw - aardige voorbeelden. Denk maar aan het besluit Alcoholonderzoek van 24 september 1987, Stb. 432, de Regeling bloed-en urine-onderzoek, de Regeling ademanalyse en de Regeling voorlopig ademonderzoek, allen regelingen van 25 september 1987, Stert. 187.

234. Vgl. (uit de "strafrechtelijke doos") Groeneveld, a.w., p. 927-928.

235. Respectievelijk besluiten van 22 mei 1981 (Stert. 107); 2 november 1982 (Ster. 228); 20 augustus 1982 (Stert. 161).

236. Vergelijkbaar met de criteria voor algemene regels (Titel $8.2 \mathrm{Wm}$.). 
In de tweede plaats rijst de vraag of de rechter "geformaliseerde experti$\mathrm{se}^{1237}$ in het bestuursproces buiten discussie zou moeten plaatsen. Materieel beschouwd zou hij er aldus vanuit gaan dat de geformaliseerde expertise een grotere betrouwbaarheid heeft dan niet geformaliseerde, anders luidende, deskundigen-adviezen of deskundigenberichten. Als ter procedure inzichten worden gepresenteerd die een nieuw wetenschappelijk licht werpen op de geformaliseerde wijze van bewijsvoering, lijkt het toch moeilijk om in dit a priori van betrouwbaarheid te volharden.

Ik meen echter dat hier uitdrukkelijk onderscheid gemaakt moet worden tussen nieuwe inzichten die ten tijde van het nemen van de bestreden beslissing bekend dan wel redelijkerwijs voorzienbaar waren en nieuwe inzichten van later datum. Bij inzichten "van later datum" zie ik niet in hoe deze in het kader van een rechtmatigheidstoets ex tunc nog een rol kunnen spelen. Anders is het gesteld met de inzichten die reeds bekend of voorzienbaar waren. Deze kunnen mijns inzien wel degelijk in de discussie betrokken worden. Ik zou menen dat er ruimte moet zijn om een regeling buiten toepassing te laten indien na deskundig onderbouwd verweer of beroep, betrekkelijk eenduidig blijkt dat het daaraan ten grondslag gelegde onderzoek (reeds op het moment van het nemen van de bestreden beslissing) als uiterst aanvechtbaar, zo niet achterhaald moest worden beschouwd. Wel zou uit deze "contraire bewijsvoering" ook naar voren moeten komen dat de toegepaste regeling niet langer het daarmee beoogde doel dient en dat volharding in de toepassing daarvan tot ernstige, zo niet irreversibele schade zal (kunnen) leiden. ${ }^{238}$

In dit verband roep ik de zaak "Beek" in herinnering. ${ }^{239}$ Een regeling houdende geluidsnormen inzake luchtverkeer werd als een belemmering voor het beschrijven van geluidshinder-effecten gezien. Bij beschrijving en waardering van de activiteit dienden vervolgens ook andere normen te worden toegepast. In dat specifieke geval maakte art 7:35 Wm het mogelijk scherpere normen voor te schrijven. Toch zou ik menen dat zulks (in aperte gevallen) ook op ongeschreven grondslag mogelijk zou moeten zijn. ${ }^{240}$ Uiteraard dient de rechter er wel voor te waken dat hij de normen ruimer of scherper gaat stellen dan de desbetreffende regelgever kennelijk heeft gewild. Anders gezegd: het moet aannemelijk zijn dat zo deze regelgever tijdig over de nieuwe inzichten had beschikt, hij zijn regeling zou hebben aangepast. In dat spoor kan de rechter dan de feitenvaststelling beoordelen. ${ }^{241}$

237. Een term die ik ontleen aan Borst en Nijboer, a.w., p. 108.

238. De laatste eis vloeit voort uit de opvatting dat in principe herziening van de voorgeschreven analyse het meest in de rede ligt.

239. Zie $\$ 7.2 .2 .6$.

240. Ik denk in het bijzonder aan het willekeurverbod. Voor contra legem gaan zie ik onder omstandigheden (apert onevenredig nadeel) goede gronden.

241. Nogmaals alleen in aperte gevallen met dreiging van ernstige of irreversibele schade. 
Als de rechter zelf in de zaak wil voorzien en dit overeenkomstig de regeringsvoorstellen ex nunc zou doen ligt de zaak anders. Dan zouden ook nieuwe inzichten (onvoorzienbaar bij het nemen van de onrechtmatige beslissing) kunnen worden meegewogen. Opnieuw geldt hier dat er goede gronden moeten zijn om van de formele regels af te wijken.

\subsubsection{Afrondende opmerkingen}

\subsubsection{Samenvatting}

Vooreerst heb ik mij gericht op de kwestie van de rechterlijke overtuiging. Dit is immers de hoeksteen van de bewijswaardering. Voor het bekomen van de overtuiging is een aantal normatieve uitgangspunten van elementair belang: het fair-play beginsel en het vermoeden van rechtmatigheid. Ook is het van groot belang dat de rechter zich kritisch opstelt tegenover bewijsmiddelen, zoals deskundigenberichten - zonder daarbij "superdeskundigheid" te pretenderen. Hij moet een juridische toetsing uitvoeren. Wat de feitenvaststelling betreft zal daarbij erkend moeten worden dat onzekerheden onvermijdelijk zijn. In dat verband zal de rechter een maatstaf van "redelijke zekerheid" moeten aanleggen. Door zo'n maatstaf als grondslag voor zijn rechterlijke overtuiging te nemen, kan de (wetenschappelijke) onzekerheid worden overbrugd. Onder omstandigheden zal redelijke zekerheid praktisch een grote zekerheid vereisen; bij voorbeeld bij betrokkenheid van kwetsbare belangen bij riskante activiteiten. Daarmee zal de bestuurlijke bewijslast niet gering zijn. Dat impliceert echter niet dat de burger het gemakkelijk zal hebben om gerede twijfel te zaaien. Last but not least heb ik mij gericht op de motivering welke de rechter voor zijn overtuiging geeft. Zelfs als deze niet meer dan een rationele reconstructie is, biedt zij houvast voor controle van de uitspraak en voor het gezag dat van een uitspraak kan uitgaan. Het lijkt in het bijzonder van belang dat voorbijgaan aan "serieuze" bewijsmiddelen uitdrukkelijk wordt gemotiveerd.

In de paragraaf over beperkingen in de rechterlijke waarderingsvrijheid ben ik eerst op het spoor van de motivering voortgegaan. In het bijzonder ben ik stil blijven staan bij het voorbijgaan aan goed onderbouwde methodische kritiek op een ander bewijsmiddel. Allereerst heb ik gesteld dat een rechterlijke motivering hierbij op haar plaats zou zijn. In het verlengde daarop heb ik er op gewezen dat een dergelijke plicht een bevestiging biedt van het recht van partijen om in redelijkheid de gelegenheid te krijgen contra expertise te leveren. Mede in verband met de motiveringsverplichting heb ik nogmaals onderstreept hoe belangrijk het is om beroep te kunnen doen op een tweede rechterlijke instantie. In verband met het recht op contra-expertise heb ik er op gewezen dat niet elke afwijking in de uitkomsten van deskundigen-onder- 
zoek significant behoeft te zijn. Zulks zal mede afhankelijk zijn van de gestelde mate van zekerheid welke voor het bewijs noodzakelijk is.

Als tweede beperking van de rechterlijke beoordelingsvrijheid besprak ik de formalisering van het bewijs. Voordeel van zodanige formalisering zou moeten zijn dat de rechter weer vat krijgt op de bewijsvoering, door objectivering van de bewijswaardering. Een gevaar is echter dat de rechter zich blindelings aansluit bij de feitenvaststelling van het bestuur zodra vaststaat dat het bestuur overeenkomstig de regel heeft gehandeld. Wellicht echter past ook binnen het geformaliseerde bewijs nog de mogelijkheid van contra-expertise. ${ }^{242}$ Daarnaast is het de vraag of het geformaliseerde bewijs wel de meest betrouwbare uitkomst geeft. Wat te doen als er nieuwe inzichten zijn waarin zulks betwist (of zelfs weerlegd) wordt? In het kader van de ex tunc toetsing zullen slechts de inzichten kunnen worden meegenomen die bij het nemen van de bestreden beslissing bekend waren of behoorden te zijn. Onder omstandigheden moet afwijken - naar mijn oordeel - mogelijk worden geacht. Bij zelf voorzien kan de rechter ook "echt nieuwe" inzichten bij zijn oordeel betrekken.

\subsubsection{Enkele slotopmerkingen}

Ik heb bij de kwestie van de bewijswaardering niet gesproken over gespecialiseerdheid van de rechter. Onder $\$ 9.2 .5$ gaf ik reeds aan weinig te zien in een dergelijke figuur, voorzover deze impliceert dat rechters zich ter legitimatie van hun uitspraken ook gaan beroepen op hun niet-juridische deskundigheid - in de vorm van een soort geprofessionaliseerde 'eigen wetenschap'. Dat sluit niet uit dat het de rechtspraak ${ }^{243}$ ten goede kan komen als rechters zich specialiseren in het soort zaken dat zij beoordelen. Zulks kan de kritische opstelling tegenover bewijsmiddelen slechts ten goede komen. Het wordt echter riskant als deze specialisatie een zelfstandige bijdrage aan de legitimatie van het rechterlijk oordeel gaat vormen. Dan dreigt - althans naar mijn oordeel - dat de juridische controle van de feitenvaststelling ondergeschikt raakt aan de (niet-juridische) eigen deskundigheid (eigen wetenschap) van de rechter.

Het moge duidelijk zijn dat ik op zichzelf geen bezwaar heb tegen het buiten de bewijsvoering houden van feiten welke de rechter uit eigen wetenschap bekend zijn. ${ }^{244}$ Net als bij het buiten de bewijsvoering houden van 'feiten van algemene bekendheid' en 'algemene ervaringsregels', zie ik daarin een toepassing van het vinden van een bevredigende beslissing in het contentieuze

242. Bovendien is er vaak toch nog een zekere marge in de bewijsvoering, ook al is deze geformaliseerd.

243. En in dat opzicht ook het besturen.

244. Vgl. Hoogendijk-Deutsch, a.w. (1992), p. 311. 
proces. Toch zal de rechter restrictief met 'eigen wetenschap' om moeten gaan, en dicht bij de 'feiten van algemene bekendheid' of de 'algemene ervaringsregels' moeten blijven. In dat opzicht vind ik het derhalve ook niet zo'n slecht idee om rechters te laten rouleren, al zou ik daarin - ook al met het oog op de juridische deskundigheid! - niet al te grote stappen willen zetten.

Een tweede aspect dat ik heb laten rusten is de vraag waar de bewijswaardering plaatsvindt. Meer in het bijzonder ben ik niet blijven stilstaan bij de vraag of het houden van een zitting voor de bewijswaardering (bijzondere gevallen daargelaten) ${ }^{245}$ een essentiële schakel vormt. In het strafprocesrecht bestaan op dit punt "strong feelings". Als verbijzondering op het verdedigingsbeginsel, wordt daarbij gesproken van het onmiddellijkheids- of confrontatiebeginsel. ${ }^{246}$

Volgens dit beginsel dient het (eind)onderzoek in het openbaar, mondeling te worden gevoerd ten overstaan van een onafhankelijke en tot beslissing bevoegde rechter. $\mathrm{Zo}$ is $\mathrm{Mols}^{247}$ van mening dat de eis van openbaarheid van het onderzoek een belangrijke waarborg biedt doordat partijen ter zitting de "beste argumenten en kwaliteiten" waarover zij beschikken, kunnen presenteren. ${ }^{248}$

Mij lijkt toch dat zich hier een duidelijk verschil aftekent met het bestuursproces. Daar wordt een openbare zitting zeker niet onbelangrijk gevonden. In de concept wetsvoorstellen Whrol werd het onderzoek ter zitting zelfs als een zwaartepunt van de procedure genoemd. ${ }^{249}$ De regering stelde daarbij dat een mondelinge behandeling van het geschil nu juist wenselijk was met het oog op deelname door niet-professionals, c.q. uit een oogpunt van ongelijkheidscompensatie. ${ }^{250}$ In de definitieve voorstellen wordt slechts nog opgemerkt dat indien geen vereenvoudigde behandeling plaatsvindt of tijdens het vooronderzoek geen mondelinge uitwisseling van standpunten heeft plaatsgevonden, "het onderzoek ter zitting van groot gewicht zal blijven, zeker als een persoon in burger en zonder rechtsbijstand procedeert". ${ }^{251}$ Ook in andere gevallen zal de rechter - volgens de toelichting - de burger zijn "day in

245. Als aan termen voor een vereenvoudigde behandeling is voldaan.

246. De Waard, a.w., pp. 317-318. Vooral in verband met de kwestie van de anonieme getuigen.

247. Mols, G.P.M.F., Staande de zitting, oratie Maastricht, Arnhem 1989.

248. Ibidem, p. 8.

249. Concept-MvT-Whrol, a.w., p. 30 onder h.

250. Tijdens het Congres Nieuw Bestuursprocesrecht, waarbij het concept centraal stond, liepen de opvattingen over het nut van een zitting overigens uiteen. Vgl. B.J.M. van der Meulen, a.w., p. 16.

251. MvT-Whrol, p. 38. 
court" niet mogen onthouden. ${ }^{252}$ Deze nuancering in het belang van het onderzoek ter zitting lijkt ingegeven door de kritiek van de Raad van State op het concept wetsvoorstel. Daarin wordt er op gewezen dat het vanwege de bewaking van de proceseconomie en de intensivering van de mogelijkheden tot vooronderzoek niet langer voor de hand ligt het onderzoek ter zitting als zwaartepunt van het proces te zien. ${ }^{253}$ Wellicht heeft bij dit advies ook de gedachte meegespeeld, dat een zeer substantieel deel van de zaken thans zonder zitting wordt afgedaan.

Ik kan met de gekozen nuancering in belangrijke mate meegaan. Ik meen overigens ook dat niet moet worden vergeten dat partijen vaak ook in de noncontentieuze procedure reeds mondeling argumenten hebben uitgewisseld. Meer in het algemeen zou ik menen dat - anders dan in het strafprocesrecht van geval tot geval de wenselijkheid van een zitting kan worden beoordeeld. De aard van de betrokken belangen, de hoedanigheid van de betrokken personen en de omstandigheden van het geval kunnen hierin richtinggevend zijn. Een belangrijk aspect lijkt mij wat de regering in haar reactie op het advies van de Raad van State overweegt: "ondertussen blijft van belang, dat het rechtsgevoel van de justitiabele zoveel als redelijkerwijs mogelijk is wordt bevredigd". ${ }^{254}$ Zulks impliceert dat indien een zitting overbodig voorkomt, de rechter daartoe besluit maar daarbij deze keuze naar de burger toe uitdrukkelijk motiveert, of dat hij zich zo "inschikkelijk" toont door de burger toch zijn "day in court" te gunnen. Dat punt lijkt mij soms juist ook in geschillen met een sterk technische inhoud van groot belang. Na alles wat over expertise gezegd is (hier en in een concreet geding) is het goed te kijken naar de persoonlijke waardering van betrokken personen. Niet alleen om deze te contenteren maar ook omdat het rechterlijk oordeel doorgaans niet alleen op calculeerbare waarnemingen en uitspraken kan rusten.

\subsection{Afronding, conclusies en aanbevelingen}

\subsubsection{Samenvatting}

Het vierde Deel van deze studie begon met een korte studie naar de contentieuze waarborging van non-contentieuze waarborgen. Het profiel van het bestuursprocesrecht volgens het Whrol was daarbij de inzet van bespreking. Ik heb mij daarbij uitdrukkelijk uitgesproken ten faveure van de rechtsbeschermingsfunctie van het bestuursproces. Uitdrukkelijk heb ik daarbij gewezen op het feit dat de lijdelijkheid van de rechter niet aan zijn activiteit in de

252. Ibidem.

253. A.w., p. 37.

254. Ibidem. 
weg hoeft te staan. In het bijzonder noemde ik daar de aanvulling van rechtsgronden en van feiten op voet van het beginsel van ongelijkheidscompensatie. Voorts heb ik mij in het bijzonder bekommerd om de relatie tussen de noncontentieuze en de contentieuze procedure. Mijn uitgangspunt is daarbij steeds geweest dat de rechter moet voorkomen dat hij onnodig (ongevraagd) activiteiten verricht die bij uitstek thuis horen in de non-contentieuze fase. In dat perspectief heb ik er op gewezen dat de non-contentieuze procedure zelf ook een rechtsbeschermingsbelang dient. De mogelijkheid om "in natura" aan belangen tegemoet te komen zou zoveel mogelijk tot zijn recht moeten komen. Het bestuursproces moet er op gericht zijn dat een ieder krijgt wat hem toekomt: als dat een andere bestuursbeslissing is, moet die ook zoveel mogelijk worden verzekerd. ${ }^{255}$ In dit verband sprak ik over het streven naar de "meest optimale individuele rechtsbedeling", stelde ik het besluit als object van geschil voorop en verklaarde ik mijn instemming met de vernietigingsbevoegdheid van de administratieve rechter. Vervolgens heb ik betoogd dat de rechter zich rekenschap moet geven van de beoordelings-opportuniteit die aan feitenvaststelling verbonden is. Het karakter van de non-contentieuze procedure en de plaats van de het bestuur daarbinnen, brengen - mijns inziens mee dat de rechter zich tot een "objectieve redelijkheidstoets" zou moeten toeleggen. Dit geldt in het bijzonder voor normatieve keuzes inzake wetenschappelijke waarderingen (waar het bestuur zelf reeds een marginale toets aanlegt) en het vinden van een bevredigende beslissing (c.q. de selectie van alternatieven en het bereiken van "redelijke zekerheid"). ${ }^{256}$

In het verlengde van deze kwestie heb ik mij voorts bezig gehouden met de kwestie van het zelf door de rechter in een zaak voorzien. In dat bestek kwamen opnieuw de bestuurlijke discreties (ten aanzien van de betrokken belangen en de vast te stellen feiten) aan de orde. Ook ben ik ingegaan op de publieke werking van bestuursbesluiten en de kwestie "ex nunc of ex tunc". Een belangrijke ondertoon in deze analyse was steeds de vrees voor een rechterlijke doorkruising van de non-contentieuze besluitvorming. Ik hecht bijzonder aan de mogelijkheid van rechterlijke controle, maar ik hecht er evenzeer aan dat non-contentieuze besluitvorming niet als een gratuite affaire wordt afgedaan: een traject waarvan de fouten wel in het contentieuze proces kunnen worden hersteld. In dat opzicht hoop ik twee punten voldoende duidelijk te hebben gemaakt:

- het intrinsieke belang van de non-contentieuze procedure als een (geaspireerd) open discours over vaststelling van feiten en afweging van belangen in een concreet geval;

255. Als het dan toch op schadevergoeding uitdraait is dat eigenlijk "second best".

256. Ten aanzien van het verdisconteren van onzekerheden omtrent de feiten bij de belangenafweging past uiteraard weer een marginale (subjectieve) redelijkheidstoets. 
- de beperking van de rechterlijke macht, als niet democratisch gelegitimeerde en niet in de non-contentieuze procedure betrokken instantie. Juist in die beperking ligt de kracht van de rol van de rechter. Dat vereist echter wel dat zijn taakvervulling congruent is met die beperking. De rechter moet niet proberen bestuursbeslissingen te nemen of te forceren waar zulks naar inhoud van de betrokken feiten en belangen), naar vorm (van open beraadslaging over feiten en belangen) en naar geëquipeerdheid (in termen van ambtelijke ondersteuning) niet voor de hand ligt. Te lange leste zou dat het vertrouwen in de rechterlijke controle naar mijn stellige overtuiging schaden. In samenhang daarmee zou ook de betrokkenheid (en wellicht zelfs het vertrouwen) van burgers in het bestuur verminderen wat vermag immers een bestuursorgaan dat, discretie of geen discretie, toch te pas en te onpas door de rechter wordt gepasseerd?

Voor de controle op de feitenvaststelling heb ik in het voetspoor van het voorgaande de wenselijkheid van de "objectieve redelijkheidstoets" benadrukt. Ten aanzien van het zelf in de zaak voorzien heb ik de suggestie van een "relatieve voorziening" (een declaratoire uitspraak) gedaan. In algemene zin heb ik gewezen op de noodzaak van hoger beroep en cassatie-beroep juist ook in kwetsbare en complexe geschillen.

In het onderhavige hoofdstuk heb ik mij toegelegd op de bewijsproblematiek, met bijzondere aandacht voor de rol van de deskundige daarin. Bewijsrechtelijke waarborgen stonden hierbij centraal.

Vooraleer ik op specifieke bewijsrechtelijke kwesties ben ingegaan heb ik aandacht besteed aan enkele regels voor de procesvoering volgens het Whrol. Daarbij kwam onder andere de positie van de rechter als dominus litis - een lijdelijke maar actieve rechter - naar voren. In verband daarmee onderstreepte ik de noodzaak van controleerbaarheid en kritiseerbaarheid van het rechterlijk handelen; een punt dat (opnieuw) de noodzaak van een tweede instantie onderlijnt. Zeer nadrukkelijk komt de kwestie van controle en kritiek aan de orde bij de rechterlijke opdracht tot deskundigenonderzoek in het kader van het vooronderzoek. De nieuwste wetsvoorstellen inzake art. 8:47 Awb zijn een ernstige verslechtering van de procespositie van partijen. Ook valt te vrezen dat de rechter op voet hiervan eerder tot integrale hertoetsing van de feiten zal overgaan en de partij-autonomie op de achtergrond zal raken. In verband met die partij-autonomie rijst ook de vraag waarom er niet expliciet in is voorzien dat partijen reeds in het vooronderzoek eigener beweging bewijs kunnen leveren.

Een belangrijk punt van procesvoering was voorts het dualisme rechter-deskundige. Onder verwijzing naar de vaste-deskundigenprocedure volgens de Beroepswet kwam dit punt aan de orde. Ik heb daarbij verwezen naar de 
eerste en tweede vuistregel uit het tweede deel van deze studie. Deskundigheid van rechters mag geen zelfstandige bron van legitimatie van het rechterlijk oordeel vormen. Die bron is en blijft het juridisch oordeel. Waar een minimale "dosis" deskundigheid een kritische waardering van het bewijs op zichzelf genomen ten goede komt, is het zaak dat technische deskundigheid geen belemmering gaat vormen voor een (zuiver) juridisch oordeel inzake de feitenvaststelling (en het op voet daarvan genomen of te nemen besluit).

Bij de start van de uiteenzetting over het bewijsrecht heb ik in het bijzonder op twee punten gewezen. Allereerst op het uitgangspunt dat in het bestuursprocesrecht gestreefd wordt naar het vinden van de materiële waarheid. Voorts dat dit streven niet alleen wordt bepaald door inzichten van wetenschappelijke rationaliteit maar in het bijzonder ook door normatieve uitgangspunten die verband houden met de functie van de procedure en de (daarmee verbonden) rechtspositie van partijen. ${ }^{257}$

Bij het punt van de bewijsomvang heb ik in het bijzonder de nadruk gelegd op het feit dat de rechter niet aanstonds uit zou moeten zijn op een integrale hervaststelling van de feiten. Nu gekozen is voor het rechtsbeschermingsperspectief zal in het bestuursproces de partij-autonomie een duidelijker kenmerk moeten zijn. Dat brengt mee dat in beginsel alleen die feiten aan onderzoek worden onderworpen waar over appellant zich beklaagt. ${ }^{258}$ Ook vloeit uit de partij-autonomie voort dat partijen in de gelegenheid moeten worden gesteld zich uit te laten over de feiten die bij de rechterlijke oordeelsvorming een rol kunnen spelen.

Bij de bewijslastverdeling zal de partij-autonomie al evenzeer een belangrijke rol moeten spelen. Dat brengt mee dat de rechter niet aanstonds zelf de bewijsvoering voor zijn rekening moet nemen. Dat gezegd zijnde staat vast, dat er voor de rechter nu juist goede redenen kunnen zijn om - nadat partijen zelf in de gelegenheid zijn gesteld bewijs te leveren - zelf een deel van de bewijslast op zich te nemen. Ik noemde in dat verband de ongelijkheidscompensatie, de beperkingen in de partij-autonomie, het eigen oordeelsvermogen van de rechter en processtrategische redenen.

Wat de bewijslastverdeling tussen partijen betreft, waren twee uitgangspunten toonaangevend: het vermoeden van rechtmatigheid en de ongelijkheidscom-

257. Ik heb daar aan toegevoegd dat de laatste eisen zeer wel een bijdrage kunnen leveren aan een "rationele heuristiek".

258. In beginsel: de rechter kan ambtshalve (met het oog op de belangpositie van appellant) feiten aanvullen. 
pensatie. Terwijl het bestuur geen absolute zekerheid hoeft te bieden, behoeft de burger slechts gerede twijfel te wekken. ${ }^{2.59}$

Ten aanzien van de bewijsmiddelen heb ik allereerst (nogmaals) op het belang van het verdedigingsbeginsel gewezen. Essentieel daarin is - het reeds eerder genoemde punt - dat geen enkel bewijsmiddel buiten de procedure om tot de rechter mag komen: alle stukken moeten voor partijen ten overstaan van de rechter kritiseerbaar zijn. Dit impliceert in algemene zin dat de procedure moet voorzien in de mogelijkheid tot het leveren van contra-expertise.

Ik ben vervolgens in het bijzonder ingegaan op het deskundigenbericht. In verband daarmee heb ik een korte schets gegeven van hetgeen bekend is over de rol van het ambtsbericht in milieugeschillen. Daaruit blijkt dat het van belang is na te gaan hoe kan worden voorkomen dat het deskundigenbericht de positie van de rechter, en indirect ook die van de partijen, bedreigt. Als de praktijk van een standaardadvies bij een vaste instantie wordt bestendigd zijn in dat opzicht verschillende waarborgen nodig. Daarbij moeten we denken aan de zelfstandigheid van de adviseur, het louter technisch karakter van dit advies, de mogelijkheid van het horen van de adviseur en de mogelijkheid van contra-expertise.

Met Brenninkmeijer ben ik echter van mening dat een meer radicale verandering in de adviescultuur wenselijk is. Als eerste regel zou moeten gelden dat vooraleer de rechter een deskundigenbericht vraagt, partijen tot bewijsvoering en het maken van opmerkingen over de adviesopdracht in staat worden gesteld. Vervolgens zal de rechter voor specifieke vragen een "ad hoc-deskundige" kunnen benaderen. In een dergelijke benadering raakt de positie van de rechter als dominus litis niet in het geding. Voorts is de verleiding tot integrale hervaststelling van de feiten in een dergelijke aanpak minder groot. Ook de partij-autonomie komt beter tot uitdrukking. Niet onbelangrijk is ook dat in deze benadering het bestuur meer nadrukkelijk op zijn bewijslast kan worden aangesproken. Ten slotte speelt mee dat aan de kwaliteit van de feitenvaststelling al in belangrijke mate zou kunnen worden bijgedragen door een vaste deskundige in de non-contentieuze fase.

Ten slotte ben ik ingegaan op de bewijswaardering. De conclusies heb ik in de voorgaande paragraaf betrekkelijk uitgebreid samengevat. Hierbij staan twee punten centraal.

Allereerst de zelfstandige positie van de rechter. In verband daarmee ben ik ingegaan op de kwestie van de rechterlijke overtuiging, de noodzaak van een kritische opstelling en de juridisch vereiste mate van "redelijke zekerheid".

259. Terwijl de rechter daarbij nog de helpende hand kan bieden. 
Ook heb ik het aspect van de formalisering van het bewijs, en de effecten daarvan op de rechterlijke bewijswaardering besproken.

In de tweede plaats was het mij te doen om de positie van de procespartijen. In dat verband heb ik aandacht gevraagd voor de rechterlijke motiveringsplicht en het recht op contra-expertise.

\subsubsection{Een regeling van bewijsrecht?}

Vooraleer ik dit hoofdstuk afsluit, en de conclusies en aanbevelingen uit deze studie opteken, wil ik nog even ingaan op de wenselijkheid van een regeling voor het bestuurlijke bewijsrecht.

In zijn preadvies voor de NJV zet Blaauw zich af tegen de stelling van Van Galen en Van Maarseveen, in hun VAR-preadvies van 1978: "Het beste bewijsrecht is geen bewijsrecht". ${ }^{260}$ Van Galen en Van Maarseveen is het daarbij te doen om de vrees dat formalisering van het vrije bewijsstelsel de snelheid, soepelheid en simpelheid van het bestuursprocesrecht zal terugdringen. ${ }^{261}$ Blaauw stelt daar tegenover dat partijen er recht op hebben "dat een zorgvuldige redengeving omtrent bewijs en beslissing in de uitspraak tot uitdrukking wordt gebracht". ${ }^{262}$ In dat verband verwijst hij naar de stelling van Ten Berge en Tak, dat indien de rechter niet wordt gestuurd en gecorrigeerd door regels, deze zich "onbewust een autoritaire houding kan aanmeten, als van iemand die het allemaal al weet", waardoor subjectieve overtuiging de boventoon gaat voeren. Ook de rechtszekerheid is volgens Blaauw (nog altijd in het voetspoor van Ten Berge en Tak) gediend met formalisering.

IJsselmuiden juicht het daarentegen juist toe dat in het wetsvoorstel AWB geen bewijsregels (althans geen regels voor bewijslastverdeling) zijn opgenomen. Hij stelt voorop dat bewijsregels niet afhankelijk behoren te zijn van rechtsgebieden maar veeleer van "de aard van de rechtsbetrekking, de kennis en macht van iedere partij, het voorhanden zijn van gegevens bij één partij en het belang van derden bij de rechterlijke uitspraak." "Mitsdien" missen (ook) art. 176 en $177 \mathrm{Rv}$ reden van bestaan, terwijl schrappen van deze bepalingen de eenheid van procesvoering (c.q. bewijsrecht) bevordert. ${ }^{263}$

Mij dunkt dat de kans op rechterlijke ontsporing niet wezenlijk wordt beinvloed door formalisering, tenzij de formalisering zeer precieze en strikte

260. Blaauw, a.w., p. 211 en p. 215. Van Galen/Van Maarsseveen, a.w.. p. 68.

261. Ibidem. p. 66.

262. Blaauw, a.w., p. 215.

263. A.w., p. 1488. 
regels betreft maar dan dreigt ook de wenselijk geachte vrijheid van bewijsrecht juist weer verloren te gaan.

Een aantal wezenlijke elementen van het bewijsrecht in het bestuursproces, zoals het uitgangspunt van partij-autonomie, van een actieve rechter, van het vermoeden van rechtmatigheid van het bestreden besluit, van ongelijkheidscompensatie en het verdedigingsbeginsel, behoeven mijns inziens geen uitdrukkelijke codificatie.

Belangrijk acht ik vooral dat het rechterlijk oordeel (over de feiten) controleerbaar is. In dat opzicht acht ik de mogelijkheid van hoger beroep en (of in elk geval) cassatie-beroep onmisbaar. ${ }^{264}$

264. Vgl. Ten Berge/Tak, a.w., p. 356: "Het gemis van een algemene cassatiemogelijkheid in het administratiefprocesrecht doet zich (ook) hier pijnlijk voelen." Zulks in verband met de correctiemogelijkheid terzake van de bewijsvoering. 


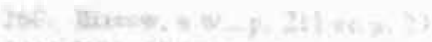

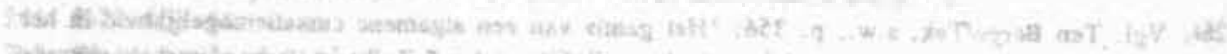

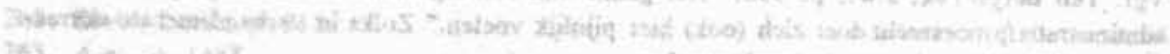

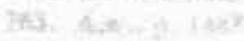

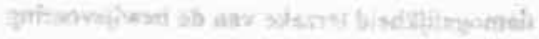




\section{Deel V}

Conclusies en aanbevelingen 



\section{Hoofdstuk 10}

\section{Normstelling en expertise}

Dit laatste hoofdstuk van deze studie bestaat uit drie paragrafen. De eerste paragraaf bevat een samenvatting van hetgeen in de voorgaande hoofdstukken aan de orde kwam. Vervolgens wordt nagegaan welke antwoorden uit het voorafgaande zijn af te leiden voor de in het eerste hoofdstuk geformuleerde probleemstelling. In de laatste paragraaf worden nog enkele concrete aanbevelingen besproken.

\subsection{Samenvatting}

Het eerste deel van deze studie heeft een inleidend oogmerk. Daartoe wordt een schets gegeven van de aanleiding tot deze studie en worden de belangrijkste elementen daarbij (soms nog slechts summierlijk) omschreven.

In hoofdstuk 1 staat de probleemstelling van de studie voorop: Welke juridische waarborgen dienen in acht te worden genomen bij de inbreng van technisch-wetenschappelijke expertise bij het verlenen van milieuvergunningen? Bij deze probleemstelling gaat het niet alleen om een milieurechtelijke studie; de gekozen onderzoeksopzet voorziet er in ook voor het bestuursrecht in algemene zin conclusies te trekken. Wat het milieurecht betreft zal de vergunningverlening ingevolge de $\mathrm{Wm}$ centraal staan.

Op voet van de probleemstelling gaat het niet om een speurtocht naar het vergroten van de inbreng van technisch-wetenschappelijke expertise in de besluitvorming - althans, niet zonder meer. Het uitgangspunt is veeleer van kwalitatieve strekking: hoe moet in de besluitvorming met expertise worden omgegaan. Daarbij staat een tweetal veronderstellingen voorop. Allereerst het niet objectieve en (fundamenteel) onzekere karakter van technisch-wetenschappelijke expertise. Daarnaast de onwenselijkheid dat bestuur en rechter "superdeskundigheid" pretenderen, waarmee de suggestie van een objectieve en bestendige grondslag van genomen beslissingen wordt gewekt.

De onuitgesproken stelling is in dit verband dat, indien deze veronderstellingen houdbaar zouden blijken, dit gevolgen moet hebben voor de specifieke juridische waarborgen die zien op de inbreng van expertise. Teneinde geen enkele waarborg over het hoofd te zien is een brede optiek voor het onderzoek verkieselijk: de idee van rationeel beslissen. Daarmee, in het bijzonder met theorieën over wetenschappelijke rationaliteit, kan de eerste veronderstelling getoetst worden. Voorts kunnen theorieën over rationeel beslissen wel- 
licht een koersaanwijzing geven voor het omgaan met wetenschappelijke onzekerheid.

Voorop staat dat deze studie op tenminste vier punten in praktisch relevante uitspraken moet kunnen resulteren: uitspraken over de verantwoordelijkheid voor de inbreng van deskundigheid, over de noodzaak tot het inwinnen van adviezen, over procedurele waarborgen en over het inhoudelijk verdisconteren van technisch-wetenschappelijke onzekerheden.

In het tweede hoofdstuk wordt de normstelling uit het milieurecht, als exempel van deze studie, nader in kaart gebracht. Allereerst is het de bedoeling duidelijk te maken hoezeer de milieuproblematiek als empirische context van het milieurecht, de samenleving voor technisch-wetenschappelijke problemen stelt. Uit die schets komt een tweetal zeer belangrijke karakteristieken naar voren: het ecologische en het technologisch-dynamische karakter van de milieuproblematiek. In beiderlei opzicht is de milieuproblematiek in sterke mate onderhevig aan een proces van verwetenschappelijking. Als we dit feit verbinden met de voor (delen van) het leefmilieu bestaande vrees voor grootschalige en irreversibele aantasting, dan vormt het belang van een goed leefmilieu in termen van besluitvorming een complex belang.

In het voetspoor van deze vaststelling worden de normen uit het positieve milieurecht nader bestudeerd. In het licht van de technische complexiteit van de milieuproblematiek, moet er vooreerst - in het voetspoor van Waismann op worden gewezen, dat het geven van complete en definitieve beschrijvingen van de empirische werkelijkheid onmogelijk is: slechts incomplete en voorlopige, kortweg "open" omschrijvingen kunnen worden gegeven. Deze stellingname sluit goed aan bij de gegeven karakterisering van de milieuproblematiek èn bij het gebruik van open normen in het milieurecht.

Een aantal van deze normen wordt vervolgens beschreven. In de eerste plaats een aantal open publiekrechtelijke milieunormen, waaronder grondrechten, vergunningen, zorgplichten en milieu-delicten. Vervolgens behoeft ook de voor het milieurecht belangrijke open privaatrechtelijke norm van de aansprakelijkheid uit onrechtmatige daad de aandacht. Bij wijze van contrast is het opmerkelijk dat de tendens bestaat om in bepaalde gevallen juist gesloten normen, waaronder de zogenoemde "algemene regels", te hanteren.

De conclusie bij het tweede hoofdstuk is dat in het milieurecht bij voortduring sprake zal zijn van "voortschrijdende normstelling". Het gevaar voor grootschalige en onomkeerbare milieuschade enerzijds en de ecologische en technologisch-dynamische karakteristieken anderzijds, staan daarvoor garant. De noodzaak tot open en voortschrijdende normstelling vormt het paradigma van het milieurecht. In aansluiting daarop zal de rol van het ongeschreven milieurecht steeds van vitaal belang zijn. 
In het derde hoofdstuk wordt nagegaan welke aanknopingspunten er zijn voor een juridische analyse en beoordeling van de inbreng van expertise bij open (milieurechtelijke) normen.

Openheid van normen noodzaakt, zo luidt het uitgangspunt van dit hoofdstuk, steeds weer tot kennisvergaring. Twee vormen van openheid zijn te onderscheiden: openheid in termen van de toepassingscondities van een bevoegdheid en openheid in termen van keuze of en zo ja, hoe een bevoegdheid zal worden gebruikt. De bijbehorende termen, beoordelingsruimte, beoordelingsvrijheid en beleidsvrijheid, worden nader omschreven. Vervolgens wordt nagegaan wat de rol is van expertise bij beoordeling en bij belangenafweging. In beide gevallen is vaststelling van feiten noodzakelijk en juist daarbij kan de inbreng van expertise wenselijk zijn.

Bij de beoordeling vloeit de bestuurlijke plicht tot vaststelling van de feiten voort uit het legaliteitsbeginsel (is aan de toepassingscondities voldaan?). De feitenvaststelling is ingebed in een proces van interpretatie en kwalificatie. Art. 3:2 Awb vormt hierin een belangrijke maatstaf voor de inbreng van expertise. De bijzondere verantwoordelijkheid van het bestuur tot vaststelling van de feiten vloeit overigens voort uit de plicht tot het maken van een belangenafweging. Hierbij speelt het onderkennen en waarderen van belangen een grote rol. Een belangrijk deel van het werk betreft het vergelijken van alternatieve besluitvormingsopties. Ook in dit bestek vormt art. 3:2 Awb een belangrijke maatstaf voor kennisvergaring. Daarnaast speelt met name art. 3:4 Awb een vooraanstaande rol.

Bij beoordeling en bij belangenafweging wordt de feitenvaststeller geconfronteerd met onzekerheid over de feiten. Daarin kunnen twee vormen worden onderscheiden: de principiële en de praktische onzekerheid. De principiële onzekerheid is onvermijdelijk in al ons inzicht aanwezig: wij kunnen nimmer met zekerheid zeggen of wij de empirische werkelijkheid in onze theorieën op adequate en accurate wijze hebben verklaard. Praktische onzekerheid legt op besluitvorming een meer concrete druk: soms ontberen we de noodzakelijk geachte theorieen en is er (aldus) sprake van schaarste in kennis.

Tegen deze achtergrond worden de beoordeling en belangenafweging bij verlening van Wm-vergunningen nader geanalyseerd. Daarbij wordt zichtbaar op welke punten door het bestuur kennis zal moeten worden vergaard teneinde de relevante feiten vast te stellen.

In het tweede deel van deze studie wordt gezocht naar aanknopingspunten voor rationeel beslissen. Dit geschiedt in het vierde hoofdstuk, alwaar in het voetspoor van Snellen vier rationaliteiten worden onderscheiden: politieke, juridische, economische en wetenschappelijke.

De wetenschappelijke rationaliteit staat in de aandacht voorop. De veronderstellingen daaromtrent vormen immers de basis tot de onderhavige studie. De 
verkenning van de wetenschappelijke rationaliteit omvat tevens een nadere analyse van de principiële onzekerheid waarover in het derde hoofdstuk is gesproken. Praktische onzekerheid komt vervolgens onder de noemer van de economische rationaliteit aan de orde. Ten slotte worden onder de noemer van juridische rationaliteit de consequenties van een en ander in de vorm van een aantal vuistregels voor rationeel beslissen neergelegd.

Op het punt van de wetenschappelijke rationaliteit worden de veronderstellingen uit het eerste hoofdstuk bevestigd. Door onderdeterminatie moeten wij aanvaarden dat onze theorieen steeds fundamenteel onzeker zullen zijn. In het voetspoor daarvan zijn waarden van groot belang voor de keuze van theorieën bij het verrichten van wetenschappelijk werk. Aldus wordt de schijn gewekt van wetenschappelijke rationaliteit als een contingente sociale consensus. Ook een positievere visie is mogelijk. Het wetenschappelijke werk leidt, als produkt van een "succesvolle groep" tot een steeds groter puzzeloplossend vermogen. In die zin is wel degelijk sprake van wetenschappelijke vooruitgang. Daarbij kunnen niet-wetenschappelijke waarden, meet- en rekenfouten in de wetenschappelijke praktijk worden geëlimineerd. Over het hanteren van bepaalde waarden kan wellicht overeenstemming bereikt worden en in die zin kan dan zelfs van "objectiviteit" gesproken worden. Essentieel in de wetenschapsbeoefening is bovenal het uitoefenen van kritiek in een open debat tussen betrokkenen.

Economische rationaliteit wordt in dit hoofdstuk in verband gebracht met praktische onzekerheid. Dit type onzekerheid staat in de weg aan een rationeel-synoptische wijze van besluitvormen. Als alternatief wordt de theorie van de bevredigende oplossing (Simon) onderzocht op zijn toepasbaarheid bij het geven van rechtsnormen. Dit leidt tot een "theorie" over juridisch bevredigend beslissen in drie stappen (selecteren, onderzoeken en toetsen). In deze "theorie" ligt besloten dat de eisen van zorgvuldigheid en redelijkheid een relatieve strekking hebben - verwijzend naar "redelijkerwijs in beschouwing te nemen alternatieven", "redelijke zekerheid" omtrent de feiten en "nietonevenredigheid" van besluiten. Ook past in deze "theorie" het streven naar reductie van onzekerheid.

Voor juridische rationaliteit is (het bestendigen van) vertrouwen in het recht essentieel. Voor de legitimatie van rechtsnormen is het wenselijk dat deze in een (zoveel mogelijk) open discours tot stand worden gebracht. Dat geldt niet alleen voor wetgeving met medewerking van het parlement maar ook voor bestuurlijke besluitvorming ter uitvoering van de wet. Naast een procedurele rechtvaardiging is ook een inhoudelijke legitimatie gewenst. Opvattingen over democratie en mensenrechten kunnen in dat verband een belangrijke rol vervullen.

Voor juridisch rationeel beslissen in gevallen van onzekerheid kunnen vervolgens vijf vuistregels worden geformuleerd. Respectievelijk betreffen deze de 
bestuurlijke verantwoordelijkheid, de bevredigende beslissing, de openheid van besluitvorming, gangbare opvattingen en kritiek en het omgaan met waarden. Deze vijf regels worden ingezet als referentiepunten bij het vervolg van deze studie.

Ten slotte is een aantal praktische kwesties van belang: wanneer moet expertise worden ingewonnen, de eenduidigheid van beschikbare kennis, schijnzekerheden, de deskundige, de onafhankelijkheid van deskundigen en soorten adviezen. In het voetspoor daarvan wordt voor een aantal normatieve keuzes bij de vaststelling van feiten nagegaan welke opstelling van het bestuur mag worden verwacht. In het verlengde hiervan moet het belang van de bestuurlijke verantwoordelijkheid voor alle facetten van de feitenvaststelling opnieuw worden benadrukt. Ook enkele andere vuistregels behoeven naar aanleiding van de besproken praktische kwesties aanscherping.

In het derde deel van deze studie wordt een speurtocht ondernomen naar juridische waarborgen voor de inbreng van expertise in de non-contentieuze procedure. Daarbij staat een piramidale opzet voorop: eerst wordt bezien of rationeel beslissen als een leidende eis van het publiekrecht kan worden beschouwd, vervolgens worden meer specifieke waarborgen in het algemene deel van het bestuursrecht onderzocht, en ten slotte volgt een analyse van enkele specifiek milieurechtelijke waarborgen voor het omgaan met expertise. Waar mogelijk worden bevindingen vergeleken met de vuistregels uit het tweede deel van deze studie.

In hoofdstuk 5 gaat het - in de geschetste opzet - om de vraag of rationeel beslissen kan worden gezien als een eis van rechtmatig bestuur. De eerste inzet is na te gaan wat het bestuursrecht eigenlijk kan bieden. Daartoe wordt aangeknoopt bij de "drie dimensies van het bestuursrecht" van Van der Hoeven: legitimatie van de regeermacht, instrumentatie en normatieve begrenzing. Omdat het in deze studie primair om waarborgen te doen is krijgt vooral de rechtsbescherming (in ruime zin) de aandacht. Daarbij wordt allereerst gerefereerd aan het standpunt van Van der Hoeven dat het "microbesturen" een onafhankelijke rechterlijke controle behoeft. En passant wordt er overigens op gewezen dat de democratie-gedachte, vanwege het accent op openbare meningsvorming, kan bijdragen aan een rationele besluitvorming mits rechtsstatelijke waarborgen in acht worden genomen.

Aan de hand van het 'rationaliteitspostulaat' van Van Male en de 'evidente rationaliteit' van Nicolaï, volgt een meer indringende analyse. Hoewel de schets die genoemde auteurs geven van de opkomst van ongeschreven waarborgen als dragers van een relativistische rationaliteitsidee verhelderend is, komt in hun analyses juist de begrenzing in de eis van rationeel beslissen nog onvoldoende naar voren. In deze studie wordt daartoe de spanning tussen de 
behartiging van het algemeen belang en de burgerlijke vrijheid als startpunt genomen. Daarbij wordt de politieke wil tot machtsuitoefening, mits democratisch gelegitimeerd, getypeerd als een onmisbare motoriek voor het overheidsbestuur. Juridische inperking daarvan, ter bescherming van de burgerlijke vrijheid, is nodig, maar op zodanige maat dat ruimte blijft voor de werking van deze motoriek. Dit leidt tot de stelling dat het willekeurverbod een toonaangevende rol vervult.

Het verbod van willekeur (in ruime zin) wordt in het voetspoor hiervan omschreven als het paradigma uit het bestuursrecht; een ongeschreven genusbeginsel dat de uiterste grens van de politieke machtsuitoefening stelt. Dit willekeurverbod draagt èn begrenst de eis van rationeel beslissen. Meer concreet impliceert dit dat het relativisme in het hedendaagse rationaliteitsidee tot uitdrukking kan komen in eisen van een open besluitvorming en in het verbod van irrationeel handelen. Met het oog op de inbreng van expertise wordt daarbij gewezen op een tweetal bij uitstek belangrijke aspecten: het corrigeren van onjuistheden (waartoe ook het kritiseren en kritiseerbaar maken van (ontwerp-) beslissingen behoort), en de eis van een juridisch bevredigende beslissing.

In het zesde hoofdstuk worden specifieke waarborgen in het algemeen deel van het bestuursrecht gezocht. Uitgangspunt is dat de aan de non-contentieuze procedure verbonden juridische waarborgen, in aansluiting op de democratische legitimatie, moeten bijdragen tot een 'publiekrechtelijke legitimatie' van bestuursbesluiten. Deze opvatting is een logisch sequeel van de stelling dat ook het micro-besturen een eigen legitimatie en een onafhankelijke controle behoeft. Tegelijkertijd onderstreept dit het zelfstandige en "materiële" belang van de non-contentieuze procedure.

De naleving van ongeschreven rechtsbeginselen vormt het fundament voor de publiekrechtelijke legitimatie. In het bijzonder wordt - opnieuw - het willekeurverbod in ruime zin (als genusbeginsel) genoemd, en met het oog op de expertise problematiek, ook een drietal speciesbeginselen: het willekeurverbod (in enge zin), het zorgvuldigheids- en het motiveringsbeginsel.

De procedures uit de Awb vormen een belangrijke (positieve) neerslag of uitwerking van (aspecten van) genoemde beginselen. Derhalve worden de algemene standaardprocedure, de openbare voorbereidingsprocedure, de uitgebreide openbare voorbereidingsprocedure en de bezwaarschriftenprocedure uit de Awb besproken. Eén van de conclusies daaruit is de afwijzing van de idee van een (bijna) algemeen verplichte bezwaarschriftenprocedure als verlengde besluitvorming. Deze keuze miskent het belang van de noncontentieuze besluitvorming als een vorm van open beraadslaging, voorafgaand aan het nemen van een in beginsel definitief besluit. Het voorstel wordt gedaan om in de non-contentieuze besluitvorming steeds een tweede- 
ling te hanteren: eerst een voornemen- of aanvraag-fase en dan een ontwerpfase. Daarop volgt dan de mogelijkheid van (contentieus) beroep in twee (feitelijke) instanties. Een andere conclusie is dat de zorg voor de deskundigheid van de burger er toch wat bekaaid af komt. Hoewel in de non-contentieuze procedure (in beginsel) geen zware bewijslast bij de burger moet worden gelegd, lijkt het wijs om in bepaalde gevallen toch in deskundige ondersteuning te voorzien.

Vervolgens worden de specifieke regels over advisering nader bestudeerd. Wat de gerichte advisering betreft gebeurt dit in drie stappen: verwerving van deskundigen-advies, kritiseerbaarheid van deskundigen-advies (voorzorg en controle) en het gezag van deskundigen-advies. In de conclusie bij dit onderdeel komen de vuistregels uit het vierde hoofdstuk weer aan bod. Allereerst de bestuurlijke verantwoordelijkheid voor het advies: het bestuur moet randvoorwaarden scheppen en een marginale toetsing uitvoeren (redelijkheid en zorgvuldigheid). In de tweede plaats moet het advies (indien basis van het voorbereidend onderzoek) alle essentiële elementen betreffen, zij het binnen de grenzen van de bevredigende beslissing. In de derde plaats komt het grote belang van de controleerbaarheid van het advies, in het bijzonder langs de weg van inspraak, aan de orde. Daarbij wordt het punt van de ondersteuning van de deskundigheid van burgers opnieuw aangekaart. Ten vierde wordt ingegaan op de vraag of een advies steeds de wetenschappelijk gezien (meest) 'gangbare visie' moet uitdragen. Mede met het oog op tegenstrijdige adviezen wordt de wenselijkheid van een vaste, onafhankelijke adviseur en een 'worstcase scenario' besproken. In de vijfde en laatste plaats komt het belang van onafhankelijkheid van een adviseur aan bod.

Bij ongerichte advisering staan de zogenoemde richtlijnen centraal. Na een korte omschrijving van de motieven tot het geven van richtlijnen, van richtlijngevers en van het juridisch gezag van richtlijnen (wanneer kan worden afgeweken?), wordt een beoordeling gegeven. Daarin staat voorop dat de overtuigingskracht van richtlijnen telkenmale kritisch moet worden geanalyseerd. Het is noodzakelijk om elk onderdeel - wetenschappelijke onderbouwing, interpretatie van vage termen en beleidskeuzes - afzonderlijk nauwkeurig te bezien. De rechter moet zich op het punt van beleidskeuzes in richtlijnen rekenschap geven van de beleidsvrijheid van bestuursorganen. Met het oog op de beleidskeuzes doet hij er tevens goed aan te waken voor de onafhankelijkheid van de richtlijn(gever). Wat het technisch-wetenschappelijke aandeel van de richtlijn betreft, kan een vergelijking met het deskundigenadvies worden gemaakt. In het bijzonder is te bezien of de technische onderbouwing van (bestendig gebleken) kwaliteit is en of er sprake is van nieuwe inzichten danwel bijzondere omstandigheden in het concrete geval. Het bestuur zal steeds uitdrukkelijk de mogelijkheid tot contra-expertise (via inspraak) mogelijk moeten maken. 
In de conclusie van hoofdstuk 6 wordt nogmaals het belang van openheid van besluitvorming benadrukt. Ook komen de bezwaren tegen de verplichte bezwaarschriftenprocedure en het gebrek aan aandacht voor de deskundigheid van de burger-belanghebbende aan de orde. Voorts wordt, met het oog op advisering, de eigen verantwoordelijkheid van het bestuur, de eis van het nemen van een bevredigende beslissing, de onpartijdigheid van de adviseur, de kenbaarheid en inzichtelijkheid van adviezen, en de noodzaak van een kritische opstelling (en de mogelijke rol van vaste-deskundigen daarbij) onderstreept. Het hoofdstuk wordt afgesloten met een aantal uitwerkingspunten voor het vervolg van de studie.

In hoofdstuk 7 wordt de speurtocht naar juridische waarborgen voor de inbreng van expertise toegespitst op het milieurecht. Daarbij gaat het in het bijzonder om vier onderwerpen: de m.e.r., de zorg voor de deskundigheid van burgers, de inbreng door vaste deskundigen en enkele aanknopingspunten voor onzekerheidsreductie.

De m.e.r. wordt tamelijk uitgebreid besproken, juist omdat de pretentie ervan is dat het een "rationele besluitvormingsprocedure" is, waarin de inbreng van technische-expertise een belangrijke rol speelt. Bij de bespreking van de m.e.r.-procedure en de werkingssfeer van de m.e.r. speelt de evaluatie door de ECW een belangrijke rol. Ook wordt ingegaan op het regeringsverslag inzake de evaluatie van de m.e.r. In conclusie komt een drietal punten aan de orde.

Allereerst de scheiding van verantwoordelijkheden. Het regeringsstandpunt dat de Cmer zich tot advisering zou moeten beperken - ook als het bevoegd gezag tevens initiatiefnemer is verdient ondersteuning. Openheid van besluitvorming moet kunnen waarborgen dat het bestuur zich van het advies van de Cmer voldoende rekenschap geeft. Scheiding van verantwoordelijkheden moet tevens impliceren dat indien het MER door het bevoegd gezag is aanvaard, eventuele latere bijstelling van het MER primair een verantwoordelijkheid van het bestuur is. In het voetspoor hiervan zou overeenkomstig het voorstel van de ECW een omwisseling van de derde en vierde stap uit de m.e.r.-procedure (beoordeling aanvaardbaarheid MER - inspraak en toetsing MER) moeten worden doorgevoerd. Vooreerst zou de Cmer haar advies moeten geven, daarna zou het bestuur over de aanvaardbaarheid van het MER moeten beslissen. In die optiek ligt het voor de hand dat de initiatiefnemer tussen beide stappen in nog tot bijstelling kan worden aangesproken. De procedurele bezwaren van de regering overtuigen hier niet. Het is weliswaar juist dat deze aanpak besluitvorming in twee stappen vergt, maar in Hoofdstuk 6 werd reeds uitgesproken dat het juist ook wenselijk is om de noncontentieuze besluitvormingsprocedure te splitsen in een voornemen- en een ontwerpfase; in die visie valt het procedurele bezwaar weg. 
In de tweede plaats kan de m.e.r.-procedure bijdragen aan open milieurechtelijke normering. Art. $7.35 \mathrm{Wm}$ leidt er toe dat het bevoegd gezag zich moet bezinnen op de technische en maatschappelijke adequaatheid van de voorgeschreven normen. In die stellingname is het risico van ernstige milieuschade niet alleen grondslag voor m.e.r.-plichtigheid, maar ook van een open verbinding met "voortschrijdende normstelling".

De conclusie luidt dat de m.e.r.-procedure goed aansluit bij de theorie van de bevredigende beslissing. Daarbij springt de selectie van te onderzoeken alternatieven mede in verband met het opstellen van richtlijnen, in het bijzonder in het oog. Afsluitend kan met de ECW en de regering worden gesteld dat de m.e.r.-regeling een redelijk (om niet te zeggen "bevredigend") functionerend instrument is.

Het tweede onderwerp in dit hoofdstuk is de zorg voor de deskundigheid van burgers. Bij besluitvorming over technisch-complexe belangen, zal de openheid, c.q. de toegang tot het debat over het te nemen besluit ook materieel moeten worden geëffend. Het bestuur heeft niet alleen een zorgplicht om burgers relevante informatie te verschaffen, maar ook om burgers in de gelegenheid te stellen zich met een onafhankelijke deskundige te verstaan. Als mogelijk aanknopingspunt lijkt de "gedachtenwisseling" van art. 3:25, eerste lid Awb geschikt. Tegelijkertijd zal in de non-contentieuze procedure het uitgangspunt moeten blijven dat burgers slechts hun belang behoeven te stellen. Al te riante voorzieningen zouden in een verhoging van de noncontentieuze bewijslast van burgers kunnen resulteren.

Voorts bevat hoofdstuk 7. het pleidooi om bij technisch-complexe besluitvorming een algemeen adviesrecht voor een onafhankelijke deskundige in het leven te roepen. Daarmee kan het leveren van contra-expertise institutioneel gewaarborgd worden. Qua vormgeving ware te denken aan een organisatie met regionale vertakkingen. In dat verband worden twee 'instanties', de Cmer en de Inspectie milieuhygiëne onderling vergeleken. Daaruit komt naar voren dat de inspectie niet voldoet aan de in acht te nemen waarborgen voor onafhankelijkheid. Wat de inhoud van de adviezen betreft staat overigens vast dat deze zich niet alleen zou moeten richten naar technische inzichten maar ook naar de opdracht van de wet (in het bijzonder het streven naar de hoogst mogelijke milieubescherming).

Ten slotte wordt ingegaan op de juridische aanknopingspunten voor onzekerheidsreductie. In dat verband komen de openheid van besluitvorming, het vergelijken van alternatieven, het expliciteren van leemtes in kennis, het ALARA- en voorzorgbeginsel, evaluaties, de actualiseringsplicht, compenserende maatregelen en verzekeringen aan de orde.

In het vierde deel van de studie gaat het om het waarborgen van de (noncontentieuze) waarborgen. Een kwestie die de vraag opwerpt hoe de admini- 
stratieve rechter omgaat met (de inbreng van) expertise. Deze kwestie wordt in twee etappes besproken. Allereerst komt daarbij de functie van de administratieve rechter aan bod. Interessant is met name vanuit welke optiek, op welke wijze en in welke mate de administratieve rechter zich met de feitenvaststelling moet of mag inlaten. Vervolgens is het interessant om in te gaan op de feitenvaststelling zelf en de rol van de factor deskundigheid daarbij. De opzet van het onderzoek en de regels van het administratieve bewijsrecht zijn daarbij in het bijzonder van belang.

Hoofdstuk 8 begint met een schets van de contouren van het nieuwe bestuursprocesrecht. Uitdrukkelijk wordt ingestemd met de keuze voor de rechtsbeschermingsfunctie van het bestuursproces. Daarmee wordt ook het uitgangspunt van de partij-autonomie aanvaard. Dit uitgangspunt laat echter uitdrukkelijk ruimte voor toepassing van 'ongelijkheidscompensatie' door de administratieve rechter - met name door de mogelijkheid tot aanvulling van rechtsgronden en feiten.

Een belangrijk aandachtspunt is de relatie tussen de non-contentieuze en de contentieuze procedure. Uitgangspunt is daarbij dat de rechter moet voorkomen dat hij onnodig of ongevraagd activiteiten verricht die juist in de noncontentieuze procedure thuishoren. Ter schraging van deze zienswijze wordt er (nogmaals) op gewezen dat de non-contentieuze procedure ook een democratisch en rechtsbeschermend oogmerk heeft. Een en ander komt tot uitdrukking in de open procedure waarin over het te nemen besluit in zijn totaliteit (dat wil zeggen met het oog op alle denkbare gevolgen) kan worden beraadslaagd. Daarbij staat het streven naar de meest optimale individuele rechtsbedeling voorop. Zulks omvat ondermeer het streven naar effectief respect voor betrokken belangen - in 'natura'). In dit bestek is het zaak dat de rechter bijdraagt aan de mogelijkheden om langs non-contentieuze weg zo passend mogelijke beslissingen te nemen. In die optiek past - op praktische grond dat in het bestuursproces het bestreden bestuursbesluit als object van geschil wordt aangemerkt en dat de rechter dit besluit, zo het onrechtmatig blijkt, kan vernietigen. Daarbij speelt in zoverre nog een principieel punt dat na vernietiging het bestuur niet aan zijn verantwoordelijkheid voor herbeslissen kan ontkomen.

Voorts is uitdrukkelijk gewezen op de aan de feitenvaststelling verbonden bestuurlijke beoordelings-opportuniteit. In verband hiermee zal de rechter moeten uitgaan van het primaat van het bestuur tot feitenvaststelling. Dienovereenkomstig zal de rechter het feitenvaststellend handelen van het bestuur inhoudelijk moeten toetsen aan de maatstaf van de "objectieve redelijkheid".

In het voetspoor van deze opstelling behoeft vervolgens de wenselijkheid (om niet te zeggen, toelaatbaarheid) van het zelf door de rechter in de zaak voorzien aandacht. Indien en voorzover bestuurlijke discretie in het geding is - en 
de stelling is dat zulks ook ten aanzien van de feiten het geval is (de normatieve keuzes) - zal zelf voorzien achterwege moeten blijven. Ook de publieke werking van besluiten en de beoordeling ex nunc of ex tunc vormen in dit verband een hindernis. Kernpunt van de beschouwing in het achtste hoofdstuk is de bescherming van de waarden van de non-contentieuze procedure èn de vrees voor een te groot vertrouwen op de (draagkracht) van rechterlijke geschilbeslechting. Per saldo wordt daarom bepleit om bij de rechterlijke toetsing het primaat van het bestuur bij de feitenvaststelling en het criterium van de "objectieve redelijkheid" voorop te stellen. Wat het zelf in de zaak voorzien betreft lijkt de beperking tot het treffen van voorzieningen met een 'relatief' karakter een praktische garantie te kunnen bieden voor respect voor bestuurlijke discretie. Last but not least wordt (nogmaals) gewezen op het grote belang van rechtspraak in twee instanties - juist (ook) als het gaat om technisch complexe geschillen.

In hoofdstuk 9 staan naast een korte schets van het verloop van de contentieuze procedure, de regels van het administratief bewijsrecht centraal. Vooreerst komt (echter) de rol van de administratieve rechter als dominus litis, meer precies als lijdelijke maar actieve rechter aan de orde. Gegeven de grote rechterlijke invloed op het geding is het belang van kritiseerbaarheid en controleerbaarheid van rechterlijke beslissingen groot - waarbij alweer op de wenselijkheid van rechtspraak in twee instanties kan worden gewezen. Vooral op het punt van de kritiseerbaarheid van de rechterlijke beslissing tot het verrichten van een onderzoek door deskundigen bestaat er reden tot zorg. Art. 8:47 Awb biedt de procespartijen weinig soelaas. Daarbij valt te vrezen dat de rechter in technisch complexe geschillen autonoom tot een deskundigenonderzoek zal beslissen, waarbij - alle partij-autonomie ten spijt - een zodanig ruime opdracht wordt gegeven dat het al snel tot een integrale hervaststelling van de feiten zal komen - alle non-contentieuze waarborgen ten spijt. Mitsdien is een sterkere positie voor de procespartijen in het vooronderzoek beslist aan te bevelen.

Aan de hand van een korte bespreking van de "vaste-deskundigenprocedurenieuwe-stijl", komt de kwestie van het dualisme van rechter en deskundige weer in beeld. Hier past toch het in de eerste vuistregel geformuleerde standpunt: eigen technische deskundigheid is nuttig (en een bepaald minimum lijkt zelfs noodzakelijk), maar eigen deskundigheid moet geen zelfstandige grondslag worden ter legitimatie van het (bestuurlijk of) rechterlijk oordeel.

Het administratief bewijsrecht wordt aansluitend nader verkend door in te gaan op de problematiek van de bewijsomvang, de bewijslastverdeling, de bewijsmiddelen en de bewijswaardering. Vooreerst moet daarbij worden opgemerkt dat het vinden van de materiële waarheid - als primair oogmerk - is 
ingebed in normatieve uitgangspunten die verband houden met de functie van de procedure en de belangenpositie van partijen daarin.

Ten aanzien van de bewijsomvang zal de rechter, gegeven het rechtsbeschermingsperspectief, de partij-autonomie serieus moeten nemen. Mitsdien zou een ambtshalve integrale hervaststelling van de feiten achterwege moeten blijven. De procespartijen moeten zo vroeg mogelijk in de procedure in de gelegenheid worden gesteld om zich over de feiten uit te laten.

Ook bij de bewijslastverdeling moet de partij-autonomie tot uitdrukking komen. De rechter zou echter ter compensatie van de (negatieve) ongelijkheid van de burger-partij in de procedure, een deel van het bewijs voor zijn rekening kunnen nemen. Voor de bewijslastverdeling tussen partijen is overigens het vermoeden van rechtmatigheid als een belangrijk ijkpunt aan te wijzen. Zowel in het 'voorportaal' van de bewijsvoering, bij de motivering van het beroepschrift en de preprocessuele adstructie door het verwerend bestuursorgaan, als bij de echte bewijsvoering speelt dit vermoeden met de ongelijkheidscompensatie een belangrijke rol. Overigens lijkt het wijs om hier de verleiding te weerstaan om het adagium "wie stelt moet bewijzen" toe te passen; daarvoor is het patroon van de bewijslastverdeling beslist te grillig. Op het punt van de bewijsmiddelen is het verdedigingsbeginsel van groot belang. Procespartijen moeten zich over alle voor het rechterlijk oordeel relevante processtukken kunnen uitlaten. Bij technisch-complexe geschillen zou de mogelijkheid tot het leveren van contra-expertise dan ook regel moeten zijn. Sprekend over expertise zijn vooral de deskundigenberichten interessant. Met het oog daarop zijn de ervaringen met het ambtsbericht in milieugeschillen veelzeggend. Daarbij blijkt hoezeer toch moet worden gewaakt voor uitholling van de positie van de rechter als dominus litis en voor het automatisme van integrale hervaststelling van de feiten. In het verlengde daarvan lijkt het wijs te kiezen voor advisering aan de rechter op ad hocbasis. Daarbij moet het steeds gaan om specifieke vragen, nadat partijen eerst in de gelegenheid zijn gesteld zelf bewijs te leveren. In elk geval dienen partijen de mogelijkheid te hebben om zich over de opdracht aan een deskundige uit te laten - zoals de regering oorspronkelijk ook voorstelde. Bij een dergelijke aanpak behoeft niet te worden gevreesd voor een standaard-hervaststelling van de feiten, noch voor aantasting van de partij-autonomie; het bestuur kan aanstonds op zijn "preprocessuele bewijslast" worden aangesproken. Daarbij kan de rechter kan zijn lijdelijke maar actieve rol ten volle waar maken, en de non-contentieuze procedure behoudt zijn zelfstandige waarde.

Ten slotte komt de bewijswaardering aan bod. De zelfstandige positie van de rechter is hierin evident. Daarom verdient het fenomeen van de "rechterlijke overtuiging" nader de aandacht. In dat verband komt alras de wenselijkheid van een kritische rechterlijke opstelling naar voren. Voor alle duidelijkheid: de rechterlijke overtuiging strekt er niet toe onzekerheid in de bewijsvoering 
te elimineren. Het gaat er om dat althans een juridisch noodzakelijke mate van zekerheid wordt bereikt: het gaat om "redelijke zekerheid". Bij kwetsbare belangen zal de bewijslast doorgaans groter zijn - voor het bestuur, maar dientengevolge vaak ook voor een opponerende burger. Erg belangrijk is dan de motivering van de rechterlijke bewijswaardering. Met name waar het gaat om een oordeel over methodisch kritiek. In het verlengde daarvan moet (opnieuw) op de wenselijkheid van een recht op contra-expertise en rechtspraak in twee rechterlijke instanties worden gewezen. Ten slotte moeten de voor- en nadelen van de formalisering van bewijs onder ogen worden gezien. Een belangrijk punt daarbij is de stelling dat het bestuur onder omstandigheden op grond van nieuwe inzichten tot afwijking (of aanvulling) van formele regels van bewijsrecht kan besluiten.

\subsection{Conclusies}

Welke juridische waarborgen dienen in acht te worden genomen bij de inbreng van technisch-wetenschappelijke expertise bij het verlenen van milieuvergunningen? Op voet van deze probleemstelling is het zojuist samengevatte onderzoek verricht. Het zou praktisch zijn indien nu op deze plaats kortweg het antwoord op deze probleemstelling zou volgen.

'Kortweg', impliceert aanstonds dat details buiten beschouwing blijven. Op vele plaatsen in het onderzoek is detail-commentaar gegeven op bestaande (of juist ontbrekende) regels of op de toepassing (of juist het achterwege blijven) daarvan. Het heeft geen zin om daar nog op terug te komen. Een aantal kwesties mag hier echter niet onvermeld blijven.

In de eerste plaats is uit het onderzoek naar voren gekomen dat het zoeken naar juridische waarborgen voor de inbreng van expertise niet enkel beschouwd moet worden vanuit het oogmerk hoe deze inbreng kan worden gemaximeerd. Inbreng van expertise is in die zin geen kwantitatief maar een kwalitatief probleem. Teneinde te voorkomen dat de aandacht beperkt blijft tot het beschikken over meer of minder deskundigheid, zou het wellicht ook beter zijn te spreken over het 'omgaan met' expertise.

Deze kwalitatieve oriëntatie houdt direct verband met de principiële en praktische onzekerheid van technisch-wetenschappelijke kennis. Als omtrent de feiten absolute zekerheid zou bestaan, zou de kwestie van deskundigen-advisering zich in juridisch opzicht beperken tot enkele beknopte overwegingen terzake van de lasten, inbreuken en beperkingen die burgers zich bij het onderzoek naar de feiten zouden moeten laten welgevallen en (mede in verband daarmee) het expliciet maken van de weg naar de waarheid: de te volgen methodologische regels. Onzekerheid in kennis voegt aan de proble- 
matiek een dimensie toe. In formeel opzicht komt een zeer groot gewicht toe aan de openheid van de besluitvorming ten einde kritiek te kunnen uitoefenen op de inzichten die ter schraging van de feitenvaststelling worden opgevoerd. Deze inzichten (veelal adviezen van deskundigen) dienen daartoe in een kritiseerbare vorm te zijn neergelegd. In materieel opzicht worden we naast de marginale toetsing door bestuur of rechter van het deskundigen-onderzoek geconfronteerd met de noodzaak onszelf tevreden te stellen met (juridisch) bevredigende beslissingen.

In de tweede plaats is in het onderzoek voor de juridische waarborgen als algemeen uitgangspunt genomen dat het besturen een eigen formele en materiële rechtvaardiging behoeft. In negatieve zin komt dit tot uitdrukking in de alom gestelde noodzaak van een beroepsrecht tegen bestuursdaden - bij een onafhankelijke rechterlijke instantie. Het micro-besturen kan de individuele rechtspositie van burger immers zodanig raken dat rechtsbescherming in de vorm van een rechtmatigheidstoets niet mag ontbreken. In positieve zin is de "publiekrechtelijke legitimatie" van bestuursbeslissingen, door toedoen van (de naleving van) specifieke non-contentieuze waarborgen, benadrukt. De non-contentieuze procedure is meer dan een "administratieve voorprocedure", waarvan de eventuele foutjes in een later stadium zonder problemen kunnen worden verholpen. De procedure staat in functie van het bieden van rechtsbescherming aan belanghebbenden, het democratisch gehalte van de te nemen beslissing en de "technisch-inhoudelijke" kwaliteit van de besluitvorming. De rechtsbeschermingsfunctie van de non-contentieuze procedure sluit aan op het gegeven dat het bestuur eenzijdig, voor de belangenpositie van burgers ingrijpende beslissingen kan nemen. De procedure voorziet er in dat belanghebbenden aanstonds blijk kunnen geven van de vrees voor aantasting van hun belang, opdat het bestuur daarmee in zijn besluit direct rekening kan houden. Het democratisch gehalte komt vooral goed tot uitdrukking als "een ieder" zijn opvatting over een te nemen besluit naar voren kan brengen. Hier is het ideaal van een open discours tussen betrokkenen, waarbij onderling argumenten kunnen worden uitgewisseld in het geding. Het bestuur dient zich bij zijn beslissing rekenschap te geven van het draagvlak dat daarvoor bij betrokkenen aanwezig is.' De technisch-inhoudelijke kwaliteit van de besluitvorming

1. Ik wil hierin niet zover gaan te stellen dat de overheid als een neutrale actor op het non-contentieuze toneel te werk zou moeten gaan. In die taakopvatting zou bestuurlijke beleidsvrijheid worden gereduceerd (van subjectieve) tot objectieve redelijkheid. Het bestuur zou de "dichtst benaderde consensus" uit het debat moeten distilleren, en op voet daarvan kiezen. Betrokkenen fungeren als een forum dat als een soort orakel aanwijzingen geeft voor de (objectieve) bepaling van het "grootste netto-belangenresultaat". Mij dunkt dat dit niet realistisch is. In elk geval heb ik beleidsvrijheid nimmer als de ruimte voor zodanig directe democratie geinterpreteerd gezien. Het bestuur wordt juist door het electoraat aangesproken op het maken van (niet onredelijke) politieke 
betreft ondermeer het verzamelen van de nodige kennis omtrent relevante feiten en betrokken belangen. Bij een grote kring van inspraakgerechtigden zullen veel aspecten (gegevens en argumenten) boven tafel kunnen komen, waarmee het bestuur zijn voordeel kan doen. De non-contentieuze procedure kan in dit opzicht een bedding zijn voor het leveren van contra-expertise. Het goed doorlopen van de non-contentieuze procedure is - kortom - een terechte eis van rechtmatig bestuur. Het accent ligt daarbij bovenal op wisselwerking tussen betrokkenen in een proces met een zo optimaal mogelijke open meningsvorming. Dat veronderstelt dat het bestuur niet alleen toehoort, maar juist ook deelneemt aan de discussie en daarin positie kiest. Van groot belang is daarbij dat het bestuur zich "beïnvloedbaar" opstelt. Dat impliceert dat het bestuur weliswaar voorkeuren (in een ontwerp-besluit) tot uitdrukking kan brengen, maar dat het nog niet besluit zolang er wordt ingesproken. Dit is ook de kern van de aanduiding "non-contentieus": er kunnen verschillende voorkeuren bestaan, dat is echter (nog) geen basis voor een rechtsstrijd maar juist een basis voor een gedachtenwisseling. De non-contentieuze procedure is in die zin dan ook breder dan de contentieuze procedure, waar slechts de vraag naar de juridische aanvaardbaarheid van een genomen besluit aan de orde is. ${ }^{2}$

Vanuit dit oogpunt is te begrijpen dat in deze studie afwijzend is gereageerd op de (algemene) bezwaarschriftenprocedure in de thans voorgestane vorm. De bezwaarschriftenprocedure is een contentieuze procedure. $\mathrm{Er}$ ligt een besluit voor dat formeel rechtsgeldig is; er is met andere woorden sprake van een belangenconflict. Beter zou het zijn om de non-contentieuze procedure te verdelen in twee fases, de voornemen- en de ontwerpfase. Als deze fases zijn doorlopen rest voor de burger slechts het beroep op de rechter, c.q. op de onafhankelijke rechtmatigheidstoetsing.

Alhoewel de non-contentieuze procedure aldus wordt voorgesteld als een toneel waarin een open uitwisseling van informatie en opvattingen plaatsvindt, moeten daarin toch ook de scherpe kanten worden onderkend. Met name de kwestie van de bewijslast verdient de aandacht. Een open discours vereist dat de deelnemers gelijkelijk in staat zijn hun standpunt te bepleiten; ook materieel gelijk. ${ }^{3}$ De vraag rijst welke conclusies hieraan voor de des-

keuzes. In dat perspectief moeten we de democratische functie van de non-contentieuze procedure primair beschouwen als de verwezenlijking van een juridisch niet bindend mini-referendum (waarbij het op politieke gronden wijs kan zijn geventileerde opvattingen serieus te nemen). Daarbij kan het debat helderheid bieden inzake het gewicht van de betrokken bijzondere èn algemene belangen.

2. Vgl. Tak, a.w.(1992). p. 18 ("Vóór het moment $X^{\prime}$. "het proces gericht op een besluit dat in alle opzichten zo 'juist' mogelijk is: sociaal, economisch, financieel. politiek, enz.").

3. Het gaat hier om de non-contentieuze 'bewijslast'. 
kundige ondersteuning van burgers moeten worden verbonden. In de juridische vorm van bestuurlijke besluitvorming staat voorop dat het bestuur op voet van het legaliteitsbeginsel en (bij beleidsvrijheid) de plicht tot het maken van een belangenafweging, gehouden is de feiten vast te stellen. Art. 3:2 Awb verplicht het bestuur hiertoe de nodige kennis te vergaren. Van de zijde van de aanvrager kan op voet van art. 4:2, tweede lid Awb een bijdrage aan de kennisvergaring worden verlangd. Gegeven deze uitgangspunten en gelet op de juridische positie van het bestuur, c.q de bestuurlijke bevoegdheid tot het eenzijdig verrichten van rechtshandelingen, kan van derde-belanghebbenden niet worden verlangd dat zij voor al hun stellingen sluitend bewijs leveren. Wel zijn zij er toe gehouden hun belang te stellen. Dat wil zeggen dat zijn aannemelijk moeten maken dat voor aantasting van hun belang moet worden gevreesd. Van deze aanzet tot bewijs zal het bestuur zich vervolgens rekenschap moeten geven. Anderzijds is de stelling betrokken dat er met name in technisch-complexe besluitvorming deskundige ondersteuning aan burgers moet worden geboden. $\mathrm{Zij}$ moeten immers in de geschetste optiek vooreerst in staat zijn voor zich zelf vast te stellen welke aantasting van hun belangenpositie van het voornemen valt te duchten. Eerst dan kunnen zij besluiten zich in het discours over dat voornemen te begeven.

In het vierde deel van de studie komt de intrinsieke waarde van de non-contentieuze procedure, voor de administratieve rechter, uitdrukkelijk aan de orde. Kernpunt was daarbij dat de administratieve rechter bovenal moet voorkomen dat hij de non-contentieuze procedure (op onaanvaardbare wijze) doorkruist. Wat betreft de uitspraakbevoegdheden is de bevoegdheid tot vernietiging van een bestuursbesluit omschreven als een (op praktische gronden) aanvaardbare doorkruising. Meer gevaren zijn gelegen in de rechterlijke bevoegdheid tot het zelf in de zaak voorzien. Materieel beschouwd zou dit alleen denkbaar zijn als geen van de hierboven geschetste functies van de non-contentieuze-procedure, bij het nemen van een nieuw besluit, nog op een zinvolle wijze tot uitdrukking zouden kunnen worden gebracht. Dit brengt de rechter, gelet op het discretionaire karakter van bepaalde bestuursbevoegdheden en de opportuniteiten bij de feitenvaststelling, tot hachelijke afwegingen. Mitsdien is een formele wijziging van de in het geding zijnde bevoegdheid bepleit: het zelf in de zaak voorzien als een relatieve voorziening.

Ten aanzien van het rechterlijk oordeel over de feiten(vaststelling) is naast de verwijzing naar het primaat van het bestuur (in de zin van het recht zich als eerste over de feiten uit te laten), in het bijzonder gesproken over normatieve keuzes bij de feitenvaststelling. Deze keuzes impliceren een beoordelingsopportuniteit. Binnen die 'ruimte' moeten beslissingen worden genomen over redelijkerwijs in beschouwing te nemen alternatieven en de (per alternatief) vereiste mate van zekerheid ("redelijke zekerheid"). Ten aanzien hiervan is 
de stelling betrokken dat sprake is van een bestuurlijk primaat inzake de feitenvaststelling welke de rechter verplicht tot een terughoudende toets - en wel die van de "objectieve redelijkheid". De van het bestuur verlangde zorgvuldigheid en redelijkheid bij de feitenvaststelling is mitsdien geen absolute maar een relatieve eis. Achtergrond van deze optiek is dat de non-contentieuze procedure bij uitstek de plaats is om in een toegankelijk, open debat over de feiten te beraadslagen. Daaraan kan - in praktische zin - worden toegevoegd dat het bestuur meer dan de rechter geëquipeerd lijkt om in dit open discours een sleutelrol te vervullen.

In de derde plaats - en in het verlengde van het voorgaande punt - komt naar voren dat voor het nemen van rechtsgeldige beslissingen wetenschappelijke zekerheid geen vereiste is. In juridische zin gaat het er "slechts" om dat "redelijke zekerheid" wordt verkregen. De vraag hoeveel zekerheid daarvoor nodig is, is nauw verbonden met de hoegrootheid van de betrokken belangen. Belangrijk is in dit verband ook dat bestuur noch rechter dienen te veinzen dat zij op grond van eigen technische deskundigheid beslissen omtrent de feiten. Allereerst wekt dit de veelal onjuiste indruk dat bestuur of rechter in kwestie de deskundige bij uitstek is. In de tweede plaats moet bedacht worden dat het bij de feitenvaststelling niet gaat om het vinden van de grootste deskundige, die het laatste woord heeft, maar om het in de procedure genereren van kritiseerbare kennis, c.q het aangaan van een discussie over de feiten. Het bestuur heeft tot taak over die procedure de regie te voeren. Dat betekent allereerst het scheppen van procedurele randvoorwaarden (de openheid van het debat, de geïnformeerdheid van betrokkenen). Daarnaast zal het bestuur een marginale toets van door deskundigen ingebrachte adviezen dienen te volvoeren. Afwijken van een deskundigenadvies door het bestuur is mogelijk, maar alleen indien daaraan voorafgaand contra-expertise is ingewonnen. Deze regel uit het positieve bestuursrecht onderstreept dat het niet wenselijk wordt geacht dat het bestuur zich als de superdeskundige profileert. Als het bestuur meent van een deskundigenadvies af te moeten wijken is het zaak dat daaromtrent de argumenten zo helder mogelijk worden. Desgevraagd kan een rechter dan een oordeel uitspreken over de redelijkheid van dat afwijken. Op de achtergrond speelt bij dit alles de idee dat het juist met het oog op de beoordelingsopportuniteit die met de feitenvaststelling gemoeid is, niet wenselijk is als normatieve keuzes en technische-inhoudelijke beoordeling te zeer vervlochten raken. In elk geval moet worden gevreesd dat een te grote technisch-wetenschappelijke betrokkenheid van het bestuur de rol van het bestuur als hoeder van een open discours over het te nemen besluit zal kunnen hinderen. Uiteraard - het is al vaker gezegd - neemt een en ander niet weg dat een minimale dosis inhoudsdeskundigheid bij bestuur of rechter 
uiteraard gewenst is - iets dat ook geldt voor de betrokken burgers (en daarbij reden vormde tot het voorstel van deskundige-ondersteuning).

In de vierde plaats kan worden gewezen op de in het tweede hoofdstuk voor het milieurecht als paradigmatisch omschreven "voortschrijdende normstelling". Dit paradigma komt tot uitdrukking in de keuze voor open normering in het milieurecht. Het tot op heden belangrijkste voorbeeld daarvan zijn de verschillende vergunningsstelsels, die ter behartiging van (en deel of aspect van) het milieubelang in het leven zijn geroepen. Het maatwerk waartoe deze stelsels verplichten biedt ruimte aan toepassing van voortschrijdende, ongeschreven milieunormen. Een belangrijk voorbeeld van die voortschrijdende normering wordt daarbij geboden door de zogenoemde richtlijnen. Ook de meer recente (en in voorbereiding zijnde) zorgplichtbepalingen bieden ruimte voor voortschrijdende normstelling. Deze zijn immers aldus geformuleerd dat ze (ad hoc) in de actuele situatie op voet van redelijk inzicht en een redelijke belangenafweging in een redelijke gedragsnorm moeten kunnen resulteren. In het kader van de m.e.r.-regeling zij voorts gewezen op de rol van art. 7.35 Wm (de verruimde beslissingsbevoegdheid). Hier werd de positie ingenomen dat het bestuur zich binnen de grenzen die volgens dit artikel uit het specialiteitsbeginsel voortvloeien, terdege moet bezinnen op de geschiktheid van de geschreven (sectorale) milieunormen. Als deze normen een belemmering vormen voor de onderkenning van het te beschermen belang zal het bestuur moeten waarborgen dat alle relevante effecten worden beschreven en afgewogen. Het ligt voor de hand dat daarbij het ongeschreven milieurecht een belangrijke rol zal spelen. Een vergelijkbare regel lijkt verdedigbaar als het gaat om de formalisering van het bewijs door het geven van meet- en rekenvoorschriften voor bepaalde milieu-effecten.

Een krachtig pleidooi voor voortschrijdende normstelling vloeit voort uit de actualiseringsplicht van art. $8.22 \mathrm{Wm}$. Het bestuur is op voet van deze bepaling gehouden regelmatig te bezien of een vergunning nog wel "bij de tijd is". Enerzijds moet zij daarbij het oog houden op verbeterde technische mogelijkheden, anderzijds op een (eventueel) verminderen van de kwaliteit van het leefmilieu. In het concrete geval kan hieruit een aanscherping van de in de verleende vergunning neergelegde gedragsnorm voortvloeien. De idee van voortschrijdende normstelling is hier wel heel manifest.

Ten slotte verdient het opmerking dat we ook langs de weg die door het BW wordt geëffend, ${ }^{4}$ te denken valt aan de convenanten, de acties uit onrechtma-

4. Ik omschrijf het nu - ten slotte - eens niet als de privaatrechtelijke weg; misschien betreft het wel regels die onder omstandigheden een publiekrechtelijk karakter dragen. Vgl. Tak, A.Q.C.. Overheid en burgerlijk wetboek. Naar een invullende rechtsleer, R\&K'93/2, p. 174-190. 
tige daad en - last but not least - aan de eisen van verzekeraars, met voortschrijdende normstelling geconfronteerd worden.

Het paradigma van voortschrijdende normstelling, en op voet daarvan de keuze voor open normering, is de basis voor de rol van de deskundige in het milieurecht. Hij is het die signaleert, verkent en adviseert en aldus zijn bijdrage levert aan het normstellingsproces. Uit een oogpunt van voortschrijdende normstelling is het vooral belangwekkend te achten wanneer de deskundige met "nieuwe inzichten" op de proppen komt. Voorzover zich dit in het kader van vergunningverlening voordoet, vloeien elementen uit de twee voorgaande kwesties samen. Zolang de non-contentieuze procedure loopt kunnen alle bestaande inzichten, oud of nieuw, worden ingebracht. Daarover is dan debat mogelijk. Als deze procedure is afgesloten doordat het bestuur een besluit heeft genomen (en bekendgemaakt), is geen aantasting van het besluit mogelijk op grond van na het nemen van het besluit gerezen nieuwe inzichten. De rechter toetst het besluit ex tunc. Wel is aanpassing van het besluit mogelijk; alsdan wordt een nieuwe procedure tot wijziging of intrekking van het genomen besluit ingesteld. Ook bij de herziening van rechterlijke uitspraken staat voorop dat herziening slechts mogelijk is als het gaat om (niet onderkende) inzichten die voor het ex tunc oordeel relevant konden zijn. Slechts als de rechter zelf in de zaak voorziet, geschiedt zulks ex nunc waardoor inzichten van na het nemen van het bestuursbesluit alsnog kunnen worden meegenomen. In feite gaat het dan om een specifieke vorm van herbeslissen - een vorm waarbij de nodige kanttekeningen zijn gemaakt.

Deze gang van zaken onderstreept niet alleen het belang van de non-contentieuze procedure. Ook ligt er de erkenning in besloten dat met het oog op de rechtszekerheid wenselijk kan zijn bepaalde besluiten te nemen alhoewel niet is uit te sluiten dat de kennis op basis waarvan die besluiten worden genomen (bij wijze van spreken) morgen weer achterhaald blijkt. Het risico van "tweedehands-kennis" wordt geaccepteerd als het gewicht van de in het geding zijnde belangen verlangt dat niettegenstaande principiële en praktische onzekerheid een beslissing wordt genomen. Hierboven werd in dat opzicht in herinnering geroepen dat rechtens "redelijke zekerheid" voldoet. In gevallen waar zwaarwichtige belangen in het gedrang dreigen te komen, is aansluitend nog denkbaar dat in de besluitvorming zoveel mogelijk wordt gezocht naar mogelijkheden om onzekerheid te reduceren. Zo kan de zwaarwichtigheid van het milieubelang aanleiding zijn tot toepassing van het voorzorgsbeginsel: de enkele indicatie van schadelijke effecten kan voldoende zijn voor een restrictieve bejegening van het milieubedreigende voornemen in casu.

Tot slot past hier nog een opmerking over de vuistregels. De vuistregels uit het tweede deel van deze studie vormen geen beantwoording van de probleemstelling. Ze vormen een "theorie" of - liever - een "verzameling aan- 
knopingspunten" voor juridisch-rationeel beslissen, en daarmee voor de speurtocht naar juridische waarborgen. In die zin vervullen ze primair een heuristische functie. Voorzover ze als 'ijkpunten' worden gekwalificeerd, is dat niet met de bedoeling te suggereren dat deze verzameling een normatief uitgangspunt van de discussie vormt. De enkele bedoeling is de vuistregels te gebruiken om waarborgen op te sporen en dan tevens een ingang te hebben voor een inhoudelijke bespreking daarvan. Terugkijkend kunnen de vuistregels ook als samenvatting worden gelezen. Bestuurlijke verantwoordelijkheid voor de feitenvaststelling, met inbegrip van de marginale toetsing van deskundigen-adviezen, blijkt een evidente juridische eis te zijn. De idee van de bevredigende beslissing heeft bijgedragen aan de relativering van juridische eisen ten aanzien van de feitenvaststelling. De eis van open besluitvorming vloeit voort uit een relativistisch rationaliteitsbegrip (kritiseerbaar maken), en blijkt (in samenhang met de eerste en tweede vuistregel) uiteindelijk de grondslag voor het bestuurlijk primaat, c.q. het "primaat" van de non-contentieuze procedure. De vuistregel inzake gangbare opvattingen (de stand van wetenschap en techniek) is relevant voor de vraag of bij de feitenvaststelling elk technisch-wetenschappelijk inzicht op zijn (actuele) merites moet worden bestudeerd. Oriëntatie op gangbare opvattingen wordt onderschreven, maar tegelijkertijd moet daarbij worden onderstreept dat het bestuur zich goed rekenschap moet geven van nieuwe (afwijkende) opvattingen die gepaard gaan met gerede onzekerheid in het wetenschappelijke forum. ${ }^{5}$ Met het oog hierop wordt aanbevolen om bij technisch-complexe besluitvorming een vastadviesrecht voor een onafhankelijke deskundige in het leven te roepen. De vuistregel inzake het omgaan met waarden betreft de waakzaamheid ten aanzien van niet-wetenschappelijke waarden (de eis van onpartijdigheid van deskundigen-adviseurs) en de noodzaak om feiten en waarden in de besluitvorming goed te scheiden. Niettemin blijkt dat de vaststelling van feiten bij het nemen van bestuursbesluiten gepaard gaat met normatieve keuzes. Het maken van die keuzes en de controle daarop is, primair in het voetspoor van de idee van de juridisch-bevredigende beslissing, in het verloop van deze studie genoegzaam aan bod gekomen.

\subsection{Aanbevelingen}

Op een aantal punten mondt deze studie uit in concrete aanbevelingen, waaronder voorstellen tot aanpassing van geldende voorschriften. Enkele van deze aanbevelingen wil ik hier nog eens uitdrukkelijk noemen. Achtereenvolgens

5. Opvattingen die de potentie hebben om een significante en i.c. relevante wijziging in algemeen aanvaarde inzichten te veroorzaken - vgl. \$ 8.3.3.6. 
zullen daarbij de verschillende actoren in het normstellingsproces centraal staan: de burger, het bestuur, de rechter en - last but not least - de deskundige.

Om te beginnen de burger. Om hem was het bij de voorbereiding tot deze studie in het bijzonder te doen. Hij lijkt immers wel bij uitstek de zwakke schakel in het beeld van open communicatieve besluitvorming. Welke burgers zijn in technisch-complexe besluitvorming in staat hun voorkeuren goed onderbouwd kenbaar te maken? In hoeverre zijn burgers zelfs maar in staat te onderkennen in welke mate hun belangen mogelijk in het geding zijn?

Aanvankelijk vormde alleen het rechtsbeschermingsperspectief de grondslag voor de zorg over de deskundigheid van burgers in technisch-complexe besluitvorming. In deze studie hebben de democratische en kwalitatieve functies van de non-contentieuze procedure die grondslag verder verbreed. Voor belanghebbenden is er een rechtstreekse noodzaak om over deskundigheid te beschikken: de bescherming van hun eigen belangpositie zal doorgaans in belangrijke mate afhankelijk zijn van hun eigen mondigheid. Hier lijkt de noodzaak van extra waarborgen evident. De democratische en kwalitatieve functies van de non-contentieuze procedure blijken in deze studie relevant te zijn vanuit het bredere perspectief van de publiekrechtelijke legitimatie van bestuursbesluiten. In het perspectief van de inbreng van expertise staat daarbij het bieden van de mogelijkheid tot het kritiseren van de bestuurlijke (ontwerp) feitenvaststelling voorop - en in het verlengde daarvan de vraag op welke wijze onzekerheden over de feiten in de belangenafweging moeten worden verdisconteerd. Het is wenselijk hiertoe een zo breed mogelijk forum te creëren, teneinde de kansen op een weloverwogen beslissing te vergroten - een en ander binnen de grenzen van het doelmatige. In dit perspectief is een grotere groep van burgers in het geding: in beginsel een ieder. Op veel plaatsen in deze studie is kortweg gesproken over "betrokkenen", daarbij impliciet een subjectief criterium hanterend: een ieder die zich door een voornemen of ontwerp-besluit zo aangesproken voelt, dat hij zich daarover tegenover het bestuur in kwestie uit wenst te laten. Het motief daarvoor kan dan gelegen zijn in de eigen belangpositie, maar ook in de belangpositie van anderen, opvattingen over algemene belangen of het feit dat iemand zich uit hoofde van zijn deskundigheid geroepen voelt zijn opvatting kenbaar te maken.

Toch gaat het doorgaans vooral om de belanghebbenden omdat zijn positie persoonlijk in het geding is. Zo is de vraag naar de 'bewijslast' van hen die zich in de non-contentieuze fase tot het bestuur wenden, met name voor de belanghebbenden relevant. Het antwoord moet dan ook op maat van deze groep worden gegeven. Daarbij dient de primaire verantwoordelijkheid van het bestuur voorop te staan. Het bestuur moet zich er van vergewissen dat het 
(meest) "juiste" besluit wordt genomen. Voorzover het de aanvrager van een beslissing betreft, is zijn belang bij een positief besluit grond om ook hem een expliciet aandeel in de bewijslast te geven. Codificatie van deze plicht (in art. 4:2, tweede lid Awb) voorkomt dat het bestuur aanvrager overvraagt, of dat de aanvrager zich voor het verstrekken van bepaalde informatie verschuilt achter de primaire verantwoordelijkheid van het bestuur. Ten aanzien van derde-belanghebbenden mag de bewijslast niet worden overtrokken. Gelet op de primaire verantwoordelijkheid van het bestuur moeten zij ermee kunnen volstaan de vrees voor belangenaantasting aannemelijk te maken. Op voet daarvan heeft het bestuur dan de plicht nader onderzoek te doen. ${ }^{6}$ Niettemin kan die bewijslast juist in technisch-complexe besluitvorming reeds tamelijk zwaar zijn. Met het oog daarop lijkt het aanbevelenswaard om te voorzien in een recht op (mondelinge) consultatie van een onafhankelijke deskundige. Daartoe zou een aanvulling op de procedure van Afd. 3.5 Awb noodzakelijk zijn. Zulks kan geschieden door aanpassing van de regeling van deze afdeling zelf, maar ook door een aanvulling in Afd. $13.2 \mathrm{Wm}$.

Als het bestuur in zijn beslissing het advies van een deskundige volgt, kan een burger ter bestrijding van dit besluit niet volstaan met hartekreten. De burger zal een goed onderbouwd standpunt naar voren moeten brengen. Toch behoeft hij zich daarbij slechts te richten op zijn eigen belang. De vrees voor aantasting van dat belang zal hij (met het oog op het deskundigen-advies van het bestuur) nader moeten motiveren. Bewijs wordt echter niet verlangd, laat staan bewijs van gebreken in het voorgenomen bestuursbesluit. Het is aan het bestuur zich - in de non-contentieuze procedure - rekenschap te geven van de positie van belanghebbenden.

Als echter vervolgens een voor de belanghebbende onwelgevallig besluit wordt genomen, dat steun vindt in een deskundigen-advies, zal de burger toch aannemelijk moeten maken dat er aan de stellingname van het bestuur iets schort. De bewijslast zal daarmee doorgaans zwaarder worden, er moet nu immers een gebrek worden aangewezen; de eiser zal twijfel aan het bestuursbesluit moeten opwekken. Op dat moment is de contentieuze procedure - met de klacht van eiser tegen het genomen bestuursbesluit - begonnen. Het vermoeden van rechtmatigheid en de (relatieve) autonomie van partijen brengen mee dat de burger verder moet gaan dan zijn belang te stellen.

Dit uitgangspunt zal in de eerste plaats vergezeld moeten gaan van een goede voorziening voor de vergoeding van in redelijkheid gemaakte redelijke kosten voor ondersteuning. Op dit moment wenst de regering met het geregelde in art. 8:75 Awb daarin slechts te voorzien voorzover het een beroep op de administratieve rechter betreft: de kosten terzake van de bezwaarschriftenprocedure worden niet vergoed. Men zou zich op het standpunt kunnen stellen

6. Tenzij het belang in kwestie niet relevant zou zijn. 
dat in de bezwaarschriftenprocedure van burgers in beginsel ook niet meer bewijs wordt verlangd dan in de non-contentieuze procedure. De noodzaak om de gebreken in de bestuursbeslissing aannemelijk te maken zou ontbreken, en dus behoeven geen extra onkosten te worden gemaakt. Dit zou de enige rechtvaardiging voor de door de regering gemaakte keuze kunnen zijn. Tegelijkertijd sterkt deze ambivalentie de opvatting dat de bezwaarschriftenprocedure als "contentieuze bestuurlijke heroverwegingsprocedure" moet verdwijnen. Kern van de zaak blijft toch dat als het definitieve bestuursbesluit is genomen, er sprake is van een geschil. Partijen moeten in staat worden gesteld zich maximaal in te spannen om hun posities te beschermen - en liefst zo snel mogelijk hun gelijk te krijgen! Daarbij moet uitgangspunt zijn dat het bestuur het bestreden besluit naar beste weten en overtuiging heeft genomen ${ }^{7}$ en dat elementaire beginselen van procesrecht in de behandeling van het geschil worden gerespecteerd. Passender is het dan ook om de bezwaarschriftenprocedure te schrappen en over de hele linie een non-contentieuze procedure in twee fases (een voornemen- en een ontwerpfase) door te voeren.

In de tweede plaats zal de administratieve rechter, waar nodig, de burger moeten bijstaan in zijn poging om het bestuursbesluit aan te vechten. Het ongelijkheidsbeginsel vormt voor de rechter een van de motieven om de bewijsvoering (voor een bepaald deel) op zich te nemen. Het verdient echter stellig aanbeveling dat de rechter, met het oog op het verdedigingsbeginsel, ruimte laat voor de partij-autonomie van de burger: de laatste moet niet alleen (in beginsel) op de hoogte zijn van alle bewijsmiddelen, maar bovendien in de gelegenheid gesteld worden zich daarover uit te laten. De partijautonomie van de burger brengt - uiteindelijk - ook mee dat hij tot het leveren van bewijs kan worden aangesproken. Pas als aannemelijk is dat hij "te ongelijk" is om aan een bewijsopdracht te voldoen, zal de rechter moeten overwegen het desbetreffende deel van de bewijslast op zich te nemen. ${ }^{8}$ Wat de kwestie van het verdedigingsbeginsel betreft zij herhaald dat het van het grootste belang is dat burgers ook rechterlijke beslissingen kunnen kritiseren. Dat geldt ten aanzien van de - ten onrechte - beperkte regel inzake het deskundigenonderzoek (art. 8:47, derde lid Awb), alsook ten aanzien van de regel van rechtspraak in meerdere instanties.

7. En niet onder het motto: "we merken in de bezwaarschriftenprocedure wel of er nog problemen zijn".

8. Ik wees er in Hoofdstuk 9. overigens op dat ook processtrategische motieven, de beperkingen in de autonomie van partijen (m.n. het bestuur) of het eigen oordeelsvermogen van de rechter grond kunnen zijn voor eigen onderzoek (al dan niet met behulp van deskundigen) door de rechter. 
toch zal moeten nagaan of die "gangbaarheid" nog bestendig lijkt te zijn." Indachtig de relativerende overwegingen inzake 'super-deskundigheid' kan daarbij van het bestuur niet het uiterste worden gevergd: het moet "blijk geven van onderzoek naar". Het uitgangspunt blijft dat van het bestuur niet bij elk besluit een uitgebreid, fundamenteel wetenschappelijk onderzoek kan ondernemen (c.q. gelasten). Een concrete aanbeveling in dit verband is dat in procedures van technisch-complexe besluitvorming een vaste, onafhankelijke deskundige in de gelegenheid wordt gesteld naar aanleiding van het ontwerpbesluit een advies te geven. Deze aanbeveling houdt verband met de wens om op enigerlei wijze een (institutionele) waarborg voor contra-expertise te realiseren. Meer specifiek staat daarbij ook de gedachte voor, dat deze deskundige adviseert over de bestendige gangbaarheid van de opvattingen die aan de feitenvaststelling ten grondslag liggen.

In het verlengde hiervan past ook een bepaalde volgorde in de besluitvorming. Een ontwerp-besluit volgt op informatieverstrekking door de aanvrager en het eigen onderzoek door het bestuur. Daarna kan de vaste, onafhankelijke deskundige, tegelijk of tezamen met de andere betrokkenen, reageren, waarna het definitieve besluit wordt genomen. Indien de m.e.r.-procedure toepasselijk is doet zich een bijzonder geval voor. De basis van de besluitvorming wordt gelegd in het MER. Dit is een stuk van de initiatiefnemer, opgemaakt volgens (wettelijke regels èn) de richtlijnen van het bevoegd gezag. De beoordeling van het MER is een zelfstandige stap in de procedure, waarbij de onafhankelijke Cmer een grote rol speelt. In de huidige regeling adviseert de Cmer nadat het bestuur zich over de aanvaardbaarheid van het MER heeft uitgesproken. Inzoverre is de vergelijking met het voorgestelde model van de vaste onafhankelijke deskundige goed te maken. Punt is echter dat de aanvaarding van het MER iets anders is dan het formuleren van een ontwerpfeitenvaststelling. Het gaat immers (tevens) om een definitieve beslissing over de vraag of de aanvrager/initiatiefnemer aan zijn verplichting heeft voldaan. In dat licht heeft de toetsing door de $\mathrm{Cmer}$ toch een wat andere functie dan het voornoemde onafhankelijke advies. Mitsdien lijkt het passender om het oordeel van de Cmer in te winnen alvorens het bestuur over de aanvaardbaarheid van het MER beslist. Daarna verschijnt dan het ontwerp-besluit, dat op zijn beurt weer gekritiseerd kan worden - maar nu als bestuurlijke beslissing.

Niet alleen draagt het bestuur een eigen verantwoordelijkheid voor de feitenvaststelling, ook vermag het eenzijdig in te grijpen in de belangenpositie van

11. In feite lost deze kwestie zich op in de toevoeging bestendig. Mijn wens is dat het bestuur zich laat leiden door "bestendig gangbare kennis". Wat gangbaar is, is daarin slechts een vertrekpunt. Er moet redelijke zekerheid $7:{ }^{n}$ dat de gangbare visie niet onder serieuze dreiging van een nieuw inzicht ligt. 
burgers. In die combinatie valt goed te begrijpen dat het bestuur in de contentieuze procedure (in reactie op het beroepschrift, ter adstructie van zijn besluit) met een "preprocessuele bewijslast" wordt opgezadeld. De aanduiding preprocessueel maakt duidelijk dat - als het goed is - het bestuur zijn werk eigenlijk al heeft gedaan. De eis van een verweerschrift dient er vooral toe een startpositie voor de bewijsvoering te bepalen. De rechter wenst zo spoedig mogelijk te weten welke bezwaren de appellant heeft en wat het bestuur precies van de klacht van eiser vindt - niet in het minst om te bepalen of nader onderzoek eigenlijk wel nodig is. ${ }^{12}$ Het verweerschrift kan daarbij overigens inzoverre aanvullen dat eiser wellicht een geheel nieuw bezwaar inbrengt, dat bij het bestuur eerder niet bekend was, terwijl tegelijkertijd moet worden erkend dat in de motivering van een besluit niet altijd in volle diepte op de belangen van elke betrokkene kan worden ingegaan.

Als het bestuur er in slaagt "redelijke zekerheid" te bieden en de normatieve keuzes die het bestuur inzake de feitenvaststelling makt, de toets aan de "objectieve redelijkheid" doorstaan, zal betwisting van de feitenvaststelling falen.

Een belangrijk, op de feitenvaststelling aansluitend punt is nog dat van de onzekerheidsreductie. Het bestuur dient zich bij technisch-complexe besluitvorming inzake kwetsbare belangen, uitdrukkelijk te bezinnen op onzekerheidsreductie.

De rechter is de derde schakel. Ook in het bestuursproces kan de inbreng van deskundigheid een belangrijke rol spelen. Dit wordt duidelijk zichtbaar als het gaat om het contentieuze deskundigenbericht ex art. 8:47 Awb. Tot het doen verrichten van dergelijk deskundigen-onderzoek kunnen verschillende gronden bestaan. Zo kunnen twijfel over zijn eigen oordeelsvermogen of processtrategische gronden (de mogelijkheid van een schikking) de rechter tot dergelijk onderzoek bewegen. Belangrijker nog lijken het motief van de ongelijkheidscompensatie en de beperkingen in de autonomie van partijen. Wat het laatste betreft gaat het in algemene zin om het onderzoek naar feiten met het oog op rechtsgevolgen die niet ter bepaling van partijen zijn. In het bijzonder moeten we denken aan de beperkingen in de autonomie van het verwerend bestuursorgaan (inzake de eigen bevoegdheid, het meewegen van de positie van derden en dergelijke).

De rechter dient overigens de autonomie van partijen (voorzover aanwezig) te respecteren. Dat verplicht allereerst tot een lijdelijke houding ten aanzien van de afbakening van het object van geschil. Ook zal hij zijn actieve optreden in het onderzoek op de partij-autonomie moeten afstemmen: partijen dienen in

12. Het is wenselijk om geschillen met bekwame spoed af te doen - als het 'kennelijk' mogelijk is met een vereenvoudigde behandeling. 
de gelegenheid te worden gesteld om bewijs te leveren en om rechterlijke beslissingen te kunnen kritiseren. In het verlengde daarvan zal de rechter moeten bewaken dat partijen (als regel) van elk processtuk kennis kunnen nemen en contra-expertise kunnen inbrengen. De wijze waarop de rechter op eventuele kritiek reageert zou eigenlijk ook getoetst moeten kunnen worden. Mitsdien lijkt de mogelijkheid van hoger beroep en cassatie-beroep noodzakelijk ook (of misschien wel juist) waar het kwetsbare geschillen betreft.

Een lijdelijke maar actieve rechter kan zich manifesteren als dominus litis. Met het oog op de ongelijkheidscompensatie en de beperkingen in de partijautonomie lijkt dat stellig gewenst. Daarbij is het juist in technisch complexe geschillen zaak dat de rechter zich niet laat overvleugelen door deskundigen (iets dat overigens ook in verband met het verdedigingsbeginsel van belang is). Daarom past een kritische opstelling jegens de bestaande praktijk van de ambtsberichten (in milieuzaken). Een eventuele rechtspositionele verzelfstandiging van de huidige Adviseur Beroepen Milieubeheer kan enige verbetering geven, maar daarnaast zullen andere waarborgen - zoals ook door Michiels voorgesteld - noodzakelijk zijn. Toch lijkt het voor de positie van rechter en partijen beter om, zoals ook Brenninkmeijer bepleit, te kiezen voor een systeem van "ad hoc-advisering" aan de rechter. Een belangrijk voordeel van die wijze van (ad hoc) adviseren is, dat de neiging tot een ambtshalve integrale hervaststelling van feiten, op voet van een omvattend deskundigenbericht, wordt getemperd. Daarin ligt een belangrijke waarborg voor het respecteren van de non-contentieuze besluitvorming.

Dat respect is ook in het geding als het gaat om de rechterlijke toetsing (het oordeel over de bestuurlijke feitenvaststelling) en om de uitspraakbevoegdheid (in het bijzonder het zelf in de zaak voorzien). Wat de toetsing betreft is, ten aanzien van de bestuurlijke feitenvaststelling, de 'objectieve redelijkheidstoets' aangewezen. Dit volgt uit de stelling dat het criterium van art. 3:2 Awb (de 'nodige kennis') bestuurlijke beoordelingsopportuniteit inhoudt. Deze opportuniteit impliceert een zekere mate van bestuurlijke vrijheid bij de feitenvaststelling, al naargelang de toepassingsconditie in kwestie en (in samenhang daarmee) de complexiteit van het feitensubstraat. Deze vrijheid heeft echter geen subjectieve strekking, zoals bij het maken van een belangenafweging. Derhalve past een objectieve redelijkheidstoets. Daarin zal de vraag of het bestuur zich rekenschap heeft gegeven van hetgeen in advies en inspraak naar voren is gebracht een grote rol spelen. Wat de uitspraakbevoegdheid betreft kan de vernietiging van het bestreden bestuursbesluit het (noodzakelijke) begin zijn van een non-contentieuze herbeslissingsprocedure. 
Het zelf in de zaak voorzien zou slechts bij wijze van relatieve voorziening mogelijk moeten zijn. ${ }^{13}$

Dan ten slotte de deskundige. Om hem is het in zekere zin allemaal te doen. In zekere zin, want allengs wordt duidelijk dat omgaan met expertise meer behelst dan de selectie van een goede deskundige en het stellen van de juiste adviesvraag. Het omgaan met deskundigen is slechts een onderdeel van het omgaan met deskundigheid. Dat heeft als prettig voordeel dat het uiterst ingewikkelde oordeel over iemands deskundigheid (wie is nu eigenlijk deskundig?) enigermate wordt omzeild. Enigermate, want als tegenstrijdige adviezen worden gegeven, rijst toch al snel de vraag welke adviseur in casu het meest deskundig is te achten. Er is dan eigenlijk altijd wel een criterium te bedenken, zoals het criterium van de grootste gespecialiseerdheid, of de grootste ervarenheid (in casu). Wetenschapsfilosofisch bezien is denkbaar dat tegelijkertijd meerdere, onderling tegenstrijdige verklaringen voor 'waar' worden gehouden; al is ingebouwd dat in een discours over de onderliggende wetenschappelijke waarden dan toch een keuze wordt gemaakt. In de praktijk ontkomen bestuur en rechter aan een dergelijk discours door op - voornoemde - praktische criteria te kiezen. ${ }^{14}$ Eigenlijk is dat een truc - het gaat immers om de status van de verklaring en niet om de status van de deskundige maar hij lijkt mij acceptabel. Zowel voor bestuur als rechtspraak geldt immers in veel gevallen dat de knoop op een bepaald moment moet worden doorgehakt en rechter noch bestuur 'superdeskundigheid' kunnen en ook niet mogen pretenderen.

Deskundigheid wordt in de praktijk ook sterk verbonden met onpartijdigheid, c.q. de afwezigheid van andere dan wetenschappelijke interesses. Onpartijdigheid lijkt welhaast een maat voor deskundigheid. In elk geval zal ook dit criterium bij tegenstrijdigheid van opvatting een rol kunnen spelen. Ook zal het bestuur (of de rechter) zich ervan moeten vergewissen dat de ingewonnen adviezen onpartijdig gegeven zijn. In dat opzicht past een kritische houding tegenover de mogelijkheden om over bepaalde partijdigheden heen te zien. De enkele schijn van partijdigheid (mits objectief aannemelijk gemaakt) is afdoende reden om af te zien van het desbetreffende advies.

Essentieel in het handelen van deskundige-adviseurs is het zich kritiseerbaar opstellen. In het verlengde daarvan dienen adviezen goed gemotiveerd te worden en behoren zij (als geheel) voor betrokkenen kenbaar te zijn.

13. Ik ga hier niet nader in op de andere aspecten van de verhouding non-contentieuze - contentieuze procedure; die zijn inmiddels toch ruim aan bod gekomen.

14. Wat onverlet laat dat de afgewezen verklaring(en) wel een rol zou(den) kunnen spelen bij de beoordeling van de mate van zekerheid die over de feiten is verkregen en - in het verlengde daarvan - bij het beraad over onzekerheidsreducerende maatregelen. 
Die stellingname is cruciaal voor de in deze studie betrokken positie inzake het omgaan met expertise. Het ware denkbaar om met het oog op een efficiënt omgaan met technische complexiteit in de besluitvorming te bepleiten dat é́n instantie wordt aangewezen welke (in de non-contentieuze procedure) een énmalig, grondig advies uitbrengt. Dat advies zou dan bindend moeten zijn, ook voor de rechter, behoudens evidente (al dan niet door een appellant duidelijk aannemelijk gemaakte reden tot) ernstige twijfel.

In deze studie wordt dit 'pleidooi' afgewezen. Tegenover dit autoritaire of gesloten model wordt het open model van de vrije uitwisseling van opvatting en kritiek bepleit. In dit open model is (het bieden van) de mogelijkheid tot contra-expertise een essentiële eis. Deze eis zal in gevallen van technischcomplexe besluitvorming moeten worden aangescherpt. In de non-contentieuze procedure kan daarin (onder anderen) worden voorzien door een vaste adviesinstantie; die niet meer doet dan - onverbindend - adviseren en aldus het discours juist moet dienen. Ook zal er moeten worden voorzien in deskundige ondersteuning van de deskundigheid van burgers. In het contentieuze proces zullen de mogelijkheid van contra-expertise en de rechterlijke motiveringsverplichting, voor partijen een grote rol spelen. Daarbij zal de zorg voor de deskundigheid gewaarborgd moeten worden door een goede proceskostenregeling.

In dit open model ligt het primaat voor de feitenvaststelling bij het discours in de non-contentieuze procedure. Daarin vormt het bestuur de spil. De rechter toetst "slechts" of het bestuur in 'objectieve redelijkheid' tot de bestreden feitenvaststelling heeft kunnen komen.

Essentieel is dat in het open model zelfs de suggestie van wetenschappelijke zekerheid wordt vermeden. Deze erkenning van onzekerheid heeft overigens wel twee belangrijke consequenties. Allereerst dwingt zij tot het vinden van een maatstaf voor minimaal noodzakelijke kennis (c.q. minimaal noodzakelijke zekerheid) en het daarop afstemmen van juridische eisen - zoals het zorgvuldigheidsbeginsel, de 'redelijke zekerheid' en de 'objectieve redelijkheidstoets'. In de tweede plaats kan zij er bij kwetsbare belangen toe noodzaken om 'buffers' te ontwikkelen voor als het misgaat. Preventieve en repressieve buffers kunnen daartoe worden ontwikkeld, zoals reductie van risico's, compensatie, en zonering, alsmede evaluaties, actualisering en verzekering.

Aldus beschouwd grijpen het open-model voor omgaan met expertise en de idee van de bevredigende beslissing ineen. $\mathrm{Zij}$ sluiten aan bij het uitgangspunt van de bestuurlijke verantwoordelijkheid voor de feitenvaststelling, het kritisch bezien van gangbare visies en het kritiseren van waarden. Het voorkomen van schijnzekerheid vormt de ondertoon van de juridische waarborgen voor het rationeel omgaan met expertise. Als bij technisch-complexe besluitvorming over de feitenvaststelling geen openheid wordt geboden, verliezen 
de daarbij genomen beslissingen (mettertijd) hun geloofwaardigheid, zulks ten detrimente van het te behartigen belang. Er is - kortom - geen 'easy way out'. Hoezeer wij over al het kwetsbare dat ons dierbaar is ook zekerheid wensen, tot 'autoritaire' waarborgen moeten wij ons niet laten verleiden. Voortschrijdende normstelling ter bescherming van die kwetsbare belangen dient te geschieden langs de lijn van de 'lof der kritiek'! 


\section{Literatuurlijst}

Aalders, M.V.C., R.J.J. van Acht (red.), Afspraken in het milieurecht, Zwolle 1992.

Addink, G.H., De term inrichting, een vaag begrip in het kader van de harmonisatie van milieuwetgeving, in: Steenbeek, J.G., M.C.Burkens en J.B.J.M. ten Berge (red.), Bestuur en norm, Deventer 1986.

Addink, G.H., Milieurecht en privaatrecht, Publiek domein'89/5, p. 180186.

Addink, G.H., Uitgebreide openbare voorbereidingsprocedures in de Awb, NTB'92/9-10, p. 290-299.

Allewijn, D., Een nieuw procesrecht voor ambtenarenzaken, NJB-speciaal '91/36, p. 1469-1475.

Bakker, R.E. en A.Q.C. Tak, De centrale rol van het willekeurverbod bij de toetsing van overheidshandelen, in: Heringa, A.W. en N.Verheij (red.), publiekrechtelijke bewegingen, Deventer 1990, p. 205-218.

Bal, Peter, Procedurele rationaliteit en mensenrechten in het strafproces, R\&K '90/3, p. 259-279.

Banda, P.H., Administratief procesrecht, in vergelijkend perspectief, prft. KUB 1989, Zwolle 1989.

Banda, P.H., Het onderzoek door de rechter, in: Berge, J.B.J.M. ten, F.A.M. Stroink, A.Q.C.Tak, B.W.N. de Waard en R.J.G.M. Widdershoven (red.), Nieuw bestuursprocesrecht, Deventer 1992, p. 99-109.

Barning, L. en J.F. Nijboer, Het anatomisch correcte poppenarrest, NJB '89/32, p. 1173-1177.

Berge, J.B.J.M. ten en A.Q.C. Tak, Nederlands Administratief procesrecht, Zwolle 1983 (twee delen).

Berge, J.B.J.M. ten en F.A.M.Stroink, Arob in vogelvlucht, Alphen aan den Rijn 1989.

Berge, J.B.J.M. ten, F.A.M. Stroink, A.Q.C. Tak, B.W.N. de Waard en R.J.G.M. Widdershoven (red.), Nieuw bestuursprocesrecht, Deventer 1992. Bier, L., De zorgvuldige veroorzaker van milieuschade, in: Koeman, N.S.J., W.J. Ouwerkerk en J.M. van Dunné (red.), Civielrechtelijke aansprakelijkheid voor milieuschade, Zwolle 1987.

Biezeveld, G.A., De wabm gaat veranderen, M\&R'89/11, p. 442-452.

Blaauw, J.H., De rechterlijke habitus in burgerlijke en administratieve zaken, in: Brenninkmeijer, A.F.M., P.C.E. van Wijmen en J.H. Blaauw, Harmonisatie van procesrecht bij integratie van rechtspraak, NJV-preadviezen, Zwolle 1991, p. 177-223.

Bolt, H., De Awb en het begrip 'belanghebbende', NJB'93/15, p. 553-554. 
Borman, J.A., Aspecten van de AROB-bezwaarschriftenprocedure, oratie, Deventer 1979.

Borst, W.L., De bewijsmiddelen in strafzaken, prft. Leiden 1985, Arnhem 1985.

Braams, W.Th., Een oude kennis, Over de rol van "schuld" bij milieuaansprakelijkheid, in: Koeman, N.S.J., W.J. Ouwerkerk en J.M. van Dunné (red.), Civielrechtelijke aansprakelijkheid voor milieuschade, Zwolle 1987.

Braams, W.Th., Ontwikkelingen in het Nederlands recht, preadvies, in: Braams, W.Th., A. van Oevelen en W.W.Sturms, Risico-aansprakelijkheid voor milieuschade, Zwolle 1992.

Brenninkmeijer, A.F.M., in: Jurgens, G.T.J.M., T. ter Brugge en J.Veltman (red.), bestuursrechtspraak ingevolge de Tijdelijke wet Kroongeschillen, verslag van het TwK-congres, Zwolle 1991, p. 80.

Brenninkmeijer, A.F.M., Het procesrecht als proces, in: Brenninkmeijer, A.F.M., P.C.E. van Wijmen en J.H. Blaauw, Harmonisatie van procesrecht bij integratie van rechtspraak, NJV-preadviezen, Zwolle 1991, p. 1-105.

Breeuwsma, C.M. c.s., Beeld van de Arob-bezwaarschriftenprocedure, Deventer 1982.

Breeuwsma, C.M., c.s., Arob-praktijken, Deventer 1984.

Brouwer, E., J.N.M. Dekker, G.H.E. Nieuwdorp en A.A.A. van der Schaaf (red.), Strategieën voor ecologische normstelling, 's Gravenhage 1990.

Bröring, Lambers, Scheltema, Bolt, Kroonberoepen Milieuhygiëne, Deventer 1985.

Bröring, H.E., Juridisch onbestemde regels in het bestuursrecht: richtlijnen, NTB' $88 / 3$, p. 80-86.

Brugge, T. ter, J. Veltman, H.E. Bröring, K.F. Schuiling en M. Scheltema, Kroongeschillen en het nieuwe bestuursprocesrecht, Deventer 1991.

Brussaard, W., Th.G. Drupsteen, P.C. Gilhuis, N.S.J. Koeman (red.), Milieurecht, Zwolle, 1991.

Burg, Wibren van der, De rechtstheorie van Jürgen Habermas, R\&K'85/1, p. 6-26.

Burg, Wibren van der en Willem van Reijen, Inleiding in: Jürgen Habermas, recht en moraal, Kampen 1988.

Buuren, P.J.J. van, Codificatie van administratief recht in de algemene wet bestuursrecht, NJB 21 mei 1988 speciaal.

Buuren, P.J.J. van, Codificatie en vernieuwing van milieurecht in Duitsland en in nederland, NJB'92/12, p. 377-383.

Callebaut, W., Filosofische en maatschappelijke beschouwingen over ecologie, in: Goosens, M. en D.Vanderhallen (red.), Ecologische vorming in het secundair onderwijs, K.U.Leuven 1982. 
Callebaut, Werner (mod.), Taking the naturalistic turn, or how real philosophy of science is done, Chigaco/Londen, Un. of Chigaco press, 1993.

Cobben, Paul, Kan legitimiteit zuiver procedureel gegarandeerd worden? Een kritische beschouwing over Habermas' conceptie van de verhouding tussen moraal, recht en politiek, R\&K'89/3, p. 262-279.

Commissie van Maarseveen, Concept voorstel Wet Algemene Bepalingen van Administratief Recht, VAR-geschriften LXXII, Alphen aan den Rijn 1974.

Cramer, Jacqueline, gebruik van ecologische gegevens in de besluitvorming, Amsterdam 1983.

Cup, P.C., Het begrip inrichting, Een rechtsonzeker begrip?, M\&R'86/6, p. $174-180$.

Dommering, E.J., Algemene belangen in het burgerlijk recht, Deventer 1982.

Dooren, W.J.M. van en L.A. Clarenburg, Normstelling in het milieubeleid, zoveel hoofdsen zoveel zinnen, M\&R'79/7, p. 173-186.

Dorhout, L., De beroepswet, nu en straks, NJB-speciaal '91/36, p. 14611466.

Dresden, M.J., De zorgplicht in de milieuwetgeving, M\&R'89/2, p. 50-67.

Drexhage, E.C., Twee nieuwe hoofdstukken voor de Wabm, Het voorontwerp voor een wet tot uitbreiding van de Wabm met regelen inzake de milieubeleidsplanning en milieukwaliteitseisen (c.a.), M\&R'87/8, p. 258-265.

Drion, Coen, Grondslagen van de onrechtmatige overheidsdaad, R\&K'88/14, p. 333-363.

Duk, W., De zachte kern van het bestuursrecht, RMTh'78, p. 564-575.

Duk, W., Beoordelingsvrijheid en beleidsvrijheid, RMTh'88, p. 156-169.

Dworkin, R., Taking rights seriously, London 1978.

Dijk, G.R.M. van, Wabm; wetsvoorstel VAR.

Enschedé, Ch.J., Bewijzen in het strafrecht, RMTh'66, p. 488-518.

Feyerabend, Paul, Against method: outline of an Anarchistic Theory of Knowledge, London 1975.

Galen, A.G. van en H.Th.J.F. van Maarseveen, Beginselen van administratief procesrecht, VAR-geschriften LXXXIII, Alpen aan den Rijn 1981.

Gaastra, A.F., F.C.M.A. Michiels en P.J.J. van Buuren, Gelet op het ambtsbericht, Ambtsberichten van de Adviseur ten behoeve van de Raad van State in geschillen omtrent bestemmingsplannen en planschadevergoeding, Zwolle 1990.

Gilhuis, P.C., M.e.r.-plicht op twee snelheden, M\&R'92/11, p. 577.

Goorden, C.P.J., Commentaar bij art. 4:2, in: Berge, J.B.J.M. ten et al. (red.) Commentaar Awb (losbladig).

Groeneveld, E.R., Is de onafhankelijke deskundige in het strafproces uitgediend?, AA'89/11, p. 928-929. 
Groot, G.R.J. de, Een proceskostenveroordeling in het ambtenarenrecht, NTB '92/5, p. 169-172.

Gunsteren, H.R. van, The Quest for control, A critique of rational-centralrule approach in public affairs, London 1976.

H.M. Koningin Beatrix, kersttoespraak 1988.

Haentjes, R.C.P., Deskundigen in strafzaken, contra-expertise, het Europees verdrag tot bescherming van de rechten van de Mens en bijzondere wetten, NJCM-Bulletin, 85.

Heldeweg, M.A., Inspectie milieuhygiëne: rijksheer in de regio of kleine zelfstandige?, Bestuur' $86 / 1$, p. 26-29.

Heldeweg, M.A., De prijs van codificatie, TvO'88, p. 391-394.

Heldeweg, M.A., interventie op VAR-vergadering van 21 april 1989, VARgeschriften $\mathrm{nr}$ 103, p. 28-30.

Heldeweg, M.A. en E.A. Messer, Bestuurscompensatie en het specialiteitsbeginsel, RMTh. '90, p. 147-166.

Hendriks, L.E.M., Milieustrafrecht behoeft sanering, M\&R'88/9, p.334340 .

Heringa, A.W. en T. Zwart, Facelift van een oude dame?, De Grondwet 1983, NJB'83/8, p. 233-247.

Heringa, A.W., Sociale grondrechten, prft. 's-Gravenhage 1989.

Hirsch Ballin, E.H.M., Handelingen NJV 1983-I, p. 63.

Hoeven, J. van der, De drie dimensies van het bestuursrecht: ontstaan en vorming van het Nederlandse algemene bestuursrecht, Alphen aan den Rijn 1989.

Hoeven, J. van der, Toetsen aan de Grondwet. Hoe en door wie?, rede, NJB' $91 / 19$, p. 784-786.

Hoogendijk-Deutsch, S.V., Advisering in het bestuursrecht (in het bijzonder aan de centrale overheid), VAR-geschriften LXXX, Alphen aan den Rijn, 1978 , p. 11-65.

Hoogendijk-Deutsch, S.V., Boekhespreking prft. Kummeling, NJB'89/4546, p. $1695-1697$.

Hoogendijk-Deutsch, S.V., Beginselen van behoorlijk bewijs in de administratieve rechtspraak, RMTh'92/7, p. 308-323.

Hutten, D.J., Zelf in de zaak voorzien, in: Berge, J.B.J.M. ten, F.A.M. Stroink, A.Q.C.Tak, B.W.N. de Waard en R.J.G.M. Widdershoven (red.), Nieuw bestuursprocesrecht, Deventer 1992, p. 195-207.

Janswoude, J.J., Juridische aspecten van vergunningverlening door Gedeputeerde Staten, prft. Zwolle 1987.

Jaspers, A.Ph.C.M. en J. Riphagen (red.) Schets van het sociaal zekerheidsrecht, Deventer 1991.

Jurgens, Victor, Texaco: "Hoe m.e.r.-plichtig is de electriciteitsvoorziening anno 1991?", M\&R'91/4, p. 194-199. 
Kan, J.M., Bewijzen in het administratief recht, RMTh'66, p. 519-541.

Kobussen, M.H., Commentaar op art. 3:2, in: Ten Berge et al. (red.), Commentaar Awb (losbladig).

Koch, K., Rationaliteit en rationeel gedrag: Definitie en hypothese, Acta politica'76/3, p. 312-364.

Koeman, N.S.J., De mogelijkheden van de burgerlijke rechter om het bestuur uit onrechtmatige daad tot schadevergoeding te veroordelen, VARgeschriften nr. 102, Alphen aan den Rijn 1989.

Koeman, N.S.J., Het nieuwe bestuursprocesrecht, NJB'91/36, p. 14541458.

Koeman, N.S.J., Uniform bestuursprocesrecht en de herziening van de rechterlijke organisatie: enkele beschouwingen vanuit de rechtspraktijk, NTB'91/10, p. 293-297.

Koningsveld, Herman, Het verschijnsel wetenschap: een inleiding tot de wetenschapsfilosofie, Meppel 1982.

Koopmans, T., Compendium van het staatsrecht, bewerkt door J.E. Goldschmidt, A.W. Heringa en R.E. de Winter, Deventer 1992.

Krijnen, G.J.A.M. en B.W.N. de Waard, Omgaan met welstandsadviezen, NTB' $88 / 5$, p. $155-163$.

Kuhn, T.S., The structure of scientific revolutions, Chicago 1962 (hier toegepaste versie met naschrift 1969: T.S.Kuhn, De structuur van wetenschappelijke revoluties, Meppel 1987.

Kummeling, H.R.B.M., Advisering in het Publiekrecht, prft, 's-Gravenhage 1988.

Kunneman, H., Habermas' theorie van het communicatieve handelen: een samenvatting, Meppel, 1985.

Lakatos, I., Falsification and the methodology of scientici Research Programmes, in: Lakatos, I. en A. Musgrave (red.), Criticism and The Growth of knowledge, Cambridge 1974.

Lohmar, U., Politik und Sachverstand, Zur freiheit parlamentarischer Entscheidung in der wissenschaftlichten Zivilisation, Aus Politik und Zeitgeschichte, bijlage bij: Das parlament, B42/87.

Maanen, G.E., Publiek domein en het belang van de overheid bij bodemsanering, Een ongewasschen varken, oratie R.U.Limburg, Deventer 1990.

Maanen, G.E., Publiek domein en twee-wegenleer, R\&K'90/3, p. 198-209.

Maanen, G.E., Van de vogelen des hemels en de stranden der zee, Publiek domein en ander overheidseigendom, WPNR 6074, p. 970-977.

Maanen, G.E., J. Spier, C.H.W.M. Sterk, Van schuld naar risico? Enkele opmerkingen over ontwikkelingen in het aansprakelijkheidsrecht, In: Raaymakers, M.J.G.C., R. van Rooij en J. Spier (red.), Aaansprakelijkheden, Opstellen rond het thema Ontwikkelingen in het aansprakelijkheidsrecht, Deventer 1990. 
Male, R.M. van, Rechter en bestuurswetgeving, prft., Zwolle 1988.

Male, R.M. van, Beredeneerd besluiten, NTB'88/3, p. 73-79.

McMullin, E., Values In Science, Presidential Address, Philosophy of Science Association (PSA) 1982, Vol.2, 1983.

Melaï, A.L., Getuigen en deskundigen als exclusieve informanten van de rechter, D\&D’74, p. 176-182.

Meulen, Bernd van der, Nieuw bestuursprocesrecht, NTB'92/1, p. 11-20.

Meijden, Dick van der, As Low as Reasonably Achievable, M\&R'91/1, p. 12-19.

Michiels, F.C.M.A., Rechtsbescherming in het milieurecht, in: Michiels, F.C.M.A. en G.J.M. Cartigny, Rechtsbescherming in het milieurecht, Vereniging voor Milieurecht, Zwolle 1992, p. 3-14.

Michiels, F.C.M.A., De Wet milieubeheer, Zwolle 1992.

Mols, G.P.M.F., Staande de zitting, oratie RL, Arnhem 1989.

Neuerburg, E.N., P. Verfaille, Schets van het Nederlands milieuhygiënerecht, Alphen aan den Rijn, 1991.

Neuteboom, W., Bloedproef, contra-expertise en het schijvenstelsel, D\&D '86/5, p. 467-472.

Nicolaï, P., Advisering in het bestuursrecht, RMTh'81/6, p. 511-531.

Nicolaï, P., Kroniek NTB'89/4, p. 124.

Nicolaï, P., beginselen van behoorlijk bestuur, prft, Deventer 1990.

Nollkaemper, A., Progressie en stagnatie in het internationale regime voor grensoverschrijdende waterverontreiniging, M\&R'93/1, p. 11-23.

Noordam, F.M., Inleiding Sociale zekerheidsrecht, Deventer 1992.

Oosting, M., Beginselen van bestuur, Oratie RUG 1980, Alphen aan den Rijn 1980.

Overhoff, R.W., De Europese "technologische gemeenschap", normalisatienormen en nationale wetgeving, Rgelmaat'88/1, p. 9-14.

Planque, J.H.W., de, De mogelijkheden van administratieve rechters en de Kroon om het bestuur tot schadevergoeding te veroordelen, in: Koeman, N.S.J. en J.H.W. de planque, Overheidsaansprakelijkheid, administratieve en burgerlijke rechter, VAR-preadvies, Alphen aan den Rijn 1989, p. 7-160.

Polak, J.M., Uitbesteding van wetgeving, NJB'89, p. 1080.

Popper, K.R., The logic of scientific discovery, London 1959.

Popper, K.R., Conjectures and refutations: the growth of scientific knowledge, New York 1962-1965.

Popper, K.R., Rede uitgesproken als dank voor de toekenning van de Leopold Lucas Preis, in: Schavemaker, C., H.Willemsen (red.), Over het weten van de mens, Alphen aan den Rijn 1986.

Pot, C.W. van der, Handboek van het Nederlandse Staatsrecht, bewerkt door A.M. Donner, Zwolle 1983, alsmede de bewerking door L.Prakke, Zwolle 1989. 
Prakke, L., T. Koopmans en J.M. Barendrecht, Toetsing, Preadviezen voor de NJV 1992, Zwolle 1992.

Remmelink, J., Enige opmerkingen over de deskundige in strafzaken, Tijdschrift voor strafrecht, Deel 1 XXIV (1965), p. 75.

Reijnders, L., Milieurisico's, in: Boerssema, J.J., J.W.Copius Peereboom en W.T.de Groot (reds.), basisboek milieukunde, Meppel 1986, p. 439-446.

Reijntjes, J.M., Strafrechtelijk bewijs in wet en praktijk, Arnhem 1980.

Rosenthal, U., Rampen rellen gijzelingen, crisisbesluitvorming in Nederland, Amsterdam/Dieren 1984.

Rossum, E.R.C. van, M.V.C. Aalders, Milieuconvenanten: zacht recht of nieuw recht?, M\&R'89/6, p. 242-249.

RIVM, Zorgen voor Morgen, Bilthoven/Alphen aan den Rijn, 1989.

Schoonenberg, J. en H.D. Vleesch Duhois, Het administratieve procesrecht volgens de Beroepswet, Amsterdam 1957.

Schreuder-Vlasblom, M. Tussen Domininus Litis en knecht van twee meesters, NTB'91/3, p. 69-83.

Sectie bestuursrecht R.U.Limburg, Beleidsregels,: gebruiksaanwijzing van bestuursbevoegdheid, regelmaat'93/2, p. 54-60.

Simon, H.A. Models of bounded rationality, Volume 2, Behavioural economics and business organization, Cambridge USA 1982.

Simon, H., Publiekrecht of privaatrecht, prft., Zwolle 1993.

Snellen, I.M.Th., Boeiend en geboeid, Ambivalenties en ambities in de bestuurskunde, Oratie KUB 1987, Alphen aan den Rijn 1987.

Spelt, N. en Ph.Langbroek, Vergoeding van proceskosten in het bestuursprocesrecht, NTB'91/10, p. 298-309.

Spelt, N. en Ph.Langbroek, Proceskostenveroordeling in de Algemene wet bestuursrecht, NJB'92/27, p. 852-854.

Stroink, F.A.M., Inspraak vooraf of bezwaar achteraf?, in: Steenbeek J.G., M.C.Burkens en J.B.J.M. ten Berge (reds.), Bestuur en norm, Bundel opstellen aangeboden aan Prof. mr. R Crince le Roy, Deventer 1986, p. 243-253.

Stroink, F.A.M., A.Q.C. Tak en J.M.H.F.Teunissen, Een analyse van één jaar TwK-jurisprudentie, NJB'89/8, p. 253-257.

Tak, A.Q.C., Normaal bestuur, in: Steenbeek, J.G., M.C. Burkens, en J.B.J.M. ten Berge (red.), Bestuur en norm, bundel opstellen opgedragen aan Prof.mr. R. Crince le Roy, Deventer 1986, p. 255-263.

Tak, A.Q.C., Verlengde besluitvorming?, NJB'89/45-46, p. 1688.

Tak, A.Q.C., Terugtocht van twee-wegen, NTB'89/9-10, p. 297-314.

Tak, A.Q.C., Publiek domein, overheidscontract en rechterlijke wetshandhaving, NTB'90/9, p. 265-270.

Tak, A.Q.C., Het moment X, TvO'90, p. 134-138. 
Tak, A.Q.C., De ongewenste discussie, in: Berge, J.B.J.M. ten, F.A.M. Stroink, A.Q.C.Tak, B.W.N. de Waard en R.J.G.M. Widdershoven (red.), Nieuw bestuursprocesrecht, Deventer 1992, p. 67-84.

Tak, A.Q.C., De algemene wet bestuursrecht (het nieuwe bestuursprocesrecht), Zwolle 1992.

Tak, A.Q.C., Overheid en burgerlijk wetboek. Naar een invullende rechtsleer, R\&K'93/2, p. 174-190.

Teunissen, J.M.H.F., Een met voldoende waarborgen omgeven procedure.., Gemeentestem no. 6887 en 6888 .

Teunissen, J.M.H.F., het plan van aanpak Schiphol: Rechtsbescherming gewaarborgd?, In Tan, T.G., J.M.H.F. Teunissen en F.P.C.L. Tonnaer, het plan van aanpak Schiphol, Zwolle 1991.

Teunissen, J.M.H.F., Commentaar art. 7:2 e.v Awb, in: Berge, J.B.J.M. ten et al. (red.), Commentaar Awb (losbladig).

Teunissen, J.M.H.F., Toetsing ex nunc of ex tunc? in: Berge, J.B.J.M. ten, F.A.M. Stroink, A.Q.C. Tak, B.W.N. de Waard en R.J.G.M. Widdershoven (red.), Nieuw bestuursprocesrecht, Deventer 1992, p. 111-129.

Tonnaer, F.P.C.L., Het Nederlands milieurecht in ontwikkeling, Alphen aan den Rijn 1990.

Udo de Haes, H.A. en J.P.M. Bol, Voorspelling en beoordeling van effecten op het natuurlijk milieu, in: Nijkamp, P., H.E. van de veen en P.Winkel (red.), Milieu-effectrapportering, Assen 1981.

Uylenburg, Rosa, Rechtsbescherming in het milieurecht, prtt. Zwolle 1992.

Veltman, J., Het passeren van procedurele gebreken, Artikel 6.2.14 Awb in rechtsvergelijkend perspectief, NTB'89/2, p. 37-38.

Verheij, N., Een klantvriendelijke rechter, in: Berge, J.B.J.M. ten, F.A.M. Stroink, A.Q.C.Tak, B.W.N. de Waard en R.J.G.M. Widdershoven (red.), Nieuw bestuursprocesrecht, Deventer 1992, p. 131-149.

Verschuuren, J.M., Wettelijke algemene zorgplichten in het milieurecht, in: Backx, H.A.M. et al. Recht doen door wetgeving, Zwolle 1990.

Waard, B.W.N. de, Beginselen vary behoorlijke rechtspleging, met name in het administratief procesrecht, prft., Zwolle 1987.

Waismann, F., Verifiability, in: Logic and language, Anthony Flew (ed.), Oxford 1968.

Waller-Hunter, J.H., de VN-Conferentie over milieu en ontwikkeling, M\&R '92/11, p. 578-590.

Warendorf, F.C.S., Verplichte financiële zekerheidsstelling voor de nakoming van overheidsvoorschriften, M\&R'88/7, p. 254-262.

Widdershoven, R.J.G.M., Commentaar art. 7:1 Awb, in: Berge, J.B.J.M ten et al. (red.), Commentaar Awb (losbladig). 
Widdershoven, R.J.G.M., G.T.J.M. Jurgens, P.J.J. van Buuren en G.H. Addink, Bestuursrechtspraak in milieugeschillen, Evaluatie van de Tijdelijke wet Kroongeschillen op het gebied van het milieurecht, Zwolle 1991.

Wolferen, M.D. van, Ervaringen van de Afdeling geschillen van bestuur als milieurechter, in: Damen, L.J.A. en R. Uijlenburg (red.), Rechtsbescherming in het milieurecht, Zwolle 1990, p. 9-15.

World Commissions on Environment and Developement ("Commissie Brundtland"), Our Common Future, 1987.

Wulffraat-van Dijk, M.S.E., et al., Bestuursprocesrecht en burgerlijk procesrecht onder é́n dak, NJB-speciaal '91/36, p. 1489-1493.

Wulffraat-van Dijk, Marja, De onderzoeksbevoegdheden van de rechter in het nieuwe bestuursprocesrecht, in: Berge, J.B.J.M. ten, F.A.M. Stroink, A.Q.C. Tak, B.W.N. de Waard en R.J.G.M. Widdershoven (red.), Nieuw bestuursprocesrecht, Deventer 1992, p. 151-168.

Wijk, H.D. van, Hoofdstukken van administratief recht, hewerkt door Willem Konijnenbelt, Culemborg 1988.

Wijmen, P.C.E. van, Harmonisatic van procesrecht bij integratie van rechtspraak, in: Brenninkmeijer, A.F.M., P.C.E. van Wijmen en J.H. Blaauw, Harmonisatie van procesrecht bij integratie van rechtspraak, NJV-preadviezen, Zwolle 1991, p. 107-176.

IJsselmuiden, Th.S., Over eenheid van belastingprocesrecht en burgerlijk procesrecht, NJB-speciaal '91/36, p. 1484-1488.

Zippelius, R., Zur rechtsfertigung des mehrheitsprinzips in der Demokratie, Aus Politik und Zeitgeschichte (bijlage bij Das Parlament, B42/87).

\section{Overheidspublikaties \& aanverwanten}

Europese commissie, brief van 25 april 1990 (inzake milieu-effectrapportage).

Centrale Raad voor de Milieuhygiëne ( $\mathrm{CRMH})$, Advies naar aanleiding van het verslag van de werking van de mer-regeling, Den Haag, september 1991.

Commissie voor de toetsing van wetgevingsprojecten, Advies van 20 augustus 1990, CTW 90-6 en CTW-jaarverslag '89-'90, TK'90/'91, 21800 VI, 24.

Deregulering op het gebied van Ruimtelijke Ordening en Milieubeheer (DROM), TK'82/'83, 17 931, nr. 4.

Evaluatiecommissie Wabm, Advies nr. 3, Naar een volwaardige plaats, Advies over de werking van de regeling milieu-effectrapportage uit de Wabm.

IMP-Milieubeheer'85-'89, TK'84/'85, 18 602, nrs 1-2.

Minister van VROM, brief van 28 januari 1985, TK'84/'85, 18 602, nr. 5. 
Ministeries van VROM en L\&V, Jaarverslagen Cmer 1984 en 1985, Den Haag 1985 en 1986.

Ministeries van VROM en L\&V, Handleiding MER, Lelystad 1987.

NMP'90, TK'88/'89, 21 137, nrs. 1-2.

NMP-plus, TK'89/'90, 21 137, nr 20-21.

Nota milieuhygiënische normen 1976, TK'76/'77, 14 318, nr. 1-2.

Normennota'74, TK'74/'75, 13 100, Hfst. XVIII, nr. 2.

Nota Omgaan met risico's, TK'88-'89, 21 137, nr. 5.

Regeringsverslag over de werking van de m.e.r.-regeling, TK'90-' 91,22 103 , nr. 1.

Urgentienota milieuhygiëne, TK'71/'72, 11 906, nr. 2.

\section{Jurisprudentie}

EHRM 6 mei 1985, case 6/1984/78/122 (Bönisch), Vgl. NJCM-Bulletin'85, p. 447 e.v.

EHRM 23 oktober 1985, AB'86, 1 m.nt. Hirsch Ballin.

EHRM 29 mei 1986, NJCM-Bulletin'86, p. 452 (Feltbrugge).

EHRM 25 oktober 1989, AB'90, 334 (Jacobsson).

HR 23 mei 1921, NJ p. 564 (Electriciteits-arrest).

HR 25 februari 1949, NJ 558 m.nt. Veegens (Doetinchemse woonruimtevordering).

HR 5 juni 1964, NJ 405 (Gendringe/Koster).

HR 8 januari 1982, NJ 614 (Natronloog-/Vuilnisman-Dorpshuis Kamerikarrest).

HR 24 februari 1984, AB 399 m.nt. Van Eijden (St. Oedenrode-Driessen).

HR 11 maart 1986, NJ 613, m.nt. A.C.'t Hart.

HR, 16 mei 1986, AB 547 m.nt. P.J.J. van Buuren (Heesch/Van de Akker).

HR 20 september 1986, AB'87, 70 m.nt. Van der burg (Hoffman-La Roche).

HR 28 februari 1989, NJB'89/14 (Anatomisch correcte poppen).

HR 14 april 1989, AAe'89/38, nr 6, m.nt. Hirsch Ballin (Harmonisatie-wetarrest).

HR 17 november 1989, AB'90,81 m.nt. G.P.Kleijn (Velsen-De Waard).

HR 26 januari 1990, RvdW 36 (Windmill).

HR 9 maart 1990, NJ 561.

HR 6 april 1990, NJ 573.

Hof Den Haag 15 februari 1990, BR'90, p. 447 (Blankenburgtunnel).

Rb. A'dam, 29 maart 1990, M\&R'90, 58, m.nt. Fransen. 
ARRvS 17 november 1977, AB'78, 97 m.nt. B.de Goede.

ARRvS 19 december 1977, AB'78, 157.

ARRvS 4 januari 1978, AB 190 m.nt. FHv/dB.

ARRvS 9 maart 1978, AB'79, 55 m.nt. v.d.V.

ARRvS 2 mei 1978, AB 344.

ARRvS 14 augustus 1978, tB/S III, p. 86 (Welstandsadvies dakkapellen).

ARRvS 27 maart 1979, AB 367 m.nt. S.V.Hoogendijk-Deutsch.

ARRvS 28 juni 1979, AB'80, 110.

ARRvS 31 augustus 1979, AB'80, 302 m.nt. v/dV.

ARRvS 23 januari 1980, AB 564.

ARRvS 3 februari 1981, tB/S III, 237.

ARRvS 2 februari 1982, AB'83, 240.

ARRvS 26 februari 1982, AB 364.

ARRvS 11 december 1982, AB'82, 216 (Vuilcontainers Hoorn).

ARRvS 23 december 1982, AB'83, 256.

ARRvS 11 februari 1983, AB 317.

ARRvS 21 april 1983, AB 478.

ARRvS 16 juni 1983, tB/S III, 449 (Ambtenaar-secretaris hoorzitting).

ARRvS 1 juli 1983, in aantekening bij ARRvS 16 juni 1983, tB/S III, 449.

ARRvS 27 november 1984, AB'85, 354 (medisch-deskundigenadvies).

ARRvS 3 januari 1985, AB'86, 61.

ARRvS 3 mei 1985, AB 72 m.nt. JHv/dV.

ARRvS 1 juli 1985, AB'86, 241.

ARRvS 11 november 1985, AB'86, 170.

ARRvS 25 november 1985, AB'86, 259.

ARRvS 3 maart 1986, Gemeentestem 6841.10 m.nt. J.Teunissen.

ARRvS 23 september 1986, AB'87, 387 m.nt. RF.

ARRvS 9 oktober 1986, AB'87, 321.

ARRvS 23 januari 1987, AB 304 m.nt. JHv/dV.

ARRvS 20 maart 1990, Gemeentestem nr. 6910.4 (Haps).

VzARRvS 25 juni 1979, AB'80, 306.

VzARRvS 24 augustus 1979; AB'80, 8.

AGRvS 24 augustus 1988, AB 513 m.nt. BJ v/d N.

ACRvS 3 oktober 1988, GO5.86.0817.248.88.

AGRvS 9 maart 1989, M\&R'90, 11 (richtlijnen voor kolengestookte installaties).

AGRvS 20 november 1989, M\&R'91/1, nr. 106 m.nt. Jans.

AGRvS 19 april 1990, AB 464 m.nt. F.C.M.A.Michiels.

AGRvS 19 juni 1990, AB'91, 295 m.nt. FM (onder nr. 293).

AGRvS 1 oktober 1990, M\&R'91/4, nr. 41 m.nt. Gilhuis. 
AGRvS 23 mei 1991, AB 697 m.nt. FM.

AGRvS 29 juli 1991, G05.90.0872, Michiels, Vereniging voor milieurecht 1991-4.

AGRvS 26 augustus 1991, AB 608 m.nt. FM/M\&R'92/2, nr 37 m.nt. Jans AGRvS 19 december 1991, AB'92, 122 m.nt. FM

CRvB 25 november 1977, AB'78, 292.

CRvB 28 september 1979, AB'80, 455.

CRvB 16 juli 1980, AB'81, 61 (Adviesverzoek KvK).

CRvB 1 juli 1987,, RSV'88, 234.

CRvB 8 juli 1987, RSV'88, 74.

CRvB 14 september 1988, RSV'89, 95.

CRvB 17 december 1991, AB'92, 163 m.nt. HH

Ambtenarengerecht Utrecht 14 juni 1971, AB'72, 216 (Willem Arntzhoeve).

VzCBB 4 januari 1991, M\&R'91/4, nr. 42 m.nt. Uylenburg en Jans.

KB 28 juni 1985, Gemeentestem 6845.9 m.nt. Bomhof. 


\section{Summary}

The First Part of this study has an introductory character. To that end the occasion for undertaking this study is sketched and furthermore the most important elements are (at this point sometimes rather summarily) described.

The most important matter in chapter one is the statement of the problem to be treated in the study: which legal guarantees should be observed when technical-scientific expertise is sought with respect to the granting of environmental licences? This question not only concerns a study of environmental law; the chosen approach purports to allow conclusions to be drawn for administrative law in a general sense. As far as environmental law is concerned the granting of licences pursuant to the Environment Act' will have a central position.

On the basis of this statement of the problem it is not the intention to embark on a quest for ways of increasing the contribution made by technical-scientific expertise in the decision-making process - at least, not without more. The starting-point is rather concerned with qualitative issues: what role should the expertise have in the decision-making process? In this regard there are two assumptions of primary importance. First, the lack of objectivity and the (fundamentally) uncertain character of technical-scientific expertise. Furthermore the undesirability that the administration and the judiciary assert a claim to a 'super-expertise', according to which the appearance is created of an objective and sound basis to the decisions taken.

The implicit proposition is, in this connection, that if these two assumptions prove correct, this must have consequences for the specific legal safeguards concerned with the obtaining of expertise. In order to avoid overlooking one single safeguard, a broad approach to the research is preferable: the idea of rational decision-making. The first assumption can be tested against this idea, in particular with theories on scientific rationality. Moreover theories on rational decision-making can perhaps indicate which tack to take in dealing with scientific uncertainty.

It is a primary concern that this study should result in pronouncements of practical relevance to at least four matters: pronouncements concerning responsibility for the obtaining of expertise, concerning the necessity to obtain expert advice, concerning procedural guarantees, and concerning the taking account of technical-scientific uncertainties.

1. Hereafter referred too as EA. 
In the second chapter the provisions of environmental law, which are central to this this study, are more specifically indicated. First it is the intention to demonstrate the great extent to which the environmental question - as the empirical site of action for environmental law - confronts society with technicalscientific problems. Two very important characteristics emerge from the sketch: the ecological and the technical-dynamic character of the environmental question. In respect of both characteristics the environmental question is, to a considerable extent, becoming increasing subject to scientific influence. If we link this fact to the fear of extensive and irreversible harm to (parts of) the inhabited environment, then the interest in a good environment comprises, in terms of decision-making, a complex interest.

In the wake of this finding the provisions of positive environmental law are studied more closely. In the light of the technical complexity of the environmental question, it must first and foremost - following Waismann - be pointed out that it is impossible to give complete and definitive descriptions of empirical reality: only incomplete and provisional, so-called 'open' descriptions can be given. This position is entirely in accordance with the given characterisation of environmental law as well as with the deployment of open provisions in environmental law.

A number of these provisions will subsequently be described. First, a number of open public law environmental provisions, including basic rights, licences, duties of care and environmental crimes. Subsequently also the open private law provision of liability in tort - which is also of importance for environmental law - requires attention. By way of contrast it is remarkable that there is a tendency, in certain cases, to use specifically closed provisions, which include the so-called 'general provisions'.

The conclusion of the second chapter is that in environmental law the prevailing question is of a continuous progression in the setting of norms. The risk, on the one hand, of extensive and irreversible environmental damage and, on the other hand, the ecological and technological-dynamic characteristics, make certain that such is the case. The necessity for open and continuous setting of norms is the paradigm of environmental law. As a complement to this paradigm, the role of environmental law revealed in case law will remain of vital importance.

In the third chapter it is investigated what points of departure are afforded for a legal analysis and evaluation of the contribution of expertise in case of open (environmental law) provisions. Openness of provisions necessitates, according to the starting-point of this chapter, the amassment of knowledge. Two forms of openness should be distinguished: openness in terms of the conditions under which a power may be applied and openness in terms of the choice whether, and if so, how, a power will be used. The associated terms, margin of appreciation and discretion are described. Subsequently the role of exper- 
tise in evaluation and in the weighing up of interests is investigated. In both cases it is necessary to establish the facts and that is just the occasion upon which the obtaining of expertise can be desirable.

In evaluation the administrative duty to establish the facts flows from the legality principle (are the conditions of application satisfied?). The establishment of the facts is enmeshed into a process of interpretation and characterisation. Art. 3:2 Administrative Law $\operatorname{Code}^{2}$ provides a valuable gauge for the obtaining of expertise. The administration's special responsibility for the establishment of the facts furthermore stems from the duty to weigh up various interests. The recognition and evaluation of interests plays a large part in this process. An important part of this work concerns the comparison of alternative decision-making options. Art. 3:2 ALC provides, also in this sphere of operation, an important measure for the collecting of information. Additionally Art. 3:4 ALC in particular plays a primary role.

In evaluation and in the weighing up of interests the authority charged with establishing the facts is confronted with uncertainty as to the facts. Two forms of uncertainty can be distinguished: uncertainty of principle and practical uncertainty. Uncertainty of principle is unavoidably present in all our perceptions: we can never say with certainty whether we, in our theories, have explained the empirical reality in an adequate and accurate way. Practical uncertainty places a more concrete pressure upon decision-making: sometimes the theories considered necessary are lacking and there is (accordingly) said to be a lack of information.

Against this background the evaluation and weighing up of interests in the grant of EA-licences will be analysed. In this analysis it will become apparent at which points it is necessary for the administration to obtain information in order to establish the relevant facts.

In the second part of this study points of departure for rational decisionmaking will be sought. This will be done in the fourth chapter, in which, following Snellen four sorts of rationality are distinguished: political, legal, economic and scientific.

Scientific rationality receives central attention, since the assumptions concerning scientific rationality form the basis of the present study. The investigation of scientific rationality includes further an analysis of the uncertainty of principle discussed in chapter three. Practical uncertainty is subsequently considered under the heading of economic rationality. Finally, under the heading of legal rationality, some consequences emerging from the findings

2. The administrative Law Code will hereafter be referred too as ALC. The Code consists of three parts. The first two parts should be implemented on 1 January 1994. The third part is still in the draft stage. 
will be set down in the form of a number of rules of thumb for rational decision-making.

The assumptions made in the first chapter in respect of scientific rationality are confirmed. We have to accept that, as a result of under-determination, our theories will always be fundamentally uncertain. In the light of this fact values are of great importance for the choice of theories in carrying out scientific work. Accordingly the appearance is created of scientific rationality as a contingent social consensus. Also a more positive vision is possible. Scientific work leads, as the product of a successful group, to an ever increasing capacity for resolving puzzles. In that sense there can indeed be said to be scientific progress. In so doing non-scientific values, measurement- and calculation errors can be elimated in the scientific practice. Agreement can perhaps be reached in respect of the application of particular values and in that sense can even be spoken of 'objectivity'. Above all, the exercise of criticism in an open debate between concerned parties is essential to the practice of science.

Economic rationality is linked in this chapter with practical uncertainty. This type of uncertainty obstructs a rational-synoptic manner of decision-making. As an alternative the applicability of the satisfactory solution theory (Simon) to the laying down of legal norms is investigated. This leads to a 'theory' of legally satisfactory decision-making in three steps (select, investigate and examine). It is implicit in this 'theory' that the requirements of care and reasonableness have a relative sphere of application - referring to 'alternatives which should reasonably be considered', 'reasonable certainty' with respect to the facts and the 'not unproportional' character of decisions. The endeavour to reduce uncertainty is also accommodated within this theory.

It is essential, for legal rationality, to secure confidence in the law. For the legitimation of legal norms it is desirable that they are the product of an (inasfar possible) open debate. This does not only apply to legislation enacted by parliament but also to administrative decision-making to implement parliamentary statutes. In addition to procedural justification legitimation of the contents is desirable. Opinions about democracy and human rights can have an important role to play in that connection.

Subsequently, five rules of thumb can be formulated to achieve legal rational decision-making in cases in which uncertainty is present. These are, respectively: administrative responsibility, the satisfying decision, the openness of decision-making, current opinions and criticism and working with values. These five rules will be used as points of reference thereafter in this study.

Finally there are a number of practical points of importance: when should expert advice be sought, the unequivocality of available kwowledge, apparent certainties, the expert, the independence of experts and the different kinds of advice. Following upon this, for a number of normative choices with regard 
to the establishment of the facts it will be investigated what approach should be expected of the administration. In this context the importance of administrative responsibility for all aspects of the establishment of the facts must be emphasised anew. As a result of the discussion of practical questions, some other rules of thumb also require refinement.

The third part of this study contains an investigation into the legal guarantees in respect of the seeking of expertise in the non-contentious procedure. Primary in this investigation is a pyramidal approach: first it will be considered whether the requirement of rational decision-making can be considered to be a guiding requirement in public law, then more specific guarantees to be found in the general part of administrative law will be investigated, and finally there is an analysis of some guarantees, specific to environmental law, in respect of the approach to expert advice. Where possible, findings will be compared with the rules of thumb discussed in the second part of the study.

Chapter five revolves - in the sketched plan - around the question whether rational decision-making can be viewed as a requirement of lawful administration. The first approach is to investigate what administrative law actually can offer. To this end a link is made to Van der Hoeven's 'three dimensions of administrative law': legitimacy of the governing power, instrumentation and the imposition of normative limits. Because this study is primarily concerned with guarantees, the most attention is given to judicial review of administrative action (in the broad sense). First of all reference will be made to the opinion of Van der Hoeven that 'micro-administration' requires an independent judicial supervision. In passing it will furthermore be pointed out that the idea of democracy, because of the stress placed upon the public forming of opinion, can contribute to rational decision-making - if constitutional guarantees are observed.

A more penetrating analysis follows, based upon Van Male's 'rationality postulate' and Nicolaï's 'evident rationality'. Although the vision which those authors give of the emergence of unwritten guarantees as carriers of a relativist idea of rationality is enlightening, in their analyses precisely the limits of the requirement of rational decision-making are insufficiently emphasised. In this study the tension between the promotion of the general interest and the individual liberty of citizens is taken as a starting-point. In this context the political will to exercise power, as long as it enjoys legitimacy through democracy, is identified as an indispensible driving-force in the governmental administration. Judicial restrictions upon this will, in order to protect individual liberties, are necessary, but at such level that room remains for the driving-force to remain effective. This leads to the proposition that the prohibition against arbitrariness fulfills the role of setting the tone. Prohibition of arbitrariness (in the broad sense) is described, following upon the above, as 
the paradigm of administrative law; an unwritten generic principle which sets the outer boundaries of the exercise of political power. This prohibition upon arbitrariness both upholds and limits the requirement of rational decisionmaking. More specifically this implies that the relativism in the modern idea of rationality can be expressed in the requirements of open decision-making and in the prohibition against irrational actions. In respect of the contribution of expertise two important aspects are pointed out: the correcting of inaccuracies (including also the criticism and making available for criticism of (draft-) decisions), and the requirement of a legally satisfying decision.

In the sixth chapter specific guarantees in the general part of administrative law are sought. The starting-point is that the legal guarantees connected to the non-contentious procedure, linked to democratic legitimacy, should contribute to a 'public law legitimacy' of administrative decisions. This opinion is a logical sequel to the proposition that also micro-administration requires its own legitimation and an independent control. Simultaneously this underlines the independant and 'substantive' importance of the non-contentious procedure.

The observance of unwritten principles of law provides the foundations of public law legitimacy. In particular the prohibition against arbitrariness in the broad sense (as generic principle) is - again - mentioned, and in the light of the expertise problem, also three species-principles are mentioned: the prohibition against arbitrariness (in the narrow sense), the duty of care and the duty to give reasons.

The ALC procedures constitute important (positive) results or effects of (aspects of) the principles mentioned. Accordingly the general standard procedure, the (extended) public preparatory procedure and the notice of objection procedure under the ALC are discussed. One of the conclusions flowing therefrom is the rejection of the idea of an (almost) generally-required notice of objection in the form of extended decision-making. This choice fails to recognise the importance of non-contentious decision-making as a form of open consultation, preceding the taking of an - in principle at least final decision. The proposal is made to always use two steps in the noncontentious decision-making: first an intention or request stage and then a draft stage. From this follows the possibility of (contentious) appeal in two (factual) instances. Another conclusion is that the care for the expertise of the citizen appears to be rather limited. Although in the non-contentious procedure (in principle) a heavy burden of proof must not be placed upon the individual, it seems wise nevertheless, in certain cases, to provide for expert support.

Subsequently the specific rules on the giving of advice are more closely studied. As far as specific advice is concerned this takes place in three stages: obtaining expert advice, rendering expert advice available for criticism 
(prevention and control) and the authoritativeness of expert advisors. In the conclusion in this part the rules of thumb mentioned in the fourth chapter again apear. First of all the administrative responsibility for the advice; the administration must establish limiting conditions and carry out a marginal review (reasonableness and carefulness). Secondly, the advice (if the basis for the preparatory research) must deal with all essential elements, albeit within the limits of a satisfactory decision. Thirdly, the great importance of the ability to check and review the advice, particularly by way of the right to participation, is considered. In this context the point about supporting the expertise of ordinary citizens is reiterated. Fourthly, the question is considered whether an expert advice must always represent the (most) prevailing scientific vision. Also, bearing in mind the risk of contradictory advice, the desirability of a fixed, independent advisor and a 'worst-case scenario' is discussed. Fifthly and lastly the importance of independence of an advisor is considered.

The so-called guidelines are essential when one is concerned with general advice. After a short description of the reasons for laying down guidelines, about those who develop guidelines and the legal authority of guidelines (when may they be departed from?), there comes an evaluation. In the evaluation the primary consideration is that the persuasiveness of guidelines must, in every case, be critically examined. It is necessary to have separate regard to each element - scientific basis, interpretation of vague terms and policy choices. With respect to policy choices in guidelines a court must take account of the freedom to form policy which is entrusted to administrative organs. In the light of the policy choices a court should, at the same time, to be watchful for the independence of the maker of the guidelines. In respect of the technical-scientific aspect of the guideline, a comparison with the expert advice can be made. In particular it should be considered whether the guideline is supported by a technical basis of (proved and tested) quality and whether account should be taken of new insights or special circumstances in the particular case. The administration should always specifically make it possible (via participation) for contradictory expertise to be introduced.

In the conclusion to chapter six again the importance of openness is decisionmaking is stressed. Also the demerits of the obligatory notice-of-objection procedure and the lack of attention for the expertise of interested citizens will be considered. Furthermore, emphasis will be placed, with a view to the giving of advice, upon the administration's own responsibility, the requirement to make a satisfactory decision, the independence of the advisor, the distinctiveness and degree of insight offered by expert advice, and the necessity for a critical attitude (and, connected thereto, the possible role of permanent advisors). The chapter closes with a number of points requiring further attention subsequently in the study. 
In chapter seven the search for legal guarantees in the obtaining of expert evidence is focussed upon environmental law. This concerns, in particular, four subjects: the Environmental Impact Assessment ${ }^{3}$, making provision for the expertise of citizens, the input of permanent experts and a number of leads to reducing uncertainty.

The EIA is discussed at some length, exactly because it is pretended to be a 'rational decision-making procedure' in which the input of technical-expertise plays an important role. In discussing the EIA-procedure and the sphere of operation of the EIA, the evaluation by the EA-Evaluation Committee ${ }^{4}$ plays an important role. Also the government's report evaluating the EIA will be considered. In conclusion three points are considered.

First the separation of responsibility. The attitude of the government that the EIA-comittee should confine itself to the giving of advice - even if the competent authority is also the initiative-taker - deserves support. The openness of decision-making should be able to guarantee that the administration takes adequate account of the advice of the EIA-committee. The separation of responsibility should, besides, imply that if an Environmental Impact Statement ${ }^{5}$ is accepted by the competent authority, any later adjustments to the EIS which becoome necessary should be the primary responsibility of the administration. Accordingly, following the proposal of the ECW, a reversal of the third and fourth steps in the EIA-procedure (evaluation of the acceptability of the EIS -consultation and examining EIS) should be brought into effect. First the EIA-committee should give its advice, and thereafter the administration should decide the question of acceptability of the EIS. In this perspective it is evident that the person taking initiative can be required to make adjustments between these two steps. The procedural objections of the government in this respect are not convincing. It is, however, correct that this approach requires decision-making in two steps, but in chapter six it has already been stated that it is desirable that the non-contennsious procedure be split into intention and a draft phases; in this vision the procedural objections fall away.

Secondly, the EIA-procedure can contribute to the formation of open norms in environmental law. Art. 7.35 EA has the effect that the competent authority must reflect upon the technical and social adequacy of the norms laid down. From this point-of-view the risk of serious environmental damage is not only the basis for the obligation to deploy EIA, but also for an open link to 'continued setting of norms'.

\footnotetext{
3. Hereafter referred too as EIA.

4. Hereafter referred too as ECW.

5. Hereafter referred too as EIS.
} 
The conclusion is that the EIA-procedure fits in well with the theory of the satisfactory decision. In this connection the selection of alternatives to be investigated in connection with the laying down of guidelines are particularly striking. By way of conclusion it can be stated, in accordance with the ECW and the government, that the ElA-provision is a reasonably (not to mention 'satisfactorily') functioning instrument.

The second subject in this chapter is the care for the expertise of citizens. In decision-making in matters of technical complexity, the way should be paved, also substantively, for openness or access to the debate in respect of the decision to be taken. The administration not only has a duty of care to provide citizens with relevant information, but also to place citizens in the position to consult an independent expert. The 'exchange of ideas' in Art. 3:25 first section ALC seems to provide a possible point of reference. At the same time the starting-point in the non-contentious procedure must remain that a citizen only has to provide the initial initiative to the obtaining of evidence. Too generous provisions would result in an increase in the burden of proof laid upon citizens in non-contentious procedures.

Furthermore chapter seven contains a plea for the creation of a general right in independent experts to give advice in technically complicated decisionmaking. Thus the provision of contradictory expertise can be institutionally guaranteed. This could be achieved through the creation of an organisation with regional branches. In this connection two 'instances', the EIA-committee and the Environmental Hygiene Inspection Service, are compared. This comparison reveals that the Inspection Service does not meet the required standards of independence. As far as the content of the advice is concerned it is established that such advices should not only be concerned with technical insight but also with the task set by the legislature (in particular to strive for the highest possible level of protection of the environment).

Finally the legal points of departure for the reduction of uncertainty will be considered. In that connection will be considered: the openness of decisionmaking, the comparison of alternatives, the making explicit of gaps in knowledge, the ALARA- and principle of taking precautions, evaluation, the duty to keep up to date, compensation provisions and insurance.

The fourth part of the study is concerned with safeguarding the (non-contentious) guarantees. This is an issue which invokes the question how the administrative court treats (the input by) expertise. This question will be discussed in two steps. First the function of the administrative judge will be considered. It is, namely, interesting to consider from which point-of-view, in which way, and to what extent that administrative judge should engage in the establishment of the facts. Moreover it is interesting to examine the establishment of facts itself and the role of the factor expertise in that process. The aim of 
the research and the rules of evidence in administrative law are, in this matter, especially of immportance.

Chapter eight begins with a sketch of the contours of the new administrative procedural law. The choice for the judicial review function of administrative procedure is expressly approved. At the same time the starting-point of autonomy of the parties is accepted. This starting-point does, however, expressly leaves room for application of 'compensation for inequality' by the administrative court - particularly through the possibility of supplementing the legal grounds of the claim and the facts.

An important matter is the relationship between the non-contentious and the contentious procedure. The point-of-departure is that the court must avoid performing unnecessary or unrequested activities which are precisely belonging to the non-contentious procedure. In support of this perspective it is (once again) pointed out that the non-contentious procedure also has a democratic character and the character of offering the individual judicial protection against the administration. Several features are expressed in the open procedure in which consultation can take place about the decision to be taken in its entirety (having regard to all possible consequences). In this process the endeavour to achieve optimal individual administration of justice is primary. This includes the endeavour to accord effective respect to interests affected in specie rather than in financial terms. In this context it is appropriate for the judge to contribute to the possibilities of taking decisions, in a non-contentious manner, which are as fully as possible adjusted to the situation. It is entirely in accordance with this approach that, for practical reasons, in administrative law the disputed administrative decision is identified as the object of dispute and that the court, if the decision turns out to be unlawful, can quash the decision. In this regard there is a point of principle at play to the extent that, the decision having been quashed, the administration cannot escape its responsibility to take a new decision.

Furthermore express attention is drawn to the margin of appreciation connected with the establishment of the facts by the administration. In connection herewith the court has to proceed on the basis of the primacy of the administration in establishing the facts. Accordingly the court must conduct a substantive review of the establishment of the facts by the administration according to the test of 'objective reasonableness'.

Following from this approach the desirability (not to mention, permissibility) for the court to take the decision itself requires attention. If and insofar administrative discretion is at issue - and the presumption is that such will be the case in respect of the facts (the normative choices) - the court should not take the decision itself. Also the public effect of decisions and the decision whether to set the decision aside or to quash it completely constitute a limitation for the courts to take the decisions themselves. The kernal of the discus- 
sion in the eighth chapter is the protection of the value of the non-contentious procedure as well as the concern for an excessive trust in (the capacity of) judicial resolution of disputes. On balance therefore it is argued that in the case of judicial review the primacy of the administration in establishing the facts and the criterium of 'objective reasonableness' come to the fore. Concerning the question whether the court should take the decision itself the restriction to taking measures with a 'relative' character seems to offer a practical guaranter for respect for administrative discretion. Last but not least attention is (again) drawn to the importance of judicial decisions at two instances - exactly (also) because it concerns technically complicated disputes.

Chapter nine, apart from a short outline of the contentious procedure, gives central attention to the law of evidence in administrative law. First the role of the administrative judge as dominus litis is considered, more specifically as resigned but active judge. In the light of the great judicial influence upon the proceedings, considerable importance is attached to the ability to criticise and control judicial decisions - in connection with which the desirability of a judicial decision at two instances must be recalled. There is, above all, reason for concern about the ability to criticise the judicial decision to commission research to be undertaken by experts. Art. 8:47 ALC offers the parties to the proceedings little consolation. It is to he feared that the judge in technically complicated cases will make an autonomous decision to commission expert research, by which - notwithstanding all the autonomy of the parties such a broad term of reference will be given that it will all too quickly become a complete re-establishment of the facts - notwithstanding all the garantees in non-contentious proceedings. Therefore a stronger position of the parties to the proceedings in the stage proceeding research is to be recommended.

On the basis of a short discussion of the 'new-style permanent-expert-procedure' the issue of the dualism of the judge and expert again emerges. Here the point of view formulated in the first rule of thumb is appropriate: inhouse technical expertise is useful (and to a certain minimum would appear even necessary), but in-house expertise must not become the sole basis for legitimating an (administrative or)

judicial judgment.

The law of evidence in administrative law is subsequently more closely investigated by studying the problem of the scope of the evidence, the distribution of burden of proof, the various sorts of evidence and the evaluation of the evidence. At the outset it must be pointed out that the determination of the substantive truth - as primary objective - is embedded in a number of normative propositions which are connected with the function of the procedure and the role of the parties therein. 
In respect of the scope of the evidence the court, given the judicial review element, will have to take party autonomy seriously. On this basis the court should abstain from any integral re-investigation of the facts on its own initiative. The parties to the procedure should be given the opportunity as early as possible in the proceedings to make their views of the facts known.

Also in the distribution of the burden of proof the autonomy of the parties should make itself felt. The court could, however, by way of compensation for the (negative) inequality of the citizen who is party to the proceedings, bear part of the burden of proof. Furthermore the presumption of lawfulness is an important gage to the distribution of burden of proof between the parties. As well as in the 'porchway' to the production of evidence, the motivating of the appeal and in the pre-procedural explanation given by the defending administrative body, as well as in real leading of evidence this presumtion with the compensation for inequality plays an important role. Moreover it appears a good idea to resist the temptation to apply the maxim 'he who makes a proposition, must prove it'; the pattern of distribution of burden of proof is distinctly too capricious for that.

In the matter of the various sorts of evidence the defence principle is of great importance. The parties to the proceedings must have the opportunity to express their views on all procedural documents relevant to the judicial decision. In technically complicated disputes the possibility to call contraexpertise should be the rule. On the subject of expertise, expert reports are particularly interesting. In this respect the experience with official reports in environmental disputes is instructive. From this experience it becomes apparent the extent to which it is necessary to guard against undermining of the judge's position as dominus litis and for automatically going for re-examination of the facts. In this light it seems advisable to opt for giving advice to the judge on an ad hoc basis. Such advice should be directed to specific questions, after the parties have been given the opportunity to provide evidence themselves. In any event the parties should have the possibility, as originally suggested by the government, to give their opinion of the terms of advice requested of the expert. With such an approach there is no need to fear for standard re-examination of the facts, nor for infringement of the autonomy of the parties; the administration can immediately be held accountable for its 'pre-procedural burden of proof'. In this way the judge can realise his passive but active role to the full, and the non-contentious procedure retains its independent value.

Finally the evaluation of evidence is considered. The independent position of the judge is evident in this. Therefore the phenomenon of ' convincing the court' requires attention. In that connection the desirability of a critical judicial attitude comes quickly to the fore. In the interests of clarity: "convincing the court' does not mean that uncertainty can be eliminated in the lea- 
ding of evidence. The point is to attain the legally required level of certainty: namely, 'reasonable certainty'. In the case of vulnerable interests the burden of proof will be heavier - for the administration, but in consequence also for the opposing citizen. The motivation for the judicial evaluation of the eviden$c e$ is then very important. Especially when it concerns a judgment about methodological criticism. In this context the desirability of a right to introduce contra-expertise and case law in two judicial instances is (again) indicated. Finally the pros and cons of formalising evidence must be considered. An important point is the proposition that the administration may decide, in some circumstances, on the basis of new insights, to depart from or to supplement the formal rules of evidence.

In the last and fifth part of the study (chapter ten) it is time, with the assistance of a summary of the matters which emerged in the earlier parts of the study, to reach certain conclusions and recommendations.

In this context it is attractive to bring attention once more to the formulation of the problem: which legal safeguards should be observed when technicalscientific evidence is obtained in applications for environmental licences?

By way of conclusions there are five points which require further attention.

First, the insight that the problem of expertise is not so much a question of more or less expertise (quantative analysis), but much more the question how 'to work with' expertise (qualitative analysis).

Second, the importance of a specific 'public law legitimation' of the work done by the administration requires attention. Here the non-contentious procedure plays an essential role, especially in the light of democratic calibre, the administration of justice to individuals (judicial review) and the technical-substantive quality of the decision-making. Here the opportunity for reciprocal argumentative influence by the concerned bodies and individuals is of vital importance. In that regard a two-phase procedure must be chosen (intention and draft) which is a departure from the present notice of objection procedure. In the procedure the substantive equality between the various bodies and individuals must be regarded. Although the administration primarily has responsibility for the establishment of the facts, whereas an opposing citizen 'only' has to indicate his or her interest, it is desirable, in technically complicated decision-making, to make provision for technical-expert support for third parties.

The crucial role of the non-contentious procedure has consequences for the contentious proceedings concerning the administration. It must be avoided that the court undermines the non-contentious guarantees. In particular powers of judicial review and judicial rulings must take account of the opportunity given to the administration in the establishment of the facts. 
Thirdly, it cannot be stressed enough that it is impossible to achieve certainty in respect of the facts. Legally speaking only 'reasonable certainty' can be required of the administration. Neither the administration nor the court should pretend to a 'super-expertise'. The point is not to find the greatest expertise but to create knowledge which is open to criticism. In this respect the administration fulfills legally a pivotal function, which implies that normative choices are made.

Fourth, the paradigm of progressive setting of norms requires attention. The connected creation of open norms is apparent in many places: in the license system, the duties of care, the extended competence to make decisions, the duty to bring things up to date, the guidelines and the the legal concepts derived from the Civil Code. Progressive laying down of norms is the basis for the role of the expert in environmental law. Progression of norms does not detract from the fact that it must be realised when decisions are taken that we are only able to make 'satisfactory decision'. The point is to make a decision which is, from a legal point of view, rationally acceptable, but being fully aware that decisions once taken may require revision in the light of later acquired insights.

Finally there are still the rules of thumb. Actually it coinsists of a collection of points-of-departure with an heuristic function. With hindsight the guidelines provide a peg upon which to hang the summary of the study.

At the last stage in the study it is attractive to inventarise the recommendations made within the study. It is useful to approach this task from the point of view of the various actors in the process of establishing norms: citizens, the administration, judge and the expert. Consideration of the position of the expert provokes the following remarks. In this study the model of the expertauthority, who unilaterally and more-or-less without being vulnerable to contradiction reaches a (binding) expert-conclusion, is expressly rejected. On the contrary an open, argumentative model is preferred. It follows from this choice that some form of measure must be found for the degree of certainty (or minimal required knowledge), and 'buffers' must be considered with a view to preventing or managing damage attributable to technical-scientific mistakes. The open model for working with expertise will (in the longer term) serve to promote confidence in the laying down of norms and in the protection of vulnerable interests. It implies for techically complicated decision-making that there is no easy way out. Decision-making will do well to take place on the basis of 'the praise of criticism'. 


\section{Zakenregister}

Aanvraag 10, 54, 80-83, 103, 151-153, $156-164,214,244,248,249,252,253,274$, 395

Aanvrager 39, 55, 83, 104, 151-154, 156, 158-161, 164, 173, 175, 227, 234, 252, 253, $309,364,404,410,413$

Abbb 53, 122, 125-127, 133, 136-139. $141,145,175,176,278,287$

Adviseur Beroepen Milieuhygiëne (ABM) 206, 354-357,359

Actualiseringsverplichting 271

Afdeling Bestuursrechtspraak 285. 322

Afdeling Geschillen 206, 224, 234. 253, 299, 312, 313, 319, 352, 353

Afdeling Rechtspraak 29, 182, 183, $187,346,353$

ALARA 112, 261, 267.269, 271, 274, 397

Algemeen belang 121, 128-131, 133$136,138,142,205,287,288,296,309,394$ Algemene regels $7,8,28,36,38-40$, $54,57,175,256,267,270,374,390$

Ambtsbericht(en) 263, 337, 339, 348. $350-355,357,358,360-363,383,400,415$

Beleidsregels $89,91,106,136,203,352$, 358

Beleidsvrijheid 33, 42, 45-47, 49, 51, $53-55,81,83,86,91,99,109,131$, 203-205, 208, 209, 296, 302, 306, 307, 309. $312,319,391,395,402,404,412$

Beoordelings-opportuniteit 300,302 $303,309,335,380,398$

Beoordelingsruimte 45-47, 53, 205, 208, 224, 391

Beoordelingsvrijheid 45-48, 81, 205 206, 308, 311, 335, 377, 391

Bevredigend beslissen 78, 93, 94, 99 , $142,146,213,217,250,251,278,392$

Bezwaarschriftenprocedure 90, 151 . 154-156, 158, 164-176, 214, 215, 217, 394, $396,403,410,411,412$
Bmer 233, 237-240, 245-247. 250

Burgerlijke rechter 129, 133, 136, 286. 292, 332, 346

Cmer 221-226, 228-230, 232, 237, 241244, 246-249, 251, 255-257, 259-261, 265, $275,396,397,413$

Compartimenten 30

Compensatie 242, 272, 274, 364, 400, 417

Contentieux objectif 288, 289, 295

Contentieux subjectif 288,334

Context of discovery 64

Context of justification 64,369

Contra-expertise 6, 101, 108, 141, 185, $187,193-196,212,249,261,264,265,349$. $359,363-365,371-373,376,377,383,384$, $395,397,400,401,403,405,412,413$, 415,417

Cruciale besluit(en) 238, 239

Democratie $98,122-124,131,297,392$ 393. 402

Deskundigenonderzoek 324-325, 331, 339, 356, 359, 362, 363, 366, 371, 373, 374, 381, 399, 411

Deskundigenverklaring $350,351,366$ 367,374

Détournement de pouvoir 53, 122, 273

Dominus litis $305,312,322,324,327$, 332, 333, 360, 363, 374, 381, 383, 399, 400,415

DROM 38, 39, 227, 238

Duurzame ontwikkeling 15, 17, 241, 267

ECW 219-229, 231, 237-245, 248, 251, 275, 396, 397

Erga omnes/publieke werking 291, 293, 306, 309, 310, 319, 380, 399

Evaluatie-plicht 271 
Evidente regels 126, 136, 137

Ex nunc 288-290, 292, 303, 307, 309-312, $314,317,319,352,376,380,399,407$

Ex tunc 289, 290, 292, 303, 307, $309-312,314,317,319,352,375,377,380$, 399, 407

Fair-trial-beginsel 284

Falsificatie 66-69. 75

Formele rechtskracht 144, 213, 278

Geheimhouding(splicht) 184, 253

Gerichte advisering 114, 177, 179. 198, $211,216,314,395$

Getalsnormen 36

Herziening $8,27,41,158,171,172$, $245,284,285,290,317-319,328,375,407$ Hoorplicht 147, 153-155, 166, 171, 214. 304

\section{IMP $36-38$}

Individuele rechtsbedeling 128, 129 . $135,144,293-295,297,318,380,398$

Informele voortoets 225, 226, 229, 242, 244,248

Initiatiefnemer 221-223, 225-228, 230, 239, 241-244, 246-248, 251, 275, 396, 413 Inrichting $13,24-26,38,55,56,163$. $175,183,207,215,267,271,273,353$

Inspectie/inspecteur milieuhygiëne $203,227,254,258,397$

Kwalitatieve aansprakelijkheid 34 Kwetsbare geschillen 285, 316, 373 , 415

Legaliteitsbeginsel $48,56,100,125$, $133,135,138,140,145,302,306,391$. 404, 412

Marginale meeropbrengst(en) 87,88 , 195, 199

Marginale toetsing 46, 47, 101, 395, 402,408
Materiële waarheid 289, 305, 332, 333, $348,362,365,382,399$

Meest milieuvriendelijk alternatief 266

Milieu-effectrapportage (m.e.r.) 82, 114. 219-221, 223-228, 230-247, 249-252, $256,257,259,266,267,271,272,274-276$, 279, 299, 396, 397, 406, 413

Milieu-effectrapport (MER) 41, 82, 114. 220-233, 236-239, 241-244, 247-253, 257-259, 265-267, 274, 275, 364, 396, 413

Micro-bestuur 122

Milieubeheer 17, 36, 38, 202, 203, 227, 238, 258, 354, 415

Milieukwaliteitseisen $7,36,37,54,55$. 57. $268,270,273$

Motiveringsbeginsel 146, 149, 150, $155,191,201,204,206-208,284,302,308$, 394

Nationaal Milieubeleidsplan (NMP) $14,16,17,241$

Netto-belangenresultaat $83,90, \quad 133$, 402

Normennota 15

Nota milieuhygiënische normen 36

Nova $167,181,190,310-316$

Object van geschil 288, 289, 291, 293, $304,305,314,316,318,335,380,398,414$ Objectieve redelijkheidstoetsing 297, 319

Onderdeterminatie $64,65,68,71,73$, 110, 392

Ongelijkheidscompensatie 288, 289, $304,305,318,325,333,335,336,338-340$, $342,343,345,346,347,348,350,361-363$, $369,378,380,382,385,398,400,414,415$ Onrechtmatige daad 29, 31, 40,41, 57, 129, 390, 406

Onzekerheidsreductie $107,219,251$, 266, 272-274, 276, 277, 396, 397, 414 Openbare voorbereidingsprocedure 150, 155-157, 174, 214, 217, 394 
Paradigma 41, 69-72, 74, 76, 128, $138-140,278,390,394,406.407$

Partij-autonomie 288, 304, 305, 315. $334-336,345,347,356,361-363,381-383$. 385, 398-400, 411, 414, 415

Praktische onzekerheid 51, 63, 64, 77. 78, 93, 94, 106, 110, 111, 225, 391, 392, 401,407

Principiële onzekerheid 51, 52, 63, 64 . 77, 93, 110, 391, 392

\section{Procesingang 322}

Publiekrechtelijke legitimatie

143-145, 149, 156, 170, 175, 213, 214, 217. 278, 279, 283, 284, 293, 297, 298, 308 . $311,330,394,402,409$

Rationaliteitspostulaat 125, 140, 278, 393

Rechterlijke overtuiging $364,367-369$. $374,376,383,400$

Rechtsgronden 288-290, 304, 305, 318, $333,335,380,398$

Rechtsstaat 96, 98, 123, 125, 129, 132, 137-139

Rechtszekerheid 39, 40, 62, 83, 95, $100,125,130,139,174,384,407$

Redelijke zekerheid $86,88,89,92,94$, $99,101,103,111-113,195-197,225,299$, $300,308,315,368,369,376,380,383$, $392,401,404,405,407,413,414,417$

Reformatio in peius 129, 169, 173, 288, 289, 291, 296, 333, 352

Regeringsverslag 221, 237, 240-248, $250,271,272,275,396$

Richtlijn 201-207, 209-213, 239, 240, $245,246,312,313,371,373,395$

Schadevergoeding 129, 133, 292, 295 . $297,315,316,327,380$

Specialiteitsbeginsel 46-48, 57, 83, 133 , $145,231,234,235,275,406$

Startnotitie 221, 222, 240, 245

Stelplicht 289, 340, 341, 347

Stopregel 86, 88, 92-94, 99, 195

Superdeskundigheid 298, 301, 362, $376,389,416$
Toepassingsconditie $47,81,84,86-88$, $103,111,195,273,415$

Toetsingsrapport 228

Uitgebreide openbare voorberei-

dingsprocedure 150, 157, 174, 214, 217, 394

Ultra petitum 129, 288, 291, 295, 333, 352

Vage term(en) 24-29, 41, 42, 44, 45, 46, $48,49,56,57,86,205,208,209,395$

Vaste-deskundige 256, 328, 329, 356361

Verdedigingsbeginsel 254, 284, 336, $347-349,355,356,360,365,372,378,383$, 385, $400,411,415$

Vereenvoudigde afdoening 290, 322, $328,329,364,373$

Vergunning $7,8,10,13,20,24,25,27$. $36,38,41,42,44-46,48-50,53-55,57,62$. $80-82,87,88,91,95,101,208,209,219$. $236,267,271,273,274,297,310,311$, 316,406

Verlengde besluitvorming 164, 168 , $170-172,214,263,394$

Vermoeden van rechtmatigheid 144 , $213,278,300,340-343,363,365,368,369$, $376,382,385,400,410$

Vernietiging 151, 190, 207, 208, 291, 296, 297, 306, 315, 370, 398, 404, 415

Verruimde beslissingsbevoegdheid 230, 231, 233-236, 244, 249, 275, 406

Versnelde behandeling 290, 322, 328, 329

Verzekering 272, 318, 417

Verzorgingsstaat 98,129

Volksvertegenwoordiging 121, 148 , 283

Vooringenomenheid $148,182,356$

Vooronderzoek 290, 321-324, 326, 327, $331,338,339,348,358,359,361,362$, $378,379,381,399$

Voorzorgsbeginsel 267, 269, 270, 274. 407 
Wet Arob 136, 165, 183

Willekeurverbod $53,119,122,128$, $134-142,145,148,214,278,284,298,306$. 375, 394

Wm-vergunning $8,10,20,27,42,44$, $48,53,57,62,80,81,95,209,219,236$, 274

\section{Zekerheidstelling 273}

Zelf in de zaak voorzien 63, 289, 291 . $306-308,310,314-316,319,381,399,404$, 415, 416

Zitting 290, 305, 322, 326-329, 339, 341 , $352,355,358,359,361,362,378,379$

Zorgplicht $14,20,27-29,32,33,35$, 253, 397

Zorgplichtbepaling 29 Zorgvuldigheidsbeginsel 49, 134, 147. $148,150,154,190,193,195,201,211,417$

Zorgvuldigheidsnorm 28, 29, 35, 270 


\section{Curriculum vitae}

Michiel Heldeweg werd op 27 januari 1957 geboren te Nijverdal. In 1975 behaalde hij het HAVO-diploma aan het Christelijk Lyceum te Almelo. Van 1975 tot 1978 doorliep hij de HEAO te Groningen (economisch-juridische richting). Vervolgens studeerde hij van 1978 tot 1987 aan de Faculteit der Rechtsgeleerdheid in Groningen. In 1985 behaalde hij het doctoraal Bestuurswetenschappen en in 1987 het doctoraal Nederlands Recht, afstudeerrichting Publiekrecht.

Sinds februari 1985 is hij werkzaam aan de Rijksuniversiteit Limburg, sinds 1988 als universitair docent staats- en bestuursrecht bij de vakgroep Publiekrecht. 
